\title{
Universiteit
}

Leiden

The Netherlands

\section{Het bolwerk van de vrijheid : De Leidse universiteit in heden en verleden} Otterspeer, Willem

\section{Citation}

Otterspeer, W. (2008). Het bolwerk van de vrijheid : De Leidse universiteit in heden en verleden.

Leiden University Press. Retrieved from https://hdl.handle.net/1887/21097

Version:

Not Applicable (or Unknown)

License:

Leiden University Non-exclusive license

Downloaded from: https://hdl.handle.net/1887/21097

Note: To cite this publication please use the final published version (if applicable). 


\section{Willem Otterspeer}

\section{Het bolwerk}
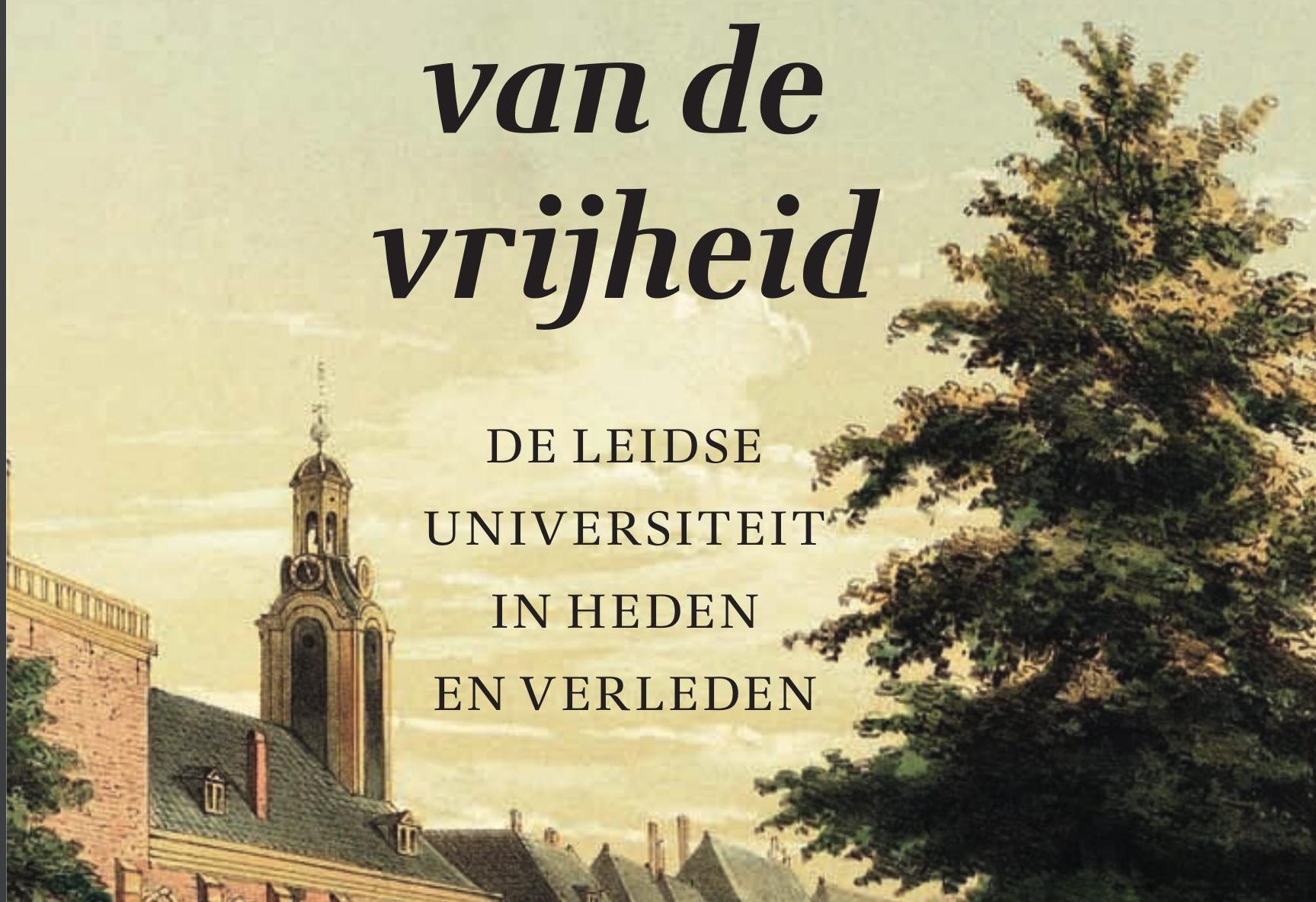

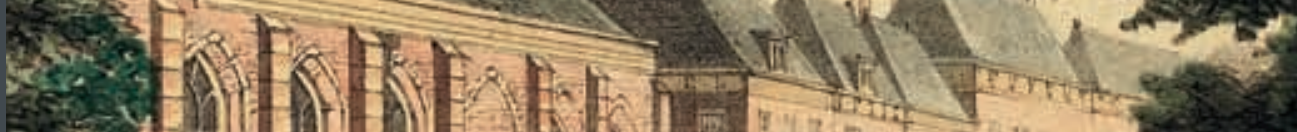

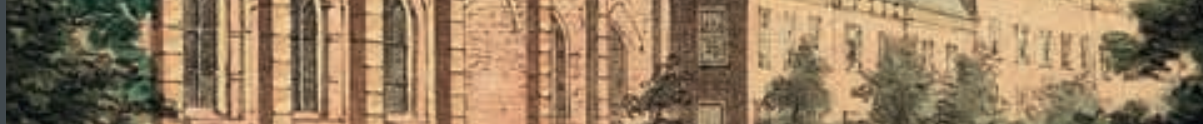

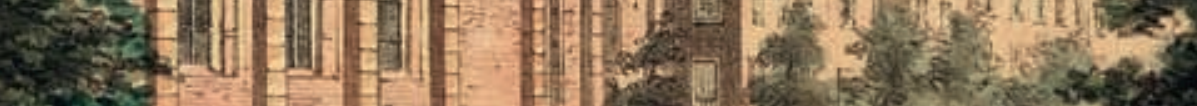

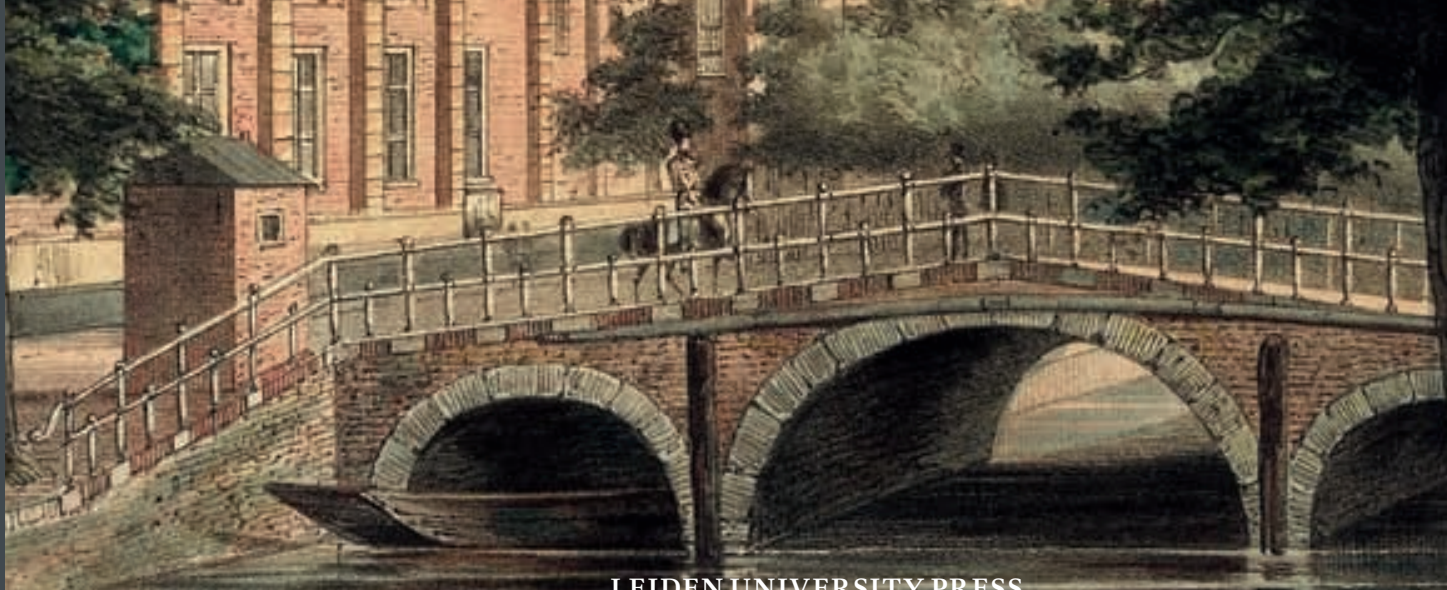

LEIDENUNHVERSTY PRESS

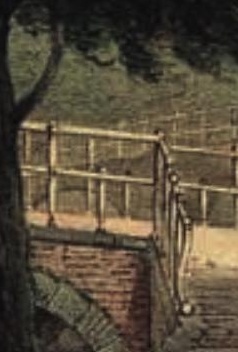


Het bolwerk van de vrijheid 


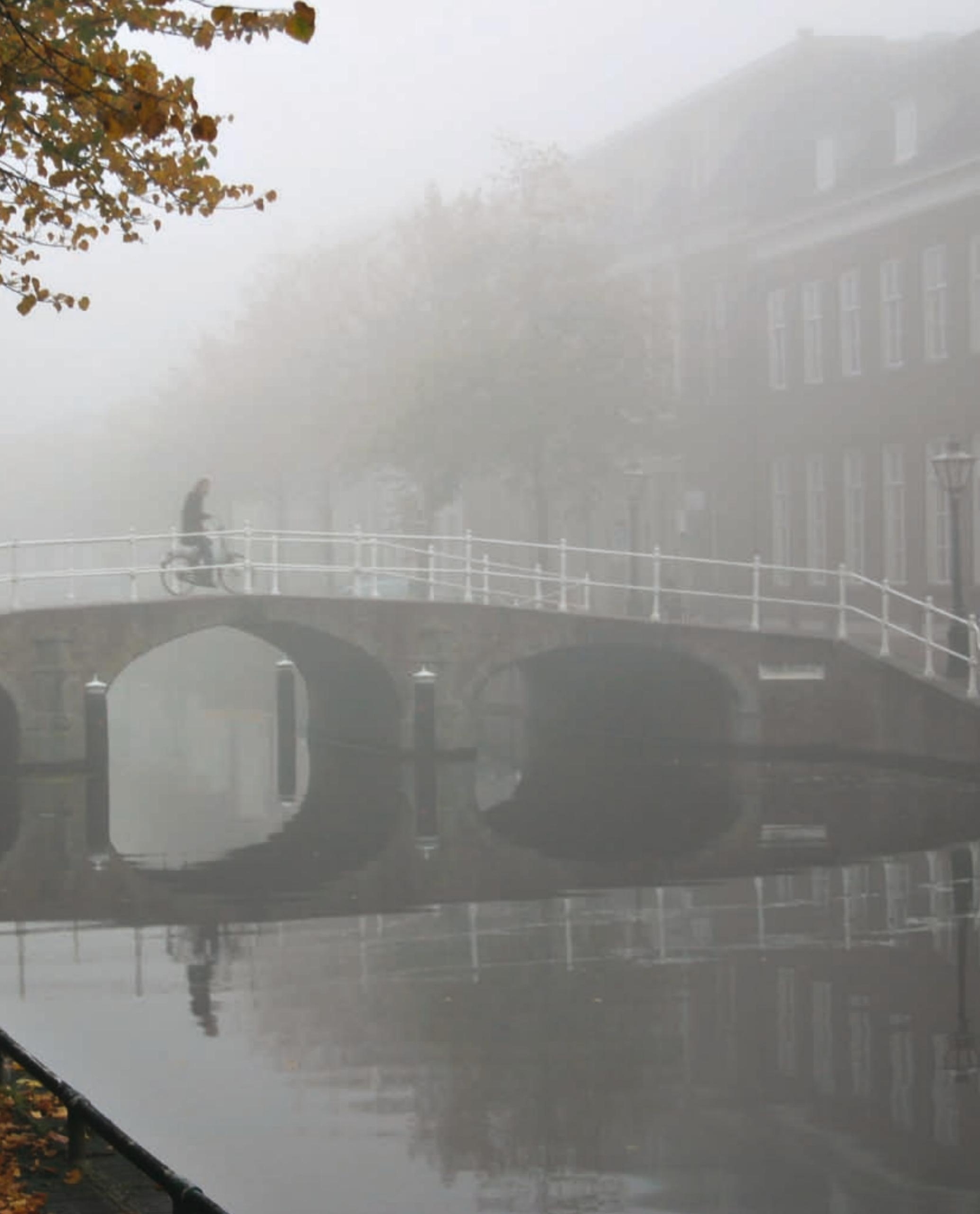




\title{
Willem Otterspeer
}

Het bolwerk

\author{
van de \\ vrijheid
}

\author{
DE LEIDSE \\ UNIVERSITEIT \\ IN HEDEN \\ EN VERLEDEN
}


Ontwerp omslag en binnenwerk: Suzan Beijer, Weesp

Afbeelding omslag: P.W.M. Trap, Rapenburg met het Academiegebouw, ca. 1850. Beeldbank Regionaal Archief Leiden

Afbeelding pagina 2: Het Rapenburg in de mist met op de achtergrond het Rijksmuseum van Oudheden

Omslag en binnenwerk zijn gezet uit de DTL Antares

ISBN 9789087280246

NUR 680

(C) W. Otterspeer / Leiden University Press, 2008

Alle rechten voorbehouden. Niets uit deze uitgave mag worden verveelvoudigd, opgeslagen in een geautomatiseerd gegevensbestand, of openbaar gemaakt, in enige vorm of op enige wijze, hetzij elektronisch, mechanisch, door fotokopieën, opnamen of enige andere manier, zonder voorafgaande schriftelijke toestemming van de uitgever.

Voor zover het maken van kopieën uit deze uitgave is toegestaan op grond van artikel 16B Auteurswet $1912 \mathrm{j}^{\mathrm{O}}$ het Besluit van 20 juni 1974, Stb. 351, zoals gewijzigd bij het Besluit van 23 augustus 1985, Stb. 471 en artikel 17 Auteurswet 1912, dient men de daarvoor wettelijk verschuldigde vergoedingen te voldoen aan de Stichting Reprorecht (Postbus 3051, 2130 кв Hoofddorр). Уоог het overnemen van gedeelte(n) uit deze uitgave in bloemlezingen, readers en andere compilatiewerken (artikel 16 Auteurswet 1912) dient men zich tot de uitgever te wenden. 


\section{Inhoud}

$\begin{array}{ll}\text { Voorwoord } & 7\end{array}$

Inleiding 9

1 Wapens en woorden 20

DE LEIDSE UNIVERSITEIT 1575-1775

2 Vrijheid en gebondenheid $\quad 114$ DE LEIDSE UNIVERSITEIT 1775-1975

3 Eenheid en veelheid 200

DE LEIDSE UNIVERSITEIT 1975-HEDEN

Grafieken en tabellen $\quad 290$

Illustratieverantwoording 296

$\begin{array}{ll}\text { Bibliografie } & 297\end{array}$

$\begin{array}{ll}\text { Register } & 307\end{array}$ 


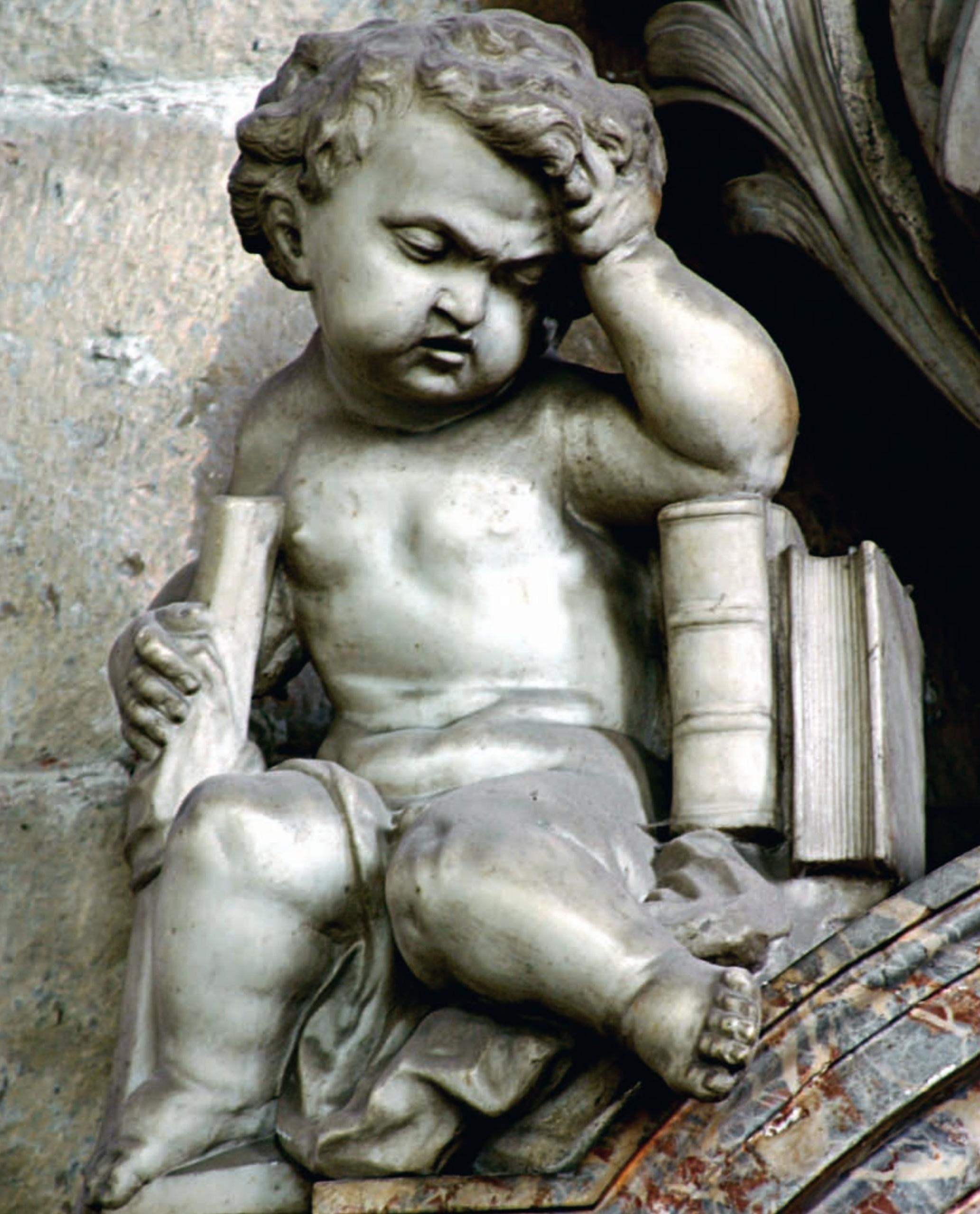




\section{Voorwoord}

De aanleiding voor dit boek is een ander boek. De eerste gedachte die zich bij de voorbereiding tot het vierde deel van mijn geschiedenis van de Leidse universiteit aan mij opdrong, was dat dit een ander boek zou zijn dan de drie voorafgaande. Moderniteit en schaalvergroting maakten van de Leidse universiteit in de twintigste eeuw een andere instelling, nauwelijks vergelijkbaar met wat егаan voorafging. Zo kreeg ik de behoefte een stap terug te doen, om in kort bestek te zien waar ik vandaan kwam en te kijken waar ik heen moest. Reculer pour mieux sauter, dat is de reden van dit boekje.

Toen ik dit voorstelde aan het college van bestuur van mijn universiteit, luidde de reactie: prima, maar maak er dan meteen een mooi boek van, voor het plezier van onze Nederlandse alumni en onze buitenlandse studenten. En dus kwam er een klein en mooi boek, zowel in het Nederlands als in het Engels. Zo is het gegaan.

\ Treurengeltje op hetrouwmonument van hoogleraar Theologie Johannes Coccejus (1603-1669) 


$$
\text { istans }
$$

\section{Prot. \\ i)}

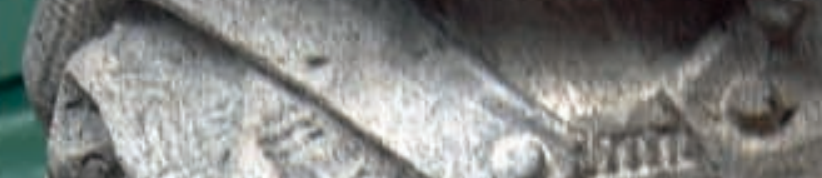

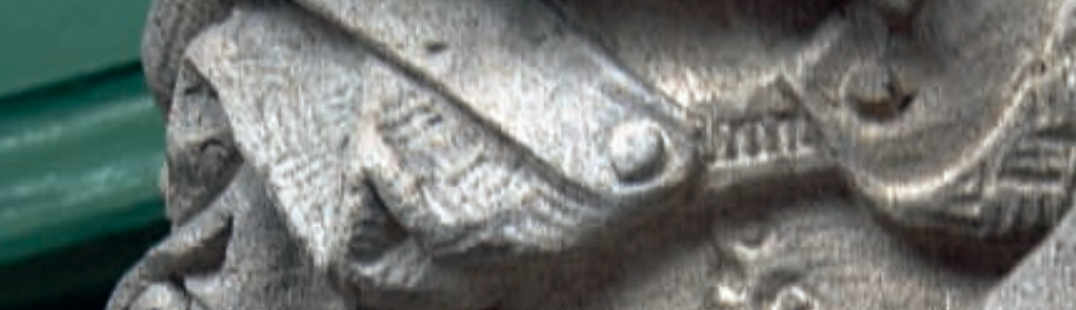

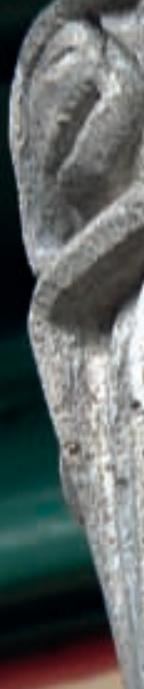

(.) $=\frac{+\infty}{2}$

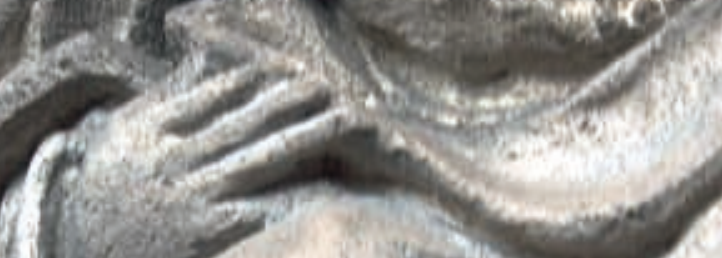




\section{Inleiding}

Om tot de kern van de universiteit door te dringen, hebben geleerden van oudsher hun toevlucht gezocht tot uiteenlopende metaforen. De universiteit zou een burcht van behoud zijn of juist een broeinest van verandering, een bolwerk van de heersende klasse, maar ook het huis van de zuivere kennis. Dergelijke metaforen zijn vaak misleidend. De universiteit is een ingewikkelde instelling met een lange geschiedenis. Toch is de omschrijving van Walter Rüegg, hoofdredacteur van A History of the University in Europe, een vierdelige geschiedenis van de universiteit, stimulerend. Dat komt doordat ze niet alleen stoelt op kennis, maar ook geïnspireerd is door hoop. Alfa en omega van de universiteit is voor Rüegg reformatio in melius, hervorming en verbetering. In zijn inleiding tot het eerste deel van A History of the University schrijft hij dat het idee of doel van de universiteit de belichaming was van een academische ethiek die de maatschappij zou verbeteren door een cumulatief proces van kennisverwerving.

Deze visie is ook het raamwerk van dit boek. Tegelijk suggereer ik een behoudender alternatief. Op basis van het algemene idee dat wordt uitgewerkt in de canonieke delen waarvan Rüegg de hoofdredacteur is, stel ik voor 'evenwicht' en 'bemiddeling' te gebruiken als belangrijke noties om de universiteit te begrijpen. Met de geschiedenis van de Leidse universiteit als voorbeeld wil ik laten zien dat de universiteit een vorm van maatschappelijk kapitaal is, een antwoord van de westerse maatschappij op het dilemma van collectieve actie,

\ Neogothische console in de togakamer van het Academiegebouw 
een bijdrage aan de noodzaak het evenwicht te bewaren en te herstellen en zo continuïteit mogelijk te maken. In deze optiek is de universiteit een mechanisme om vertrouwen te genereren en oplossingen aan te dragen voor grote maatschappelijke problemen.

Het scholastische humanisme waагuit de universiteit geboren werd, zag de mens als een verkorte versie van de wereld. Door zijn samengestelde natuur was de mens bij uitstek geschikt om de wereld te begrijpen en de tegenstellingen daarin met elkaar in overeenstemming te brengen. Zoals Dante schrijft, aan het einde van De Monarchia: 'De mens is het midden tussen het vergankelijke en het onvergankelijke. Zoals elk midden deel heeft aan beide uiteinden, zo heeft de mens een tweeledige natuur. En omdat elke natuur is voorbeschikt voor een bepaald doel, volgt daaruit dat de mens twee doeleinden heeft: enerzijds het geluk van dit leven, en anderzijds het geluk van eeuwigleven.'

Ook de middeleeuwse universiteit was zo'n midden, in haar geval tussen de twee universele machten van die tijd. Zoals Herbert Grundmann in een briljant essay heeft uitgelegd, kreeg de standaarddoctrine van de twee wereldlijke machten, die van Sacerdotium en van Regnum, van het religieuze en het politieke, er in de dertiende eeuw een derde principe bij: dat van Studium, van de kennis, van de universiteit als tertium comparationis in de veranderende politieke omstandigheden van de middeleeuwen. Aangezien men er inmiddels van uitging dat de macht in de wereld verdeeld was over drie belangrijke volken - de Italianen, de Duitsers en de Fransen -, maakte deze theorie het mogelijk om de toenemende politieke invloed van Frankrijk te erkennen. Zo kreeg de universiteit van Parijs een eervolle plaats toebedeeld tussen paus en keizer.

Als 'derde weg' moest de middeleeuwse universiteit een stabiliserende invloed hebben, een functie die zowel paus als keizer erkende. Vanzelfsprekend was de studie van kerkleer en canoniek recht bedoeld om de centrale macht van de paus te versterken, net zoals de studie van het Romeinse recht en de politieke theorie bedoeld was om de aanspraken van de keizer te ondersteunen. Maar vanaf het moment dat de paus een rationeel gefundeerde geloofsleer bevorderde als toetssteen van afwijkende overtuigingen, legde hij

- Raam in het voormalige Rijksherbarium in de Nonnensteeg 


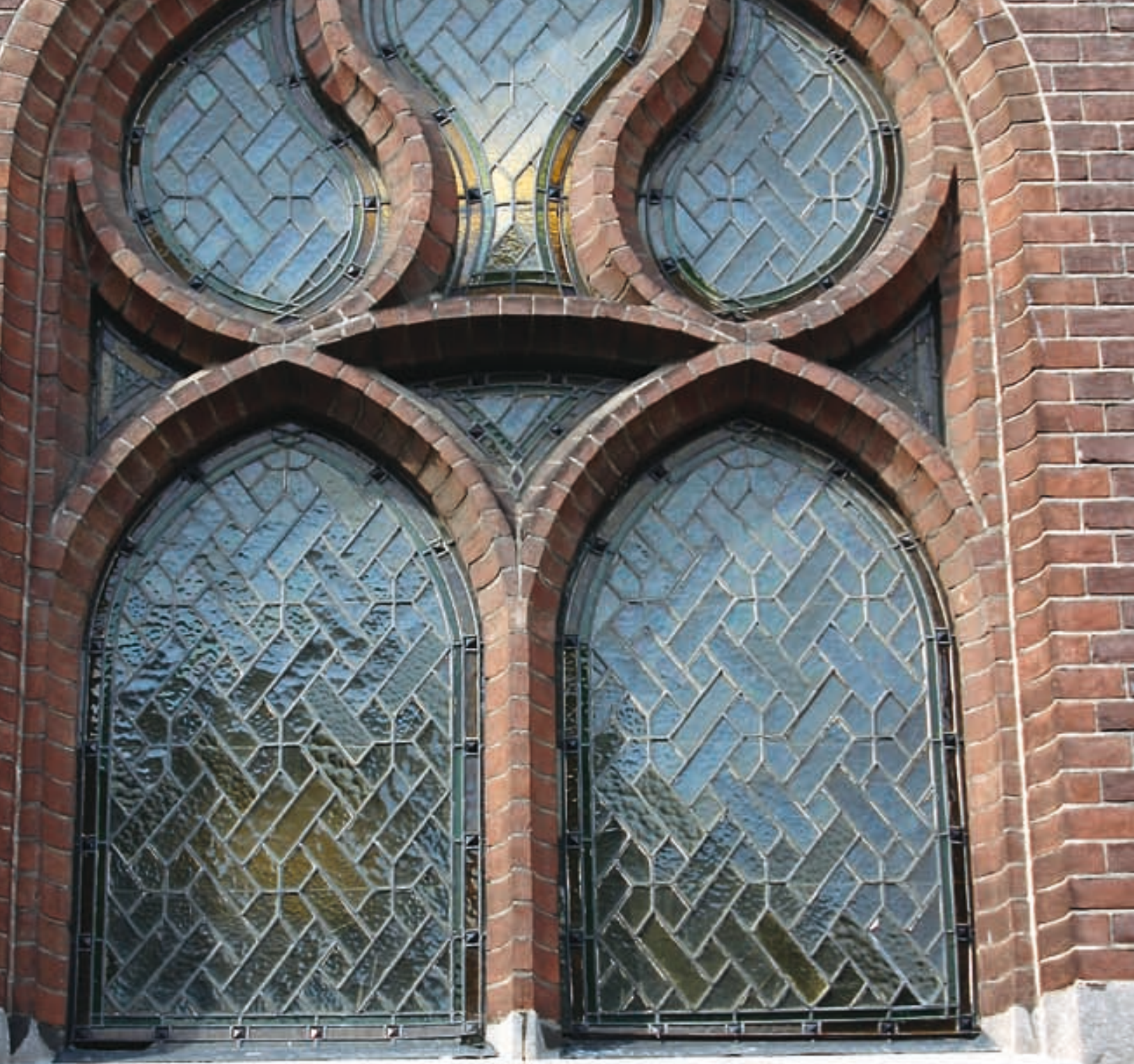




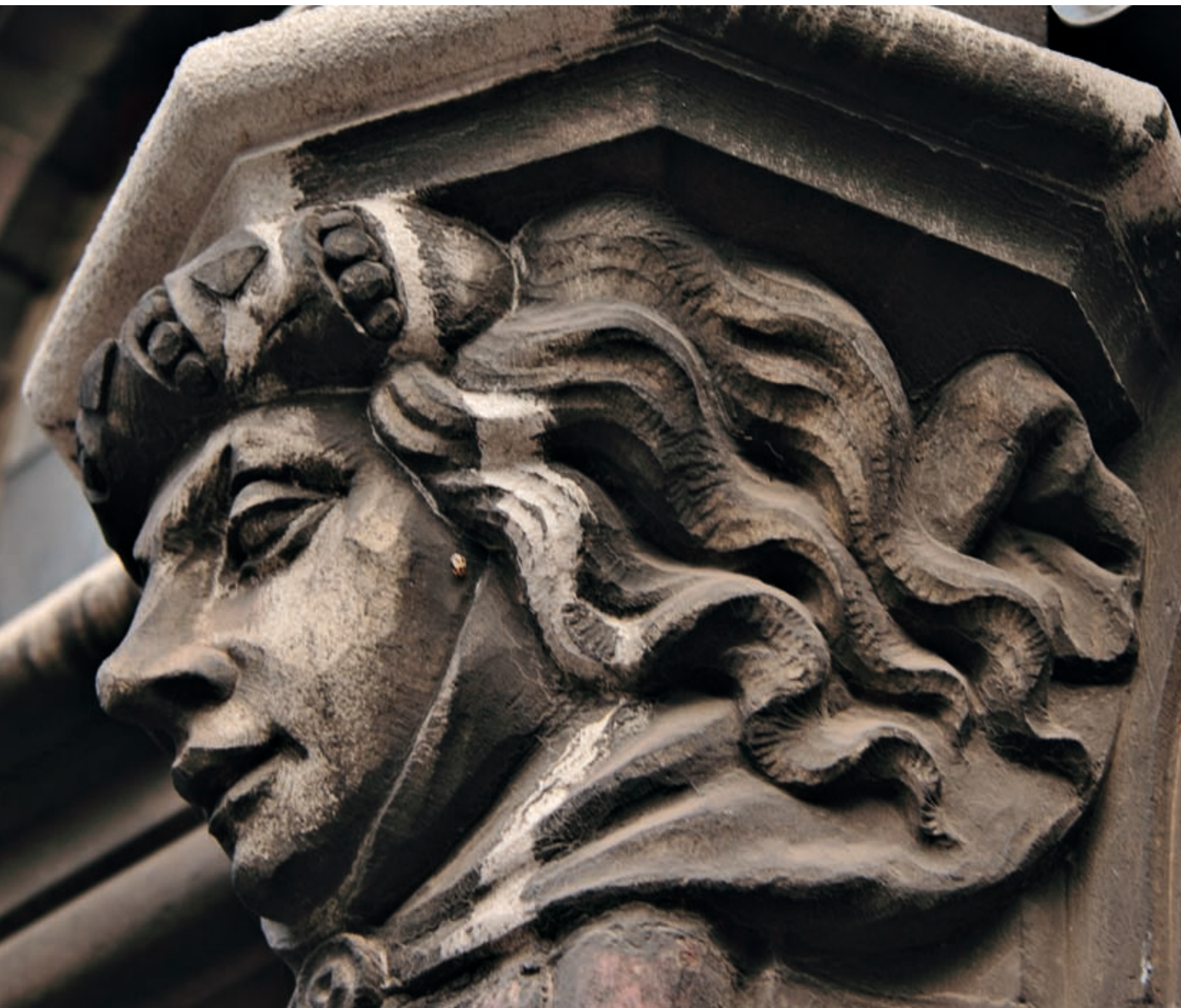

\ Ornament aan het voormalig Chemisch en Farmaceutisch Laboratorium aan de Hugo de Grootstraat 
ook beperkingen op aan zijn eigen vrijheid. En toen Frederik I bevestigde dat de keizerlijke troon zijn macht ontleende niet alleen aan de macht van wapens, maar ook aan de kracht van wetten, beperkte hij daarmee ook zijn eigen mogelijkheden.

Als we ons vervolgens afvragen hoe de universiteit verankerd was in de middeleeuwse maatschappij, wat de rol was van de afgestudeerde en zijn carrière na het afstuderen, dan stuiten we op hetzelfde kenmerkende verschijnsel. In een wereld die een minimum aan politieke en juridische stabiliteit kende en een hoge mate van maatschappelijke diversiteit, had de universiteit veeleer een stabiliserende invloed. De veranderingen die ze teweegbracht, hielpen de stedelijke of hogere overheden zich aan te passen en te overleven.

Ook het middeleeuwse curriculum, met de canonieke werken van Aristoteles als middelpunt, was in wezen een juste milieu. Het probeerde verschillende soorten kennis en disciplines samen te brengen onder een gezamenlijke noemer. Volgens Aristoteles was wetenschap een eclectische bezigheid, waarbij men probeerde om 'zo mogelijk de waarheid van alle gedegen meningen over een bepaalde zaak - en anders toch de meeste en de meest gezaghebbende - te behouden'. Voldoende bewijs werd gezocht, niet doorslaggevend bewijs. Het was de methodologische tegenhanger van Aristoteles' beroemde 'doctrine van het midden', waarin elke deugd beschouwd werd als het midden tussen twee ondeugden en de beste wet gold als een haalbare wet, geworteld in een mengsel van democratie en oligarchie, gedragen door een middenklasse (hoi mesoi, letterlijk 'de middenmensen').

De medische en de juridische theorie gingen uit van hetzelfde criterium. Zo kreeg het middeleeuwse curriculum een fundamentele eenheid. De aristotelische filosofie bevatte veel hippocratische elementen en voor Hippocrates, de belangrijkste medische autoriteit, waren gezond verstand en evenwicht centrale noties. Gezondheid was een soort balans tussen de verschillende levenssappen en manieren van leven. De hippocratische geschriften hadden ook veel invloed op het juridische gedachtegoed, waarin natuurlijk evenwicht de vorm aannam van aequitas: het idee dat eerlijkheid en onpartijdigheid essentieel waren voor juridische regels.

Dit evenwicht was er ook in de theologie. Er is een ononderbroken traditie 
- van Augustinus via Thomas van Aquino tot aan Melanchton - waarin het Romeinse recht gold als een deel van het natuurrecht en waarin natuur en bovennatuur op elkaar afgestemd werden. Gratianus, de grote twaalfde-eeuwse jurist van het kerkelijk recht, gebruikte de dialectiek om de tegenstrijdigheden tussen de kerkvaders met elkaar te verzoenen. De rationalisering van het theologische denken van die tijd resulteerde in de bereidheid werkelijk alle dogmatische problemen die speelden te bespreken, zij het zonder de behoefte om definitieve oplossingen te bieden.

De scholastische pedagogiek die deze disciplines omzette in een curriculum was opvallend uniform in haar methoden. Van de artes liberales, de vrije kunsten, tot aan de theologie, maakten deze methoden gebruik van elementaire handboekjes, die uiteenliepen van een tabula die acht boeken Physica van Aristoteles in zes pagina's tabellen samenperste, tot aan compendia met samenvattingen van bepaalde delen van het aristotelische corpus. Er is in feite veel overeenkomst tussen het gebruik van de hippocratische aforismen - een collectie gezegden met bijna allegorische expressiviteit - en de twee titels van de Digesten: 50.16, 'De verborum significatione' en 50.17, 'De diversis regulis iuris antiqui', die samen een vrij natuurlijke inleiding vormden tot het juridisch denken. Op dezelfde manier vormden de Tien Geboden een beknopte inleiding tot de dogmatiek.

Op deze manier maakte de universiteit deel uit van een prachtige middeleeuwse samenhang: de religieuze eenheid van paus en kerk en de politieke eenheid van keizer en staat werden als het ware gereflecteerd in de wetenschappelijke eenheid van filosofie en theologie. De vroegmoderne periode maakte een einde aan deze samenhang. Ze maakte een einde aan de eenheid van de kerk en gaf 'aanzijn' aan een baaierd van wedijverende overtuigingen. Ze maakte ook een einde aan de politieke eenheid van Europa om daarvoor in de plaats de competitie te zetten van nationale staten en politieke systemen. Ten slotte maakte ze een einde aan de eenheid van de wetenschap, die uiteenviel in een keur van wedijverende methoden.

Op die versplintering lijkt het humanisme het meest adequate antwoord te hebben gehad. Door zijn geslaagde infiltratie in bestaande universiteiten en door de humanistische inspiratie voor het stichten van nieuwe, met name 
vanaf de vijftiende eeuw in Noord-Europa, kregen onderwijskundige ideeën van een andere strekking de overhand. De nadruk op methode boven inhoud, op waarschijnlijkheid boven waarheid, op algemene kennis boven specifieke kennis, het was allemaal van invloed op het universitaire curriculum en op het doel van het universitaire onderwijs.

Nieuwe vakken als Hebreeuws en Grieks kwamen op naast een hernieuwde nadruk op oude vakken als retoriek en ethiek. Geїnspireerd door de bonae litterae hechtte het curriculum veel waarde aan een literaire en historische gevoeligheid die ook de hogere faculteiten doordesemde. Repeteren en uit het hoofd leren waren de pijlers van deze methode, bruikbaarheid was het belangrijkste criterium voor haar succes. Het doel was voor te bereiden op het openbare leven - 'in forum, in Senatum, in concionem populi, in omnem hominum conventum', zoals Ramus schreef - en het inprenten van praktische wijsheid of christelijke ethiek.

De inhoud van het curriculum en de benadering van het leren mochten veranderd zijn, ze waren nog altijd bedoeld voor hetzelfde resultaat. De humanistische universiteit speelde misschien zelfs meer dan haar middeleeuwse tegenhanger de rol van middelaar. Door de harmonisering van religieuze controversen, de ondersteuning van de staatsbureaucratie en de ritualisering van het wetenschappelijke debat had de universiteit een stabiliserend effect op de maatschappij. Doordat ze disciplinair onderwijs bood dat leren en training combineerde, was ze van grote invloed op de maatschappelijke structuur, waarin ze adel en hoge bourgeoisie samensmolt tot een nieuwe elite. De Leidse universiteit die, zoals een van de eerste voorstellen voor een curriculum het formuleerde, een seminarium ecclesiae et reipublicae wilde zijn, een leerschool voor kerk en samenleving, is een van de beste voorbeelden van deze bemiddelende rol. 


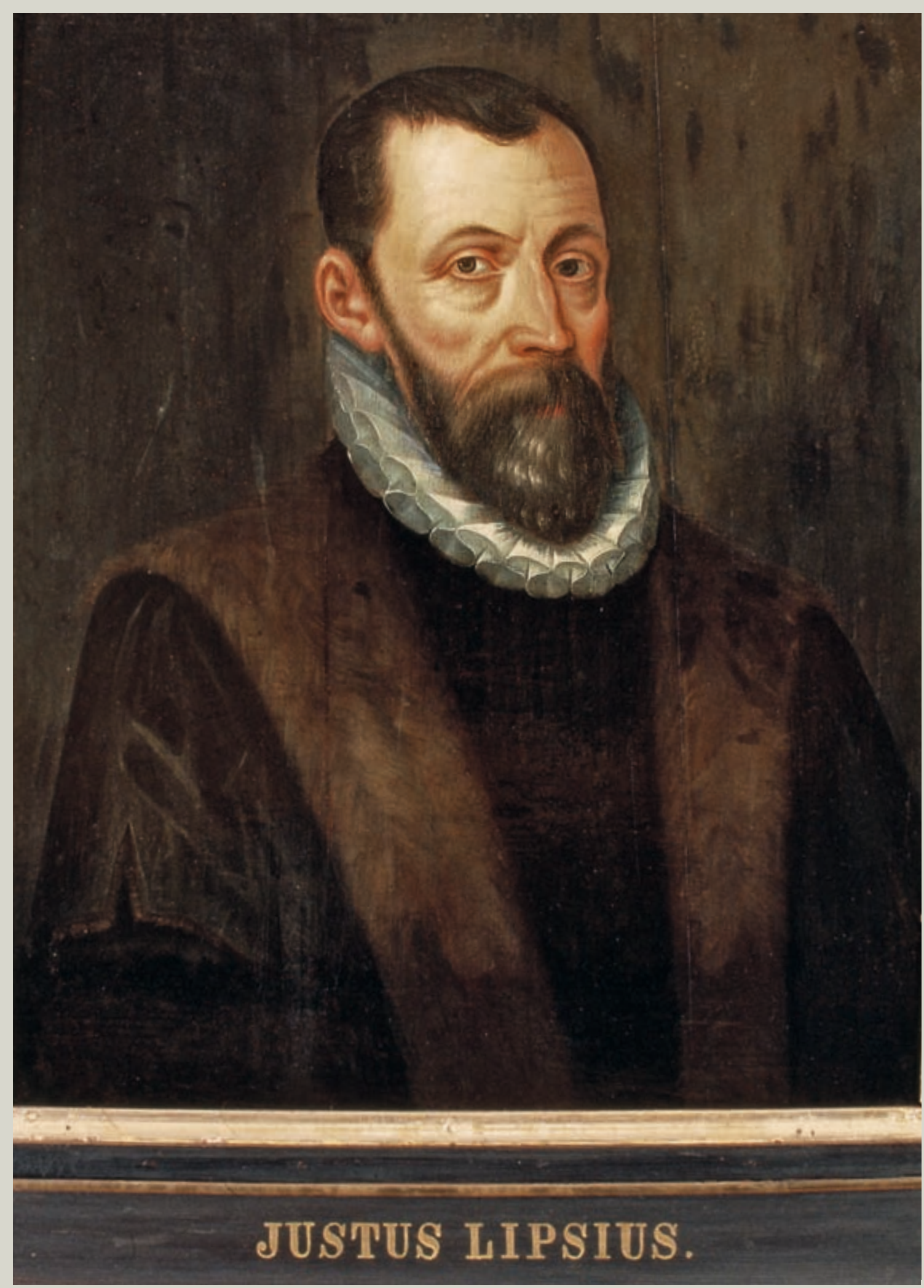




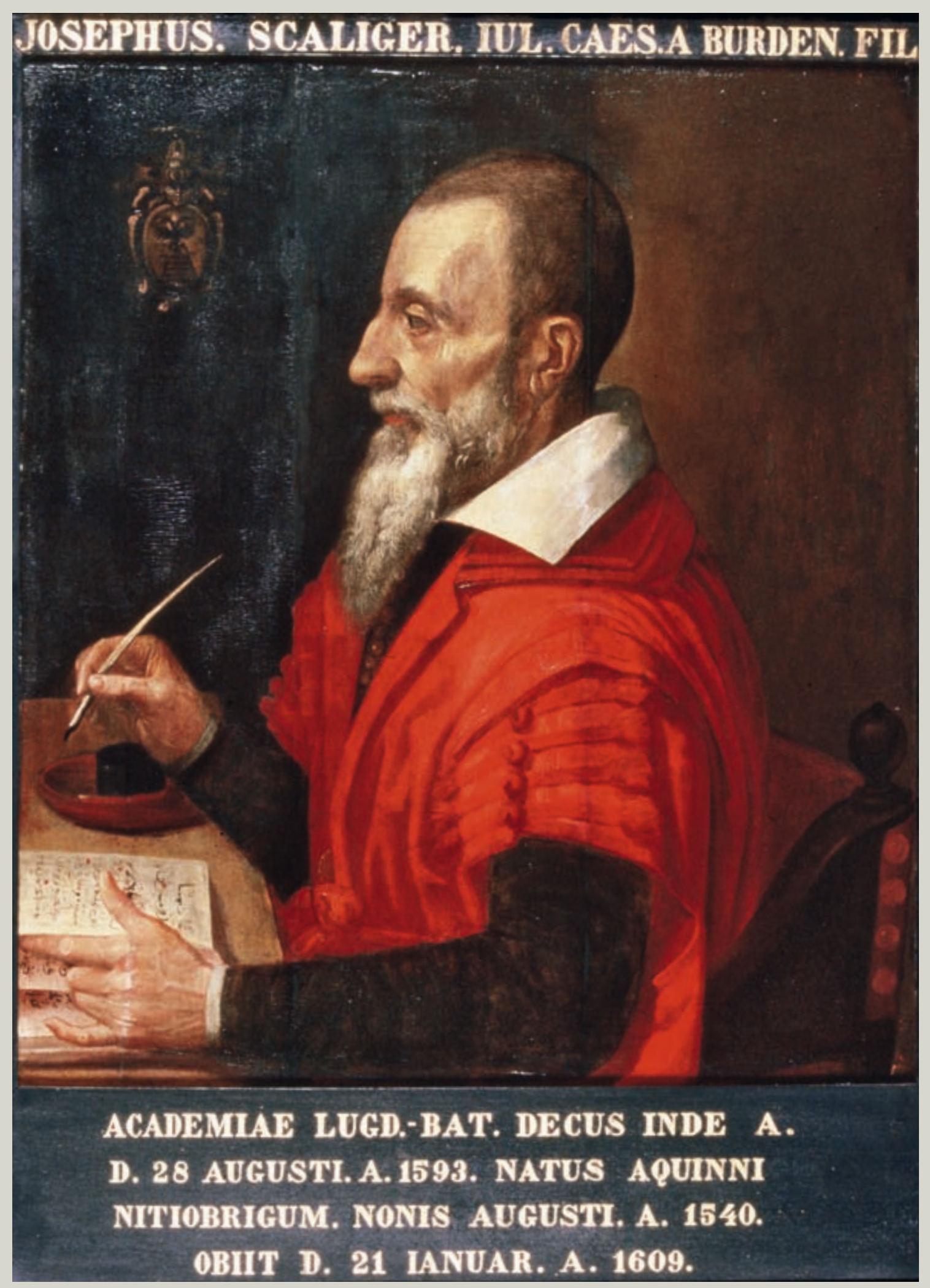




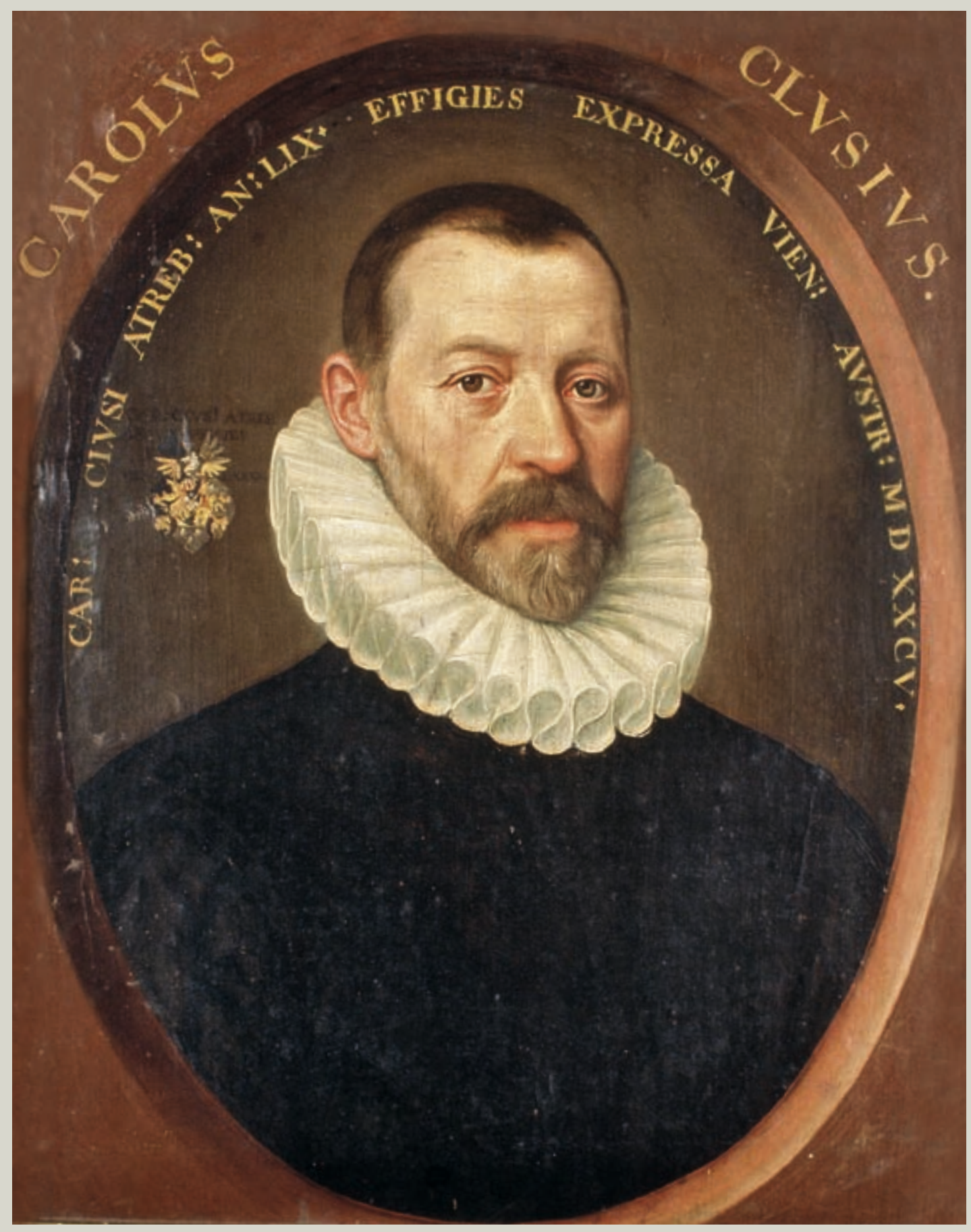




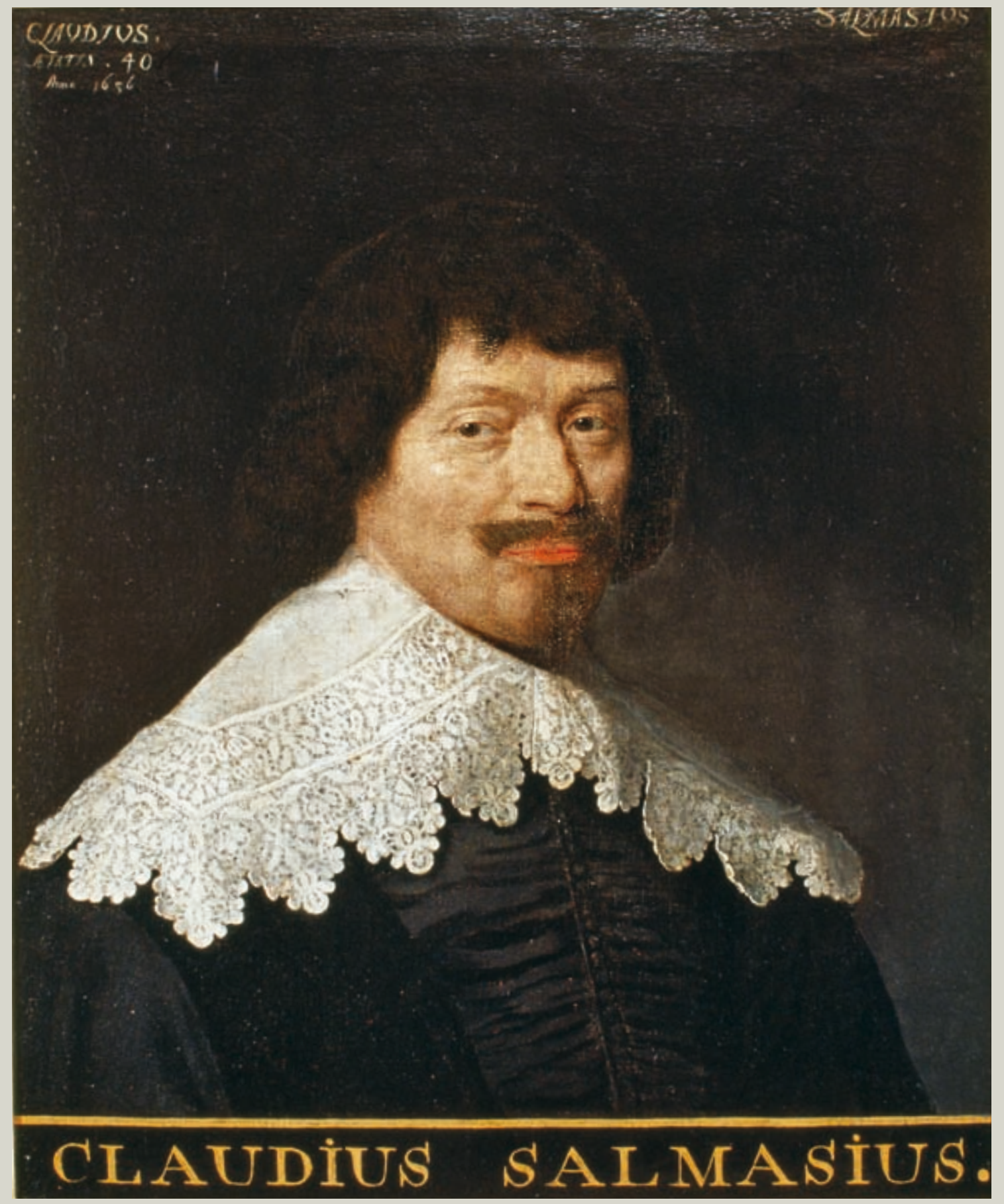




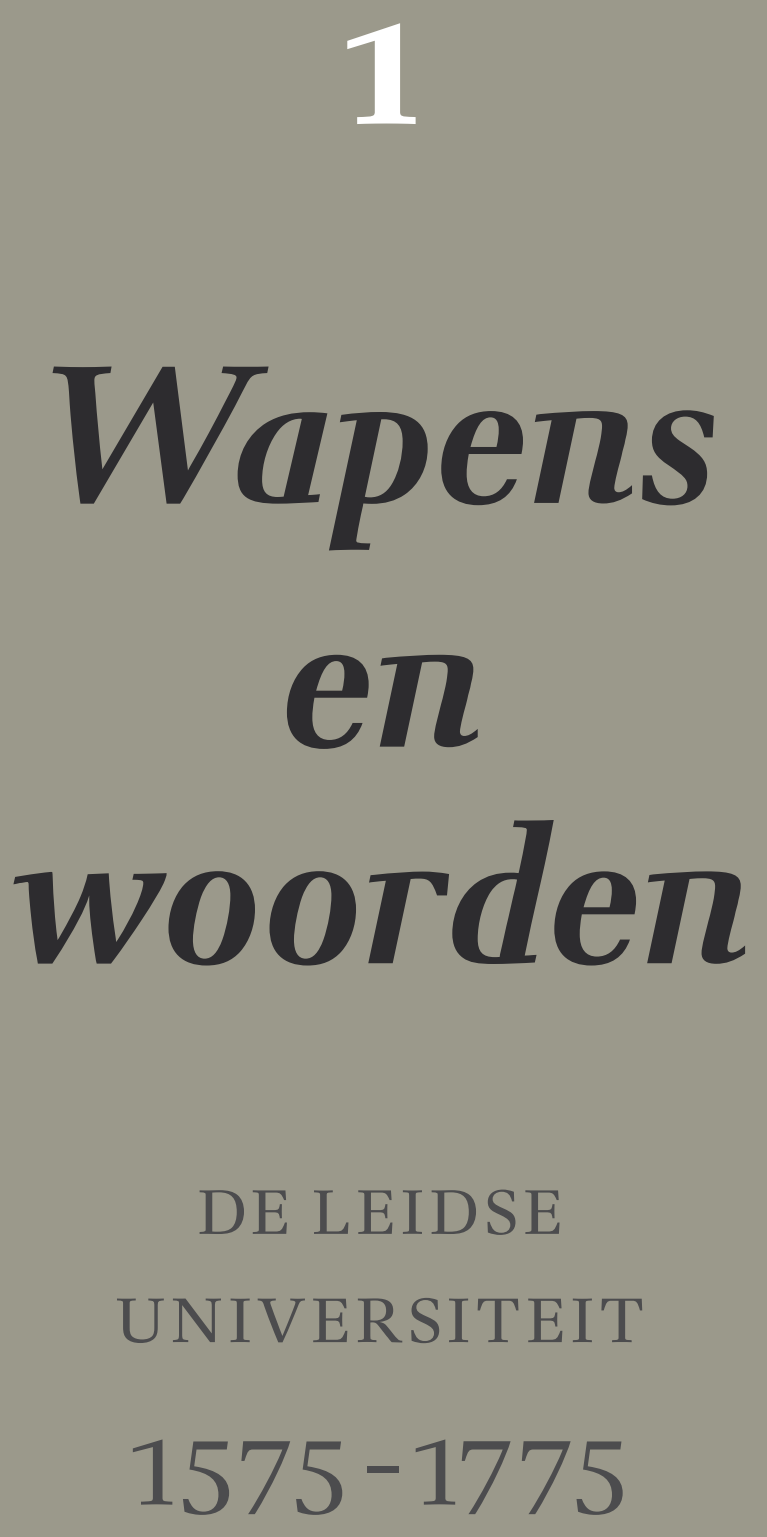




\section{Een schepping uit het niets}

Het wonder dat de Leidse universiteit was, een schepping uit het niets, een daad van geloof, vond plaats tegen de achtergrond van een nog groter wonder, een mirakel dat Europa in zijn ban hield. Diplomaten en geleerden, kooplieden en toeristen, ieder die de Republiek bezocht, weigerde zijn ogen te geloven. De bij uitstek gunstige ligging van het land, de veelheid en properheid van zijn steden, de eigenaardigheid van zijn politieke bestel, de gedisciplineerdheid van zijn bevolking, het technische en economische vernuft, de rijkdom en de veiligheid, de vrijheid vooral, het hield niet op de beschouwer te verbazen.

Het waren overigens vaak dezelfde elementen die tegengestelde emoties losmaakten. De schraalheid van de bodem en de versnippering van het land, de ondoorzichtigheid van de politiek en de meedogenloosheid van de handel, de inhaligheid van de elite en de vulgariteit van de rest, het algehele gebrek aan decorum en hiërarchie, het was eigenlijk weinig anders dan de achterkant van hetgeen anderen zo loofden. Wat de één zag als vrijheid, was voor de ander een uitwas. Zelfs de welwillendste beschouwer moest toegeven: in de Republiek kon je beter reizen dan wonen.

De Republiek, Holland vooral, de achtergrond waartegen de Leidse universiteit opereerde, was een amalgaam van tegenstellingen die de dynamiek van haar geschiedenis bepaalden. De belangrijkste tegenstellingen waren die 
tussen land en water, adel en burgerij, nijverheid en handel, monarchale versus democratische tendensen en maritieme, op vrede gerichte politiek versus territoriale, expansieve politiek. Deze tegenstellingen, gecombineerd als ze werden met een grote individuele gewetensvrijheid, genегеerden een specifieke 'discussiecultuur' in de Nederlanden waarbinnen de universiteit een voогаanstaande plaats innam. De Republiek probeerde de tegenstellingen die haar onmiskenbare identiteit uitmaakten in vele vormen te neutraliseren. Het hoger onderwijs, de Leidse universiteit, was daarvan een van de belangrijkste.

\section{Stichting}

Op 8 februari, om zeven uur op dinsdagochtend, kwam een enorme menigte bijeen in de grootste kerk van Leiden, de voormalige Sint Pieter. Ieder die gevolg gegeven had aan de aanplakbiljetten en 'uitroepingen' - afkondigingen waren gedaan tot aan Delft, Gouda en Rotterdam - verzamelde zich onder het gehoor van dominee Pieter Cornelisz. Daar, in die koude, kale kerk werd de Leidse universiteit aanbevolen aan Gods genade. Ze zou Zijn naam prijzen en Zijn gemeenschap stichten en de nijverheid en welvaart van stad en land dienen. 'Zaligheydt' en 'ervarentheydt in alle eerlycke en pryselycke Konsten', daar was het de universiteit volgens deze gereformeerde stijfkop om te doen. En 'gheleertheydt', dat ook, al werd die wat klem gedrukt tussen zielenheil en praktisch nut.

Dit was het beeld dat de nieuwe Gereformeerde Kerk van de nieuwe Hollandse universiteit had. De eerste academische rede van die dag kwam ook van een geestelijke. Caspar Coolhaas, dominee van de stad en eerste hoogleraar theologie, sprak volgens zijn tijdgenoot, de stadschroniqueur J.J. Orlers 'tot lof van de Theologie'. Маar ook andere partijen waren betrokken bij de stichting van de Leidse universiteit en ook zij presenteerden die dag hun visie.

Als vehikel gebruikten zij een plechtige processie die om negen uur's ochtends bij het stadhuis vertrok. Na een korte rondgang en via enkele zeer sim- 
pele 'triomfbogen', bereikte de stoet het eerste onderkomen van de universiteit, het vгоegere klooster van Sint Вагbara. Het begin en het einde van de stoet werden gevormd door een vendel van de schutterij. Hun aandeel was logisch, volgens Orlers, 'zulcx zy verstonden haer vryheydt gewonnen te hebben en van meyninghe te wezen, hem zelfs beschermende te houden'.

De Leidse universiteit, gesticht in een cruciale fase van de opstand van Holland tegen Spanje, belichaamde de twee canonieke redenen voor die opstand: twee vormen van vrijheid, religieus en politiek, die zo moeilijk te verenigen zijn. Toen Willem van Oranje, de leider van de opstand, de Staten van Holland en Zeeland suggereerde om een universiteit te stichten, deed hij dat 'tot een vast stuensel ende onderhoudt der vryheyt ende goede wettelicke regieringe des lants niet alleen in zaeken der religie, maer oock in tgene den gemeynen borghelicken welstandt belanght'.

Oranje beval Leiden aan als een goede plaats. Het grote belang van de rol die deze stad speelde in de opstand - Leiden was de tweede grote stad in Holland die een Spaans beleg weerstond - was waarschijnlijk doorslaggevend bij de keuze van de Staten. De aanwezigheid in de processie van drie burgemeesters, de schout en drie schepenen onderstreepte de bijzondere band tussen stad en universiteit.

De houding van de universiteit zelf tegenover haar dienstbaarheid aan kerk en staat valt af te leiden uit de allegorische voorstellingen van de vier faculteiten in de optocht. Pièce de résistance van de processie was een uiterst sober opgetuigde wagen met Sacra Scriptura, de Heilige Schrift. De prominente positie daarvan benadrukte die van de theologie als de belangrijkste faculteit. Daarna kwam Justitia, geblinddoekt, met weegschaal en zwaard, gevolgd dоог Medicina, met kruiden en een urinaal. Minerva, gewapend met schild en speer, zinnebeeldige voorstelling van de artes, de faculteit van de vrije kunsten, ook wel de filosofie genoemd, sloot de rij. Deze volgorde gaf de gebruikelijke Рarijse hiërarchie van vakken weer, die hun maatschappelijk belang weerspiegelde.

De specifieke functie van de universiteit als een instituut dat de belangen van kerk en stad diende, en met name de rol die zij moest gaan spelen in de nieuwe politieke situatie, bleek zodra de optocht het academiegebouw be- 


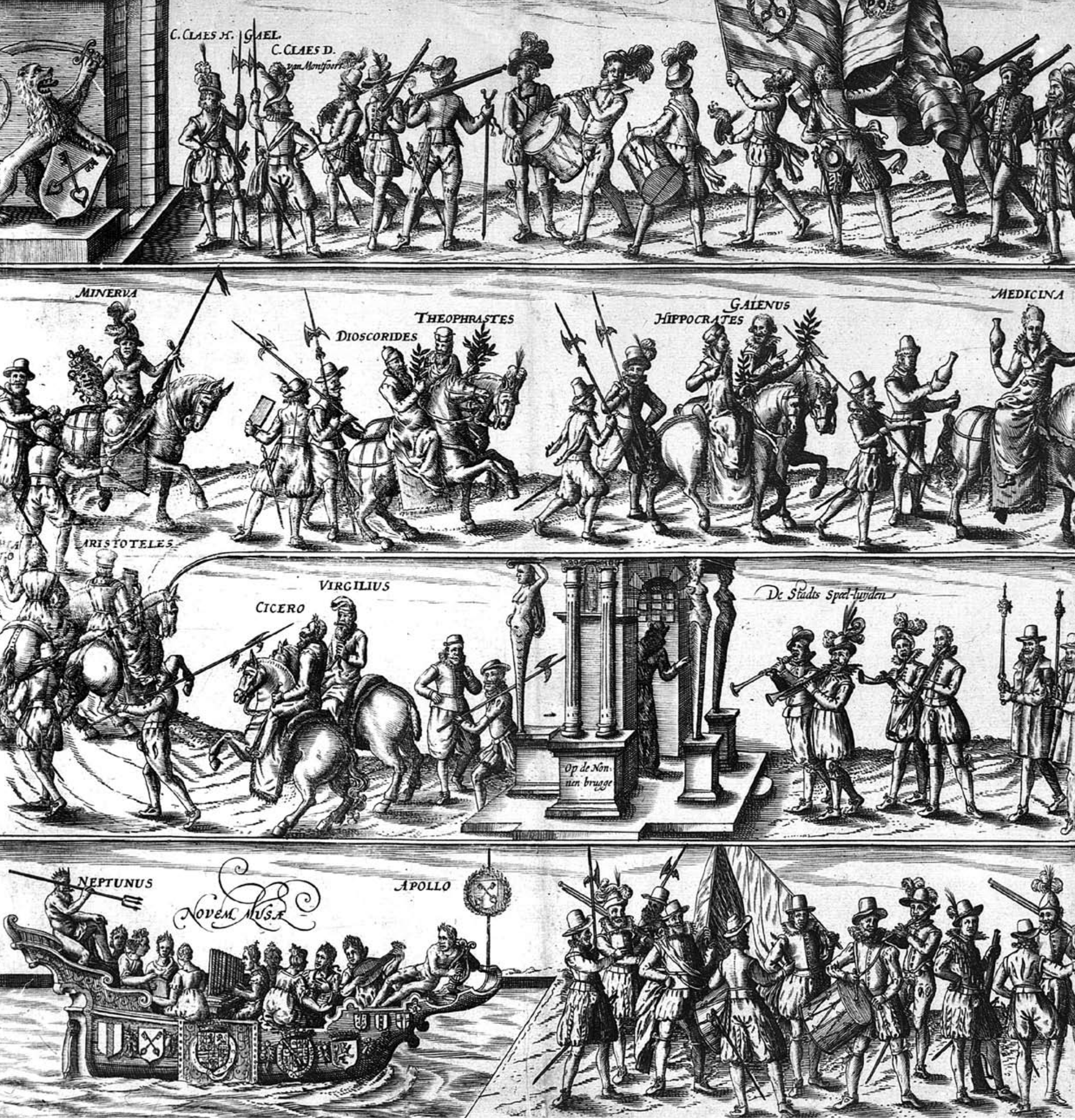




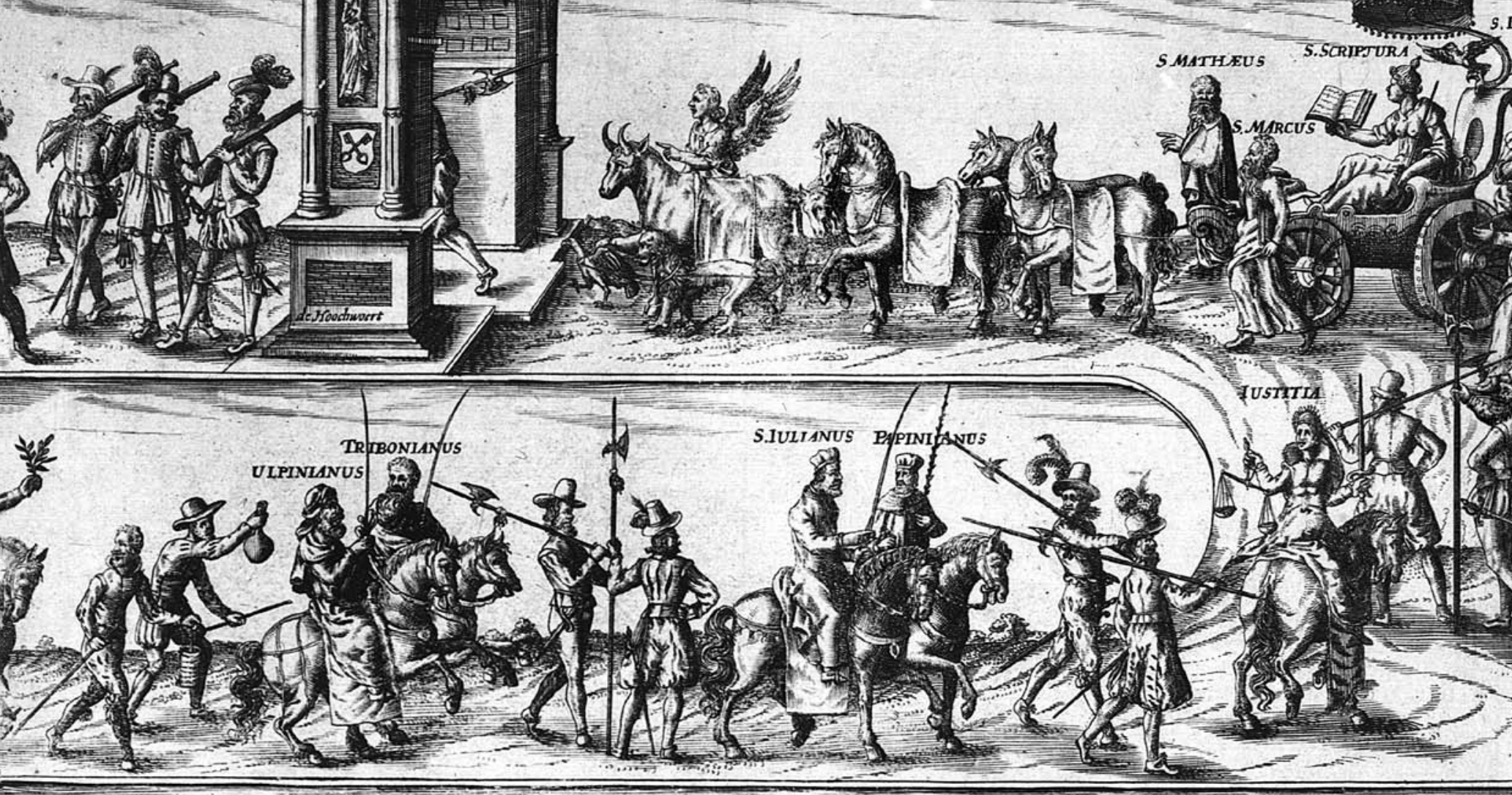


reikte. Vanaf de tweede brug over het Rapenburg, halverwege de gracht, werd de stoet vergezeld door een kleine boot waarin Apollo en de negen muzen voeren. Voor de Academie gingen ze aan wal om de optocht te verwelkomen met Latijnse verzen, geschreven door Janus Dousa, de eerste curator van de universiteit.

Dousa boog in zijn poëzie plichtsgetrouw voor de verschillende autoriteiten. Hij verwierp daarbij het rooms-katholicisme en de Spaanse overheerser in ruil voor een protestants Leiden en het Huis van Oranje. Maar het hoofdthema van zijn verzen was de vredelievende aard van de vrije kunsten. Neptunus, die aanlegde tegenover het academiegebouw, zei tegen de muzen: 'Nu

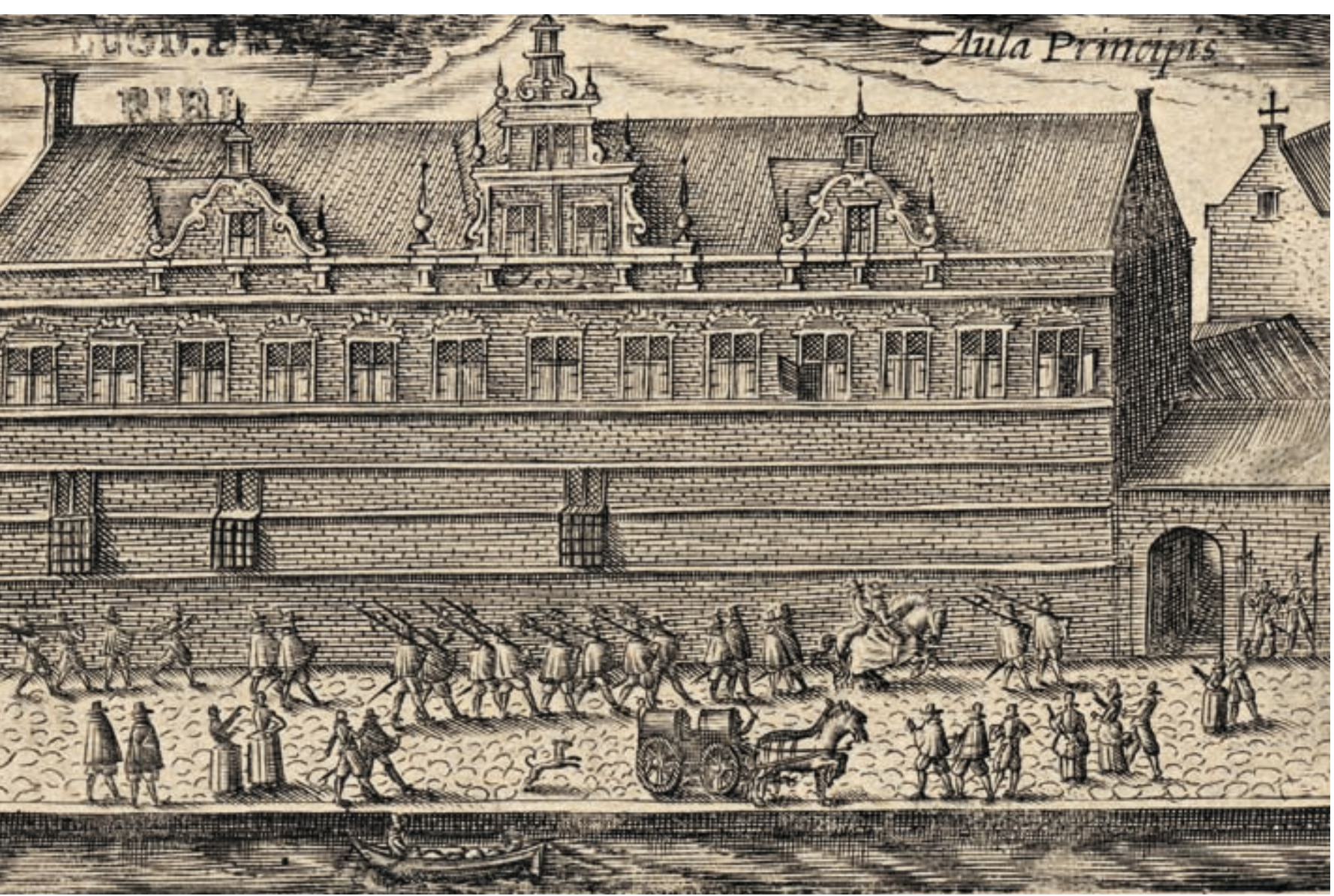

^ HetBarbaraklooster aan het Rapenburg, waar de universiteit tot 1577 gevestigd was 
Musae zyt goets moets, Mars zelf u plaets gaet maken. Want hy heeft niets gemeens met u geruste zaken.'

Volgens Dousa ging het de universiteit in de eerste plaats om wijsheid en geleerdheid. De stad had inmiddels genoeg van de strijd, liet hij Apollo tegen de muzen zeggen. Zij had nu behoefte aan onderwijs in de vrije kunsten. De muzen antwoordden: 'Apollo t'uwen dienst ghy ons altyd zult vinden. Wilt door geleertheyts konst ons houlick t'samen binden.' Dit huwelijk, de eenheid van wetenschap en kunst, van geleerdheid en wijsheid, zou de staat in evenwicht brengen en het volk beschaven. De Leidse universiteit moest de muzen onderdak bieden; ze zou een Musarum domicilium zijn.

Tegelijk bevatten deze verzen een zekere paradox. Ze openen weliswaar met de retorische vraag 'kunnen de muzen en Mars, kunnen kunst en wetenschap en de oorlogsdemon naast elkaar bestaan?' 'Onmogelijk,' was het antwoord. 'Maаг nu, muzen, is de krijgsgod geweken om voor u plaats te maken.' Toch luiden de laatste regels, waarinJustitia de beroemde Romeinse arts Сornelius Celsus aanspreekt, die ook boeken schreef over retoriek en de kunst van het oorlog vоегеn: 'Door uw verdiensten werd wat ruw was beschaafd en de geneeskunde is door uw boeken niet minder luisterrijk geworden. Als retor heeft u ook de voordelen van de krijgskunst behandeld en hebt u Mars met de muzen verenigd.'

\section{Wapens en woorden}

Er bestaat een anekdote over een zekere Jacob Maestertius, die geboren zou zijn in Denemarken, vanwaar hij naar Leiden reisde. Daar kwam hij aan, haveloos en zonder een rooie cent, maar in het bezit van een zwaard en een corpus juris. 'Met het een of met het ander,' zou hij gezegd hebben, 'zal ik mijn brood verdienen.' De kroniekschrijver die deze anekdote optekende, is niet erg betrouwbaar en de anekdote zelf bevat veel fouten - Maestertius was bijvoorbeeld niet geboren in Denemarken maar in Dendermonde, een dorpje in Vlaanderen. Maar fouten doen er in dit geval niet toe. Het verhaal over de twee manieren om in het levensonderhoud te voorzien is een topos, een te- 
rugkerende frase, versleten door literair gebruik. Het hoefde niet waar te zijn, het moest passen.

Don Quichote, bijvoorbeeld, kende dezelfde twee manieren om rijkdom of glorie te verwerven: 'Er zijn twee wegen, mijn dochters, waarlangs men eer en rijkdom kan verwerven. De ene is de weg van de Letteren; de andere de weg van Wapenen. Zelf heb ik meer wapens dan geleerdheid en ik neig tot de wapens, want ik ben geboren onder invloed van de planeet Mars.' Het bezorgde hem een dwalend leven, armoedig als dat van een kerkrat, maar vol van de meest wonderlijke misverstanden. Maestertius' leven was minder avontuurlijk, maar zijn keuze bracht hem een succesvol рrofessoraat in Leiden en zelfs een Engels ridderschap.

De keuze tussen woorden en wapens, tussen arte et marte, is een literair thema dat zo oud is als Homerus. Homerus' grootheid, zei een zeventiendeeeuwse schrijver, zat hem in de wijze waarop zijn beide boeken de twee voornaamste mogelijkheden van het menselijk bestaan weerspiegelden: de Ilias stond voor de militaire, de Odyssee voor de burgerlijke manier. Steeds opnieuw zette de literaire kritiek Achilles tegenover Homerus, de één een grote generaal, de ander een groot dichter - de man van roemrijke daden tegenover de man die ze bewaarde voor het nageslacht.

Traditioneel werden beide mogelijkheden op twee manieren gecombineerd: ze waren met elkaar in strijd of ze versterkten elkaar. Volgens Plato moest een koning kracht en wijsheid hebben - fortitudo en sapientia kenmerkten de ideale heerser. In zijn Politeia schreef Plato dat alleen zij die bewezen hadden 'de besten te zijn zowel in de filosofie als in de oorlog' koning konden zijn. De imperator literatus was dan ook een constante figuur in de klassieke literatuur, een vorst die bedrevenheid met de wapens paarde aan kennis van poëzie en retoriek, filosofie en muziek.

Маar deze eenheid bleek niet zelden fragiel. In Cicero's bekende halfvers - 'cedant arma togae' - moest de kracht van de wapens wijken voor de heerschappij van de wet, waarvan de weerklank te horen is in Dousa's eerste epigrammen. In Cicero's overtuiging dat de muzen zwijgen waar de wapens spreken - 'inter arma silent musae' - staan wapens en woorden nadrukkelijk tegenover elkaar: een oppositie die in de middeleeuwen bevestigd werd met 
het verschil in status tussen adel en clerus en de verschillende associaties verbonden aan het gebruik van wapens en het nastreven van vroomheid.

De christelijke cultuur compliceerde deze tegenstelling op een opmerkelijke manier. In het Oude Testament, in het boek Job, wordt het leven op aarde vergeleken met militaire dienst - in de tekst van de Vulgaat: 'Militia est vita hominis super terram.' Hoewel deze militaire notie niet exclusief christelijk is - in de vroege Stoa, in Plato's Apologie en bij Seneca is dezelfde vergelijking te vinden - ontwikkelde deze militia christiana zich tot een zorgvuldig uitgewerkte literaire figuur, die de strijd symboliseerde tegen de wreedheid van de natuur en de duisternis van de zonde.

Daarmee vergrootte het christendom de spanning die er bestond in de ou-

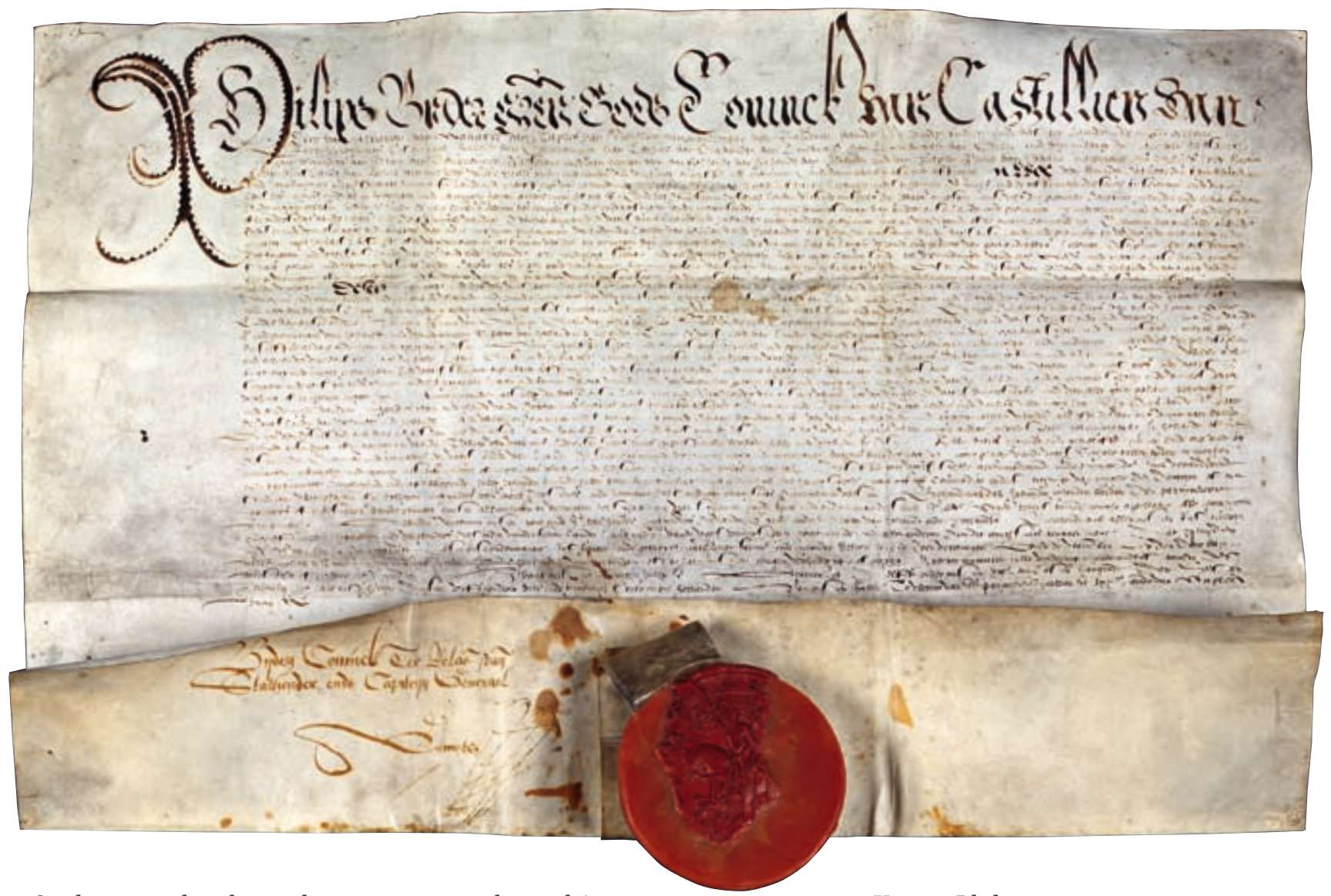

^ Stichtingsoorkonde van de universiteit, gedateerd 6januari 1575, op naam van Koning Philips II 


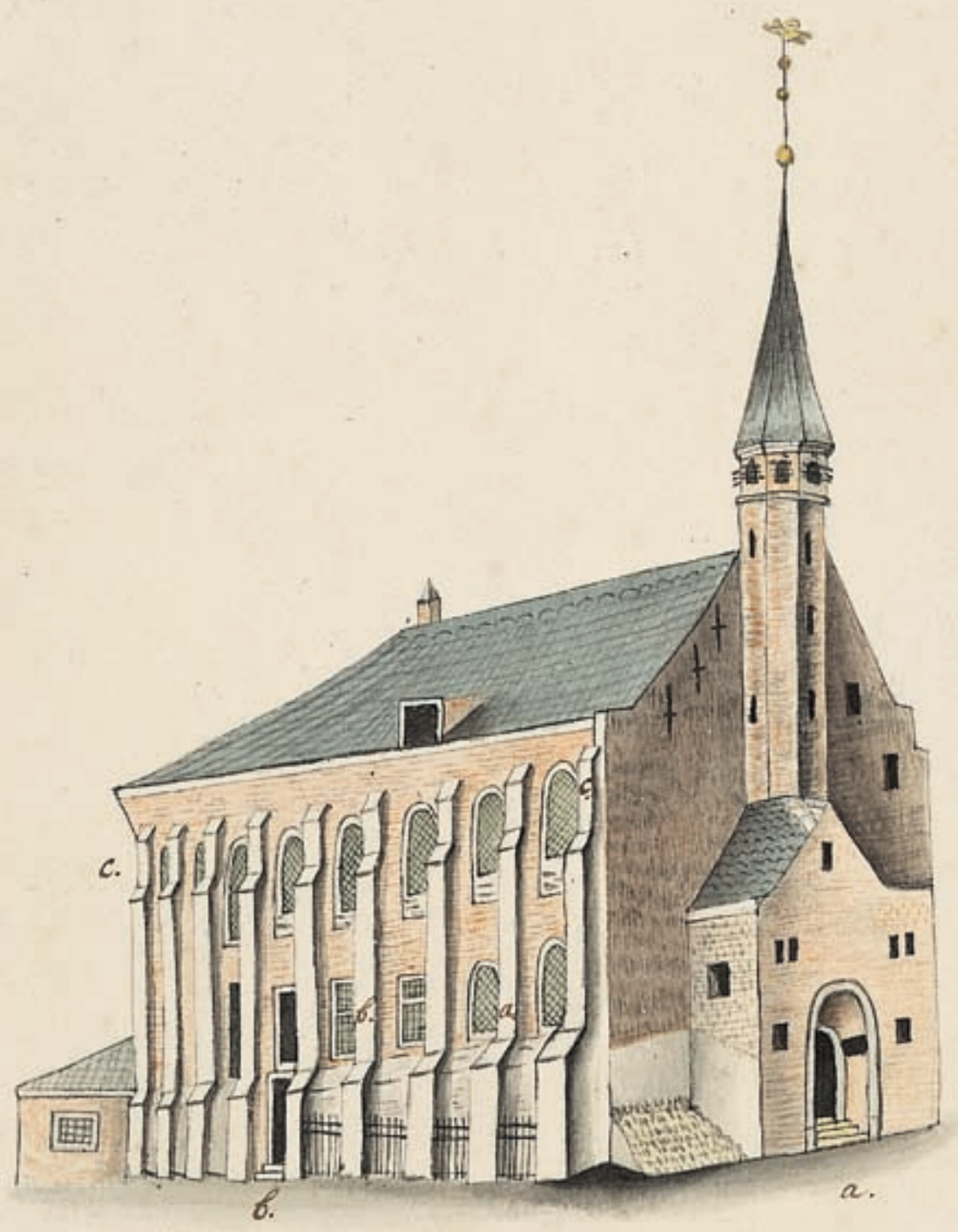

\ De Faliede Bagijnkerk, tussen 1577 en 1581 Academiegebouw, later onderkomen van bibliotheek, anatomisch theater en schermschool 
de tegenstelling tussen wapens en woorden. Opnieuw zijn er twee tradities te onderscheiden. Enerzijds was er het fundamentele dualisme tussen God en de wereld, tussen de Civitas Dei en de Civitas terrena. Anderzijds werd een tweede onderscheid zichtbaar, tussen het verdragen van het lijden van het leven, belichaamd door de figuur van Job, en een missionaire activiteit, gekenmerkt door de brieven van Paulus.

In de embleemboeken van de renaissance en later werd de tegenstelling van wapens en woorden op verschillende manieren afgebeeld: door pen en zwaard, wapens en toga, boek en speer, dolk en laurierkrans, lier en trompet. Een reeks van filosofische en psychologische mogelijkheden werd ermee geassocieerd: dulden en doen, reinheid en promiscuïteit, theorie en praktijk, vita contemplativa en vita activa. Het zijn allemaal variaties van het dualisme waarvan de westerse cultuur zo doordrongen was. Tot op zekere hoogte raakten ze verzoend in die bij uitstek westerse uitvinding: de universiteit.

\section{Bestuursstructuur}

De statuten van de Leidse universiteit - die van 1575 en de herziene versie van 1631 - probeerden een evenwicht te vinden tussen de drie betrokken partijen, de Staten van Holland, de stad Leiden en de universiteit. Ze voorzagen in de aanstelling van drie vertegenwoordigers van de Staten van Holland als 'Patronen, Curateurs ofte Toesienders vander Universiteyt'. Daarmee weerspiegelde de Leidse universiteit de laatmiddeleeuwse trend die de academie veranderde van een supranationaal centrum in een nauw bij overheden en seculiere autoriteiten betrokken instelling.

Duidelijke richtlijnen voor de benoeming van de curatoren waren ег niet. Gedurende de eerste vijftig јаar орегеerde men op basis van de consensus dat de eerste curator de adel vertegenwoordigde (als zodanig was hij ook voorzitter), dat een andere, gekozen uit de Hoge Raad of het Hof van Holland, de rechterlijke macht representeerde, en dat een derde, gekozen uit de gemeenteraad van een van de grotere Hollandse steden, de politieke macht in het algemeen vertegenwoordigde. 
Na 1635 slaagden de steden erin zich ook het tweede curatorschap toe te eigenen. Vanaf 1641 waren het bijna altijd (vгоegere) burgemeesters van Amsterdam, Haarlem, Dordrecht of Delft die benoemd werden op twee van de drie posten. In de achttiende eeuw ging de benoeming van een curator deel uitmaken van het nationale systeem van factiepolitiek. De machinaties tussen heersende elites omtrent aanstellingen gingen soms ver. Amsterdam en Haarlem probeerden zelfs een permanente plaats in het Leidse curatorium te bemachtigen. De invloedrijkste curator in de achttiende eeuw, Bentinck, wist

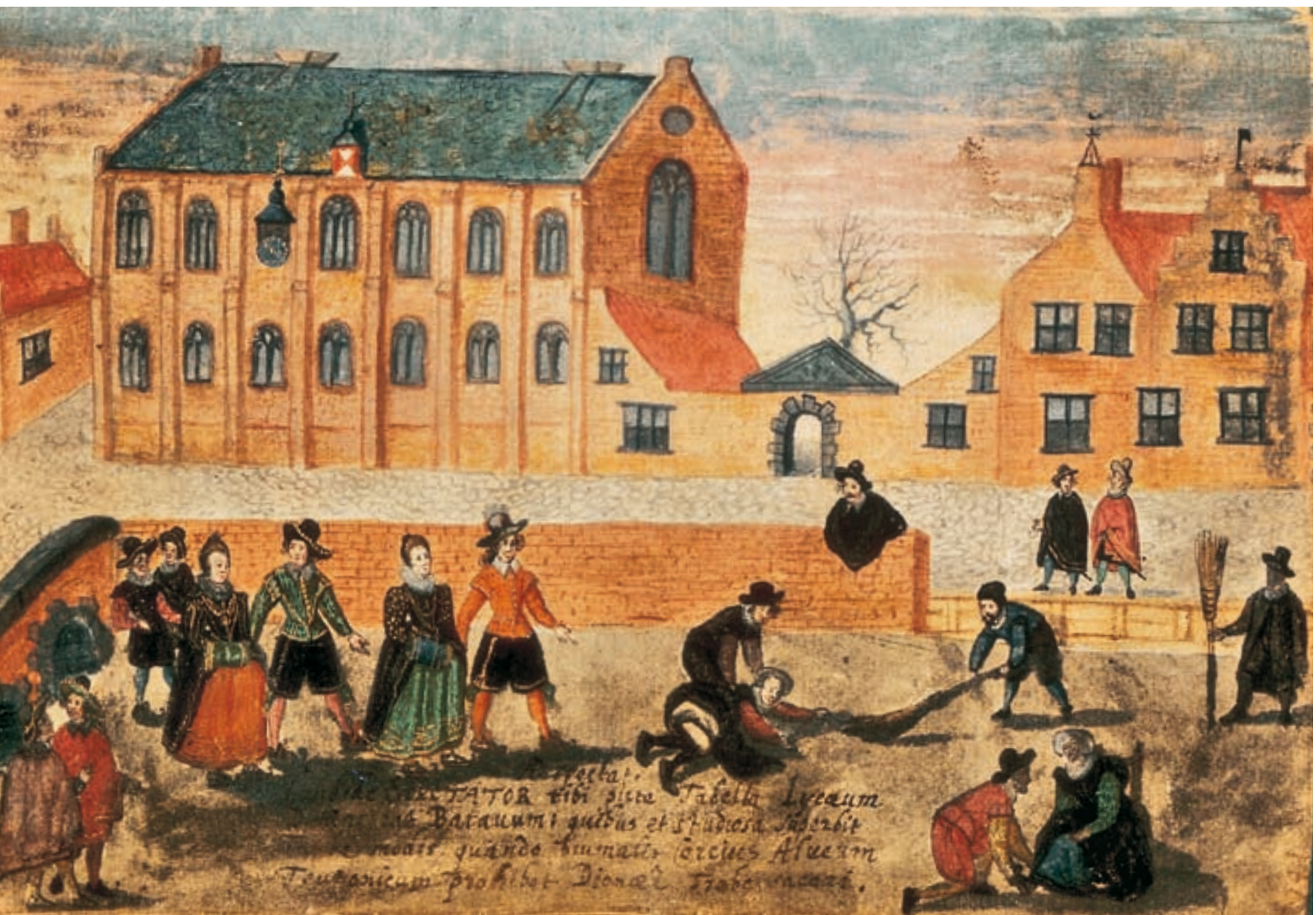

\ Een van de vroegste afbeeldingen van het Academiegebouw, uit het liber amicorum van een Leidse rechtenstudent 
heel goed 'dat congsi's en intriges erbij hoorden en dat wie er niet aan meedeed, niets bereikte'.

In het algemeen waren curatoren mannen die hun kwaliteit hadden bewezen. De meerderheid had gestudeerd - vooral in Leiden en meestal rechten en kon zich laten voorstaan op een grote politieke en bestuurlijke ervaring. Onder hen waren invloedrijke lieden als François van Aerssen en Cornelis de Witt, Coenraad van Beuningen en Willem Bentinck, en erudiete personen als Janus Dousa en Cornelis van der Mijle, Cornelis van Beveren en Hiëronymus van Beverninck. Dat het Leidse curatorschap veel aanzien genoot, valt af te leiden uit het feit dat zelfs pensionarissen van Holland zoals Paulus Buys en Adriaen Pauw, Jacob Cats en Pieter Steyn de post ooit bekleedden. De hoogste ambtenaar van de provincie, samen met de stadhouder de machtigste man in de politiek, vond het blijkbaar niet beneden zijn waardigheid om curator te worden van de Leidse universiteit en vijf of zes keer рег јаar de vergaderingen van het college van curatoren en burgemeesters bij te wonen.

Omdat de universiteit gefinancierd moest worden uit de revenuen van een aantal vroegere kloosters - voornamelijk de abdij van Egmond - werden de curatoren bijgestaan door een rentmeester. Voor het papierwerk hadden ze een permanente secretaris. Beide functionarissen werden gevonden in de Leidse elite. Doorgaans waren ze actief in het stadsbestuur. De combinatie van de functies van rentmeester of secretaris van de universiteit en die van burgemeester van de stad kwam herhaaldelijk voor. Een bijzonder invloedrijke figuur als Johan van den Bergh had twee schoonzoons die tot secretaris werden benoemd. In het tweede geval was de aanstelling zelfs onderdeel van het huwelijkscontract.

De klemtoon op evenwicht in het bestuur van de universiteit kunnen we ook afleiden uit de regeling dat het college niet alleen zou worden gevormd door drie curatoren, maar ook door de vier burgemeesters van de stad. Daarmee hadden de burgemeesters een meerderheid, maar dat werd gecorrigeerd door de beperkte duur van hun benoeming (slechts twee jaar), terwijl curatoren benoemd werden voor het leven. Desalniettemin was de relatie tussen curatoren en burgemeesters delicaat. Belangenverschillen of persoonlijke animositeit konden de verhoudingen onder druk zetten. 


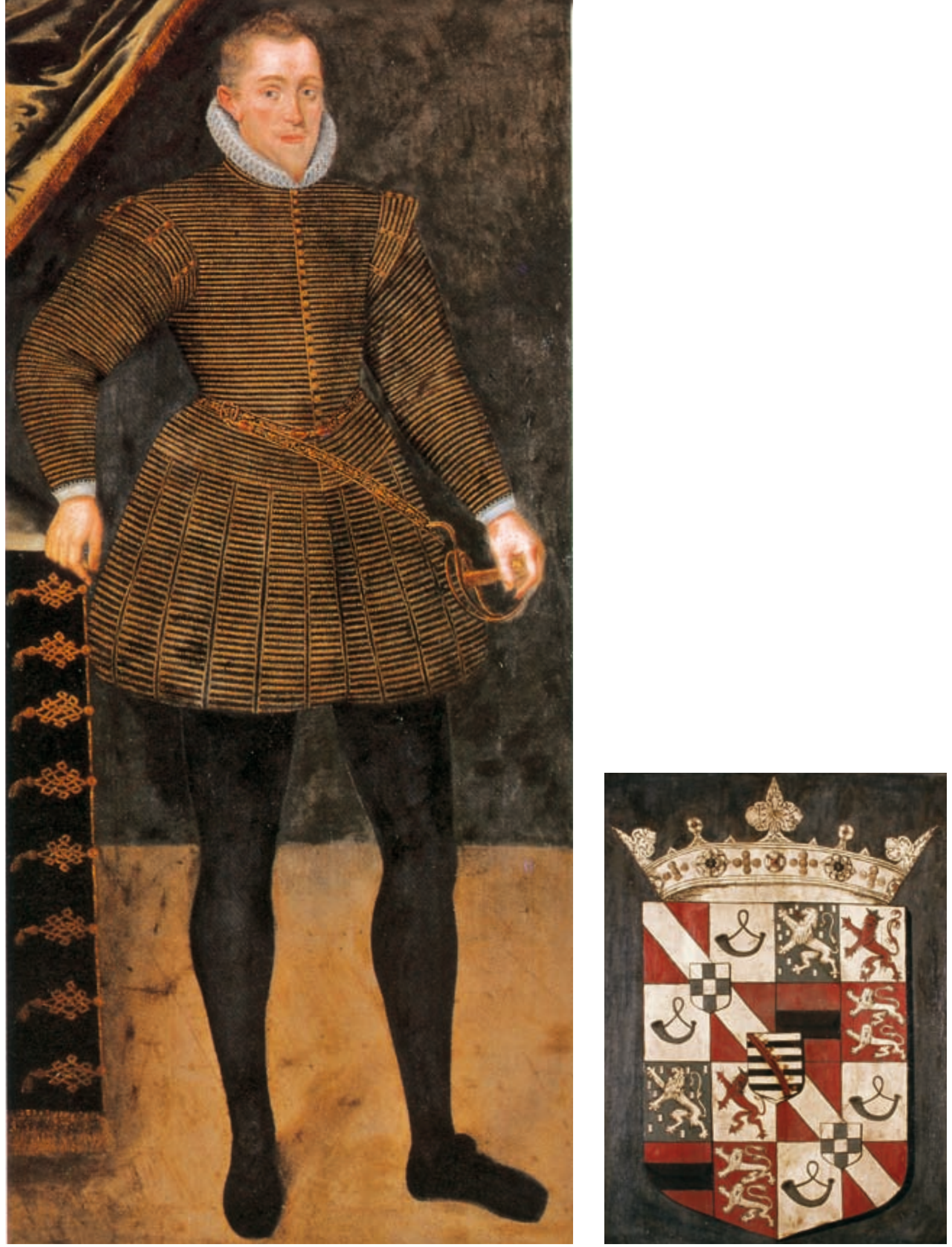

\ Maurits, Prins van Oranje (1567-1625), met wapenbord 
Uiteindelijk legden de Staten van Holland het meeste gewicht in de schaal. Het waren hun vertegenwoordigers, de curatoren, die de eerste viool speelden. Totdat de stad zich in 1594 bij de autoriteit van de Staten neerlegde, bemoeiden de Staten zich ook direct met de universiteit. Daarna delegeerden ze hun macht naar de curatoren. Alleen in zeer roerige tijden, vaak veroorzaakt door godsdienstige crises als in 1618 (arminianisme) en in 1656 (cartesianisme), namen ze het heft weer in eigen hand.

Een ander wankel evenwicht bestond tussen universiteitsbestuur en stadhouder. Willem van Oranje was weliswaar sterk betrokken bij 'zijn' universiteit, maar ook de bemoeienis van zijn zoon Maurits werd gezocht, onder meer bij pogingen om beroemde professoren (Scaliger, Vorstius, Molinaeus) aan te trekken. De speciale ingenieursopleiding die in 1600 in Leiden startte, was een initiatief van Maurits. Na de wetsverzetting van 1618 moest elke professorale benoeming zijn goedkeuring hebben. De invloed van Willem III, eerbiedig aangeduid als de 'Hoogste Curator van deze Universiteit', was alomvattend, maar ook de veel zwakkere Willem Iv bleek, door het toekennen van hoge subsidies, en in 1750 zelfs volledige ontheffing van belastingen, bijzonder invloedrijk.

Over de verhouding tussen universiteitsbestuur (curatoren en burgemeesters) en professoren (de senaat) zeiden de statuten nauwelijks iets. Het bestuur benoemde de professoren en stelde hun salaris vast. Tegelijk moesten de bestuurders nogal wat taken samen met de senaat uitvoeren. Ze bepaalden bijvoorbeeld gezamenlijk welke onderwerpen de nieuwe professor moest onderwijzen en wat de structuur moest zijn van het volledige curriculum. In al die zaken had het bestuur het laatste woord. Slechts eenmaal, in 1593, onder bijzondere omstandigheden - een curator was net overleden, een andere lag niet goed bij de burgemeesters en een derde had het te druk bij de Hoge Raad in Den Haag - verklaarde de senaat dat curatoren overbodig waren en werd voorgesteld de pensionaris van Holland te benoemen als kanselier.

Dit voorstel werd niet opgevolgd. In de toekomst zouden alleen nog kwesties van eer - de volgorde in een processie, de tafelschikking bij officiële diners - de verhoudingen verstoren. Hoe belangrijk zulke kwesties waren en hoe scherp een breuk met de gebruikelijke procedures werd gevoeld, bewijst 
het feit dat de burgemeesters na 1725 acht jaar lang het diner ter viering van de dies natalis van de universiteit niet bijwoonden, omdat de rector in zijn jubileumoratie van dat jaar de senaat toesprak vóór de schepenen van de stad.

\section{Stad en studie}

Stad en universiteit deelden nog een ander tеггеin van mogelijk conflict, de zogenaamde universiteitsprivileges. De meeste daarvan waren immuniteiten en vrijstellingen van het betalen van belastingen (tol, bier- en wijnbelastingen) of van het leveren van bepaalde diensten (inkwartiering, schuttersplicht). Ze werden gegund door de stad, zij het met tegenzin en onder voortdurend gepingel. De universiteit liet te veel mensen toe, klaagde de stad, die zich slechts inschreven om de belastingvoordelen. Men hoefde maar te wachten, zo werd in 1582 ironisch opgemerkt, totdat alle inwoners van de stad lid van de universiteit zouden zijn.

Dit probleem was zo oud als de universiteit zelf. De eis dat elke student zich inschreef, was zelfs ingevoerd, omdat, zoals de Parijse letterenfaculteit in 1289 had gesteld, het niet mogelijk was onderscheid te maken 'tussen degenen die goede en reguliere studenten zijn, en degenen die niet echt zijn en doen alsof ze aan onze Faculteit studeren om de privileges en vrijheden te genieten die ermee verbonden zijn'. ‘Nepstudenten en andere bijhang' moesten als 'onnuttig' worden verwijderd 'uit de schoot en de organisatie van de faculteit'.

De Leidse studentenlijsten laten zien hoe ingewikkeld het probleem was: de 'bijhang' had vaak wel degelijk banden met de universiteit. Hele huishoudens werden op de lijst van de belastinginner gezet. Het was dan ook niet ongebruikelijk dat een gezin de zoon(s) naar een universiteitsstad vergezelde. Petrus Doorninck, bijvoorbeeld, 'vir literatus', die zich op 27 maart 1650 inschreef, gaf expliciet de opvoeding van zijn kinderen op als reden voor zijn inschrijving: 'alens hic liberos suos.' En elk jaar schreef de nieuwe rector tien of twintig jongens in, veelal tussen twaalf en vijftien jaar oud, die leerlingen waren van de Latijnse School. De laatste twee klassen daarvan hadden het recht zich in te schrijven aan de universiteit. Hoewel de grens tussen universiteit en school in de loop van de zeventiende eeuw duidelijk werd getrokken, 
weerspiegelt het feit dat deze leerlingen dezelfde rechten hadden als studenten toch het traditionele gebrek aan onderscheid tussen beide categorieën.

Ook allerlei functionarissen schreven zich in. Onder hen bevonden zich niet alleen direct aan de universiteit verbonden personen, zoals pedellen en portiers, maar ook gouverneurs en bedienden ( $f a m u l i$ ) van studenten en allerhande lieden die zich in het studentenleven bewogen, zoals scherm-, dansen muziekmeesters, onderwijzers voor tekenen, Frans of Italiaans. Een omvangrijk rapport uit 1750, opgesteld door de геctor en bedoeld om een einde te maken aan deze praktijken, noemt talloze soorten kunstzinnige en technische beroepen, waaronder tekenaars en schilders, graveurs en wiskundigen, landmeters en allerlei instrumentenmakers. Plus natuurlijk alle plaatselijke chirurgijns en apothekers en hun leerlingen, de stadsartsen, de plaatselijke advocaten, militairen, kerk- en postmeesters, secretarissen van landhuizen, dominees en zelfs - maar dat is omdat we een eind op weg zijn in de achttiende eeuw - katholieke priesters en journalisten.

Er blijkt zelfs een levendige handel in belastingvrijstellingen te hebben bestaan. Met name buitenlandse studenten, die maar een paar maanden bleven, terwijl de vrijstelling gold voor een heel jaar, gaven zich егаan оver. De Duitse chroniqueur van het studentenleven Friedrich Luca schreef over zijn verblijf in Leiden: 'Man kan baer auch sothane Freiheit an einen Bürger verkaufen, was denn auch viele und ebenfalls ich gethan haben.' Ook professoren zagen de lucratieve kanten van de belastingvrijstellingen. In 1613 haalden curatoren de senaat bijeen, omdat er ernstige klachten waren van de wijnpachters, 'datter soo veel wijnen by den professeuren wierden ingeleit [...] dat se nadencken hadden datter enige boeverye onder gespeelt werde'.

Verreweg het belangrijkste privilege was het Forum Privilegiatum, de eigen rechtbank van de universiteit. Behalve studenten hadden alle geregistreerden in het Album Studiosorum het recht hun zaak daar voor te leggen, als verdediger of als aanklager. Dit gebruik stamde uit de tijd van de beroemde 'Authentica' Habita die op initiatief van Frederik Barbarossa was uitgevaardigd op de Rijksdag van Roncaglia in 1158. Het bood buitenlandse studenten de bescherming en vrijheid om te gaan waar ze wilden, 'zodat allen die van zins zijn om te studeren vrij zijn om te komen en gaan en in vrijheid te verblijven'. 


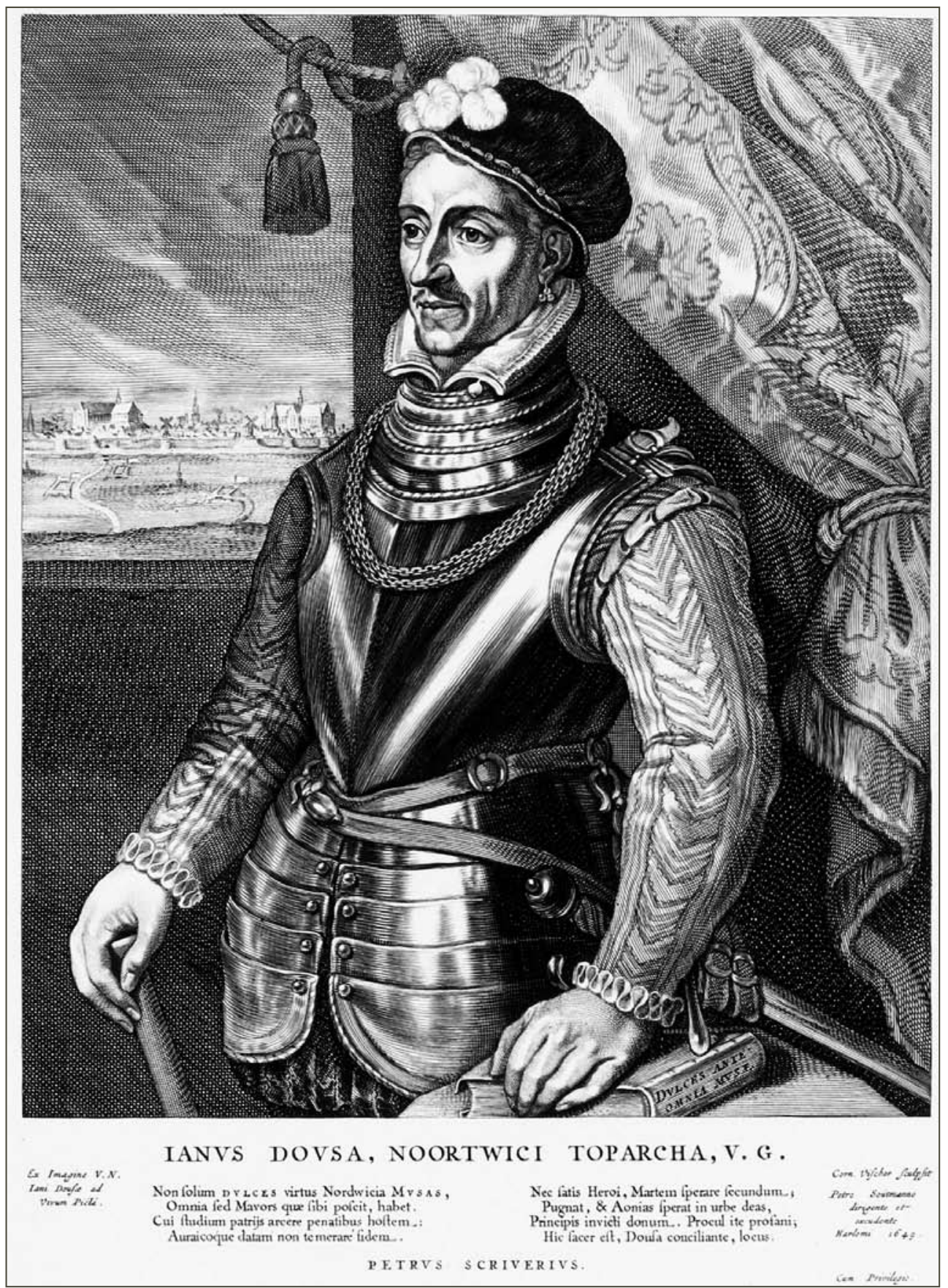

\ Janus Dousa (Jan van den Does) (1545-1604), eerste curator van de universiteit (1575-1604) 


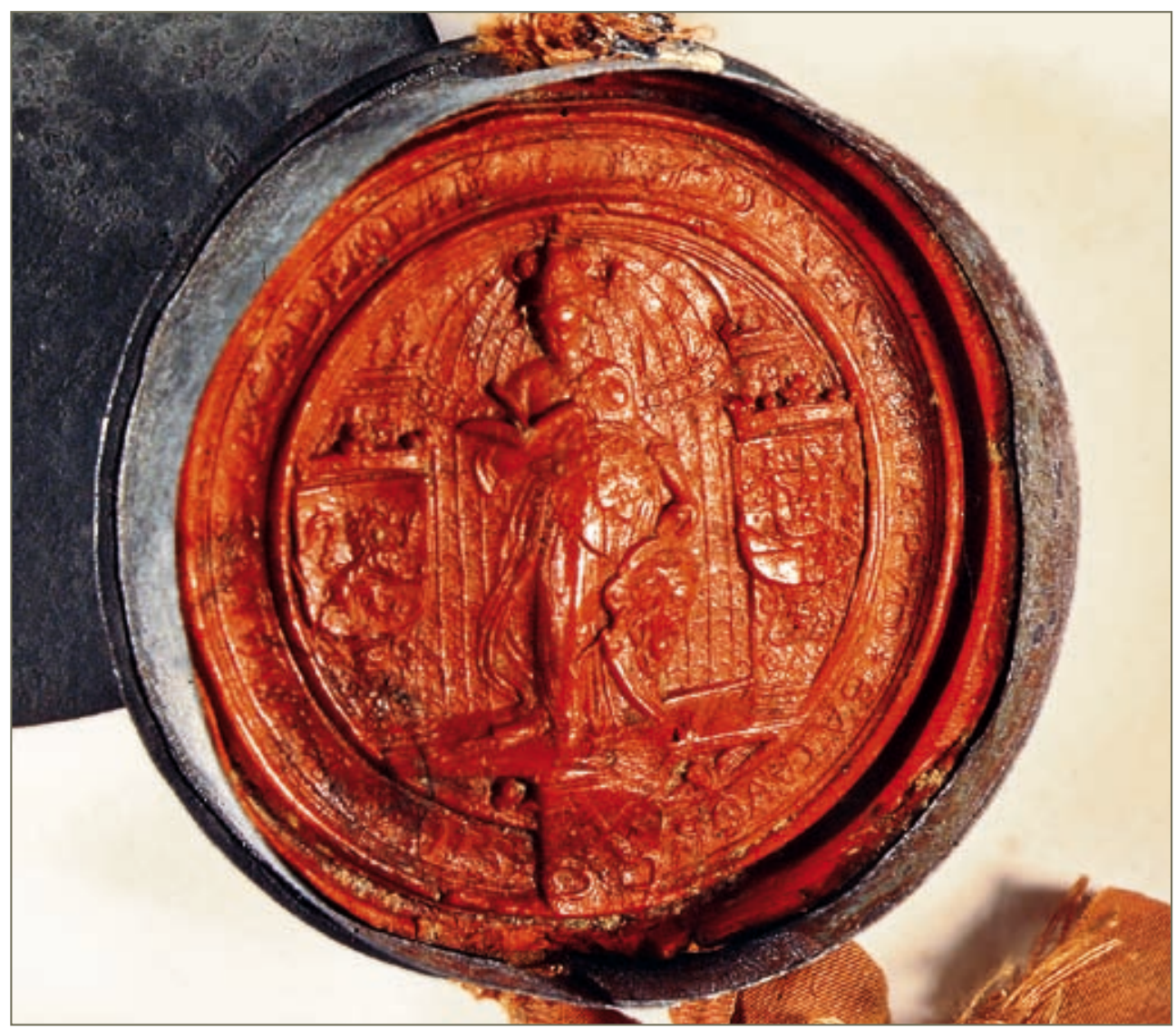

Het bestaan van zo'n hof maakte natuurlijk inbreuk op de rechten van andere plaatselijke gerechtshoven. En omdat het meer dan waarschijnlijk was dat de meeste zaken te maken hadden met problemen tussen studenten en burgers van Leiden, eiste en kreeg de stad een belangrijke stem in de rechtbank. Tijdens rechtszittingen werd de senaat vertegenwoordigd door de rector en de vier assessoren van de faculteiten. De vier burgemeesters en twee schepenen vertegenwoordigden de stad. Bovendien trad de schout van de stad op als promotor of openbare aanklager.

Er was de universiteit veel aan gelegen om dit privilege te behouden. De zaak tegen een katholieke schoolonderwijzer, in 1587, bleek in dit verband cruciaal. Deze Willem van Assendelft bood onderdak aan studenten en werd

^ Grootzegelvan de universiteit 
ervan beschuldigd zijn pupillen te onderwijzen 'inde Jesuytschen cathechismum die opten naeme van Petrus Canisius'. Zodra de senatoren hoorden van de aanklacht door het Hof van Holland, deden zij een verzoek om de aanklacht te seponeren. De senaat verbood Van Assendelft zelfs om voor het Hof van Holland te verschijnen op straffe van het verlies van zijn universitaire privileges. IJlings werd een zitting van de rechtbank belegd, waar Van Assendelft vrijgesproken werd. Wel kreeg hij het verbod iets te onderwijzen wat strijdig was met de protestantse godsdienst. Ook het Hof van Holland zette zijn zaak voort en zorgde zo voor wonderbaarlijk theatrale scènes en een vracht aan bureaucratie. Maar ten slotte geboden de Staten van Holland het Hof de zaak te laten rusten en het Leidse privilege te erkennen. Tot aan het einde van de achttiende eeuw zou de universiteit zich tegen elke inbreuk op haar rechten verdedigen door te verwijzen naar de zaak-Assendelft en de uitspraak van de Staten van Holland.

Dit wil overigens niet zeggen dat de privileges niet meer ter discussie stonden. Problemen met het Hof van Holland, met de verschillende hoven in de provincie en met de onafhankelijkere studenten bleven zich voordoen. Мaаr de grootste kwesties speelden tussen stad en universiteit. De aanwezigheid in de stad van studenten met andere maatschappelijke en regionale achtergronden gaf aanleiding tot stevige interpretatieproblemen. De verschillende nationaliteiten - vooral Duitsers, maar ook Fransen en Engelsen - kenden verschillende gebruiken en erecodes. Bovendien ontstond er een lichte maatschappelijke spanning tussen een overwegend protestantse bevolking van arbeiders in de lakenindustrie en een voornamelijk uit de hogere klassen afkomstige studentenpopulatie met een zeer gevarieerde religieuze achtergrond.

Op 9 februari 1600 schreef een aantal vertegenwoordigers ‘ex ordine Studiosi Leidenses' een brief aan de curatoren waarin ze bescherming eisten en expliciet verwezen naar de 'Authentica' Habita. Ze weigerden afhankelijk te zijn van een volslagen losbandige nachtwacht, zoals ze het noemden, en wilden evenmin op gelijke voet behandeld worden met wat ze omschreven als schandknapen en uitdragers, marketenters en kappersknechts. Ze protesteerden ook heftig tegen de voortdurende scheldpartijen jegens de verschil- 


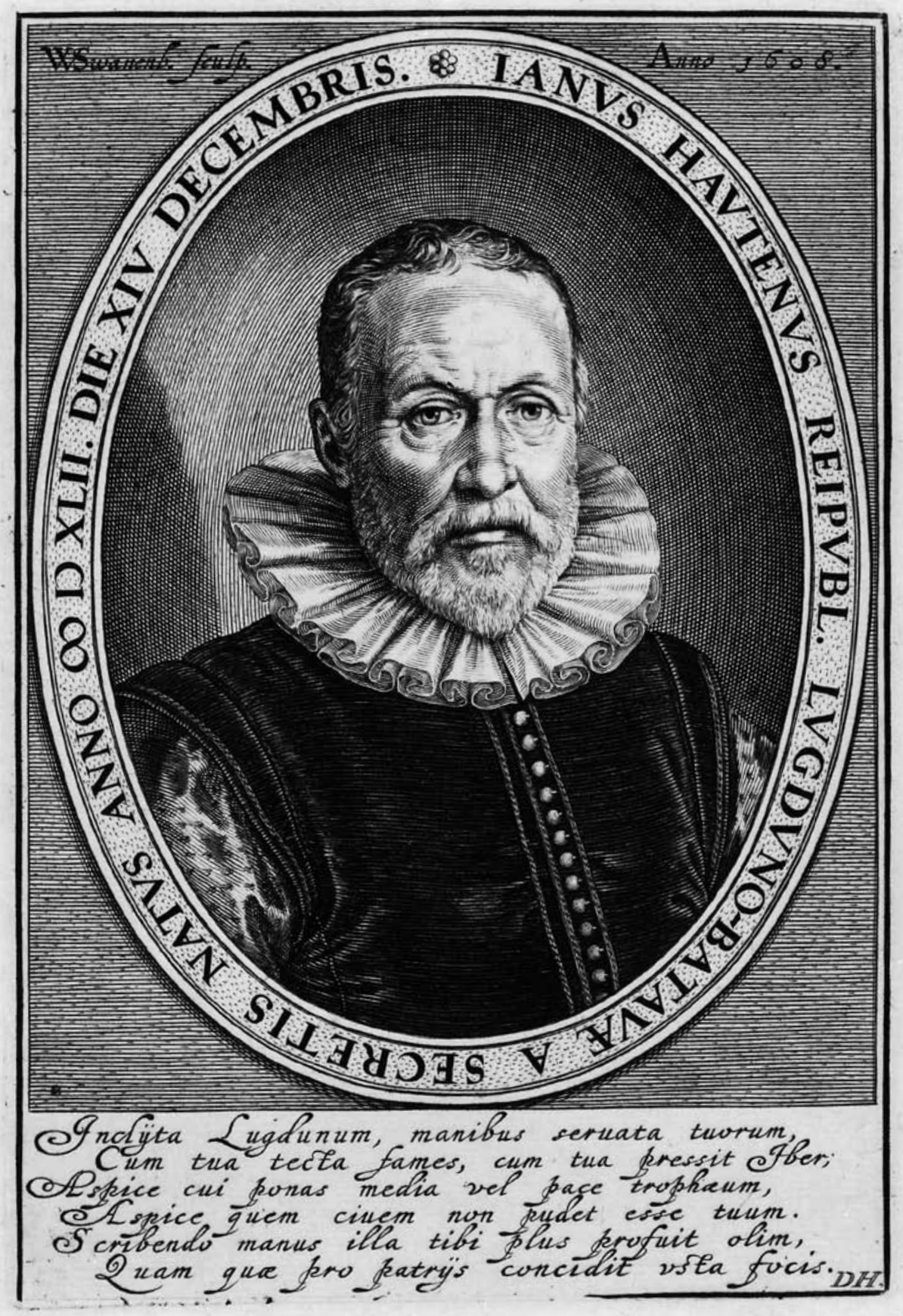

4 Jan van Hout (1542-1609), secretaris van Curatoren (1575-1596) 
lende studentennaties, bijvoorbeeld de gewoonte om 'mofmaff, mofmaff' te roepen naar Duitse studenten.

De maat was vol toen in 1607 een rechtenstudent die de goede afloop van een disputatie vierde, door eenentwintig kogels en in het bijzijn van zijn ргоfessor werd doodgeschoten. Volgens de professor, de beroemde jurist Everard Bronchorst, die het verhaal aan zijn dagboek toevertrouwde, was het enige dat de studenten gedaan hadden 'vrolijk lachen'. Volgens de chef van de nachtwacht had de agressiviteit van de studenten, die wraak wilden voor voorgaande confrontaties, de soldaten ertoe gebracht zich te verdedigen.

Het incident leidde tot de oprichting van een speciale studentenwacht van meer dan vijftig man, die beter getraind en gecommandeerd werd dan de gewone stadswacht. Deze nachtwacht moest in nauwe samenwerking met de senaat de veiligheid op straat garanderen. De instelling was het resultaat van een compromis tussen de Staten van Holland en de stad Leiden, die er gezamenlijk vоor betaalden. De uitgebreide instructies van deze studentenpolitie gaven heel precies aan wat gold als een overtreding en hoe men zich tegenover studenten diende te gedragen. Als een student aangehouden werd, moest de volgende morgen volledig rapport worden uitgebracht aan de rector en/of de burgemeester.

Dit soort gezamenlijke instellingen toont de speciale positie van de universiteit in de stad. Ze losten overigens niet alleen problemen op, zе сгеёегden ze ook. Al snel stond de stad op het recht de aanvoerder van de studentenpolitie te benoemen. De universiteit gaf omwille van de vrede toe, net zoals ze later, in 1652, toegaf toen de stad de benoeming opeiste van de secretaris van de universitaire vierschaar. Vijf jaar later liet het stadsbestuur professor Thysius naar het raadhuis komen om uit te leggen waarom hij een boek had durven publiceren met op de titelpagina de 'Hollandse Academie', 'Academia Batava', terwijl het 'Academia Lugduno-Batava' had moeten zijn, de Leidse Academie. Onmiddellijk protesteerde de senaat bij de Staten van Holland dat de stad 'een van de grootste regalia, die eenigh souverein competeert' probeerde te stelen.

Dit was ook de aanleiding voor de senaat om een onderzoek in te stellen naar de exacte verdeling van verantwoordelijkheden tussen curatoren en 
burgemeesters. In april 1658 kreeg de pensionaris van Holland een lijst van zeventien 'gravamina' voorgelegd, klachten over overtredingen van de privileges van de universiteit. Burgemeesters waren naar believen wel of niet aanwezig bij vergaderingen van de senaat en ontboden niet alleen gewone professoren, maar ook de rector. Ze hadden de benoeming opgeëist van een aantal universitaire posten, secretarissen en pedellen. Ze verwijderden de namen van personen die ze kenden uit de inschrijvingsregisters en kenden universitaire privileges toe aan mensen die er geen recht op hadden. Ze dwongen professoren om allerlei mensen te huisvesten en bij te dragen aan de financiering van de stedelijke infrastructuur. Bovendien hadden ze leden van de universiteit, 'onder dewelcke veeltijdts sijn princen, hertogen, edellieden en de gequalificeerste kinderen van het landt' gevangengezet, benadeeld en gekwetst.

In hun verdediging beklemtoonden de burgemeesters dat ze 'onafscheidelijk van het curatorium' waren. Maar dat was nu net wat de senaat ontkende. Artikel 3 van de statuten stelde dat de senaat het advies van curatoren moest vragen 'over sware ende hoochwichtige saecken'. Wat was van groter belang dan de privileges van de universiteit en wat was ongerijmder dan de tegenpartij om advies te vragen? De professoren stelden een nieuwe formulering voor het derde artikel voor, waarbij advies gevraagd werd van alleen curatoren, 'ende buyten de Burgemeesteren'. Maar de Staten van Holland verkozen vaagheid boven helderheid en de behoefte aan voortdurende aanpassingen boven duidelijke begrenzing van verantwoordelijkheden.

\section{Werving van professoren}

Zoals we zagen, hoorde de benoeming van nieuwe professoren tot de verantwoordelijkheden van zowel curatoren als burgemeesters. Маar ook andere partijen waren hierbij betrokken. Van buiten de universiteit waren dat niet alleen leden van het Huis van Oranje, maar ook de Synode van de Gereformeerde Kerk. Daarnaast probeerden sommige niet-officiële politieke en culturele groepen beslissingen te beïnvloeden. Het universiteitsbestuur won 
bovendien advies in bij belangrijke diplomaten of intellectuelen in het buitenland of van belangrijke professoren in eigen land. Lipsius en Scaliger, Rivet en Salmasius kregen met regelmaat het verzoek namen te noemen of te bemiddelen bij onderhandelingen.

Soms werd de leerstoelhouder gevraagd kandidaten te noemen voor zijn opvolging. Vaker vroeg men de faculteit, de decaan of een belangrijke professor om raad. Dat ging meestal informeel. Het dagboek van Bronchorst, hoogleгаaг rechten tussen 1587 en 1621, geeft hier en daar bewijzen van regelmatig contact tussen curatoren en de faculteit als het om nieuwe benoemingen ging. Soms werd zelfs de hele senaat om advies gevraagd. In 1620 probeerden de leden, tevergeefs, hun betrokkenheid in zulke gevallen vastgelegd te krijgen in de statuten.

Het benoemingsbeleid dat zich in de eerste eeuw van het bestaan van de universiteit ontwikkelde, was eveneens een kwestie van evenwicht. In de eerste plaats was er het evenwicht tussen reputatie en belofte. Vanaf het begin probeerden curatoren met de naam en faam van een paar uiterst beroemde intellectuelen tegenwicht te bieden aan het feit dat men in Europa niet van het bestaan van hun nieuwe instituut afwist. De kost gaat voor de baat uit, moeten ze gedacht hebben. Daarom benoemden ze een aantal 'honorarii', zoals ze heetten. De eersten waren Justus Lipsius en Hugo Donellus. Janus Dousa beschouwde het als zijn grootste verdienste dat hij de jonge en onbetekenende universiteit, 'schola rudis novitiaque pulpita', met de benoeming van Lipsius haar eerste beroemdheid had gegeven. 'De universiteyt weten wy hoe cleyn ende ongesien was ten tijden van u ancompst,' herinnerden curatoren zich toen Lipsius in 1591 vertrok, 'hoe ende doer wiens toedoen ende beleyt die zedert gewassen, vermeerdert en de tot haer wezen gecomen zy.'

Het succes van Lipsius' benoeming leidde tot die van Carolus Clusius en Josephus Justus Scaliger in 1593 en die van Claudius Salmasius in 1632. Ze verdienden niet alleen twee of drie keer zoveel als de andere professoren, sensu strictu waren ze niet eens professor. Ze woonden geen senaatsvergaderingen bij, hoefden geen college te geven en hun namen kwamen niet voor op de $\mathrm{Se}$ ries Lectionum. Het portret van Scaliger dat boven zijn legaat in de universiteitsbibliotheek kwam te hangen, vermeldde dat hij 'decus Academiae' was, 


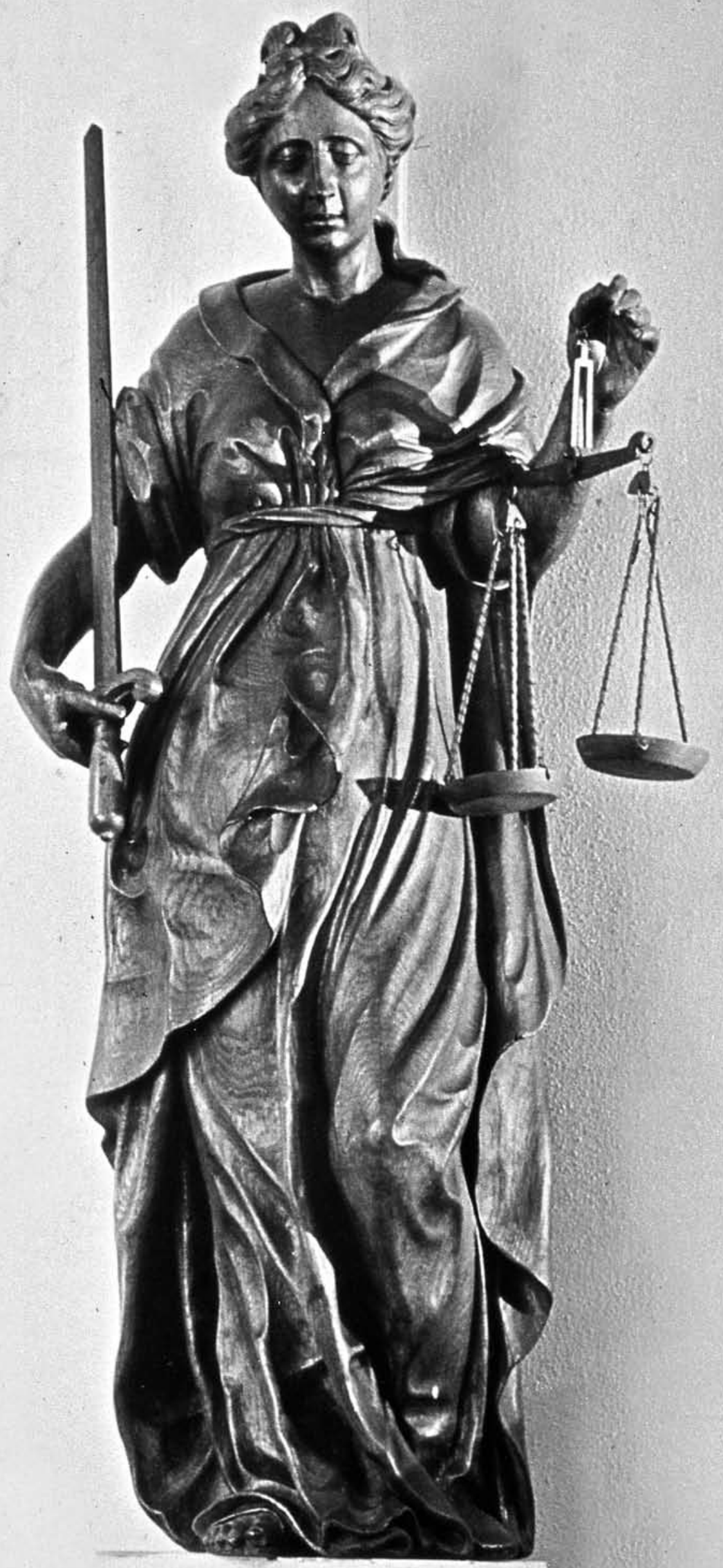


geen professor maar een ornament van de universiteit.

Maаг roem was duur. Daarom nam men, ter compensatie, zijn toevlucht tot de belofte, die weinig kostte. Niet alleen om financiële redenen, ook om te kunnen kiezen uit een kleine voorraad van jonge, vaak nog maar net afgestudeerde, veelbelovende wetenschappers, сгеёегden curatoren de mogelijkheid te onderwijzen 'om ervaring op te doen', 'experiendi causa'. Dat idee was niet nieuw. Het ging terug op de oorspronkelijke verplichting van jonge doctoren aan de grote artesfaculteiten van Parijs en Oxford om een paar jaar te onderwijzen. De middeleeuwse universiteit kende eveneens het onderscheid tussen 'gewone' en 'buitengewone' docenten, waarbij de laatsten lesgaven over minder belangrijke teksten aan jongere studenten.

De Leidse universiteit betaalde niet voor deze colleges. De bedoeling was de jonge doctor in de gelegenheid te stellen zijn geschiktheid voor het onderwijs te bewijzen en zich zo te kwalificeren voor een professoraat. Dat kon ook de vorm aannemen van een concours, waarbij twee, soms drie of vier jongemannen hun kwaliteiten mochten tonen. In 1599, toen er maar één filosofieprofessor was overgebleven, liet de universiteit zelfs vijf studenten college geven: Bertius, Bontius, Murdison, Vossius en Heurnius, die allen op een moment een professoraat wisten te bemachtigen. Wedstrijden als deze konden zelfs leiden tot een dubbele benoeming, waarbij twee jonge professoren het magere salaris van een beginnende professor deelden, zoals voor het eerst het geval was in 1597, toen Swanenburch en Pynacker beiden benoemd werden op een leerstoel in rechten.

Wat het 'middenkader' betreft letten curatoren niet zozeer op het wetenschappelijk werk van de kandidaat, als wel op het verloop van zijn studie en de praktijkervaring die hij had opgedaan. De Leidse professor uit de eerste eeuw van het bestaan van de universiteit bezocht gemiddeld bijna drie universiteiten - 2,7 om precies te zijn - waarvan tweederde buiten de Republiek. Het ging dan vooral om Duitse universiteiten, gevolgd dоог Рarijs en Orléans. Bij ргоfessoren van de medische faculteit was Italië nog favoriet. In de volgende eeuw vernauwde de academische horizon van de Leidse professoren zich ietwat. Nu bezochten ze een gemiddelde van twee universiteiten - 1,9 om weer exact te zijn - waarvan driekwart binnen de Republiek. 
De toekomstige professor had, na een studie van zes jаar of langer, gemiddeld tien jaar praktijkervaring - meestal in lijn met zijn studie - voordat hij in Leiden werd aangesteld. Ongeveer dertig procent was eerder рrofessor geweest aan een andere universiteit. Еr is maar één algemene uitzondering op deze sterke voorkeur voor егvaren docenten: wie meteen na de voltooiing van zijn studie in het onderwijs terechtkwam, was bijna altijd de zoon van een professor. In de achttiende eeuw vond de overgang van een bepaald beroep naar een Leidse leerstoel steeds meer plaats via een рrofessoraat elders. En eenderde van de Leidse professoren had in die eeuw alleen maar academische ervaring.

\section{De senaat}

De eerste statuten stelden dat het 'lichaam' van de universiteit niet alleen bestond uit rector en рrofessoren, maar ook uit 'de Doctores ende Magistri die inder selver Universiteyt gegradueert zullen zijn ende aldaer hare residentie zullen houden'. In 1587 drong Lipsius er zelfs op aan - 'imo et ii qui non professores' - om deze bepaling in praktijk te brengen. Toch is er geen aanwijzing dat een Leidse afgestudeerde ooit senaatsvergaderingen heeft bijgewoond. Vergaderingen vonden plaats met onregelmatige tussenpozen en onder toezicht van de rector.

De rector werd gekozen door de stadhouder (of door de Staten in periodes dat er geen stadhouder was) uit een lijst van drie professoren die de senaat elk јаar in februari opstelde. De Leidse burgemeesters moesten met deze lijst instemmen, maar de uiteindelijke beslissing lag bij de stadhouder. De enige vereiste voor de functie was dat de rector Nederlands moest kunnen spreken. En daar beriep men zich alleen op als de gelegenheid erom vroeg. In het geval van de zeer gewaardeerde Donellus schijnt het bijvoorbeeld niemand gedeerd te hebben dat hij geen woord Nederlands sprak. Maar toen de hooghartige Drelincourt gekozen wilde worden, was de taal wel een probleem, ondanks zijn bewering dat hij het Nederlands uitstekend verstond.

In het begin werd de keuze van de rector voornamelijk bepaald door de au- 


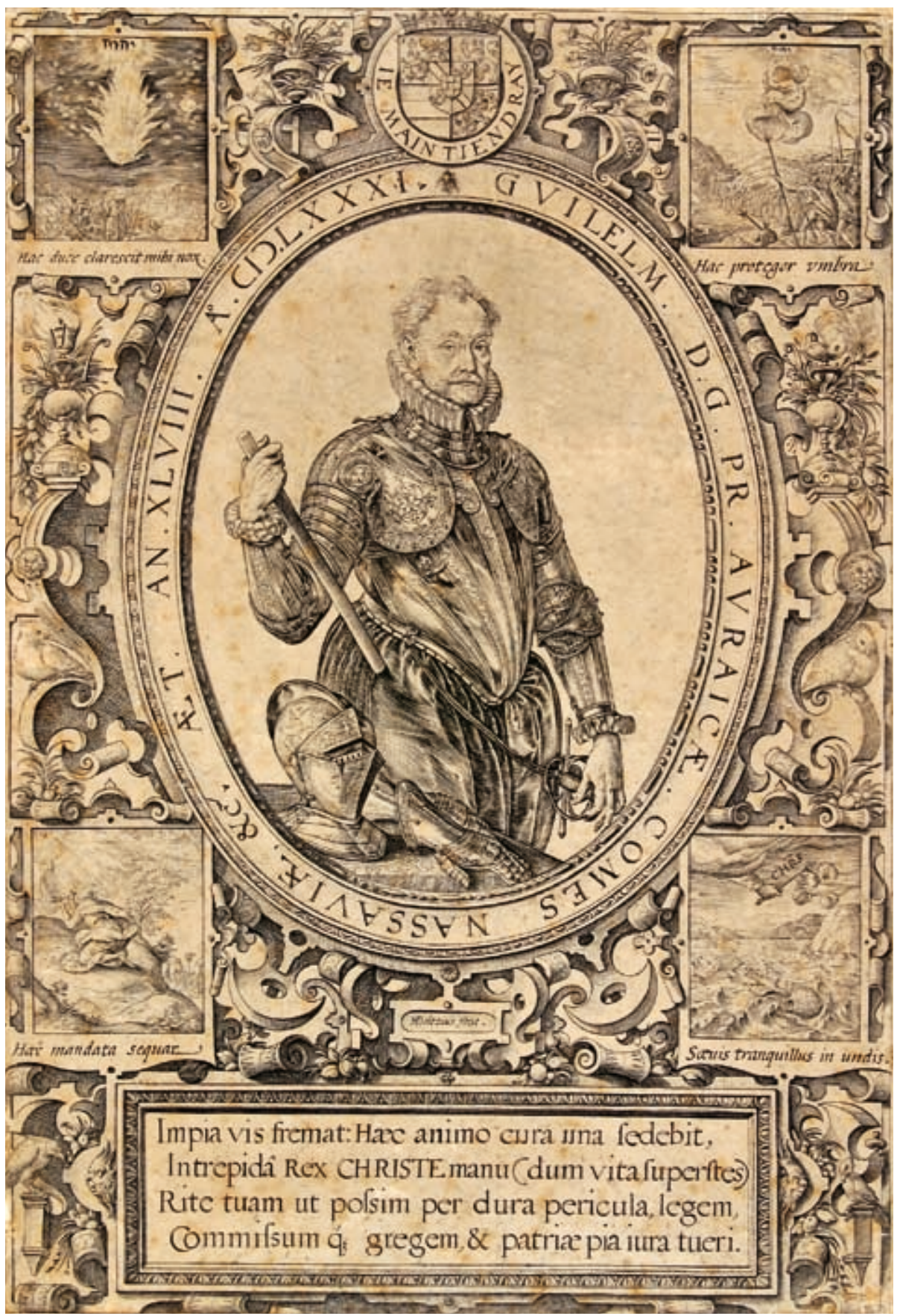

^ Willem van Oranje, afgebeeld als vader des vaderlands en christensoldaat 


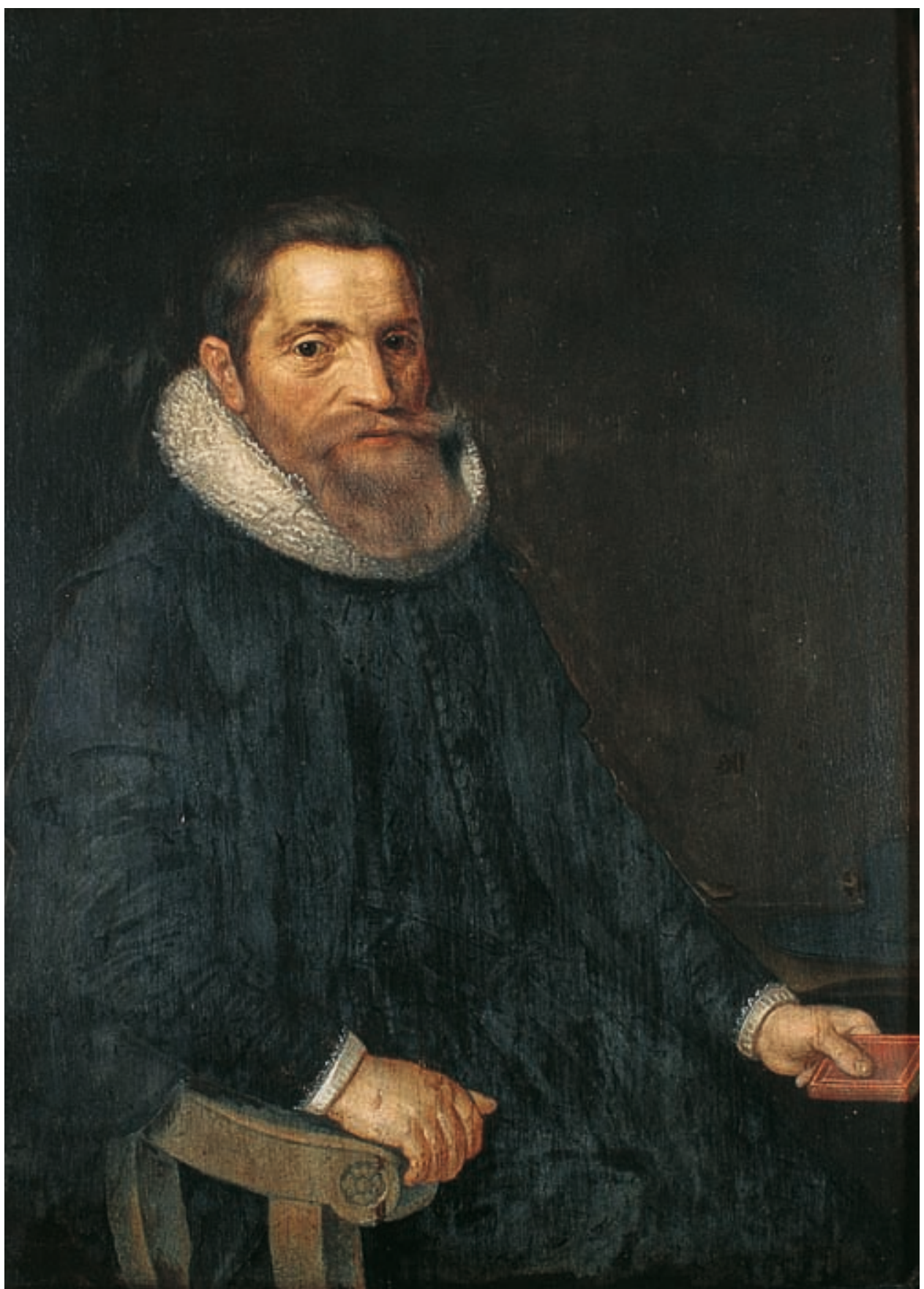

^ Thomas Erpenius (1584-1624), hoogleraar Arabisch en Oosterse Talen (1613-1624) 
toriteit die een professor genoot onder zijn collega's. Lipsius en A.E. Vorstius werden vier keer gekozen, Cornelis de Groot en Johannes Heurnius zes keer en Polyander werd zelfs acht keer benoemd. De nieuwe statuten van 1631 bepaalden dat de vertrekkende rector vier jaar moest wachten voordat hij opnieuw benoemd kon worden. Dit gold ook voor de faculteit die de rector leverde. Zo ontstond een roulerend systeem waarin anciënniteit het belangrijkste criterium werd voor een faculteit om een kandidaat voor te dragen.

Behalve het voorzitten van de senaatsvergaderingen was de belangrijkste taak van de rector het vertegenwoordigen van de universiteit in de wereld erbuiten. Hij had regelmatig contact met de dienstdoende burgemeester en was vaak in Den Haag om vergaderingen van de Staten bij te wonen. Hij moest ook de eer van de universiteit ophouden, ambassadeurs en andere belangrijke gasten ontvangen, arme studenten hulp bieden en voorzieningen treffen voor reizende intellectuelen. En hij moest natuurlijk voor de studenten zorgen, ze registreren en recht doen gelden.

De rector werd bijgestaan door de vier vertegenwoordigers van de faculteiten, de assessoren. Twee van hen werden steeds in februari vervangen. De belangrijkste taak van dit gremium was om samen met de curatoren te besluiten welke vakken de nieuwe professoren moesten onderwijzen. Dit konden ze op een heel precieze manier doen, door een bepaald boek of een school of uitleg te noemen, maar vaker was de bewoording van de opdracht tamelijk algemeen en vaag. Er was bovendien altijd een mogelijkheid om te sjoemelen. Zo was Dominicus Baudius niet van plan een bepaalde oratie van Cicero te behandelen en mocht hij college geven over iets wat hem nader aan het hart lag, de lofrede op Trajanus van Plinius de jongere.

De omvang van de senaat was aan een maximum gebonden. De statuten van 1575 stonden elf gewone professoren toe, die van 1631 hooguit vijftien. Buitengewone professoren hadden geen toegang tot de senaatsvergaderingen. De senaat had reden om zich aan het maximum te houden, omdat de gelden van inschrijvingen en disputaties verdeeld werden onder de leden. Tegelijk speelde evenwicht ook hier een rol. Toen Henricus Bornius in 1654 benoemd werd tot professor in de filosofie, protesteerde de senaat met de opmerking dat er zestien professoren waren, van wie al zes afkomstig van de fi- 
losofische faculteit. Met Bornius erbij zouden er 'in de laeghste faculteyt meer professoren sijn als in beyde de hooftfaculteyten van de Theologie ende de Rechten'.

De rangorde van de faculteiten was in Leiden, net als elders, een bron van voortdurende problemen binnen de senaat. Het verschil in hiërarchie was een kwestie van traditie en werd weerspiegeld in de Series Lectionum. Als verschillende professoren op dezelfde tijd college gaven, werd eerst de theoloog genoemd, dan de jurist of de medicus en ten slotte de filosoof. Gewone professoren werden altijd genoemd vóór de buitengewone. Dit mag helder en duidelijk lijken, maar in de praktijk deden zich talloze problemen voor, vooral wanneer vergelijkbare vakken verdeeld waren over hetzelfde uur, of wanneer onderwerpen niet duidelijk omschreven waren. Aanvullende private colleges dоoг de professoren gaven ook aanleiding tot scherpe debatten.

Verschillen in her- en afkomst bleken eveneens een bron van misverstanden. In de eerste twintig jaar van de Leidse universiteit waren buitenlandse professoren in de meerderheid. In de eerste eeuw kwam meer dan eenderde van de professoren, tussen 37 en 44 procent, uit het buitenland. Het ging daarbij vooral om theologen en filosofen. De meerderheid (32 personen, meer dan eenvijfde) kwam uit de zuidelijke Nederlanden, maar ег waren ook Fransen (tien in totaal). Vóór 1650 kwamen er slechts een paar Duitsers, maar daarna nam hun aantal gestaag toe.

Ook de verschillen in maatschappelijke afkomst waren groot. De meerderheid van het Leidse professoraat kwam uit de hogere middenklassen: tussen 73 (rechten) en 86 procent (artes). Toch had twintig procent van de theologen en zelfs 25 procent van de medici een nog voornamere, patriciërsachtergrond. Daarbovenop kwamen de verschillen in godsdienst. In de eerste decennia van het bestaan van de universiteit zaten erkende libertijnen als Lipsius en Vulcanius, Raphelengius en Erpenius bijeen met radicale calvinisten als Danaeus en Saravia. Zelfs verstokte katholieken als Sosius en Tuning waren erbij.

Na de wetsverzetting van 1618 - het gevolg van de overwinning van Maurits op Van Oldenbarneveldt en van het strenge calvinisme op de vrijzinnigheid - verdween die godsdienstige verscheidenheid en werd Leiden bijna uit- 


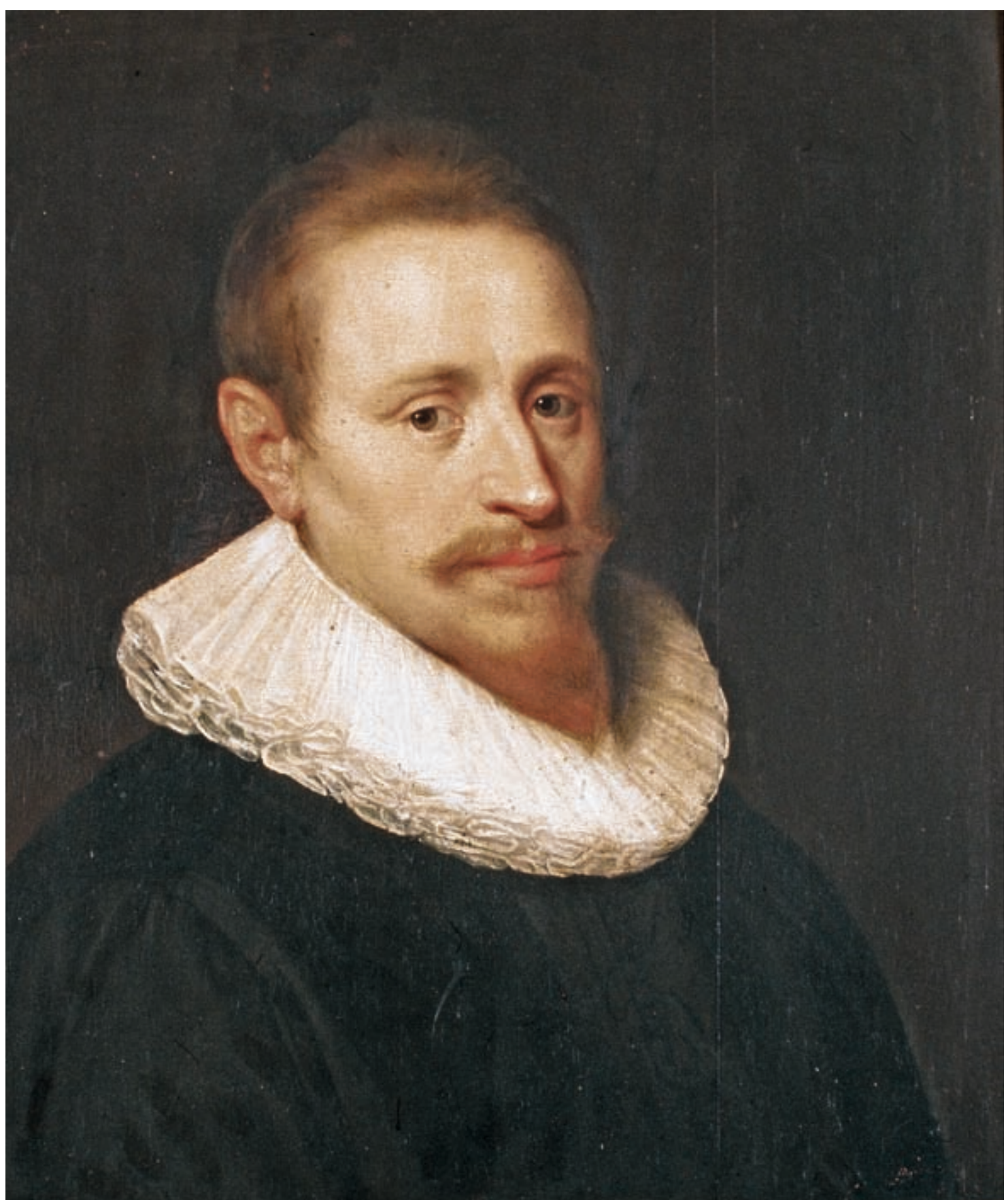

\ Hugo de Groot (1583-1645), alumnus van de Leidse universiteit 


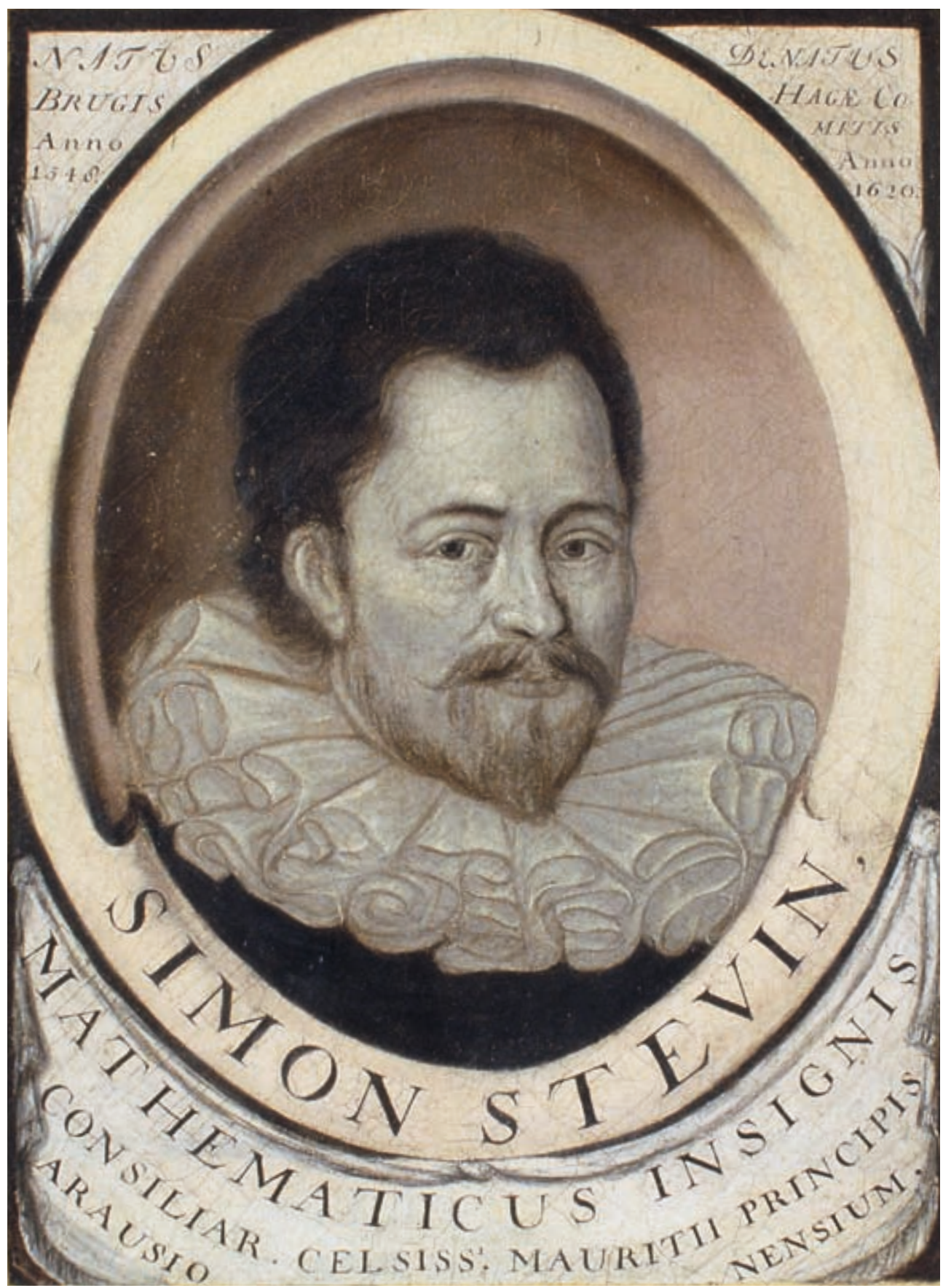

\ Simon Stevin (1548-1620), ontwerper van de Nederduitsche Mathematique (160o) 
sluitend calvinistisch. De benoeming van een lutheraan zorgde altijd voor discussie, een mennoniet als Golius moest calvinist worden. Andere verschillen werden minder duidelijk. Het Leidse рrofessoraat werd in de tweede eeuw van zijn bestaan nationaler. Tussen een kwart en eenderde kwam nog uit het buitenland, voornamelijk uit Duitsland. Deze рrofessoren onderwezen vooral rechten en veranderden de juridische faculteit van de meest nationale in de meest internationale van de universiteit. Zij ruilde in dit opzicht van plaats met de theologische faculteit, die overwegend nationaal werd. Bijna alle professoren kwamen nu uit de hogere middenklassen en uit de geleerde beroepen, minder uit de handel en bureaucratie zoals in de zeventiende eeuw.

Ег waren ook andere factoren die het aanvankelijk diverse en soms sterk verdeelde Leidse professoraat tot grotere eenheid kneedden. Afgezien van de herhaalde waarschuwingen van de rector om zich netjes te gedragen als goede christenen en geleerde collega's - 'ordine et ut Christianis, eruditis et collegae' - werd de vrede tussen ргоfessoren bewaаrd doог geregeld maaltijden met elkaar te delen. Het eerste voorstel daartoe werd gedaan in 1580: 'ad convivia publica aliosque honestos sumptus.' Zulke maaltijden groeiden uit tot een ritueel, dat eerst één- maar al snel tweemaal per jaar, 's winters en 's zomers, gehouden werd. In de achttiende eeuw kwamen daar andere maaltijden bij, zoals het 'convivium aditiale', dat elke nieuwe professor zijn collega's aanbood, of de maaltijd waarmee de 25 ste verjaardag van een professoraat werd gevierd.

Ook bepaalde rituelen brachten meer eenheid in de senaat. De inaugurele rede, uitvloeisel van de eerste rede die een middeleeuwse doctor uitsprak, werd vaker gehouden. In de tweede helft van de zeventiende eeuw hield ongeveer de helft van het Leidse professoraat zo'n oratie en na 1700 deed vrijwel elke nieuwe professor het. De rede werd inmiddels beschouwd als het officiële moment van aanvaarding van een ambt. Ze gaf de рrofessor de gelegenheid om, zoals Boerhaave in 1718 stelde aan het begin van zijn professoraat in de scheikunde, 'omme by die occasie de nuttigheyt van haere aanbevole instituties aan te wijzen ende de studenten tegelijck tot naerstigheit te encourageren'.

Deze officiële aanvaarding van het ambt ging gepaard met het vaker dra- 

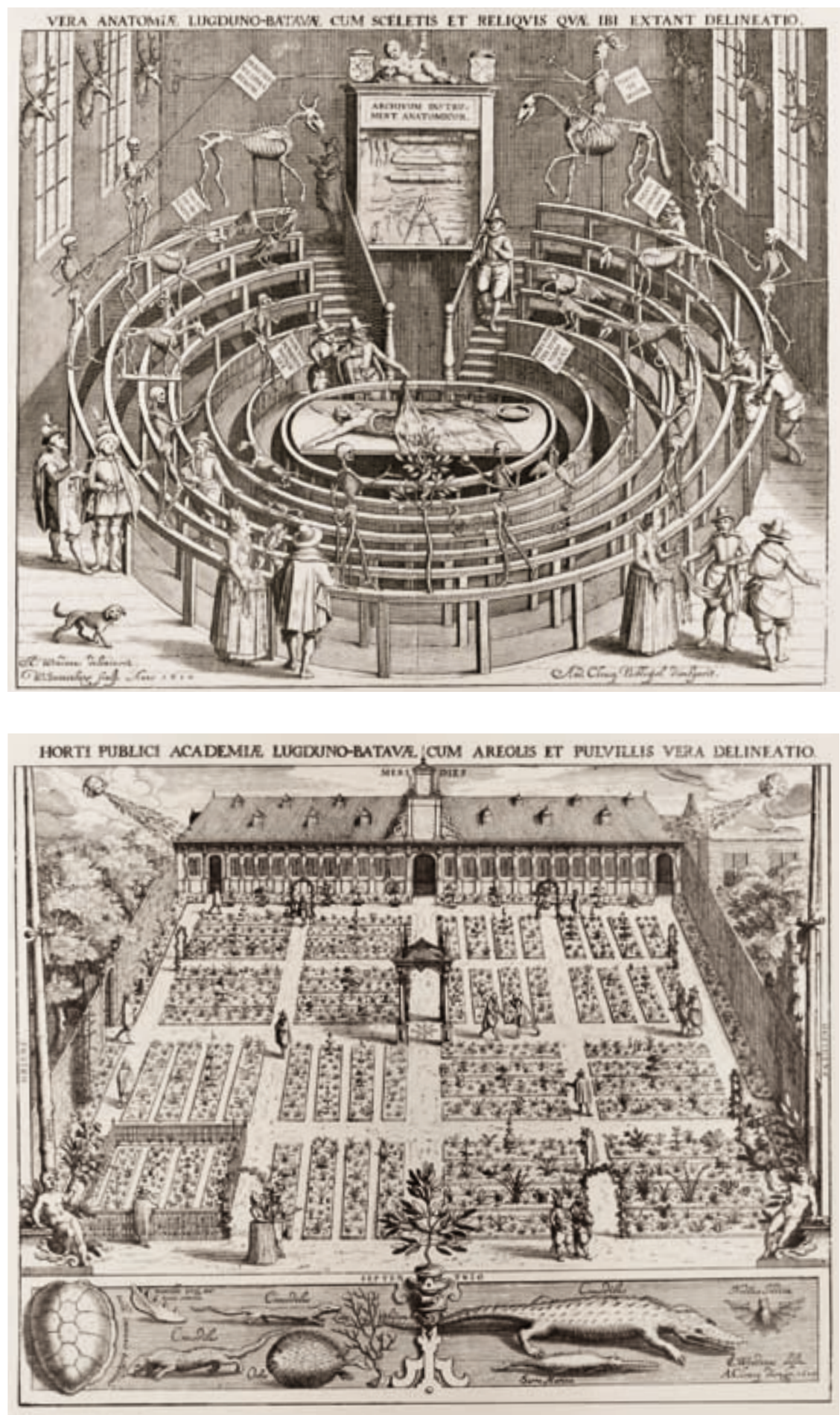

4 Anatomisch Theater, 1610

$\checkmark$ Hortus Botanicus, 1610 


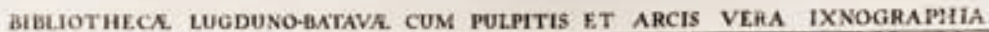
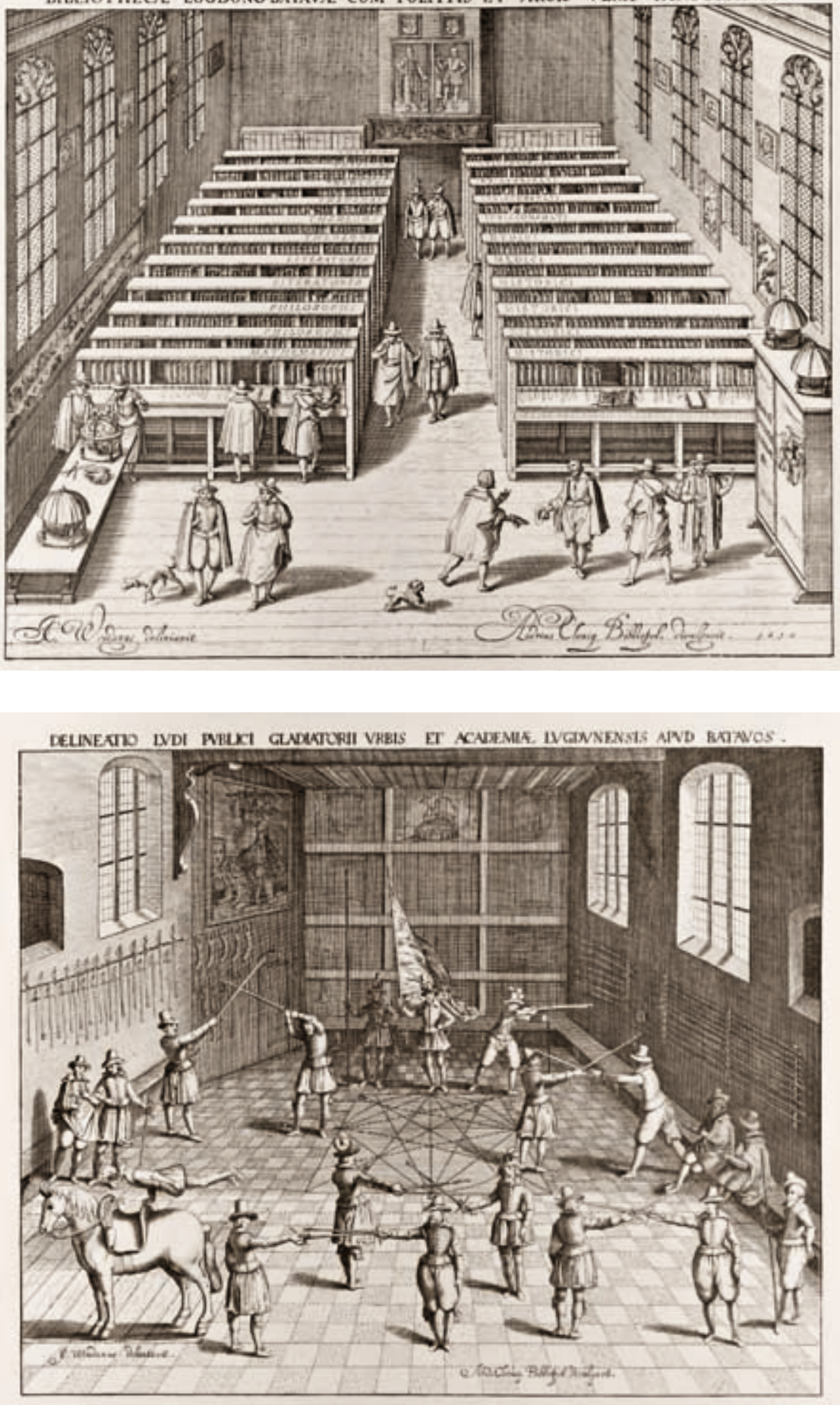

4 Bibliotheek, 1610

$\checkmark$ Schermschool, 1610 
gen van officiële kleding. Vanaf 1677 golden boetes voor het niet in toga verschijnen bij publieke promoties. Twee jaar later werd de plicht uitgebreid tot het in toga bijwonen van begrafenissen. Vanaf 1730 werden professoren aangespoord om zelfs bij private promoties in toga te verschijnen ('non nisi palliati'). Tegelijk werd het 'ius togae' nauwkeuriger omschreven. De schout van de stad mocht er eentje dragen vanwege zijn functie bij de universitaire vierschaar, maar predikanten die dat deden, handelden tegen de gevestigde gewoonte, 'contra morem pristinum'.

\section{Dogmatisch evenwicht}

De meest voorkomende oorzaken van onrust in de senaat waren waarschijnlijk 'ideologisch' van aard. In een senaatsvergadering in 1665, bijvoorbeeld, die uitliep in een debat over Descartes, verdedigde De Raei het standpunt van de radicale twijfel, dat wil zeggen: ook wanneer er geen specifieke reden voor twijfel was, zoals aan het bestaan van de menselijke geest of aan God. Toen Coccejus, wiens rationele theologie vaak voor cartesianisme werd aangezien, zei dat zo'n standpunt paradoxaal was en dat de cartesianen zelf niet zoveel in twijfel trokken als ze beweerden, riep De Raei: 'U bent een filosofische onbenul.'

Scherpe debatten waren gedeeltelijk het resultaat van een andere eigenaardigheid van het personeelsbeleid van de Leidse universiteit. Curatoren deden hun best om een evenwicht te vinden tussen de verschillende ideologische, filosofische en wetenschappelijke trends van hun tijd. Met name op het gebied van de theologie en filosofie konden dogmatische verschillen op die manier heftige discussies veroorzaken en zelfs politieke onrust. Toch benoemden curatoren in 1603 niet alleen Arminius, maar ook Trelcatius junior en in 1611 niet alleen Conrad Vorstius, maar ook Petrus Molinaeus. In 1650 benoemden ze Coccejus naast Trigland, in 1653 Hoornbeek naast Coccejus.

Dus steeds als ze een rekkelijk iemand aanstelden, zochten ze eг een 'preciezere', dogmatische denker naast. Bij filosofie leidde dat tot de benoeming van vertegenwoordigers van verschillende versies van het aristotelisme: Jack 
naast Burgersdijk, Stuart senior naast Неereboord en Stuart junior naast De Raei. Omdat de artes zich aan de Leidse universiteit een centrale plaats zouden veroveren, verdient het soort aristotelisme dat de jonge universiteit koesterde een nadere beschouwing.

De Schotse filosoof Gilbert Jack was een typische vertegenwoordiger van het vroege Leidse aristotelisme, in de zin dat hij vrij getrouw de jezuïet Francisco Suárez navolgde en diens compromis tussen natuurlijke theologie en christelijke openbaring. Mocht dit wat bevreemding wekken in een protestantse omgeving, ook op Jacks jongere collega Petri Burgersdijk was de invloed van Suárez duidelijk merkbaar. Маar hij was zo verstandig om, met de natuurlijke theologie als uitgangspunt, een strikte scheiding aan te brengen tussen theologie en filosofie.

Dit standpunt werd vervolgens officieel bekrachtigd door de Staten van Holland in hun 'Ordre' tegen de vermenging van theologie en filosofie. Deze maatregel leek een compromis dat de inmenging van de filosofie in theologische kwesties moest voorkomen. Маar op termijn bleek het omgekeerde егdoor bewerkstelligd: een adequate bescherming van de filosofie tegen inmenging van de kant van de theologie.

Niet minder eclectisch was Burgersdijk in zijn natuurlijke filosofie. Op het gebied van de astronomie behandelde hij zowel het copernicanisme als het ptolemeïsche wereldbeeld. Burgersdijk noemde de argumenten van Philippus van Lansbergen, een volgeling van Copernicus, en beklemtoonde hun plausibiliteit. Maаг hij weigerde toe te geven dat deze argumenten de aristotelische gedachtegang ondermijnden. Hetzelfde gold voor zijn leerling Adriaan Неeгеboord, eclecticus in optima forma. Неereboord bleef binnen de grenzen van het aristotelisch denken, hoewel hij probeerde te breken met de invloed van de jezuïeten en hij een protestantse metafysica wilde ontwikkelen waarin een aangeboren licht de mens dwingt om Gods bestaan te erkennen. Aan het einde van zijn leven probeerde hij zelfs Aristoteles met Descartes te verzoenen.

De volgende stap was aan Johannes de Raei, de enige echte cartesiaan die ooit een Leidse leerstoel bezette. Zijn Clavis philosophiae naturalis (1654) wilde 'een inleiding tot de Aristotelisch-Cartesiaanse visie op de natuur' zijn (In- 
troductio ad naturae contemplationem Aristotelico-Cartesiana). In wat leek op een traditioneel mengsel, een philosophia novantiqua, draaide De Raei de oude volgorde om en knoopte hij wat hij van Aristoteles wilde behouden aan een cartesiaanse draad. Even origineel was de manier waarop hij filosofie onderscheidde van theologie, namelijk door het contemplatieve karakter van de filosofie te benadrukken en verschil aan te brengen tussen het strikt theoretische en het praktische.

Uit dit alles is een belangrijke conclusie te trekken. De universiteit slaagde er blijkbaar in om niet alleen de verschillende wetenschappelijke scholen in het curriculum aan het woord te laten, maar ook hun onderlinge strijd te beheersen. Ook waar de scholen ronduit polemisch tegenover elkaar stonden bij verschillende vormen van aristotelisme of in de verhouding aristotelismecartesianisme - bleek universitaire wetenschap toch vooral gedefinieerd te worden als het vinden van een eclectisch midden of een geleidelijke overgang.

En als de geleerden zich daar niet uit eigen beweging aan conformeerden, werden ze er statutair toe aangemoedigd. In diezelfde tijd vertegenwoordigden Adam Stuart en zijn zoon David het conservatieve aristotelisme. Om hen in het gareel te houden, hadden curatoren hun opgedragen de tekst van Aristoteles zo letterlijk mogelijk te behandelen, dat wil zeggen: woord voor woord. Ook dit bleek een uitstekende manier om het filosofische debat in de filologische kiem te smoren.

In haar tweede eeuw zette de universiteit dit benoemingsbeleid voort. Wolferd Senguerdius werd bijvoorbeeld benoemd naast de cartesiaan Burchardus de Volder als professor 'in peripathetische Philosophie', 'tot beter hanthavinge van de goede saecken'. En hoewel Senguerdius trouw bleef aan de aristotelische, kwalitatieve noties van materie en vorm, stelde hij vorm gelijk aan materie in beweging, en definieerde hij materie, evenals Descartes, als uitgebreidheid. In de tang tussen zijn wens om het cartesianisme zijn plaats te geven en tegelijk vast te houden aan een kwalitatieve manier van redeneren, zocht hij een uitweg door zich te concentreren op het experiment. In die tijd vroeg De Volder, net terug van een reis naar Engeland, waar hij een bijeenkomst had bijgewoond van de Royal Society, de curatoren om hem de

- Egyptische oudheden uit het anatomisch theater 

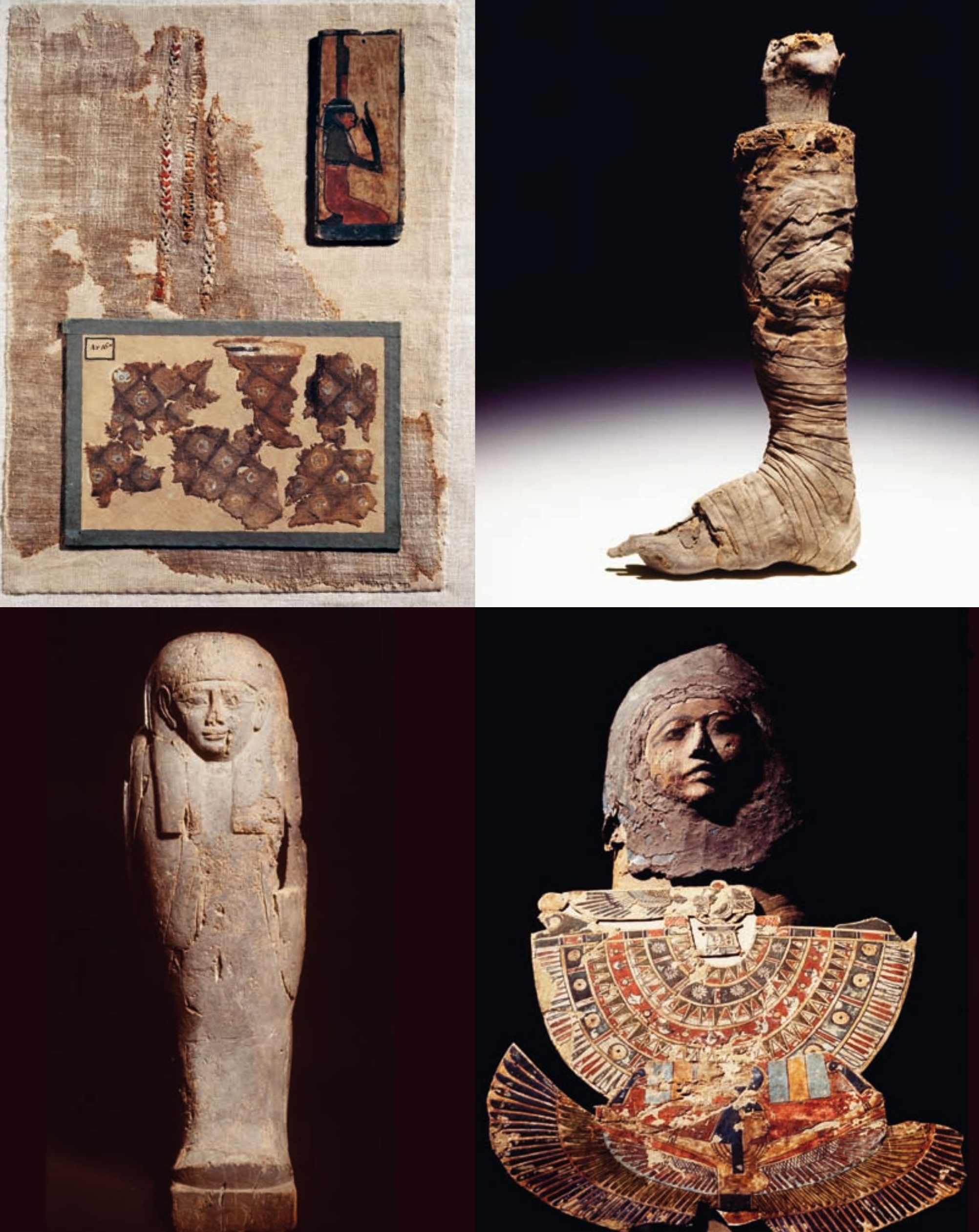


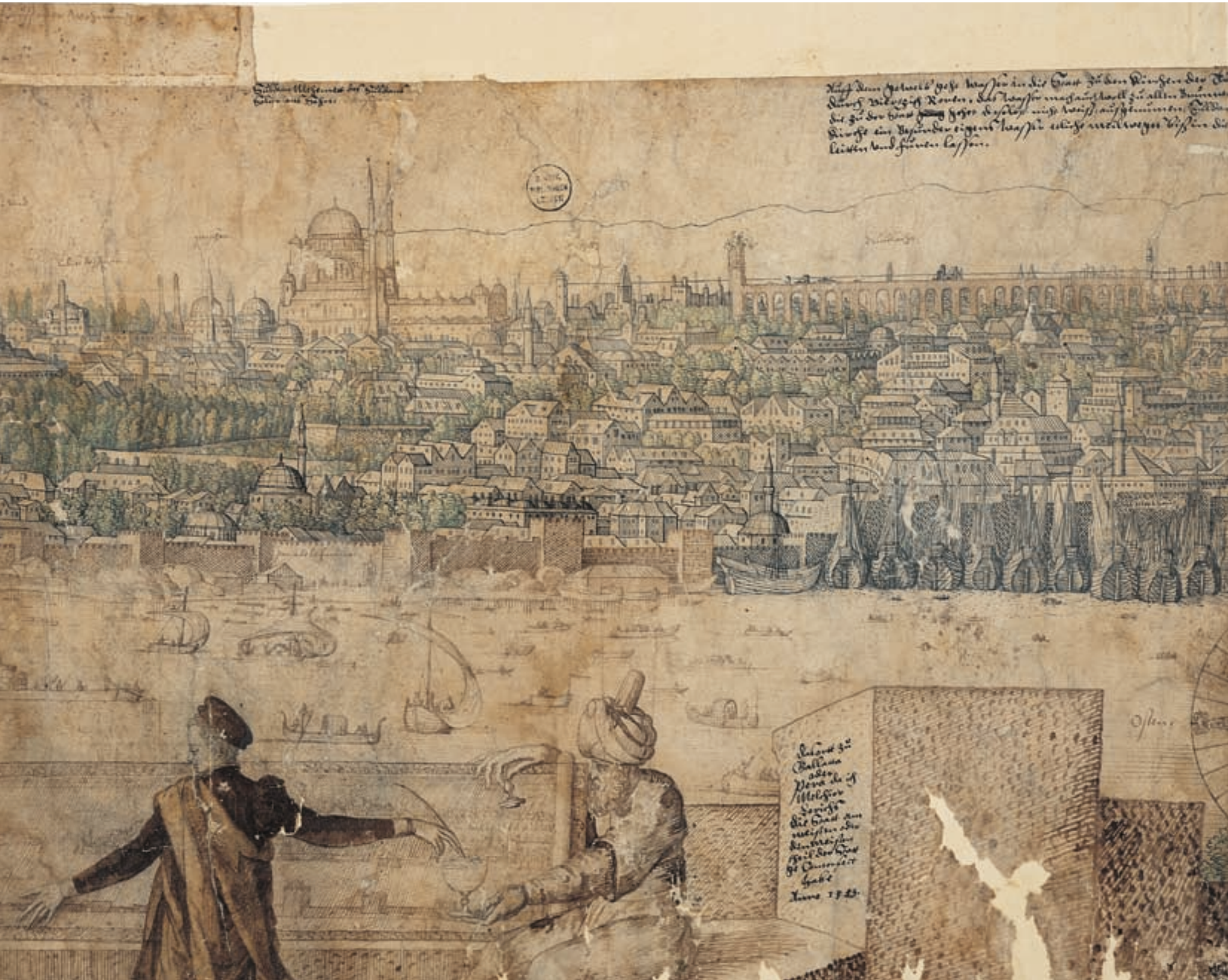

4 Prospect van Constantinopel, hing sinds 1598 langs de noordwand van de bibliotheek 
functie van 'Professor Physicae experimentalis' op te dragen.

Senguerdius en De Volder deden dus eigenlijk wat vader en zoon Stuart opgedragen kregen: ze ontweken de polemiek door zich in dit geval niet op de tekst maar op de werkelijkheid te concentreren. Wat voor de Stuarts puur conservatisme was, was hier echter welhaast revolutionair. De gematigde aristotelicus Senguerdius en de al even gematigde cartesiaan De Volder vonden elkaar in het eerste fysisch kabinet in de noordelijke Nederlanden, waar ze de eerste volledig op experimenten gebaseerde lezingencycli gaven. Ze initieerden daarmee een educatieve ommekeer: voor Boerhaave, 's Gravesande en Van Musschenbroek was het experiment onmisbaar in hun onderwijs. Bovendien vermeden ze zo niet alleen dogmatische conflicten en speculatie, ze herstelden ook de oude eenheid tussen filosofie en theologie en plaveiden de weg voor de zogenaamde fysico-theologie, 'the wisdom of God manifested in the works of creation', om de titel te gebruiken van John Rays invloedrijke boek.

Deze veranderingen waren van invloed op het hele curriculum. Logica, tot dan toe het belangrijkste vak in de filosofie, maakte plaats voor natuurlijke filosofie, het syllogisme voor de analogieredenering. Of men nu een cultuur met een taal vergeleek, de fysiologie van planten met de menselijke seksualiteit, chemische processen met menselijke gevoelens of de diversiteit van de juridische werkelijkheid met de rationaliteit van het Romeins recht, overal bleek de analogie een handig gereedschap. Het hielp, als aan bepaalde voorwaarden was voldaan, om het onbekende tot het bekende te herleiden en de werkelijkheid te verhelderen door het gebruik van rationele of ideaaltypische modellen.

De klemtoon op dogmatisch evenwicht beperkte zich niet tot theologie en filosofie. Ook bij rechten en geneeskunde waren de verschillende 'mores' vertegenwoordigd, een filologischer houding naast een meer praktische, een systematischer interpretatie naast een meer chronologische, een encyclopedischer manier van onderwijzen naast een meer experimentele. Een goed voorbeeld biedt de aanpak van curatoren toen ze een opvolger zochten voor de medicus Van derLinden.

Johan Antonides van der Linden was een devoot volgeling van Hippocrates. 
Waar zijn directe collega's Franciscus (de la Boe) Sylvius en Johannes Hornius oorspronkelijke wetenschappers waren - beiden bekend om hun empirisch onderzoek, waarmee de één de samenstelling van lichamelijke vloeistoffen wilde bepalen en de ander de manier waаrop ze door het lichaam werden vervoerd - was Van der Linden een conservatieve, meer encyclopedische onderwijzer. Hij ontkende niet dat het bloed circuleerde - hij noemde Harvey zelfs 'nunquam satis laudatus', nimmer genoeg geprezen - maar hij hield wel vol dat Hippocrates de eerste was die het ontdekt had.

Van der Linden was een invloedrijke onderwijzer geweest en Nederlandse gezanten in Engeland en Frankrijk werd gevraagd om uit te zien naar een me-

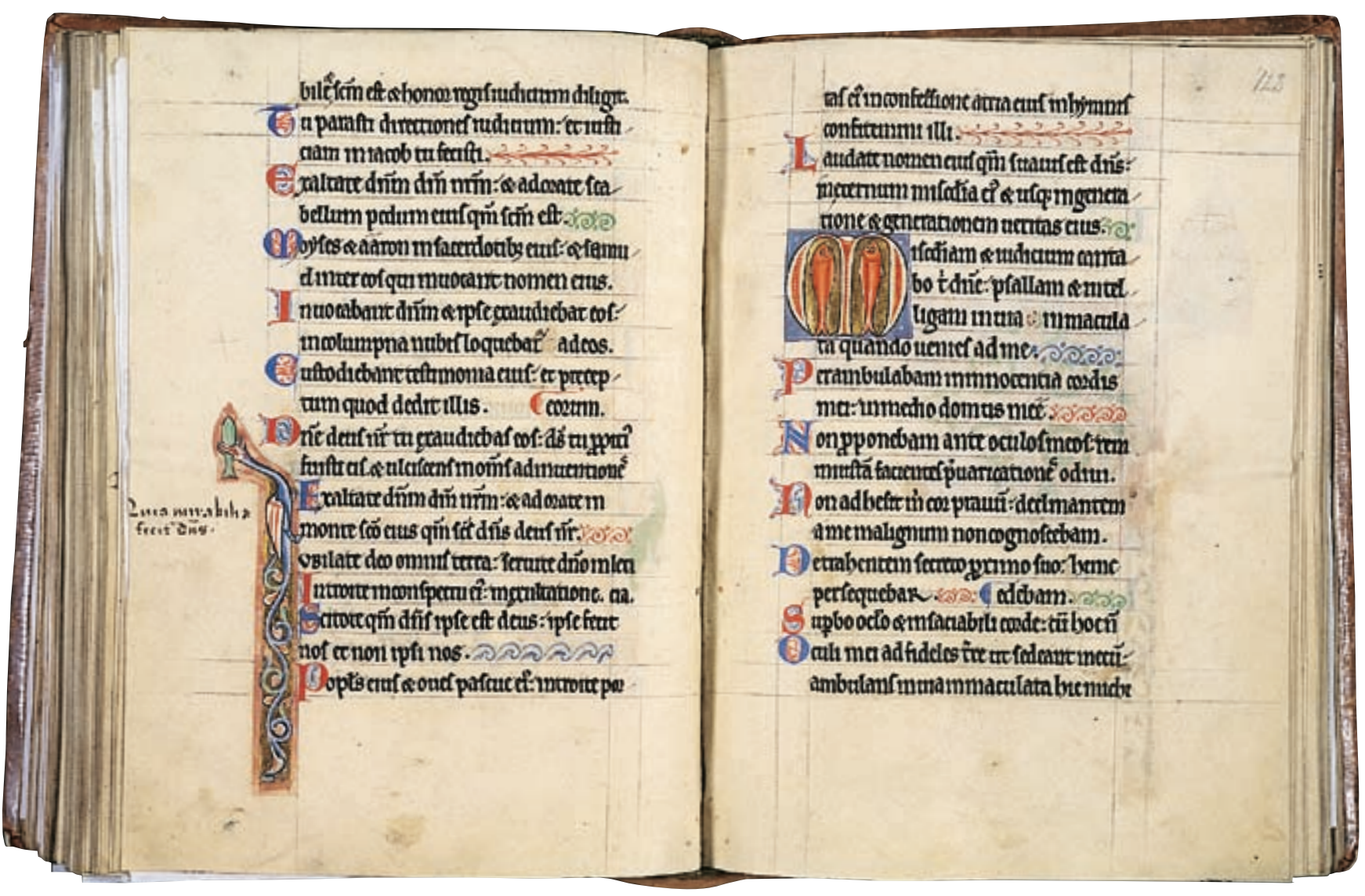

^ Psalterium van de Franse koning LodewijkIX (1214-1270), door de Leidse burgemeester Van den Bergh aan de bibliotheekgeschonken 
dicus 'de oude Galenisse maniere profiteerende'. Ambassadeur Meerman in Engeland stelde Thomas Willis en zelfs Robert Boyle voor. Er was ook een zekere Ludovicus Molinaeus, die kort daarvoor het boek Medicina universalis Galenica had gepubliceerd. Hij was zestig jaar, maar had een jonge vrouw en omdat zijn vader een hoge leeftijd had bereikt, dacht Meerman dat Molinaeus ook nog dertig jaar te gaan had. Maar omdat Willis niet wilde, Boyle veel te rijk was en Molinaeus niet aanzienlijk genoeg, vond men het beter om George Castle, professor te Oxford, te vragen, of Carolo Offredi, een ongetrouwde protestantse arts in Padua. Uiteindelijk vond men Charles Drelincourt, Medicus Regis, de arts van de koning van Frankrijk, zoals hij zich graag noemde,

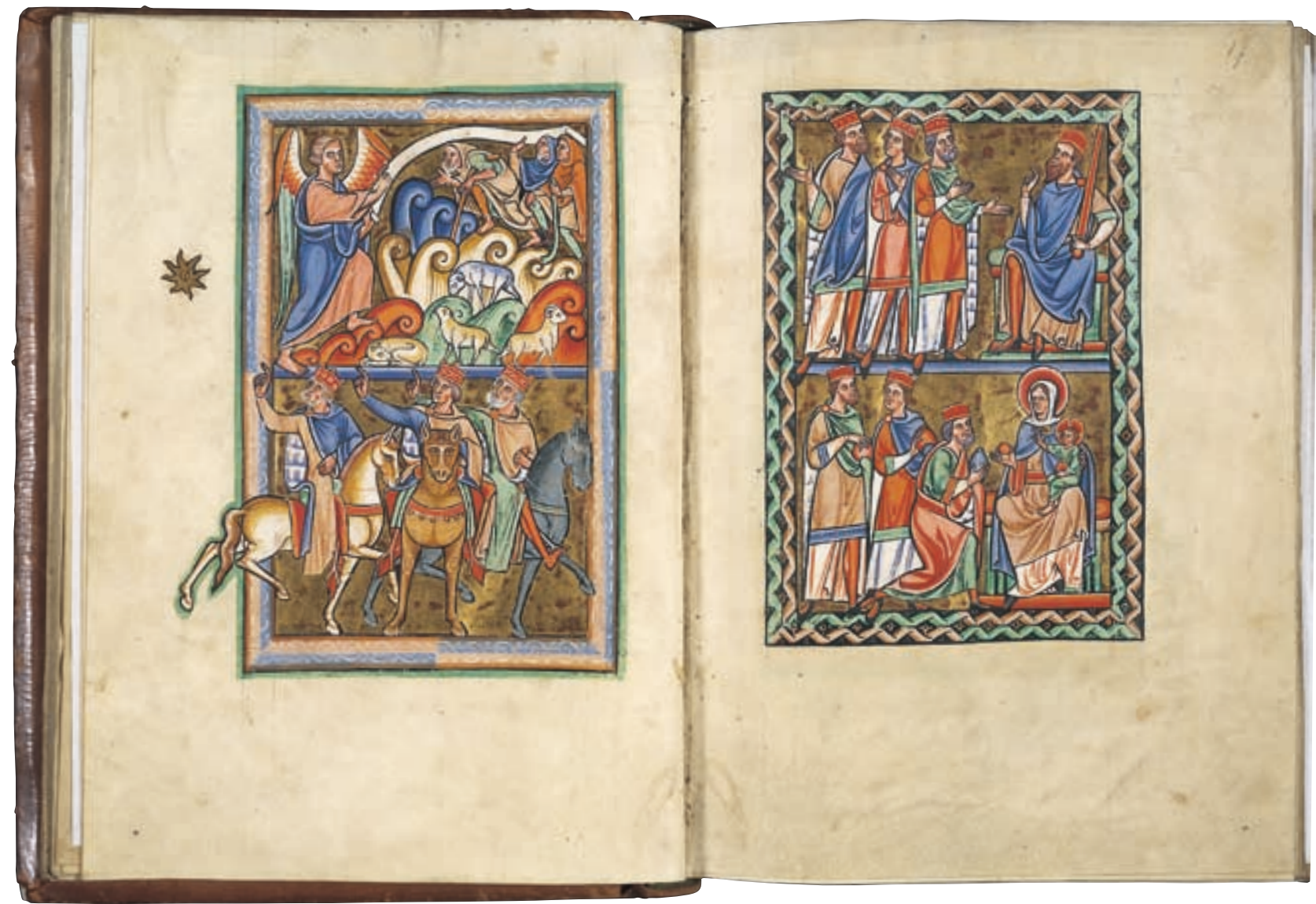

^ PsalteriumvanLodewijk IX 


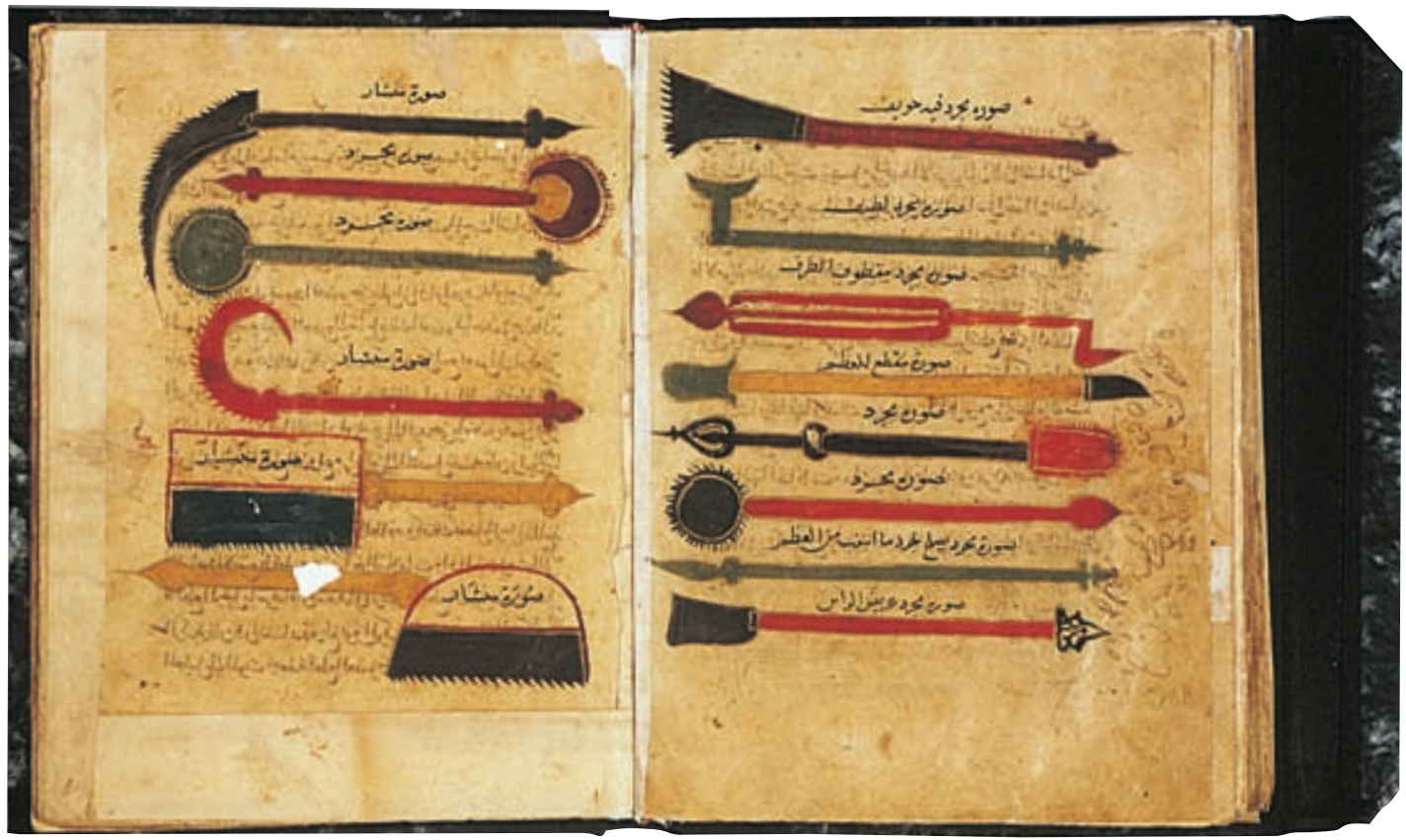

behoudend genoeg en bereid om de uitnodiging te aanvaarden.

Uiteraard was het bij een dergelijk wervingsbeleid onmogelijk polemische discussies te voorkomen. Die debatten waren om drie redenen van belang: ten eerste voedden ze de voortdurende discussie over fundamentele wetenschappelijke principes, zoals systematische versus empirische kennis of mechanische versus organische verklaring. Ten tweede vormden ze, omdat ze bijna altijd van invloed waren op theologische en politieke problemen, een soort afleider, waar de bliksem van de discussie weliswaar insloeg, maar tegelijk (meestal) onder controle gebracht werd. Ten derde functioneerde de universiteit op deze manier als een soort gids voor de verwarden, een intellectuele informatiedienst die de grote onderwerpen van de tijd voor het publiek vertaalde en toegankelijk maakte.

Een goed voorbeeld van de manier waагоp dit mechanisme werkte, een van de vele, is 'de hairige oorlog', een pennenstrijd over het dragen van lang haar. In de ogen van calvinistische dominees was lang haar een teken van de overvloed van die dagen, die hen deed terugverlangen naаг soberder tijden.

\Veertiende-eeuws handschrift met chirurgische instrumenten uit het Midden Oosten 
De Spaanse inquisitie had alleen maar het lichaam gedood, terwijl de Franse manieren ook de ziel vermoordden. Tijdens de Provinciale Synode van 1640 zette de classis van Den Haag het onderwerp op de agenda van de Synode en kwam het terecht op de preekstoel, waar met behulp van 1 Corinthiërs 11:14 gezegd wordt dat de natuur zelf leert dat het een schande is als een man lang haar draagt. Consistoriekamers weergalmden ervan, predikanten dreigden elkaar met ontslag en de bevolking vreesde pest, oorlog of nog егger: hogere prijzen.

De eerste Leidse reacties kwamen van Boxhorn en Salmasius. De eerste publiceerde direct in het Nederlands. In zijn Spiegeltien vertoonende 't lanck hayr ende hayrlocken, by de oude Hollandse ende Zeelanders gedragen (1644) zocht hij vooral naar historische relativering. De Batavieren, bijvoorbeeld, droegen lang haar en sindsdien was dat zo gewoon geweest dat men van 's lands еer kon spreken. In een ander spiegeltje uit hetzelfde jaar liet hij zien dat kort haar juist 'van vreemde ontleent' was.

De 747 pagina's lange Epistola ad Andream Colvium die in 1644 in het Nederlands vertaald werd, was een typisch Salmasius-product: het resultaat van enorme geleerdheid, geboren in grote verwarring. Geen enkele haarmode, geen drager of commentator, geen klasse of cultuur, liet hij weg in zijn berg van verwijzingen met maar één argument, dat er twee soorten apostolische geboden waren: alom geldige geboden en geboden die gebonden waren aan tijd en plaats. Wat Paulus had geschreven over het haar behoorde duidelijk tot de tweede categorie. Salmasius kreeg de steun van niet alleen de oude en gematigde Polyander, wiens Judicium werd goedgekeurd door de theologische faculteit, maar zelfs van de streng calvinistische Revius, die zes disputaties aan de zaak wijdde. Ten slotte overwon de Leidse gematigdheid.

Dit soort discussies laat duidelijk zien welke rol de universiteit speelde in de publieke opinie en in de maatschappelijke en politieke meningsvorming. De Leidse universiteit was nooit dermate intensief betrokken bij het openbare bestuur en de rechtsspraak als haar Duitse tegenhanger - 'Aktenversendung' was hier onbekend - maar toch waren de professoren tamelijk actief in de maatschappelijke dienstverlening. Het godsdienstige debat, erudiet met de joden of polemisch met de katholieken, werd gezien als een essentieel deel 
van het werk van professoren in de theologie, net als het geven van advies over bepaalde boeken of controverses. De rechtenfaculteit werd regelmatig officieel geraadpleegd in allerlei aangelegenheden, van het huwelijk tussen leden van eenzelfde familie tot aan zaken met betrekking tot woekerrente, ordeverstoring, pacht, testamenten, eigendomsrecht, zeeroverij en kaping. Een vergelijkbare dienstverlening werd verwacht van de andere faculteiten. Zo beantwoordden de medische en de filosofische faculteit in 1594 gezamenlijk een vraag die het Hof van Holland ze had voorgelegd. Het Hof wilde weten of een vrouw die in het water was gegooid en bleef drijven dit kon dankzij toverkracht of met behulp van natuurlijke vermogens. Beide faculteiten concludeerden op grond van logische en empirische overwegingen dat de zogenaamde waterproef niet het minste juridische bewijs verstrekte.

\section{Humanistische didactiek}

Het academisch jaar was intensief maar kort: naast de vrije woensdag en zaterdag, waаrop disputaties gehouden werden, waren er de vele vakanties meestal twee weken met Pasen, Pinksteren en Kerst en anderhalve maand in de zomer - terwijl bovendien veel lessen uitvielen tijdens boekveilingen, anatomische demonstraties en grote jaarmarkten. Zo bleven er meestal slechts zo'n 160 tot 170 collegedagen over.

Die bestonden uit de publieke en de private colleges. De publicae waren gratis toegankelijk voor iedereen die zich had ingeschreven. Ze werden gegeven op maandag en dinsdag, donderdag en vrijdag. Op woensdag en zaterdag waren het altijd 'buitengewone lessen'. Op die dagen werd er gedisputeerd, hielden professoren hun privélessen en kregen lectores, mensen die bij wijze van sollicitatie lesgaven, een kans. Vanaf 1587 kende de universiteit een 'biljet' dat elk jaar op 1 oktober en 1 maart vervangen werd, een Series Lectionum, waагор vоor de gewone collegedagen per uur aangegeven werd welke professor wat voor college zou geven. Een professor gaf dus vier uur in de week over één, hooguit twee onderwerpen college.

De grote hoeveelheid 'alternatief' onderwijs die de universiteit aan zich 

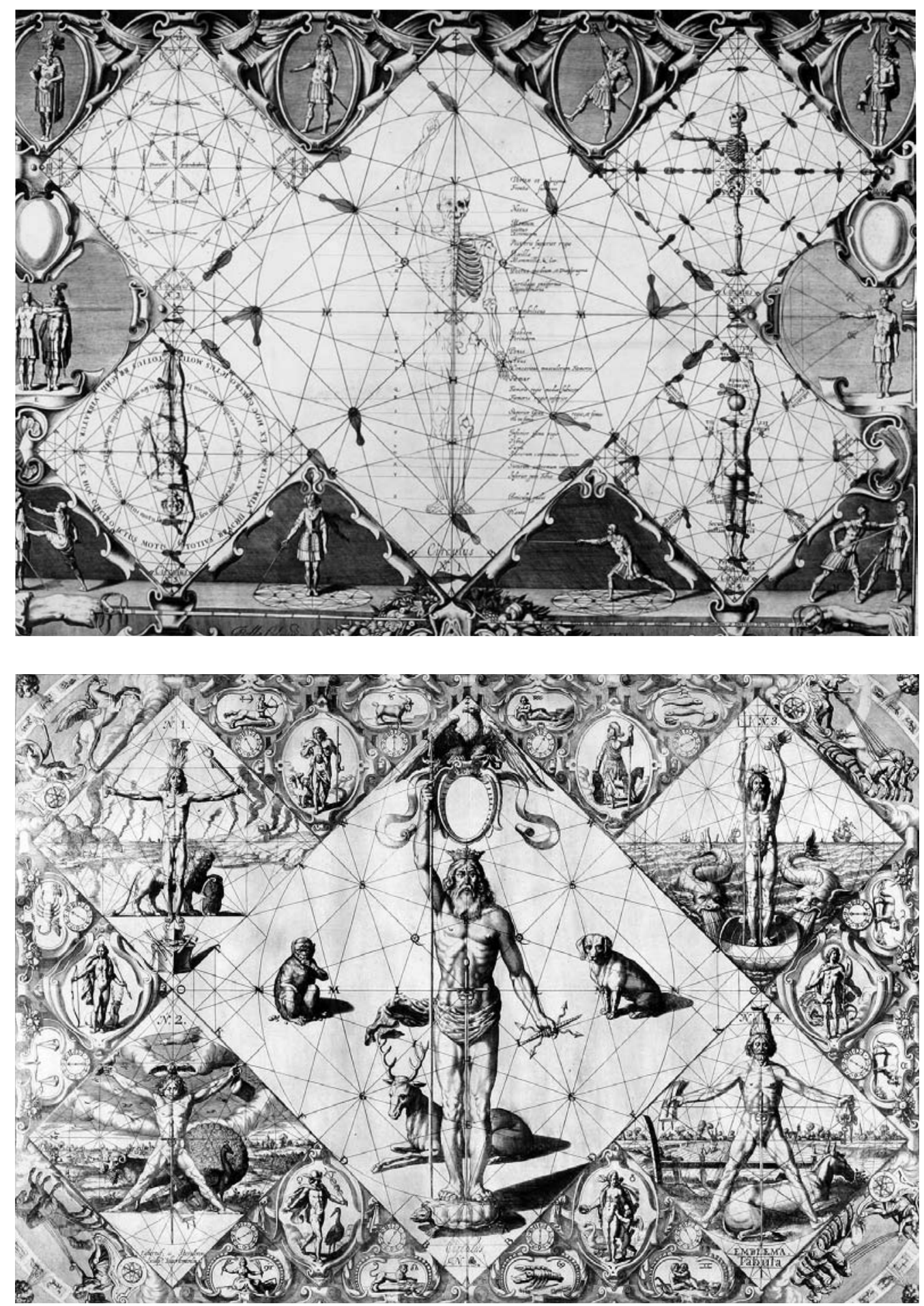

\ Afbeeldingen uit de Académie de l'espée van Girard Thibault (1628) 
trok, werd hoofdzakelijk door privépersonen bij hen thuis verzorgd. Zij lieten zich bij de universiteit inschrijven en gaven les in uiteenlopende vakken. Soms overlapten ze met die van de professoren, soms - als het schermen of paardrijden, zang of dans, Frans of Italiaans, tekenen of rekenen betrof vormden ze daагор een aanvulling. Мааг ook professoren gaven dergelijke privécolleges. De senaat probeerde deze praktijk wel aan banden te leggen, maar noch de professoren, noch de docenten van buiten de senaat lieten zich daar veel aan gelegen liggen. Hoewel het geven van de privatae hand in hand ging met het verwarlozen van de publicae, veroverden ze zich een vaste plaats in het curriculum. Op termijn zouden ze, als een koekoeksjong, de $p u^{-}$ blicae zelfs uit het curriculum werken.

Aangezien studenten niet alleen verschillende vooropleidingen hadden, maar ook kwamen en gingen wanneer ze wilden - er was geen voorgeschreven studieparcours - waren het curriculum en het daarop gebaseerde onderwijs opmerkelijk coherent. Deze samenhang was het resultaat van vallen en opstaan, aanpassing en vernuft. Het curriculum kreeg zijn meest wezenlijke kenmerken al in het begin van de zeventiende eeuw; de belangrijkste daarvan was ongetwijfeld dat het onderwijs in Leiden in het algemeen de fundamentele regels van de humanistische didactiek getrouw volgde.

Dit betekende dat het een mengsel was van materiële, methodische en normatieve overwegingen. Kennis van het Latijn en een zekere bekendheid met de klassieke literatuur waren nodig om de colleges te kunnen volgen. Ook de rudimenten van de logica, van het methodisch denken en redeneren, werden vanzelfsprekend aanwezig geacht. Die kennis werd getoetst. Als ze onvoldoende was, werd daarmee, zoveel als doenbaar was, rekening gehouden bij de keuze van het onderwerp en de manier van behandeling.

De universitaire student moest zich dus een aantal vaardigheden verwerven. Hij moest in staat zijn het 'argument' van een tekst weer te geven, de korte inhoud ervan, en de strekking en consequenties van een redenering. Hij moest zijn kennis ook bij de hand hebben, opgeslagen in zijn geheugen of in een soort van 'apparaat'. Ten slotte moest hij in staat zijn om die te gebruiken voor kerk en staat: hij moest kunnen spreken in bestuurlijke gremia, op politieke of religieuze bijeenkomsten. Hij moest, in de woorden van Cato de $\mathrm{Ou}^{-}$ 
dere, een 'vir bonus dicendi peritus' zijn, een fatsoenlijk en welbespraakt mens.

Een goede collegecyclus was goed georganiseerd, had een redelijke hoeveelheid stof en een vaste lengte. Ten eerste moest de professor zich ervan verzekeren dat het cursusmateriaal beschikbaar was. Als er weinig voorradig was, zoals in de oosterse talen het geval was met grammatica's of oefenteksten, moest hij het zelf samenstellen. De studenten werden geacht het boek dat de professor behandelde voor zich te hebben. Soms kon de behandeling van een bepaalde auteur niet doorgaan door een gebrek aan exemplaren ('exemplarium inopia'). Hóé een boek behandeld werd, was afhankelijk van het intellectuele niveau van de studenten. Het college kon alleen inleidend zijn en woorden en concepten verklaren, maar dоoг рагаfrase en vertaling kon het ook doordringen tot de algemene teneur ervan of morele implicaties aan de orde stellen.

Soms dicteerde de professor zijn college, maar in het algemeen moedigden curatoren dat niet aan. Professoren moesten bij voorkeur 'uit het hoofd' lesgeven. De studenten moesten aantekeningen maken en kregen zelfs het advies om verschillende soorten dictaat aan te leggen, alfabetische registers of systematische verzamelingen van uitspraken en voorschriften. Ze werden aangemoedigd om na te denken over wat ze gehoord hadden en het op hun kamer uit te werken. 'Een student die dagelijks colleges volgt, maar niet recapituleert en annoteert, trekt geen of weinig profijt,' wist Coccejus. 'Zoals we in kerkelijke samenkomsten constateren,' voegde hij егаan toe.

In het ideale geval begon een cursus met het algemenere en werkte de professor gaandeweg toe naar het specifieke. Eerst werd de theorie behandeld, dan de praktijk, waarbij de professor begon met wat als certum of erkend feit werd beschouwd, om vervolgens het controversum te behandelen, datgene wat niet vaststond. Veel aandacht werd besteed aan de training van het geheugen. En men wilde vooral concreet zijn. Wie met een bepaald voorbeeld of een specimen kwam, een stukje bewijs of een behandelingsmethode bij de hand had, werd zeer gewaardeerd.

Inleidende cursussen waren bijna altijd behoudend van karakter. Filosofie had haar eigen canon, met Aristoteles als raamwerk waarin nieuwe vindin- 


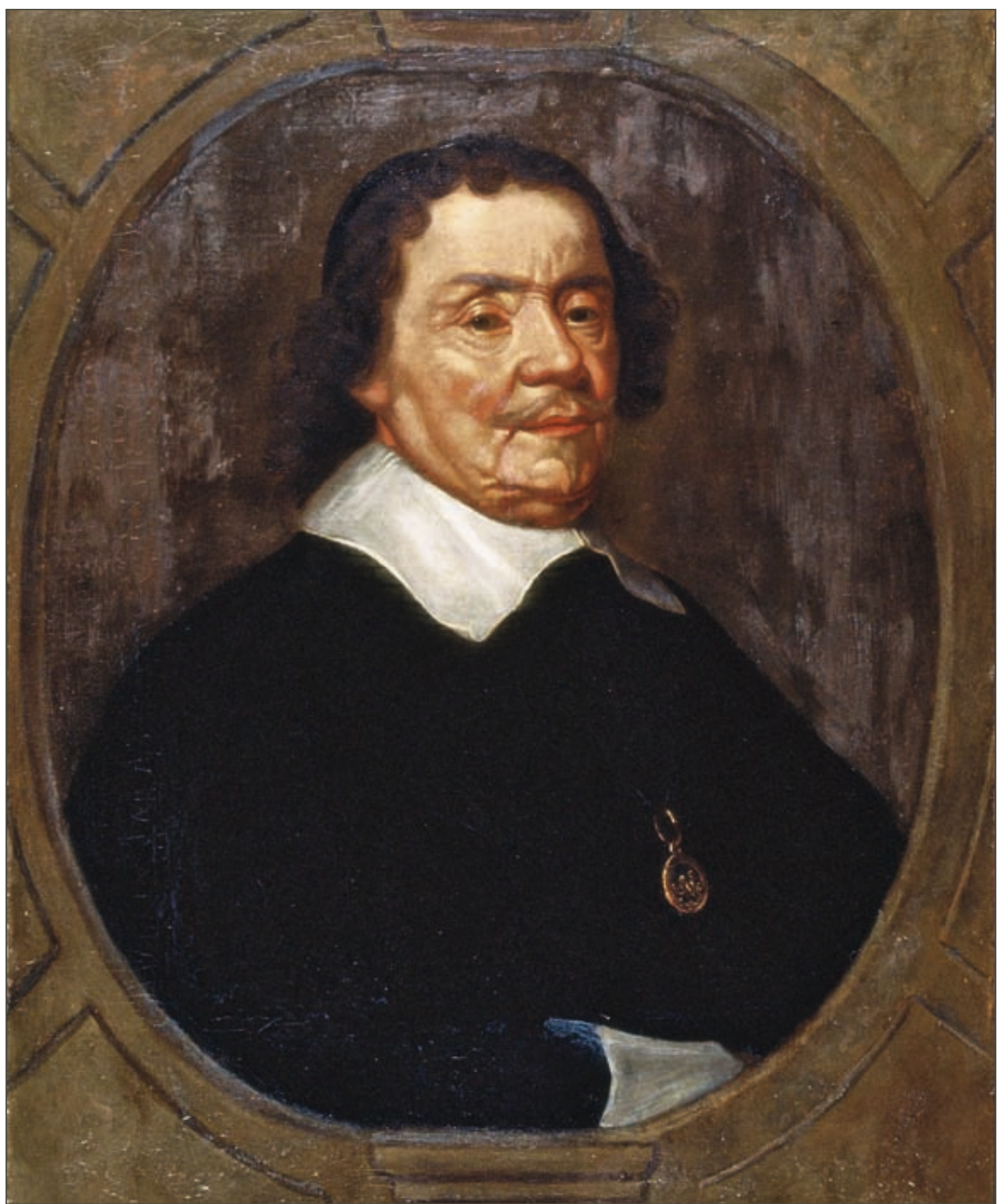

\ Daniel Heinsius (1580-1655). Hoogleraar Grieks en Geschiedenis (1603-1655) en bibliothecaris (1607-1653) 
gen op het gebied van de natuurlijke historie of kosmografie werden ingepast. De medische faculteit hield vast aan Galenus en zijn interpretatie door Fernel, de rechtenfaculteit bracht een zeer traditionele behandeling van Justinianus' Instituten, en de theologische faculteit behandelde de kerkelijke dogma's. In een latere fase van het onderwijs evenwel - in de fysiologie en anatomie, in de behandeling van de Digesten en in de polemieken met niet-calvinistische auteurs - werden gevarieerdere meningen en modernere methoden geïntroduceerd.

De volle breedte van het eclectische principe waarvan het onderwijs doordrongen was, kwam tot uiting in de context van de disputaties. Met name als ze georganiseerd werden in de vorm van een zogenaamd Collegium (waarbij een klein aantal studenten onder leiding van een professor samenkwam om een bepaald thema of boek te bestuderen), werden disputaties gezien als een onmisbaar didactisch middel. ‘De lessen sijn als predicatien, de collegia als cathechizatien,' schreef Gronovius. Tijdens die collegia konden alle soorten meningen aan de orde komen, ook de modernste, gewaagdste of meest geavanceerde.

De bestaansreden van de disputaties was oefening, niet alleen in het spreken in het openbaar, ook in het ondernemen van actie, het behandelen van patiënten, het functioneren in een rechtspraktijk of het stichten van een kerkelijke gemeente. Disputaties behandelden voornamelijk onderwerpen met een praktisch belang: voor medische studenten farmacologie, therapie, de systematische behandeling van bepaalde ziektes; voor rechtenstudenten (huwelijks)contracten, testamenten, vruchtgebruik en beloften; voor theologen de zogenaamde controversiae, dogmatische kwesties en polemische standpunten.

Ook al was het curriculum evenwichtig van opbouw, het stond niettemin bloot aan fundamentele veranderingen, vooral in samenhang met de veranderingen in vooropleiding. De meest wezenlijke daarvan was de geleidelijke emancipatie van de artes of filosofie, en de steeds grotere diversiteit als het ging om het doel van het studeren. 


\section{De emancipatie van de filosofiefaculteit}

Het curriculum van de Leidse universiteit moet gezien worden tegen de achtergrond van het eigenaardige Hollandse schoolsysteem. De Republiek had aan het einde van de zestiende eeuw, in de woorden van Jonathan Israel 'een cultuur gebaseerd op een maatschappij waarin de meerderheid kon lezen'. Ze was daarmee een totale uitzondering in Europa en eeuwen voor op de rest. De combinatie van vergevorderde verstedelijking en een gebrek aan universiteiten had geleid tot de ontwikkeling van grote stadsscholen, die honderden leerlingen aantrokken vanuit het hele land.

De didactische ideeën van de moderne devotie en de morele ideeën van het humanisme hadden een grote invloed op deze scholen. Het curriculum bestreek de hele geleerde vorming: godsdienstige instructie, passieve en actieve beheersing van het Latijn met stilistische oefening, Grieks en Hebreeuws en wat wiskunde, logica en kosmografie. De verdeling van de school in een aantal klassen en van het curriculum in een hiërarchie van vakken - gepaard aan een concentratie op welsprekendheid en welgemanierdheid ontleend aan de klassieke literatuur - gaf deze scholen een eigen karakter en maakte ze tot toegangspoort par excellence tot de culturele elite die begon te ontstaan.

Meteen na het begin van de opstand tegen Spanje ontwikkelden deze zogeheten Latijnse scholen zich tot de ideale vooropleiding voor de universiteit. Toen de stad Alkmaar in 1584 een nieuwe school stichtte, omschreef zij het doel daarvan 'omme daerinne spruyten der kennisse voor de Leydsche Universiteyt aentqueecken ter opbouwinge der Kerke Gods en Conservatie der Politie'. Zelfs de hoofdmeester van een eenmansschool in Rhenen moest beloven 'dat hij de kinderen met goede bequaemheyt op de Academie sal brengen'.

De eerste plannen voor een curriculum van de Leidse universiteit - voorstellen van buitenlandse professoren die de Nederlandse situatie niet kenden - schetsten een volledige studiecyclus, onmiskenbaar geïnspireerd door het middeleeuwse curriculum van de Parijse universiteit, van veertien jaar en beginnend bij het zevende jaar van de student. De eerste zeven jaar werden gevormd door de 'schola puerilis' met lessen in het Latijn, Grieks en Hebreeuws. Dan volgde een 'professorum collegium' voor de hogere studies. 


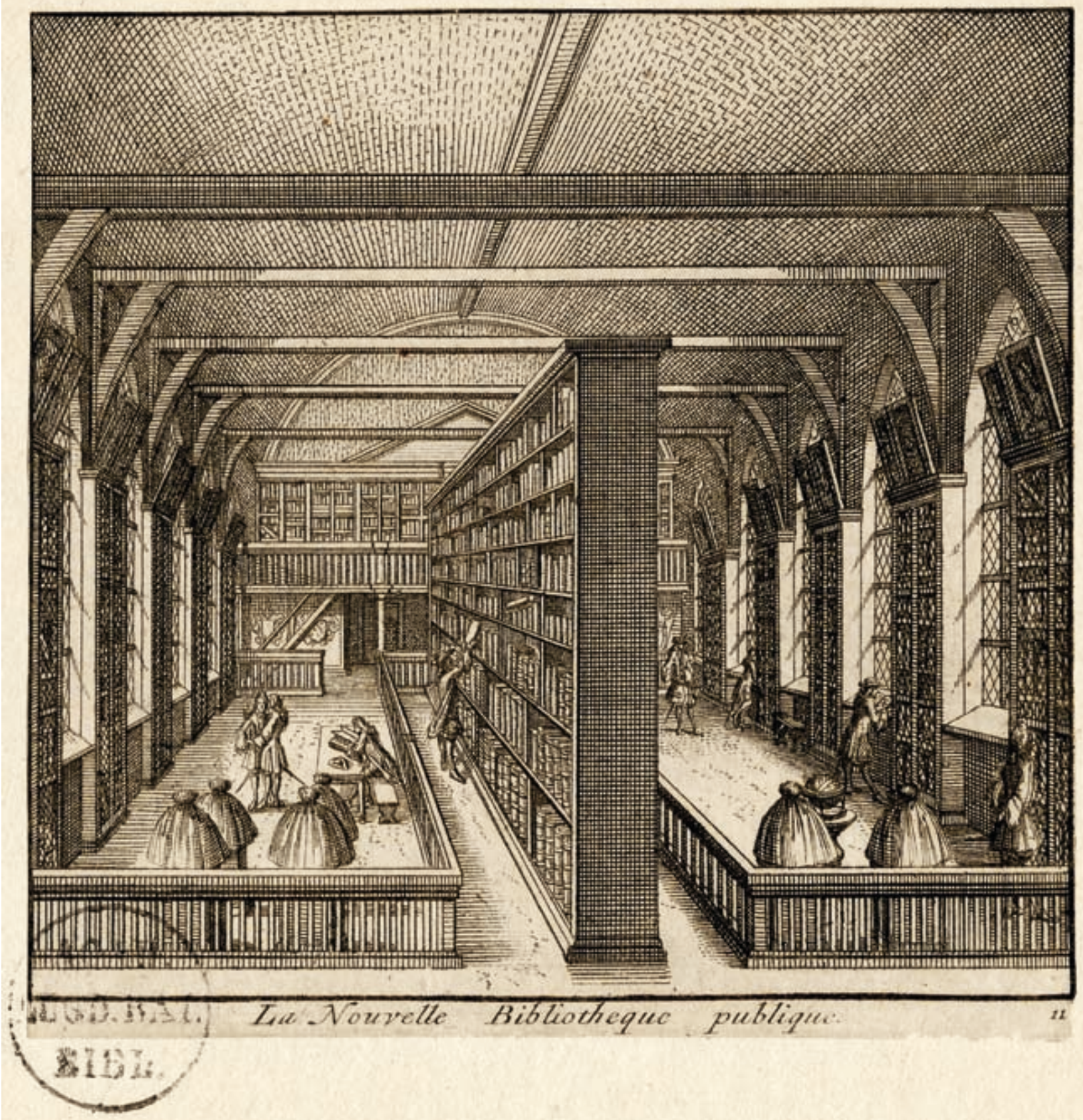

\ Interieur van de bibliotheek, 1712 


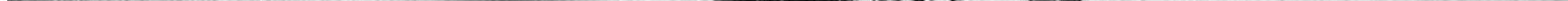


Voor wie bekend was met de Nederlandse situatie moet het plan een anachronisme zijn geweest. Bijna elke grote stad in Holland had inmiddels zo'n 'schola puerilis'. De Leidse universiteit probeerde nog wel de stedelijke school binnen haar muren te halen, maar de stad dacht er niet aan die uit handen te geven. Dergelijke scholen hadden hun eigen clientèle. Tegen 1650 onderwezen de Latijnse scholen ongeveer veertien procent van de relevante leeftijdsgroep, veel meer dan de vier of vijf procent die de vier universiteiten van de Republiek bezochten.

De Leidse universiteit raakte wel actief betrokken bij de curricula van de Latijnse scholen in de provincie Holland. Door een 'Schoolordre' (1625) te maken en lesboeken te produceren probeerde Leiden zowel de structuur als het niveau van het onderwijs te beïnvloeden. De 'Огдге' was een goed en gedetailleerd plan dat zes klassen voorschreef en een strikt rooster van uren en dagen, onderwerpen en auteurs, disputaties en declamaties, prijzen en graden, en alles natuurlijk in het Latijn. Een reeks nieuwe boeken werd gepubliceerd, tekstedities en oefenboeken, grammatica's en woordenboeken, waarvan de bekendste de Logica en het Compendium van Franco Burgersdijk waren en de Latijnse grammatica van Gerard Johannes Vossius.

Deze betrokkenheid betekende ook dat de filosofische faculteit van de Leidse universiteit een ander karakter kreeg dan vergelijkbare faculteiten elders. Aanvankelijk werd - met name onder invloed van Justus Lipsius - geprobeerd om de eigenschappen van het Parijse model te bewaren. Afgezien van de volgorde van de verschillende vakken probeerde men ook het kostschoolmodel van de Colleges in te voeren. Lipsius heeft zich zeer beijverd om zo'n College пааг Рагіjs of Engels voorbeeld op te zetten. Het moest een 'seminarium voor een uitgelezen groep mannen' zijn, geselecteerd uit de jeugd van Holland en Zeeland, die opgeleid werd tot leidende posities in politiek en kerk.

In 1592 werd het Statencollege ingewijd. Het werd de proeftuin van het Leidse filosofieonderwijs. Aanvankelijk stond het daarmee slecht gesteld. Goede docenten bleken moeilijk te vinden. Het is heel waarschijnlijk dat $\mathbf{c u}^{-}$ ratoren er geen aandacht aan schonken, omdat het niveau van het curriculum van de Latijnse School zo hoog was. Voor Lipsius echter was het doel van de

^ Titelprent van de Catalogus Librorum van 1716 
universiteit prudentia en sapientia, verstandigheid en wijsheid, deugden die alleen met behulp van filosofie te bereiken waren.

Men brak zich vooral het hoofd оver het niveau waагоp de filosofielessen gegeven moesten worden. Vanaf het begin had de faculteit te maken met studenten van verschillende leeftijden en met verschillende niveaus van vooropleiding. Niet alle Latijnse scholen waren even goed; bovendien was maar ongeveer de helft van de studenten Nederlands. Deze diversiteit vereiste aanpassingen in het curriculum. Aanvankelijk weerspiegelde filosofie in Leiden het onderwijsniveau van de Latijnse scholen en richtte ze zich op verdieping van kennis van de originele klassieke teksten. Voor veel studenten betekende dit echter dat de lessen te moeilijk waren. Dit leidde tot de bekende tweedeling van het programma: in hun publica onderwezen de professoren het officiële programma, maar tijdens hun privata boden ze studenten een verdieping van eigen hand.

Het succes van deze methode, die ook in andere faculteiten ingang vond en die een redelijk hoog niveau van onderwijs garandeerde in vakken die zowel academisch noodzakelijk als maatschappelijk relevant werden geacht, droeg ertoe bij om de traditionele hiërarchie van disciplines te veranderen. Dat is niet alleen zichtbaar aan de gewijzigde manier waarop de lessen aangekondigd werden, maar valt ook te constateren aan de hand van wat de professoren van verschillende faculteiten verdienden. Aanvankelijk werd onderscheid gemaakt tussen het (hoge) inkomen van theologen en juristen enerzijds en het veel lagere van medici en filosofen anderzijds. Мaаг al rond 1600 waren de salarissen ongeveer gelijk. In het begin was de functie van de filosofie nog dezelfde als aan de middeleeuwse universiteit: een opstapje паaг de hogeге faculteiten. Маaг ook dat veranderde in de tweede helft van de zeventiende eeuw.

Hoewel het onderscheid tussen een filologisch en een natuurwetenschappelijk deel in de artes aanvankelijk uiterst kunstmatig was, betrof deze emancipatie allerеerst de letteren. Door de belangrijke filologen die de universiteit aantrok, verkregen de letteren een aanzienlijk prestige. De natuurfilosofie beijverde zich ook voor meer status door van de filologie allerhande retorische hulpmiddelen te lenen, zoals het benadrukken van haar klassieke erfe- 
D. nas Iuya telleiden

步

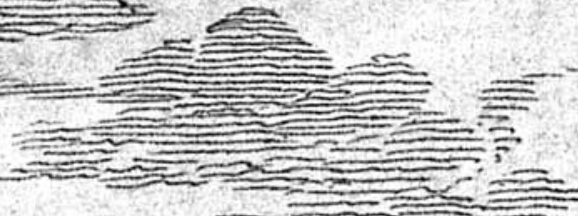

17:

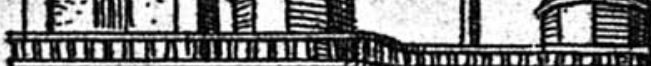
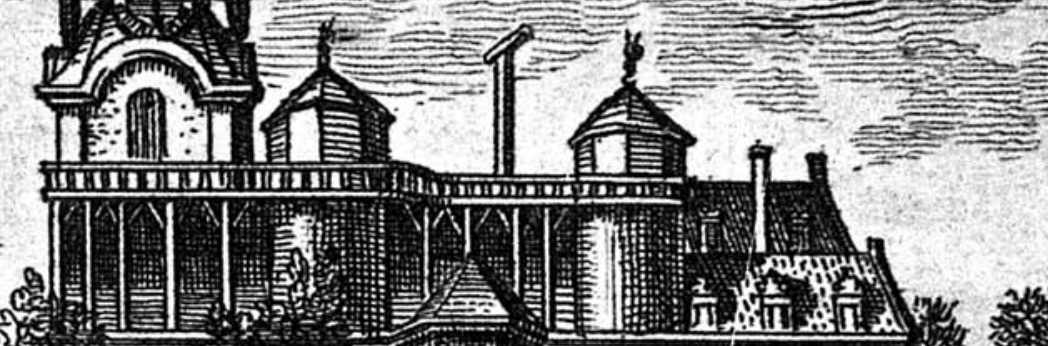

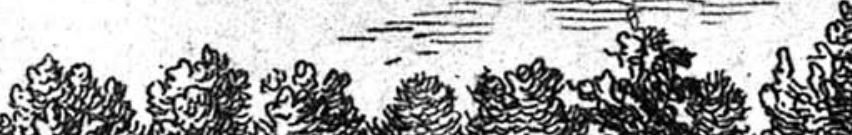

(S)

1)

7.

8

(
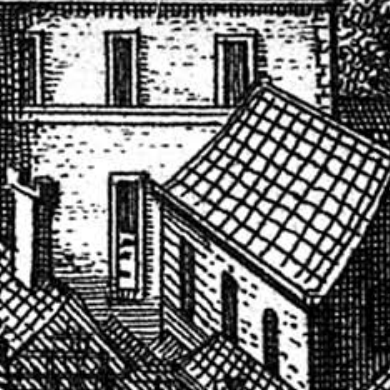

1.

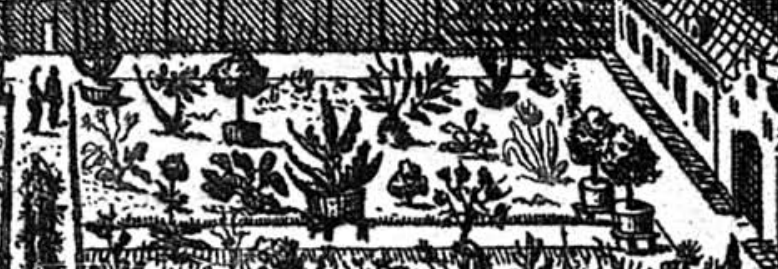

(1)

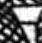

8

(1)

1)

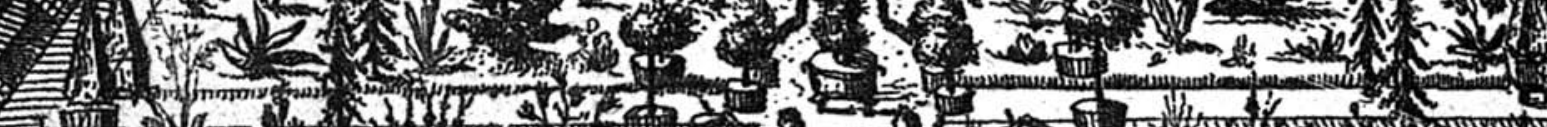

3 2010 (1)

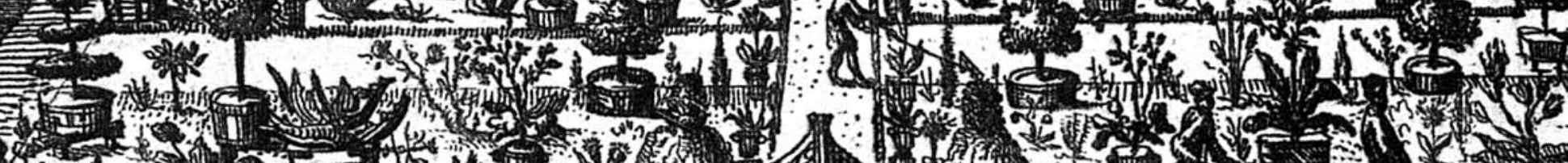
(7)

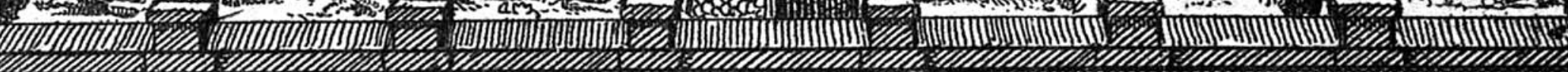


nis of de morele betekenis van haar vakken. Een ander retorisch 'argument' van filologen om de status van hun vak te verhogen, was het gebruik van grafmonumenten. Een recente studie van deze monumenten in de Pieterskerk laat zien dat vóór 1630 vrijwel uitsluitend letterenргоfessoren voor zichzelf zo'n monument oprichtten. De stelling is dat zij daartoe vooral overgingen uit de behoefte hun aanzien te vergroten en de aandacht van collega's op zich te vestigen.

Het proces van differentiatie leidde uiteindelijk tot een scheiding tussen beide delen van de faculteit. In de universitaire statuten van 1631 werd de oorspronkelijk 'filosofische' faculteit omgedoopt in die 'aengaende de Philosophie ende Goede Konsten'. Ook maakten de statuten niet langer onderscheid tussen de kosten of het belang van de graad van deze faculteiten.

De emancipatie van de filosofiefaculteit valt ook af te leiden uit de gemiddelde leeftijd van haar studenten bij inschrijving. Aan het begin van de zeventiende eeuw is die student zeventien jaar oud, aan het einde van die eeuw ouder dan twintig en rond 1775 vierentwintig jaar. Ter vergelijking: beginnende rechtenstudenten waren in dezelfde periodes respectievelijk ouder dan twintig, bijna tweeëntwintig en twintig jaar, en geneeskundestudenten bijna tweeëntwintig, meer dan drieëntwintig en drieëntwintig jaar.

\section{Het doel van een universitaire studie}

In de eerste eeuw zag de Leidse universiteit ongeveer 26.0oo studenten op haar colleges verschijnen. Binnen vijftig jaar na haar stichting trok zij gemiddeld al bijna vierhonderd studenten рег јаar. Мeer dan de helft van hen kwam uit het buitenland. De eeuw erop schreef de universiteit duidelijk minder studenten in, ongeveer 21.ooo. Het aantal buitenlandse studenten nam evenredig af.

De keuzen van de studenten voor een bepaalde faculteit laten een onmiskenbaar patroon zien. De belangstelling voor theologie bleef min of meer gelijk, met ongeveer vijftien tot twintig procent van de studenten, terwijl de belangstelling voor rechten steeg van dertig naar veertig procent. Een opval- 


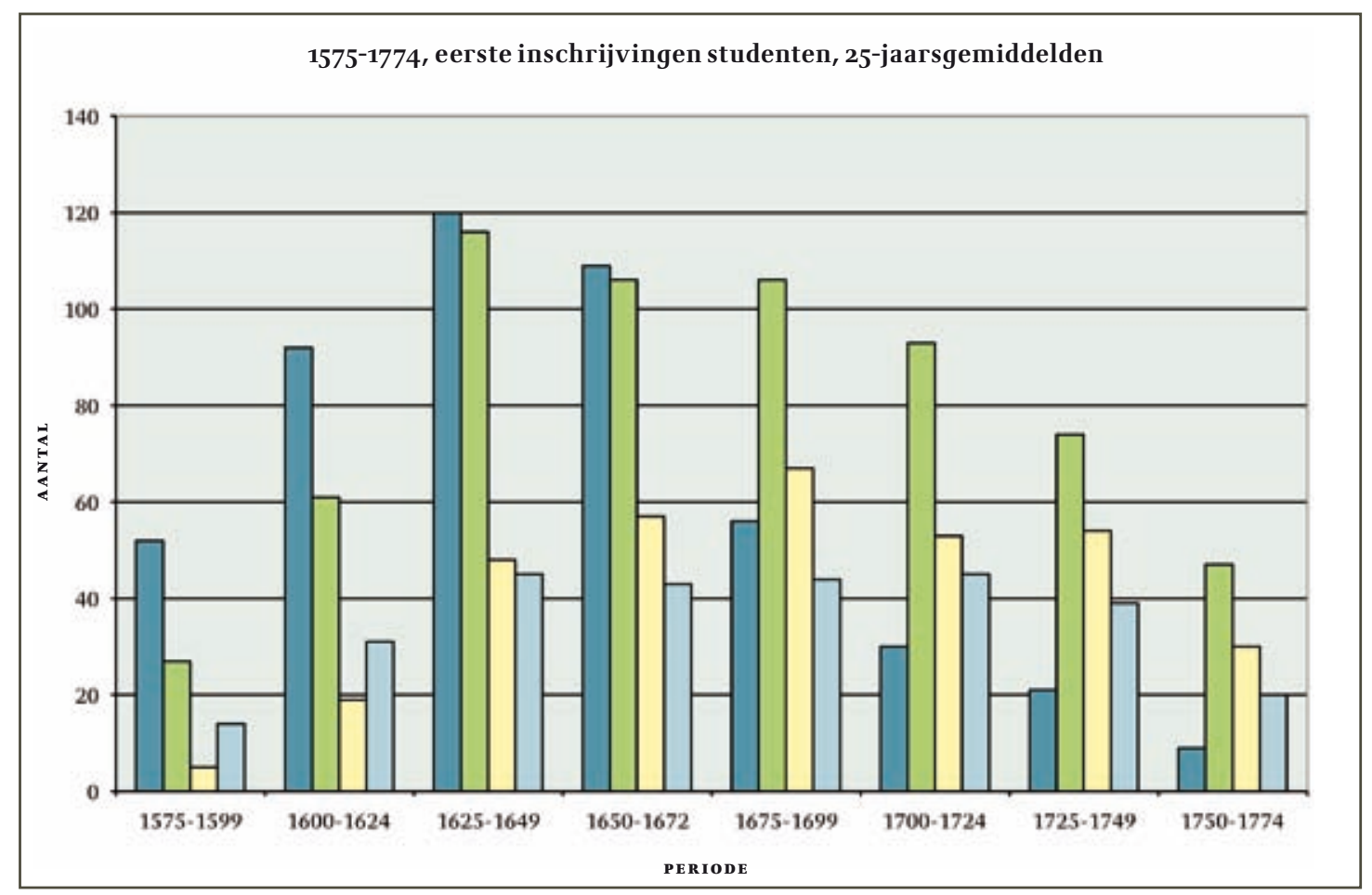

$\square$ Artes

$\square$ Rechten

$\square$ Geneeskunde

$\square$ Theologie

lende verschuiving vond plaats voor de filosofie (van meer dan de helft tot minder dan tien procent van de studenten) en de geneeskunde (van minder dan tien procent tot bijna eenderde).

Het beeld wordt scherрег als we ook de aantallen afgestudeerden meetellen. Aanvankelijk was de wens om een graad te halen erg laag. In de eerste vijfentwintig jaar van de universiteit haalde slechts zes procent van de ingeschreven studenten (151 in totaal) het doctoraat. Dat aandeel daalde in de vijfentwintig jaar daarna nog verder, naar vier procent (241 studenten op een totaal van 5607), om tussen 1625 en 1649 tot acht procent te stijgen (748 van 9393) en tussen 1650 en 1774 tot zestien procent (1270 van 7738 ).

De meesten (zeventig procent of meer) van die gegradueerden waren studenten uit de Nederlanden. Rechten was verreweg het meest gewilde vak. In 


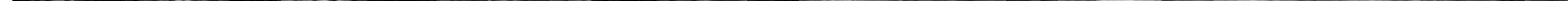




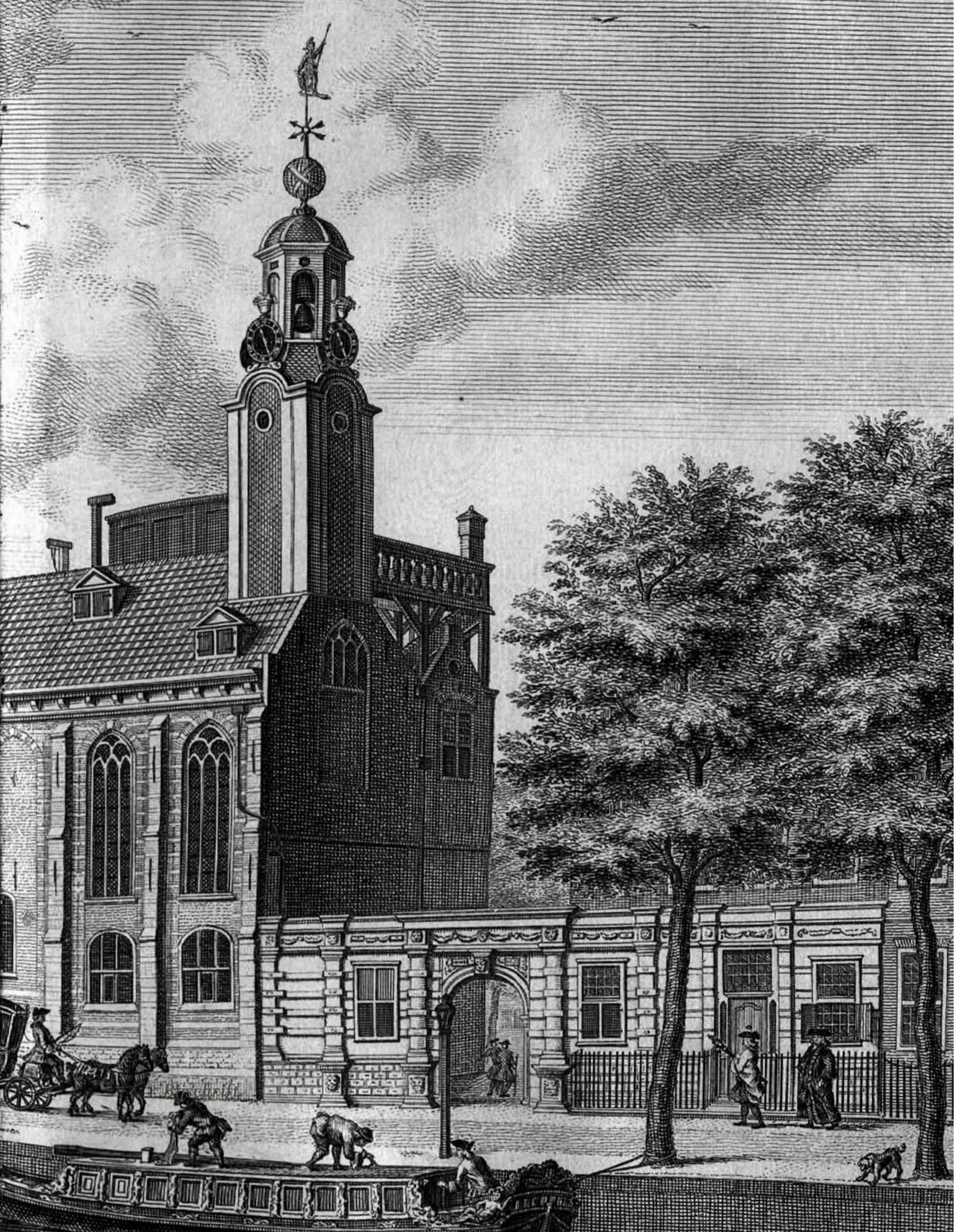


het eerste kwart van de zeventiende eeuw studeerde zeventig procent van de gepromoveerde studenten rechten. Maаг ook in de volgende vijfenzeventig jaar werd nog ruim vijftig procent van de promoties in de rechtenfaculteit gedaan. Ongeveer veertig procent kwam van de medische wetenschappen. Van de rest van de studenten studeerde ongeveer drie procent filosofie en ongeveer twee procent theologie.

In de tweede eeuw won de doctorsgraad aan gewicht. Werd hij aan het begin van de zeventiende eeuw door vijf procent van de studenten gehaald, in het derde kwart van de achttiende eeuw was dat gestegen tot 44 procent. Deze promovendi waren bijna zonder uitzondering afkomstig van de faculteiten rechten en geneeskunde. Маar er was wel verschil tussen beide faculteiten. Onder medische studenten was er sprake van een indrukwekkende toename: van twintig procent aan het begin van de zeventiende eeuw tot bijna zestig procent vijftig jaar later. Onder rechtenstudenten was de groei ronduit spectaculair: van acht tot 84 procent!

Als we beide eeuwen met elkaar vergelijken, zien we twee totaal verschillende oogmerken van de studie. In de eerste eeuw was die niet bedoeld om studenten voor te bereiden op de uitoefening van een beroep. Hoewel universitair onderwijs behalve theoretische inleiding ook praktische training omvatte, maakte slechts een klein deel van de studenten de hele cyclus af. $\mathrm{Na}$ tuurlijk moet rekening gehouden worden met studenten, buitenlandse maar ook Nederlandse, die hun graad aan een andere, meer рrestigieuze universiteit behaalden, zoals die van Orléans of Bologna. Toch haalde een groot aantal van hen nooit een graad. Deze groep zocht niet zozeer een beroepsopleiding als wel een soort initiatie in een geleerde cultuur, de opname in een maatschappij die meer nadruk legde op vorming en discipline dan op inhoudelijke training.

In de tweede eeuw werd de relatie tussen universitaire studie en beroepsopleiding sterker. De Leidse studentenbevolking van de achttiende eeuw viel nadrukkelijker uiteen in twee componenten: studenten uit de burgerij die zich voorbereidden op een bepaald beroep en studenten uit patriciaat of adel die zich eerder voorbereidden op een maatschappelijke positie. Voor de eerste groep was de studie hun belangrijkste bezigheid aan de universiteit - een 
graad halen was hun voornaamste doel. Voor de tweede groep waren het verblijf aan de universiteit en de deelname aan het sociale leven voldoende.

De overgrote meerderheid van de Leidse studentenbevolking, tweederde of meer, kwam uit de hogere middenklassen. Мaаг in de eerste eeuw waren ег ook veel studenten van tamelijk lage afkomst: onder hen kinderen van schoenmakers, timmerlieden, loodgieters, schilders, tuiniers en textielarbeiders. Voor de groep studenten afkomstig uit Leiden of uit een naburige stad als Den Haag kon dat oplopen tot vijfentwintig procent. In de tweede eeuw liep het aandeel studenten uit de lagere middenklasse terug tot tien procent.

Ook onder de studenten uit de hogere klassen is een dergelijke ontwikkeling zichtbaar. In beide eeuwen was er een kleine maar invloedrijke groep studenten van adellijke afkomst. Sommigen van hen kwamen uit de hoogste lagen: prinsen van Bohemen en Brandenburg of de Poolse prins Janus Radzivill, die zich op 14 april 1613 inschreef, samen met zijn opperhofmeester, zijn hofmeester, pedagoog en twaalf adellijke vriendjes. Ook de hogere adel van de Nederlanden, behalve uit het Huis van Oranje afkomstig uit de belangrijke families van Zeeland, Friesland, Utrecht en Gelderland, kwam naar Leiden. In totaal schreven zich in de eerste eeuw 930 adellijke studenten in, iets meer dan drie procent van het totaal aantal studenten.

Een goede indicatie van deze adellijke aanwezigheid zijn de 316 zogenaamde famuli die met hun nobele meesters meekwamen naar Leiden. In de tweede eeuw groeide hun aantal van 316 tot 616, terwijl het aantal adellijke studenten zelf daalde, van 930 tot 730 . Wat de groei van het aantal famuli verklaart, is het toegenomen percentage hoge adel. In de eerste eeuw waren ег 756 van lagere en 174 van hogere adel, in de tweede eeuw waren deze cijfers 300 respectievelijk 430. De Leidse universiteit werd in de achttiende eeuw duidelijk chiquer.

Wat bleef was een studentenpopulatie met verschillende maatschappelijke achtergronden en verschillende studieoogmerken. Dat zegt veel over de universiteit en vooral ook over de verschillende manieren waагоp men in de zeventiende en in de achttiende eeuw tegen haar aankeek. Voor de universiteit zelf was het minstens zo belangrijk dat ze erin slaagde al die groepen tot één geheel samen te smelten. In tegenstelling tot haar studenten had de uni- 


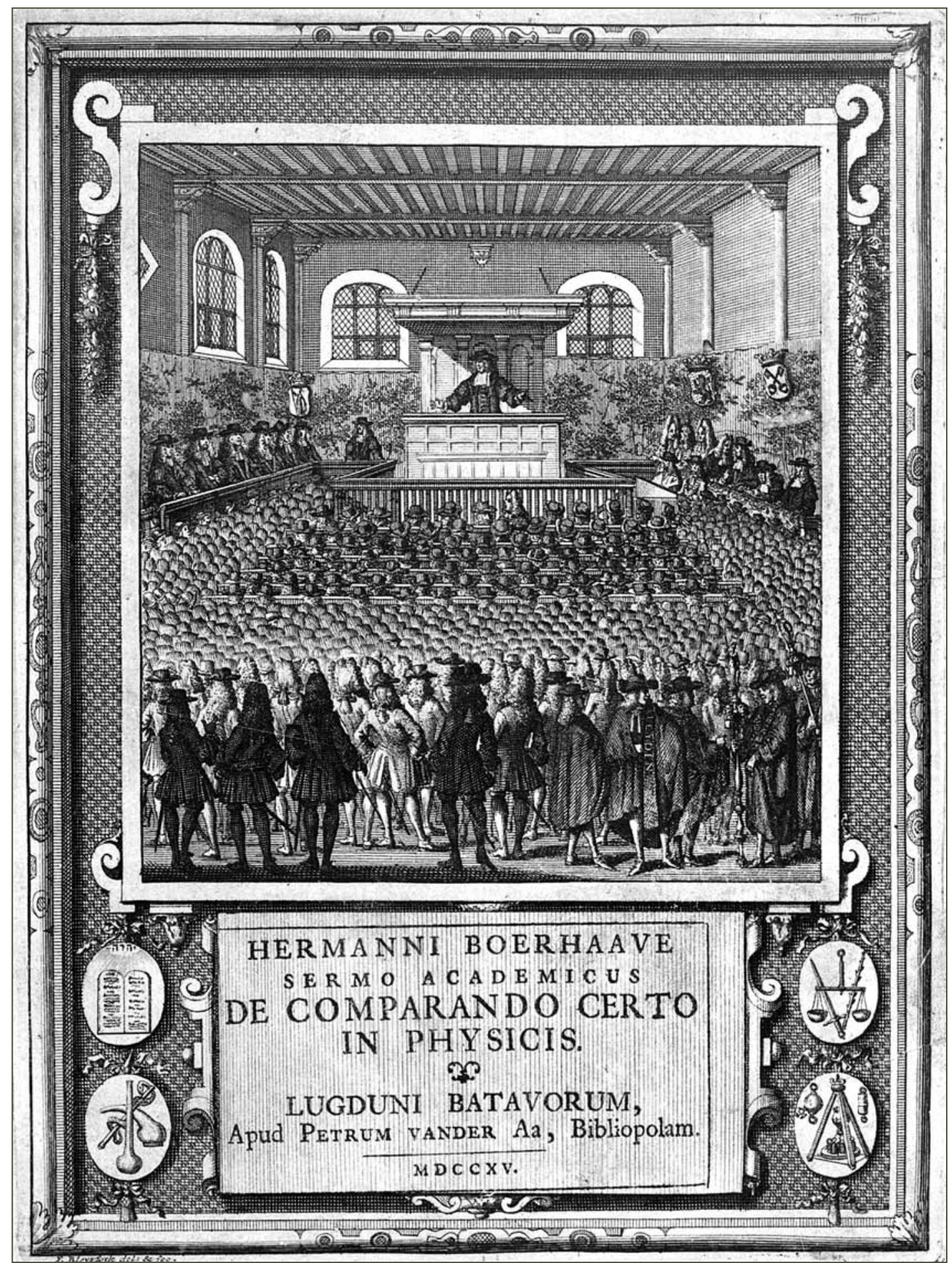

4 Titelpagina van de oratie van Herman Boerhaave (1668-1738), De comparando certo in physicis, 1715 
versiteit maar één oogmerk met het onderwijs dat ze verschafte. In de achttiende niet minder dan in de zeventiende eeuw was dit het aanleren van discipline.

\section{Studentenleven}

Het onderscheid tussen broodstudie en academische vorming gold natuurlijk niet absoluut. Sommige studenten combineerden de twee doelen en studeerden ijverig zonder hun sociale vaardigheden te verwaarlozen. De omgang van studenten concentreerde zich vooral op landgenoten, ongeacht hun sociale herkomst. Van buitenlandse studenten was bekend dat ze samen reisden en zich samen inschreven en vaak ook samen kamers huurden. De Engelsen, Fransen en Duitsers verbleven in eigen huizen of herbergen.

Zulke herbergen konden zelfs door landgenoten uitgebaat worden, zoals in het geval van de 'Yarmouth Arms' door Peter Powell, waar John Evelyn kamers huurde in 1641 en acht jаar later John Bеггy, met veertien andere Engelsen. Friedrich Luca, die in 1665 naar Leiden kwam, ging meteen langs bij 'sehr viele Landsleute', zoals hij schreef 'welche mich herzlich bewillkommten'. Hij huurde kamers in het huis van een andere Duitser, 'und renovirte so die alte Schlesische Bekanntschaft'. Van Nederlandse studenten buiten Holland was ook bekend dat ze op een kluitje woonden.

Die studenten zochten niet alleen veiligheid bij elkaar en berichten uit het vaderland, het ging hen wel degelijk om wat men tegenwoordig met een netwerk associeert. 'We pass'd our time in general very agreeably,' schrijft Alexander Carlyle, die maar een paar weken in Leiden verbleef, 'and very profitably too, for ten to 12 of us held meetings at our lodgings, thrice a week in the evenings, when the conversation of young men of good knowledge, intended for different professions, could not fail to be instructive. Much more so than the lectures, which except two, that of civil law, and that of chemistry, were very dull.' Carlyle, afgestudeerd in Edinburgh, kwam duidelijk niet voor de colleges naar Leiden. Deze zoon van een predikant, van nederige afkomst - wiens buitenlandse studie mogelijk was gemaakt door een toelage van een 
rijke vriend - kwam naar Leiden om zijn sociale netwerk te vergroten. Toen hij in november 1745 aankwam, noteerde hij meteen in zijn dagboek dat er zo'n 22 Britse studenten in Leiden waren. De lijst die hij optekende, laat de reden vоor zijn komst duidelijk zien: het omgaan met Engelsen uit hogere klassen.

Dit soort omgang gaf het studentenleven een zekere eenheid, die geïllustreerd kan worden aan de hand van de mode op het gebied van kleding. Vanaf het einde van de zeventiende eeuw waren studenten in Leiden herkenbaar aan hun Japanse rok. 'Die Studiosi gehen in Schlaffröcken zur Kirche und in die Collegia,' noteerde de Duitse reiziger Heinrich Ludolph Benthem, 'dass auch einige in etzlichen Jahren keine ordentlichen Kleider anziehen.' Een раar јаar later viel het zijn landgenoot Albrecht von Haller op dat ‘Man lebt in völliger Freyheit und geht unangefochten im Schlafroke durch die Strassen'.

Een dergelijke collectieve outfit wekte ook wel verbazing. 'In those loose gowns,' vertrouwde Knapton zijn dagboek toe, 'with sword, perukes, hats, brown slippers, and a book or two under their arms, they make an odd grotesque figure enough in the eyes of strangers.' Baron von Poellnitz vroeg zich zelfs af of de stad was getroffen door een besmettelijke ziekte: 'cela me fit сгоiгe, la première fois que je passai par cette ville, qu'il y regnait quelque maladie épidémique. En effet, tous ces deshabillés dans la rue paroissent autant de convalescens.' De baron dacht werkelijk van doen te hebben met patiënten aan de beterende hand.

Tendensen als deze naar eenvormigheid - rokken en pruiken, kleding en ontgroeningsrituelen, herbergen en theaters - werden, zelfs indirect, door de universiteit gestimuleerd. Leiden koos niet voor het systeem van Colleges om studenten te huisvesten en hun studieresultaten te volgen. Er zouden slechts twee Colleges in het leven geroepen worden, alleen bedoeld voor theologiestudenten. Het Statencollege, ondergebracht in een voormalig klooster, bood woonruimte aan dertig tot veertig studenten. Op zijn hoogtepunt, onder het bestuur van Festus Hommius, in het begin van de zeventiende eeuw, had het College ongeveer zestig studenten. Ze kregen er een volledige opleiding - eerst filosofie, dan theologie - tot protestants predikant. De Staten van Holland draaiden voor de kosten op en elk van de grote steden van 
Holland en Zeeland had het recht twee jongens te sturen - de kleinere één die vaak, maar niet noodzakelijkerwijs, van eenvoudige afkomst waren. Door de combinatie van filosofie en theologie verwierf het College zich een reputatie als 'Kuyle Josephs' waarin de grote debatten over arminianisme en cartesianisme op het scherp van de snede werden uitgevochten. Daarnaast was er gedurende de zeventiende eeuw het kleinere Waalse College, voor de vorming van predikanten van de Franstalige hervormde kerken.

Eг waren ook andere manieren om de studenten in de gaten te houden. Uit een volkstelling van 1581 blijkt dat studenten die apart werden geregistreerd in een paar grote studentenhuizen woonden. De eigenaren waren hoofdzakelijk privéonderwijzers, maar ook de rector van de Latijnse School, Nicolaus Stochius, en een professor, Rudolphus Snellius, hadden zo'n huis. Ze hadden altijd zowel jonge leerlingen als studenten om voor te zorgen. Stochius, bijvoorbeeld, huisvestte 31 leerlingen en twintig studenten, terwijl onder de 21 studenten van Snellius en de zestien van Volcker Westerwolt ook scholieren zullen zijn geweest. Samen met een раar kleinere gasthuizen gaven ze onderdak aan 92 studenten, 36 procent van de totale studentenpopulatie; 43 procent (108 studenten) huurde bij particulieren, terwijl elf procent bij zijn ouders woonde en tien procent een eigen huishouden had.

Het was in de zeventiende eeuw niet ongebruikelijk dat ook professoren kamers verhuurden. Bronchorst, bijvoorbeeld, die in zijn dagboek uitgebreid over het onderwerp schrijft, schijnt vrij гергеsentatief geweest te zijn met de drie tot zes studenten die hij in zijn huis onderbracht, voedde en onderwees. Fysiek en intellectueel voedsel gingen letterlijk samen, want het onderwijs de uitleg en overhoring van de colleges die de studenten overdag gevolgd hadden - vond plaats tijdens de maaltijden.

In de achttiende eeuw verhuurden professoren geen kamers meer aan studenten. Een ander gebruik bleef wel overeind en lijkt zelfs toegenomen te zijn. De studenten kozen een bepaalde professor, of zij kregen het advies dat te doen, die op hun welzijn lette, dienstdeed als biechtvader en studieadviseur en hun ouders informeerde over hun vorderingen. Het lag in het verlengde van de humanistische opvatting van contubernium, het samen met je pupillen wonen (letterlijk het delen van dezelfde tent), in Leiden voorgestaan door 


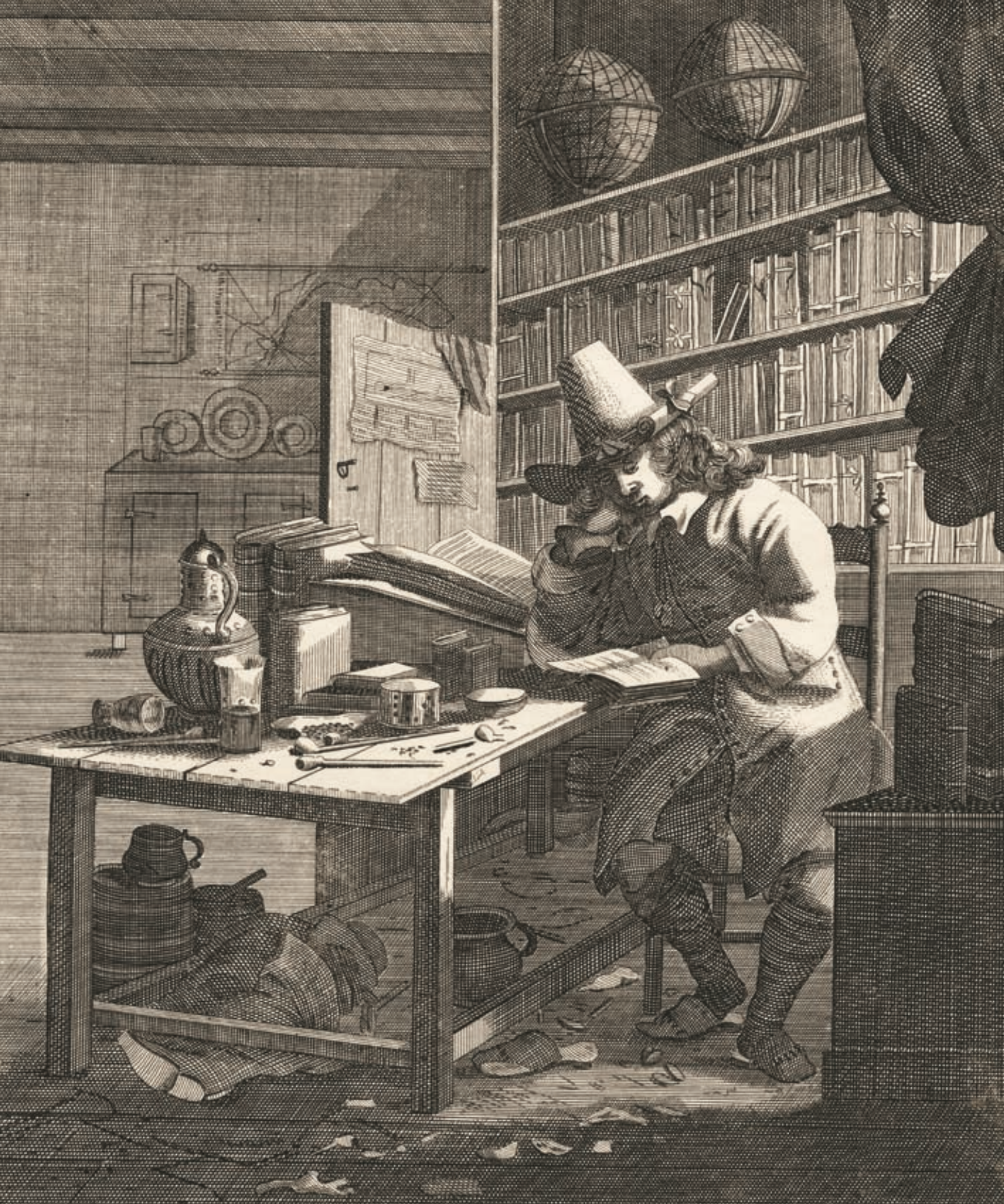

- Student, derde kwartzeventiende eeuw 
Justus Lipsius. Het vergde van de professor niet alleen dat hij intellectueel en moreel een voorbeeld stelde, het impliceerde ook een levenslange belangstelling in de loopbaan van de student.

Ondanks zijn reputatie van geweld en ontucht kwam het studentenleven, al of niet onder directe invloed van de professoren, steeds meer in de ban van disciplinaire maatregelen en morele aansporingen. Het hele idee van het Forum Privilegiatum was doordrongen van noties van discipline en correctie. Een rechtszaak kon verschillende vormen aannemen en de meest gebruikelijke was een regeling tussen de betrokken partijen. Het is waar, als het tot een veroordeling kwam, was de straf meestal erg laag. Маaг dat kwam omdat men de gevolgen van de straf ook meewoog. De 'liberalia ingenia' van de jeugd konden beter met 'zoetheid' dan met strengheid worden behandeld. Onrijp fruit moest niet geplukt worden omdat het een beetje zuur was.

Zware straffen werden alleen uitgesproken bij collectief geweld. Omdat publiek gedrag geassocieerd werd met еeг, werd het verstoren van de openbare orde, tenzij men spijt betuigde en de bereidheid toonde om de schade te vergoeden, altijd streng gestraft. 'Condonanda vitia non flagitia sunt,' zei Cunaeus tegen de luidruchtige studenten die protesteerden tegen de doodstraf voor een famulus van de Poolse prins Radzivill, die een nachtwacht had vermoord. Fouten kon men vergeven, schanddaden niet. Het was de enige keer dat zo'n zware straf werd uitgevoerd. In het algemeen werd wroeging veel belangrijker geacht dan straf.

Dit was ook de reden voor de senaat om de nationes, de regionale clubs waarin de studenten zich organiseerden, de oorlog te verklaren. Het fenomeen van de studentennaties werd gezien als een inbreuk op de autoriteit van de senaat en de oorzaak van allerhande wangedrag. Het eerste verbod op die organisaties dateerde al van 1592. In 1600, 1606, 1627 en 1641 werden de verboden herhaald, wat zowel duidt op hun geringe succes als op de volharding van de senaat. In 1659 zetten drie studentennaties hun vijandigheden opzij om met meer kracht te kunnen onderhandelen met de senaat. Het zou hun zwanenzang zijn, aangezien het de senaat noopte het verbod te koppelen aan de eed die studenten bij hun inschrijving aflegden.

Deze aanpak lijkt succes te hebben gehad. Het leidde onder andere tot de 
opheffing van de natie van studenten uit Gelderland en Overijssel, die hun wapenboek aan het nageslacht lieten. Een blik op de inhoud leert dat de studenten het disciplinaire karakter van het universitaire onderwijs onder elkaar eenvoudig kopieerden. De statuten kenden allerlei maatregelen tegen het gebruik van geweld en beklemtoonden gedragscodes die wanorde moesten voorkomen en de interne hiërarchie bewaren. Als het de senaat bij zijn bestrijding van de naties alleen te doen was om de discipline, had die het net zo goed kunnen laten. Zijn optreden lijkt еerder een uitvloeisel van het (middeleeuwse) verschil van opvatting over wie het aan een universiteit voor het zeggen had, de studenten, zoals oudtijds in Bologna het geval was, of de professoren, volgens het Parijse model.

Dit laat onverlet dat de universiteit als geheel ervan overtuigd was dat de studie niet alleen kennis moest omvatten, maar ook geestelijke en lichamelijke discipline moest bijbrengen. Een reeks met de universitaire studie geassocieerde vaardigheden, zoals schermen en paardrijden, zingen en dansen, werd gemotiveerd met de eis van respect voor de controle van de geest over het lichaam, voor een goede houding en gevoel voor maat. De universiteit bevorderde sporten als paille-maille en kolf als 'dienende tot exercitie vande studenten'.

Andere vormen van tijdspassering hadden eerder een moreel doel: het bijwonen van kerkdiensten van de verschillende denominaties of executies van veroordeelde criminelen. Executies konden zelfs het onderwijs verstoren, omdat de ргоfessor ег zijn college vоor moest afzeggen. Zelfs theaterbezoek, waarover de calvinisten sterk tegenstrijdige gevoelens hadden, werd door sommigen aanbevolen om zijn morele effect. Geestige kritiek op het toneel, vonden ze, had meer effect dan een ernstige les vanaf de preekstoel.

Dit alles vormde een tegenwicht tegen de ontwikkeling binnen het universitaire onderwijs. Dat onderwijs was ontegenzeggelijk van algemeen vormend veel specifieker geworden, zoals de universiteit niet meer de algemene maatschappelijke instelling van weleer was, maar veel meer gericht op de uitoefening van bepaalde beroepen. Toch was de maatschappelijke oriëntatie daarmee niet verdwenen. Hoewel de universiteit, grofweg gesteld, veranderde van een cursus vrije kunsten in een medische en juridische opleiding, bleef 


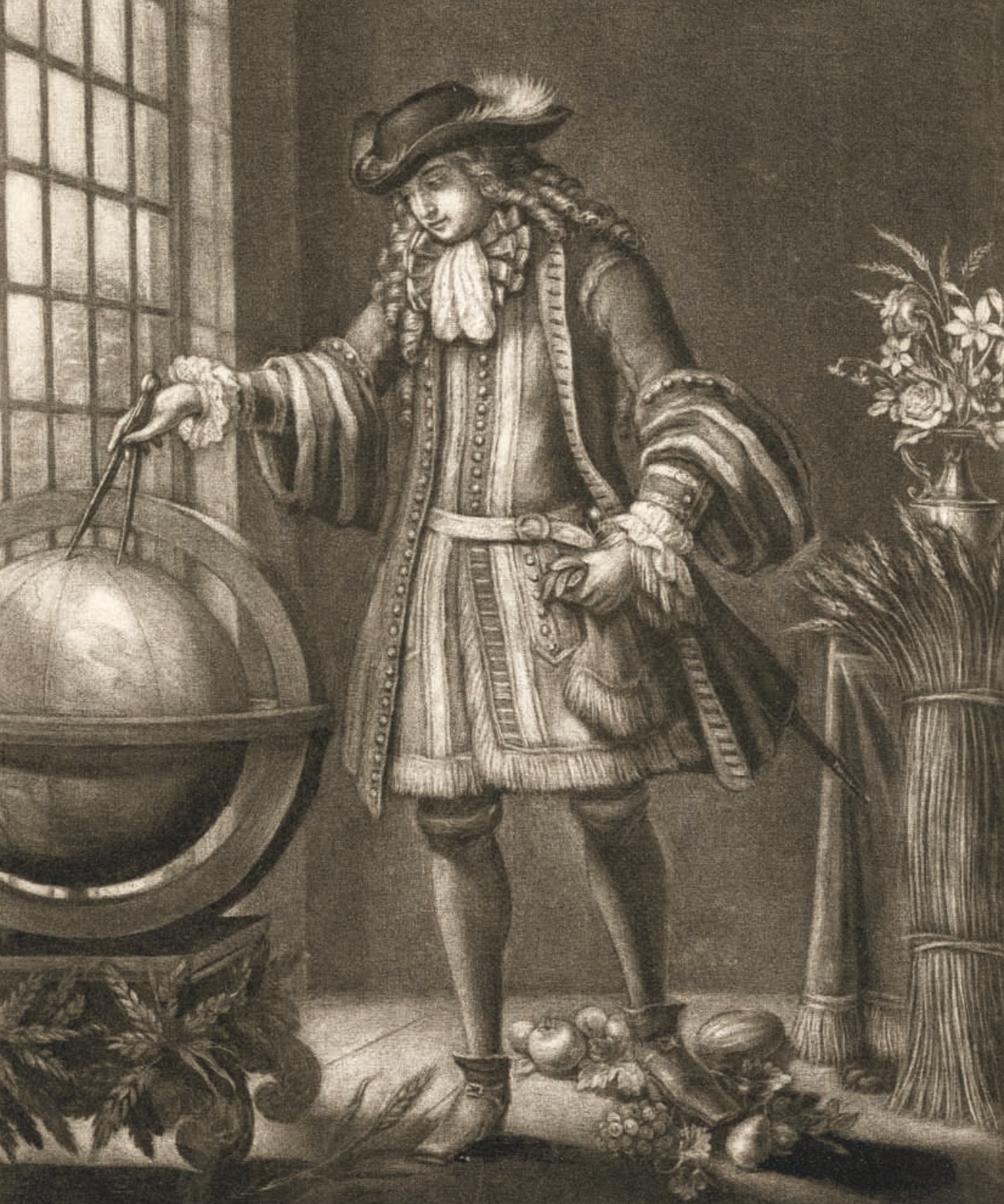


de nadruk liggen op discipline en karaktervorming. De grondgedachte bleef een bestuurlijke en professionele elite te vormen die een intermediaire positie in de maatschappij zou innemen.

In die zin waren de verwachtingen van de studenten niet anders dan die van de maatschappij in haar geheel. Of we nu luisteren naar de handboeken voor een adellijke educatie of de modellen voor burgerlijke opvoeding, en of we nu kijken in de 'spiegels' voor prinsen of bekeken worden door 'spectators' uit de middenklasse, de klemtoon ligt op algemene kennis: te veel specifieke kennis werd als nadelig gezien, voor een koning net als voor zijn onderdanen. Men beschouwde Nero's extreme muziekliefde als de verklaring voor zijn rampzalige bewind. Een algemeen gevormd mens, zo dachten de Grieken en ook veel zeventiende- en achttiende-eeuwse denkers over onderwijs, moest 'leren fluit te spelen, maar niet te goed'.

En zoals een prins naar evenwicht moest zoeken tussen kennis en macht, arte et marte, zo moest de Nederlandse handelsklasse rijkdom aan wijsheid paren, zakengeest aan de studie van filosofie. Toen Barlaeus in 1632 bij de opening van het Athenaeum Illustre de stadsraad van Amsterdam toesprak en hij het had over de Mercator sapiens, was hij geheel in lijn met de spectatoriale geschriften die een eeuw later de studenten aanrieden om het midden te houden tussen uitspattingen en betweterigheid, tussen te weinig en te veel studeren, tussen 'te veel' en 'te weinig wereld'.

\section{Wetenschappelijke cultuur}

Tussen te veel en te weinig wereld, tussen haar internationale uitstraling en haar lokale Leidse bestaan, cultiveerde de universiteit haar regionale banden. Ze was daarbij een bron van inspiratie voor een karakteristieke wetenschappelijke cultuur die zich vanuit de provincie Holland naar de rest van de $\mathrm{Ne}^{-}$ derlanden verspreidde. De beste illustratie hiervan vormen de vier universitaire instituten, die alle dateren van het einde van de zestiende eeuw (en die een symbolische eenheid moesten vormen): de bibliotheek, het anatomisch theater, de botanische tuin en de schermschool.

4 Student in galakostuum, begin achttiende eeuw 
De universiteitsbibliotheek was niet alleen een instrument voor studie, het was de eerste bibliotheca publica in de Nederlanden, bedoeld als ontmoetingsplaats voor geleerden, en onderdeel van een gemeenschap van wetenschappers, drukkers en boekverkopers die niet alleen hun meningen deelden, maar ook hun boeken. De bibliotheek bood de geleerde behalve rust een geleerd 'apparaat' voor filologische studies. Het was in die zin meer een algemene dan een gespecialiseerde bibliotheek, bedoeld voor boeken én voor interessante voorwerpen. Er waren kaarten en globes, portretten van geleerden en beroemde mannen in de Respublica Litteraria.

Halverwege de achttiende eeuw was deze bibliotheek uitgegroeid tot de respectabele omvang van omstreeks 25.00o banden, met als nadrukkelijk doel 'ten algemeene nutte' te zijn. Ze veronderstelde dan ook het gebruik in een geleerde context en kende een duidelijke klemtoon op de klassieken, theologie en geschiedenis. Het verschil met grote privébibliotheken was niet zo groot. Het langdurig lenen van boeken, niet alleen uit een publieke bibliotheek maar ook van privépersonen en zelfs van boekhandels, was heel gebruikelijk. De universiteitsbibliotheek kende tegelijk twee grote lacunes: wat in Leiden zelf geproduceerd werd, werd minder snel gekocht, en de aanschaf van contemporaine werken in het algemeen werd afgewenteld op de professoren zelf. Dit vooronderstelde een gemeenschap die Leiden, boekverkopers en drukkers incluis, als één grote bibliotheek beschouwde.

Het anatomisch theater was, 's winters als het vroor, het toneel van anatomische secties van groot spektakel. Colleges werden onderbroken, toegangskaartjes verkocht, de hele senaat was aanwezig. Er werden kaarsen aangestoken en de vloer was bedekt met geurige kruiden. Meer dan driehonderd mensen woonden de theatrale gebeurtenissen bij. 's Zomers werd de hele collectie van skeletten en preparaten, inscripties en instrumenten tentoongesteld. Het theater was dan veranderd in een museum gewijd aan de kortheid van het leven en de ijdelheid van het menselijk verlangen. Men kon rondleidingen krijgen en er waren catalogi.

De botanische tuin wilde naturalia en artificialia laten zien in een zinvol verband. De drie rijken van de natuur - stenen, planeten en dieren - werden gecombineerd met gereedschappen uit verschillende culturen. Hier is de

- Student in Japanse rok, begin achttiende eeuw 


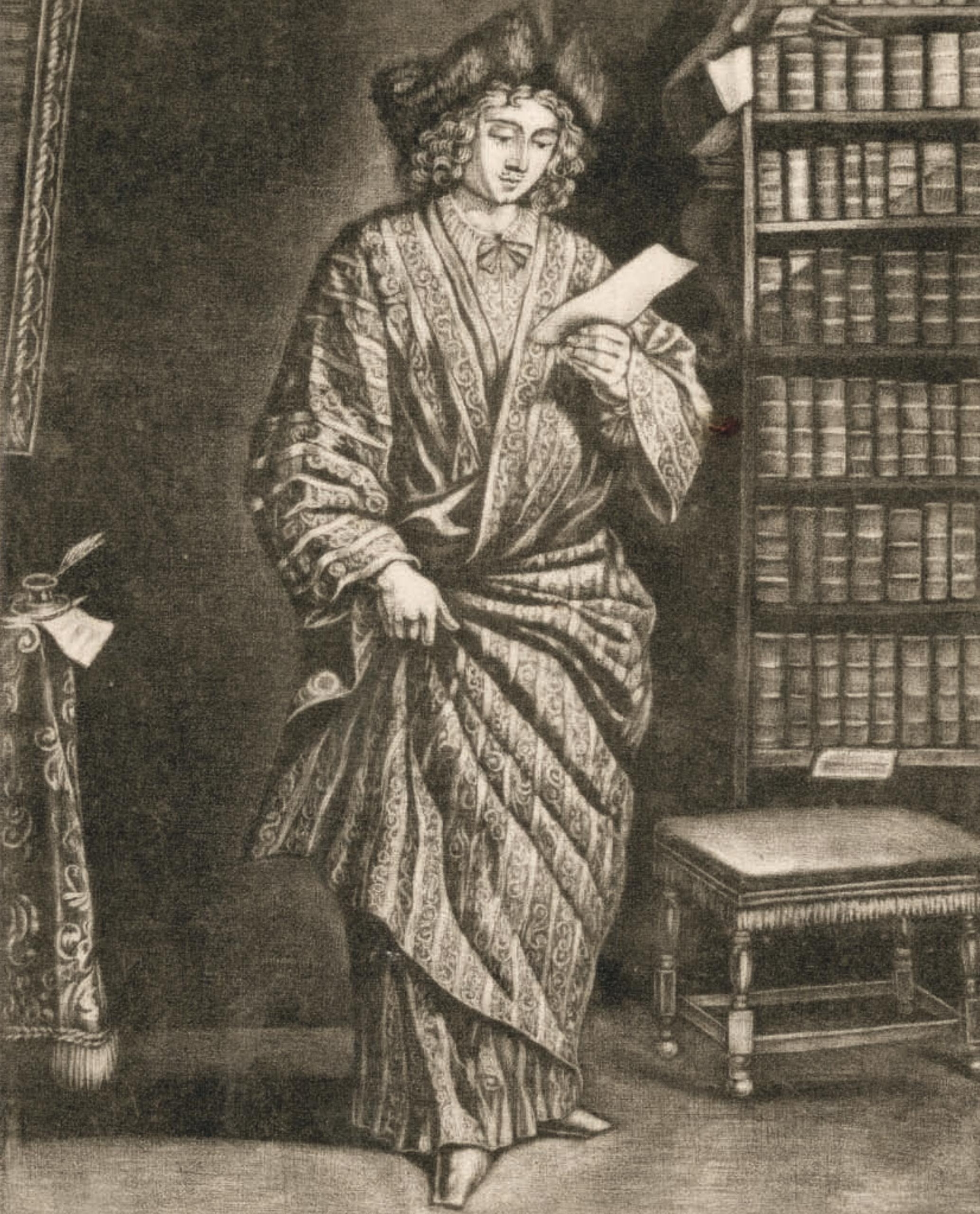


sterke eenheid van de vier instellingen het meest zichtbaar en vergelijkbaar met de vier temperamenten of de vier lichaamsvochten. Ze vertegenwoordigden de symbolische eenheid van leven en dood, van woorden en dingen, van het natuurlijke en het kunstmatige. Dat was ook de bedoeling van de vierde instelling, de schermschool, waar heel beknopt de thema's leven en dood, cultuur en natuur, geweld en controle werden herhaald.

Aan de schermschool werd niet alleen schermen onderwezen, maar ook paardrijden, schieten en vendelzwaaien, dat wil zeggen: alles wat geassocieerd werd met wat een stadswacht moest kunnen en wat burgerplicht was. Het onderwijs was gebaseerd op wiskundige principes en gebeurde met behulp van geometrische figuren op de grond die de juiste positie en houding aangaven. De lessen werden gegeven door onder anderen Ludolph van Ceulen, wiskundeleraar en de man die het getal pi benaderde tot twintig plaatsen na de komma, een wapenfeit dat hij op zijn graf zou laten vermelden. In 1600 kreeg Van Ceulen opdracht om ook civiele en militaire techniek te onderwijzen. In die opleiding, de 'Nederduytsche Mathematique', waren de lessen in het Nederlands en kregen de studenten grondig onderricht in het bouwen van forten.

Instellingen als deze maakten de universiteit het topje van een onderwijspiramide én het centrum van een netwerk van instellingen en activiteiten die samen een cultuur van geleerdheid en beschaving, nieuwsgierigheid en vorming onderhielden. Leiden was bijvoorbeeld niet alleen een centrum voor boekhandels - Albrecht von Haller schreef in zijn dagboek: ‘Ganze Strassen sind voll Buchhändler, und alle Winkel voll Druckereyen' - maar ook, met befaamde uitgevers als Plantijn, de Elzeviers, Maire, Van der Aa en Luchtmans, het centrum bij uitstek voor de wetenschappelijke boekproductie.

Tegelijkertijd was het echte boekhandelscentrum van Holland natuurlijk Amsterdam. In 1688 telde het boekverkopersgilde in die stad niet minder dan 186 leden, een bestand van grote verscheidenheid en specialisatie. Daarnaast waren Den Haag en Rotterdam eveneens bloeiende boekhandelscentra en ook Haarlem, Gouda en Delft konden bogen op een rijke traditie. Bovendien kenden ook de kleinere steden, zoals Edam, Enkhuizen en Hoorn, hun stadslibrijen. Gecombineerd met het aanzienlijke particuliere boekenbezit, al- 

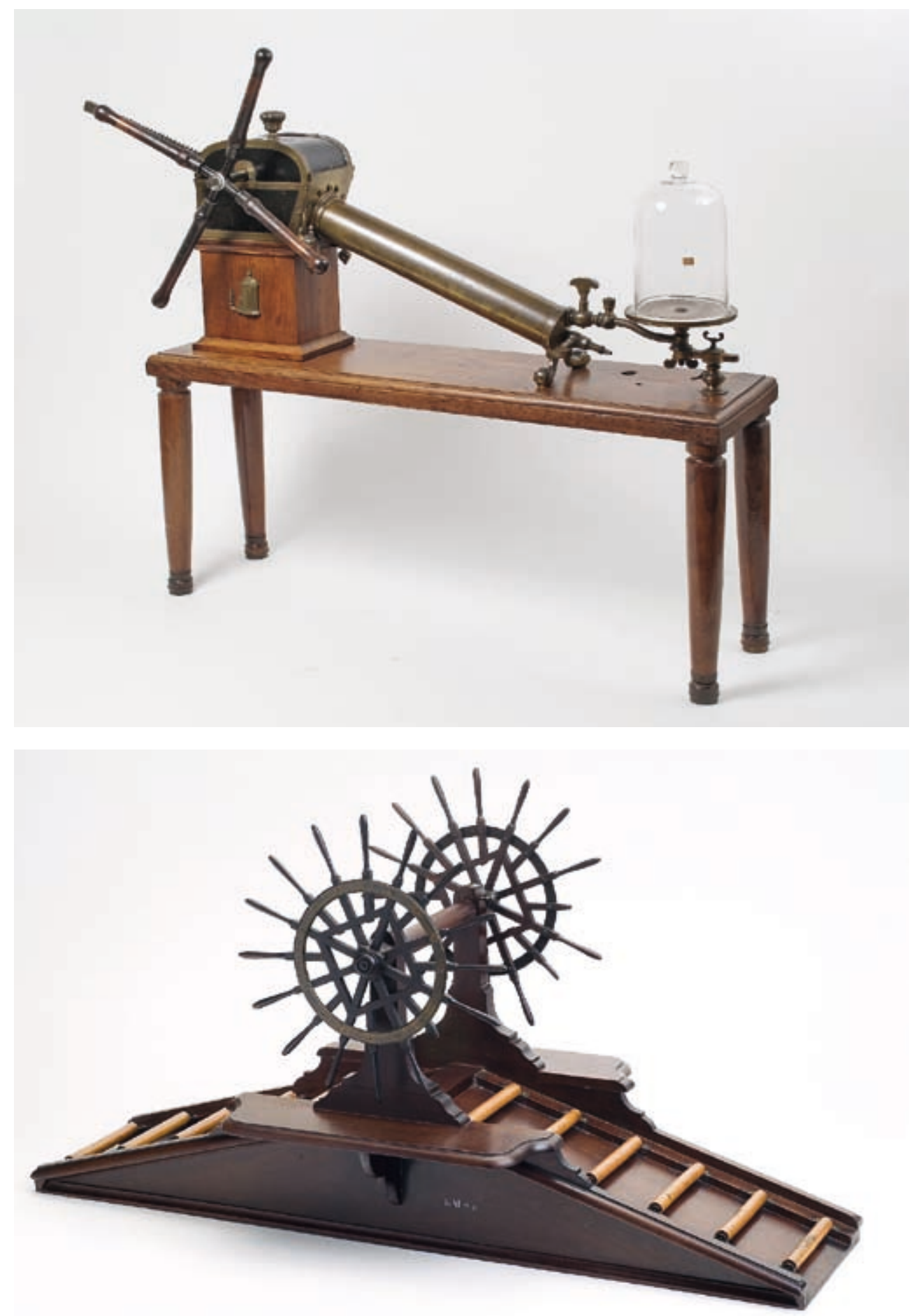

A Model van een luchtpomp, uit de collectie van het Theatrum Physicum

$\checkmark$ Model Overtoom, uit de collectie van het Theater Physicum 
thans onder de meer draagkrachtigen - de bibliotheken van regenten en rijke burgers moeten gemiddeld tussen de honderd à tweehonderd titels omvat hebben - en het in de achttiende eeuw groeiende verschijnsel van de leesgezelschappen, resulteerde dit in een, ook in internationaal perspectief, hoge leesdichtheid.

Naast het verzamelen van boeken was het aanleggen van collecties naturalia en artefacten, 'zeldzaamheden', een bezigheid die een breed deel van de burgerij in haаг ban hield. Ook hier gaf de Leidse universiteit het belangrijkste geïnstitutionaliseerde voorbeeld. Наar bezit aan zeldzaamheden, te kijk voor ieder die daarvoor belangstelling had in het 'ambulacrum' van de hortus botanicus en in de 'zomeropstelling' van het anatomisch theater, trok een menigte nieuwsgierigen uit binnen- en buitenland. Skeletten van mens en dier waren er te zien, preparaten en instrumenten, zaden en gedroogde planten, exotica uit alle werelddelen en een uitgebreide prentenverzameling.

Dit alles stond deels in dienst van de geleerdheid. De collectie was een pendant van de bibliotheek. Naast de filologie was het verzamelen van oudheden een middel om de klassieke oudheid te геstaureren. Evenals de klassieke literatuur gaf het theater een beschrijving van de volheid van het bestaan. Maar zoals er van de klassieke auteurs een morele werking uitging, zo beeldde de collectie van het theater de verscheidenheid van Gods handelen met de mensen uit. Pièce de résistance ervan werd gevormd door twee skeletten (de één met spade, de ander met appel) met daartussen een boom waarin een slang gekronkeld was. Het paradijs dus, met Adam en Eva, maar dan niet als tuin en symbool van het leven, maar omgekeerd, als 'anatomie moralisée', als symbool van vergankelijkheid en dood.

Dergelijke verzamelingen werden ook in andere steden gecombineerd met tuinen of anatomische theaters. Мaаг ze waren daartoe niet beperkt. Het verzamelen van zeldzaamheden was een bezigheid die met groot enthousiasme en geldelijke inspanning door een breed deel van de burgerij beoefend werd. Daartoe in staat gesteld door de grote handelsstromen die de provincie in contact bracht met de hele wereld, was het vooral het koopkrachtige publiek in de steden met kantoren van de handelscompagnieën, Amsterdam bovenal, maar ook Hoorn en Enkhuizen, Delft en Rotterdam, dat zich op het verzamelen van zeldzaamheden toelegde. 
In de achttiende eeuw kregen dergelijke verzamelingen een ander karakter. Wat aanvankelijk vooral een encyclopedisch doel had, waar 'de groote weerelt' maar dan 'in 't kleen' werd voorgesteld, werd meer en meer een specialistische bezigheid, met concentratie op bijvoorbeeld alleen naturalia en daarbinnen bijvoorbeeld op alleen schelpen. Tegelijk nam het aantal verzamelaars alleen maar toe, geholpen door een omvangrijke groothandel en gespecialiseerde winkels, die aan het interieur van menig Hollandse burger een exotische aanblik verleenden en die de buitenlander de indruk konden geven dat Holland zelf een zeldzaamheid was.

Naast en in het verlengde van dit verzamelen kende Holland een intensieve tuincultuur. Ook hierin ging de universiteit haar рrovincie voor. De hortus botanicus van de universiteit was aanvankelijk bedoeld 'tot bevordering van het Studium Medicinae'. Toch werd de tuin uiteindelijk niet zozeer een hortus medicus als wel een echte hortus botanicus, waarvan slechts eenderde van de planten medicinaal van karakter was en een groot deel van exotische herkomst. De eerste opzieners van de tuin onderhielden daartoe geregelde contacten met de handelscompagnieën en bouwden aparte kassen om 's winters de niet-winterharde planten op te bergen en met behulp van een kachel in leven te houden.

De Leidse hortus stond niet op zichzelf, maar gaf een accent binnen een tuinencircuit van grote variëteit. Na verloop van tijd kregen ook andere steden hun eigen hortus publicus, waarvan die van Amsterdam uit 1682 de grootste zou worden. Daarnaast was er een menigte aan kwekerijen op de zandgrond achter de duinen bij Leiden, Haarlem en Alkmaar. Samen met de particuliere tuinen, van de kleine moes- en kruidtuinen, boomgaarden en houten opstallen in de 'banlieue' van elke stad tot de grote buitens als Buitensorgh, Hofwijck en Sorgvliet, vormden ze een collectieve activiteit waarin wetenschappelijke, economische en maatschappelijke motieven moeiteloos verweven waren.

Ook met haar anatomische theater, waаг anatomische lessen gegeven werden en, in kleinere kring, proefondervindelijk onderzoek naar de fysiologie plaatsvond - in de loop van de zeventiende eeuw kwam de vivisectie van vоoral honden in zwang in het onderzoek naar de bloedsomloop, de functio- 


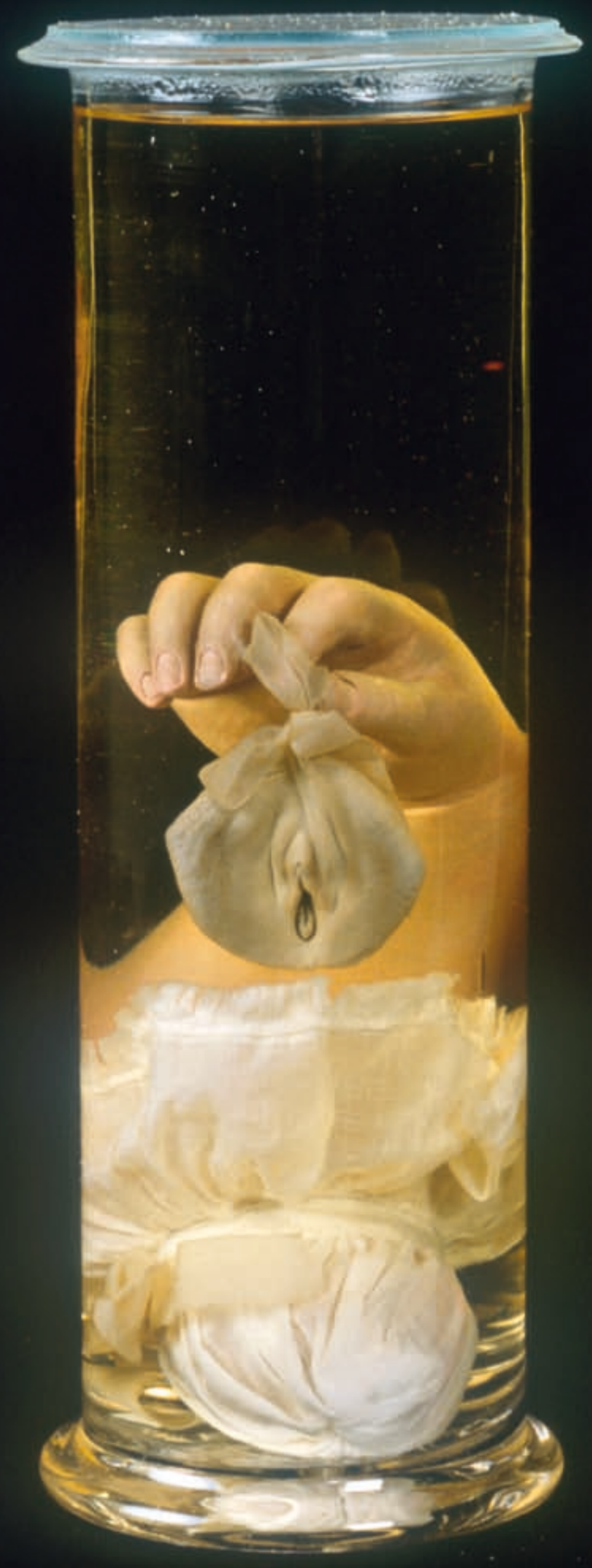


nering van de voortplantingsorganen en de werking van de klieren - ging de universiteit de Republiek voor. Er waren veel van dergelijke anatomieplaatsen. De chirurgijnsgilden van Amsterdam en Delft, 's-Gravenhage en Dordrecht, Rotterdam, Alkmaar en Haarlem hadden alle een snijzaal. Met name de theatra van Leiden en Amsterdam, Delft en Den Haag ontwikkelden zich tot meer dan locaties voor chirurgische lessen. In samenhang met bibliotheek, verzameling van zeldzaamheden en botanische tuin werden deze theatra ware culturele centra waar wetenschappelijk onderzoek, artistieke productie en economisch handelen hand in hand gingen en waar volksvermaak en maatschappelijke ordening in elkaars verlengde lagen.

Ook in de verspreiding van technische kennis, ten slotte, had de universiteit een voortrekkersrol. De 'Nederduytsche Mathematique', in 1600 op last van prins Maurits zelf in het leven geroepen en door Simon Stevin inhoudelijk opgezet, leerde een bij uitstek divers publiek van burgerlijke studenten en gewone handwerkslieden de beginselen en praktijk van uiteenlopende vaardigheden als vestingbouw, landmeetkunde en zeevaartkennis. In de achttiende eeuw ging de technische kennis zoals de universiteit die verspreidde onderdeel uitmaken van de gewone lessen in wis- en sterrenkunde, scheikunde en natuurlijke historie. De universiteit creёerde daartoe allerlei kabinetten van schei- en natuurkunde, waаг grote popularisatoren van de newtoniaanse wetenschapsopvatting als Boerhaave, 's Gravesande en Musschenbroek de proefondervindelijke wijsbegeerte combineerden met geavanceerde belangstelling in elektriciteit en stoom.

Маar hiertoe beperkte de universiteit zich niet. Een universiteitsstad was ook, zoals we zagen, bij uitstek de plaats waarheen zich allerlei privaatdocenten begaven om de studerende jeugd les te geven in wat een 'deugdzame en edele opvoeding' heette. De andere grotere steden van Holland waren eveneens het decor van het optreden van kleine 'kennisondernemers', van wie velen zich concentreerden op meer cognitieve of wetenschappelijke gebieden, zoals reken- en taalkunde, wis- en natuurkunde, sterren- en scheikunde. Ook lessen in het boerenbedrijf of wat de koopman diende te weten, werden door allerhande rondtrekkende lieden in semigeleerde of direct populaire trant gegeven.

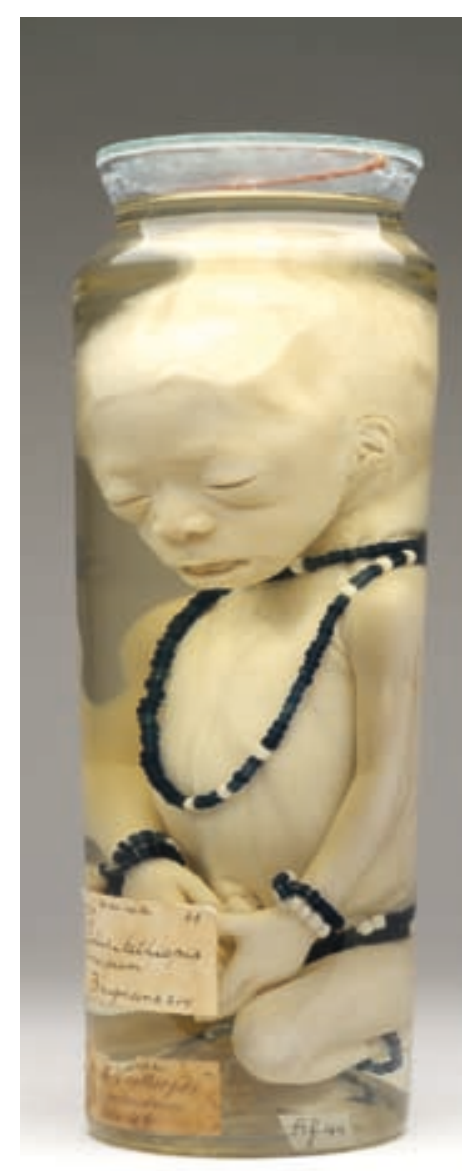

^ Preparaat, waarschijnlijk vervaardigd door FrederikRuysch (1638-1731)

- Menselijkefoetus, uit de collectie-Brugmans 
Minstens zo belangrijk was dat zowel grote professoren als kleine kennisondernemers door het vervaardigen van hand- en lesboeken menig autodidact in staat stelden door zelfstudie zijn kennis aan te vullen. Aanvankelijk waren dat vooral boeken over landmeet- en zeevaartkunde en populaire juridische of medische kennis - praktizijnswoordenboeken voor de notaris, nieuwe operatietechnieken voor de chirurgijn -, maar allengs kwamen daar onderwerpen als land- en tuinbouw, veeteelt en natuurlijke historie, experimentele natuurkunde en scheikunde, waterbouwkunde en molenbouw bij.

Er was dan ook, in intellectueel opzicht, niet zoiets als een neergang te constateren. De Leidse universiteit leek zich in veel opzichten te onttrekken aan de achteruitgang zoals die allerwegen in de Republiek geconstateerd werd. Ze werd nog in 1765, in de befaamde Encyclopédie van Diderot en D'Alembert, omschreven als 'la première de l'Europe'. Het had er alle schijn van, aldus deze verlichte auteurs, dat alle grote namen uit de republiek der

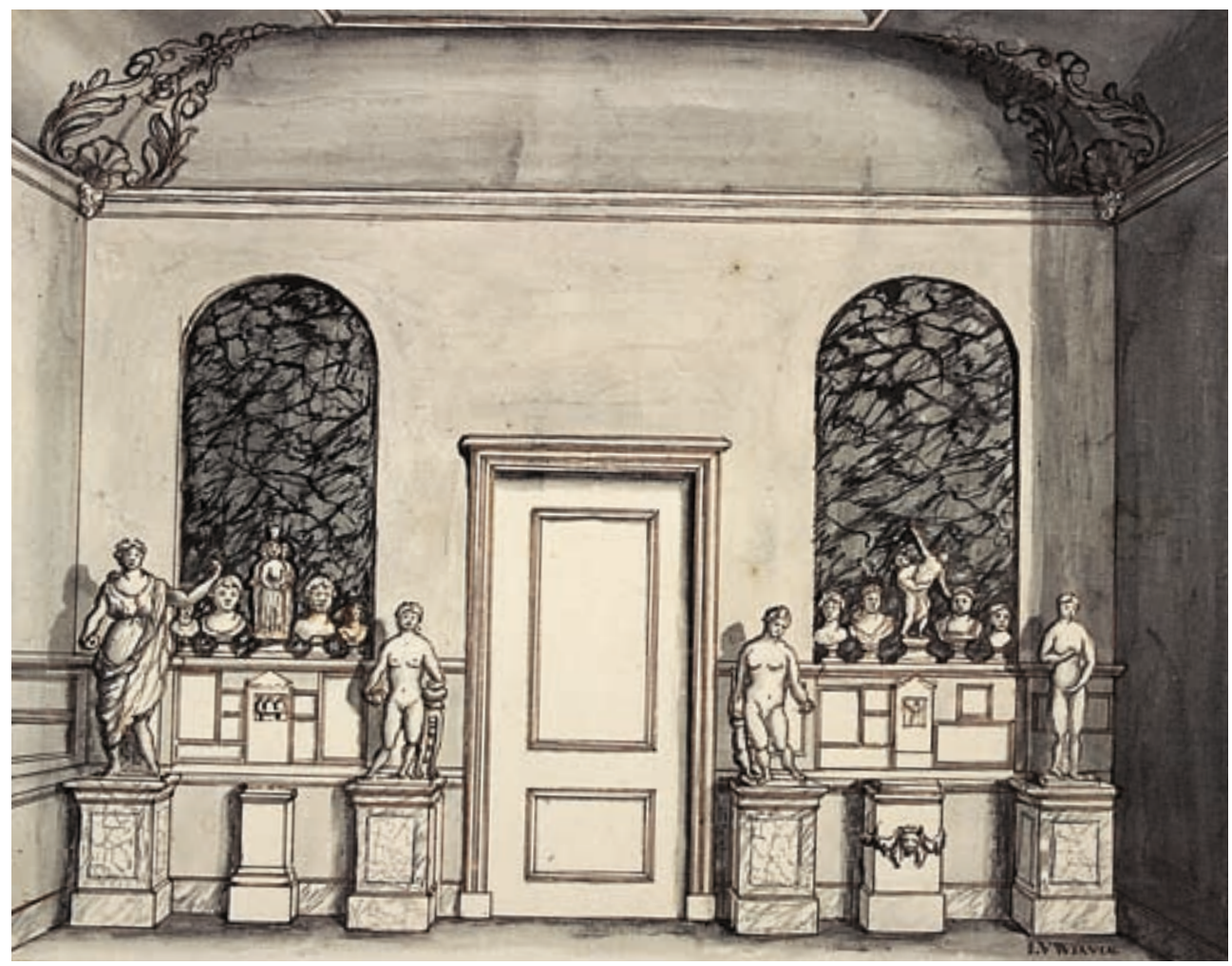

^ Ontwerp voor de opstelling van de Papenbroek-marmers in de Orangerie 
letteren daar naartoe gegaan zijn om een bijdrage te leveren aan haar bloei. Het onderwijs in de klassieke en oosterse filologie, geschiedenis en Romeins recht, theologie en filosofie, natuurwetenschap en medicijnen, stond er vrijwel de gehele achttiende eeuw op een hoog, soms zeer hoog niveau. De belangstelling уоог bestuurlijke en technische kennis, vоor de praktische kant van het universitaire curriculum dus, liep in de achttiende eeuw niet terug, maar onderging juist een intensivering.

Het werkelijke probleem school veeleer in de 'verkokering' van het onderwijs, de specialisatie van de verschillende delen van de onderwijspiramide. Die leidde ertoe dat vraag en aanbod niet langer op elkaar aansloten. Er was vraag naar een praktischer, niet specifiek academisch gericht, maar commercieel vruchtbaarder kennispakket. De 'modernere' elementen van het hoger onderwijs, zoals die tot uitdrukking kwamen in aandacht voor de beheersbaarheid van de natuur en toepasbaarheid van de staatkunde, vonden daardoor te weinig maatschappelijke verspreiding en verliepen in de klassieke geletterdencultuur, waarvan de universiteit het bolwerk bleef.

\section{Het huwelijk van Mars met de muzen}

De vier gravures die de Leidse drukker Andreas Cloucq in 1610 publiceerde, met daarin afgebeeld de vier instellingen die de universiteit aan het einde van de zestiende eeuw in het leven had geroepen, waren een doelbewuste bijdrage aan het universitaire spel met de topos arte et marte. Cloucq en de graveur Willem Swanenburgh werkten met tekeningen van Jan Cornelis van 't Woud. De universiteitsbibliotheek, het anatomisch theater, de hortus botanicus en de schermschool, ze werden afgebeeld met groot gevoel voor detail, maar ook met zichtbare trots.

Het belang van de gravures en hun invloed op het zelfbeeld van de universiteit kan nauwelijks worden overschat. Vele malen werden ze gekopieerd, afgedrukt in boeken in verkleinde vorm of meegebonden in gevouwen versie. Belangrijke boeken als Orlers' stadsgeschiedenis en Meursius' Athenae Batavae, zeer beeldbepalend voor de Leidse universiteit in binnen- en buitenland, 
lieten zien dat de universiteit niet alleen grote geleerden binnen haar muren had, maar ook kon beschikken over instellingen van groot vernuft.

In zijn oratie bij het begin van de lessen in juni 1575 omschreef de theoloog Ludovicus Capellus de nieuwe universiteit als een plek 'waar de studies van de vrede werden gecombineerd met de handelingen van de oorlog'. Wie verbaasd was over die combinatie, zei hij, wist blijkbaar niet dat de Pallas in wapenrok dezelfde was als die 'in burger', de wakkere voorgangster in wapengeweld en geleerdheid.

Capellus' collega's in de senaat herkenden deze dualiteit, zoals mag blijken uit het wapen dat ze uitkozen voor de universiteit. In het oorspronkelijke voorstel, van 20 juli 1576, was sprake van een gewapende Pallas met een schild. Op dat schild zouden de wapens afgebeeld worden van Holland en Oranje (boven) en van Zeeland en Leiden (onder). De uiteindelijke uitvoering gaf Pallas weer in een nis met daaromheen de wapens van Огаnje, Holland en Leiden.

De reden waarom het wapen van Zeeland uiteindelijk verdween, is niet overgeleverd. Мaar de bedoeling van de drie overige wapens is duidelijk. De daarin vervatte dienstbaarheid was de raison d'être van de universiteit. De definitieve uitvoering van het wapen geeft ook het dubbeltalent weer waarover Capellus sprak. Het grootzegel van de universiteit stelde Pallas namelijk lezende voor, met opengeslagen boek. Ze was nog steeds in wapenrok, met helm en kuras. Nog steeds steunde haar linkerhand op het verschrikkelijke Gorgoschild. Maar tegelijk was ze verzonken in de lectuur van haar boek. Наar houding is zowel agressief als meditatief. Нaar wapen, de speer, ligt nu werkeloos ter аarde: zij wil dat het oorlogsgeweld afgelopen is.

Ook Dousa moet deze dualiteit in zichzelf herkend hebben. Hij was een Hollands edelman, heer van Noordwijk. Hij had gestudeerd in Leuven, Douai en Parijs. Dousa was niet alleen Neolatijns dichter van een zekere renommee, hij speelde ook een cruciale rol in de organisatie van het verzet tegen het Spaanse beleg van de stad Leiden in 1574. Zo beeldt Cornelis Visscher hem ook af, als een geleerd krijger in kuras maar met zijn hand op een boek dat zijn levensmotto draagt: 'zoet bovenal zijn de muzen.' In het gedicht onder de prent, van de hand van Petrus Scriverius, staat te lezen: 'De moedige heer van 


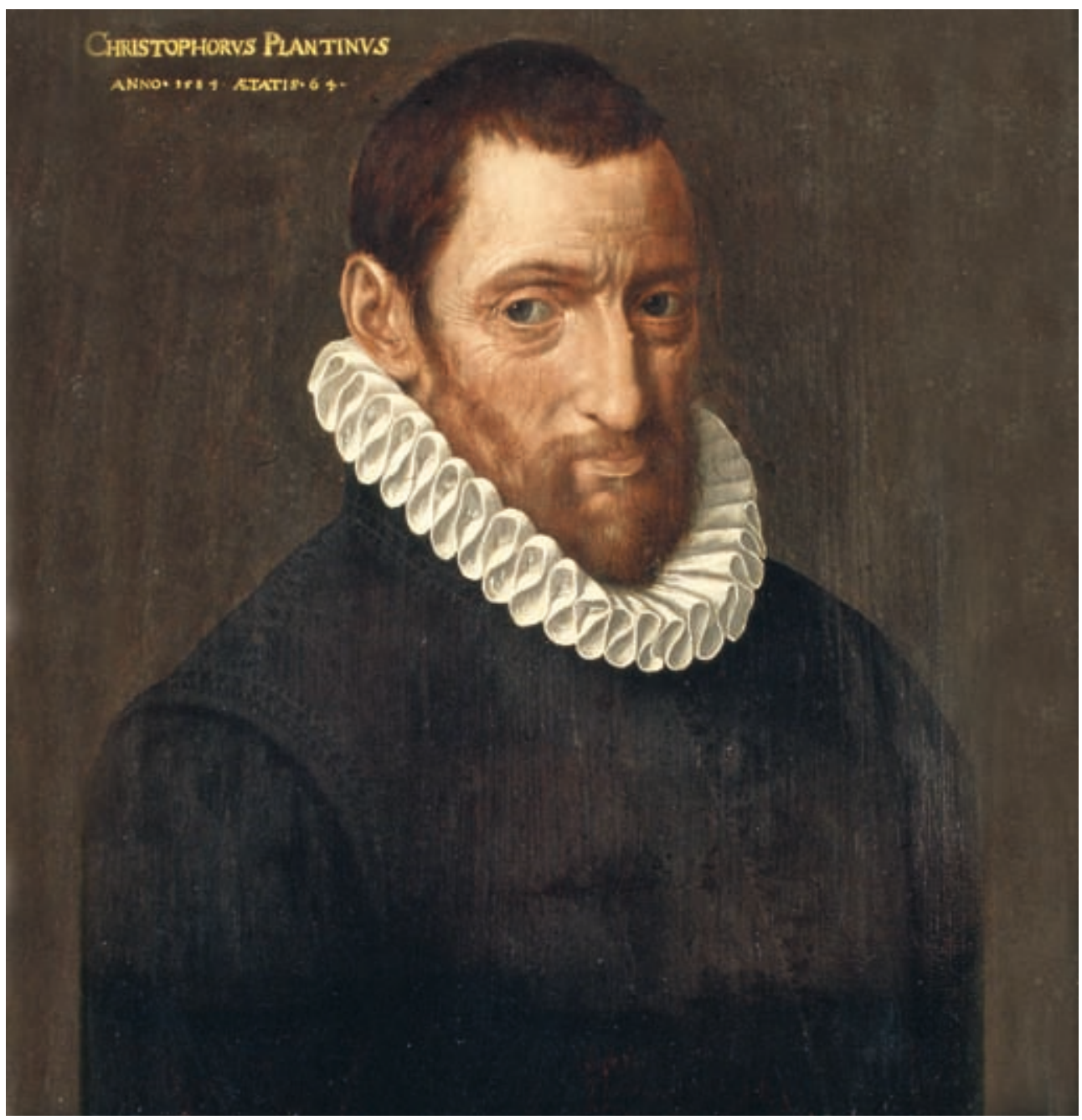

Noordwijk had niet slechts de heerlijke muzen aan zijn zij, maar hij beschikte ook over alles wat bij de oorlogsgod hoorde.'

Dit was ook het beeld dat men zich gevormd had van de stichter van de universiteit, Willem van Oranje. Bonaventura Vulcanius, de eerste echte graecus van de universiteit, verhaalde in een rede uit 1591-1592 hoe Oranje - 'hij die wij terecht de Mars togata, de geleerde krijgsgod kunnen heten' - in de wijsheid van zijn vooruitzicht de universiteit in het leven had geroepen als

4 Christoph Plantijn (1514-1589), academiedrukker (1583-1585) 

bolwerk tegen de verruwende werking van de oorlog op de Hollandse jeugd, 'opdat zijn Batavenland rijk was niet alleen aan kracht die met oorlogsgeweld het vaderland beschermde, maar ook aan beraad en wijsheid om het te bestendigen'.

De topische kwaliteit van deze combinatie zien we in haar rol bij de viering van het vijftigste en honderdvijftigste verjaardagsfeest van de universiteit (de honderdste verjaardag, in 1675, werd niet gevierd vanwege de tumultueuze politieke gebeurtenissen die егаan voorafgingen). In 1624 stelde Petrus $\mathrm{Cu}^{-}$ naeus zich de vraag waarom de universiteit zoveel voorspoed gekend had in de eerste vijfendertig jaar van haаг bestaan en zo weinig gedurende het twaalfjarig bestand met Spanje, tussen 1609 en 1621. Tijdens deze vrede was de universiteit in de ban geraakt van de stammenstrijd tussen arminianen en gomaristen, die eindigde met de nationale synode te Dordrecht en de reductie van de universiteit tot een calvinistische instelling. Cunaeus zocht zijn antwoord in het dubbeltalent van Pallas, die zowel in wapens als in woorden heette uit te blinken. Hij verzocht zijn gehoor hem te geloven als hij zei dat 'zo deze Pallas ergens woonde, het bij de Hollanders moest zijn'.

In zijn Oratio in natalem tertium Academiae Lugduno Batava van 1725 buit de rector van dat jaar, Franciscus Fabricius, de retorische mogelijkheden van de topos ten volle uit. Hij noemde Janus Dousa 'niemant in het stuk van oorlog en geleertheid (welke zamen gepaart eerst enen rechten en onsterfelijken Adeldom maken) wijkende'. Ook verder volgde Fabricius de topos trouw. Plachten de wetten onder de wapenen te zwijgen? Had Jan van Brabant Leuven niet gesticht na afloop van een oorlog? Mogelijk. Maar de Leidse universiteit was gesticht 'in het midden enes allergevaarlijksten oorlogs' en het was een feit 'dat Pallas zelve in dien tyd gewapent ging, en dat de borgers dezer Stadt de nieuwe Professoren door de gemene straten met blinkende wapenen, en onder het losbranden van allerhande schietgeweer, naar de Academie geleidden'. 


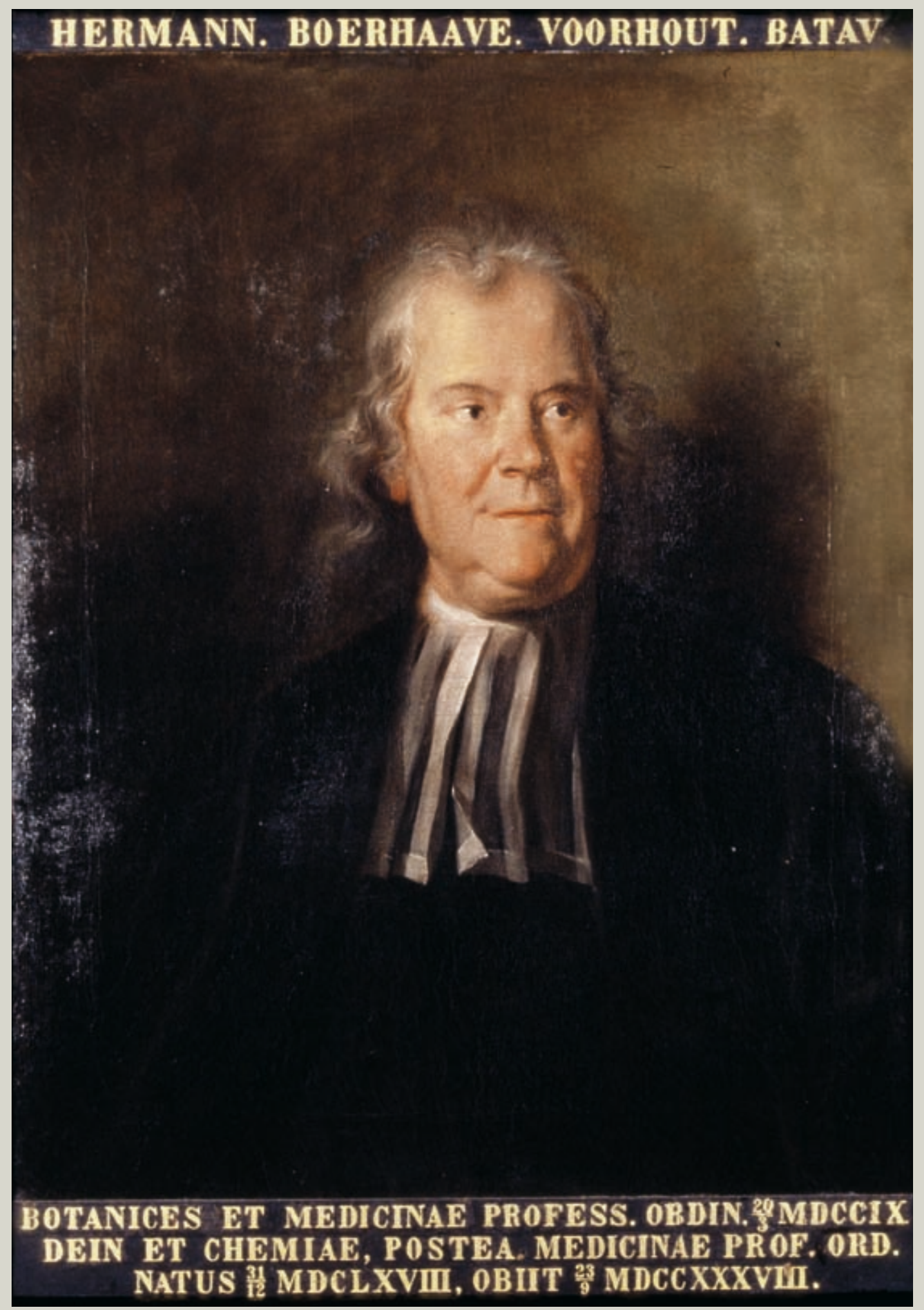




\section{GUL. IAC.'s GRAVESANIE, SILVA-DUCENSIS.}

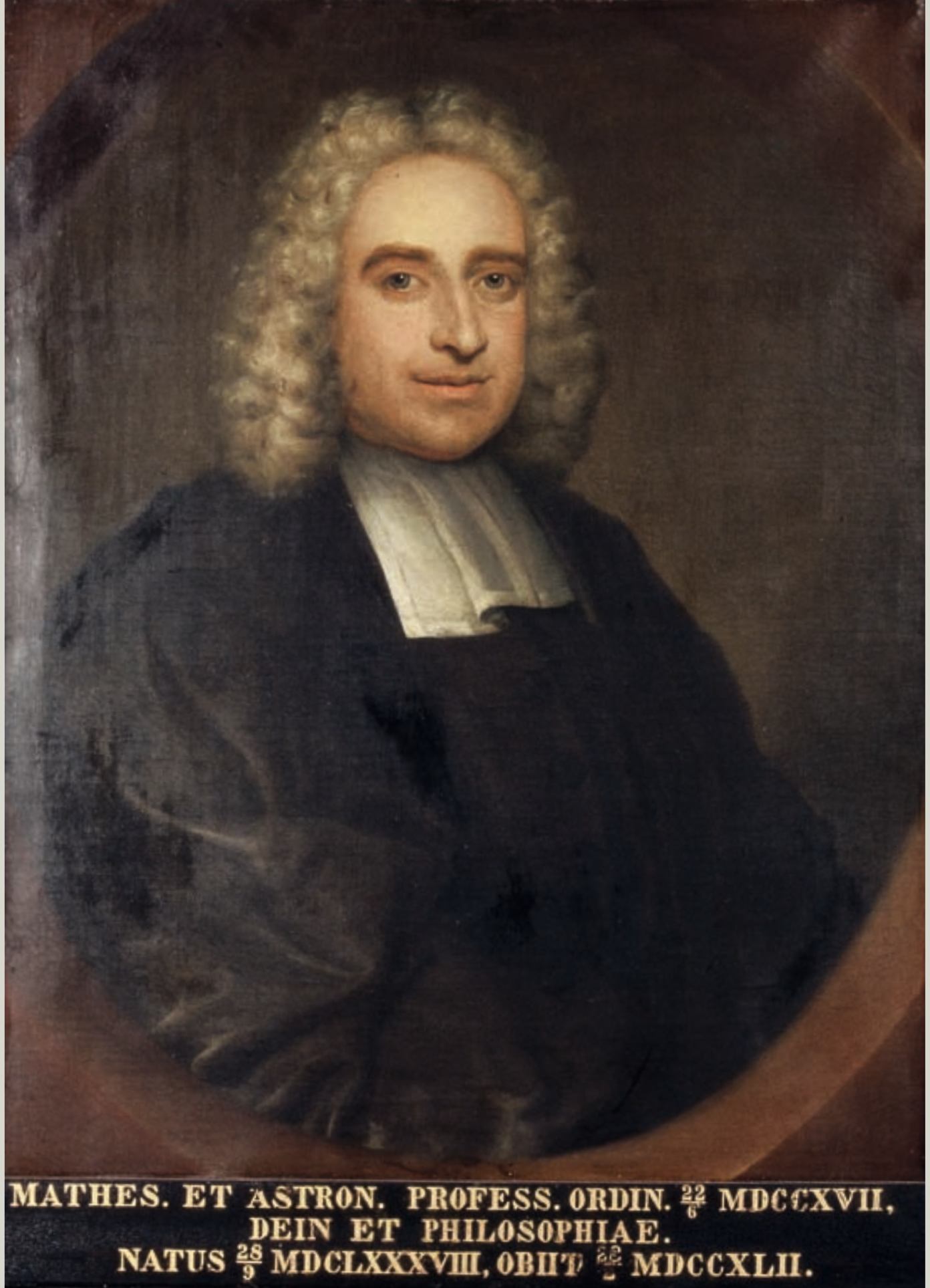




\section{BRRNARDUS SIEGFRIDUS ALBINUS, FRANCOFURT}

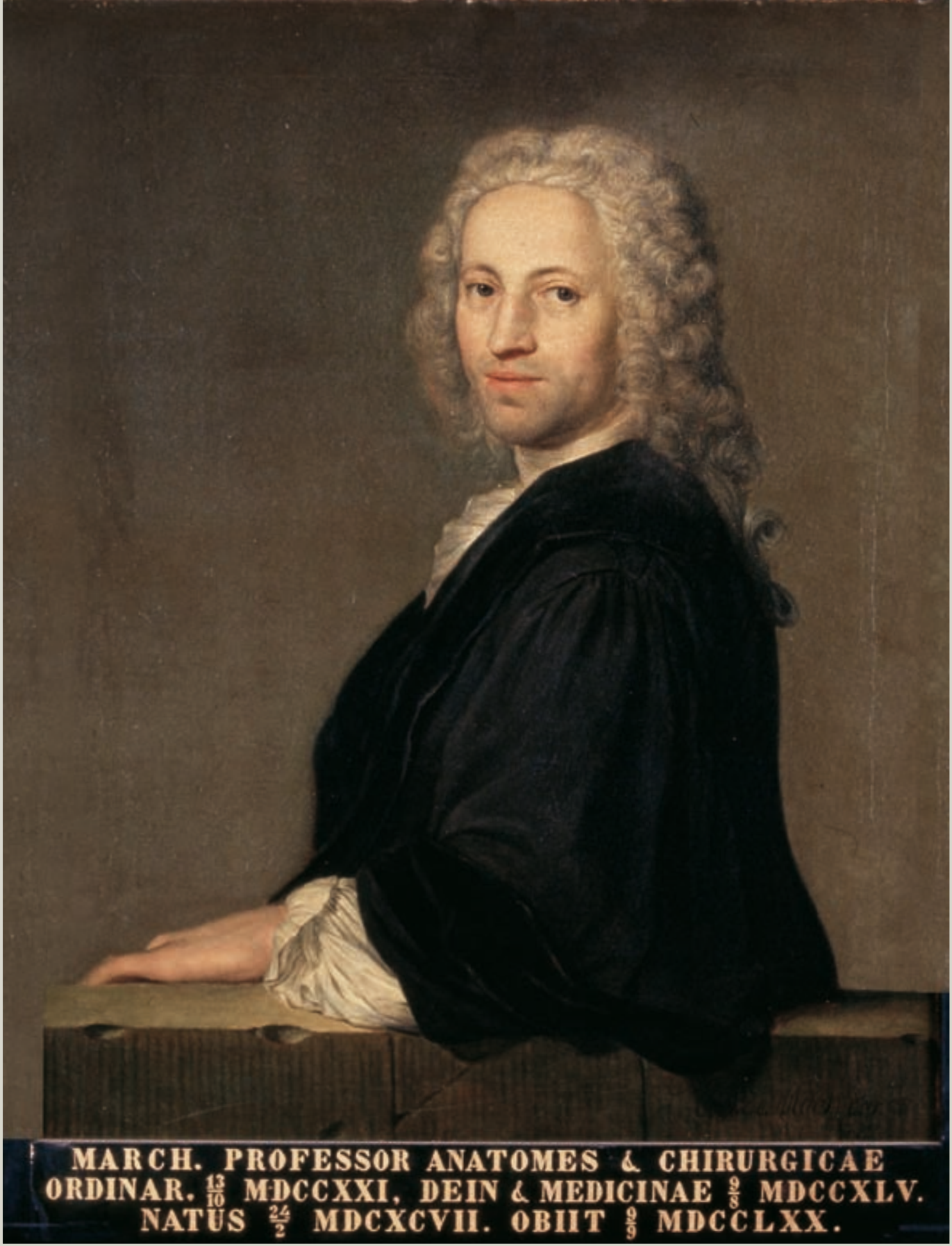




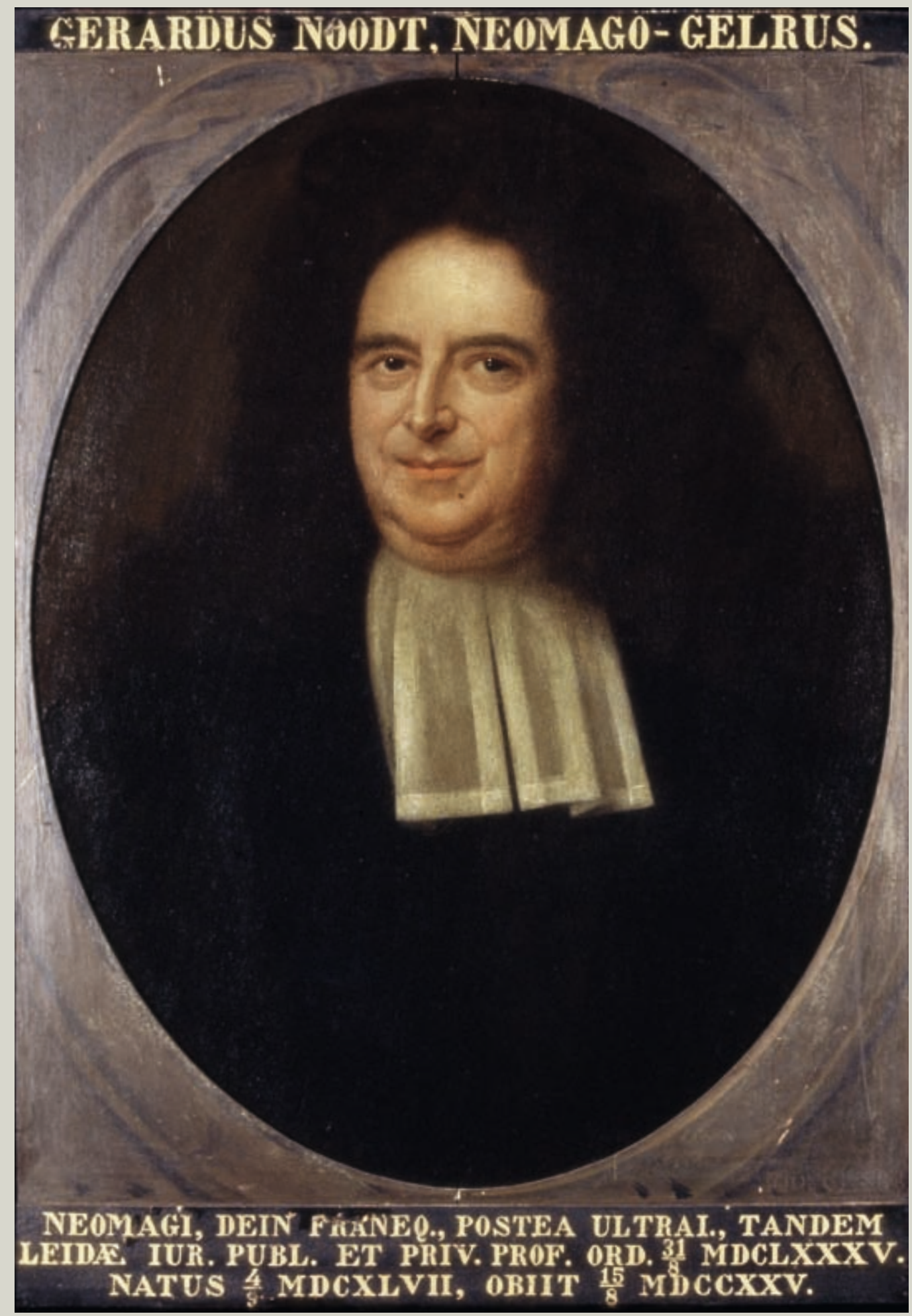




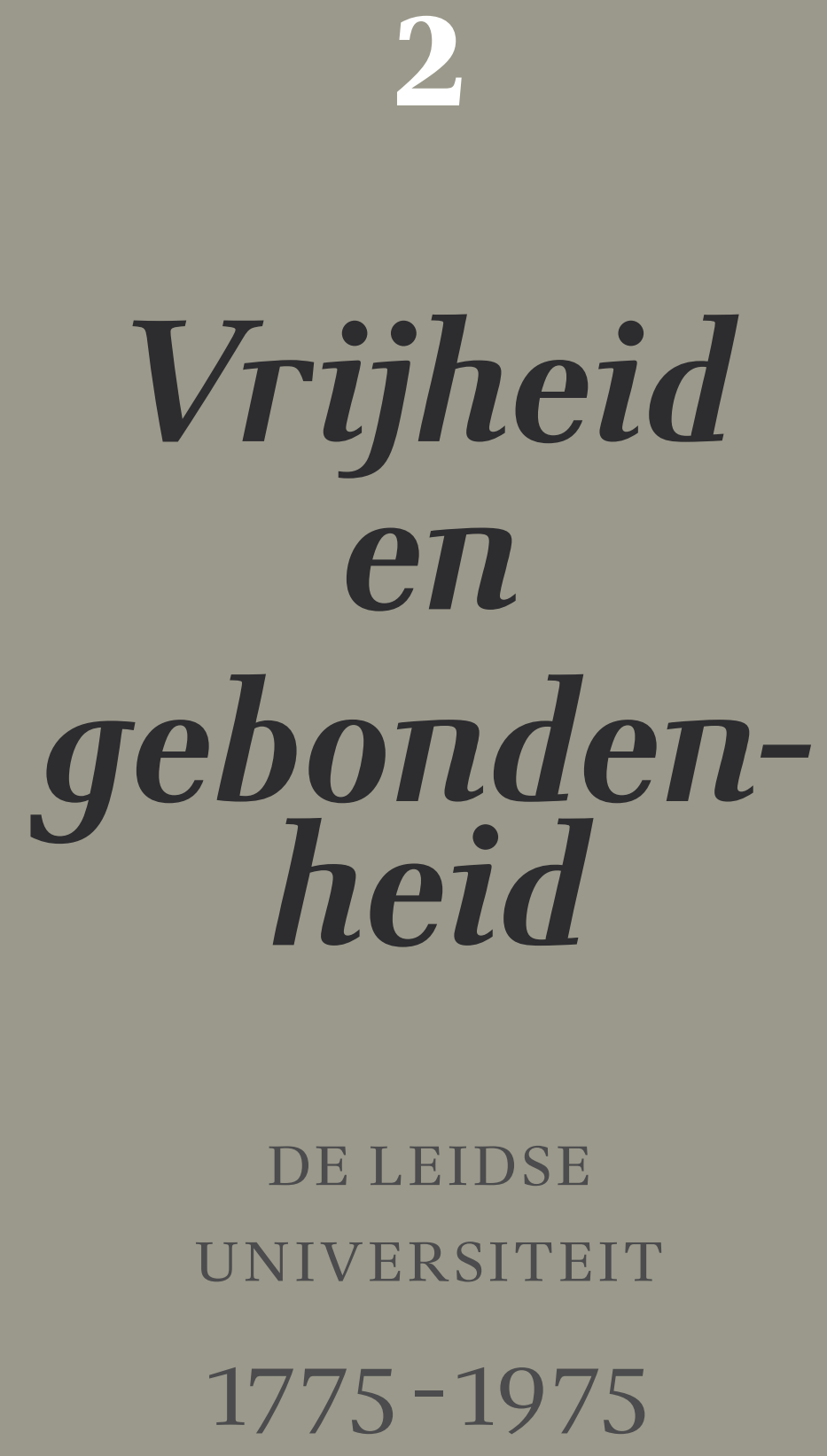




\section{Contract en compromis}

Het einde van het ancien régime ging in Nederland weliswaar gepaard met grote onrust, maar niet met grote veranderingen. Het nieuwe koninkrijk was niet minder dan de oude Republiek een evenwichtsmachine. De elite behield het vermogen het eigenbelang en het gemene best te verenigen. Waar de belangentegenstellingen in de Republiek werden opgevangen in een systeem van facties, werden de levensbeschouwelijke verschillen van het koninkrijk opgelost in de samenwerking van de zuilen. Wat voorheen 'correspondentie' heette, heette nu compromis.

Intussen was de machtige Republiek wel veranderd in het kleine Nederland, een land dat zich de invloed en zelfs inmenging van grote buren moest laten welgevallen. Niettemin verwierf deze kleine natie zich via snelle modernisering en een omvangrijk koloniaal bezit een speciale positie te midden van de grote mogendheden. Ook toen dat bezit na de Tweede Wereldoorlog teloorging, bleef de internationale oriëntatie intact. Als kleine handelsnatie huldigde Nederland een kenmerkende combinatie van eigenbelang en altruisme. De daaruit voortvloeiende dialectiek tussen vrijheid en gebondenheid is niet alleen kenmerkend voor het land, maar ook voor zijn universiteiten en in het bijzonder voor de Leidse universiteit. 


\section{Vrijheid en gebondenheid}

Hoewel de tegenstelling arte et marte, tussen woorden en wapens, tussen het passieve en het actieve leven, een totaal andere gevoelslading heeft dan die van 'vrijheid en gebondenheid', bestond er in de Nederlandse context een duidelijke samenhang. De op het breukvlak van verlichting en romantiek opererende filosoof Frans Hemsterhuis heeft die fraai verwoord. In een van zijn vertogen wees hij, doelend op de Republiek, op ‘het bijna ongeëvenaarde verschijnsel van een volk dat groots was in tijden van oorlog en verachtelijk tot in het bespottelijke in tijden van vrede'.

Hemsterhuis legde in zijn essay een verband tussen de staat van oorlog en de macht van het centraal gezag. In tijden van vrede was men geneigd de bevoegdheden van dat gezag te verminderen ten behoeve van het recht. Dat ging zover tot er van het gezag niets meer over was en het recht niet verdedigd kon worden. De samenhang van vrijheid en afhankelijkheid die Hemsterhuis zag, was een nieuwe formulering van de oude tegenstelling tussen arte et marte. Het nieuwe koninkrijk, dat een compromis moest vinden tussen koningschap en democratie, tussen constitutie en vrijheid, zou er intens mee te maken krijgen. De Leidse universiteit eveneens.

De samenhang van vrijheid en gebondenheid is een topos met diepe wortels in de klassieke oudheid en in de vaderlandse geschiedenis. Veel meer nog dan de oppositie van arte et marte is de gedachte aan vrijheid op momenten van grote rampspoed bepalend geweest bij de stichting van de Leidse universiteit. In de brief die Willem van Oranje op 28 december 1574 aan de Staten van Holland schreef, drong hij aan op de stichting van een universiteit 'tot een vast stuensel ende onderhoudt der vryheyt ende goede wettelicke regieringe des lants'. Hij zag die universiteit als middel bij uitstek om de vijanden van het land te verhinderen 'haere vierighe tirannie ende verdruckinghe so des goddelicken diensts als der vryheyt der landen tsy met gewelt ofte met listicheyt' te continueren. De universiteit zou zijn 'als een vast blochuys ende bewaernisse der gantscher landen'.

Waагаan Oranje deze typering ontleende, is niet bekend. Waar 'blochuys' een duidelijk Bijbelse connotatie heeft - denk aan de vertaling van Marnix

- Studenten verlaten het Academiegebouw na de rede van professor Cleveringa op 26 november 1940 


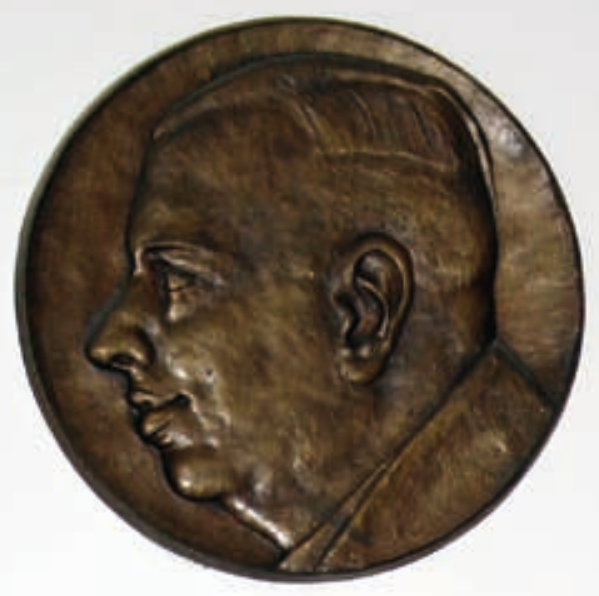

\section{BENJAMIN MARIUS TELDERS}

Geboren 19Maart1903-buitengewoon hoog leraar in het Vollkenrecht te Leiden 1931gewoon hoogleraar in het Volkenrechitende Inleiding tot de Rechtswetenschap 1937 op 18 December 1940 door de Duitseisgear resteerd wegens activiteit tegen het onrecht door hen geplecgd- draagt zijn opsluiting inde gevangenis te Scheveningen en de concentratickampente Buchenwald, Vught. Sachsenhausen en Bergen. Belsen in onge broken geestkradte \& is daar een steun voor en redder van vele medegevangenen-sturft in het vermietigingskamp Bagen Belsen

$$
\text { op6April } 1945
$$

MILES PRAESIDII LIBERTATIS 
van Sint-Aldegonde van de Psalmen: 'God is mijn borcht, mijn blochuys sterc end' vast' - daar is het minder waarschijnlijk dat Oranje bij zijn zinsnede 'tot onderhoudt der vryheyt ende goede wettelicke regieringe des lants' gedacht heeft aan Livius. In de eerste Nederlandse vertaling van diens $A b$ urbe condita uit 1541 komt de wending voor: 'tot onderhoudinghe haerder [= van het volk] ende haers rechts.' Hoe dat ook zij, het is toch Livius die in het vervolgtraject bepalend is geweest bij het ontstaan van de Leidse vrijheidsmythe.

Deze mythe is een schepping van het Leidse liberalisme. De zinspreuk Libertatis praesidium, die de universiteit in 1917 als omschrift van een nieuw logo of beeldmerk opnam - een ovale versie van het oorspronkelijke zestiende-eeuwse zegel - was afkomstig uit een rede die de ргоrector van 1875, Matthias de Vries, ter gelegenheid van het eeuwfeest hield. Нierin memoreerde hij, in het Latijn en voor vertegenwoordigers van andere universiteiten, hoe Willem van Oranje een universiteit had gewild, 'die zou dienen tot bolwerk van de onafhankelijkheid en van de beschaving'. Het jaar ervoor al had De Vries, toen zelf rector, in zijn diesrede geschetst hoe de Leidse universiteit 'te allen tijde is geweest het bolwerk der vrijheid'. Als Nederlandse uitdrukking verscheen de spreuk in de toelichtingen op de studentenmaskerade van juni 1875 en in het Latijn boven een allegorische prent met de naamlijst van alle рrofessoren sinds 1575, waarvan het opschrift luidde: 'De Leidse universiteit, monument van kracht, roem van het land, bolwerk van de vrijheid.'

Sinds het eeuwfeest van 1875 waren Libertatis praesidium en de Nederlandse versie, 'Bolwerk der vrijheid', dus gevleugelde woorden, in 1917 tot devies verheven. De Vries was overigens niet de auteur ervan. Hij had het weer van de classicus Petrus Hofman Peerlkamp, uit diens rectorale rede van 1839, waarbij De Vries als student aanwezig was geweest. Zijn vaderlandslievende hart zwol bij het aanhoren van de omschrijving van zijn universiteit als gesticht, in de woorden van Peerlkamp, 'in zulke omstandigheden, in zo'n stad, op zo'n moment, en met zo'n spoed, dat zij als bolwerk der onafhankelijkheid van Godswege uit de hemel neergedaald leek'. Maar ook Peerlkamp was niet de auctor intellectualis van deze omschrijving. Hij had deze direct uit Livius' Ab urbe condita III 55 .

Het is overigens niet zeker dat Peerlkamp Oranjes omschrijving van een

\ Plaquette van de Leidse jurist, professor B.M. Telders, in het Klein Auditorium van het Academiegebouw 


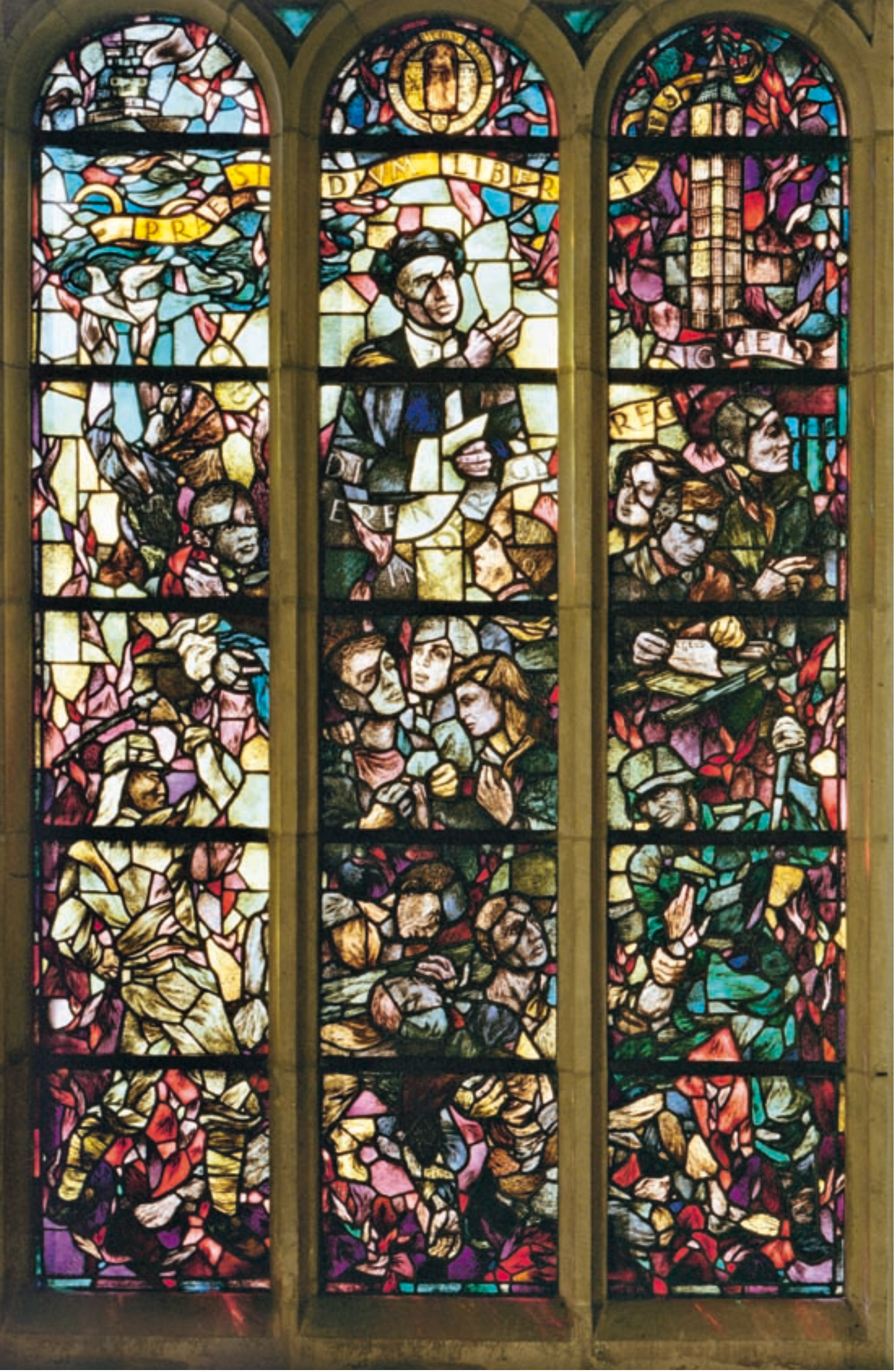

^ Gebrandschilderd raam in het Groot Auditorium, met centraal professor Telders 
60 .
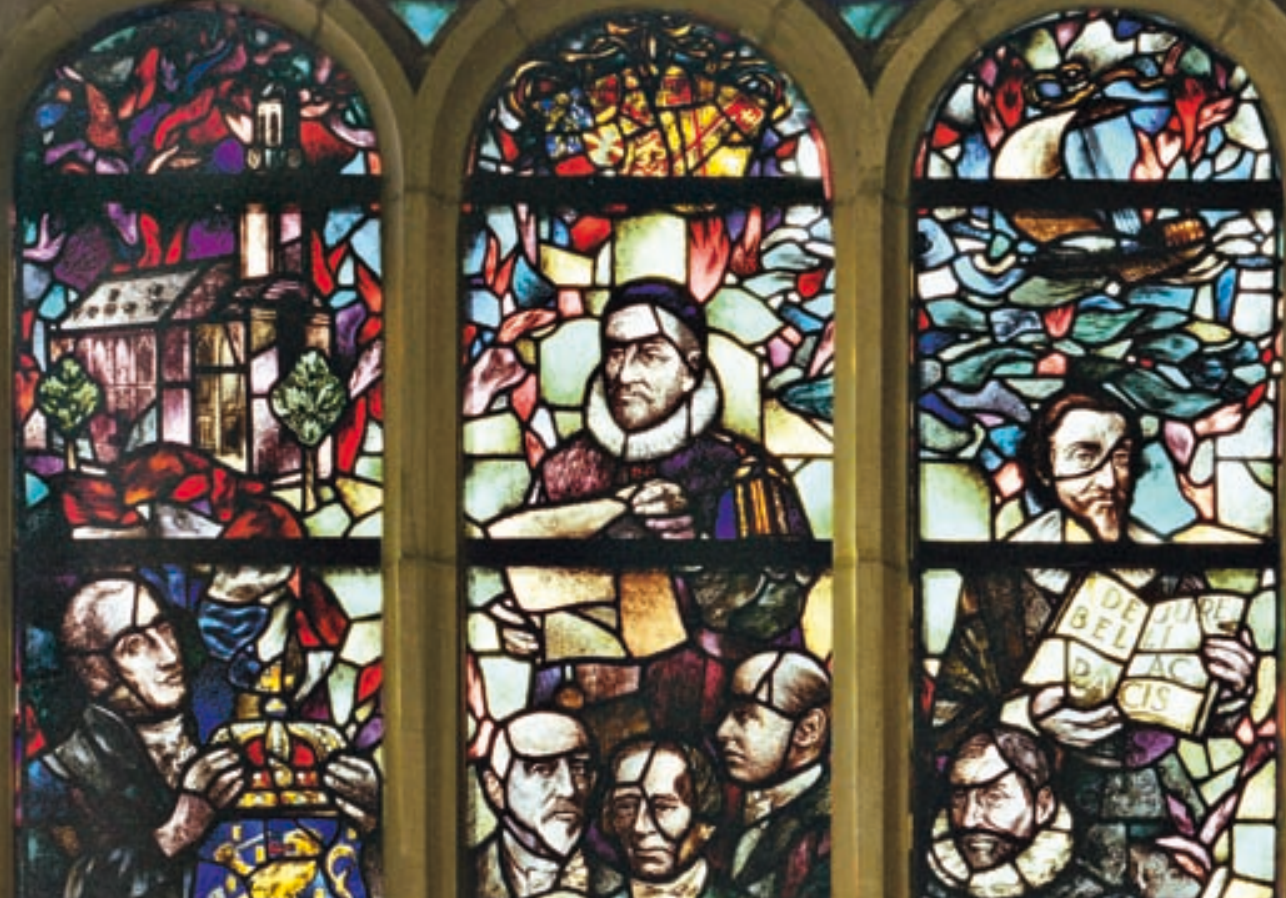

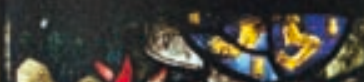

cosi.

(1)
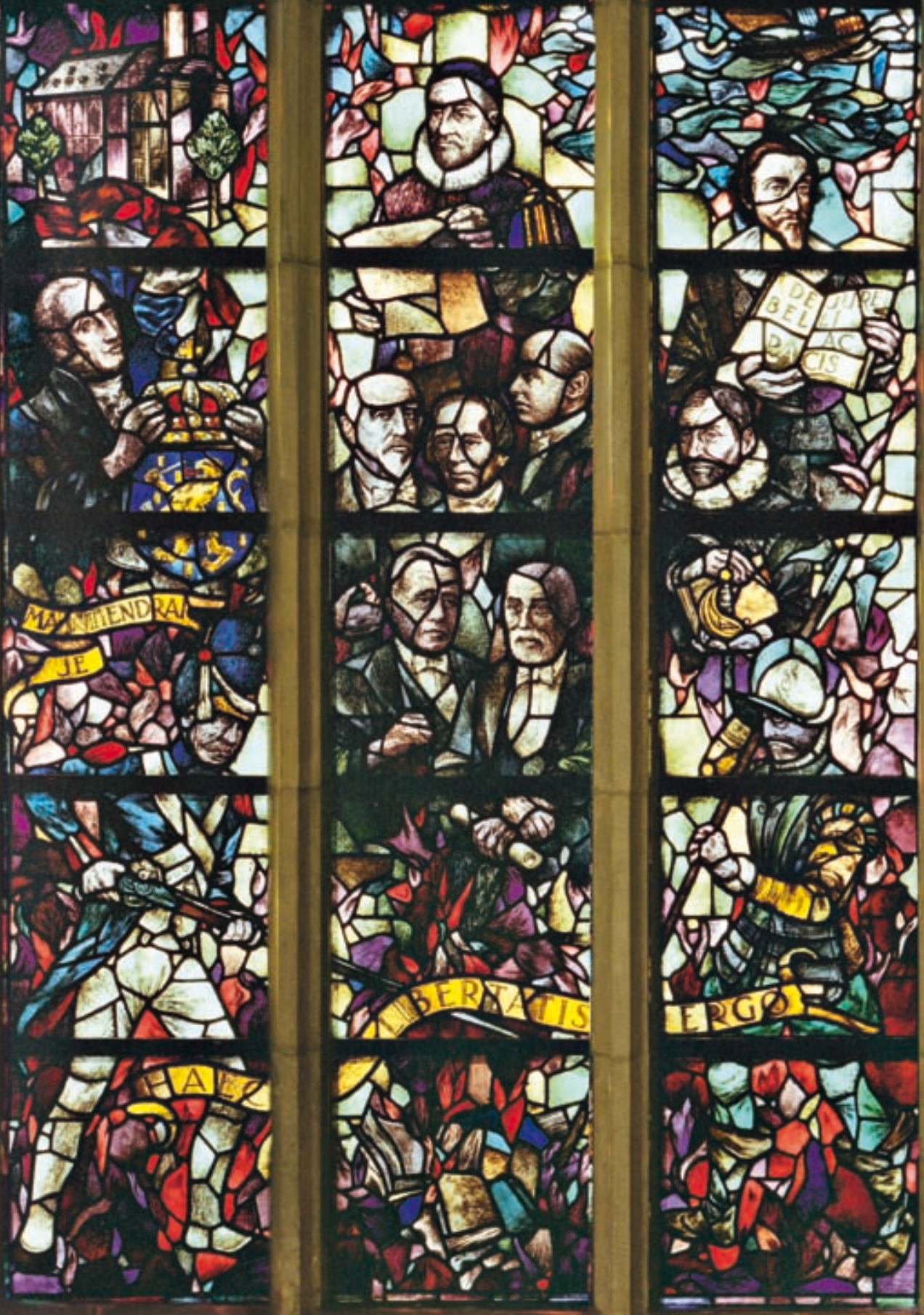

^ Gebrandschilderd raam in het Groot Auditorium: Willem van Oranje, Hugo de Groot, Van Hogendorp, Dousa, Snouck Hurgronje, Thorbecke, Van Vollenhoven, Huizinga en Lorentz 
universiteit in zijn brief van 28 december 1574 identificeert met de karakteristiek van Livius. Maаг het lijdt geen twijfel dat hij die brief van Oranje kende. Peerlkamp ging in zijn rede uitvoerig in op de betrekkingen tussen het Huis van Oranje en de Leidse universiteit en stond in het bijzonder stil bij de studies die een aantal Oranjetelgen in Leiden had verricht. Bovendien is er een onmiskenbare overeenkomst tussen het beeld dat de patriots-liberale geleerden koesterden over de nobele intenties van Oranje en het verhaal dat Livius vertelde.

Dat verhaal, uit het derde boek, waar Livius het dramatische conflict behandelt tussen de senaats- en volkspartij in het jaar 305, geeft een institutionele crisis weer van gelijke diepte als de Nederlanden ervoeren in 1574 . De hervormingen die eruit voortkwamen, dienden de rechten en de vrijheid van het volk te waarborgen. Door het volk genomen besluiten werden bindend verklaard vоor het hele volk, inclusief de edelen. Een andere wet maakte het mogelijk ‘bij de volksvergadering beroep aan te tekenen, bolwerk van de vrijheid enig in zijn soort'.

Zo verbond de vrijheidsgedachte in een hink-stap-sprong van eeuwen de oude en de nieuwe geschiedenis van de universiteit. Bovendien kreeg de hieruit afgeleide identiteit de waarde van een self-fulfilling prophecy op een moment dat die identiteit op de proef gesteld werd en de vrijheid definitief teloor leek te gaan: bij de Duitse inval van mei 1940. Weliswaar probeerde de universiteit in de eerste maanden na de wapenstilstand de gewone routine te handhaven, maar hoe moeilijk dat was, bleek in september bij de rectoraatsoverdracht van F. Muller, een groot latinist, maar een ijdel man. Met Seyss-Inquarts Beauftragte voor Zuid-Holland in de zaal besloot Muller zijn rede met een verheerlijking van het leidersbeginsel en het heerlijke vooruitzicht 'dat ons Nederlandse volk eindelijk aan tucht gewend wordt'. Na afloop van zijn rede moet er een pijnlijke stilte geheerst hebben in het groot auditorium.

Een tweede reactie van de Leidse universiteit was anders. Op 23 oktober 1940 werd de zogenaamde ariërverklaring rondgestuurd aan het universiteitspersoneel. De senaat zou daarover op 26 oktober vergaderen en wel aan de hand van een krachtig protest, opgesteld door de jurist B.M. Telders. Die vergadering werd door de bezetter verhinderd, maar men kwam toch bijeen 
in kleine 'kransjes' van minder dan twintig personen (het aantal mensen dat zonder vergunning mocht vergaderen). Uiteindelijk besloot men te tekenen, maar dat vergezeld te doen gaan van individuele protesten. Ook de studenten protesteerden met een verklaring die door 1700 van hen werd ondertekend.

Vervolgens ontsloeg de Duitse bezetter, op 23 november, het niet-arische personeel. De juridische faculteit verloor hierdoor twee van haar hoogleraren. Besloten werd het eerstvolgende college-uur van één van hen, professor E.M. Meijers, aan te grijpen om te protesteren. Op dinsdagochtend 26 november om tien uur hield de decaan van de faculteit, professor R.P. Cleveringa, zijn bekende rede. Hij las de ontheffingsbrief voor 'in zijn kale naaktheid', zonder poging tot nadere verduidelijking: 'Hun daad kwalificeert zich zelf afdoende.' Daarnaast beschreef hij de betekenis van zijn leermeester Meijers:

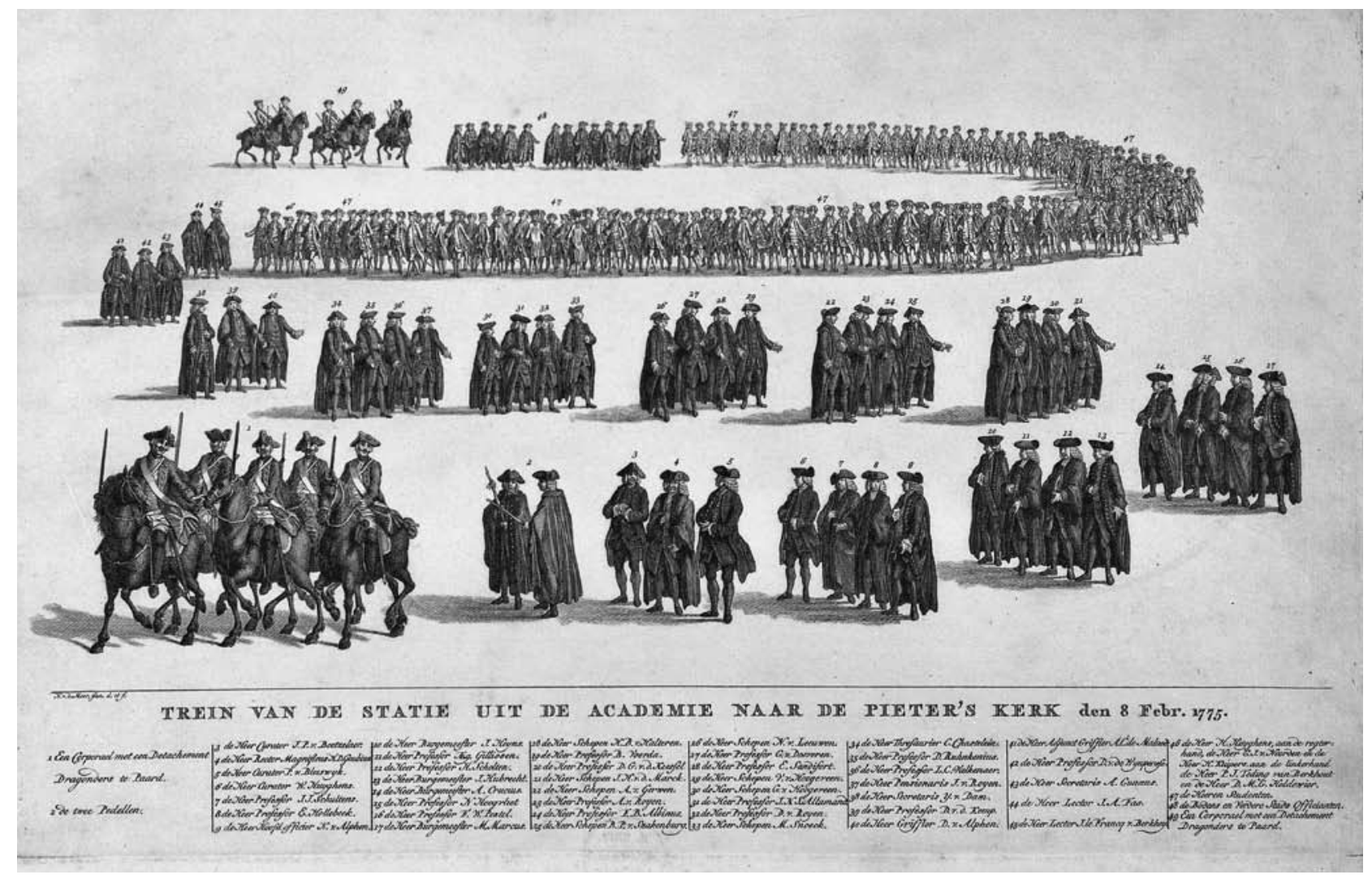

^ Cortège van hoogleraren, functionarissen en studenten op weg van het Academiegebouw naar de Pieterskerk op 8 februari 1775 
Het enige wat ik thans begeer, is: hen uit het gezicht en beneden ons te laten, en Uw blik te richten naar de hoogte, waаrop de lichtende figuur staat van hem wie onze aanwezigheid hier geldt. Want het lijkt mij goed, dat wij ons op dit oogenblik nog eens duidelijk te binnen trachten te brengen, wie het is, dien een macht, welke op niets dan enkel zichzelf kan steunen, hier na dertigjarige werkzaamheid achteloos ter zijde schuift.

De rede van Cleveringa was een even moedig als weloverwogen protest. Hij onthield zich bewust van enige politieke uitspraak en ging niet in op het racistische principe van de ontslagmaatregel. De rede was bovendien bedoeld om onberedeneerde studentenacties te voorkomen. Maar door zwart en wit zo zichtbaar naast elkaar te zetten was de rede uiterst effectief. De dag erop staakten de studenten uit protest het collegebezoek en sloot de bezetter de universiteit. De studenten hadden overigens al eerder van hun verzet blijk gegeven bij monde van het illegale blad De Geus dat vanaf 4 oktober 1940 verscheen. De anatoom Barge en de theoloog Van Holk zouden hun colleges gebruiken ter ontmanteling van de racistische nazi-ideologie.

Meer ontslagen volgden. Telders werd opgepakt en in een concentratiekamp gevangengezet. Hij zou op 6 april 1945 in Bergen-Belsen overlijden. Ook Meijers kwam in een concentratiekamp terecht, maar overleefde. Cleveringa werd bij elkaar anderhalf jaar gevangengezet, maar kwam uiteindelijk weer vrij. Intussen probeerde de bezetter de universiteit om te vormen door aanscherping van de regels, ontslagen en gelijktijdige 'deutschfreundliche' benoemingen. Maar na het gedwongen ontslag van enkelen - cruciaal was dat van R. Kranenburg in maart 1942, omdat hij in zijn boek over administratief recht onvoldoende aandacht besteed had aan de verordeningen van de bezetter - nam een groot deel van de docenten zelf ontslag (53 van de 68 professoren). Tussen oktober 1940 en augustus 1944 zouden ongeveer veertig Leidse docenten vоor kortere of langere tijd gevangengezet worden. De uitkomst was het zelfbeeld van een universiteit die bewezen had haar devies waardig te zijn. 


\section{Wetgeving}

Het einde van het ancien régime bracht niet alleen politieke discussie, ook het onderwijs werd aan een fundamentele kritiek blootgesteld. Opnieuw prevaleerde geleidelijkheid boven vernieuwing, pragmatische aanpassing boven totale ommekeer. Vooral onder het zogenaamde Bataafse bewind (1795-1806) en in de Franse tijd (1806-1813) werden visionaire plannen gelanceerd om de oude onderwijsstructuur te vernieuwen. Deze discussie gaf de contouren van drie paradigmatische alternatieven. Aan de ene kant was er de klemtoon op nut en toepasbaarheid die we gewend zijn met het Franse model te associëren: sterk centralistisch en gericht op de ontmanteling van de universiteiten in faculteitsscholen. Het tweede model legde het accent op de vertegenwoordiging van de wetenschap zoals we die associëren met de ontwikkeling van de Duitse universiteit. De gedachte was één superuniversiteit te creëren om tegelijk de overige instellingen te reduceren tot vooropleiding dan wel vakschool voor de beroepen in het algemeen en pépinière voor het professoraat in het bijzonder. Het derde alternatief zag het oogmerk van het hoger onderwijs in algemene beschaving en brede vorming en wenste de continuering van het bestaande brede veld van hoger onderwijs zoals dat in de Republiek gegroeid was.

Uiteindelijk zou dit derde alternatief, met lichte bijmenging van delen van de twee andere modellen, het pleit winnen. De Franse overheersing was van korte duur en het effect op het hoger onderwijs bleef aan de oppervlakte. De geest van de onderwijswet van 1815, het zogenaamde Organiek Besluit, was zeker niet utilitair of centralistisch. Directe toepasbaarheid van de wetenschap werd verworpen; de faculteit, of beter de professor, bepaalde de invulling van het onderwijs. Een brede propedeuse en een samenhangend humanistisch vakkenpakket bleven kenmerkend: 'een welomlijnd en uniform stelsel van kundigheden', in de woorden van Huizinga, 'practisch en edel, niet diep noch avontuurlijk'.

Het Organiek Besluit heeft vrij snel na zijn inwerkingtreding geleid tot een koor van stemmen dat riep om verandering. Toch zou het, kleine aanpassingen daargelaten, tot 1876 duren voordat eг een alternatief kwam in de vorm 


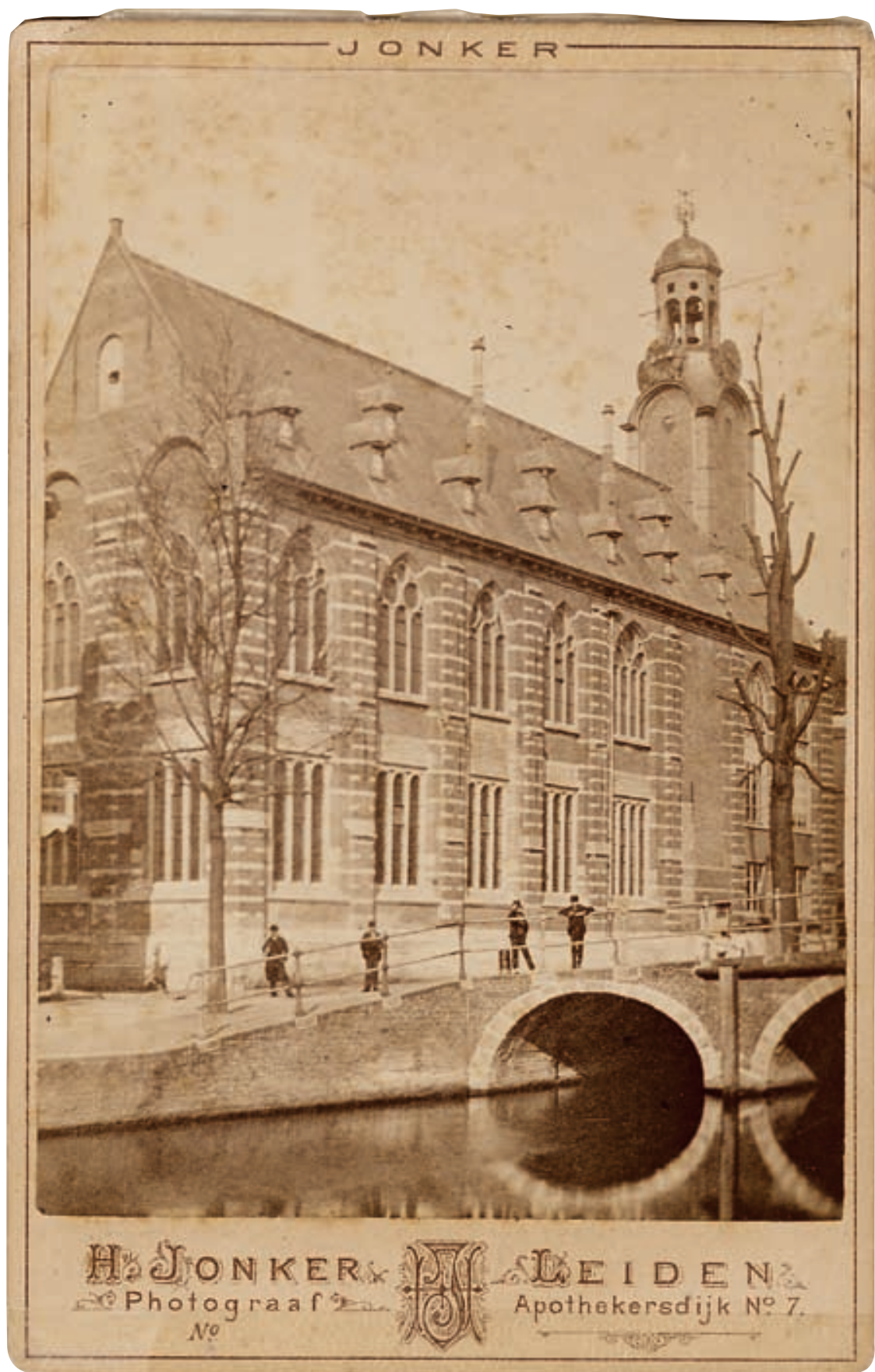

\Ansicht van het Academiegebouw, ca. 1900 
van de Hoger Onderwijswet. Het verschil met het besluit van 1815 is zonneklaar. De propedeuse werd verplaatst naar het inmiddels geschapen gymnasium. Samen met de invoering van verschillende doctoraten voor welomschreven specialismen maakte dit definitief een einde aan het encyclopedische karakter van het hoger onderwijs en de humanistische doelstelling ervan.

Voortaan zou de studie voorbereiden op een beroep. Langs een lange rozenkrans van examens bad de student zijn maatschappelijk welslagen af. Het veld van de wetenschap was voortaan nauwkeurig verkaveld: de vakken waren streng gedefinieerd en van elkaar gescheiden. Wat buiten de specialismen viel, viel buiten de universiteit. De verschoolsing van het universitaire onderwijs, de verzakelijking ervan ook, en de middelpuntvliedende krachten waaraan de universiteit zou komen bloot te staan, zouden weldra wederom een koor van kritiek losmaken, deels doortrokken van nostalgie naar het Organiek Besluit. De te ver doorgeschoten specialisatie zou een permanente klacht blijven tijdens het interbellum.

Toch zou de Hoger Onderwijswet, opnieuw onder kleine aanpassingen, vrijwel een eeuw meegaan. Pas weer in $1960 \mathrm{kwam}$ de nieuwe Wet op het Wetenschappelijk Onderwijs. Deze was onderdeel van een spectaculaire hегvorming van het hele Nederlandse onderwijssysteem, vervat in de zogenaamde Mammoetwet. Het tot dan toe in sectoren verdeelde onderwijs dat de verschillende niveaus van elkaar scheidde langs lijnen van praktijk en theorie (en bijgevolg van klasse en stand), werd herschikt in een beweeglijk systeem dat allerlei mengvormen toestond en gericht was op de persoonlijke ontplooiing van leerling en student.

Het verschil met de wet van 1876 was dat het belang van praktijk en theorie, van toepassing en wetenschap, omgedraaid werd. Het doel van het onderwijs was: 'vorming tot zelfstandige beoefening der wetenschap, voorbereiding tot het bekleden van maatschappelijke betrekkingen waarvoor een wetenschappelijke opleiding vereist is en bevordering van inzicht in de samenhang der wetenschap'. Artikel 2 van de wet voegde er een derde doelstelling aan toe: het bijbrengen van 'maatschappelijk verantwoordelijkheidsbesef'. Zo keren, in een andere formulering en tegen een totaal andere 
achtergrond, dezelfde doelstellingen terug die we bij het Оrganiek Besluit reeds tegenkwamen.

\section{Bestuur en beheer}

In de reeks van genoemde hogeronderwijswetten is de tegenstelling tussen vrijheid en gebondenheid een terugkerende figuur. Dat blijkt vooral uit de organisatie van het bestuur van de universiteit. Het Organiek Besluit continueerde weliswaar het college van curatoren, maar dit betekende niet dat de situatie van de achttiende eeuw werd voortgezet. Was de universiteit van de oude maatschappij een rechtspersoon met grote bestuurlijke en financiële onafhankelijkheid en vergaande voorrechten, die van na 1815 was een rijksinstelling zonder publiekrechtelijke zelfstandigheid en zonder uitzonderingspositie te midden van andere instellingen. Hadden curatoren in de voorgaande eeuwen hun eigen financiële beleid kunnen voeren, vanaf 1815 diende een door de koning goedgekeurde begroting als leidraad bij door of namens het departement te verrichten betalingen. Hadden ze eerst vrijelijk het recht om nieuwe hoogleraren naar eigen keuze te benoemen, voortaan was het de koning die benoemde, zij het op een voordracht van curatoren.

Ook in de verdere taakstelling van curatoren valt deze uitholling waar te nemen. Toch bleven hun taken omvangrijk: de naleving van de hogeronderwijswetten, de zorg vоor de kwaliteit van het onderwijs en voor de academische gebouwen en andere bezittingen, de benoeming van het lagere регsoneel en de besteding van de gelden en de administratie daarvan. Ook na de inwerkingtreding van de nieuwe Hoger Onderwijswet in 1876 was bij een veelheid van activiteiten het bestuurlijk handelen van curatoren vereist, hoewel bij de bepaling daarvan tevens de 'schakelfunctie' tussen ministerie en universiteit werd beklemtoond. Vanaf 1876 waren de curatoren van vertegenwoordigers der universiteit bij het ministerie eerder vertegenwoordigers van het ministerie bij de universiteit geworden.

Het college vertoonde in zijn sociale samenstelling een grote cohesie. $\mathrm{Cu}-$ ratoren waren vrijwel altijd juristen, veelal oud-alumni van de universiteit. 


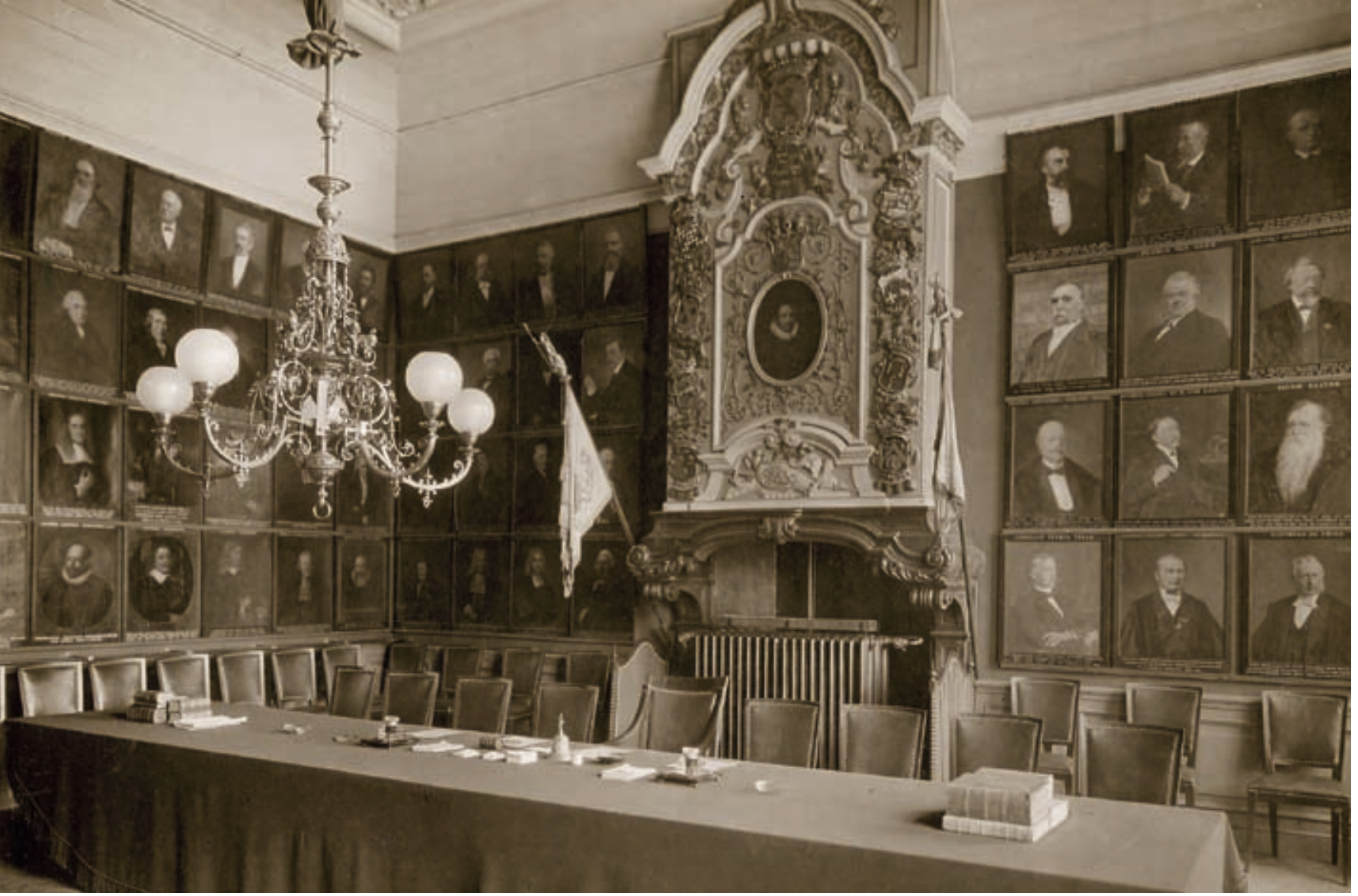

Ze waren van rijpe leeftijd - gemiddeld vijftig jaar of ouder - en hadden vaak langer dan tien jaar zitting. Meer dan vijftig procent was afkomstig uit de adel. Ongeveer driekwart van de curatoren had een politieke functie. Maar ondanks hun ontegenzeggelijke autoriteit nam hun invloed af. Aan het einde van de negentiende eeuw kreeg de faculteit, en daarbinnen de leerstoelhouder, bij benoemingen een dominante stem. Bovendien groeide de universiteit in deze periode sterk. Een college van curatoren dat minder dan één keer per maand bijeenkwam en dat slechts door één permanente secretaris werd bijgestaan, moest wel tekortschieten.

Het belangrijkste probleem was dat сuгatoren eigenlijk buitenstaanders waren. In 1922 vergeleek Huizinga de universiteit met een groot ingewikkeld bedrijf dat geen directie kende, maar enkel een raad van commissarissen en dan nog wel eentje zonder de vereiste deskundigheid. 'Een geluiddempende tusscheninstantie', dat waren de curatoria in zijn ogen en hij wenste efficiency naаг Amerikaans voorbeeld. Huizinga stelde voor de curatoren binnen de universiteit te halen en een bezoldigd president met een groot bureau hoofd van de universiteit te maken. Pas veel later zou hij zijn zin krijgen.

\ Interieur Senaatskamer, ca. 1920 


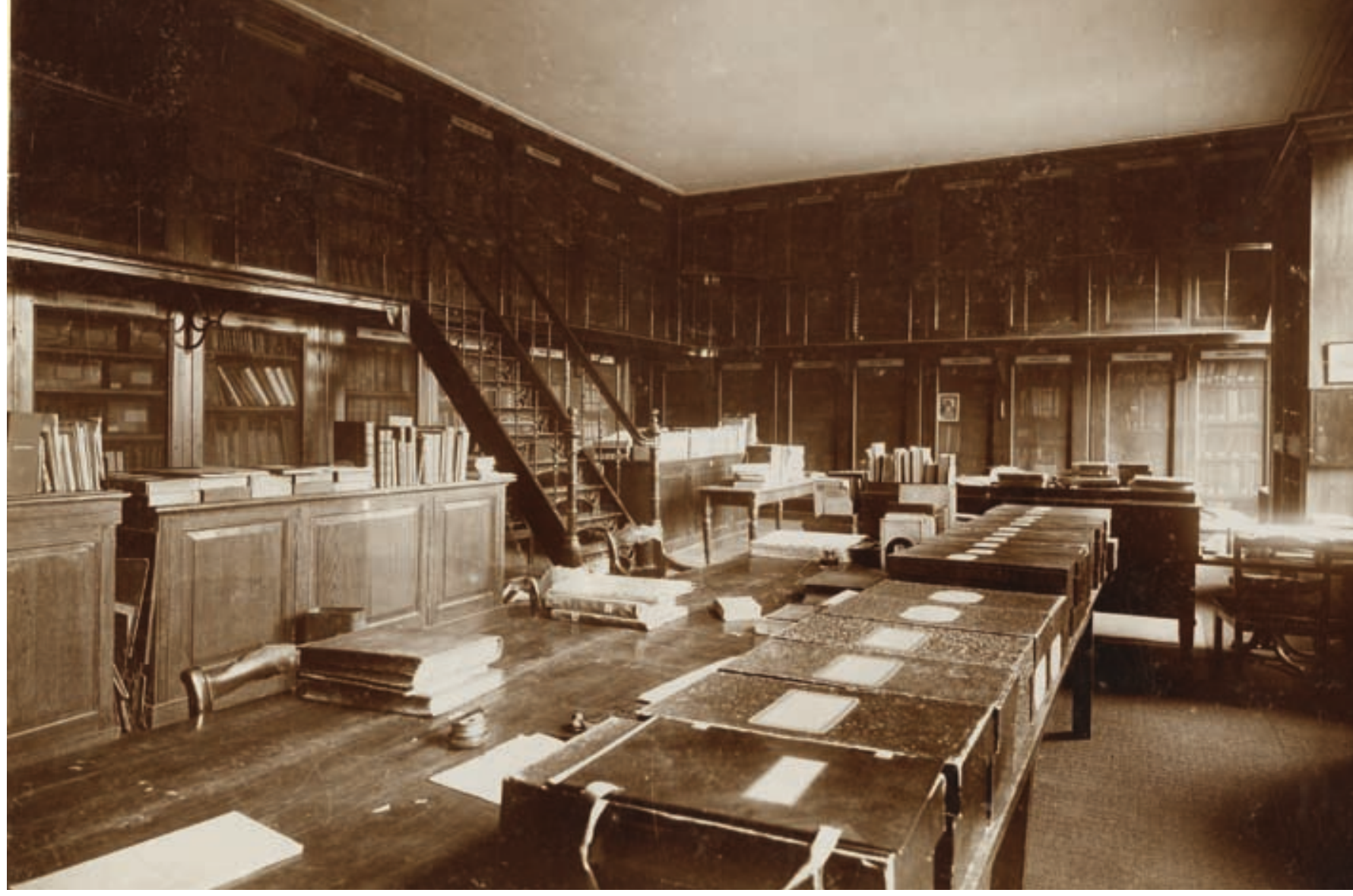

In het proces van versnelde veranderingen na 1960 sneuvelden niet alleen de curatoria, ook de duplex ordo werd afgeschaft. Dit begrip dekte de oude taakverdeling tussen curatoren en senaat, waarbij de senaat verantwoordelijk was voor studie en studenten, wetenschap en onderwijs. Met de groei van de universiteit werd de senaat echter te traag en de taken te complex, zodat binnen het overlegorgaan van de universiteiten, de Academische Raad, werd voorgesteld de duplex ordo af te schaffen en daarvoor in de plaats een toporgaan van managers in te stellen als hoogste instantie van beleid, met daarnaast een algemeen college van overleg waarin ook beroepsdecanen zitting hadden. Tegelijk bevatte het voorstel de gedachte een universiteitsraad in te stellen, bestaande uit vertegenwoordigers van de wetenschappelijke staf, de studenten en de oud-alumni.

In de discussie die erop volgde kwamen senaat en studenten in conflict. De senaat had geen bezwaar tegen beter bestuur en grotere efficiency, maar hield wel vast aan de mogelijkheid om binnen de faculteiten in collegiaal bestuur een eigen beleid te kunnen voeren. De naar buitenlands voorbeeld geradicaliseerde studenten eisten verregaande inspraak en politisering van de

^ Interieur Universiteitsbibliotheek, ca.19oo 
universiteit. Twee visies op de universiteit stonden polair tegenover elkaar: de universiteit als doelgerichte instelling voor onderwijs en wetenschap, hiërarchisch van structuur, uitgaande van expertise, en de universiteit als werken leefgemeenschap waarin het medebeslissingsrecht over alle geledingen was verdeeld. Doelmatigheid of democratie, daar ging het om. Er zou, in de jaren zestig, hartstochtelijk оver gedebatteerd en vooral actie gevoerd worden. In 1969 bezetten studenten zelfs enige tijd het academiegebouw.

Toen het stof opgetrokken was, bleek men een zogeheten wuB rijker, een Wet Universitaire Bestuurshervorming, in september 1970 door de Tweede Kamer aanvaard. Het meest radicale van de wUB was dat de senaat verdween en een systeem van democratisch verkozen raden zou worden ingevoerd, met een universiteitsraad aan de top, voorzien van de bevoegdheid tot het opstellen van een ontwikkelingsplan vоor de universiteit en het vaststellen van de begroting. Ook het college van curatoren werd afgeschaft en vervangen door een college van bestuur. Het aanvaarden van de wub betekende enerzijds het einde van veel studentenactivisme, anderzijds de invoering van een vorm van zelfbestuur op een niveau waarop veel betrokken partijen dat niet geambieerd hadden. Bovendien werd veel van de via een bestuurscollege gewonnen efficiency weer tenietgedaan door de politieke verdeeldheid van de universiteitsraad en door de sterk toegenomen bureaucratie.

\section{Infrastructuur: de oude instellingen}

De thematiek van vrijheid en gebondenheid is het meest tastbaar in de infrastructuur van de universiteit. Mogelijk gemaakt door de economische voorspoed van de tweede helft van de negentiende eeuw en voorgeschreven door de toenemende klemtoon op specialisatie en wetenschap, ontwikkelde de universiteit zich van een academiegebouw met hier en daar een schimmig collegezaaltje tot een complex van verzamelingen en instellingen, bibliotheken en laboratoria. Over dit uitdijende heelal dreigde men al snel de regie kwijt te raken en voor de instandhouding ervan moest men steeds opnieuw bij de centrale overheid aankloppen. 
Een van de informatieve aspecten van de universitaire architectuur zijn de plannen die niet doorgingen. Het academiegebouw, bijvoorbeeld, was weliswaar onderwerp van menig visionair project, maar het bleef uiteindelijk de kleine intieme kapel aan het Rapenburg. Toch reflecteerden die plannen de universitaire gedachte. Zo kregen de architecten A. van der Hart, J.F. Thibault en J. van Westenhout in 1809 opdracht een gebouw te ontwerpen voor het gat dat de ramp met een kruitschip twee jaar еerder in het hart van de stad geslagen had. Huizinga zag er 'een stukje Napoleontisch Parijs' in, 'gaaf en gesloten en welberaamd'.

Het Academiegebouw zou alles omvatten, wat de hoogeschool ooit kon schijnen noodig te zullen hebben: gehoorzalen, waаronder een plechtig groot auditorium met aanzienlijke loges voor den Koning en zijn gevolg, vergaderzalen, bibliotheek, leeskabinetten, een anatomie, een instrumentenzaal voor de physica, galerijen rondom het binnenplein, terwijl onder de kolonnades kunst- en boekverkopers geacht worden hunne tenten op te slaan.

Gebrek aan geld en aan draagkracht verhinderde de uitvoering. Maar belangrijker misschien nog was dat de universiteit zelf inmiddels andere voorkeuren koesterde. Veel liever dan aan 'een praalgebouw om ten sieraad van stad en akademie te strekken', besteedden curatoren het geld aan 'de zoo hoognoodige en volstrekt onontbeerlijke vermeerdering en uitbreiding van wetenschappelijke verzamelingen zonder welke de universiteit niet langer haren rang onder de geleerde maatschappijen van Europa kan handhaven'. Bij het driehonderdjarig bestaan van de universiteit, in 1875, laaide de discussie opnieuw op. Veel plannen en veel historische stijl waren het gevolg. Wederom ging het om een symbolisch en administratief centrum. Maar intussen zag de universiteit zichzelf veeleer als een verzameling van meer of minder zelfstandige instituten en laboratoria.

De belangrijkste universitaire instellingen van het einde van de achttiende eeuw waren de kabinetten, die in de loop van de negentiende eeuw uitgebouwd werden tot imposante musea. Big science begon in Leiden als museale 


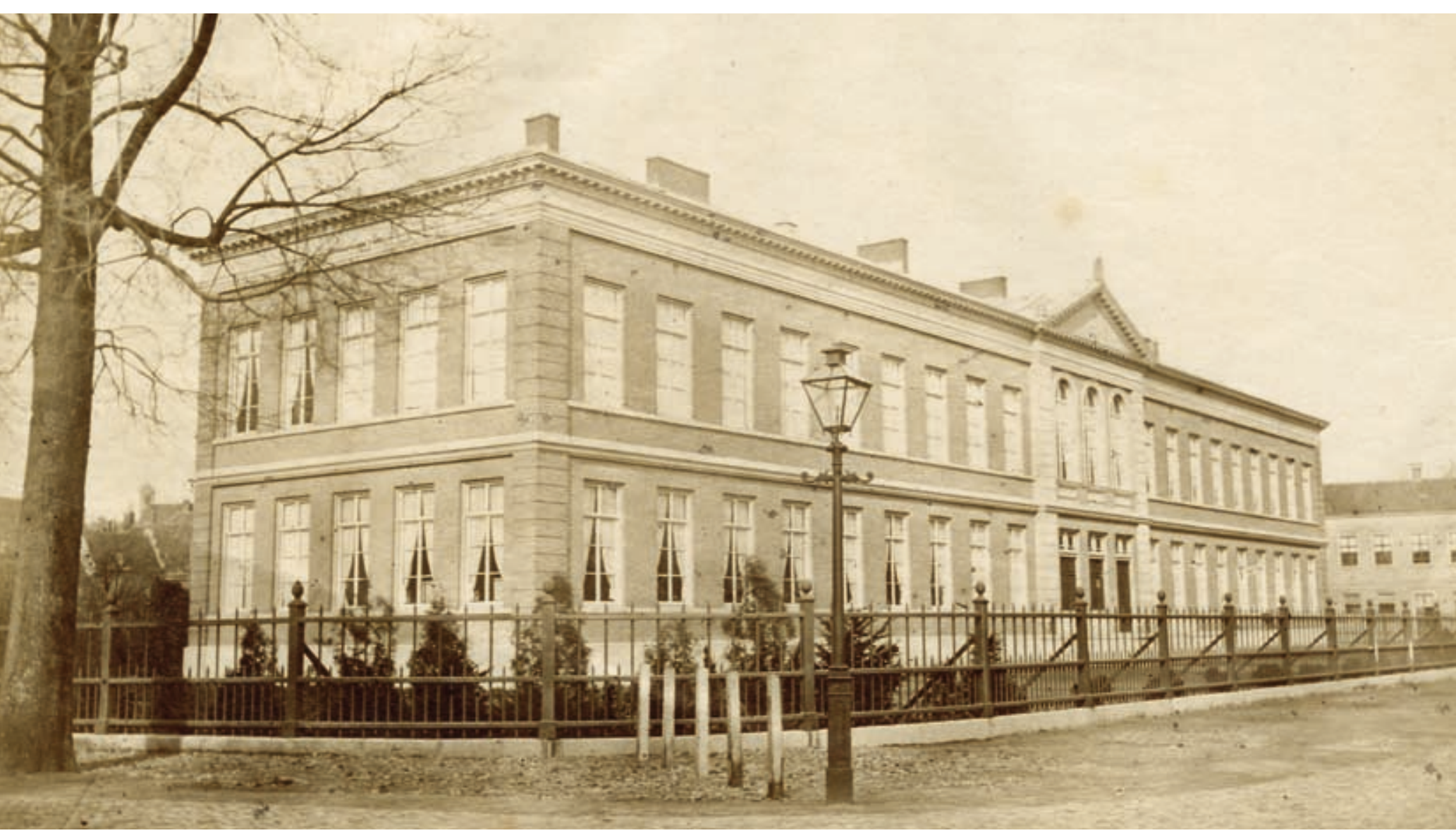

wetenschap. Tussen 1818 en 1825 werd de ruimte rond het Hof van Zessen aan het Rapenburg aangekocht en verbouwd tot museum. Aanvankelijk was dat bedoeld voor zowel natuurlijke historie en oudheden als het kunst- en fysisch kabinet, maar uiteindelijk slaagde de directeur van het Museum van Natuurlijke Historie, C.J. Temminck, erin het gebouw vrijwel alleen voor zichzelf te krijgen. Tussen 1900 en 1911 werd op de plek van de kruitramp (in de Leidse volksmond: de ruïne) zelfs een nieuw gebouw neergezet voor het museum, naar een ontwerp van J. van Lokhorst. Het Museum van Oudheden, in 1837 verhuisd naаг de Вreestraat, kreeg het vrijgekomen pand aan het Rapenburg. In 1937 kreeg ook 's Rijks Ethnografisch Museum, inmiddels omgedoopt tot

^ Laboratorium voor natuurkunde, scheikunde, anatomie enfysiologie, circa 1865 
Rijksmuseum voor Volkenkunde, zijn eigen gebouw, het voormalige Academisch Ziekenhuis aan de Steenstraat.

Deze schaalvergroting betrof ook de 'oude' instellingen: hortus, bibliotheek, sterrenwacht, fysisch kabinet. Tussen 1816 en 1819 was de hortus onder de bezielende leiding van Sebald Justinus Brugmans uitgebreid met niet minder dan $8500 \mathrm{~m}^{2}$. In $1830 \mathrm{kreeg}$ de tuin, als gevolg van de Belgische Opstand, het Rijksherbarium uit Brussel erbij, met directeur en al (C.L. Blume). Ook aan de bibliotheek werd de gehele negentiende eeuw door verbouwd, met als voorlopig finale staat in 1866 een nieuw voorgebouw naar ontwerp van J.W. Schaap. Acht jaar eerder, in 1858, had de architect Henri F.G.N. Camp het eerste echte laboratorium voor de universiteit gebouwd, bestemd voor natuuren scheikunde, anatomie en fysiologie. En in $1868 \mathrm{kreeg}$ Friedrich Kaiser een eveneens door Camp gebouwde eigen sterrenwacht, waarvoor de hortus een deelvan het gewonnen terrein moest prijsgeven.

Deze gebouwen van Camp luidden een nieuwe fase in van de universitaire architectuur. Voortaan waren het niet meer lokale architecten of aannemers die een nieuwe functie gaven aan een oud gebouw, maar werd nieuwbouw gepleegd voor specifiek wetenschappelijke of academische doeleinden. Camp, sinds 1849 architect des konings, bouwde in eclectische, classicistische trant. Hij gaf zijn gebouwen een rustig en harmonieus exterieur, een stijl die nog geheel paste bij de klassieke wetenschapsopvatting van het einde van de achttiende eeuw en bij een universiteit die zich op algemene vorming en onderwijs richtte.

Opmerkelijk is dat bij een aantal van de direct verantwoordelijken een geringe neiging bestond deze instituten in dienst van het onderwijs te stellen. De grote rijksmusea wilden vooral wetenschappelijke verzamelingen zijn. Bovendien zagen ze zich allengs meer als nationale dan als universitaire instellingen. Маar ook de toegankelijkheid van de universiteitsbibliotheek was gering. En de sterrenwacht en het grote laboratorium richtten zich eveneens veeleer op wetenschappelijk onderzoek dan op onderwijs. Daarbij kwam dat het Walenweeshuis aan de Oude Vest, dat de universiteit vanaf 1818 tot academisch ziekenhuis diende, niet geschikt was voor onderwijs. Pas in 1873 kreeg de universiteit een nieuw ziekenhuis, eveneens door Camp gebouwd, dat wel 


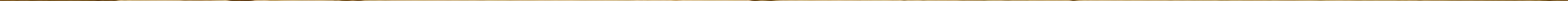


voor zijn onderwijsfunctie geschikt was, maar dat daardoor weer geen echt ziekenhuis kon zijn. Dit betekende dat van enige samenhang tussen onderzoeks- en onderwijstaak in de verschillende musea en laboratoria op een enkele uitzondering na geen sprake was.

\section{Infrastructuur: onderwijs en onderzoek}

Toch kreeg het idee van die samenhang tussen onderwijs en onderzoek met het voortschrijden van de tijd vastere vorm. De generatie medici die in de jaren zestig van de negentiende eeuw aan de universiteit kwam, voelde het gemis van een goed academisch ziekenhuis, van een grote hoeveelheid patiënten en van goed geoutilleerde laboratoria veel scherper dan de vorige generatie. De universiteit als louter onderwijsinstelling was een idee dat de meeste professoren in de jaren zestig al niet meer aanhingen. Door de invoering van de nieuwe Hoger Onderwijswet van 1876 onderging niet alleen het onderwijs, maar bijgevolg ook het geheel van universitaire instellingen een aanmerkelijke uitbreiding.

Het Zoötomisch Laboratorium op de plek van de kruitramp stamde uit 1874. Dit gebouw van Johan Frederik Metzelaar vertoont nog duidelijk trekken van de oudere laboratoria, maar deed al een stap in de richting van de Oudhollandse stijl die omstreeks die tijd de architectuur in zijn greep kreeg. In 1876 werd aan de oprijlaan van de sterrenwacht een nieuw gebouw voor biologie in gebruik genomen. En in 1877 bouwde de toenmalige rijksbouwmeester K. de Воer een vier verdiepingen tellend pand aan de bibliotheek, aan de noordzijde van de Faliebagijnkerk. In 1885 werd haaks hierop naar het Rapenburg toe nog een boekenmagazijn geplaatst. Opmerkelijk is dat hierbij rekening gehouden werd met instituutsafdelingen en het verzorgen van seminars.

Rijksbouwmeester Van Lokhorst hanteerde de Oudhollandse stijl ook bij zijn eerste Leidse laboratorium, het Boerhaavelaboratorium voor de pathologische anatomie vlakbij het ziekenhuis, dat eveneens in 1885 opgeleverd werd. In dat jaar begon ook de grote verbouwing van het chemisch-natuur- 
kundig laboratorium op de ruïne, met twee nieuwe vleugels om het geschikt te maken voor het nieuwe cryogeen- en lagetemperaturenlaboratorium voor Kamerlingh Onnes. Ook voor fysiologie (Einthoven) werd daar, aan de Zonneveldstraat, een laboratorium ingericht.

Architectonisch van groter belang was het complex van drie laboratoria voor scheikunde en farmacie, eveneens van de hand van Van Lokhorst, net buiten de singels op het landgoed Vreewijk, dat tussen 1898 en 1901 tot stand kwam. In 1899 werd het academiegebouw uitgebreid met een nieuw collegebouw aan de Nonnensteeg. In 1908 plakte Van Lokhorst hier een nieuw botanisch laboratorium aan vast. Dit gebeurde allemaal in de neogothische stijl, die veel beter dan het strenge classicisme een toegepast, rationeel ontwerp mogelijk maakte en bovendien aansloot bij de согрогаtieve ideeën die in die tijd, onder invloed van met name William Morris, ook onder protestanten van grote invloed waren. De heroriëntatie op middeleeuws gedachtegoed, de accentuering van de middeleeuwse wortels van de universiteit en de samenhang van de wetenschap - intern maar ook met de omringende maatschappij - maakten van de neogothiek meer dan een bouwstijl: het was ook een universitair visioen.

Deze instellingen waren voor een belangrijk deel ingericht voor het doen van wetenschappelijk onderzoek. Ze weerspiegelen dan ook de wetenschapsopvatting zoals die in de voorgaande periode had postgevat. Мaаг voor een ander, niet minder belangrijk deel waren ze bedoeld voor het onderwijs, beter gezegd: voor de verstrengeling van onderzoek en onderwijs, die eerst in deze tijd eveneens vaak tot uitdrukking kwam. De grootschaligheid die hierbij in het geding was, werd te Leiden voor het eerst zichtbaar in de bouw van haar cité médicale in het zogenaamde Boerhaavekwartier.

Dit terrein lag aan gene zijde van de spoorlijn en betekende voor de universiteit een cruciale sprong 'naar buiten'. Het betekende ook een experiment met een bouwvorm die vooral uit Duitsland overgenomen werd, het zogenaamde paviljoensysteem. Het ziekenhuis werd onderverdeeld in tien afzonderlijke gebouwen: I administratie en verpleging, II machines, keuken, wasserij, III chirurgie, IV verloskunde en gynaecologie, v interne geneeskunde, vi besmettelijke ziektes, VII kinderziektes, viII dermatologie en keel-, neus- 


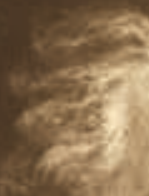

(2)

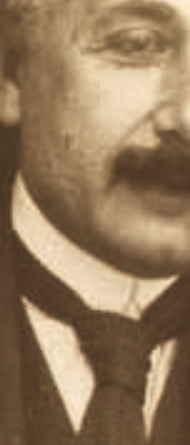

(1)

$-3$

Nin an

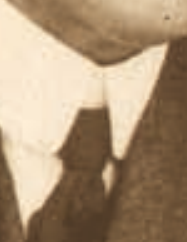

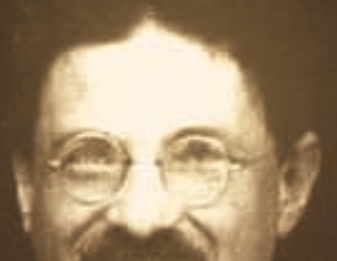

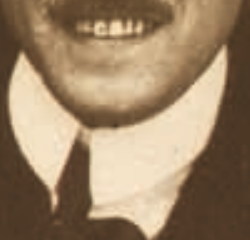

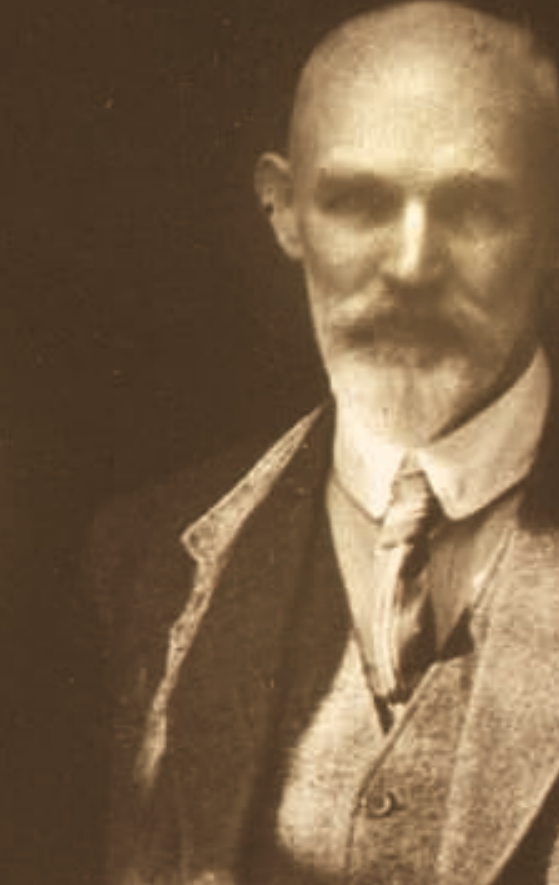
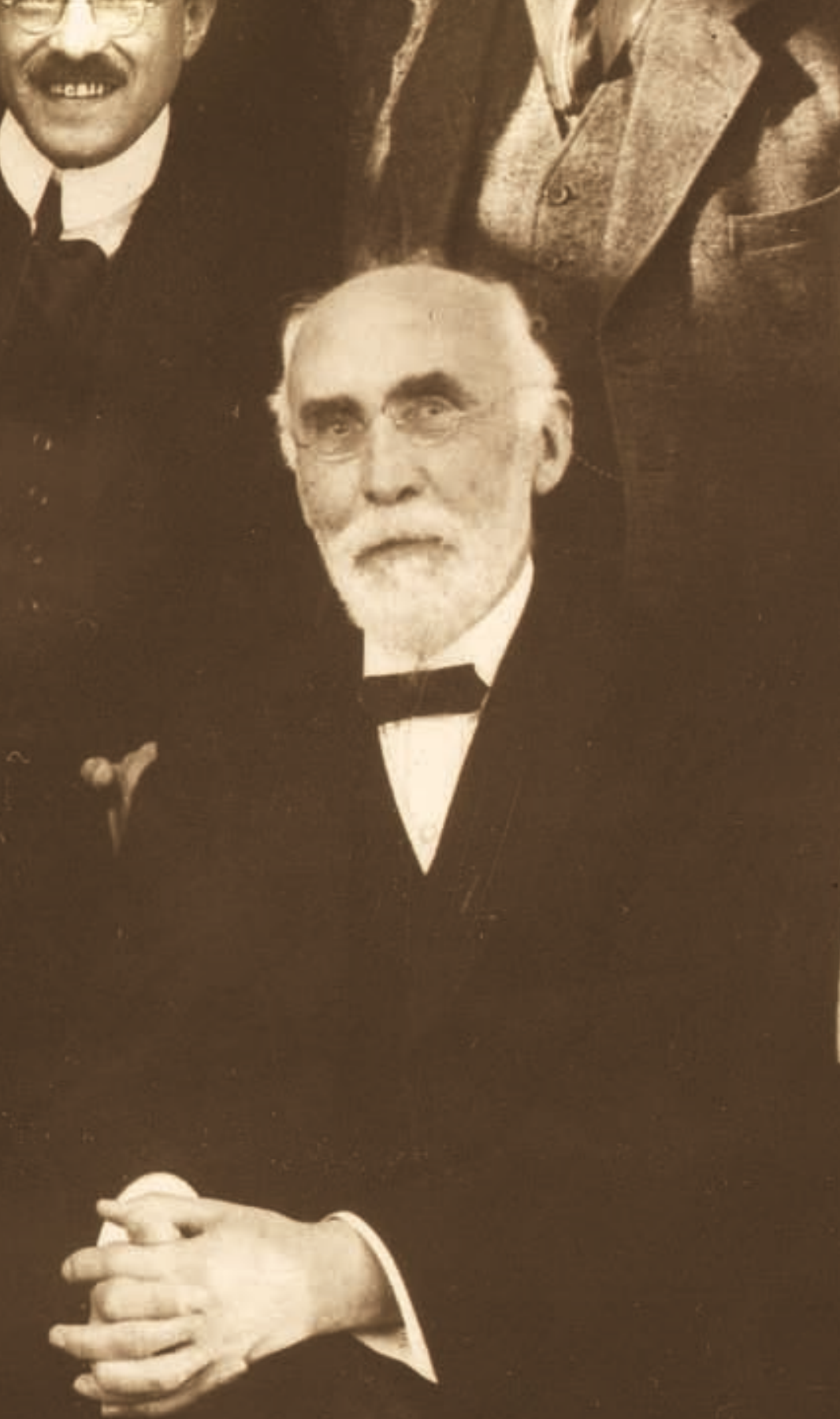

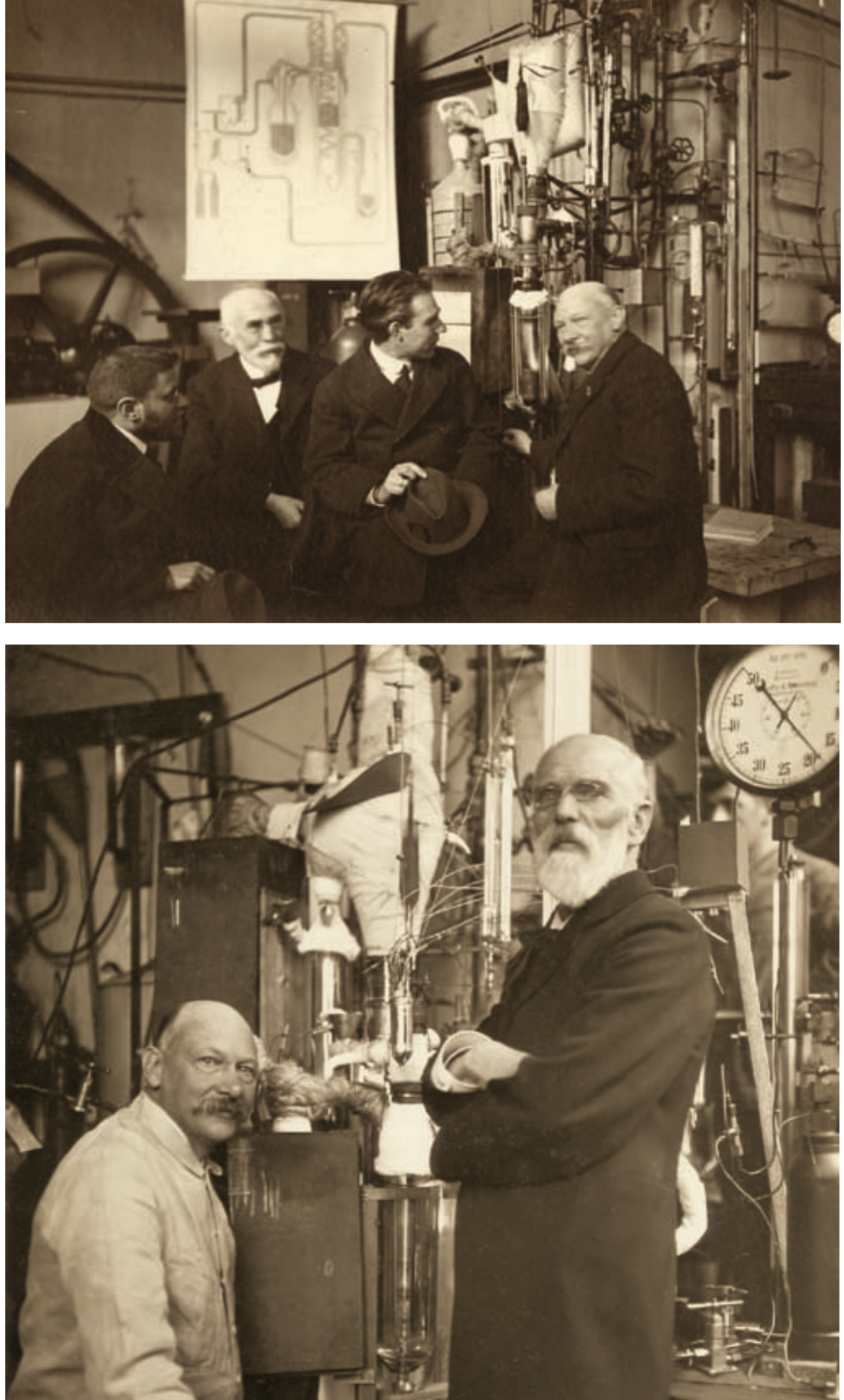

4 Einstein, Ehrenfest, de Sitter, Eddington en Lorentz, 1923

\Ehrenfest, Lorentz, Bohr en Kamerlingh Onnes bij de tweede heliumliquefactor, 1919

$\checkmark$ Kamerlingh Onnes en Lorentz, 1908 
en oorheelkunde, Ix oogheelkunde en x psychiatrie. In 1912 werd met de bouw begonnen. De omvang en de financiële problemen van het project zijn af te leiden uit het feit dat gebouw x pas in 1955 in gebruik genomen werd. De problemen met de gedecentraliseerde bouw laten zich eveneens in een cijfer vangen: volgens berekeningen moest het personeel in totaal dagelijks 327 kilometer tussen de gebouwen afleggen.

Niet minder verreikend was de manier waаrop men intussen het probleem van de studentenhuisvesting meende te moeten oplossen. In 1920 werd de Stichting Studentendorp in het leven geroepen die zich voornam een 'studententuinstad' te bouwen - in eerste instantie met een capaciteit voor 128 stu- $^{-}$ denten - паaг ontwerp van de gerenommeerde architect K.P.C. de Bazel. Veel verder dan de stichting en het ontwerp kwam het plan niet, maar de omvang en het ideaal zijn veelzeggend. Pas na de Tweede Wereldoorlog werd de Stichting Studentenhuisvesting opgericht, die allereerst de grote panden Oude Vest 35 en het Wallon aankocht, beide goed voor vijftig studenten. In 1957 volgde de oprichting van de Stichting Leidse Studentenhuisvesting, die zich op nieuwbouw concentreerde. Dit resulteerde in 1960 in de opening van de bekende 'Sterflat', later gevolgd door flatgebouwen als 'Het Hogerhuis', de 'Poddekenpoel' en de 'Pelikaanhof'.

\section{Benoemingen en verhoudingen}

In de loop van negentiende eeuw kreeg het benoemingsbeleid aan de Leidse universiteit langzaam maar zeker moderne trekken. In het begin van die eeuw was de benoeming nog volledig in handen van curatoren en lag de klemtoon nog steeds op een evenwichtige vertegenwoordiging van de wetenschappelijke richtingen. Maar halverwege de eeuw gaven curatoren het initiatief meer en meer uit handen: de emeritus, de faculteit en de minister werden bepalende factoren in het spel. Dit betekende dat meer dan voorheen interne, specialistische overwegingen een rol gingen spelen. De benoeming vond nog steeds plaats in de faculteit, maar tegelijkertijd tekende zich zoiets als het leerstoelensysteem af. 
De belangrijkste impuls tot de groei van dit systeem was natuurlijk de wetenschappelijke specialisering. Het aantal benoemingen per 25 jaar vertoont een spectaculaire groei: 47 tussen 1900 en 1924, 104 tussen 1925 en 1949, 352 tussen 1950 en 1975. Minstens zo opvallend is de gemiddelde leeftijd bij de benoeming. Die was 26 jaar in de periode 1875-1884, om op te lopen van 34,9 (1895-1904), via 40,4 (1925-1934) tot 46,1 (1965-1974). Bijgevolg liep de gemiddelde duur van het hoogleraarschap terug, in dezelfde decennia, respectievelijk van 45, via 28,3 en 25,4 паaг 11,3 jaar. Het gevolg van de specialisering was dus een langer voortraject en een geringere binding met de instelling.

De veranderende samenstelling van het professoraat laat zich ook afleiden uit de plaats van promotie. Tussen 1895 en 1904 promoveerden twee van de tien in dat decennium benoemde professoren in het buitenland, twee in $\mathrm{Ne}$ derland buiten Leiden en vier in Leiden; in 1925-1934 waren die getallen vier, dertien en zeventien en in 1965-1974 32, 59 en 69. Hieruit blijkt niet alleen een

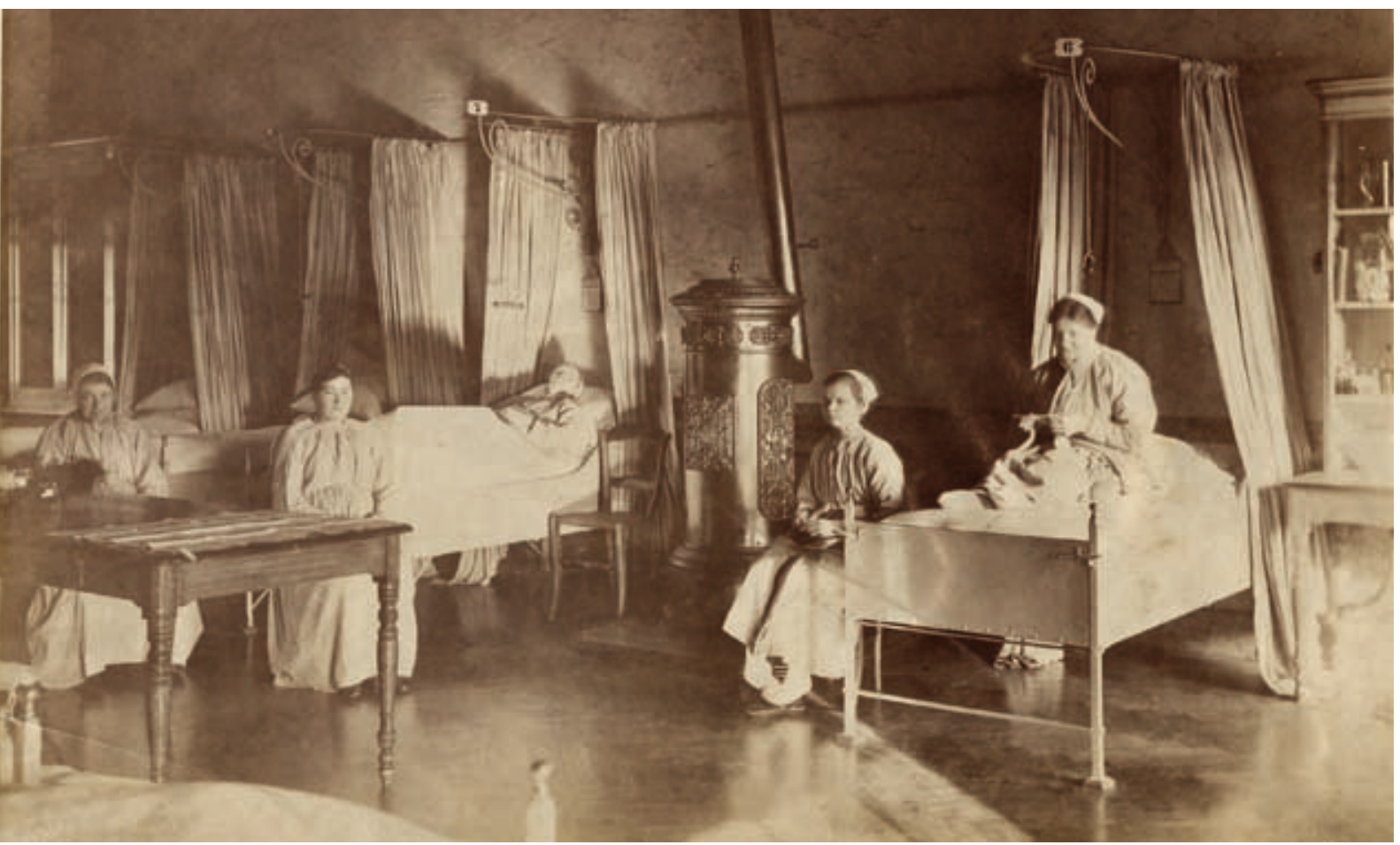

^ Interieur Academisch Ziekenhuis, 1889 
verminderde belangstelling voor 'eigen kweek', maar ook een toegenomen accent op internationale ervaring. Toch bleef het Leidse professoraat dominant Nederlands. In de honderd jaar sedert 1875 waren de meeste 'buitenlanders' afkomstig uit Indië (26), gevolgd door zestien Duitsers, twaalf Amerikanen en zeven Belgen. Verder waren er wat Zwitsers (vijf), Fransen, Tsjechen en Italianen (elk vier), Engelsen, Denen, Oostenrijkers en Polen (drie), Noren, Zuid-Afrikanen en Zweden (twee) en nog zeven individuen van elders.

De omvang van de wetenschappelijke staf was aanvankelijk gering en beperkte zich tot een select gezelschap van directeuren en conservatoren, observatoren en assistenten. Om een indruk te geven: in 1875 waren dat er 23. In 1900 bedroeg de wetenschappelijke staf van de instellingen 51 man, op 54 hoogleraren en 15 lectoren en privaatdocenten. In 1940 kende de universiteit al 436 ambtenaren, van wie 79 hoogleraren en 84 lectoren, (privaat)docenten en bijzonder hoogleraren. Met de stijging van het aantal studenten groeide ook het personeel. In 1950 waren er 137 docenten op 771 ambtenaren, in 1960 waren die getallen respectievelijk 227 en 1751. De enorme groei van de studentenaantallen in de jaren zestig betekende dat de universiteit in 19753291 ambtenaren telde, van wie 1770 niet-wetenschappelijk en 1521 wetenschappelijk personeel.

Aanvankelijk speelden kwantitatieve gegevens als deze geen rol in de bepaling van de onderlinge verhoudingen. Veel belangrijker voor de aard en de intensiteit daarvan was het zelfbeeld van de senaat. Dat werd in belangrijke mate bepaald door de opvatting die men erop na hield over doel en functie van de universiteit. Naarmate haаг encyclopedische, algemeen vormende doelstelling week vоor een meer рrofessionele of wetenschappelijke organisatie, nam het zelfbesef van het professoraat toe. Daarmee wijzigde ook de houding tegenover curatoren en studenten.

In het begin van de negentiende eeuw was de relatie tussen professoren en curatoren ronduit slecht. Het adellijk dedain waarvan curatoren tegenover de burgerlijke professoren blijk gaven, liet niet na wonden te slaan. 'Pedante Sionswachters' noemde de jurist Van Assen de curatoren. Hij verdacht ze ervan zelfs de leslijst niet te begrijpen. Veel van zijn collega's deelden zijn misprijzen. Aan het einde van de eeuw was de relatie hetzelfde, maar waren de ver- 
houdingen omgekeerd. De senaat legde een veel groter zelfbewustzijn aan de dag. Bovendien spraken de рrofessoren de voorkeur uit voor een organisatie die sneller kon reageren op ontwikkelingen in de wetenschap en in de maatschappij. Ze wilden een grotere medezeggenschap en meer onafhankelijkheid van het ministerie.

De verhouding tussen professoren en studenten was aanvankelijk vooral afstandelijk. De senaat beschouwde het studentenleven als een eigen sfeer. De onderlinge mores en de gedragingen nаar buiten werden zoveel mogelijk gerespecteerd of zo nodig met vaderlijk vermaan gecorrigeerd. Er waren wel informele betrekkingen, zoals het befaamde 'theeslaan'. Dit bestond hoofdzakelijk uit verplichte visites, waarbij opmerkingen over het weer van elkaar gescheiden werden door lange stiltes. Halverwege de eeuw ging de senaat meer in het studentenleven interfereren. Straffe maatregelen werden bedacht om de studiediscipline te vergroten, zoals het 'consilium abeundi', een klemmend advies de studie te staken. Het verschijnsel van het ontgroenen en de opdeling in rijk en arm, corpslid of niet, waren terugkerende problemen waагоver de senaat zich moest buigen.

Ook in de colleges veranderde de verhouding tot de studenten. In de eerste helft van de negentiende eeuw was de voertaal nog steeds het Latijn, ook al konden de meeste studenten dat nog slechts met moeite volgen. Bijgevolg dicteerden de professoren veel. Pas in de jaren zestig, bij de overgang van het hortend dictaat in het Latijn naar de vrije voordracht in het Nederlands, trad hierin verbetering op. Aan het einde van de negentiende eeuw werd een steeds intensiever contact nagestreefd. De tendens was om het hoorcollege zoveel mogelijk te laten waarnemen door repetitoren of te vervangen door een handboek en het eigenlijke universitair onderwijs te laten plaatsvinden in kleine werkgroepjes of via begeleiding in het laboratorium.

\section{De senaat}

Ook onder ргоfessoren onderling heerste gedurende vrijwel de gehele negentiende eeuw een zekere afstandelijkheid. Verschillen in opvattingen over 

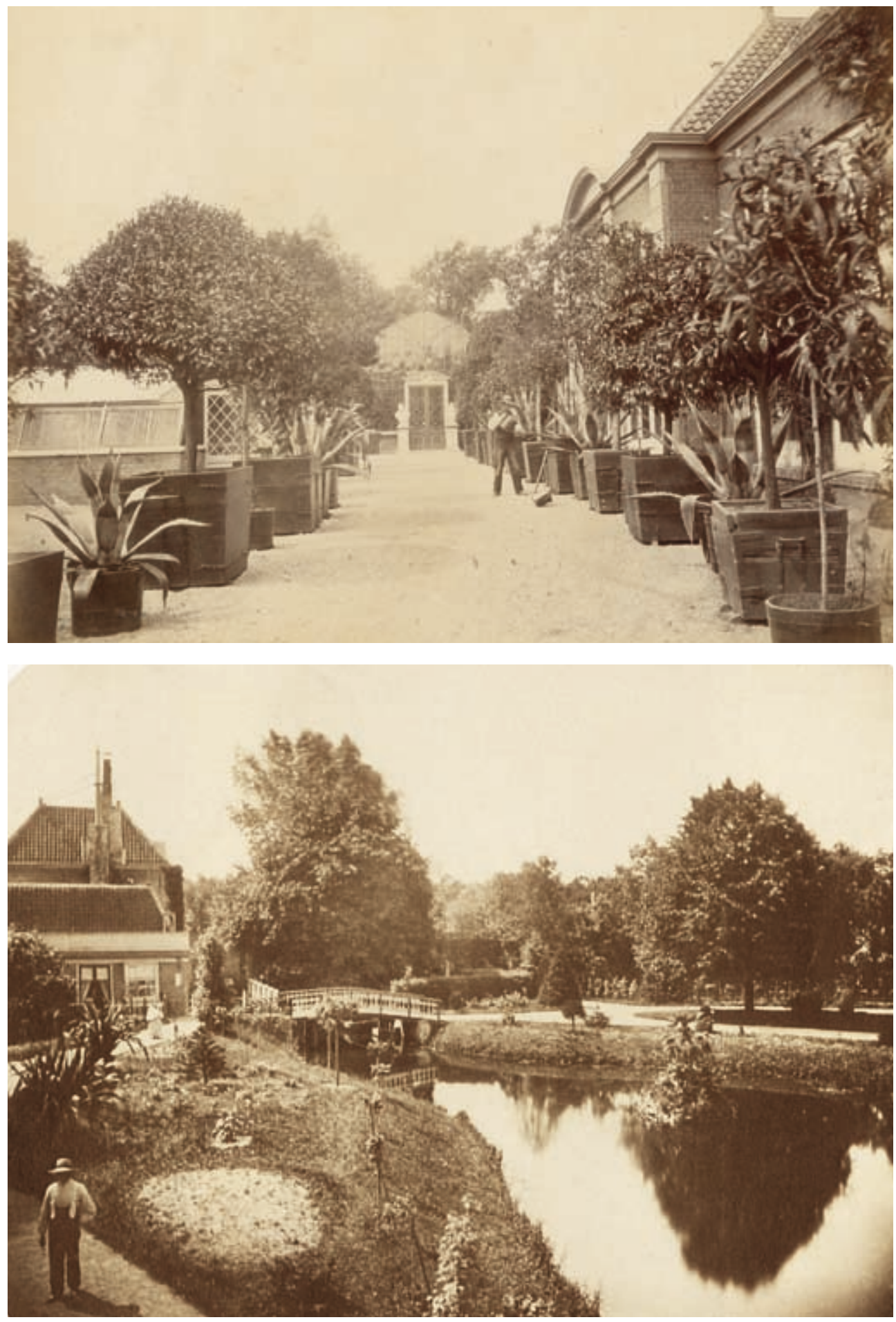

\ Orangerie en plantenkas in de Hortus Botanicus, 1866

v Vijver in de Hortus Botanicus, 1866 
de doelstelling van de universiteit - elitair of toegankelijk, wetenschappelijke training of beroepsopleiding - konden soms fel oplaaien. Tel daarbij op de verschillen in honorering, collegegelden en bijverdiensten, verschillen tussen liberalen en conservatieven, verschillen ten slotte niet alleen tussen de lidmaten van onderscheiden kerkgenootschappen, maar ook tussen hen die in de Bijbel het gezag van Gods heilig woord zagen en hen die van de verboden vrucht van de Bijbelkritiek geproefd hadden, en die distantie krijgt zijn logica.

Deze verschillen werden overigens sociaal gedempt door eenzelfde burgerlijke levenswijze en een 'gezellige' opvatting van de wetenschap. In de loop van de negentiende eeuw nam de eenheid onder professoren - zowel materieel, politiek als religieus - langzaamaan toe. Een overeenkomstige woonstrategie, een liberale consensus en een religieus gevoel dat zich bewoog binnen de grenzen van rationalisme en agnosticisme smeedden de senaat aaneen. Daar staat tegenover dat de herkomst van het professoraat gevarieerder werd. In het begin van de negentiende eeuw was 66 procent afkomstig uit het zogeheten Bildungsbürgertum, dat wil zeggen: gesproten uit vaders die zelf professor waren of hun brood verdienden als predikant, leгаaг, arts en dergelijke. Halverwege de eeuw liep dat terug naar 57 procent en rond de eeuwwende was het 52 procent. In die laatste periode was 34 procent van het professoraat afkomstig uit het Besitzbürgertum; een aantal van hen stamde zelfs uit de kleinburgerij: winkeliers, een smid en zelfs een marskramer. Van de 75 hoogleraren die in 1933 aan de universiteit verbonden waren, kwamen er 23 uit de hoogste sociale klasse, 36 uit de middenklassen en 16 uit de lagere regionen van de maatschappij.

Tegelijk bereikte de eigendunk van de professor een verzadigingsgraad die zijn weerga niet kende. 'Het ideaal is thans voor velen: de professor,' schreef de Leidse filosoof A.J. de Sopper. 'Het leven wordt reeds geruimen tijd beheerscht door den cultus der geleerden.' Een probleem was dat zij niet het gevoel hadden dat ег паaг hen werd geluisterd. Dat ontging de Allgewaltigen in hun kleine revier niet en zij hadden dan ook vele klachten. Het begon al met het onderwijs zelf: te weinig vooropleiding bij de studenten, broodstudie en overрroductie van academici. Маar de onvrede van de professoren strekte 
zich ook uit over de politiek en de cultuur als geheel. Een vrij algemeen cultuurpessimisme maakte zich van hen meester. Huizinga zou daarvan, met $\boldsymbol{I n}$ de schaduwen van morgen, de bekendste verwoording geven. 'De geest wordt vermorscht [...] Als asphalt- en benzinegeur boven de steden, hangt over de wereld een wolk van woordenkraam.'

Tegen deze achtergrond beraamden de Leidse professoren in de Tweede Wereldoorlog even gedetailleerde als utopische plannen voor de organisatie en doelstelling van de naoorlogse universiteit. Zij wensten grotere onafhankelijkheid en een beter bestuur en dachten dit te bereiken door afschaffing van de curatoren en de verkiezing van een universiteitsbestuur uit de senaat onder leiding van een vijf jaar in functie zijnde rector magnificus. Een raad van toezicht zou de controlerende functie van het departement overnemen, een universiteitsraad zou de oud-alumni aan de universiteit binden. Als praktische maatregelen om de interne eenheid te vergroten, noemden ze de opzet van een Civitas-huis voor 'ongedwongen verkeer' tussen staf en studenten en de instelling van een studium generale, een permanente collegecyclus over 'algemene levensvragen' en algemeen vormende onderwerpen. Ook uitgewerkte plannen voor sport en huisvesting, гесгеatie en gezondheidszorg kwamen aan de orde.

Maar de plannen van de wetenschappelijke staf, die in aparte groepjes bijeenkwam, gingen nog het verst. Werd van hun bestaan in de voorstellen van professoren nog slechts in licht feodale zin gewag gemaakt, zijzelf eisten voor zich in een drietal rapporten - waarbij voor het eerst de term 'wetenschappelijke staf' viel - een eigen stem. Een stapje verder was hun opvatting over de plek waar die stem gehoord zou worden, namelijk in een universiteitsraad die, anders dan die van de professoren, 'als zijnde representatief voor de geheele academische gemeenschap' ook het eigenlijke machtscentrum van de universiteit zou zijn. In al deze voorstellen lag de stof voor vele jaren naoorlogse discussie opgeslagen.

- Grafreliëfuit Smyrna, tweede eeuw voor Christus 


\section{Wetenschap}

De negentiende eeuw was de wieg van de wetenschappelijke methode. Via het klassieke wetenschapsmodel zoals dat in de achttiende eeuw gegroeid was, kreeg de wetenschap, met als belangrijk tussenstadium de museale wetenschap, haаг huidige karakter. Kenmerk daarvan is het cruciale verband tussen theorie en experiment. De klassieke wetenschap was een vorm van geleerdheid die zich afspeelde rondom verzamelingen. Zij richtte zich op classificatie en werd in belangrijke mate mogelijk gemaakt via lekenpatronage. Rond 1800 maakte dit wetenschapsmodel plaats voor een nieuw, grootschaliger, professioneler model, gecentreerd rond de grote musea en ziekenhuizen, analytisch en comparatief van methode. Omstreeks 1860 moest dit type wijken voor een wetenschap die zich hoofdzakelijk in laboratoria afspeelde, universiteitslaboratoria meestal, materieel gericht op manipulatie en beheersing, methodisch op kwantificering en precisie.

In de praktijk waren overigens de mengvormen belangrijker dan de typen. Tot ver in de negentiende eeuw waren in Leiden de klassieke begrippen van samenhang en harmonie, orde en maat, nog oppermachtig. De wetenschap bleef voor velen een geleerd vermaak, een encyclopedisch genoegen. Elk onderwerp van wetenschap vertoonde een vanzelfsprekende eenheid, zoals alle wetenschappen samen een harmonieus geheel vormden. De samenhang die het geheel kenmerkte, was van God gegeven. Het maakte van de werkelijkheid een redelijk amalgaam, een tot 's mensen baat ingericht geheel. Het impliceerde ook het bestaan van een samenhang tussen beschrijving en voorschrift, tussen verschijnsel en essentie. Het maakte van de man van wetenschap tegelijk een wijsgeer, iemand die zijn wetenschap in dienst stelde van het bewijs van de doelgerichtheid van Gods schepping, het nut van alle wezens erin en de vooruitgang van zijn belangrijkste schepsel, de mens.

Tegen deze achtergrond kreeg elke wetenschap haar eigen oogmerk en object. De natuurlijke historie, beoefend door ook in het buitenland geachte geleerden als Brugmans, Reinwardt en Jan van der Hoeven, had het grootste aanzien in de faculteit van wis- en natuurkundige wetenschappen. Daar lag de doelmatigheid van de schepping, de orde en hiërarchie, als het ware voor 
het opscheppen. Daar kregen de almacht van de Schepper en de centrale positie van de mens hun beschrijving. Medici waren in wezen menskundigen. Geleerden als Macquelin en Pruys van der Hoeven (de broer van Jan) - weliswaar niet zo beroemd als hun natuurhistorische collega's - hielden zich aan hetzelfde credo. Ze beperkten zich niet tot de ziekte, niet tot de zieke mens, maar betrokken de hele mens in hun beschouwing. Onder theologen als Van Voorst en Clarisse heerste het supranaturalisme, een vorm van religieus gezond verstand, de overtuiging dat de zaken van God wellicht de rede te boven maar er nooit tegenin gingen.

De letterenfaculteit beklemtoonde vooral de vorming van een harmonieuze persoonlijkheid en zag toe op ordening van de gedachten, op de formulering daarvan vooral. Grote namen als Wyttenbach, Bake en Cobet hielden er de filologische faam van Leiden levend. Ze wensten smaak bij te brengen en gevoel voor vormvastheid. Daarin werden ze gesteund door hun collega's van de oosterse letteren en filosofie, Van der Palm en Van de Wijnpersse. Onder juristen ten slotte - misschien met uitzondering van Kemper niet zulke grote geleerden - werd de oude elegante jurisprudentie voortgezet, een rechtsgeleerdheid met literaire middelen, het erudiete verband tussen levensvorm en rechtsstelsel. Het Romeins recht vormde de band tussen de rechtsgeleerdheid en de oude letteren.

Toch begonnen er langzaamaan gaten te vallen in dit harmonieuze geheel. Onder theologen ging men vraagtekens zetten bij het supranaturalisme, zij het alleen binnenskamers. Onder letterkundigen, bij de archeoloog Reuvens en de oriëntalist Hamaker, maar vooral bij een jurist als Thorbecke, is de omslag nog veel duidelijker te constateren. Zij legden de klemtoon op historische groei en verandering. Vоог hen was de status-quo geen ideaal maar de verkalkte gestalte van een oude werkelijkheid.

Rond het midden van de negentiende eeuw kwam de wetenschap zoals Leidse professoren die beoefenden geheel in het teken te staan van de ‘wijsbegeerte deг егvaring'. Ook buiten de faculteit der wis- en natuurkunde рrees men om strijd de natuurwetenschappelijke methode als enige ware aan. De ontwikkelingsgedachte en niet de analogie, de vooruitgang en niet de statusquo domineerden de wetenschappelijke activiteit. 

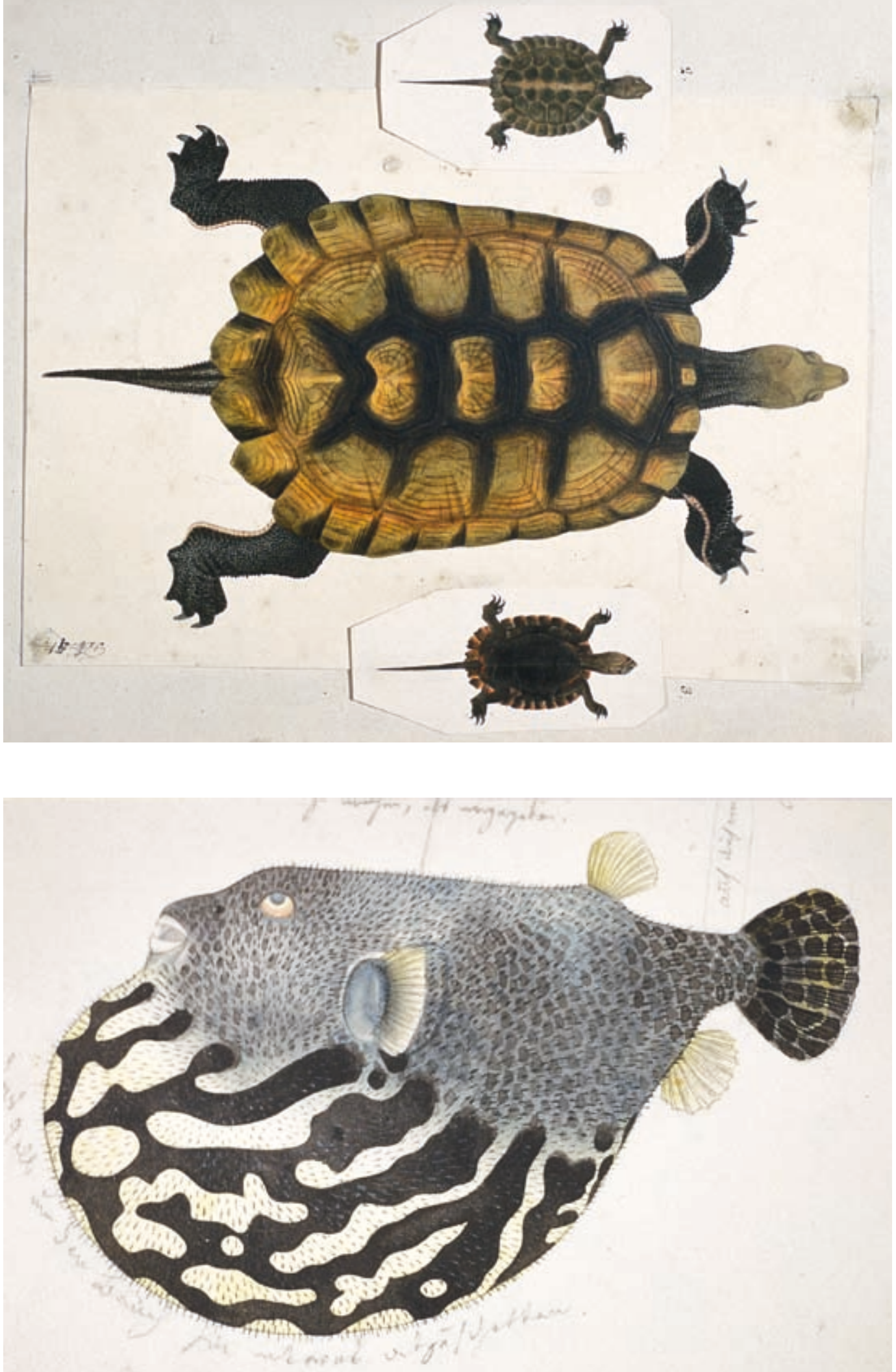

4 Schildpad, collectie Von Siebold

$\checkmark$ Koffervis, collectie Von Siebold 


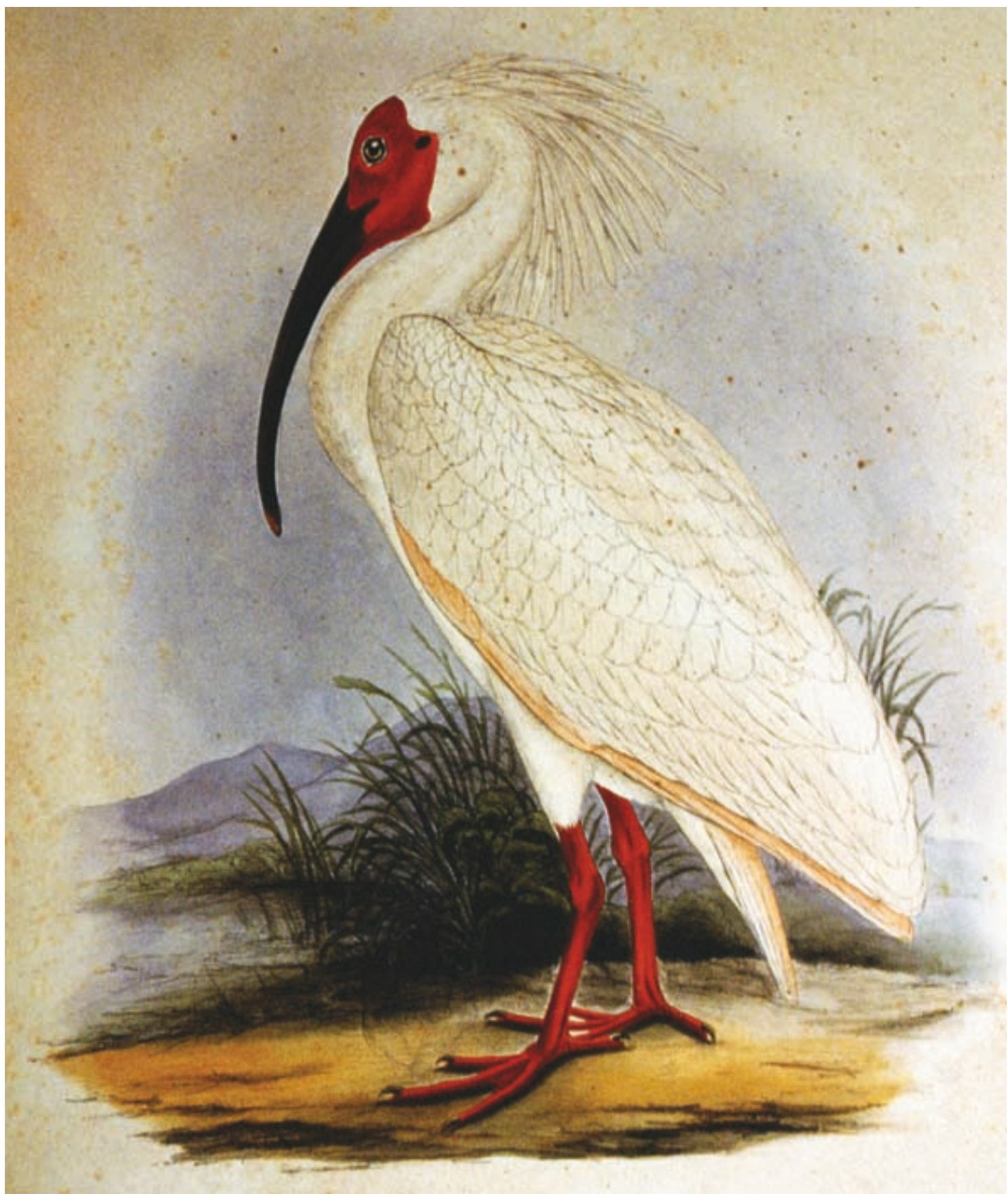

\ Ibis nippon uit de Fauna Japonica van Philip Franz von Siebold 
Bij juristen als Vissering, Goudsmit en Buys betekende dit dat de klemtoon kwam te liggen op de ontwikkeling van de rechtsstaat. Bij theologen - en we hebben het over giganten als Scholten en Kuenen - kwam de historische bestudering van de Bijbel centraal te staan. Ook bij letterkundigen als Dozy, Juynboll en Kern (oosterse letteren), Jonckbloet (Nederlands), en Fruin (geschiedenis) verschoof de aandacht van filologie naar geschiedenis, van taalbeschrijving naar woordenboek. En bij medici als Halbertsma en Schrant, Evers en Heynsius kwam de nadruk te liggen op de fysiologie, op de noodzakelijkheid van 'kracht en stof'.

In de jaren zeventig veranderde dat. Er kwamen andere geluiden, verschijnselen van onvrede met een al te overzichtelijk kennisbegrip en met een al te dwangmatig positivisme. Aan het einde van de negentiende eeuw was er van dat geharnaste kennisideaal weinig meer over. Juristen (Oppenheim en Drucker, Van der Vlugt en Asser) hielden zich liever bezig met begrippen als 'recht' en 'rechtvaardigheid', en letterkundigen (De Goeje en De Groot, Ten Brink en Kalff, Muller en Blok) legden de klemtoon meer op normatieve zaken als esthetiek en vaderlandsliefde.

Ook onder theologen (Tiele en Acqoy, Rauwenhoff en Gunning) is een ethische wending waar te nemen, terwijl medici (Rosenstein en Van Itterson, Treub en Korteweg) de behandeling van de zieke mens in het centrum van hun aandacht plaatsten. Wis- en natuurkundigen (Lorentz en Kamerlingh Onnes, Franchimont en Schreinemakers) bogen zich vooral over het onderscheid tussen empirie en theorie. Het betekende voor allen een ommekeer in de waardering van de kennis, minder afstandelijk voor sommigen, relativistischer voor anderen, abstracter voor derden.

\section{Wetenschappelijke institutionalisering}

In de loop van de twintigste eeuw drong meer en meer het besef door dat er dwars door de wetenschappen een tweetal scheidslijnen liep. Enerzijds ging men de humaniora los zien van de natuurwetenschappen (de befaamde 'two cultures' van C.P. Snow), anderzijds werd een meer sciëntistische, positivis- 
tische inspiratie in alle wetenschappen gescheiden van een meer invoelende en normatieve methodiek. Een taalkundige kon uitgaan van het streng positivistische standpunt van de Duitse Junggrammatiker, maar hij kon ook veel meer literair of historisch te werk gaan. Een belangrijk historicus als P.J. Blok was diepgaand beïnvloed door de economische geschiedenis, maar zijn collega Huizinga was daar lichtjaren van verwijderd.

Ook op het gebied van de rechtswetenschappen gold een dergelijke spanning. Zowel in het privaatrecht als in de staatsleer en het strafrecht bestonden grote verschillen tussen theorie en positiefrechtelijk standpunt, tussen wetmatigheid en vrije wil. Aan de ene kant introduceerde de socioloog Steinmetz te Leiden de volledige bepaaldheid van het maatschappelijke leven, aan de andere kant stak de archeoloog A.E.J. Holwerda de draak met alle 'soci-wetenschappen'. Leidse economen als Greven en Van Blom hielden zich nog bewust aan de 'oude economie', dat wil zeggen: aan de liberale school van vrijheid en abstracte redenering, terwijl allerwegen de nieuwe economie van de sociale gedachte en empirische methode veld won. In de psychologie is de volte face die Jelgersma van een fysiologisch psycholoog in een psychoanalyticus veranderde kenmerkend.

Binnen de exacte wetenschappen bestond een vergelijkbaar spanningsveld. Op medisch gebied was er het probleem van de vakschool contra de wetenschappelijke opleiding, de kritiek dat de universiteit wel geneeskundigen maar geen artsen afleverde. Нier en elders vormde het probleem van de specialisatie een studieterrein apart. Onder het 'nakroost van Boerhaave' bevonden zich niettemin belangrijke geleerden, zoals de oogheelkundige Van der Hoeve en de psychiater Carp. In de natuur- en scheikunde voltrok zich een scheiding tussen het oude (newtoniaanse) en nieuwe (einsteiniaanse) wereldbeeld, tussen kleinschalig onderzoek en big science. Het was de tijd van het genie Lorentz - zestien toen hij ging studeren, eenentwintig bij promotie, drie јаar later professor - die in een exemplarische samenwerking met zijn collega, de aartsexperimentator Kamerlingh Onnes, de Leidse natuurkunde wereldfaam gaf. Het bracht hun beiden, kort na elkaar, de Nobelprijs (1902 en 1913). In 1924 kreeg ook Einthoven die voor zijn fysiologisch onderzoek.

De rechtenfaculteit maakte eveneens een grote bloei door. Kon zij zich in

- Afdeling Sumatra en Borneo van het Rijksmuseum voor Volkenkunde, ca. 1900 


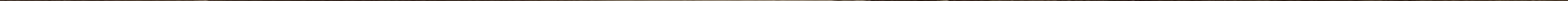


het laatste kwart van de negentiende eeuw beroemen op grote namen als Buys, Goudsmit, Modderman, Van der Hoeven en Oppenheim, na de Eerste Wereldoorlog handhaafde zij haar faam met internationaal vermaarde geleerden als Van Vollenhoven, Krabbe, Meijers en Van Eysinga. Het traditionele palet aan oosterse studies, gevoed door de collecties van de universiteitsbibliotheek en het Koninklijk Instituut voor Taal-, Land- en Volkenkunde, splitste zich allengs langs de grote antropologische onderzoekslijnen van de adatkenner Van Vollenhoven, de arabist Snouck Hurgronje en de antropoloog De Josselin de Jong.

Na de Tweede Wereldoorlog raakte de letterenfaculteit allengs opgedeeld in een westers en een niet-westers gedeelte en in een gebied van 'kleine' en 'grote' letteren, beide nogal moeizame ambtelijke indelingen van een prachtige verscheidenheid van oude taalkundige of filologische disciplines en агеa studies. De rechtenfaculteit handhaafde haаг oriëntatie op de publieke zaak en bijgevolg een breed aanbod van vakgebieden. Ze herbergde bijvoorbeeld een sterke internationale sectie, met een aantal leerstoelen voor rechtssystemen van andere landen. Daarnaast legde ze sterk het accent op historische en sociaalwetenschappelijke vakken. De universiteit had bijvoorbeeld geen economische faculteit, maar wel economen van naam binnen de rechtenfaculteit. Daar stond ook de wieg van de Leidse politieke wetenschappen.

De sociale wetenschappen waren, hoewel sociologie daarin ontbrak, breed georiënteerd en omvatten culturele antropologie, psychologie en pedagogie/andragogie. Hier bleven alfa- en bèta-invloeden, evenals vragen van theorie en toepassing, de faculteit een zekere ambivalentie verlenen, zoals dat aanvankelijk ook in de medische faculteit het geval was met het onderscheid in preklinische en klinische vakken. Toch vond al snel na de oorlog ook in klinische vakken een nieuwe oriëntatie op onderzoek plaats, niet alleen in de interne vakken, ookin de heelkunde.

Hoe ouderwets het Hugo de Groot-laboratorium ook was, de nieuwe ontwikkelingen in de organische, fysische en biochemie vonden er snel hun onderkomen. De natuurkundigen vonden nieuwe inspiratie in het onderzoek naar de superfluïditeit, terwijl de sterrenkundigen onder de geniale leiding van Oort ons eigen melkwegstelsel rond de spectraallijn structureerden. Het 
onderzoek in de informatica concentreerde zich onder andere op communicerende processen: op de logica gebaseerde programmeertalen en grammaticale methoden voor het herkennen van patronen. De biologen richtten zich vоогаl op de moleculaire plantkunde en de celbiologie.

Bij al deze onderzoekslijnen valt vooral de grootschaligheid op. Dit impliceert een onontkoombaar historiografisch manco. Het ontbrak Leiden in deze naoorlogse periode bepaald niet aan grote namen. P.A.H. de Boer en Bakhuizen van de Brink, Miskotte en Berkhof gaven de theologie een onmiskenbare uitstraling. Voor de filosofie was dit het geval bij Van Peursen en Nuchelmans. Juristen als Meijers en Van Oven, Cleveringa en Van Asbeck, Fischer en Rypperda Wierdsma, Drion en Feenstra waren elk op hun terrein zeer grote namen. Dat gold ook voor medici als Gorter (Evert) en Rademaker, Duyff en Mulder, Querido en Van Rood, Cohen en Sobels en vele anderen. Natuurkundigen als Kramers en Gorter (C.J.), De Groot en Mazur, Kistemaker en Beenakker, scheikundigen als Van Arkel en Havinga, Oosterhoff en Mandel, Staverman en Ponec zetten de faam van de Leidse exacte wetenschappen voort, samen met sterrenkundigen als Oort en Van de Hulst, wiskundigen als Kloosterman en Zoutendijk, biologen als Lam en Kuenen, Steenis en Quispel. Bij de letteren waren dit Duyvendak en Byvanck, De Josselin de Jong en Van Groningen, Van de Waal en Waszink, Den Boer en Milo, Dresden en Lunsingh Scheurleer, Uhlenbeck en Bachrach, Locher en Stutterheim, Van het Reve en Zürcher, Schulte Northolt en Bastet, Heesterman en De Rijk. Bij de sociale wetenschappen: Van Heek en Dankmeijer, Daalder en Lijphart.

\section{Studie: opzet en oogmerk}

De studie zoals die volgens het Огganiek Besluit werd ingericht, ving aan met een brede propedeuse, in de letteren voor theologie en rechten, in de wis- en natuurkunde voor geneeskunde. Het vakkenpakket werd weliswaar omschreven, maar dat gebeurde niet gedetailleerd en weinig scherp omlijnd. Er waren vijf faculteiten. Naаг Frans voorbeeld werd de filosofische faculteit gesplitst in de faculteit deг bespiegelende wijsbegeerte en letteren en de facul- 


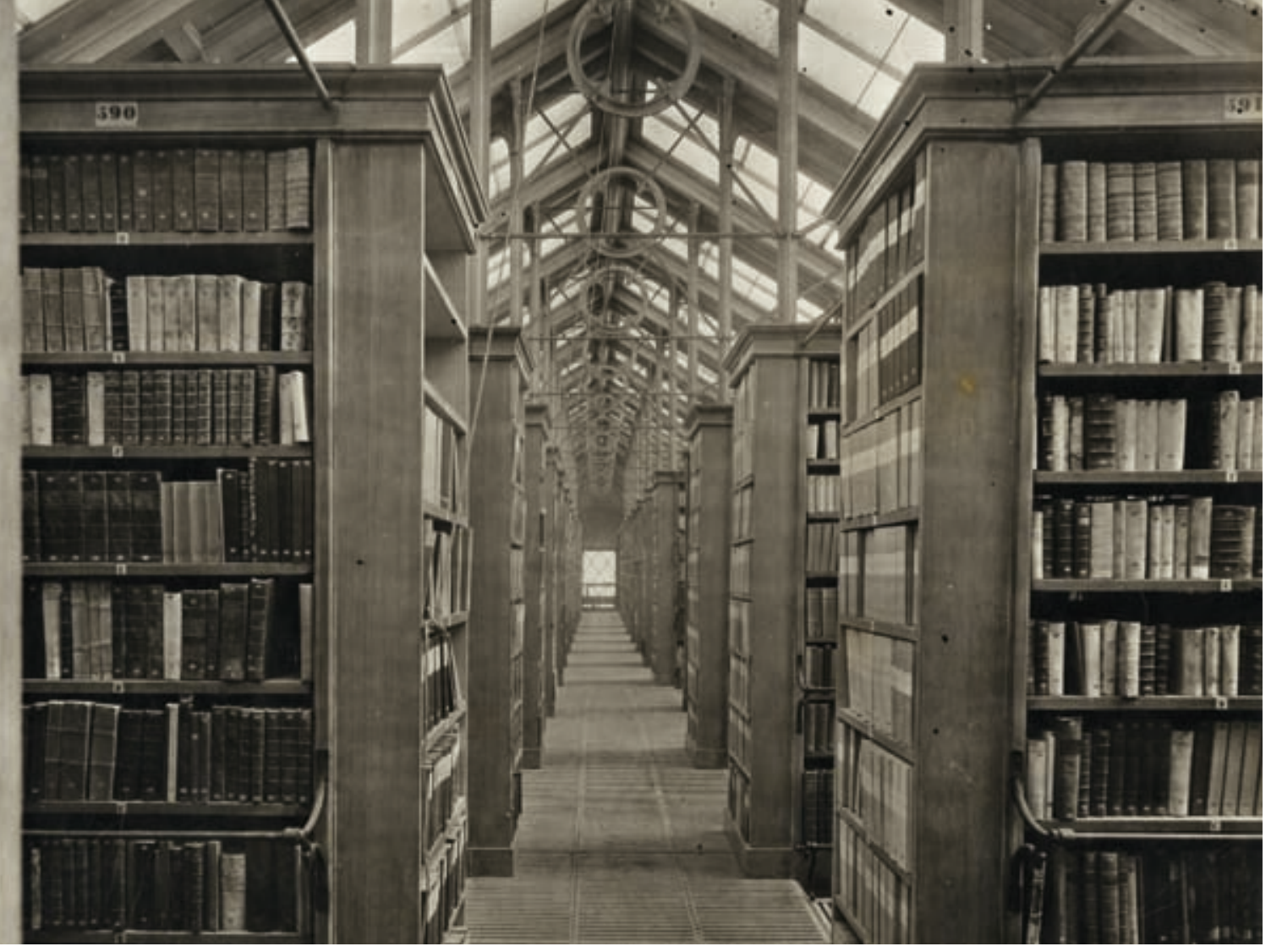

teit der wis- en natuurkundige wetenschappen. Er werd geen volgorde van studie bepaald, wel stond een minimale duur van het verblijf aan de universiteit vast (meestal drie jaar voor de hoofdvakken). Ook werden twee graden ingesteld, die van kandidaat en doctor. De laatste werd gekoppeld aan de uitoefening van allerlei maatschappelijke functies die in het diploma werden omschreven.

In 1876 verviel de verplichte propedeuse. Wel bleef voor de medici een natuurwetenschappelijke voorbereiding vereist. De nieuwe wet stelde zeventien doctoraten in en omschreef 61 verplicht te doceren vakken, terwijl nog eens zestien meest juridische of literaire vakken genoemd werden die aan enige universiteit in het land gedoceerd dienden te worden. De eisen vоor de verschillende doctoraten liepen nogal uiteen. Vooral het verschil tussen de twee grootste studierichtingen, medicijnen en rechten, is opmerkelijk. Wenste een toekomstig arts tot het kandidaatsexamen toegelaten te worden, dan moest hij eerst een omvangrijk examen afleggen aan de faculteit der wisen natuurkunde. Het kandidaats omvatte vervolgens ontleedkunde, fysiologie en weefselleer, algemene ziektekunde en geneesmiddelenleer. Het doctoraal omvatte ziektekundige ontleedkunde, farmacie, bijzondere pathologie

^ Magazijn van de Universiteitsbibliotheek (voormalige Faliede Bagijnkerk) in 1862 
en therapie, gezondheidsleer, geneeskundige praktijk aan het ziektebed, theoretische heelkunde en theoretische verloskunde. Daarbovenop bestonden nog doctoraalexamens in de heel- en verloskunde. Voor de promotie was het schrijven van een dissertatie vereist.

De jurist daarentegen kende geen propedeuse. Zijn kandidaatsexamen omvatte de encyclopedie der rechtswetenschap, de geschiedenis en grondbeginselen van het Romeins recht en de grondbeginselen der staathuishoudkunde. Het doctoraal omvatte het Nederlands burgerlijk recht en de hoofdbeginselen van de Nederlandse burgerlijke rechtsvordering, het handelsrecht, het strafrecht en de hoofdbeginselen van de Nederlandse strafvordering en het Nederlandse staatsrecht. Het afgezonderde doctoraat in de staatswetenschap kende een ander doctoraalprogramma. Tot 1921 bleef het mogelijk op louter stellingen te promoveren.

Dit verschil in curricula weerspiegelde een opmerkelijk onderscheid in maatschappelijke strategie bij de twee grootste vrije beroepen die het land destijds kende. Terwijl de juridische beroepsgroep zich in haar poging de markt te beïnvloeden concentreerde op traditie, stand en stage, kozen de medici егvoor zich via moderniteit, universiteit en wetenschap te profileren. De grootste verschillen deden zich voor in het gebruik van de promotie. Promoveerde in de periode 1815-1845 slechts zeven procent van de Leidse juristen, in de periode 1876-1905 was dat niet minder dan 75 procent. Bij de medici liggen die cijfers vrijwel omgekeerd. In de eerste periode promoveerde niet minder dan 62 procent, in de tweede periode nog slechts 25 procent. De medische dissertatie is dan inmiddels uitgegroeid tot een volwaardige monografie, vrucht van jarenlang onderzoek, initiatie in een wetenschappelijke elite. Het juridische proefschrift bestaat meestal uit een раar bladzijden stellingen of hooguit vaardig uitgevoerd compileerwerk, ook wel 'een omslachtig soort van visitekaartje' genoemd.

Waar op termijn dus 75 procent van de afgestudeerde juristen promoveerde, lieten de medici ongeveer eenderde toe tot het artsexamen en slechts een kwart tot de promotie. De eisen van de praktijk, die zo zwaar wogen in het medisch curriculum, eisten ook hun tol bij de examens. De theoretische nadruk van de juristen maakte daar de lasten van de wetenschap licht. De ironie 
van het verhaal wil dat al die gepromoveerde juristen in de volksmond evenzovele gepromoveerde ezels bleven en de op de praktijk gedrilde artsen, van wie slechts een kwart de doctorsgraad behaalde, een wetenschappelijk aura kregen.

Deze verschillen - en de daaraan gekoppelde beeldvorming - werden pas ongedaan gemaakt met de wet van 1960, zelf uitvloeisel van een hogeronderwijscommissie uit 1949. Deze commissie stelde voor negen verschillende juridische specialisaties in het leven te roepen: het privaatrecht, staatsrecht, strafrecht, internationaal recht, een economisch-juridische richting, een sociaal-juridische richting, een historisch-wijsgerige richting, een notariële richting en een specialisatie belastingrecht. Op termijn zouden er drie grote studierichtingen komen, te weten Nederlands recht, notarieel recht en de staatkundige studierichting. In alle richtingen was het civiele effect verbonden aan het doctoraal.

Ook de ontwikkeling in de medische faculteit is opmerkelijk. Daar hield men een pleidooi voor een algemene medische basisopleiding, met een niet zozeer natuurwetenschappelijke als wel biologische propedeuse. Een aparte artsopleiding voor wie zich als arts wilde vestigen, moest twee hoofdvakken omvatten, interne geneeskunde en chirurgie, met eventueel een vak waarin de mens als totaliteit werd bestudeerd. Nog opvallender is dat het academisch statuut van 1968 geen omschrijving meer gaf van de te examineren vakken in verband met de 'nog steeds voortschrijdende ontwikkeling'. Wel werd een aantal pijlers omschreven, acht voor het kandidaats en vijf voor het doctoraal. Bij zowel de rechten als de medicijnen klopte het hart van de studie bij voorkeur op het ritme van de wetenschap. En in beide gevallen stond die wetenschap in dienst van de 'voorbereiding tot het bekleden van maatschappelijke betrekkingen waаrvoor een wetenschappelijke opleiding vereist was'.

\section{Studenten: aantallen en achtergrond}

Allereerst de getallen. Tussen 1775 en 1812 schreven zich 3379 studenten in. De rechtenfaculteit was het grootst met 1270 studenten, gevolgd door de medici

- Interieur van de Sociëteit Minerva, 1829-1830 


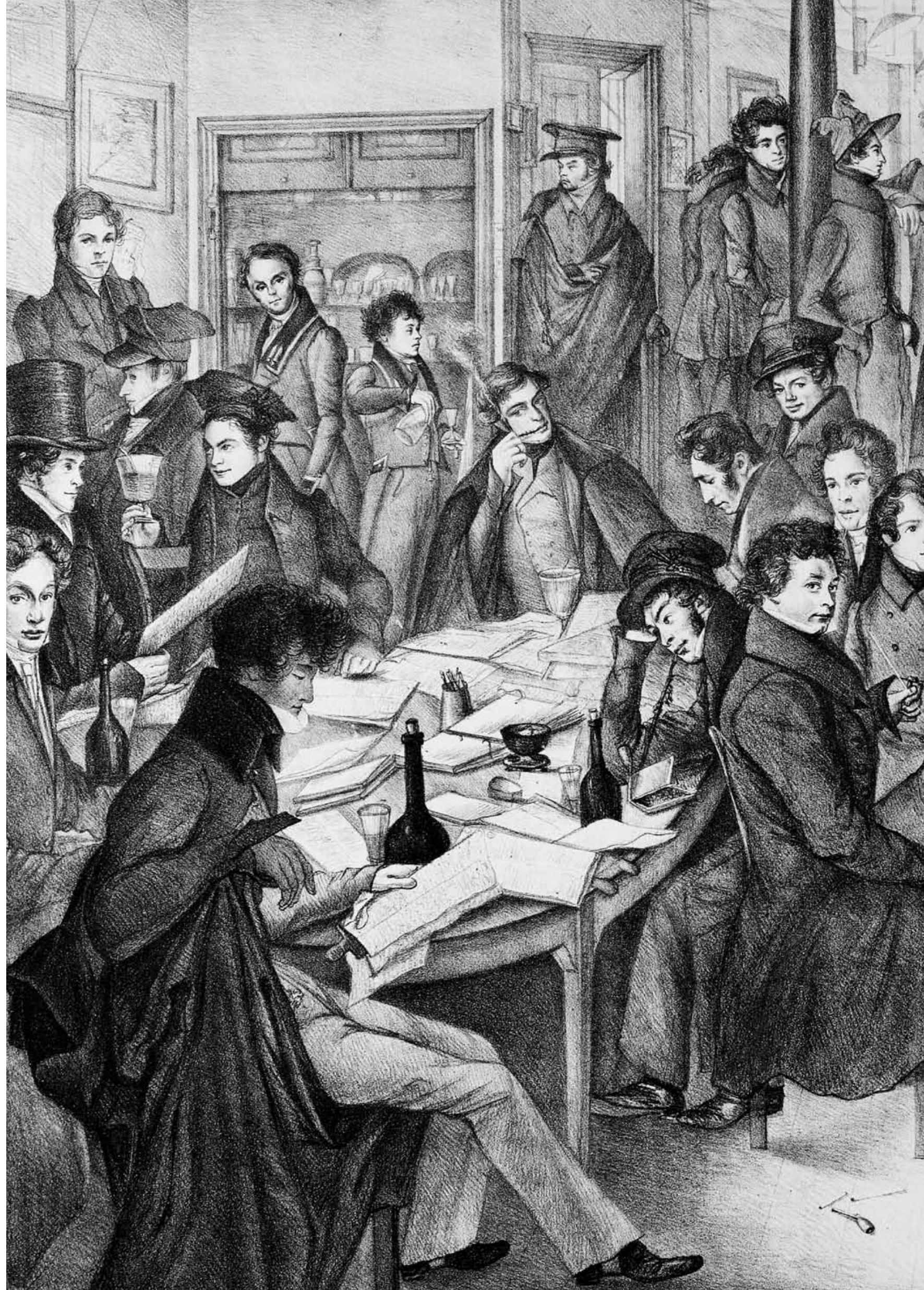




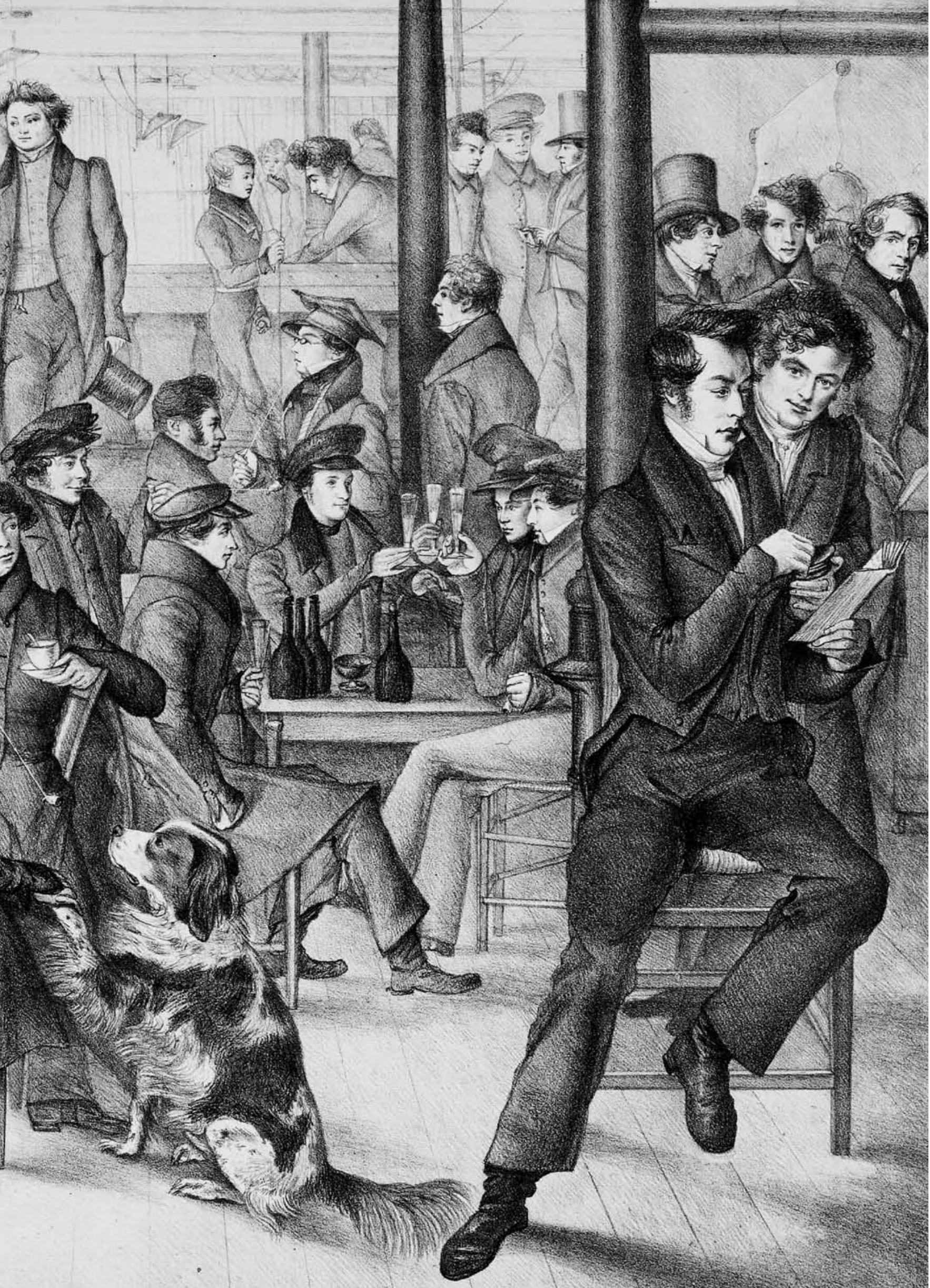


(953) en de theologen (692). De faculteit van de artes was verreweg de kleinste (314). Opmerkelijk was dat tussen 1815 en 1845 het totale aantal studenten weliswaar nauwelijks groeide (4003), maar dat de grootste faculteiten nu die van de rechten (1634) en theologie (1108) waren. Daarna volgden medicijnen(992), letteren (222) en wis- en natuurkunde (47). In de daaropvolgende dertig jaar, met 4214 inschrijvingen, bleef de juridische faculteit de grootste (1987), maar wisselden theologie (835) en medicijnen (853) van positie. De letteren (287) groeiden nauwelijks, wis- en natuurkunde daarentegen sterk (252).

In deze getallen zien we vooral het effect van de politieke verwarring van de Franse tijd, maar ook het nieuwe elan dat het Organiek Besluit aan het hoger onderwijs gaf. Met name het beurzensysteem en het feit dat theologen gedurende enkele decennia geen collegegeld hoefden te betalen, werkten aanvankelijk als een sterke stimulans op de studentenaantallen. Studenten kozen dan ook hoofdzakelijk voor de juridische of theologische studie: de eerste was traditioneel de grootste studierichting, de tweede werd kunstmatig opgeblazen.

Onder de studiebevorderende maatregelen kan ook de welwillende examinering gerekend worden: tussen de zestig en zeventig procent van de studenten voltooide de opleiding. Zeker speelt hierbij ook de encyclopedisch-didactische opzet van het onderwijs een rol, met een nadruk op aanwezigheid op college eerder dan op examens, op vorming eerder dan op training. De sociale achtergrond van de student in deze periode was hoofdzakelijk juridischbestuurlijk, in belangrijke mate hoogburgerlijk. In alles lijkt het begin van de negentiende eeuw het ancien régime eenvoudig voort te zetten.

Halverwege de eeuw trad hierin verandering op. Doordat theologen weggelokt werden door het conservatievere Utrecht en medici naar de in deze tijd opgerichte klinische scholen, werd de Leidse universiteit bijna louter een juridische faculteit. Er werd ook strenger geëxamineerd (en bij de medici nog strenger dan bij de juristen), als gevolg van de veranderende opvattingen over de doelstelling van het hoger onderwijs (meer op de praktijk gericht) en gedachten over professionaliteit.

Het is in deze tijd dat ег een uiterst opvallende omslag plaatsvindt in de sociale samenstelling van de studentenpopulatie: vanaf de jaren zestig zal de 


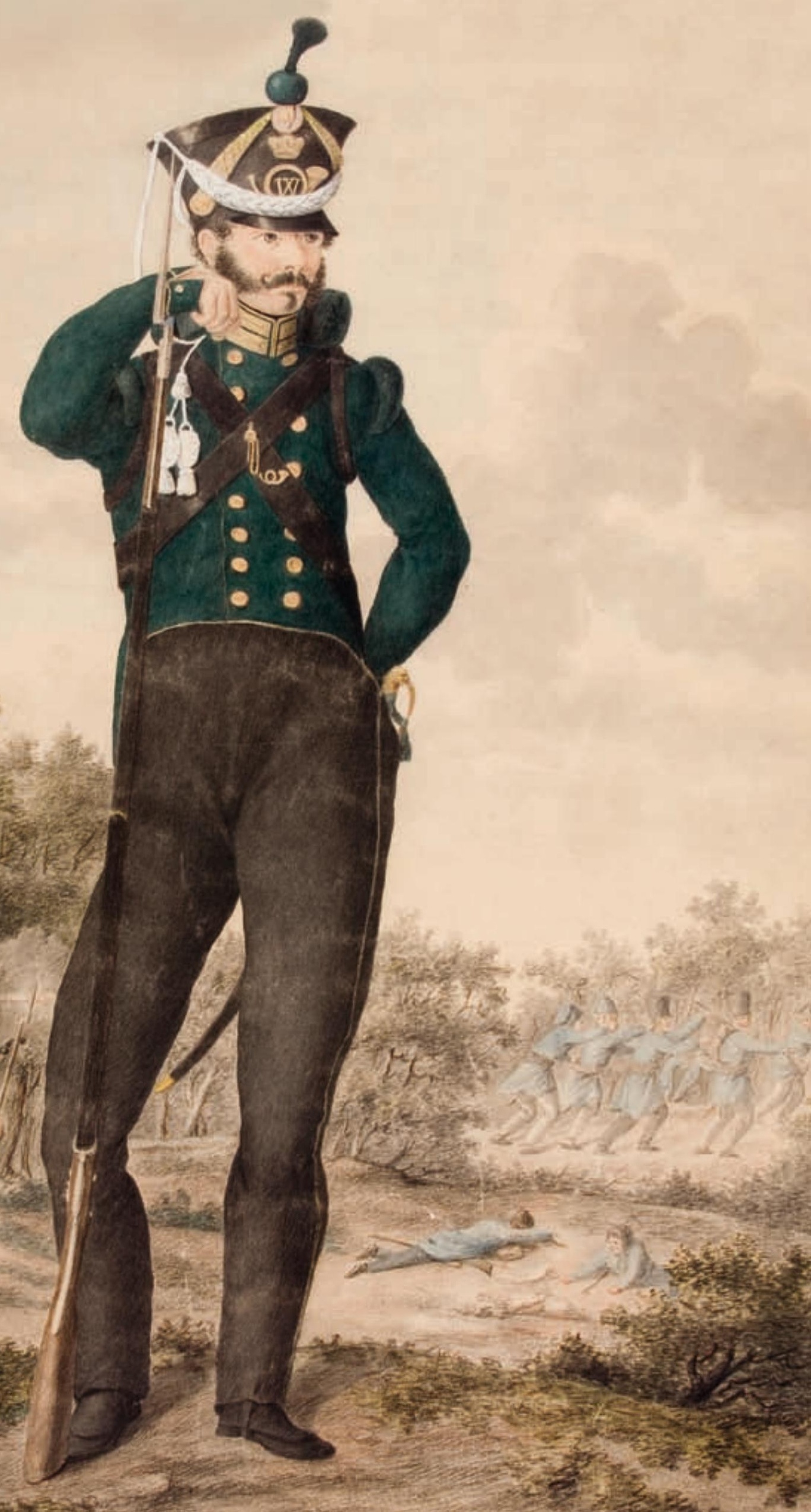



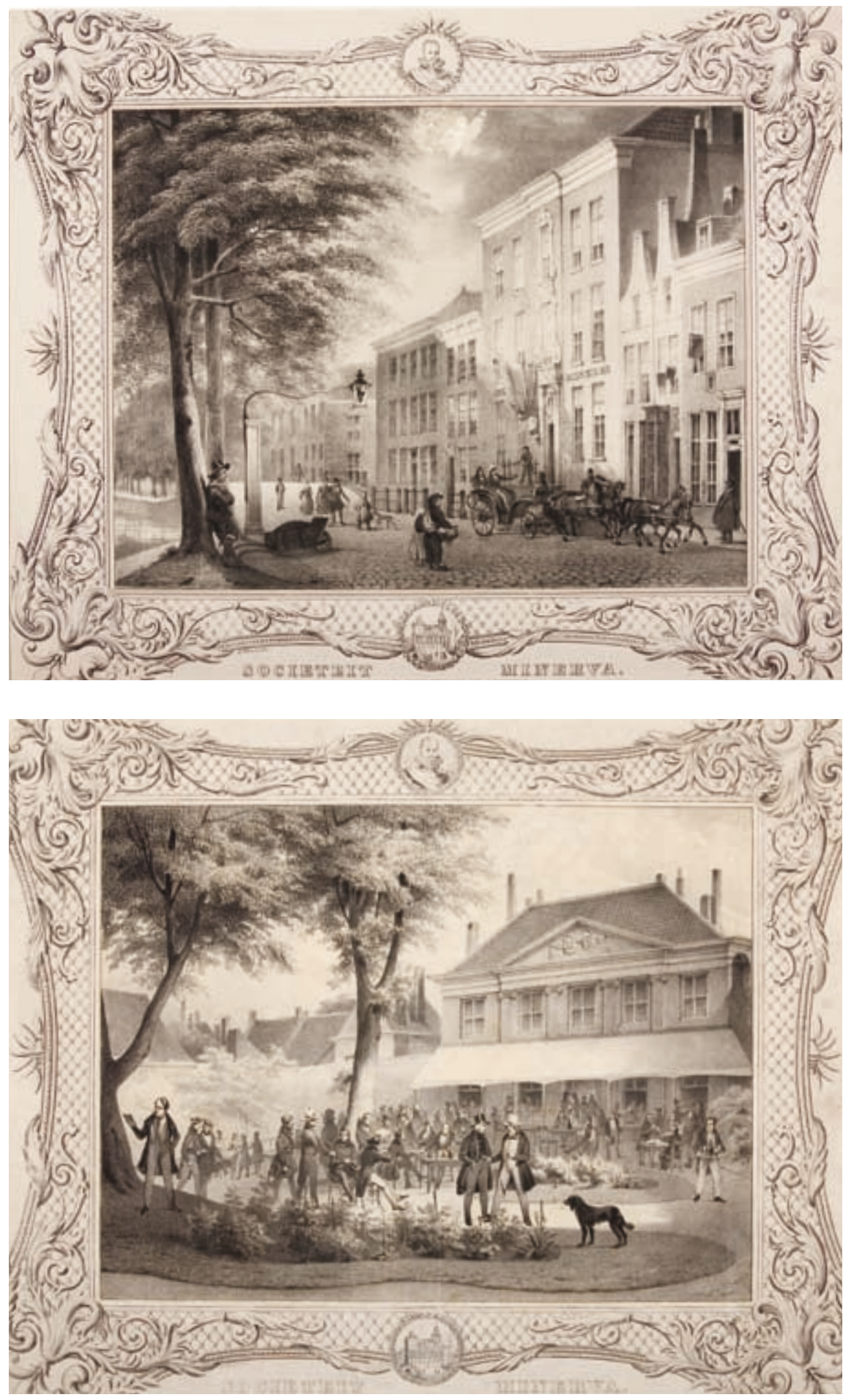

\Voorzijde van de Sociëteit Minerva aan het Rapenburg, ca. 1840

$\checkmark$ Tuinzijde van de Sociëteit aan het Rapenburg, ca. 1840 
Leidse universiteit voor ruim vijftig рrocent haar studenten uit de middenklasse rekruteren. 'Menig kleinhandelaar en winkelier die een goede zaak heeft, acht zijn zoon te goed voor dien nederigen werkkring en zendt hem vol illusiën omtrent eene schitterende toekomst nаar de universiteit,' verzuchtte de Leidse wiskundige Van Geer in 1887. Optimistische toekomstverwachtingen brachten in deze periode van economische groei neringdoende ouders ertoe althans één zoon naar de universiteit te sturen.

De sociale achtergrond van de studenten - de grote toeloop van kinderen van leraren, middenstanders, ambtenaren en van in de handel of industrie werkzame arbeiders - is een indicatie te meer voor de veronderstelling dat de universiteit in de negentiende eeuw op conjuncturele impulsen ging reageren. Bijgevolg moet zij in die periode niet beschouwd worden als een instantie die de elite versterkte en de sociale kloof verbreedde, maar еerder, zeker in de tweede helft van de eeuw, als een instrument van verbetering van sociale posities en van een eerste opvang van de sociale spanningen die het land door economische veranderingen te verduren kreeg.

De grote veranderingen dateren natuurlijk van de nieuwe Hoger Onderwijswet uit 1876. Het effect daarvan lijkt zich aanvankelijk niet in de aantallen te vertalen. Met nog geen vijfduizend studenten in de periode 1875-1905 lijkt de universiteit als geheel te stagneren. Daarbij moet echter ingecalculeerd worden dat het grote aantal Amsterdamse studenten dat onder het Organiek Besluit aan het Athenaeum Illustre niet had kunnen afstuderen, hier vanaf 1876 wel toe in staat was en dus wegbleef. Het waren vooral de rechten die stagneerden (met 1998 studenten); de medicijnen groeiden daarentegen explosief (1428), terwijl de theologie even sterk terugliep (409). Ook de letteren (527) en de wis- en natuurkunde (428) verdubbelden bijna.

Pas na 1925 zette een sterke stijging in. In dat jaar vermeldt de studentenalmanak 2493 studenten (88 theologie, 882 rechten, 625 medicijnen, 429 wis- en natuurkunde, 209 letteren en wijsbegeerte en 260 indologen). In 1960 is het totaal aantal ingeschreven studenten 5027 (106 theologie, 954 rechten, 1216 medicijnen, 1238 wis- en natuurkunde, 978 letteren en wijsbegeerte, 535 vегenigde faculteiten). Rond de Eerste Wereldoorlog bestond ongeveer eenachtste uit vrouwen, maar net voor de Tweede Wereldoorlog was dat al ruim een
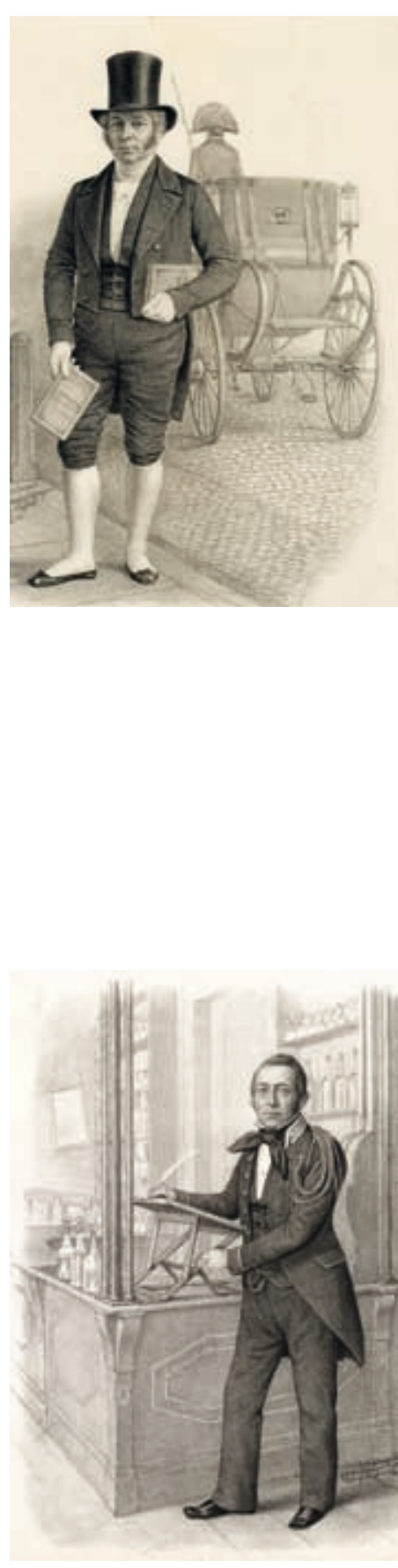

\ J. Robert, pedelLeidsch Studenten Corps, 1854

$\checkmark$ J.C.Emeis, bediende van de Sociëteit Minerva, 1854 

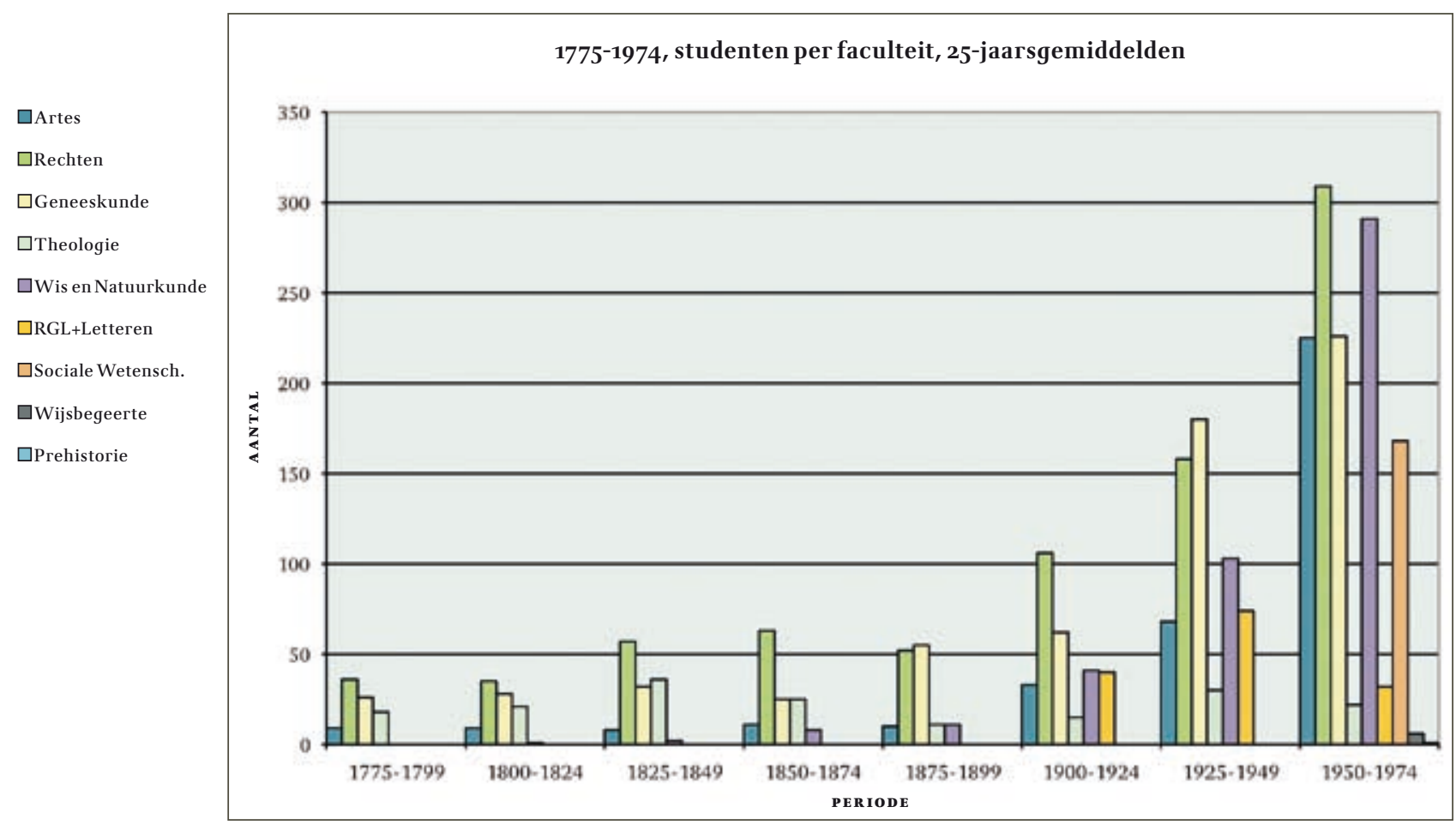

kwart. Dat bleef ook na afloop daarvan vrij lang het gemiddelde.

Tussen 1945 en 1960 was de stijging van de studentenaantallen, met een bijna-verdubbeling, eveneens nog geleidelijk te noemen: van 2824 (2111 mannen en 713 vrouwen) naаг 5370 (3723 mannen en 1647 vrouwen). Maar het decennium daагор liet wederom een verdubbeling zien (1970: 11858 van wie 8159 mannen en 3699 vrouwen). Daarna bleef het aantal mannelijke studenten vrij stabiel (bijna 9ooo in 1985), terwijl het aantal vrouwen bleef stijgen tot gelijke hoogte als dat van de mannen, zodat in het studiejaar 1985/86 bijna 18.ooo studenten ingeschreven stonden. Het hoogste aantal dat Leiden ooit kende.

Een even opmerkelijke verschuiving valt te constateren in de studiekeuze.

De substantiële afname van rechten en geneeskunde, en de overeenkomstige groei van letteren en vooral sociale wetenschappen en wis- en natuurkunde, gaven een totaal ander aanzicht aan de Leidse studentenbevolking, traditio- 
neel gedomineerd door de toekomstige bekleders van de vrije beroepen, maar voortaan evenwichtig verdeeld over de vijf grote wetenschapsgebieden van de universiteit.

De explosieve stijging van de studentenaantallen kende, zowel te Leiden als elders, twee opmerkelijke bijverschijnselen, te weten de afname van het rendement van de studie en de terugloop van deelname aan het studentenleven. Het eerste feit, aangedragen door het Centraal Bureau voor de Statistiek in zijn rapport van 1962, verontrustte de samenleving meer dan het tweede. Na vijf jaar studie bleek slechts ongeveer de helft van de studenten het kandidaats bereikt te hebben; bijna veertig procent haalde de eindstreep niet. Voor een belangrijk deel werd de oorzaak gezocht in de eenzijdige wetenschappelijke klemtoon van het onderwijs. Er klonken stemmen om dat onderwijs meer in te richten naar het Angelsaksische model, met zijn onderscheid tussen twee verschillend gerichte opleidingen, het ene bestemd voor 'practici' (korter dan de bestaande doctoraalstudie) en het andere bestemd voor echte wetenschappers.

Het јаaг егор kwam de minister met een voorstel, eerst voorgelegd aan de Academische Raad, om de studieduur te verkorten door de inrichting van de studie te vегаnderen en de stof te beperken. Het voorstel was een studieduur van vijf jaar, met een baccalaureaat vоor iedereen en een voortgezet ргоgramma voor toekomstige wetenschappers. Dit leidde tot protest uit de hele academische gemeenschap, maar was vooral het begin van de studentenvakbeweging. Die kreeg in 1964, met de eerste verhoging van het collegegeld, de wind in de zeilen. Belangenstrijd en bewustwording gingen hand in hand en resulteerden in de teloorgang van het traditionele studentenleven.

De geringe deelname aan het studentenleven had zich al еerder aan de aandacht opgedrongen. De toename van het aantal uit lagere milieus afkomstige studenten (in 1974 achttien procent, terwijl bijna vijftig procent uit de middenklassen kwam), de sterkere groei van studierichtingen (wis- en natuurkunde, sociologie) met geringe belangstelling voor de traditionele vormen van gezelligheid, het droeg allemaal bij tot het gevreesde 'nihilisme'. Ook de veroudering van de studentenbevolking, de toename van het aantal gehuwde studenten en van het aantal spoor- en werkstudenten was er debet aan. De 


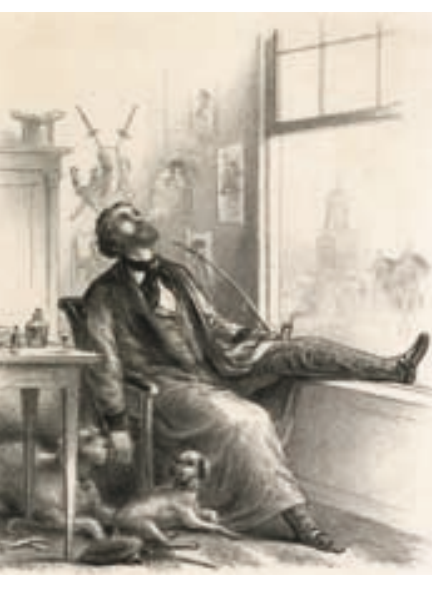

fragmentatie van de studentenbevolking, en daarmee de teloorgang van een hechte civitas, was een feit.

\section{Studentenleven}

Aan het einde van de achttiende eeuw kwam onder de Leidse studenten een proces van groepsvorming en organisatie op gang dat zijn oorsprong had in grote interne verdeeldheid. Die verdeeldheid was vooral sociaal van aard en kwam hoofdzakelijk tot uitdrukking in de ontgroening, de manier waarop nieuwe studenten opgenomen werden in de studentenmaatschappij. In 1839 vormde een groenschandaal de opmaat tot de officiële oprichting van het Studenten Corps, een autonome organisatie die op termijn de goedkeuring van de senaat kreeg en vrijwel alle studenten zou omvatten.

Daarmee kwam aan het ontgroenen geen einde, integendeel. Met grote regelmaat bleven de schandalen zich voordoen. Naast geweld en drinkdwang richtten de meeste klachten zich op het seksueel 'ontbolsteren' van de groen, dat wil zeggen: hem in zo kort mogelijke tijd op de hoogte brengen van vocabulaire en praktische vaardigheden. De meesterproef bij afsluiting van de groentijd was het zogenaamde groentheater, waarin het obscene een grote plaats kreeg toebedeeld. In 1911, toen de Leidse hoogleraar sinologie De Groot de tekst publiceerde van het libretto van een dergelijk theater, leidde dit schandaal tot dagenlange Kamerdebatten, een verhitte senaatsvergadering en het vertrek van De Groot naar Berlijn.

Het belangrijkste organisatorische aspect van het corps was, naast het uitbaten van een eigen sociëteit, met kroeg, eettafels en bibliotheek, het in het leven roepen van onderafdelingen. Dit konden sport- of regionale clubs zijn die studenten met eenzelfde herkomst bijeenhielden, maar het belangrijkste waren de jaarclubs en disputen. Jaarclubs waren groepjes die op eigen initiatief maar ook wel langs lijnen van sociale geleding samengesteld werden uit de nieuwe studenten. Die kregen een patroon toegewezen, een ouderejaars die hen op hun eerste schreden in het studentenleven begeleidde.

De al van het einde van de achttiende eeuw daterende disputen waren nog

\ Leidse student in dejaren veertig van de negentiende eeuw 
kenmerkender. Zoals de organisatie van het corps een kopie was van de senaat van professoren, zo bootste een deel van hun onderlinge contact het college na. Aanvankelijk waren het vooral literaire disputen, maar allengs kregen ze vakinhoudelijke disputen naast zich. De gang van zaken op een dispuut was als volgt. De bijeenkomsten vonden meestal één keer in de twee weken plaats, om een uur of zes. Het ledental was gewoonlijk klein, rond de tien. Men had een eigen lessenaar (bekleed met een groen laken vol inkt-, wijn- en kaarsvlekken) en een eigen archiefkist met wetboek en notulen. De avond viel meestal uiteen in twee delen: een lezing met een beoordeling en de verdediging van een aantal stellingen. Uiteindelijk volgden vele pocula en een nabroodje. Tijdens dit alles werden veelvuldig boetes uitgedeeld voor overtredingen van de wet - te lang spreken, te kort, interrumperen enzovoort.

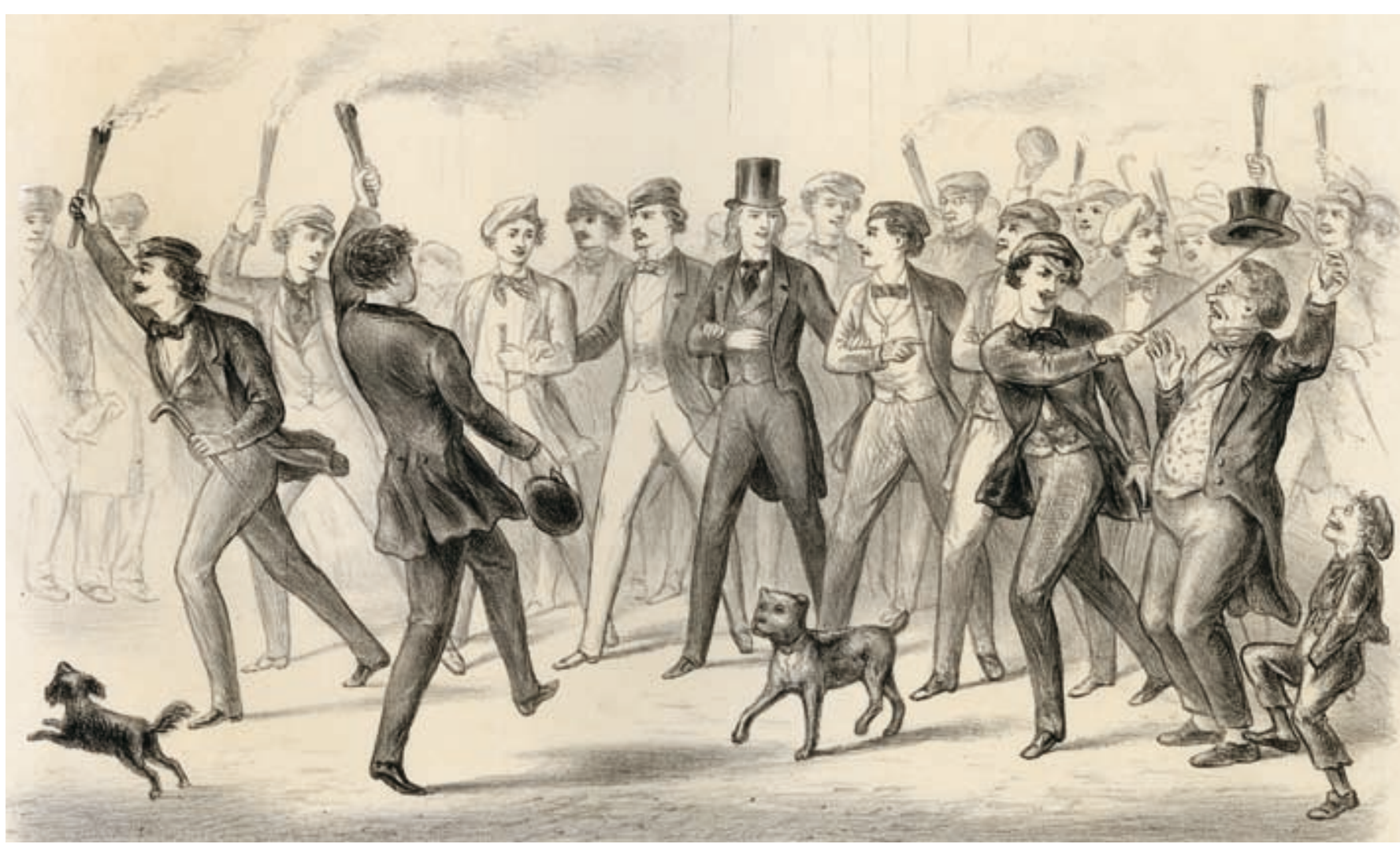

^ Ontvangstvan Franz Liszt te Leiden, 1843 


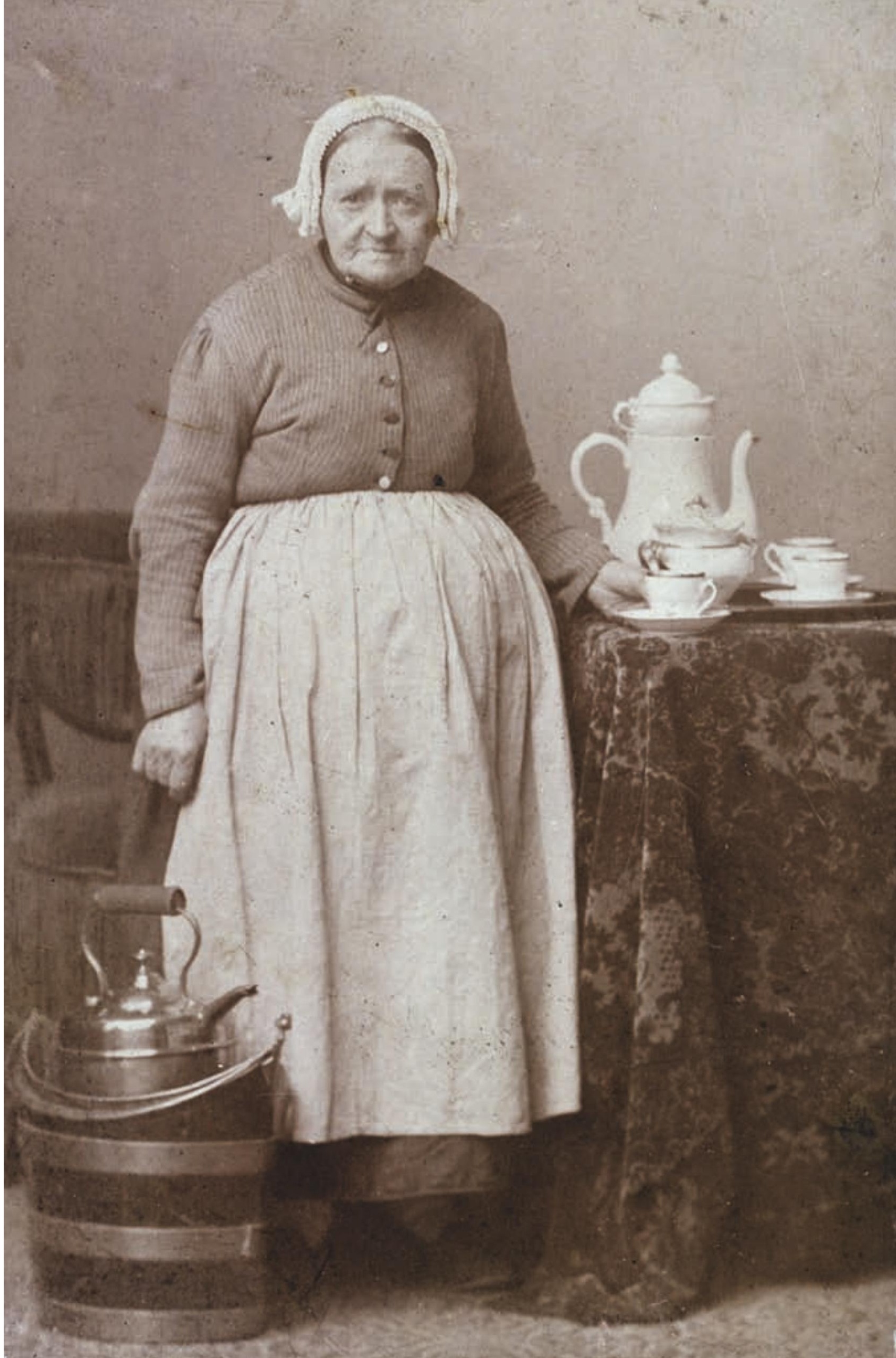


Van de opbrengst werd een kas gevormd die verteerd werd op het jaarlijkse reisje. Ten slotte waren er ook wel vriendschappelijke bijeenkomsten, bijvoorbeeld op zondagmiddag of door de week rond zes uur, doorgebracht met waterchocolade, lange beschuitjes, bommetjes bitter en glaasjes madera.

Maar ook op maatschappelijk gebied waren de studenten actief. Een van de eigenaardige vormen van engagement was de bereidheid om in tijden van politieke onrust onder de wapenen te komen. In 1784 werd het exercitiegenootschap Рго Pallade et Libertate opgericht om de leden te beschermen tegen het orangistisch gepeupel. Uit 1815 dateren de Flankeurs, die een verlate poging deden Napoleon bij Waterloo tegen te houden. Waren dit nog kleinschalige vormen van enthousiasme, in 1830, toen de koning het volk te wapen riep tegen de Belgen, zou eenderde van het studentencorps zich aanmelden, deels uit nationalisme, deels aangelokt door wat de student en dichter (en korрогаal) Gerгit van de Linde het 'maagdverleidend jager pakjen (groen en canarie)' zou noemen. In 1848 kwamen de studenten bijeen als Corps Rustbewaarders; de Pruisische dreiging deed in 1866 Pro Patria ontstaan, een studentenvaandel dat op brede professorale steun kon rekenen. In 1914 werd het Leidsche Studenten Vrijwilligers Corps opgericht.

Een van de fascinerendste verschijnselen uit het studentenleven was ongetwijfeld de maskerade. Zo'n maskerade was een gekostumeerde optocht die studenten in de negentiende en twintigste eeuw hielden in het kader van het lustrum van hun universiteit. In de ontwikkeling van de maskerade zijn vier aspecten van belang. In de eerste plaats is er een groeiende aandacht voor de historische nauwkeurigheid. In toenemende mate werden bronnen geraadpleegd en specialisten geconsulteerd. Tegelijk werden de kostuums mooier en gedetailleerder. Dat werd ook in de hand gewerkt doordat vanaf 1850 de optocht niet meer in februari en 's avonds, maar overdag in juni gehouden werd.

Daarnaast was er het nationale aspect. Het vaderlandsgevoel diende bij de maskerade centraal te staan. Bovendien werd steeds vaker de eis gehoord dat de hoofdpersoon een Oranje moest zijn. En ten slotte speelde ook het morele aspect een rol, de voorbeeldfunctie van de uitgebeelde figuren. Aan het einde van de negentiende eeuw verflauwde de historische inspiratie, om plaats te 
maken voor stilering en vertoon. De maskerade werd een Gesammtkunstwerk, met toneel en praalgebouwen. De organisatie kwam steeds meer in handen van specialisten, dramaturgen, en veel van de bijrollen werden door gehuurde krachten vervuld. In het begin van de twintigste eeuw ontwikkelde de maskerade zich tot een groots spektakel dat een week duurde en van heinde en ver bezoekers trok. Tegelijk groef het echter zijn eigen financiële graf; in de crisis van de jaren dertig verloor het elk draagvlak.

Klein- of grootschalige evenementen als deze konden niet verhullen dat het studentencorps aan het einde van de negentiende eeuw uiteenviel. Deels kwam dit doordat nieuwe studenten geen lid meer werden. Dit zogeheten nihilisme baarde ook de senaat zorgen, omdat men onder professoren inzag dat een belangrijk deel van de socialisatie en vorming van de studenten binnen het studentenleven plaatsvond. Deels ook verbrokkelde het studentenleven in verschillende levensbeschouwelijke geledingen. In 1893 werd de roomskatholieke studentenvereniging Sanctus Augustinus opgericht, in 1901 de Societas Studiosorum Reformatorum (ssR). Intussen had Leiden ook zijn vereniging voor vrouwelijke studenten gekregen, de VVSL in 1900. En in 1911 kwam daar de Bond van Leidse Studenten bij, die in 1930 opging in de gemengde vereniging Unitas Studiosorum Lugduno-Batava, die geen ontgroening kende. Gezelligheid 'in eigen kring' werd de leus. Op deze gezelligheid kreeg de politiek over het algemeen weinig vat. Wel toonden de studenten zich geëngageerd bij de Groot-Nederlandse gedachte. Aanvankelijk richtte hun enthousiasme zich vooral op Zuid-Afrika en de Воегеn in Transvaal. Later bleek de Vlaamse beweging hun harten te verwarmen. Maar ook voor de internationale vredesbeweging bleken veel studenten zich te willen inspannen.

Partijpolitiek in de zin van engagement met socialisme of liberalisme werd zoveel mogelijk vermeden. Korte tijd verdeelde de sociale kwestie ook de studenten en werden socialistische bladen waarop de sociëteit een abonnement had verscheurd. Men wilde geen politiek en al helemaal geen sociale. Corpspolitiek was toegestaan, maar voor de rest gold: schoenmaker houd je bij je leest. Het gedrag van de Leidse studenten op de in 1933 te Leiden gehouden conferentie van de International Student Service - waar de Duitse delegatie onder leiding stond van de nazi Von Leers - was op z'n zachtst gezegd naïef. 

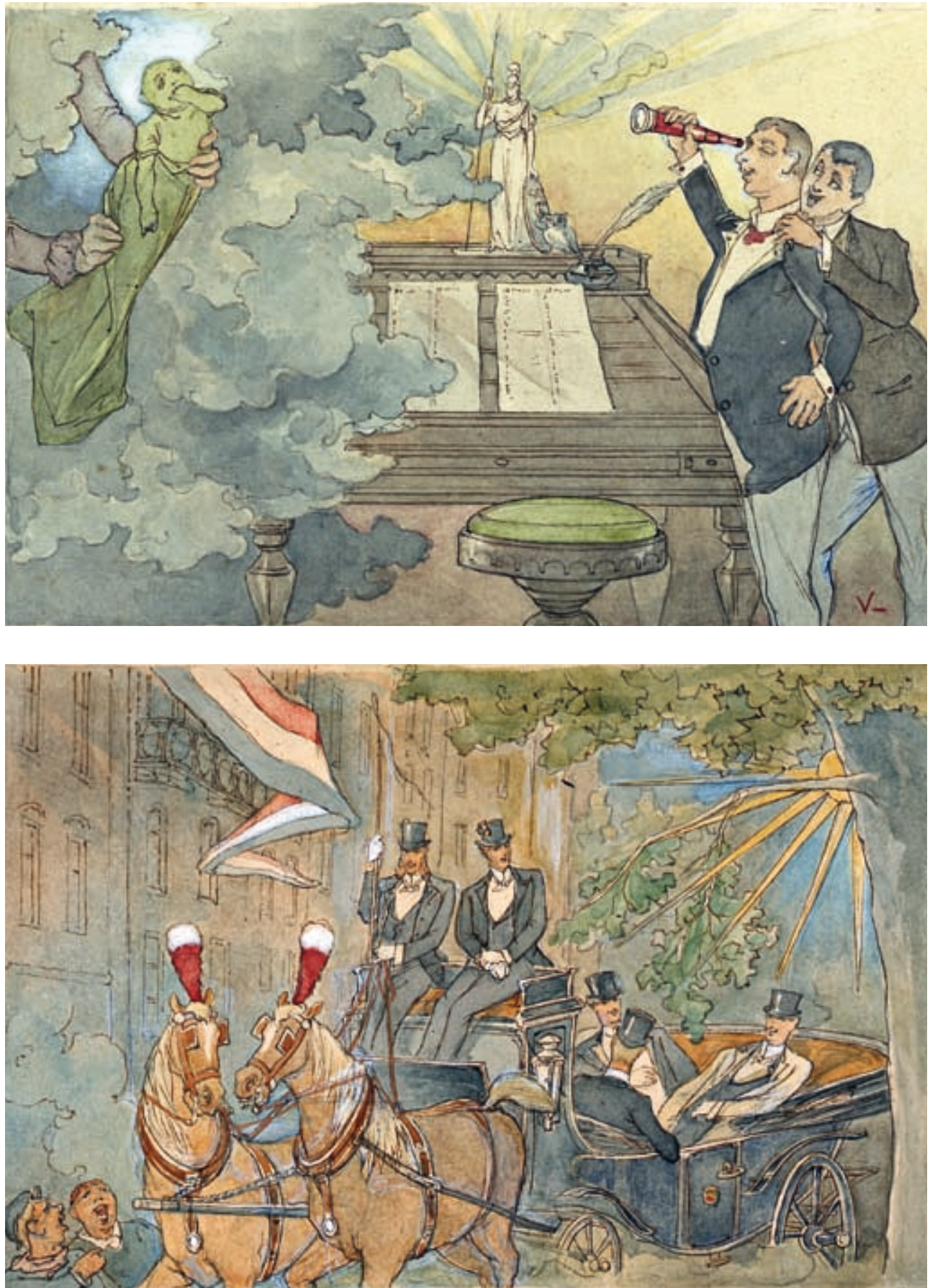

4 Ouderejaars op de uitkijknaar aankomende studenten (groenen), ca. 1920

$\checkmark$ Student met paranimfen op wegnaar de promotie, ca. 1920 


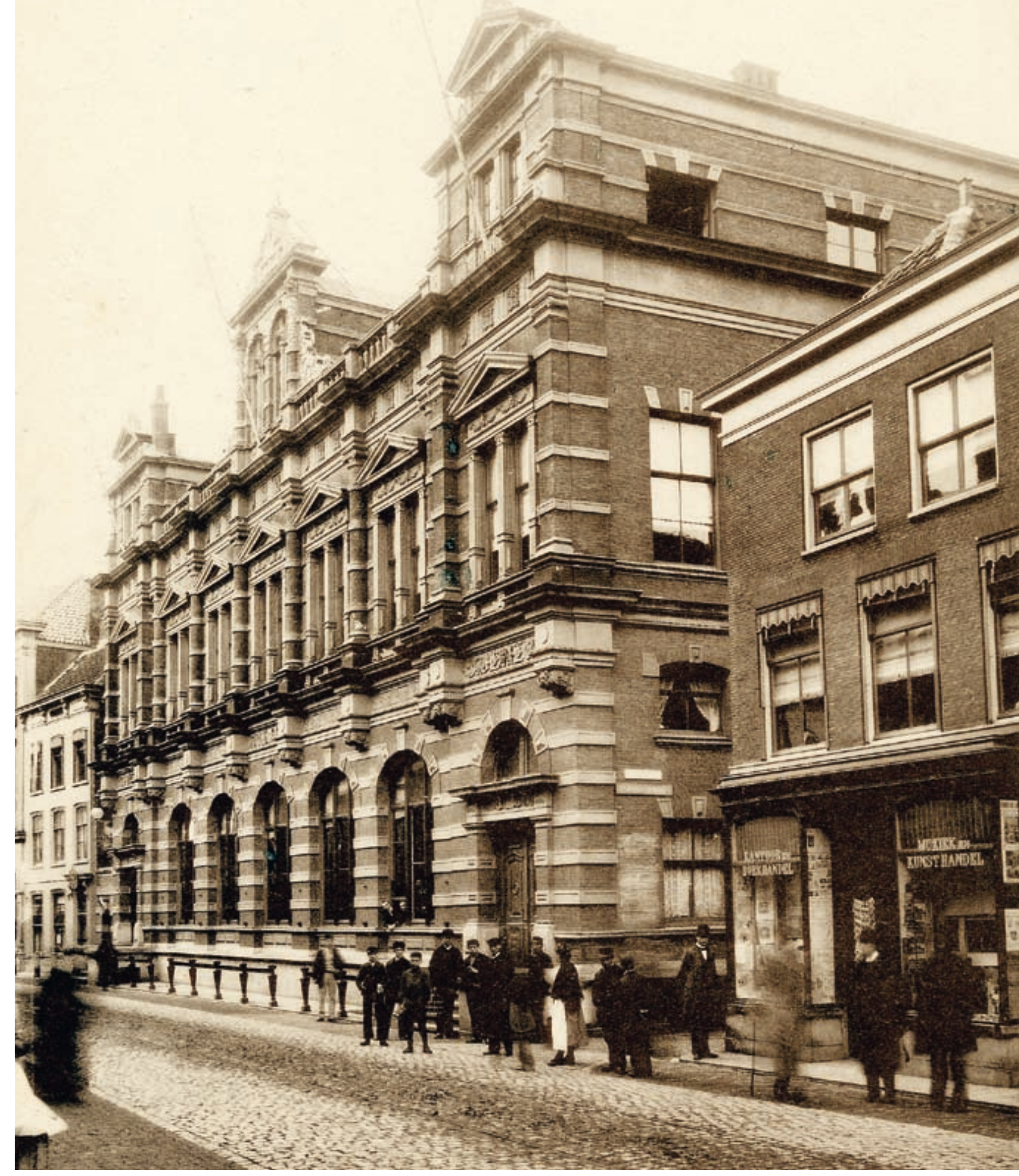

^ Het gebouw van Sociëteit Minerva in de Breestraat, net na de voltooiing in 1876 
Toen de rector magnificus van dat jaar, Huizinga, Von Leers de gastvrijheid van de universiteit weigerde, werd dat besluit, ook door de vertegenwoordigervan het corps, afgekeurd.

Evenals de senaat dachten vertegenwoordigers uit het studentenleven tijdens de oorlog intensief na оver de naoorlogse геогganisatie van de universiteit. Om de eenheid van de studentengemeenschap te herstellen, wilde het Leids Studenten Corps (LSc) zich meer dan voorheen openstellen voor groeperingen van verschillende religieuze oriëntaties, terwijl Augustinus, ssR en Unitas geheel of gedeeltelijk in het LsC zouden opgaan. Het LSC zou een echte civitas-vereniging moeten worden, met een grotere religieuze en sociale openheid, en met lagere financiële lasten voor de betrokkenen.

Hoewel tijdens het eerste decennium na de oorlog de civitas-plannen een indrukwekkende invulling kregen - gezondheidszorg en huisvesting, studium generale en mensa's, sportfaciliteiten en Academisch Kunstcentrum begon de gedachte al in het begin van de jaren vijftig haar spankracht te verliezen. Het was vooral de schaalvergroting en de allengs sterk veranderende samenstelling van de studentenpopulatie die de samenhang onder studenten en daarmee de civitas deed verbrokkelen. Het best wordt die verandering omschreven in sociologische termen. Uit een stand waarin studenten er eenzelfde, traditionele en hiërarchische levensstijl op na hielden, groeide allengs een klasse van studenten die als een onafhankelijke groep dezelfde belangen en problemen nastreefde.

Die onafhankelijkheid bracht hen snel in conflict met de senaat. In beginsel was het vоoral een mentaliteitskwestie. De senatoren begonnen zich ernstig zorgen te maken over wat zij niet anders konden zien dan als een verwildering der zeden. Een oud toneelstuk als Reigen van Schnitzler, door het studententoneel op de planken gezet, kon studenten en professoren diep verdelen. Tegelijk begon ook de politiek zich tot een splijtzwam te ontwikkelen. Juist op het moment dat het Amsterdamse Propria Cures de Leidse universiteit karakteriseerde als de 'Вогоbudur der Bourgeoisie', zorgden het regeringsbeleid inzake Nieuw-Guinea en de ontwikkeling op het gebied van de atoomenergie voor intense verdeeldheid. Weldra kwamen van alle windstreken, Midden-Amerika, Noord-Afrika, Zuidoost-Azië, de onderwerpen voor verontwaardiging aangevlogen. 
Zo kwam het ook in Leiden tot 'evenementen', zoals die elders in de wereld en in Nederland de kussens opschudden. Hoewel de golven te Leiden lager bleven dan in Nijmegen of Amsterdam, werd wel van 8 tot 20 mei 1969 het academiegebouw 'gevorderd' als permanent discussie- en actiecentrum; bij bepaalde gelegenheden was zelfs de hele Pieterskerk als zodanig in gebruik. De interne democratisering die hierop volgde en het openbreken van de oude verenigingen gaven weldra een totaal ander studentenleven te zien. In 1969 presenteerde het Collegium van het Leidse Studenten Corps zich voor het eerst niet in jacquet, maar in corduroy pak.

\section{Stad, land en wereld}

Universiteit en stad bleven intussen sterk op elkaar betrokken. De burgemeester was vanouds lid van het college van curatoren, menige professor en student was uit de stad afkomstig, verschillende universitaire instellingen waren vоог Leidse burgers toegankelijk. De musea leverden hun lering en vermaak, de hortus gaf hun gemoedsrust, de sterrenwacht een besef van eigen klein- en Gods grootheid. Naast deze meer informele of dagelijkse aanrakingen waren ег andere institutioneel van aard. Op den duur vormden ze een hecht weefsel tussen stad en studie.

Een van de eerste negentiende-eeuwse instellingen die opereerde op het raakvlak van universiteit en stad was de zogenaamde industrieschool, bedoeld om de Leidse nijverheid te bevorderen. Scholen als deze waren op initiatief van koning Willem I opgericht 'om de sluimerende natie op te wekken en tot werkzaamheid aan te sporen'. Onder de ietwat excentrieke leiding van professor A.H. van der Boon Mesch werden niet alleen aanstaande of reeds praktiserende fabrikanten en architecten, maar ook eenvoudige timmermans- en smidsjongens ingewijd in de geheimen van de scheikunde, zoals deze van toepassing waren 'op kunsten en fabrijken'.

Naarmate de eeuw vorderde, werden verschillende universitaire instellingen nadrukkelijker ingebed in het stedelijk verzorgingspatroon. Het academisch ziekenhuis, bijvoorbeeld, aanvankelijk een schimmig zaaltje voor 


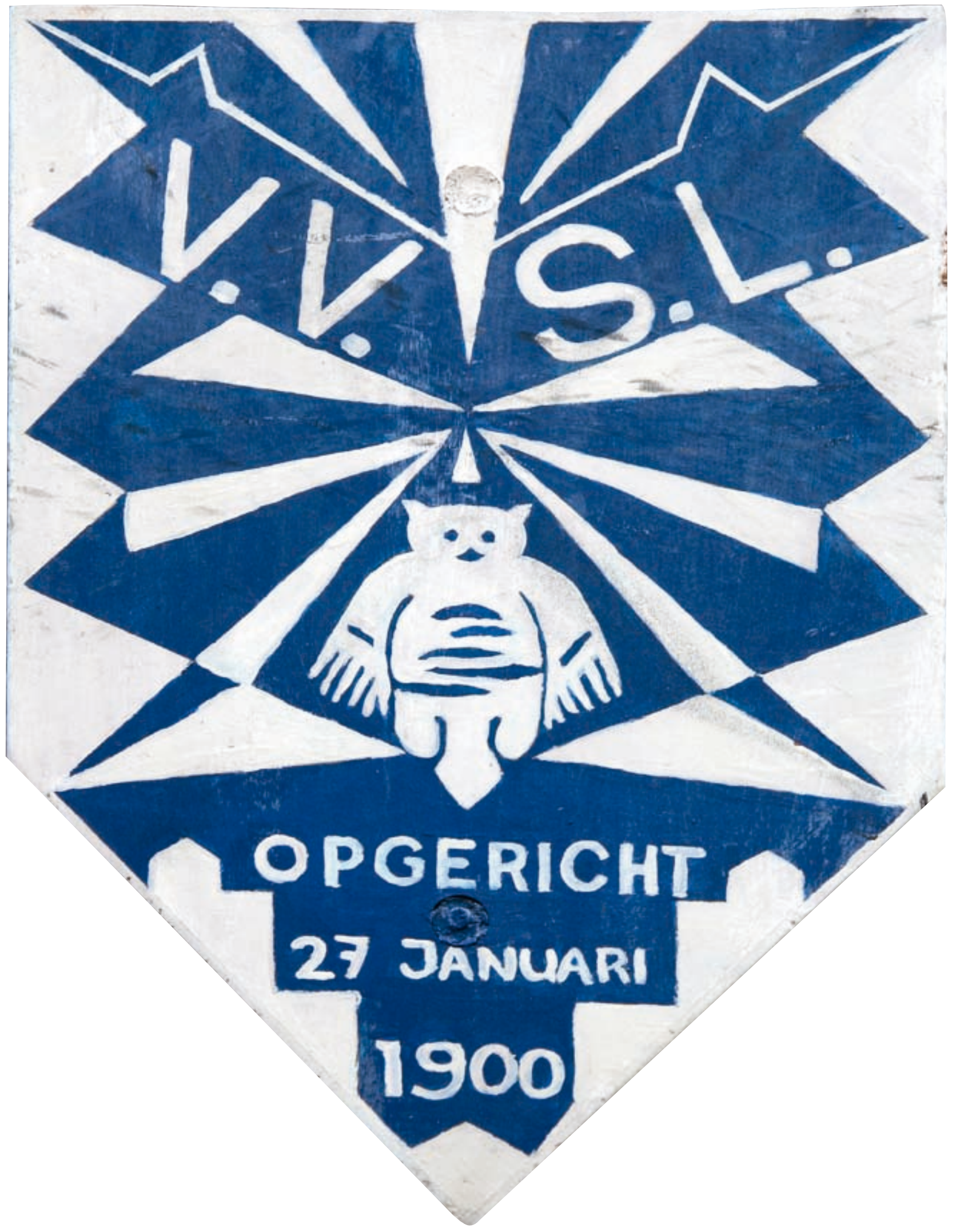


schoolbestuur, adviescollege of charitatieve instelling, of verschillende ргоfessoren waren er lid van. Ook de kiescolleges bevatten zonder uitzondering de namen van Leidse professoren.

Naarmate de negentiende eeuw vorderde, nam het stedelijk engagement van de professoren duidelijk toe. De adresboeken van de stad tonen de omvang van hun maatschappelijke functies. Zo zaten er vrijwel altijd drie of meer professoren in de gemeenteraad. Er was geen school of hofje, of er zaten ргоfessoren in het bestuur. Of het nu verongelukte vissers of een zwembad betrof, een zendelingengenootschap of instituut voor doofstommen, een vereniging tot verbetering van de volksgezondheid of maatschappij tot opvoeding van wezen in het huisgezin, een pensioenvereniging voor werklieden of de Leidse broodfabriek, steeds waren de Leidse professoren present.

In de twintigste eeuw werd de universiteit alleen al door haar groei een massieve aanwezigheid in de stad. Ze werd niet alleen de grootste werkgever, maar ontwikkelde zich met gemak ook tot de grootste bouwmeester van Leiden. Uit de jaren vijftig dateren de plannen om voor de exacte en geneeskundige wetenschappen een groot gebied ten westen van het Academisch Ziekenhuis, tussen de Wassenaarseweg en Plesmanlaan, tot aan Rijksweg 44 bouwrijp te maken. Tegelijk werd een veel smallere strook tussen de Witte Singel en de Rijn- en Schiekade bestemd voor de humaniora, samen met een nieuwe bibliotheek. De laboratoria werden in de jaren zestig en zeventig voltooid, de universiteitsbibliotheek en de faculteitsgebouwen voor de humaniога en archeologie in 1984. Ook oude panden kregen een nieuwe bestemming. In 1955 werd het Gravensteen, na een grondige restauratie, tot juridisch studiecentrum ingericht. En in 1972 werden de laboratoria in Vreewijk heropend als Juridisch Studiecentrum ‘Hugo de Groot'.

Ook op nationaal niveau kreeg de universiteit, toen de eenheidsstaat eenmaal een feit was, een eigen positie. Die status aparte was met zoveel woorden omschreven in het Organiek Besluit, dat de Leidse universiteit aanduidde als de 'eerste' universiteit van het land, met voorrang 'in subsidiën en tractementen'. Zo heeft ze ook de hele negentiende eeuw en in het begin van de twintigste eeuw gefungeerd, ook al maakte de onderwijswet van 1876 aan deze bevoorrechte positie een einde. Had het natiebesef van het Leidse professoraat

4 Ontwerp vaandel van de Vereniging van Vrouwelijke Studenten te Leiden.

COLLECTIE ACADEMISCH HISTORISCH MUSEUM 
aanvankelijk nog een classicistisch karakter, patriots eerder dan nationalistisch, toen eenmaal de romantiek vat kreeg op de harten, bloeide hier een doorbloed nationalisme op dat diep in de wetenschappelijke activiteit doordrong. Dat laat zich natuurlijk vooral aan de letterenfaculteit illustreren.

Voor Matthias de Vries was de taal niet de beschaafde schrijftaal, maar de taal, 'zooals zij in het hart des volks leeft en bloeit, vrij en onbelemmerd, los en levendig, doch tevens rein en onvervalscht'. Het Woordenboek der Nederlandsche Taal was een oorspronkelijk Leidse schepping en wilde een 'taalmuseum' zijn, 'een schatkamer van al de rijkdommen onzer moedersprake'. De Vries stond dan ook aan de wieg van de eerste en enige Nederlandse leerstoel voor de vaderlandse geschiedenis, die in een afsplitsing van de zijne in 1860 een feit werd. Nuttig en nationaal diende die leerstoel te zijn. En met bezetters als Fruin en Blok was de nationale inspiratie, hoe uiteenlopend hun invulling ook was, manifest.

Belangrijke thema's in dit nationalisme waren de nationale eenheid boven geloofsverdeeldheid en het gewicht van de cultuur eerder dan van de politiek. Daarom richtten de Leidse hoogleraren de liefde voor hun land rond de eeuwwende bij voorkeur op de strijd van de Boeren in Zuid-Afrika of op de Vlaamse kwestie. In een vergelijking die beklijfde, legde Fruin een verband tussen de Nederlandse opstand tegen Spanje en die van de Boeren tegen Engeland. Vrijwel alle Leidse hoogleraren waren enige tijd lid van de Leidse afdeling van de Nederlandsch Zuid-Afrikaansche Vereeniging. In de twintigste eeuw zou de Groot-Nederlandse gedachte zich meer op Vlaanderen richten, of op een beter bestuur in Indië.

Ten behoeve van Indië zetten de gecombineerde faculteiten van rechten en letteren zich hartstochtelijk in voor een 'ethische politiek' - door critici ook wel 'ethische verblinding' genoemd - die met behulp van wetenschap en onderwijs Indonesië wilde moderniseren en rijp maken voor de onafhankelijkheid. 'De inlandsche gemeenschap dorst naar onze kennis,' zei Colenbrander in 1918 in zijn inaugurele rede als hoogleraar in de koloniale geschiedenis, 'óók en bovenal omdat zij gevoelt die als wapen te behoeven tegen onredelijken voortduur onzer overheersing'. Vooral Snouck Hurgronje en Van Vollenhoven gaven hun enorme krediet aan deze zaak, al vochten ze te- 


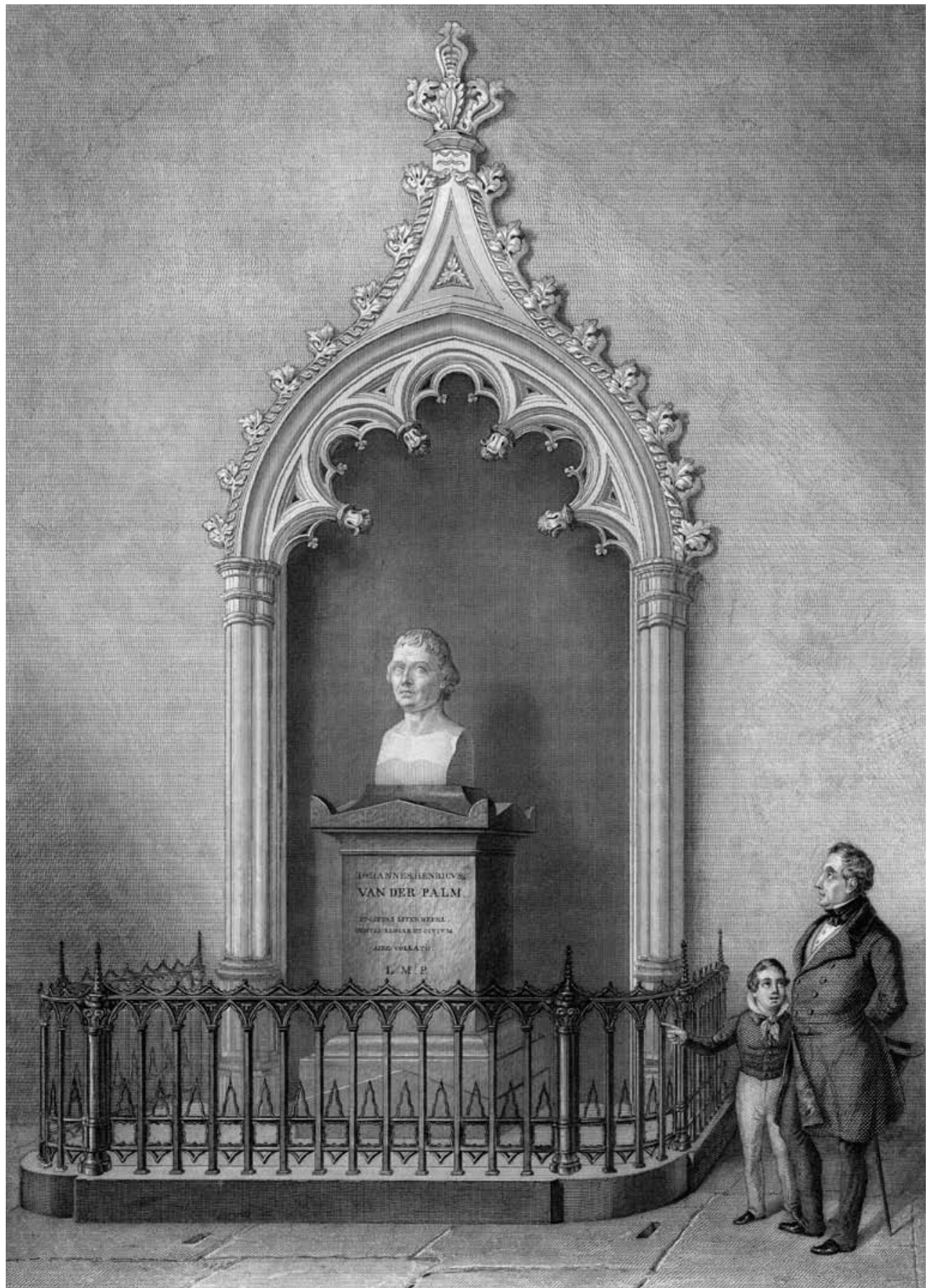

^ Hetborstbeeld van professor van der Palm in de Pieterskerk, en de verering die hem ten deelviel 


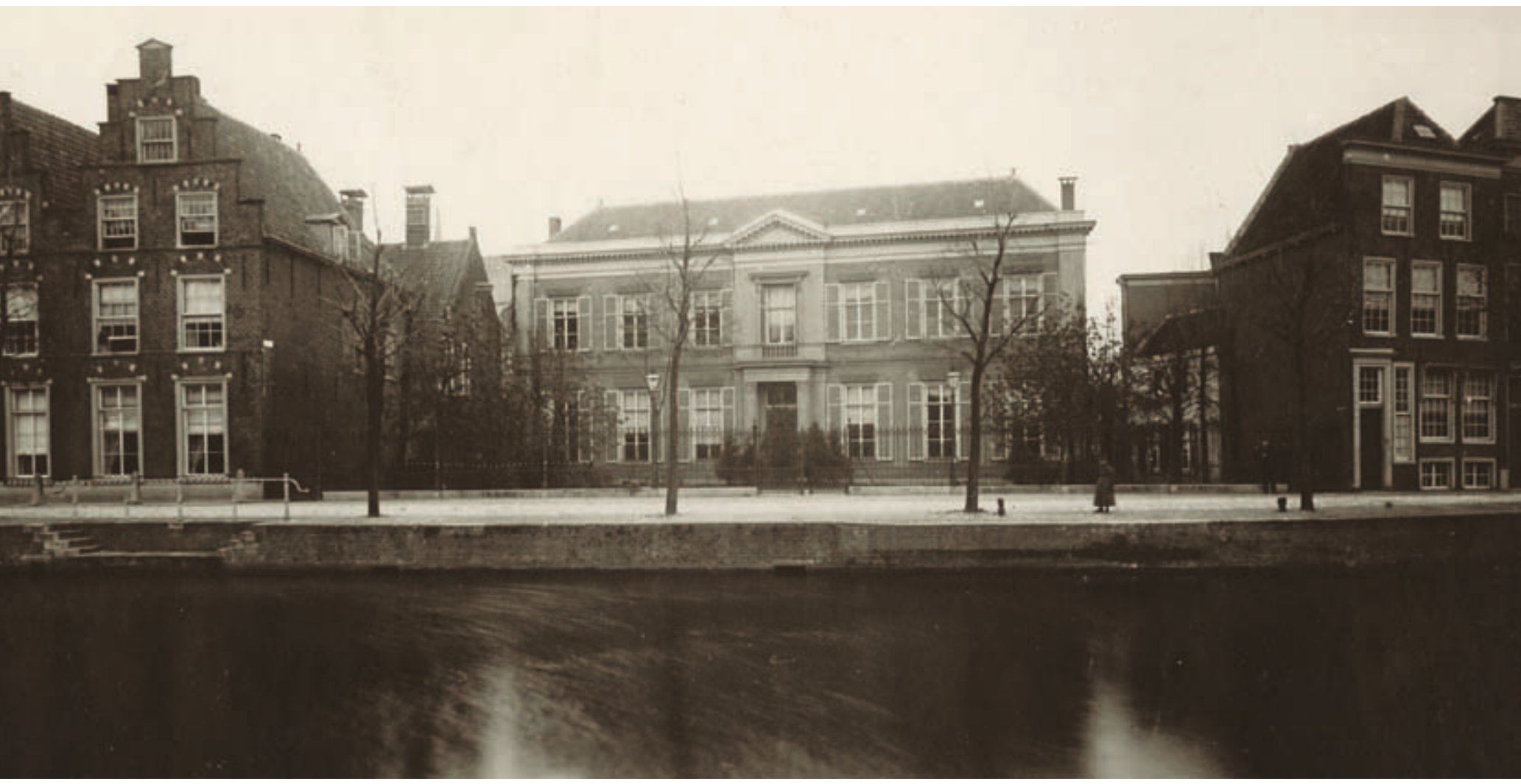

gen de conservatieve krachten in de Nederlandse samenleving een achterhoedegevecht.

Dit soort engagement gaf de nationale inspiratie meteen een internationaal accent. De internationale inspanning van Nederland lag vanouds direct in het verlengde van het besef een klein land te zijn. Een groot deel van de negentiende eeuw bracht dit kleine land door in grote twijfel aan het eigen bestaansrecht. In alle ernst zag men inlijving bij Duitsland onder ogen. Maar al snel volgde de reactie, met name vanuit Leiden. Thorbecke, Fruin en Blok brachten met grote nadruk паaг voren dat kleine staten de zetels waren van vrede en vrijheid, kosmopolitische kernen die een bemiddelende rol moesten spelen in het niet altijd even welluidende concert der naties. Zij erkenden de grote invloed die Nederland van Duitsland had ondergaan, maar wezen егоp

\Universiteitsbibliotheek, 1862 
dat Nederland geen kleine maar eigenlijk een grote natie was, klein in oppervlak maar groot door zijn verleden, door zijn koloniën, maar vooral door zijn wetenschap.

Nederland bracht aan het einde van de negentiende eeuw een aantal zeer grote juristen voort. Naast Leidenaren als Van Vollenhoven en Van Eysinga zijn dat vooral T.M.C. Asser en J. de Louter. Zij zouden door hun schitterende constructie van het internationaal recht Nederlands grootheid (én veiligheid) bevestigen. A fortiori geldt dat voor de natuurwetenschappers. De Nobelprijzen, die als een milde regen neerdaalden op de Nederlandse natuurwetenschap, maakten het land - het zijn de woorden van de Duitse chemicus W. Voigt - 'zu einer Grossmacht im Gebiete der Physik'.

Tegen deze achtergrond - en aangewakkerd door een actieve vredesbeweging - ontstond het plan om van Den Haag de zogeheten 'wereldhoofdstad van het intellect' te maken. De architect De Bazel maakte hiervoor zelfs een ontwerp, met onder andere een vredespaleis en een internationale academie (de Association des Académies). Dat de Nederlandse wetenschap niet afkerig stond tegenover dit streven blijkt wel uit een artikel van Lorentz uit 1913 in het tijdschrift Vrede door recht, waarin hij uiteenzette hoe de internationale wetenschap de vrede bevorderde. Vоогаl de geruchtmakende brochure van Van Vollenhoven, De Eendracht van het Land, ook uit 1913, bracht een vurig pleidooi voor Nederlands morele taak in de wereld.

Na de Eerste Wereldoorlog, die ook de internationale wetenschap in twee vijandige kampen splitste, ontwikkelde de Koninklijke Academie, onder leiding van Lorentz en Van Vollenhoven, een intensieve wetenschapsdiplomatie om de uitsluiting van de geleerden van de Centrale machten uit de inmiddels opgerichte International Research Council ongedaan te maken. Heen en weer pendelend tussen Berlijn en Parijs probeerden ze te komen tot 'een soort wetenschappelijkLocarno'. Ook al faalde dit plan en zat men uiteindelijk, na 1933, met nazi's aan tafel, de inspanning weerspiegelt het aanzienlijke zelfbesef van de Nederlandse wetenschap in die tijd.

Die inspanning had ook alles van doen met de autonomie van de Nederlandse wetenschap. Niet alleen politiek, ook en vooral wetenschappelijk, had in Nederland de bewondering voor het Duitse buurland gevochten met de 
DE BLEIDE INKOMSTE DER CAMERE)

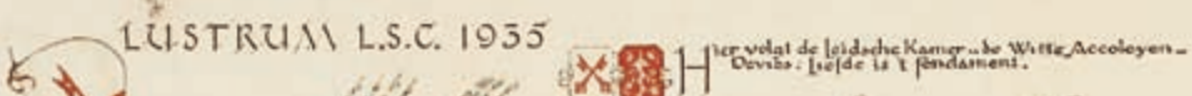
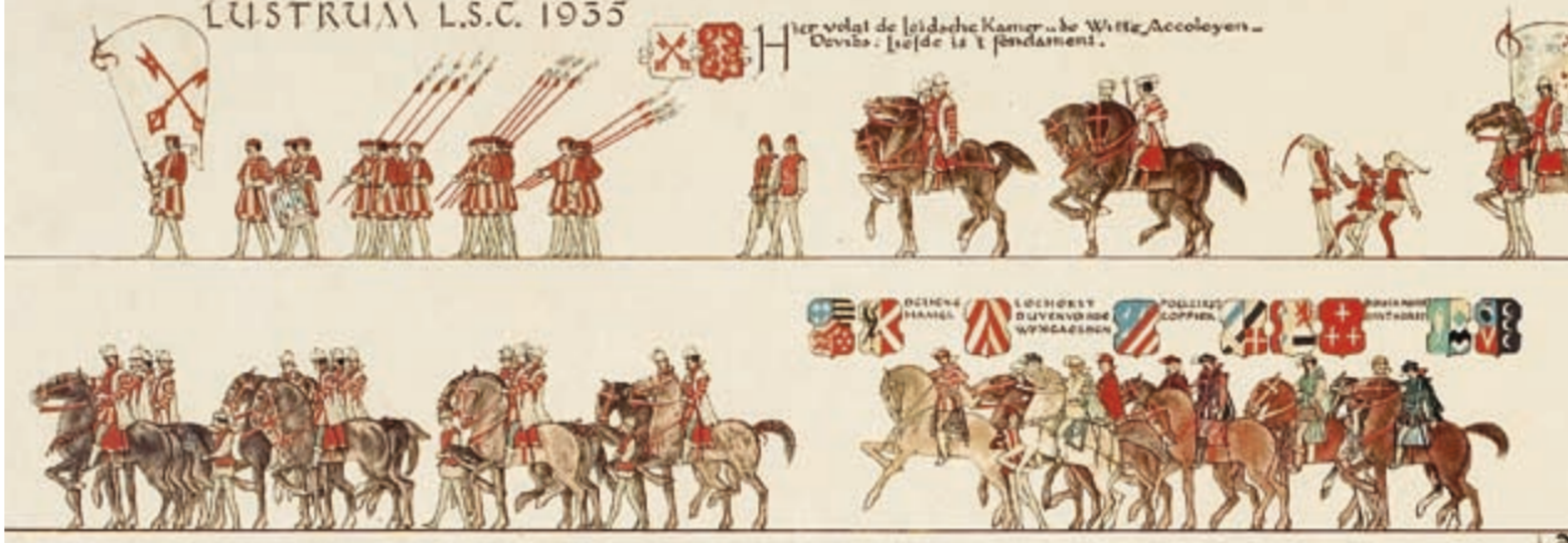

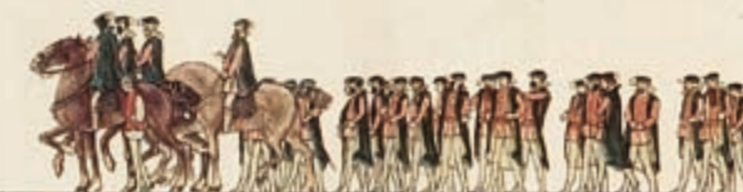

(iv) Nach ysgkants
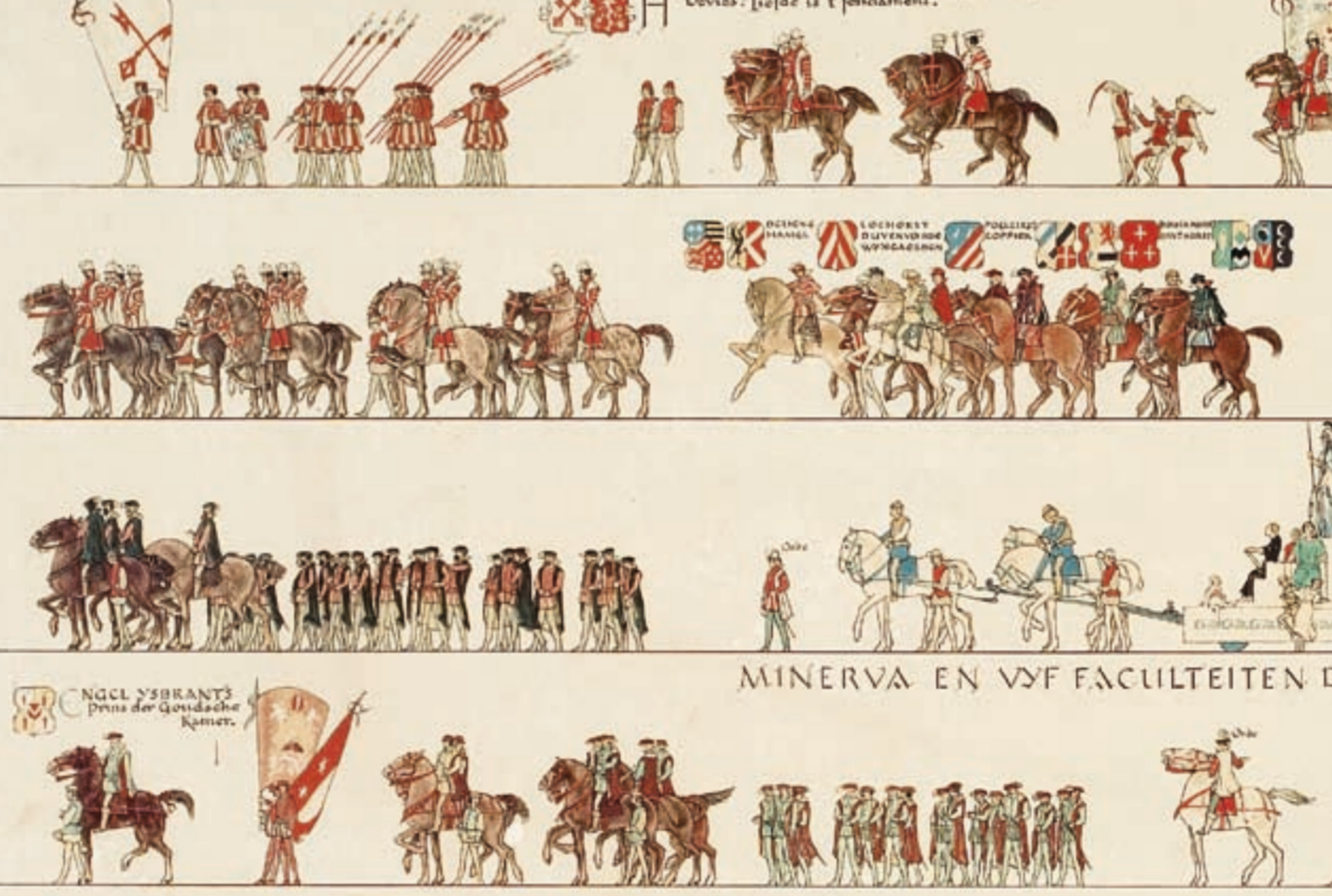

28.

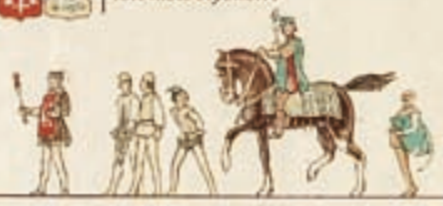

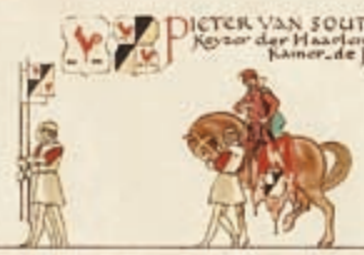

DE GE:

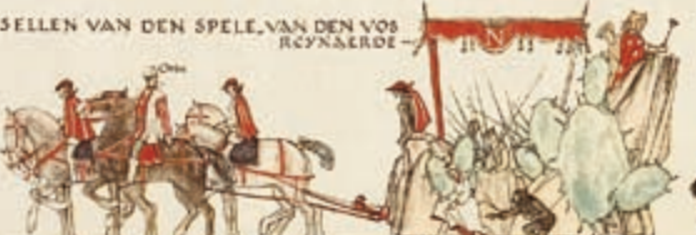

\section{1 .}

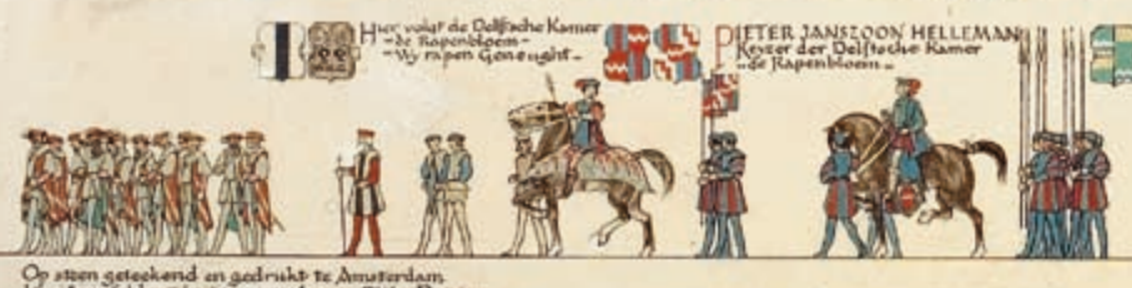

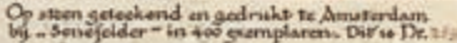

^ Maskeradeprent, 1935 


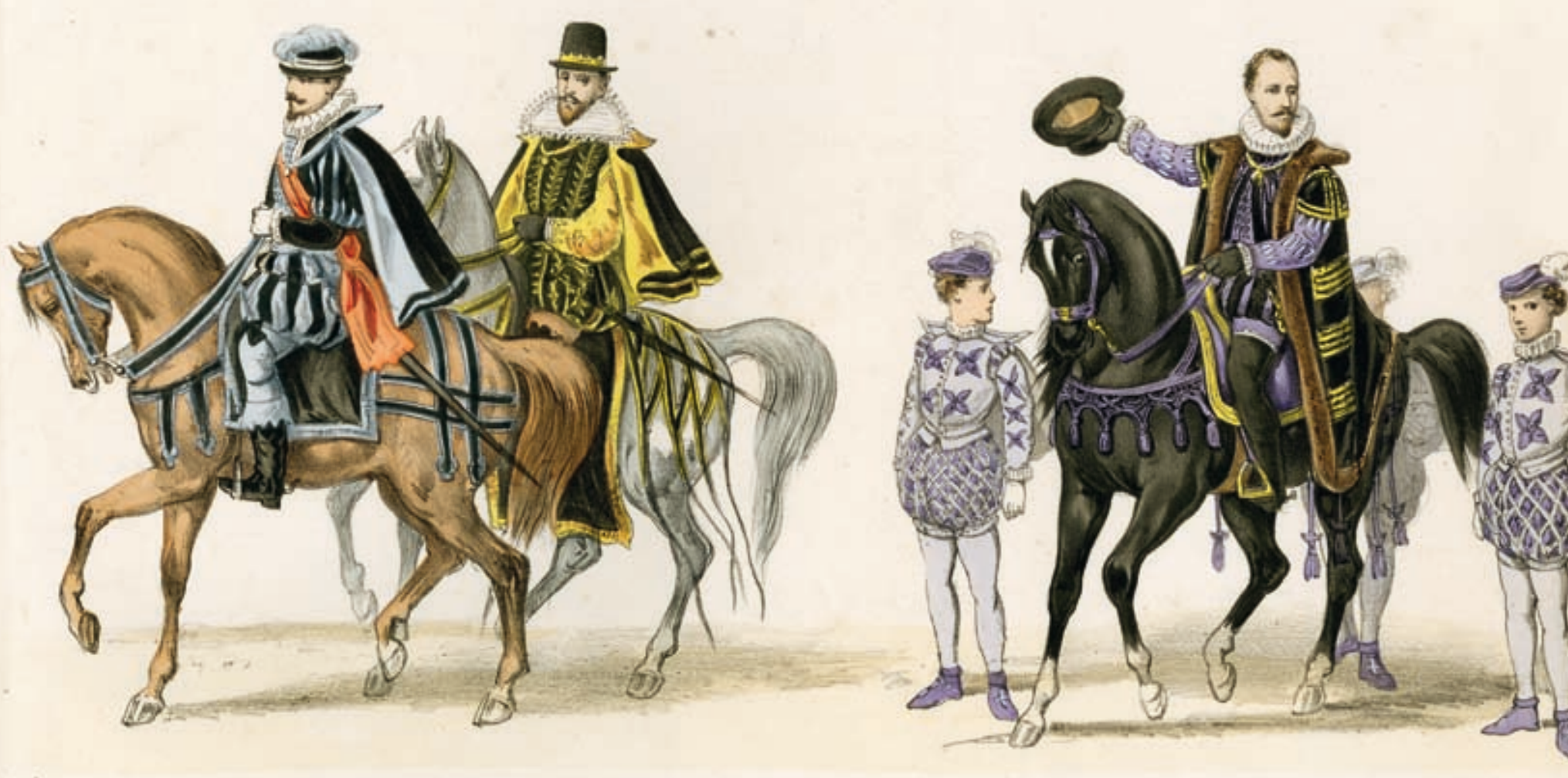

vrees een satelliet te worden. 'Omstreeks 1890 scheen de wetenschappelijke wereld in Nederland, om 't even of het geneeskunde, staatswetenschap of philologie betrof, haar heil in overgrote mate bij Duitschland en den Duitschen geest te zoeken,' schreef Huizinga in de jaren dertig. De Eerste Wereldoorlog zou in Nederland vele bewonderaars aan het denken zetten. Lorentz hield een pleidooi voor het eigen karakter van de wetenschap van kleine naties en hun vrijheid tot bloei te kunnen komen. Opnieuw was Van Vollenhoven het meest uitgesproken: 'Zelfbevrijding van de Duitsche wetenschap is een andere aanwijzing voor het zoeken van een eigen aandeel in den cosmopolitische arbeid,' schreef hij in 1925. Na de Tweede Wereldoorlog zou dat niet anders zijn, maar richtte die arbeid zich op de Verenigde Staten in plaats van Duitsland.

Ook al voor de Tweede Wereldoorlog zorgden grote Amerikaanse fondsen als de Carnegie Endowment en de Rockefeller Foundation ervoor dat de aan-

\ Detailmaskerade 1875 


\section{Gebondenheid en vrijheid}

Ook na de komst van het koninkrijk en de nationale eenheidsstaat was het niet meteen gedaan met de universitaire vrijheid. Het oorspronkelijke ontwerp van het Organiek Besluit handhaafde de onafhankelijke positie van curatoren. Alleen persoonlijk ingrijpen van de minister van Onderwijs bracht de genoemde beperkende bepalingen betreffende benoeming en financieel beleid aan. Ook de vrijheid van studenten en professoren gold vrijwel onverkort. Studenten konden hun studie naar believen inrichten; volgorde noch duur was voorgeschreven en examens waren weinig talrijk en licht. En wat de ргоfessoren betreft: de ontwerper van de wet, de Leidse jurist Kemper, ging er prat op het onderwijs ingericht te hebben ‘bijna alleen op de ondervinding, den smaak en het оогdeel dier onderwijzers zelve'.

Daaruit blijkt dat het sociale aspect bij het ontwerp van die wet vele malen zwaarder woog dan het cognitieve. 'De geleerde stand opnieuw verheven tot het oude aanzien, dat hij in Nederland steeds genoten had, [...] zoo wilde het Kemper,' schreef Huizinga. Academische vrijheid werd daarmee onderdeel van een hogere hiërarchie van burgerlijke waarden. De vrijheid die de universiteit vervolgens een halve eeuw genoot, was die van de liberale nachtwakersstaat. In de omschrijving van Jan Romein: 'De liberale staat bemoeit zich met de universiteit alleen daarom niet, omdat het niet nodig is, en het is niet nodig, omdat er alleen liberale professoren zijn.'

Aan die zondag van het leven kwam een einde aan het slot van de negentiende eeuw. Een centraliserende overheid ging zich intensiever bemoeien met de inrichting van de maatschappij. En die overheid was niet langer liberaal, maar in toenemende mate confessioneel van signatuur. Na zijn eclatante overwinning van 1901 bood de antirevolutionair Кuyper de universiteiten grotere financiële autonomie en de mogelijkheid zelf leerstoelen in te stellen. De Leidse senaat weigerde echter toe te happen. Lorentz liet optekenen: 'Hij stelt prijs op vrijheid van onderzoek en mededeeling, maar keurt daarvoor de begeerde autonomie niet onmisbaar. Zonder deze hebben wij tot nog toe ons in vrijheid verheugd. Wie zal zeggen of inwilliging van den geuiten wensch niet tenslotte zou leiden tot verkorting dier vrijheid?' 


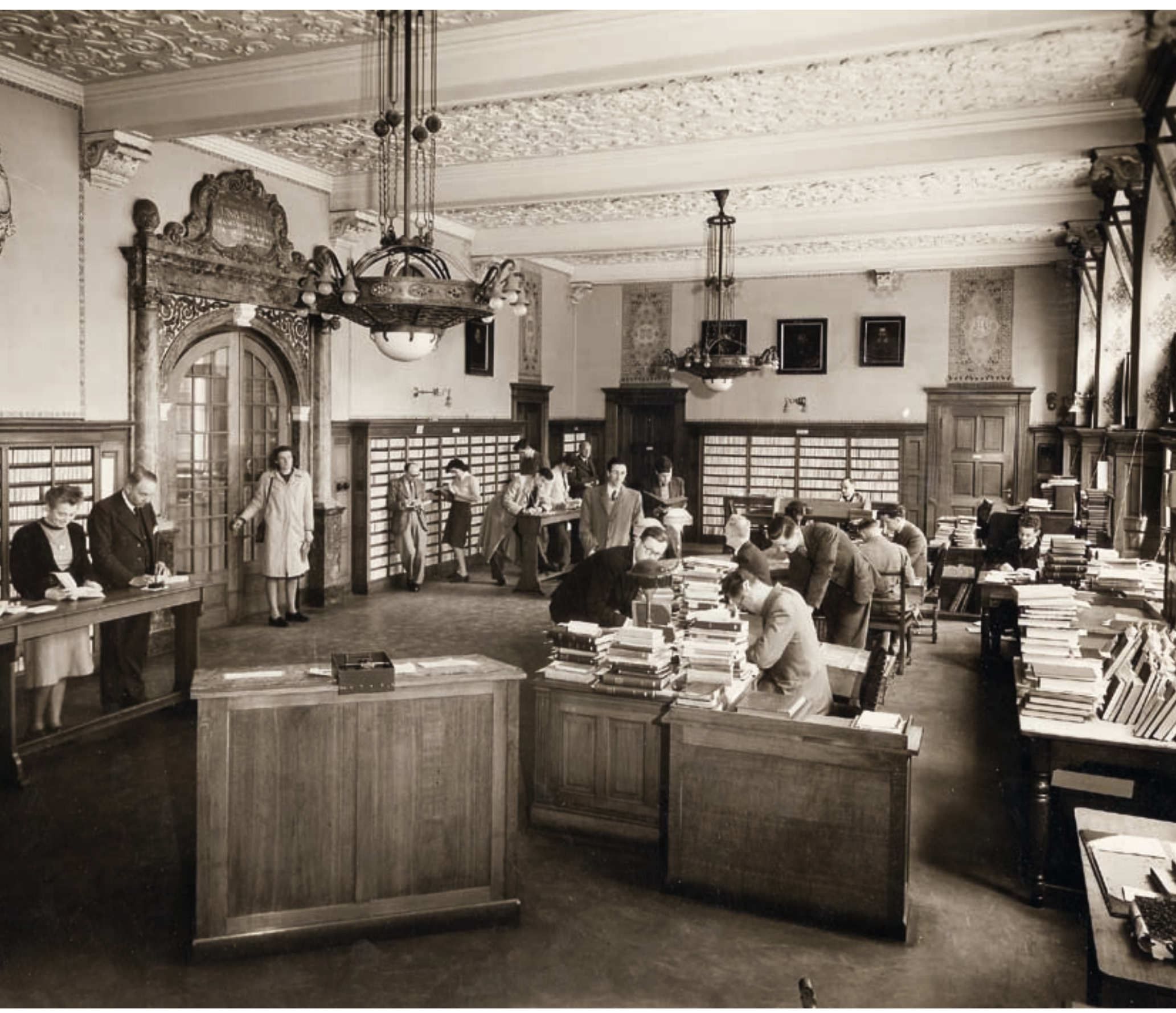

\ Uitleenbureau bibliotheek, 1948 
Blijkbaar werd academische vrijheid intussen anders gedefinieerd: niet meer als 'het wenschelijk maken van den geleerden stand', maar als de 'vrijheid van onderzoek en mededeeling'. Burgerlijke geleerdheid had plaatsgemaakt voor gespecialiseerde wetenschap. De vertegenwoordiging van die wetenschap in al haar geledingen en de samenhang van onderzoek en onderwijs definieerden de universiteit. Dat maakte het voorstel van Kuyper ook zo vernuftig: een eigen leerstoelbeleid was het hart van de academische vrijheid. Vandaar dat de universiteiten tussen 1886 en 1893 allen hun eigen universiteitsfondsen in het leven riepen om zo'n beleid te kunnen voeren.

Huizinga zag in deze fondsen 'een geheel nieuw beginsel in het beheer der universiteiten'. Maar het visioen van een universiteit met een groot eigen vermogen naar Amerikaans model, dat hij en anderen, met name Van Vollenhoven, daarbij koesterden, zou niet in vervulling gaan. Het tegenovergestelde zou het geval zijn. De Wet op het Wetenschappelijk Onderwijs van 1960 verschafte de universiteit inderdaad een eigen rechtspersoonlijkheid: ze beheerde voortaan haаг eigen гоегеnde en onгоerende goederen en mocht een eigen vermogen hebben. Маar de schaalvergroting zou elke vorm van financiële zelfstandigheid imaginair maken.

Die schaalvergroting leidde wel tot een herdefiniëring van het onderwijs. Wetenschappelijk onderzoek en de samenhang van onderzoek en onderwijs zouden maar een van de pijlers ervan zijn. Daarnaast legde de wet de klemtoon op vorming en praktijk. Daarmee kwam de academische vrijheid opnieuw in het gedrang. Die vrijheid was intussen inhoudelijk gedefinieerd: vrijheid van onderzoek en mededeling. Ooit onderscheidde Isaiah Berlin twee concepten van vrijheid, 'freedom from interference' en 'freedom for a predefined end'. Dat onderscheid bleek ook op de universitaire vrijheid van toepassing. De eerste vorm bedoelde Lorentz. De tweede zou in toenemende mate de discussie gaan bepalen. En die discussie was fel. 


\section{SDBALD JUSTINUS BRUGMANS}

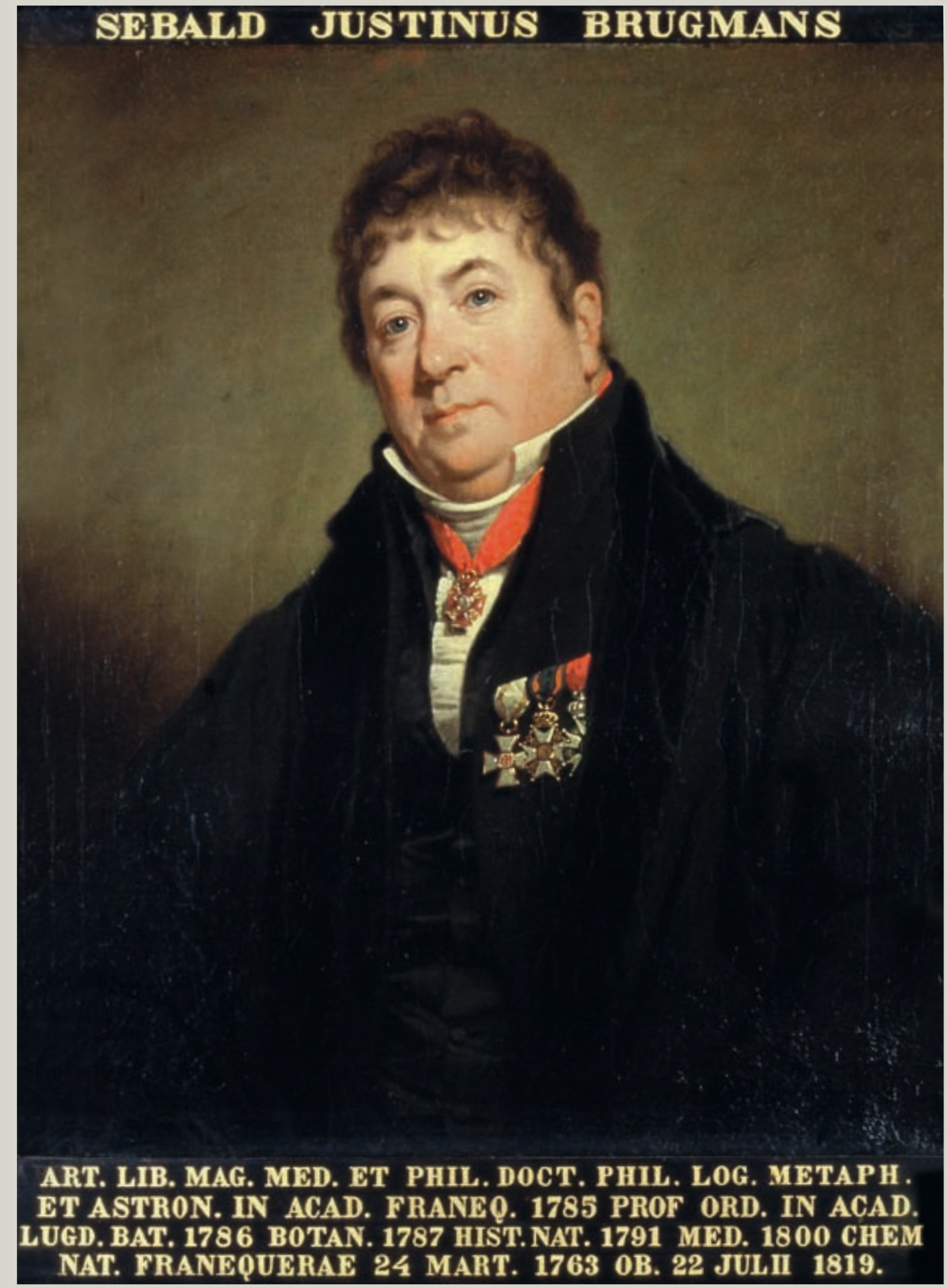




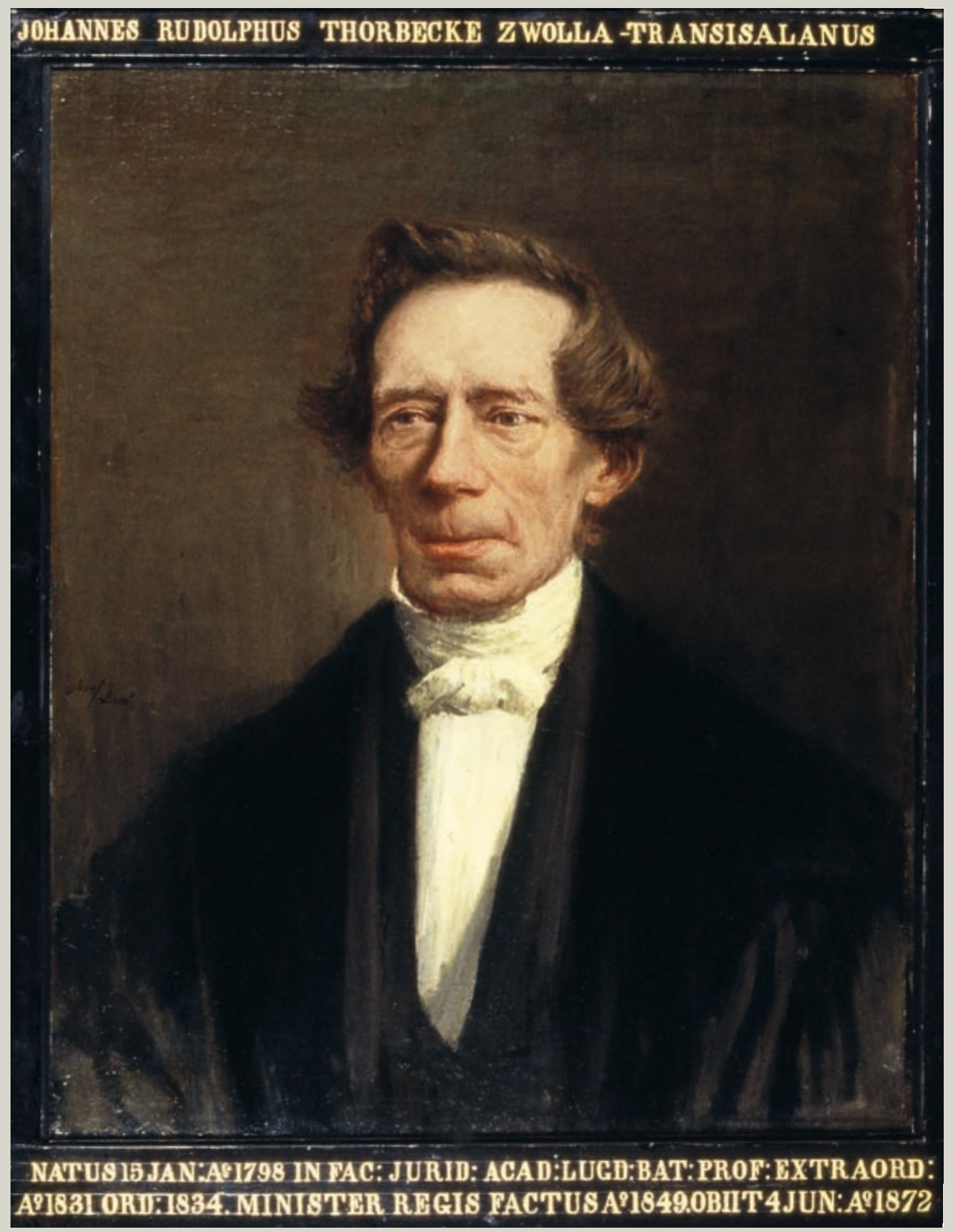




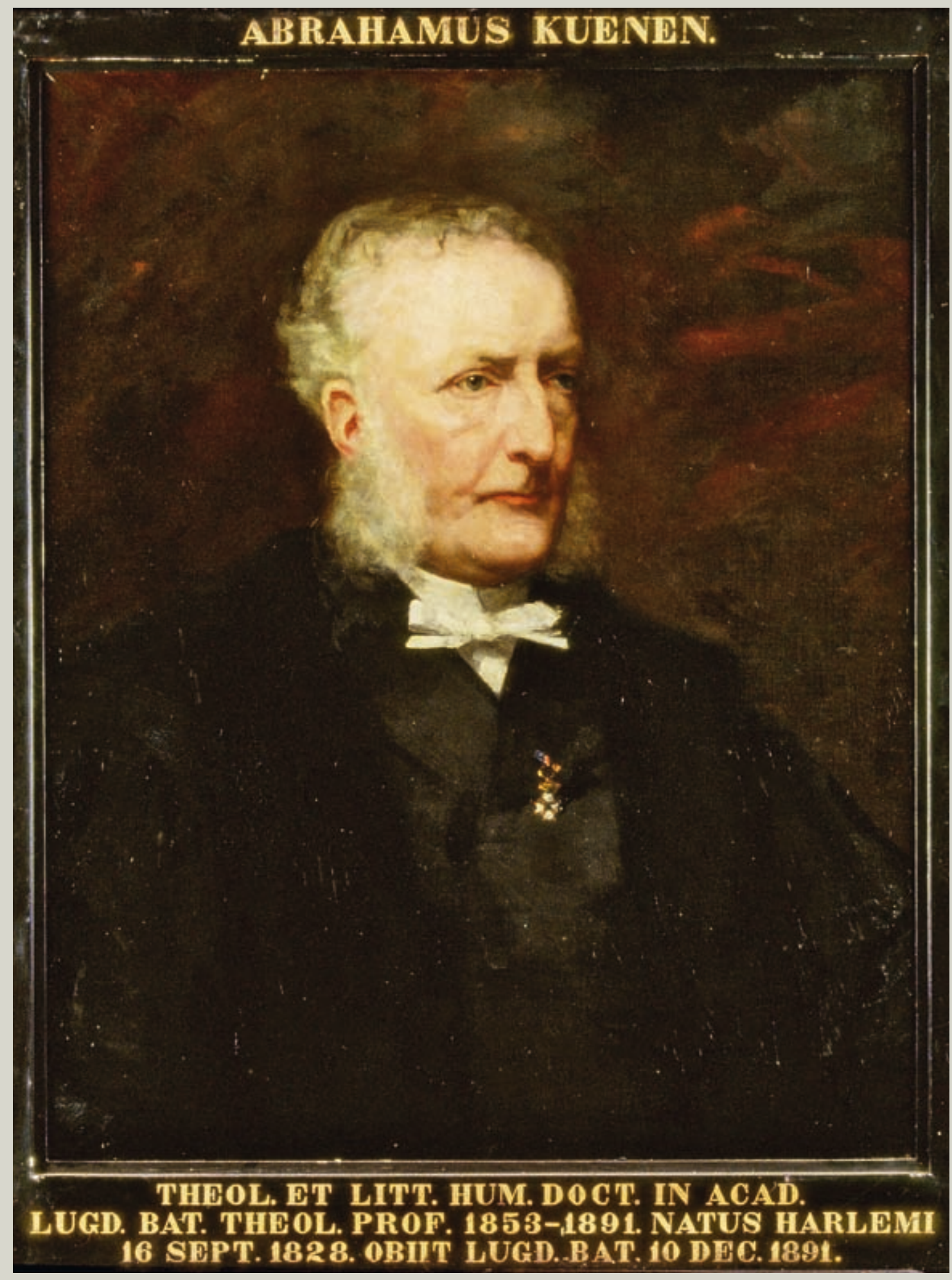




\section{JOHANNES HENDRICUS CASPARUS KERN}

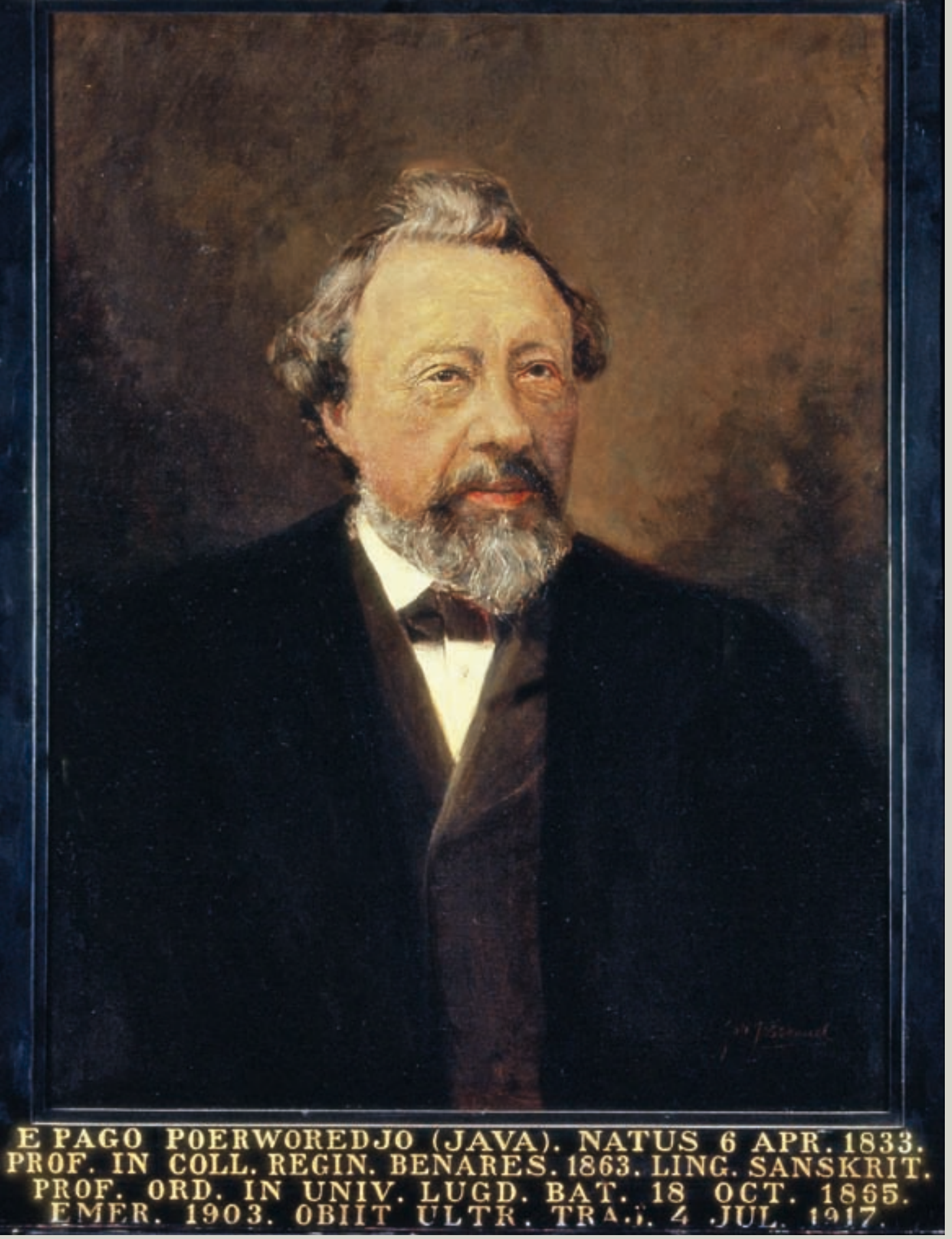




$$
\begin{aligned}
& 3 \\
& \text { Eenheid } \\
& \text { en } \\
& \text { veelheid } \\
& \text { DE LEIDSE } \\
& \text { UNIVERSITEIT } \\
& 1975 \text { - HEDEN }
\end{aligned}
$$




\section{Het juiste midden}

Als het nieuwe Nederland van de laatste decennia iets ontbeerde, was het zijn oude gevoel voor het midden. Dit kwam vreemd genoeg door's lands rijkdom. Die deed de gedachte postvatten dat Nederland en de Nederlanders producten van eigen makelij waren. En die gedachte vertakte zich vervolgens tot twee elkaar naar het leven staande loten: nivellering en individualisering. De eerste loot impliceerde een reeks van overheidsmaatregelen, erop gericht alle Nederlanders gelijkelijk in de rijkdom te laten delen. De tweede resulteerde in het afbouwen van de verzuiling, het arrangement dat Nederland tot dan toe bij elkaar had gehouden. De eerste werd geïmplementeerd door de slogan 'spreiding van kennis, macht en inkomen', de tweede karakteriseerde zich door functieverlies van kerkgenootschap en politieke partij, en bijgevolg door een polarisering van het debat.

Zo committeerde het land zich aan een geldverslindende gelijkheidsideologie juist op het moment dat de oliecrisis van een overschot op de begroting een dramatisch tekort maakte. En zo zat het land in de problemen zonder te kunnen steunen op de traditionele zuilen. Het proces van herstel - een operatie vergelijkbaar met de waterwerken - resulterend in het poldermodel, bracht niet alleen tussen werkgevers en werknemers consensus, maar ook in de politiek. Zo succesvol was dit model dat Nederland ontslagen werd van elk fundamenteel debat en in rust en op renten de regie uit handen gaf. Nederland 


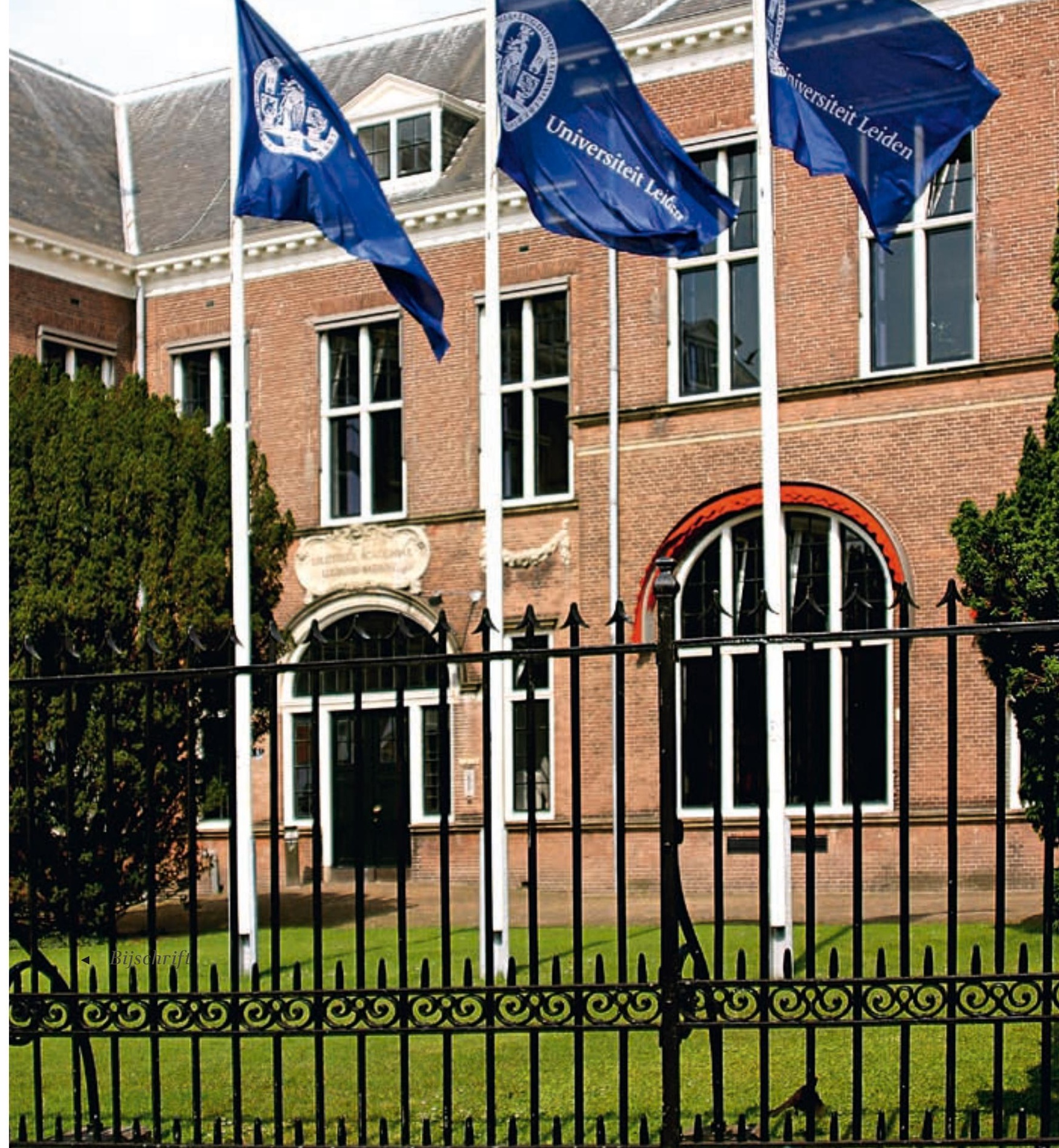


was niet langer maakbaar, het werd gemaakt: door een opdringerig buitenland dat de angst handen en voeten gaf in de vorm van een miljoen allochtonen. Twee politieke moorden later - op de politicus Pim Fortuyn en de cineast Theo van Gogh - wist het land weer waarover het ging: die permanente zoektocht naar het juiste milieu, het midden tussen de extremiteiten.

\section{Het vierde eeuwfeest}

In 1975 boog ook de Leidse universiteit zich, ter gelegenheid van haar eeuwfeest, over haar identiteit. In tegenstelling tot vierhonderd јааг еегdег ореnde het lustrum niet met een kerkdienst, niet 's morgens vroeg en niet in de winter. Ook het begin van het feest op het bordes van het stadhuis had iets ongeïnspireerds. Bij wijze van symbolische handeling werden de sleutels van de universiteit - manshoge groenhouten dingen - aan de burgemeester overhandigd. Diens dankwoorden werden vervolgens door het carillon overstemd. In de stilte die volgde, verklaarde de voorzitter van het college van bestuur, mr. K.J. Cath, de universiteit voor 'meer open dan vroeger'.

En 'open' wilde de universiteit zijn, die week in mei. Terwijl de zon over de daken buitelde en al het ludieks dat de kasten borgen, tevoorschijn werd gehaald, diende het vierde eeuwfeest een ernstig doel: de academieschouw. Het feest zou een goede gelegenheid zijn, zo had de collegevoorzitter bij de opening van het academisch jaar verklaard, 'om aan de buitenwereld duidelijk te maken wat de universiteit met haar vrijheid deed en doet en wat de universiteit als doelgemeenschap aan de ontwikkeling van de maatschappij kan bijdragen'.

Bij die gelegenheid schetste hij het beeld van een 'in de verdediging gedrongen' instelling. Het slechte imago van de universiteit, de aanwas van studenten en de pluriformiteit van hun motivatie, de toename van taken en de vermindering van middelen, de spanning tussen taakstelling en bestuursstructuur, tussen onderwijs en onderzoek, het was een litanie die als opmaat voor een eeuwfeest te denken gaf.

De feestweek zelf, met een duizelingwekkend programma, stoelde op

\ Bestuursgebouw van de universiteit, voormalige Universiteitsbibliotheek 
twee gedachten. De eerste was de universiteit aan stad en land voor te stellen, de academie uit haаг ivoren toren te halen en open huis te houden. Dat leidde tot allerlei vrolijks met sport en spel, muziek en toneel en nog veel meer: standwerkers en poppenspelers, krachtsporters en volksdansers, veel zoekgeraakte kinderen en rare kledingstukken (Volendam, Tirol), vetvlekken en vuile magen, blaren en Io Vivat. De kalklijnen op straat bleken zo bestendig dat automobilisten de volgende dag de estafettebanen als parkeervakken gingen gebruiken.

De tweede gedachte was om in allerlei academische disciplines en in de algemene gedachtevorming het devies van de universiteit te toetsen. Dat devies, Praesidium Libertatis, werd onderzocht op zijn wetenschappelijke reikwijdte en maatschappelijke grenzen. Niet minder dan 82 instellingen hielden in dit verband open huis. Boeken en tentoonstellingen, symposia en congressen, ze waren er in alle soorten en maten. De meeste aandacht ging ongetwijfeld uit naar de grote symposia van de faculteit der rechten en die der sociale wetenschappen. De juristen debatteerden met grote inzet over het thema 'de vrijheid van het individu en het recht', waarbij het Baader-Meinhof-proces de geesten sterk verdeelde. De sociologen spraken over 'afhankelijkheid, onafhankelijkheid, vrijheid, in verband met kolonisatie en dekolonisatie'. Hier zorgde het zogeheten dekolonisatiemodel van Vietnam en Cambodja/China voor een knisperende discussie.

Het belangrijkste van de eeuwfeestweek, het meest traditionele deel ervan, was de academische zitting, met veertien eredoctoraten voor geleerden uit drie werelddelen, bijgewoond door vertegenwoordigers van 32 universiteiten uit 21 landen en door koningin en kroonprinses en hun beider prinsen. Alleen al het cortège van de honderden hoogleraren van het academiegebouw naar de Pieterskerk, in een uitmonstering die in kleurrijkheid niet onderdeed voor een Balinese begrafenis en begeleid door melodieën uit Valerius' Gedenck-clanck, was een overweldigend tafereel. De veertien eredoctoren - elf waren er aanwezig - waren allen geleerden van grote faam, onder wie Emmanuel Levinas en François Braudel.

In zijn rectorale rede aan het begin van de plechtigheid deed A.E. Cohen afstand van alle superlatieven die voorgangers bij eeuwfeestredes gebruikt 


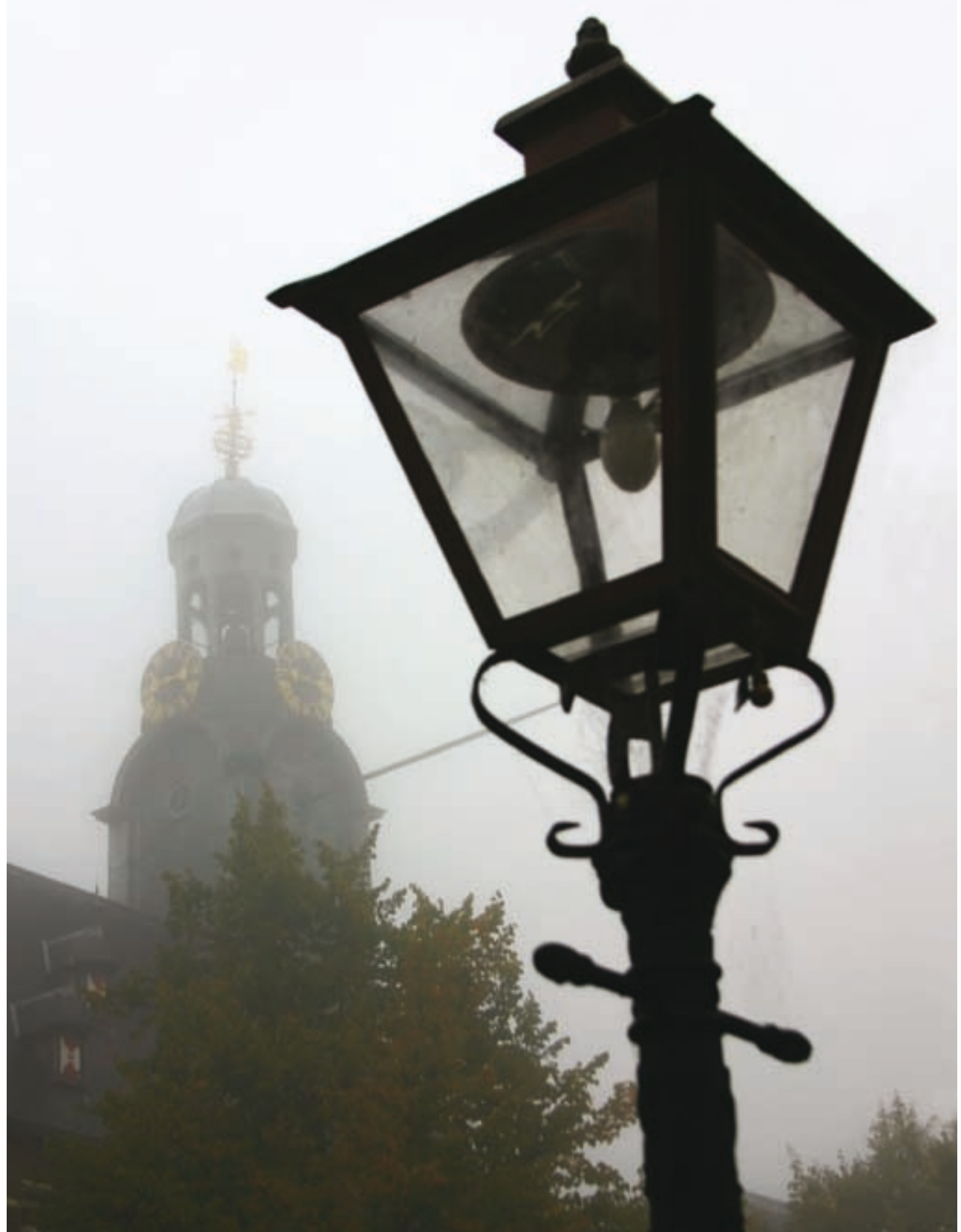

^ Toren van het Academiegebouw aan het Rapenburg 


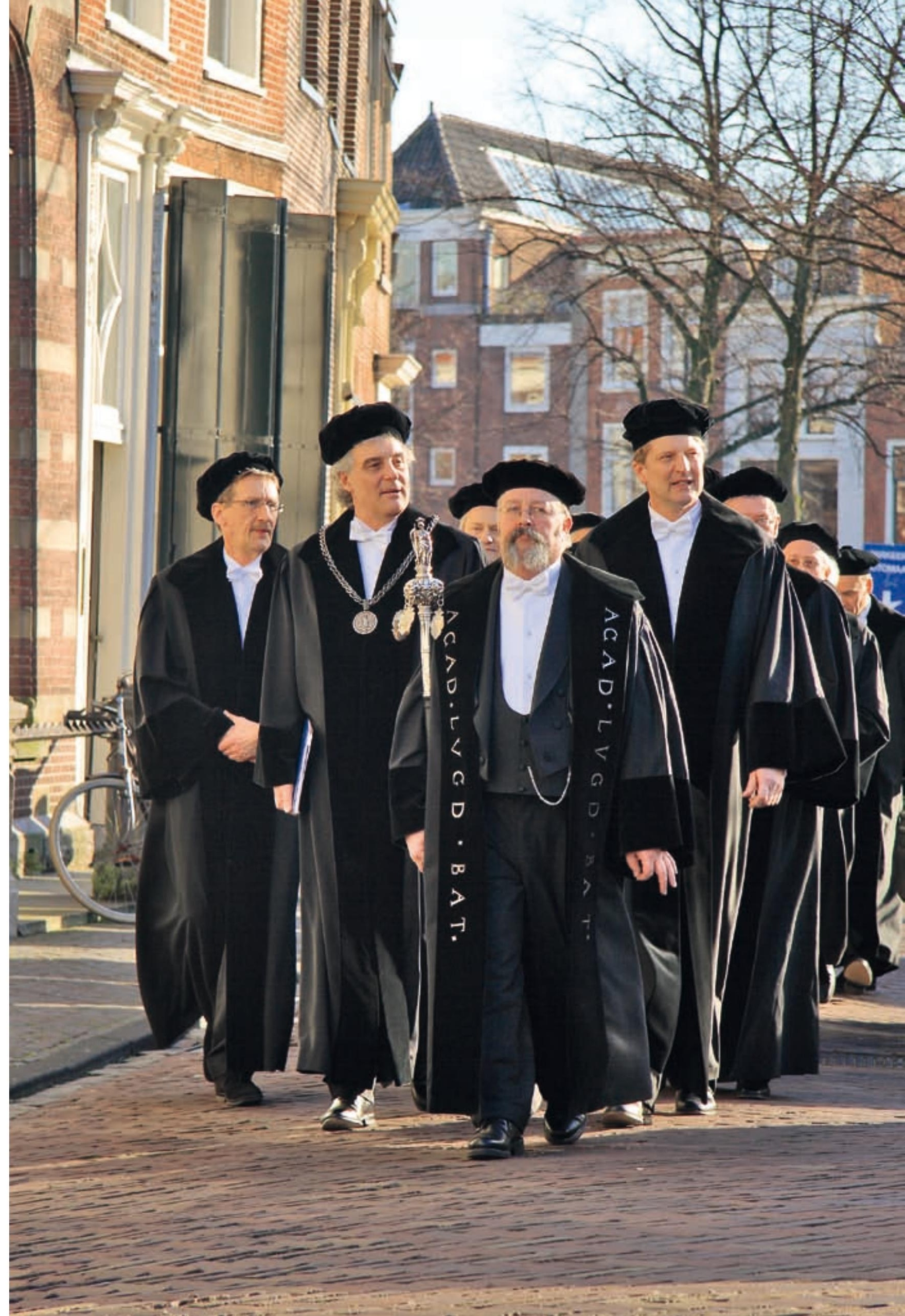


hadden om Leiden te onderscheiden van de rest der vaderlandse universiteiten. Hij hield er maar één over, die van de oudste te zijn. Het thema van deze eeuwfeestrede was de desintegratie van de instelling die de universiteit was, want 'de onderlinge verschillen tussen onze faculteiten en studierichtingen, het onderscheid tussen onze geledingen en bestuursniveaus hebben tezamen onze universiteiten het aanzien gegeven van een volstrekte pluriformiteit'.

In de visie van Cohen was het engagement van een geleerde met zijn specialisme vele malen groter dan dat met zijn universiteit. Hij voorzag dan ook de desintegratie van de individuele instelling en de totstandkoming van een Universitas Neerlandica. Van bestendiger karakter wenste hij de geest die de zestiende-eeuwse stichters van de universiteit voor ogen stond, 'die van de burgerlijke deugden respect, stijl, waardigheid en tolerantie'. Aan het slot van zijn rede voegde hij daaraan 'heilzame twijfel' toe, 'de wortel van alle wetenschap'.

De verschillen tussen de academie van 1575 en de universiteit van 1975 zijn intussen frappant. De eerste had niets te verliezen, de tweede alles, de eerste had alleen maar toekomst, de tweede vooral verleden. Elke vergelijking tussen 1575 en 1975, tussen het opstandige gewest en het gevestigde koninkrijk, tussen de belegerde stad en de gezapige gemeente, tussen de prille academie en de vier eeuwen oude universiteit, gaat mank. Toch maakt ze duidelijk dat de Leidse universiteit in 1975 voor een van de zwaarste uitdagingen in haar bestaan stond.

\section{Schandalen}

Die uitdaging werd in de jaren negentig op drie momenten verscherpt door schandalen die zowel intern grote onrust brachten als de naam van de universiteit ernstige schade berokkenden. Twee hoogleraren van naam en faam moesten ontslag nemen en zelfs een collegevoorzitter zag een abrupt einde gemaakt aan een indrukwekkende staat van dienst. Het ontslag van de hoogleraren paarde persoonlijke tragiek aan facultaire onrust. Het ontslag van de collegevoorzitter deed de gehele universiteit op haar fundamenten beven.

\ Cortège ter gelegenheid van de dies van de universiteit 20o8, met pedel, rector magnificus en diesorator 
Alle drie waren het drama's, niet in de laatste plaats omdat hybris en atè, hoogmoed en verblinding, een niet geringe rol in het geheel speelden.

De eerste kwestie, die rond de criminoloog Buikhuisen, was een zuiver tijdsverschijnsel, een product van de geëngageerde jaren tachtig. Buikhuisen was directeur van het Wetenschappelijk onderzoeks- en documentatiecentrum voor policy research van het ministerie van Justitie. In 1978 werd hij te Leiden benoemd. Bij die gelegenheid meldde het KRI, het maandblad van de Vereniging tot Reclassering, dat Buikhuisen rondliep met 'Plannen voor hersenonderzoek bij delinquenten'. Dat was echter niet het geval. Buikhuisen wilde onderzoek doen naar 'de interactie tussen biologische en sociale factoren' bij crimineel gedrag om de eenzijdige klemtoon op de sociale factoren te corrigeren. Hersenonderzoek noch het gebruik van gevangenen als proefpersonen was daarbij aan de orde. Niettemin waren zijn 'geheime plannen' meteen voorpaginanieuws en had Nederland zijn 'nieuwe Lombroso'.

Onbegrijpelijk is dit niet in een periode waarin de film One Flew Over the Cuckoo's Nest volle zalen trok en de cia overal de schuld van kreeg. In Leiden trok men zich eг vooralsnog weinig van aan. Zelfs de eenmansguerrilla die een van Nederlands meest begaafde polemici, Hugo Brandt Corstius, tegen Buikhuisen ondernam, had niet tot diens ontslag hoeven leiden. Brandt Corstius liet er geen twijfel over bestaan dat zijn polemiek een literair genre was en als zodanig gelezen moest worden. Dat minder geoutilleerde geesten de kwestie letterlijk namen en dozen met excrementen bij de Leidse hoogleraar lieten bezorgen, was minder aangenaam.

Het probleem was dat het Buikhuisen ontbrak aan sociaal vernuft en theoretisch raffinement. Diep overtuigd van de waarde van zijn onderzoek en een einzelgänger van nature, was hij weinig ontvankelijk voor kritiek en weinig subtiel in zijn verweer. Zo vervreemdde hij niet alleen zijn beroepsgroep en faculteit van zich, ook zijn naaste collega's, juristen en sociaal-wetenschappers, keerden zich van hem af. Vooral vanuit de faculteit sociale wetenschappen kwam gefundeerde kritiek op zijn voorstellen. De 'monumentale vaagheid' van zijn plannen wekte de verbazing van datatheoretici, juristen bekritiseerden zijn onvermogen de samenhang te zien tussen wetenschappelijke en morele categorieën. Zo raakte een onderzoek dat met zoveel woorden

- Murgedicht op de achtergevel van het bestuursgebouw op Rapenburg 70 


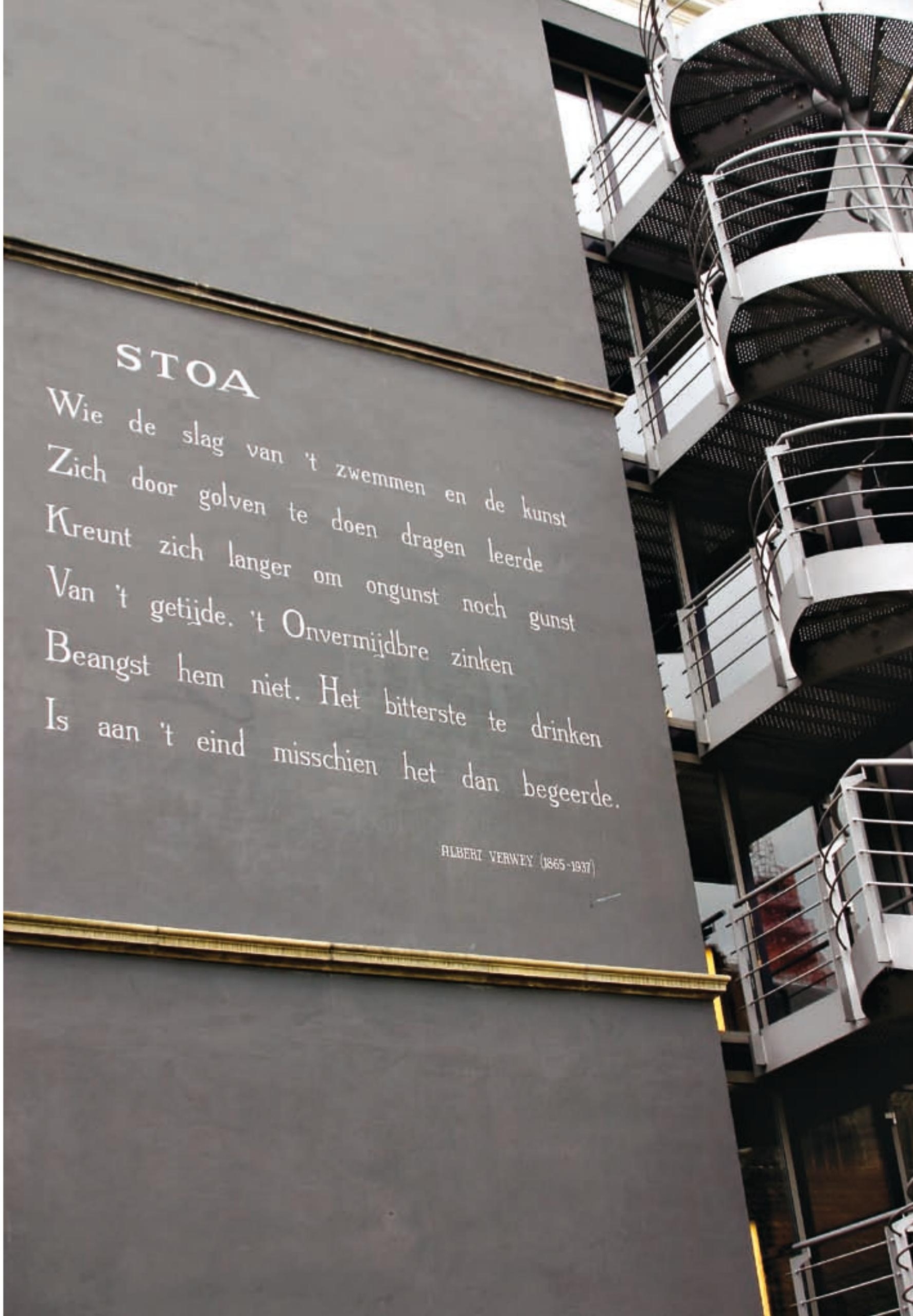


interdisciplinair wilde zijn in een isolement. Dit, gecombineerd met de aanhoudende tegenwerking en anonieme aantijgingen, deden Buikhuisen in 1989 besluiten de universiteit de rug toe te keren en antiquair te worden. Dat dit soort onderzoek tegenwoordig allerwegen plaatsvindt en de biologie ook in de rechtswetenschap en in sociaalwetenschappelijk onderzoek een centrale rol speelt, is een feit dat deze tragedie haar ware proportie geeft.

Het tweede grote schandaal betrof het beheer van het eigen vastgoed. Een mistige aanbesteding door de directeur bedrijfsvoering van de universiteit bij de bouw van een 'annex' van het Sylvius Laboratorium leidde tot een onderzoek en later tot de val van collegevoorzitter C.P.C.M. Oomen. Ook hier

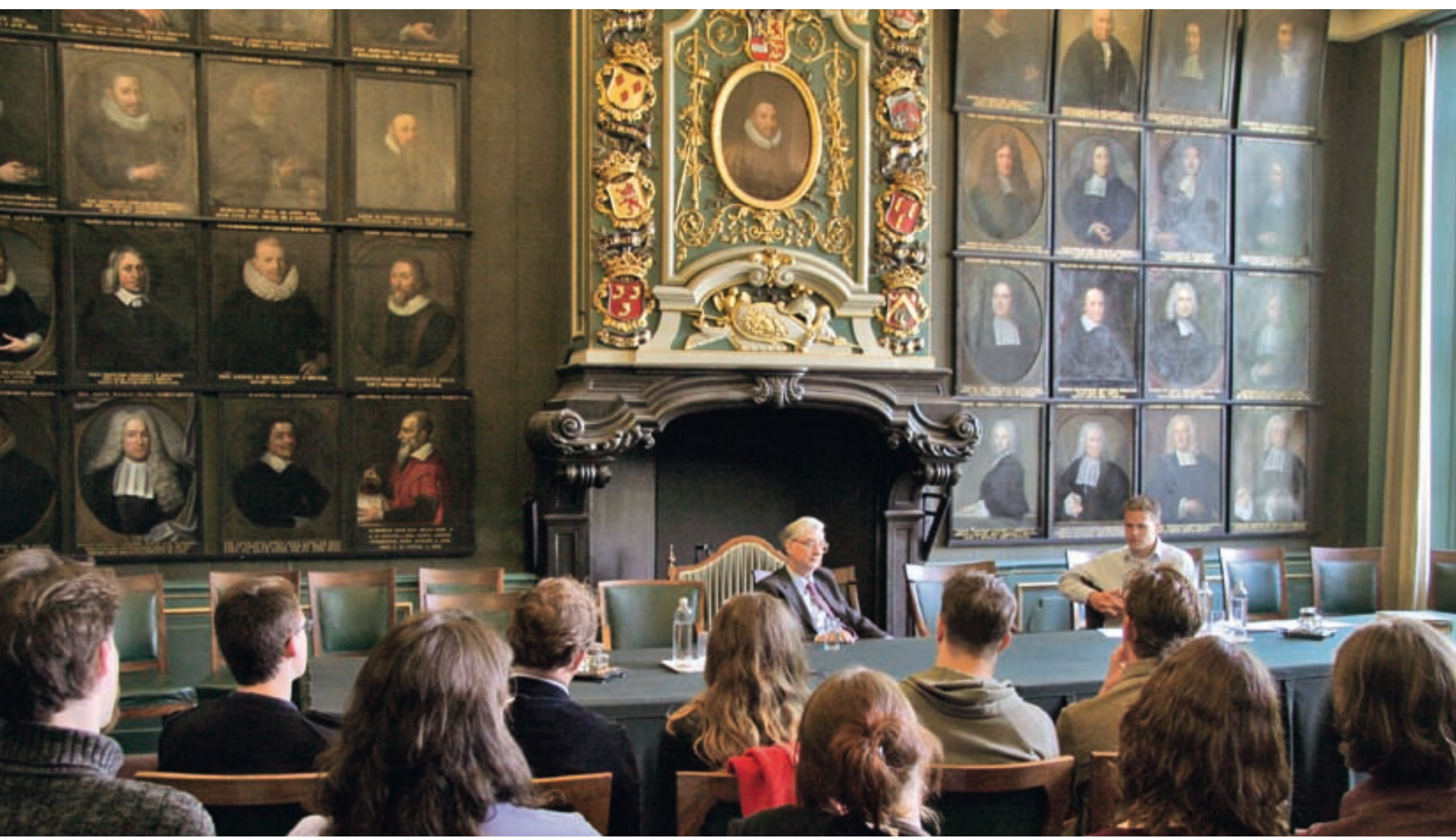

^ Voordracht van de bioloogEdward Wilson in de Senaatskamer van het Academiegebouw 
had de manier waarop een bijgebouw een hoofdzaak werd de structuur van een tragedie met karakterologische eigenschappen en een dwingende structuur als ingrediënten.

Oomen was een te Leiden gevormd jurist die al kort na zijn aanstelling als lector decaan van de faculteit werd en daarna directeur-generaal van het ministerie van Waterstaat. Hoewel een uitstekend jurist met een grote bestuurlijke slagvaardigheid, was een zekere hybris hem niet vreemd. Vanaf het begin had hij weinig op met de universiteitsraad. Deze afkeer stak hij niet onder stoelen of banken: er moesten keuzen worden gemaakt in plaats van over Max Havelaar-koffie geneuzeld. De combinatie van financiële voorzichtigheid en eindeloze vergadercircuits boezemde hem lijfelijke weerzin in. In de annex-affaire zouden dit juist de kwetsbare punten zijn.

De gedachte achter deze 'annex' was snelheid met doelmatigheid te combineren. Precies het tegenovergestelde werd bereikt. Het pand, bestemd voor preklinisch onderzoek, zou gebouwd worden door een speciaal voor dat doel in het leven geroepen financieringsmaatschappij, Fibomij. Het probleem was dat de makelaar die Fibomij had opgericht nooit een gebouw gebouwd had, een bouwbureau inhuurde waarvan de directeur een voorgeschiedenis van faillissementen had, die op zijn beurt een aannemer in de arm nam met een traditie van slechte en trage betalingen. Onder deze voorwaarden verliep de bouw aanvankelijk еerder op de manier van een blijspel dan van een tragedie. De bedrijven wisselden van directeur als betrof het een kwartetspel, de bouw lag vaker stil dan dat er vorderingen gemaakt werden, de FIOD en het Openbаar Ministerie vielen financieringsmaatschappij en bouwbureau binnen en tot overmaat van ramp leek ook de direct verantwoordelijke directeur bedrijfsvoering van de universiteit zo betrokken dat hij verdacht werd van deelname aan een criminele organisatie.

Tot dan toe hadden college en universiteitsraad samengewerkt in het zogenaamde Leidse harmoniemodel. Dit model, gebaseerd op gedeelde verantwoordelijkheid en compromisbereidheid, vertoonde inmiddels slijtage. Маar belangrijker was dat Oomen er niet de man naar was het te onderhouden. Bovendien verzuimde hij de nauwe banden met het college van decanen uit de boedel van het model over te nemen. Een door eigen machteloosheid getergde 
raad en een zich afzijdig opstellend college van decanen was er de oorzaak van dat Oomen, als portefeuillehouder bouwzaken, verantwoordelijk gesteld werd voor een ernstige fout van een van zijn hoge ambtenaren. Een koningsdrama op kleine schaal was een feit.

Deze karakterisering werd eveneens gebruikt bij het plagiaatschandaal dat in 1996 de klinisch psycholoog René Diekstra noopte ontslag te nemen. De omvang van dit drama valt af te leiden uit het feit dat nog niet eerder in Nederland een hoogleгаar om een dergelijke reden vertrokken was - bovendien ging het hier om een zeer succesvolle hoogleraar. Diekstra was in 1979 op 33-jarige leeftijd te Leiden benoemd als hoogleraаг in de klinische en gezondheidspsychologie. Veel en veelvormig publicerend was hij niet alleen een geliefd docent, maar combineerde hij zijn professoraat ook met belangrijke adviseurschappen, het redacteurschap van zes tijdschriften en een psychotherapeutische praktijk.

In deze laatste activiteit beperkte hij zich niet tot individuele cliënten, maar rekende hij het hele land tot zijn doelgroep. In de jaren tachtig legde hij zich met succes toe op het populariseren van wetenschappelijk werk via columns en de bundeling of uitwerking daarvan in boeken met titels als Je verdriet voorbij, Pleisters voor de ziel en Als het leven pijn doet. De gedachte achter deze boeken was 'dat wij allemaal hoeders van onze broeders en zusters zijn'. Het hoogtepunt van deze populaire activiteit was het eigen televisieprogramma Het onderste boven. Het gelijknamige boek dat na de serie uitkwam, zou zijn val inluiden.

Want nadat Vrij Nederland had aangetoond dat in dit boekje vijftien pagina's waren overgenomen uit een ander genees-uzelf-boekje, bleek al snel dat Diekstra, ruimhartig en met uiterst summiere verwijzingen of zelfs zonder dat, tekst van collega-popularisatoren had overgenomen, ook in zijn voorgaande boekjes. Het verweer van Diekstra - tijdsdruk, slechte redactie - was zwak en werd ondermijnd door de melding van een geval van plagiaat in zijn wetenschappelijke publicaties. Het geval kreeg zijn Bijbelse dimensie toen bleek dat een van de klokkenluiders een leerling van Diekstra was. Een speciaal ingestelde commissie concludeerde dat het populariserende werk van Diekstra niet los gezien kon worden van zijn taak als hoogleraar en dat het aan 


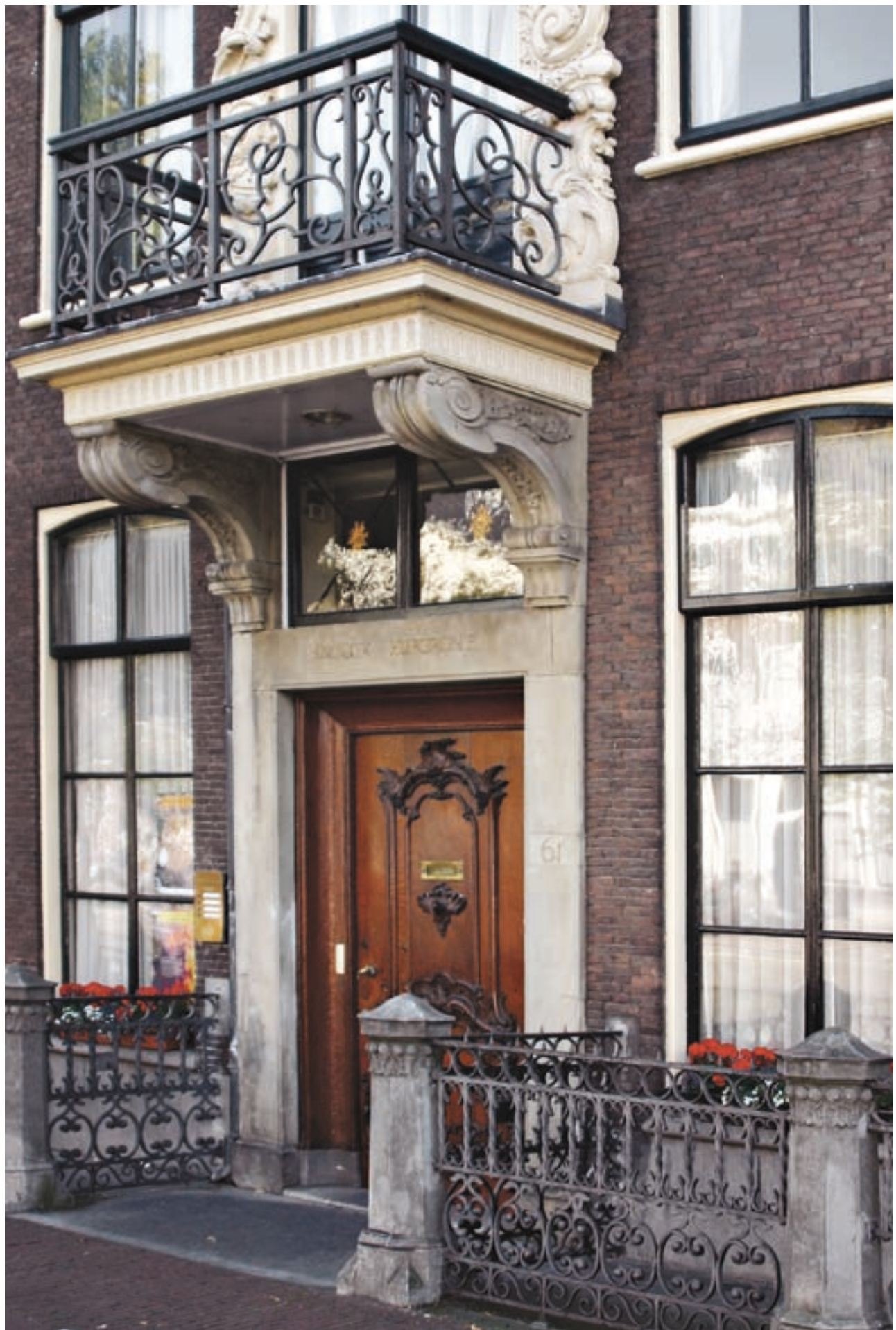

\Voormalig woonhuis van professor Chr. Snouck Hurgronje (1857-1936), nu Leids Universiteits Fonds 
dezelfde maatstaven getoetst moest worden. Het college van bestuur nam het rapport over; Leiden had niet alleen een 'nieuwe Lombroso' zien vertrekken maar ook een 'spiekprofessor'.

Eenvoudig was de zaak daarmee allerminst. Want behalve hartstochtelijke bijval van veel van zijn studenten verenigd in het Comité achter René tot het Einde (CARE) ('Stop de persen, verbrand $v N^{\prime}$ ) kreeg hij steun van wetenschappers die wel onderscheid gemaakt wensten te zien tussen populair en wetenschappelijk werk, die bewezen wilden zien dat Diekstra de intentie had met andermans veren te pronken en die concludeerden dat hier еerder een auteursrechtelijke kwestie speelde dan een geval van plagiaat. Wie de meningen naast elkaar zet, moet concluderen dat definities het aflegden tegen de huiveringwekkende combinatie van ijdelheid en val, grensoverschrijding en offer.

\section{Wetgeving}

In de drie decennia onderwijsbeleid die zich sinds de jaren zeventig laten overzien, zijn drie fasen te onderscheiden, met de jaren tachtig als omslagpunt en de ontwikkeling van regulering паaг deregulering als belangrijkste thema. In politieke termen: de socialistische jaren zeventig weken voor de christendemocratische jaren tachtig, die op hun beurt plaatsmaakten voor de liberale jaren negentig. Overigens zorgde niet alleen de politieke kleur van het beleid voor verandering, ook het economisch fortuin en de mate waarin men maatschappelijke ontwikkelingen een rol wilde laten spelen bij de vaststelling van het beleid waren van grote invloed.

De Wet universitaire bestuurshervorming (wub, 1970) voerde een medebeslissingsrecht in voor alle geledingen op alle niveaus. Dat, en niet zozeer de openheid en openbaarheid van bestuur, zorgde voor een grote weerstand bij bestuurders en hoogleraren, zozeer zelfs dat rectoren als Cohen en Beenakker hun bestuurlijk engagement in belangrijke mate zochten in het verkleinen van de door de wub toegebrachte schade. Gecombineerd met de externe democratisering - 'eenieder die daarom vraagt en daarvoor geschikt is, moet 
in beginsel worden toegelaten' - schiep de wet tweeërlei spanning: tussen democratie en bestuurskracht en tussen volumevergroting en financiering.

De combinatie van explosief stijgende studentenaantallen bij de universiteiten en de noodzaak tot bezuinigen bij de overheid leidde tot twee ingrijpende voorstellen: verkorting en fasering van de studieduur én taakverdeling en concentratie van de disciplines. De vraag was wie daarbij het initiatief moest nemen. Wat de Tvc-operatie betreft werden twee alternatieven geopperd: een gremium van landelijke vertrouwensmannen van de faculteiten of profilering рег universiteit. De eerste oplossing zou eigenlijk de universiteiten opheffen, de tweede hun autonomie en identiteit benadrukken. De definitie van een eigen profiel, het wegnemen van zwakke punten en het aanscherpen van sterke, niet via overleg maar via concurrentie, naar Amerikaans model, werd de uitkomst.

De verkorting en fasering van de studie zou uitlopen op een studieduur van maximaal vier jaar en een studieopzet in twee fasen, opnieuw aan het Amerikaanse voorbeeld ontleend. Deze keuze voor een eerste studiefase van vier јаar en een tweede in de vorm van aio's (assistenten in opleiding), sleepte andere, eveneens oorspronkelijk Amerikaanse ontwikkelingen met zich mee, bijvoorbeeld de modulaire organisatie van de individuele studieopzet, de invoering van een credit system en de wederzijdse inwisselbaarheid van credits bij andere opleidingen van hoger onderwijs.

De jaren negentig brachten het besef dat de universiteiten door een grotere autonomie veel beter in staat zouden zijn te reageren op de omgeving (maatschappij, markt), zowel in onderwijs als in onderzoek. De Wet modernisering universitaire bestuursorganisatie (MUB, 1997) voorzag de universiteiten van een raad van toezicht en gaf de colleges van bestuur verregaande bevoegdheden. Op facultair niveau gold dit voor de decaan, terwijl op het laagste bestuursniveau een opleidingsdirecteur aangesteld kon worden. Veel meer dan voorheen kregen de universiteiten zeggenschap over de inrichting van hun onderwijsaanbod. De kwaliteitsbewaking van het onderwijs werd gelegd bij de faculteiten en landelijke evaluaties georganiseerd door de brancheorganisatie Vereniging van Samenwerkende Nederlandse Universiteiten, die van het onderzoek werd geregeld via regelmatige visitatie. 


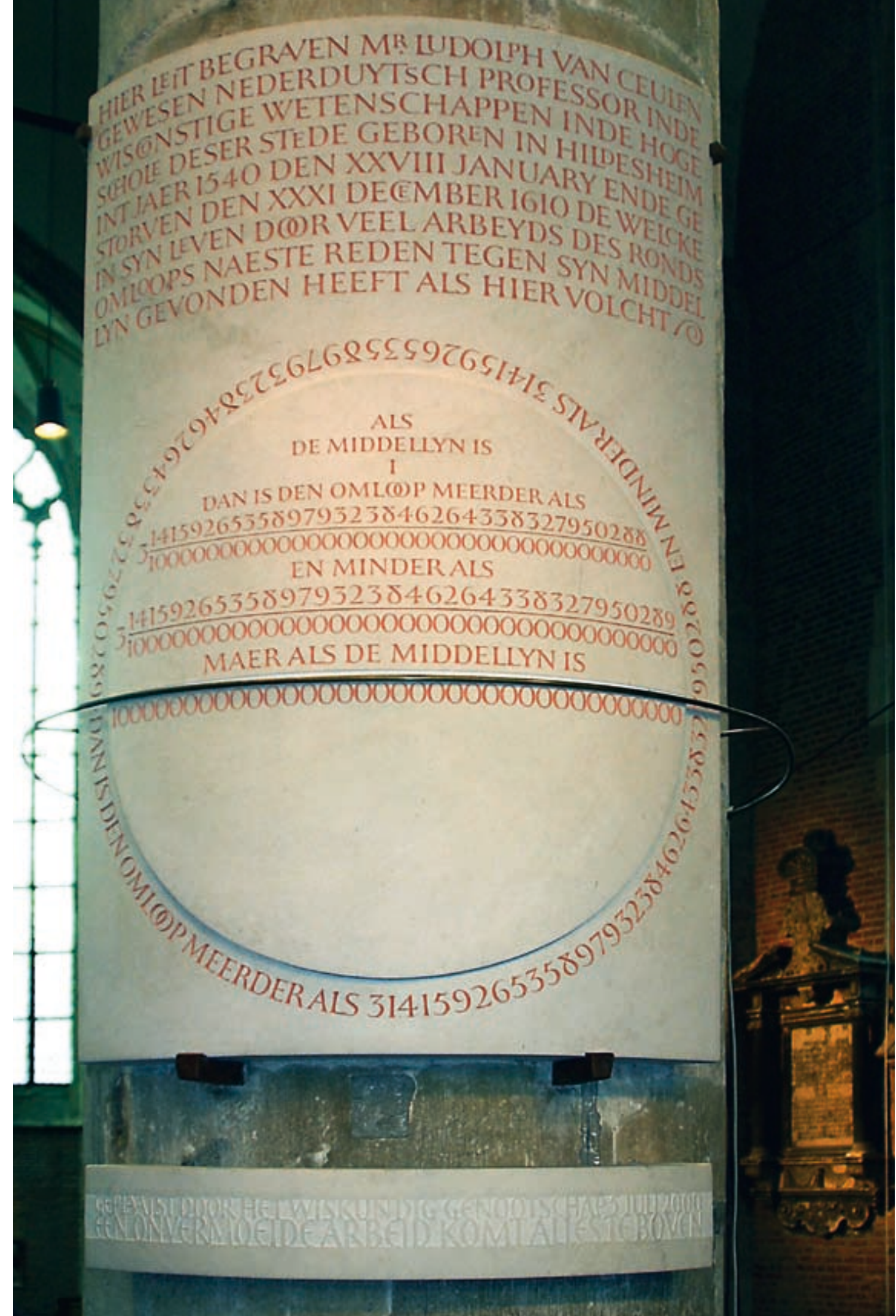

$\triangle$ Rouwmonument van Ludolf van Ceulen, lector toegepaste wiskunde en schermmeester 
De bijpassende bekostiging werd van een declaratiemodel omgebogen in een mix van input- en outputnormen. Uit een gefixeerd budget werd het onderwijsdeel van de middelen over de universiteiten verdeeld op basis van ingeschreven studenten en afgegeven einddiploma's. De universiteiten behielden de eigen collegegelden. De hoogte van die gelden was vastgesteld, maar de discussie over het vrijgeven ervan was in volle gang. Het onderzoeksdeel kende vier componenten: basisvoorziening, promoties, onderzoeksscholen en strategische overwegingen.

De klemtoon op het vergroten van de studenteninstroom werd in de jaren negentig verlegd naar kwaliteit. Financiële beheersbaarheid leidde tot beperking van de toegankelijkheid, via de studiefinanciering werd invloed uitgeoefend op het studietempo (termen als 'tempobeurs' en 'prestatiebeurs' deden opgeld), waarbij de universiteiten de mogelijkheid kregen om aan het einde van het eerste jaar een bindend studieadvies te geven.

Van groot belang ten slotte is het feit dat sinds de jaren tachtig beleid ontwikkeld werd ten aanzien van universitair onderzoek. De Beleidsnota universitair onderzoek (BUOZ, 1979) maakte een begin met plannen voor onderzoeksprogrammering, zwaartepuntvorming en dergelijke. Het wetenschappelijke verslag (1979) en de voorwaardelijke financiering van onderzoek (1982) deden hun intrede. Daarnaast werd halverwege de jaren negentig de gedachte uitgewerkt dat het universitaire onderzoek een sterkere dynamiek behoefde ter verwerving van een groter maatschappelijk draagvlak. Als middel daartoe versterkte de overheid de tweede geldstroom via de Nederlandse Organisatie voor Wetenschappelijk Onderzoek (Nwo).

\section{Bestuur}

Het belangrijkste beleid, aan een universiteit en elders, is het personeelsbeleid. Dat geldt zeker voor het voornaamste personeelslid, de voorzitter van het college van bestuur. Tussen 1972 en 2006 kende de Leidse universiteit vijf collegevoorzitters, allen goede bestuurders, maar zeer verschillende persoonlijkheden. En zoals een renaissancevorst gevormd wordt door zijn vir-

- Muurgedicht van ChristophPlantijn 



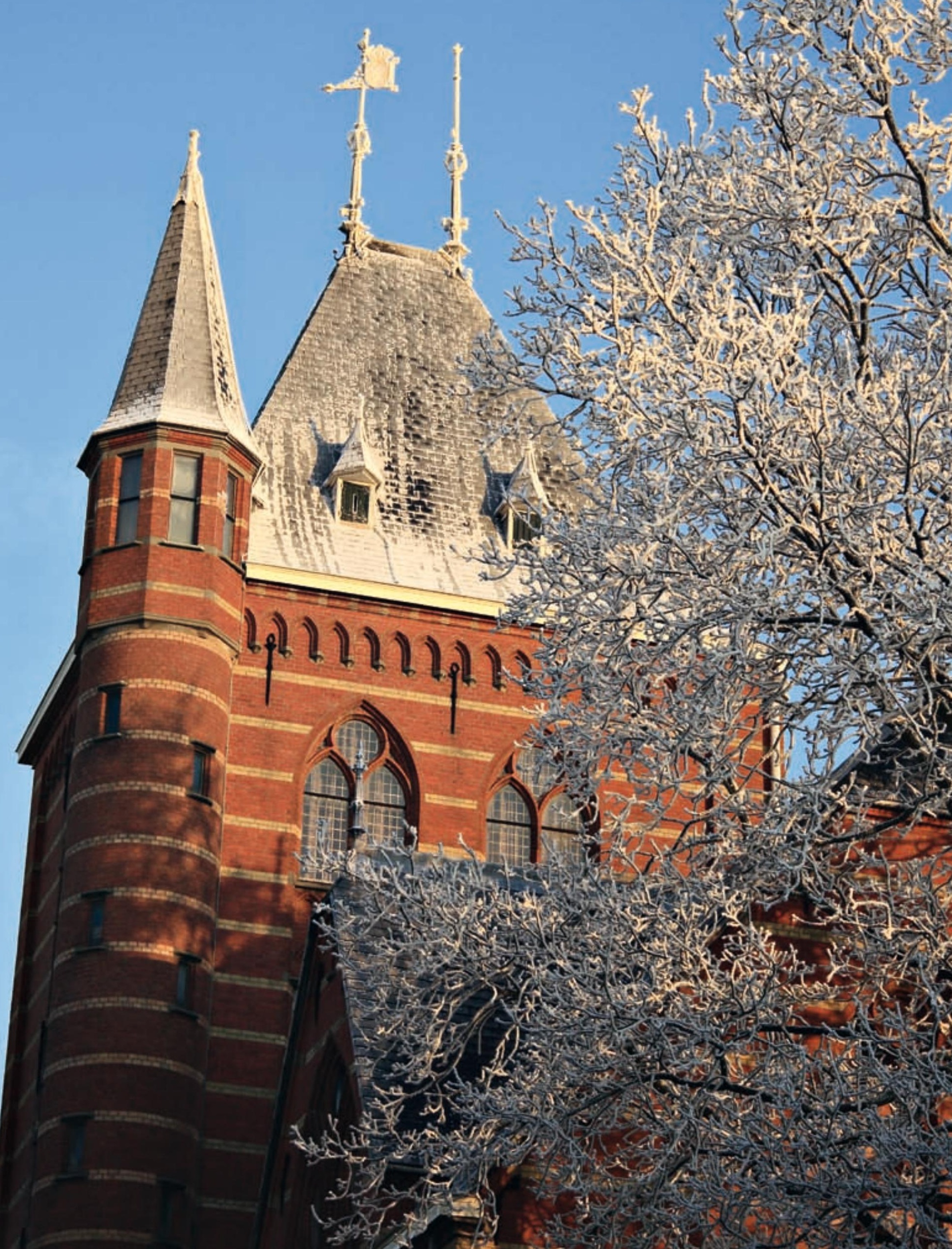


tus, bepaalt de persoonlijkheid van een collegevoorzitter het verschil tussen slagen of falen, leiderschap of lot. Terugkijkend blijkt de liberale Leidse universiteit een leninistisch parcours afgelegd te hebben: twee stappen vooruit, één terug.

De eerste voorzitter, K.J. Cath (1972-1988), was meteen de langstzittende. Hij slaagde erin de gepolariseerde verhoudingen waaronder het eerste onder de wub opererende bestuur moest werken tot een handzaam ‘harmoniemo-

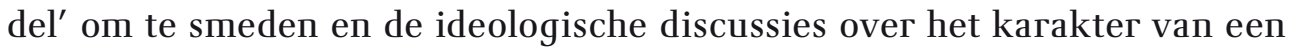
universiteit nаar pragmatisch terrein te verplaatsen. Cath was een jurist met een brede achtergrond. Hij was zeer actief in het studentenleven tijdens en na de oorlog. Na zijn studie werkte hij een aantal jaren in het bedrijfsleven. Deze ervaringen, samen met zijn Friese aard en zijn aanstekelijke gevoel voor humor, stelden hem in staat de overgang van aristocratisch bestuur naar modern management geleidelijk te doen verlopen.

Het grote probleem was het scheppen van een werkbare relatie tussen universiteitsraad en college van bestuur en tussen deze beide (het universiteitsbestuur) en de faculteiten. Het probleem van de eerste relatie lag in beider verschillende competenties. De raad ging over de algemene lijnen, het college over het daadwerkelijke bestuur (voorbereiding en uitvoering). Competentiegeschillen werden vermeden door de raad ook te betrekken bij de beleidsvoorbereiding en -uitvoering en door de voorzitters van de verschillende raadscommissies deel te laten nemen aan de vergaderingen van het college. De relatie tussen het universiteitsbestuur en de faculteiten stond onder druk door de weigering van de overheid de sterk groeiende vraag naar onderwijs adequaat te compenseren in het aantal docenten. De druk die daardoor op duur onderwijs en onderzoek kwam te liggen, vertaalde zich snel in onderlinge naijver. Door een systeem van meerjarenafspraken op basis van een beredeneerde capaciteit per studierichting werden ook hier ideologische discussies vermeden. Die capaciteit gold zowel onderwijs als onderzoek. Elke faculteit kon zo via een bepaalde profilering een beredeneerd en onderhandelbaar takenpakket krijgen waarvoor zij gedurende een bepaalde periode financiële bescherming kreeg.

Gevolg hiervan was wel dat college en faculteitsbesturen hun bestuurlijk

4 Voormalig farmaceutisch laboratorium, nu Horizon House van de Stichting Leidse Studentenhuisvesting 
handelen sterk op elkaar afstemden. Zelfs kwamen zij tot een vergaande integratie van bevoegdheden. En dat had weer tot gevolg dat de universiteitsraad de greep op het beleid verloor en terugviel in de oude geneigdheid tot ideologische discussie. Intussen waren de tijden wel veranderd. Zo deed Cath het voorstel om de raad slechts adviserende bevoegdheden te geven. Het kwam hem te staan op een anti-Cath motie en een lange vergaderavond. Maar de motie werd verworpen en zijn gelijk werd vastgelegd in latere wetgeving.

Ook in andere zaken zou Cath gelijk krijgen. Twee van de meest in het oog lopende daarvan zijn de meer bedrijfsmatige sturing van de universiteit met op termijn een presidentieel systeem én het kwaliteitscriterium als het enig zinnige bij de bepaling van het profiel van de Leidse universiteit. Het aardige van beide zaken is dat ze een veel grotere distantie tot de overheid en een grotere autonomie vooronderstelden - zaken waar de universiteit rond de eeuwwende 1900 nog niet aan toe was en die ze nu opgedrongen kreeg.

Cath werd opgevolgd door Oomen. Het schandaal dat tot diens vertrek leidde, had grote repercussies. Voortaan zou, niet alleen te Leiden, met grotere professionaliteit naar het eigen vastgoed gekeken worden. Er is een voor de hand liggend verband tussen dit in de pers breed uitgemeten schandaal en het besluit van de minister om bij de invoering van de мuв bij elke universiteit of hogeschool een raad van toezicht in te stellen. Met Hazelhoff van de Nederlandse Bank en Tabaksblat van Unilever kreeg de Leidse universiteit twee coryfeeën uit het bedrijfsleven. Ook decanen wonnen aan invloed. In veel gevallen, vooral bij de grote faculteiten, werden beroepsbestuurders aangezocht.

De nieuwe voorzitter die dit allemaal in goede banen mocht leiden, aanvankelijk aangezocht als interim om de crisissituatie te bezweren, was Vredevoogd, iemand die zijn naam eer aandeed. L.E.H. Vredevoogd was weliswaar geen Leidenaar - hij studeerde aan de Vrije Universiteit Amsterdam en was na een ambtelijke carrière bij het ministerie van Onderwijs benoemd tot collegevoorzitter van de Open Universiteit - maar hij voelde de sfeer te Leiden goed aan. En hij smeedde het ijzer toen het heet was. Dat ijzer bleek vervolgens - Vredevoogd had iets van koning Midas zonder de nare bijverschijnselen - goud te zijn. 

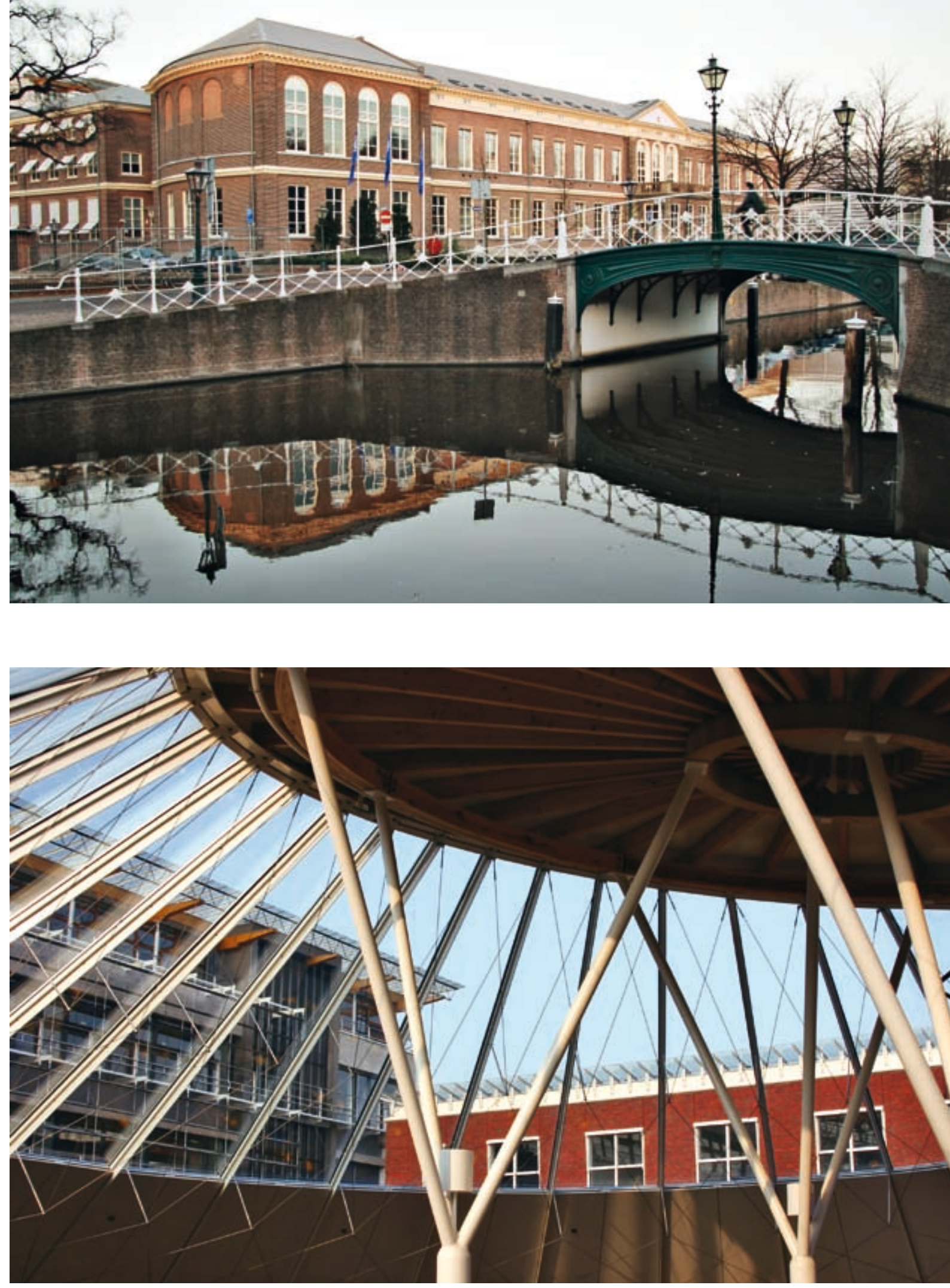

\ Voormalig Kamerling Onnes-laboratorium, nujuridisch studiecentrum

$\checkmark$ Bibliotheekvan het juridisch studiecentrum 
combineerden met intens engagement. Na het eerste langjarige rectoraat van Cohen (1972-1976), a wise man if ever there was one, kreeg de universiteit met de milieubioloog Kuenen iemand die met groot gevoel voor humor en understatement de universiteit door de woelige gebeurtenissen van het einde van de jaren zeventig loodste (1976-1979). De klinisch scheikundige Kassenaar (1979-1985) was van totaal andere karakteropmaak. Hij орегеerde weliswaar graag in de overtreffende trap onder aanroeping van de heilige Drievuldigheid, maar was uitzonderlijk effectief in wat men later met een lelijk woord valorisatie van het onderzoek of kennistransfer is gaan noemen: de contacten methet bedrijfsleven.

Kassenaars rectoraat markeert ook het begin van de gedachtevorming bij rectoren over een welomschreven onderwijsbeleid. Het was hem vooral te doen om de samenhang van onderwijs en onderzoek en het verschijnsel onderzoeksinstituut. Dat gold ook voor zijn opvolger, de experimenteel natuurkundige Beenakker (1985-1991). Deze onderzoeker in hart en nieren - kenmerkend was zijn verzuchting jaloers te zijn als hij zijn zoon en collega over hun onderzoek hoorde praten - zag zijn bestuurstaak niet als een visionaire opdracht. 'Je kunt de rivier slechts overzien tot de volgende bocht,' was zijn adagium.

Zijn opvolger, de theoloog Leertouwer (1991-1997), was uit heel ander hout gesneden. Hij was wat minder een onderzoeker, veeleer een erudiet, en iemand die het gesproken woord op een effectieve manier combineerde met zijn gebroken stem. Leertouwer was ook een echte bestuurder met grote ervaring in uiteenlopende gremia, van de media tot en met de vakbonden. Hij zou zich met hart en ziel inzetten voor de 'kleine letteren' en de leгагеnopleiding en voor de mogelijkheid van studenten om bestuurlijke functies uit te oefenen via 'bestuursbeurzen'. Op termijn ontwikkelde hij zich tot een echte onderwijsrector, iemand die het idee van intakegesprekken met aankomende studenten lanceerde en de implicaties voor het onderwijs van Koersen op Kwaliteit - het bindende studieadvies maar vooral de intensievere begeleiding - omarmde.

Zijn opvolger, de psycholoog Wagenaar (1997-2001), evenals Leertouwer een muzisch mens, met een voorliefde voor huistheater en pop-up books, ope- 
reerde eveneens bij voorkeur op het raakvlak van onderwijs en onderzoek. Ontwikkelde hij bij sociale wetenschappen een systeem voor ijking en vergelijking van onderzoek, als rector zette hij zich in voor eenzelfde controle op onderwijskwaliteiten. In tegenstelling tot de wat in het pak hangende boerenzoon Leertouwer was Wagenaar met vlinderdas en zorgvuldig getrimde snor evenzeer een 'onderwijsrector' die met zijn 'proefballonnetjes' - betere beloning van goede docenten, verplichte stage als onderdeel van het doctoraal, studiepunten voor sport - de lucht boven Leiden opvrolijkte. Zijn inzet vоor het bindende studieadvies bleek essentieel voor het postvatten van dit idee.

En toen keerde Leiden weer terug naar een boerenzoon, een Friese ditmaal ('Ik ben Douwe Durk'), de farmacoloog Вreimer (2001-2007). Als een van de meest gelauwerde wetenschappers van de universiteit wist hij in een combinatie van autoriteit en innemendheid op vrijwel alle terreinen van het universitaire bestuur zijn stempel te drukken. Ingrijpende reorganisaties bij de faculteiten, zware dossiers als de invoering van het bachelor-mastersysteem, studentenhuisvesting en -voorzieningen, intensievere relaties met het bedrijfsleven, internationale plaatsbepaling via de League of European Research Universities, het was alleen mogelijk door het enorme krediet dat Breimer binnen de universiteit genoot. Hij was dan ook de ideale figuur om het presidentiële model, de combinatie van rectoraat en collegevoorzitter, geëntameerd na de teleurstellende ervaring met Kist, te beginnen. Zijn afscheid als rector en voorzitter en emeritering in 2007 had iets van een kleine deïficatie.

\section{Profiel}

De profieldiscussie was, zoveel kan alleen al uit de wetgeving inzake het hoger onderwijs afgeleid worden, een van buiten opgelegd verschijnsel. Het was vooral de taakverdelingsoperatie die de universiteiten noopte zich af te vragen waаrop ze zich moesten concentreren. Aanvankelijk betrof dit vooral het onderwijs en werd de oplossing gezocht in maatschappelijke relevantie en in- 
terdisciplinaire onderwijsprogramma's. De invoering van de voorwaardelijke financiering leidde vervolgens tot intense discussie over de herverdeling van beschikbare onderzoeksgelden.

De financiering bleef een cruciaal gegeven. Juist op het moment dat Leiden in haar Ontwikkelingsplan 1987-1991 koos voor een 'missie' gericht op excellentie, zag ze zich geconfronteerd met teruglopende studentenaantallen en bijgevolg slinkende middelen. Toch zou de Leidse profieldiscussie bij voortduring cirkelen rond de combinatie van minder volume en meer kwaliteit, en de specifieke verhouding tussen onderwijs en onderzoek. Aanvankelijk wist de universiteit weinig anders te doen dan te laveren: nu eens werd de klemtoon gelegd op het onderzoek ten koste van het onderwijs. Dan weer noopten de financiële verwachtingen tot een drastische herformulering van het belang en de noodzaak van het onderwijs.

Hoewel deze discussie niet zonder belang was en ze de contouren aangaf waarbinnen de latere beeldvorming plaatsvond, markeert het eerste strategische plan van het college onder leiding van Vredevoogd, Koersen op Kwaliteit uit 1994, de werkelijke omslag. Die nota was tevens het begin van een zeer ingrijpend proces van besluitvorming dat de universiteit niet alleen richting gaf, maar ook een reeks van uitgangspunten die wonderwel in het verlengde van een geleefd verleden lagen. De hoofdlijnen ervan waren de overtuiging dat een aantal gelijkheidsficties van de jaren zeventig losgelaten moest worden om een nieuw klimaat van verandering en flexibiliteit te scheppen. Wie kwaliteit wilde, wilde differentiatie en selectie, zowel in onderwijs als in onderzoek, zowel in personeelsbeleid als in financieel beheer.

Misschien wel het belangrijkste kenmerk van dit plan was niet zozeer de klemtoon op kwaliteit als wel dat de voornaamste uitwerking gezocht werd op het terrein van het onderwijs. Het feit dat Leiden een zorgelijk deel van de onderwijsmarkt was kwijtgeraakt en dat aandacht voor het onderwijs alleen al uit financieel oogpunt noodzakelijk was, zal zeker een rol hierbij gespeeld hebben. Маar de klemtoon heeft eг ook toe bijgedragen dat het plan op brede steun in de universiteit kon rekenen.

Uitgaande van de academische signatuur van het onderwijs, dat wil zeggen: de intense verwevenheid van onderwijs met onderzoek, werd een aantal

- Voormalige polikliniek voor interne geneeskunde, nu Pieter de la Court-gebouw voor de Faculteit der Sociale Wetenschappen

• Trappenhuis van hetPieter de la Court-gebouw 


\section{( $17>1)$}

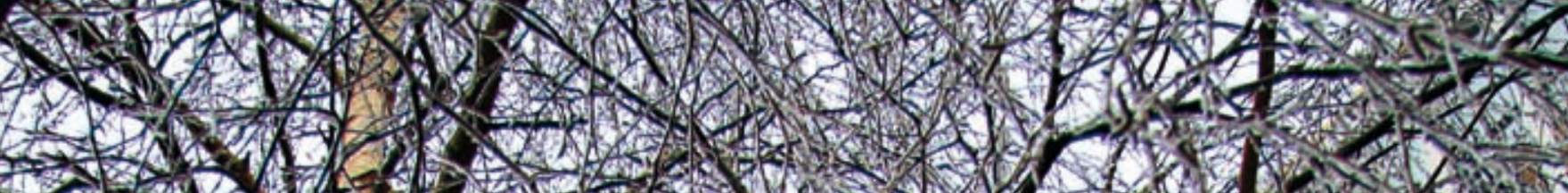

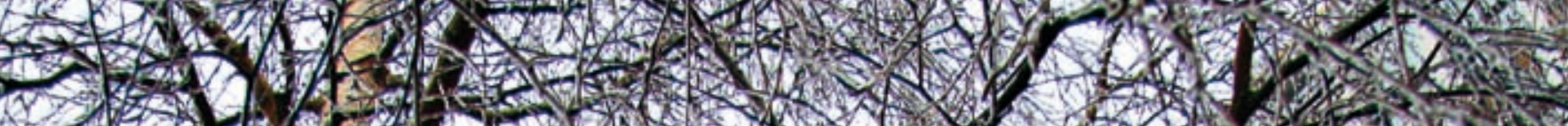

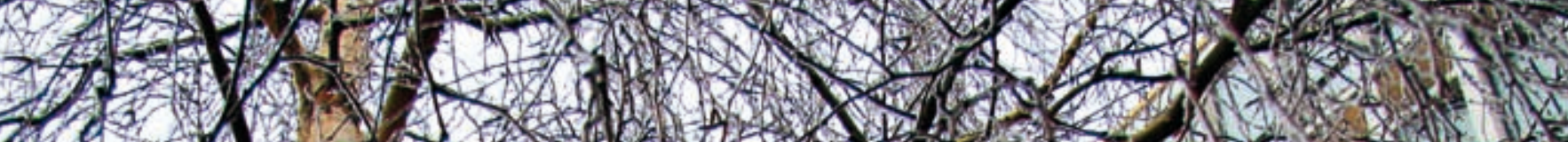
$1(2,1,1)$

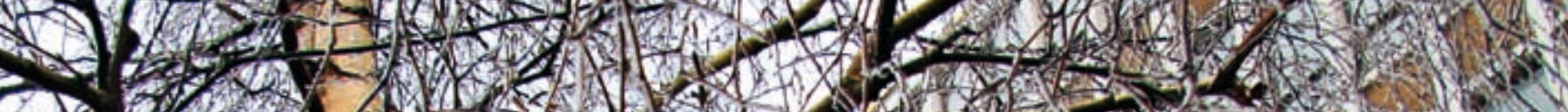
1.2

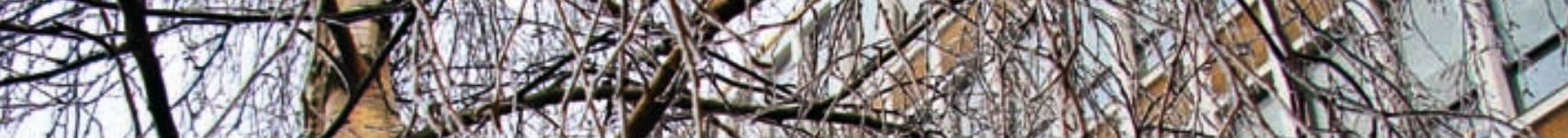
) 1.2

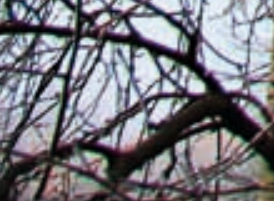

\section{(1) 212 ग}

- 4.1010

1

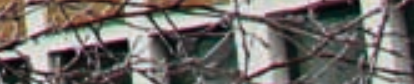

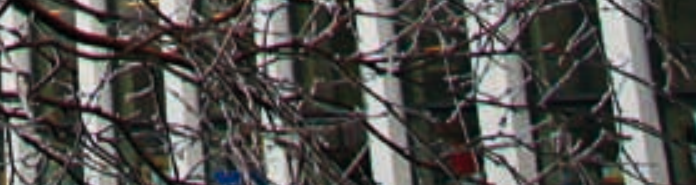

IT $-1-1=$ 


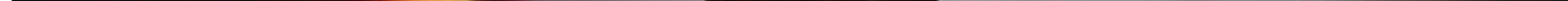


belangrijke voorstellen gedaan om de onderwijskwaliteit te verbeteren: een selectieve propedeuse (bindend studieadvies), intensivering van de contacten tussen staf en studenten, disciplinaire opbouw van het curriculum en selectie van het wetenschappelijk personeel ook op didactische kwaliteiten. De breedheid van de opleiding moest gegarandeerd worden door de invoering van een algemeen vormend interfacultair curriculumonderdeel dan wel een anders opgezet studium generale, maar ook via de versterking van de rol van de studie- en studentenverenigingen. Het onderwijs in de doctoraalfase diende vooral afgestemd te zijn op het identificeren van excellente studenten en het scheppen van faciliteiten als hoogwaardige tutorials, masterclasses en programma's ter uitwisseling van studenten met buitenlandse universiteiten.

Wat het onderzoek betreft werd vooral de nadruk gelegd op het formuleren van profiel bepalende onderzoeksprogramma's op facultair en interfacultair niveau, op het beperken van het aantal zwaartepunten en het invoeren van een interne kwaliteitscontrole. Ook beoogde men een flexibeler personeels- en beloningsbeleid, een bredere formulering van de leeropdrachten, deeltijdaanstellingen, verjonging van het personeel en het aantrekken van talent via aioplaatsen en postdocaanstellingen.

In de daaropvolgende plannen Wegen naar gehalte (1999/200o) en Kiezen voor Talent (2005) werd dit profiel verder uitgewerkt en bijgesteld. In de eerste nota lag de klemtoon vooral op wat men 'de Leidse leeromgeving' noemde en verder op kwaliteitsbewaking, internationalisering en ICT. De noodzaak van de invoering van het bamasysteem (bachelor-master), maar ook de kansen die dit bood bij de uitwerking daarvan, bepaalden in hoge mate de plannen in Wegen naar gehalte. Voor het onderwijs bleef koppeling ervan met onderzoek en een vakinhoudelijk traject kenmerkend. Maar naast de maximalisering van de academische vaardigheden werd ook de voorbereiding op een professionele carrière beklemtoond en werden de faculteiten uitgedaagd daartoe nieuwe opleidingen in het leven te roepen. Voorbeelden daarvan zijn Onderneming, Recht en Management en Letteren in praktijk.

De creativiteit in deze periode mag blijken uit de schepping van wat de 'Haagse vestiging' ging heten en het in het leven roepen van een heuse faculteit der kunsten. In 1999 werd, in samenwerking met de Technische Universi- 



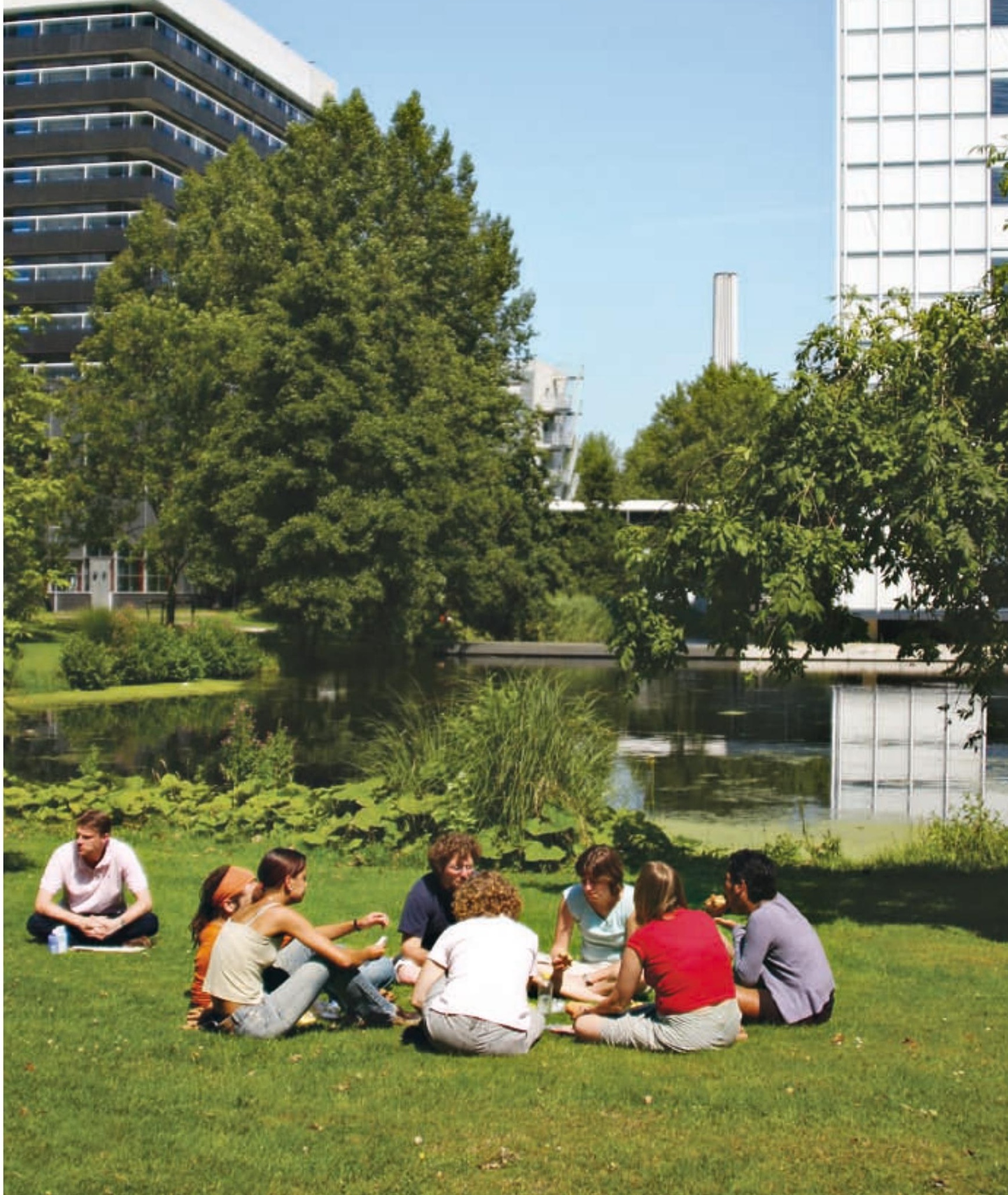


werd het onderwijs niet buiten beeld gehouden. Vernieuwingen als de instelling van het Pre-University College voor getalenteerde vwo-leerlingen, vегbreding van de bachelorfase via major-minortrajecten en verbetering van de faciliteiten voor studenten werden geëntameerd. Maar de grote klemtoon lag op de lay-out van graduate schools en op internationale werving voor de postgraduate fase. Leiden werd wat ze was: een researchuniversiteit.

\section{Infrastructuur}

De middelpuntvliedende krachten waaraan een moderne universiteit blootstaat, zijn goed af te lezen aan de plek die ze in de stedelijke ruimte inneemt. Dat zijn namelijk verschillende, en soms ver van elkaar verwijderde plekken. In Leiden zijn dit er drie. In de eerste plaats is en blijft dat het Rapenburg, uitgangspunt en punt van terugkeer. Нier was het waar vanaf het allereerste begin academiegebouw en hortus, bibliotheek en anatomisch theater zich bevonden; hier woonden de professoren, hier was het rijk van Pallas, zoals het in de zeventiende eeuw heette. Ook nadat het Latijn zijn gezag verloren had, bleef dit het quartier latin van Leiden, tot ver in de negentiende eeuw. Pas met de bouw van verschillende ziekenhuizen en de laboratoria in Vreewijk verlegde de universiteit haar actieradius naar buiten.

Na de Tweede Wereldoorlog kwamen de bouwactiviteiten pas langzaam weer op gang. Begin jaren vijftig werd het Kamerlingh Onnes Laboratorium uitgebreid met een nieuwe vleugel en werd het Gravensteen ingericht als juridisch studiecentrum. Van eind jaren vijftig, begin jaren zestig dateren de biologische laboratoria aan de Kaiserstraat en de nieuwe kliniek voor interne geneeskunde.

Na de oorlog kreeg de universiteit er twee locaties bij voor haar onderwijsen onderzoeksactiviteiten, aan de Witte Singel en in de Leeuwenhoek. In de Leeuwenhoek kwamen, in het verlengde van het academisch ziekenhuis, de laboratoria en het gebouw van de sociale wetenschappen (de voormalige polikliniek voor interne geneeskunde). Het Witte Singelterrein was bestemd vоor een nieuwe bibliotheek en de humaniora (inclusief theologie). Zo kwa-

\ Huygenslaboratorium(links) en Gorleuslaboratorium (rechts) in de Leeuwenhoek 
men er dwars door de Leidse universiteit spoorrails te liggen. Wie aan de westkant van het Centraal Station uitstapt is bèta of gamma, wie aan de oostzijde uitstapt is alfa.

In 1957 stelden Leiden en Oegstgeest samen een structuurplan vast waarin de universiteit een rechthoekig polderterrein kreeg toegewezen van ongeveer honderd hectare, tussen het Centraal Station en de snelweg A 44. Bedoeld voor de huisvesting van de faculteiten medicijnen en wis- en natuurkunde, werd het gebied vernoemd nаar Antony van Leeuwenhoek. Aanvankelijk was een campus naar Amerikaans model de bedoeling. Het eerste, visionaire plan ging uit van een centraal voorzieningengebouw met een grote collegezaal op een half verhoogd plateau met daaronder een parkeergarage. Het plateau zou via een brede trap op een centrale dreef aansluiten, terwijl een rondlopende gang, ongeveer zes meter boven het maaiveld, toegang zou verlenen tot zes laboratoria in torenvorm.

Het zou er anders uit komen te zien. Volgen we de Wassenaarseweg, dan is het eerste gebouw, nг. 64, het Clusius Laboratorium voor de biochemici. Die verhuisden in de jaren tachtig nаar het Gorlaeus en maakten plaats voor het Instituut voor Moleculaire Plantkunde. Op nг. 72 staat het Sylvius Laboratorium: twee tegen elkaar geplaatste identieke blokken van negen bouwlagen voor medisch-biologisch onderzoek en onderwijs. Weer verderop, met de ingang aan de Einsteinweg, staan de uit de jaren zestig stammende Gorlaeus Labогаtoria, kubusvormige hoogbouw, met daaraan een spectaculair collegezalengebouw in de vorm van een schotel en een groot, bijna transparant, laboratorium voor wat men toen voorkandidaats noemde (het LMUY).

Het tweede hoge torengebouw omvat het Huygens Laboratorium en het Snellius, beide uit de jaren zeventig. Het Snellius huisvest het Centraal Rekeninstituut en de studierichting informatica (LIACs). Veel recenter en daarom modieuzer is het schuine J.H. Oortgebouw en de trillingvrije Kamerlingh Onnes Meethal. Rondom het Gorlaeus-Huygens-Oort complex is na 1982 het Bio-Science Park ontstaan. Ook het in 1970 geopende universitaire sportcentrum bevindt zich daar. Studenten kunnen kiezen uit 35 sporten in en buiten het centrum. Weer terug bij het station ziet men de blauwgele blokken van het nieuwe academisch ziekenhuis, nu Leids Universitair Medisch Centrum 


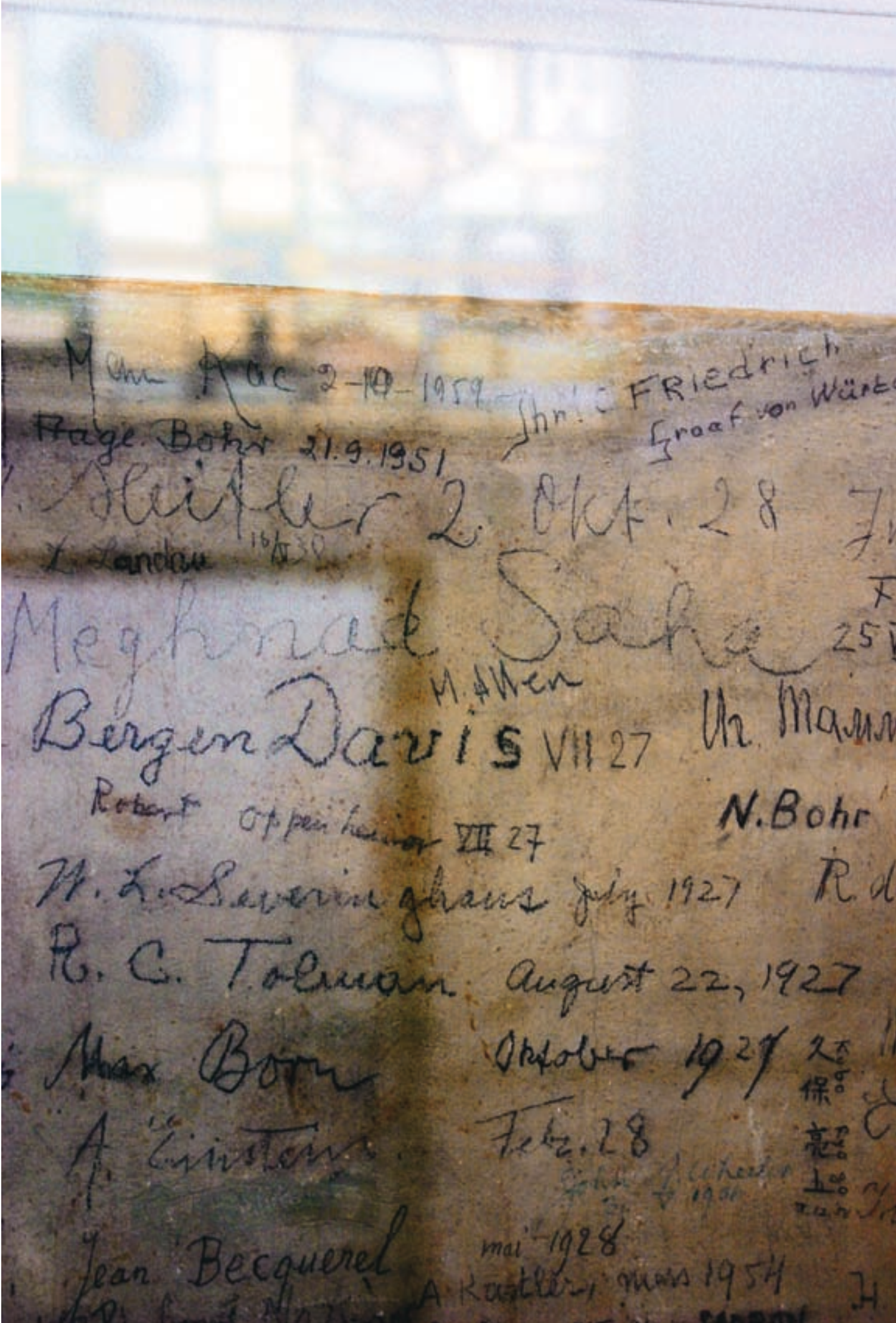

\ Mur met handtekeningen van deelnemers van het Ehrenfest Colloquium, met namen als Bohr, Oppenheimer, Einstein, Becquerel. Voorheen in het Kamerlingh Onnes-laboratorium, nu in hetOortgebouw 


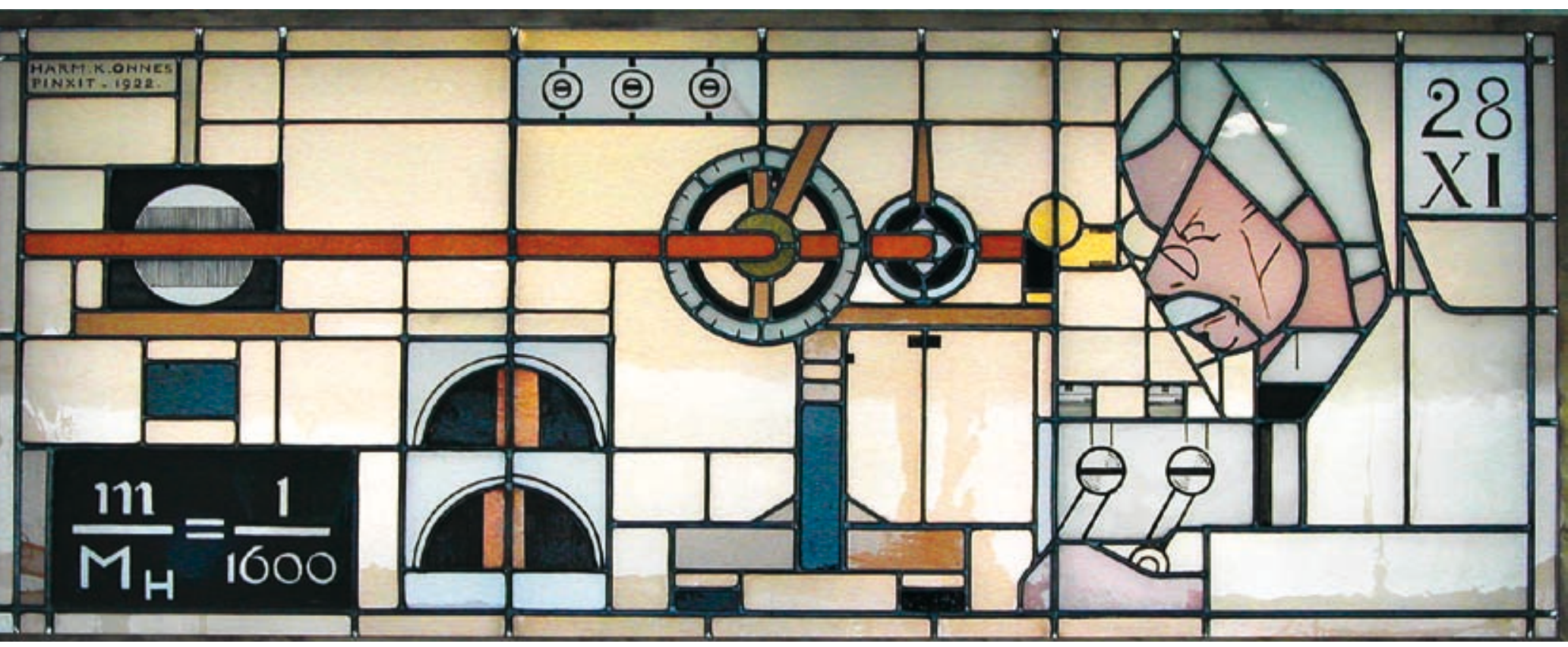

(LUMC) geheten. Het eerste deel werd in 1985 geopend, het tweede in 1996. Nog recenter zijn de imposante onderzoeks- en onderwijsgebouwen, die van respectievelijk 2005 en 2007 dateren.

De barse scheiding van de two cultures met een spoorlijn had nog een graadje grimmiger kunnen zijn als de oorspronkelijke plannen voor de Witte Singel, met daarin een 125 meter hoge toren, waren uitgevoerd. Маar de toren stuitte op veel verzet en toen de koksschool van het ministerie van Defensie op het Doelenterrein werd ontruimd, kwam er voldoende ruimte aan de Witte Singel voor laagbouw. Besloten werd tot de bouw van een aantal clusters, een bibliotheek met flankerende complexen voor de westerse talen, Semitische talen, Turks en Arabisch en overige faculteiten (theologie, wijsbegeerte, archeologie) ten oosten van de Witte Singel, en ten westen daarvan een complex voor de talen van het Vегге Oosten op het Doelenterгein (inclusief de restauratie van de gebouwen naast de Doelenpoort), een centraal faciliteitencomplex in het verlengde daarvan en een cluster klassieke filosofie/ geschiedenis/kunstgeschiedenis. Dit laatste complex valt vooral op door zijn

• Twee van drie glas-in-loodramen van kunstenaar Harm Kamerlingh Onnes met afbeelding van de ontdekking van het Zeemaneffect 


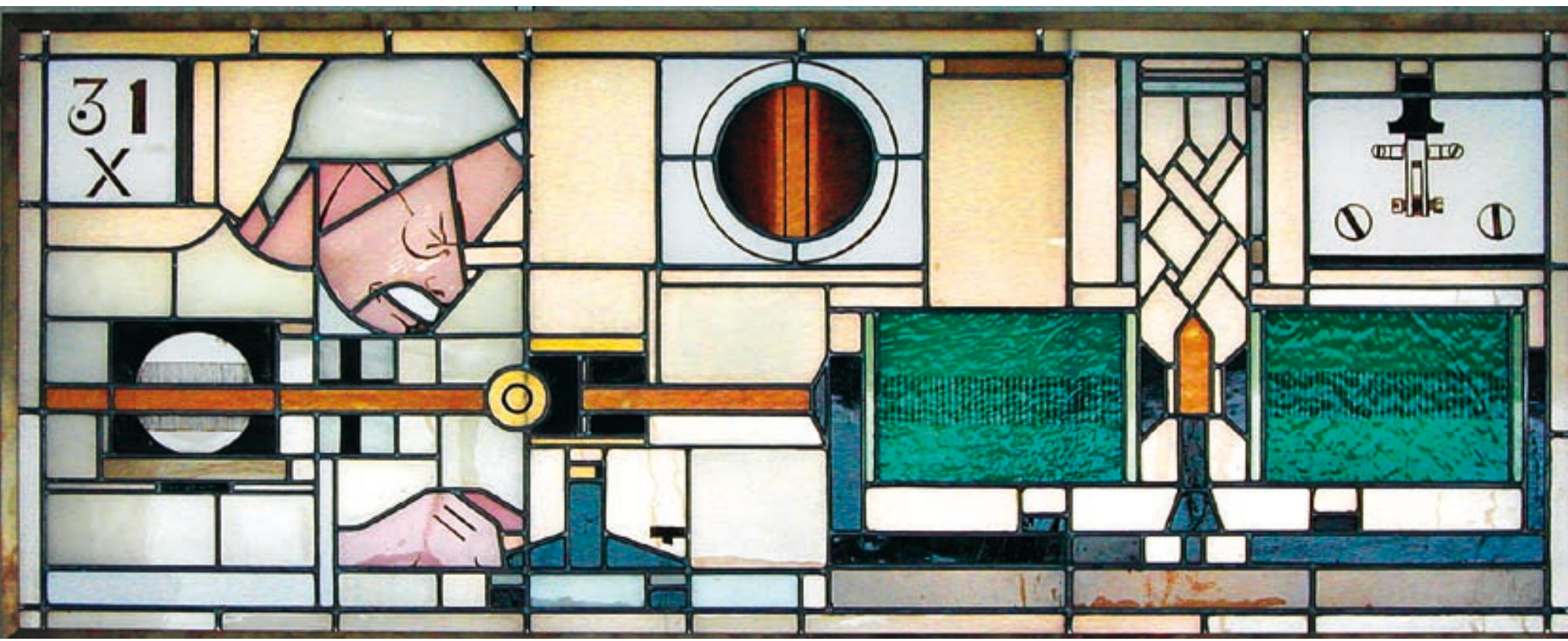

onopvallendheid en past dan ook uitstekend tussen de omgeving van sociale woningbouw. De bibliotheek heeft iets van een voorwereldlijk reptiel geflankeerd dоог еen serail zonder harem en het faciliteitengebouw lijkt een beetje op een graansilo. In 1984 werd de bibliotheek geopend.

Ten slotte was het Rapenburg weer aan de beurt. Na enige jaren gefungeerd te hebben als onderkomen van het herbarium kreeg het voormalige bibliotheekgebouw in 1999 een nieuwe bestemming. Als 'Oude ub' herbergt het nu het bestuursgebouw van de universiteit. College en Bureau van de universiteit hadden vanaf de jaren zestig gebivakkeerd in het lelijkste (en tochtrijkste) gebouw denkbaar, Stationsweg 46, inderdaad op de scheidingslijn van de scientific cultures, maar vooral een utiliteitsblok dat alle verbeelding dempte. Door een combinatie van smaakvolle restauratie en heldere modernisering voegden de oude kapel en de negentiende- en vroeg-twintigsteeeuwse elementen zich tot een eenheid die Bildung en bezonnenheid ademt, pregnant verbeeld in de vroeg-achttiende-eeuwse plafondschildering van de centrale vergaderzaal met de vier seizoenen. 


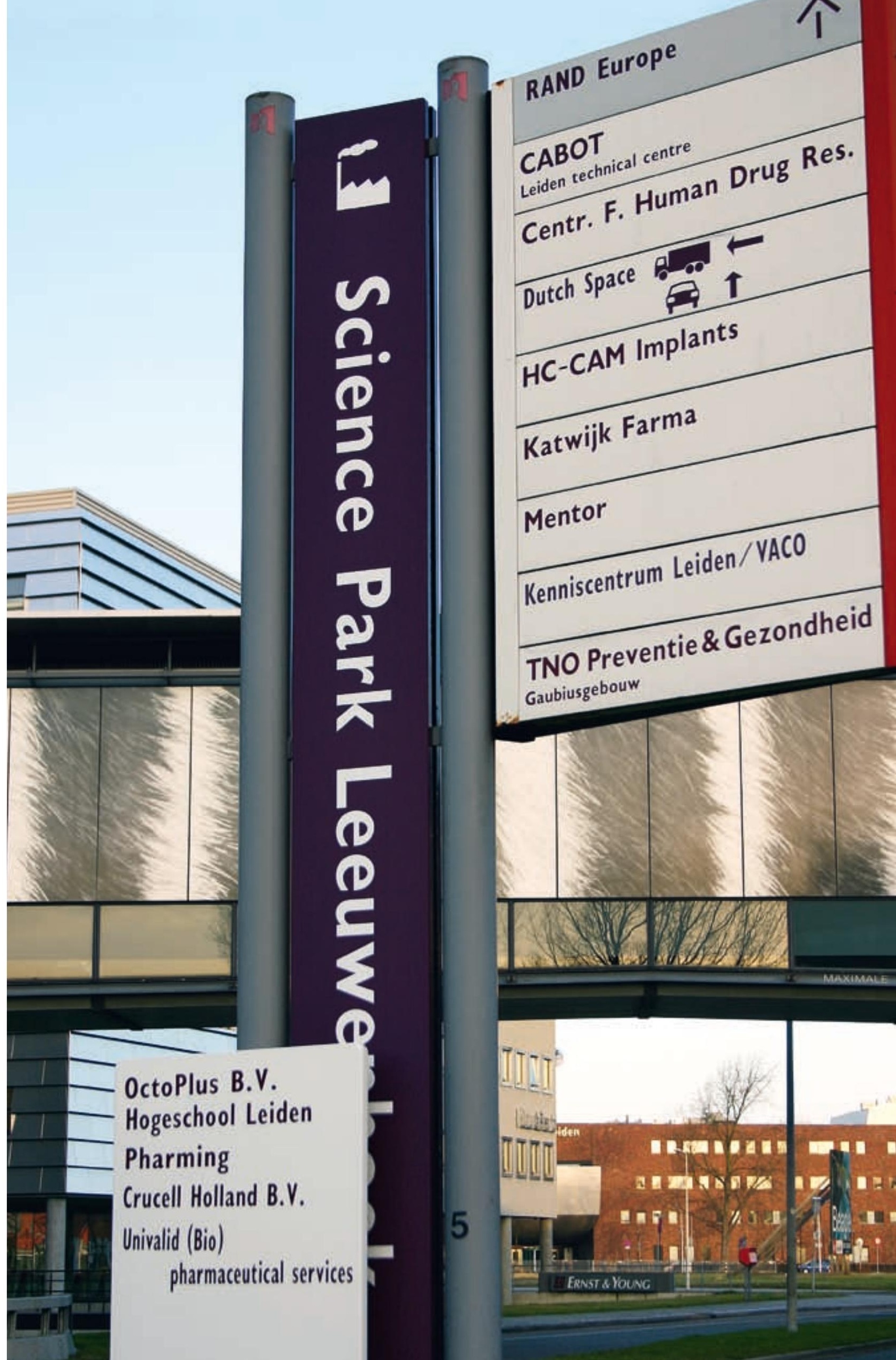


Deze verhuizing was een van de uitingen van de omslag in het denken over de architectonische vertegenwoordiging van de universiteit. In die omslag kreeg het Rapenburg de rol toebedeeld van beeldbepalende locatie van de universiteit. De gedachte om dit tot het hart van de moderne universiteit te maken, werd al 1927 door Van Vollenhoven geformuleerd. Hij zag de aankoop van oude Rapenburgpanden als centrale doelstelling van het Leids Universiteitsfonds (LUF) om zo deze oude gracht met zijn zeventiende- en achttiendeeeuwse panden tot een universitaire campus om te vormen waar hoogburgerlijke wooncultuur en universitaire institutionalisering hand in hand zouden gaan. Een initiatief dat hierop aansluit, was de oprichting in 1997-1998 van de Leidse Faculty Club en de vestiging daarvan in Rapenburg 6, evenals de vestiging van het luf in het oude huis van Snouck Hurgronje, Rapenburg 61. De universiteit bezit nog steeds een zevental panden aan het Rapenburg.

Eveneens in het verlengde van deze politiek is de nieuwe inrichting van de hortus botanicus en de herinrichting van het oude Kamerlingh Onnes Laboratorium als unilocatie voor de rechtenfaculteit. De hortus bevat tegenwoordig diverse tuintypen en sinds 1990 zelfs een Japanse tuin. Het nieuwste gebouw is de wintertuin uit 2000: een groot, transparant geheel met een subtropische kas en een bezoekerscentrum. Plannen zijn in ontwikkeling om van hortus en sterrenwacht één geheel te maken en de sterrenwacht te verbouwen tot studiecentrum, gastenverblijf en sterrenkundig bezoekerscentrum. Van 2004 stamt de renovatie van wat ooit het Staten College vormde en wat later manege en nog later studentenmensa was (De Bak), nu omgevormd tot een modern studentencentrum, Plexus, onderkomen van ruim tien studentenorganisaties en een aantal studentenvoorzieningen. In 2004 werd ook het oude Kamerlingh Onnes Laboratorium, na een elegante restyling, in gebruik genomen door de rechtenfaculteit, nu als Kamerlingh Onnes Gebouw.

\section{De faculteiten}

Hoe verschillend de faculteiten ook waren, in omvang en opbouw, in doelstelling en sex-appeal, allemaal gingen ze onder het juk van de tijd door. Ze groei-

4 Bio-science parkLeeuwenhoek 
den en differentieerden op het fortuin van de economie, om daarna door de tuchtiging van de markt weer te krimpen en te concentreren. Terwijl de faculteiten de natuurwet van de fragmentatie volgden, liet het college van bestuur zich leiden door het menselijk verlangen van de eenheid. Het grote debat binnen de faculteiten was zo oud als de Nederlandse staat: was de faculteit een los verband van disciplines of een disciplinaire eenheid, was zij een statenbond of een bondsstaat?

\section{Medicijnen}

De medische faculteit is, inclusief het academisch ziekenhuis, niet alleen de grootste faculteit, zowel in personeel als budget, maar kent tevens de meest uitgebreide taakstelling: naast onderzoek en onderwijs ook patiëntenzorg. Hoewel die zorg een afgeleide is van de andere taken, maakt ze dat de praktijk bij medicijnen een grotere rol speelt dan elders. Dit zou uiteindelijk resulteren in een tweedeling tussen de strikt natuurwetenschappelijke basis van de geneeskunde en de op interventie gerichte vakken, tussen de zogenaamde preklinische en de klinische vakken. In Leiden kreeg deze tweedeling zelfs fysiek vorm: de ingang van het academisch ziekenhuis bevond zich aan de Rijnsburgerweg, die van de preklinische laboratoria aan de Wassenaarseweg.

In het begin van de jaren tachtig werd de tendens tot overbrugging van de scheidslijn tussen kliniek en prekliniek steeds duidelijker. Technieken die oorspronkelijk in het fundamentele onderzoek ontwikkeld waren, vonden toepassing in de kliniek; onderzoekers zochten contact met clinici in het besef dat hun onderzoek zijn bestaansrecht ontleende aan de toekomstige klinische relevantie. Een aantal vakken ging zich als brugvakken profileren. Pathologie, bacteriologie, virologie en parasitologie werden 'paraklinisch' genoemd: ze waren niet direct op patiëntenzorg betrokken, maar ze droegen ег wel aan bij. De patholoog schoof als het ware dichter naar het ziekbed toe. Eenzelfde ontwikkeling was te zien bij farmacologie en genetica.

In de tweede helft van de twintigste eeuw ontwikkelde de faculteit zich 

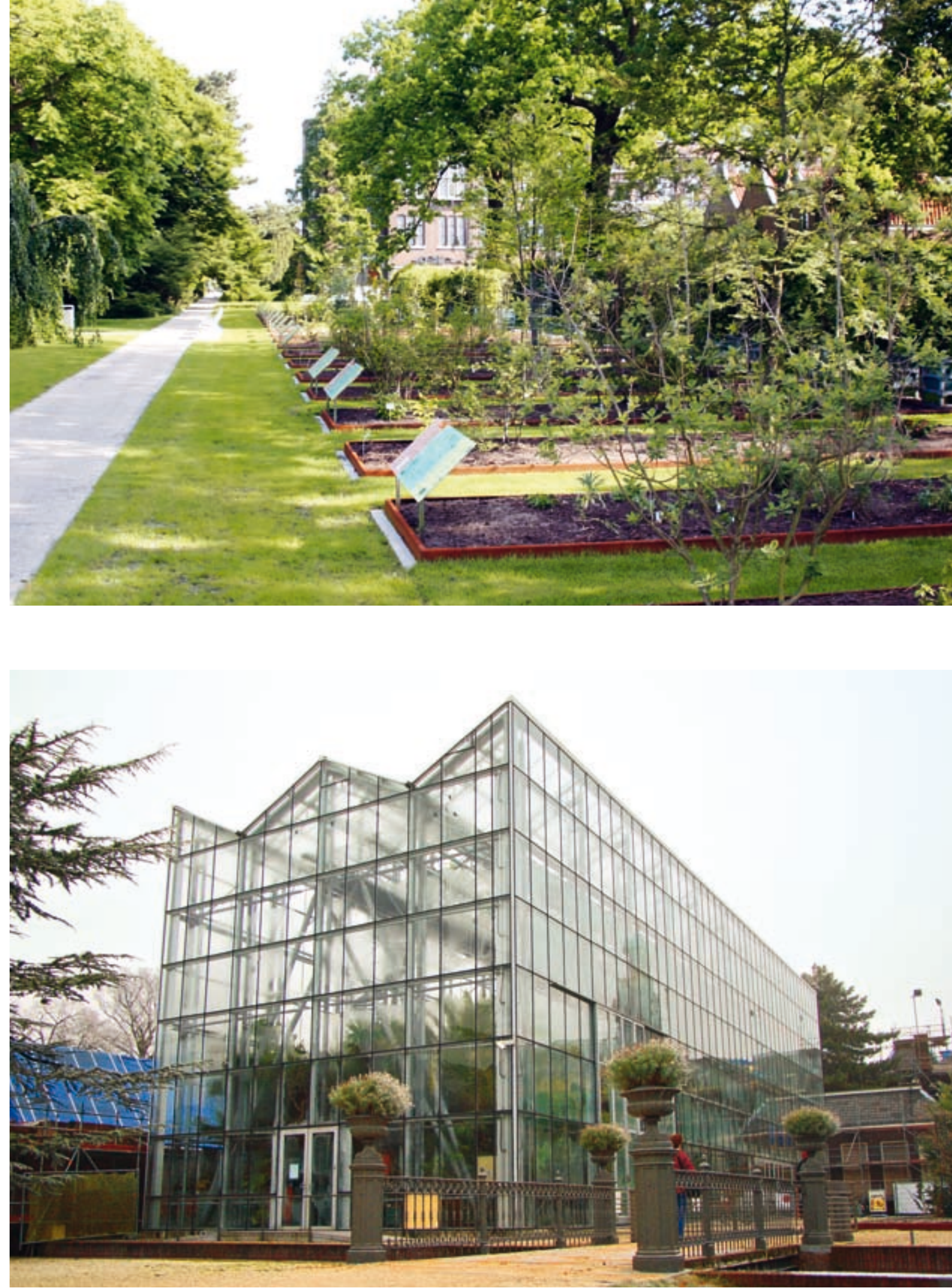

- Systeemtuin Hortus Botanicus

$\checkmark$ Wintertuin Hortus Botanicus 
vakken. Reflectie op de beroepsuitoefening en de inbreng vanuit de sociale wetenschappen, naast de introductie van het algemene coassistentschap, огіenteerden de opleiding sterk op de beroepsuitoefening. Ook werd in 1984 de studierichting biomedische wetenschappen ingesteld, bedoeld voor hooggekwalificeerde onderzoekers.

De groei van de faculteit van 21 hoogleraren in 1950 naar meer dan honderd in 1985, noopte tot professionalisering van het bestuur. Begin jaren zestig werd voor een indeling van de faculteit in vier secties gekozen, ruwweg: nietklinisch, paraklinisch, inwendige ziekten, en heel- en verloskunde. In 1969 werd het meerjarige decanaat ingevoerd. Er kwamen vier directeur-beheerders, die direct onder het universiteitsbestuur vielen en zich een zekere onafhankelijkheid konden permitteren tegenover het faculteitsbestuur. In 1983, bij de taakverdelingsoperatie, formuleerden faculteit en ziekenhuis een еегste aanzet tot profilering van hun onderzoek. In het begin van de jaren negentig legden zij zich vooral toe op immunologie en transplantatie, genetica, kwantitatieve cytologie, oncologie, hemostase en trombose.

De relatie faculteit-academisch ziekenhuis veranderde intussen drastisch. In 1969 werden de ziekenhuizen weliswaar zelfstandige organisaties onder het ministerie van Onderwijs, maar de disciplines bleven onder het beheer van universiteit én ministerie. Geopperd werd een eenduidiger beheer te scheppen in de vorm van een Universitair Medisch Centrum (UMC), een samenwerkingsverband tussen universiteit, academisch ziekenhuis en faculteit. Pas vijfentwintig jaar en een nieuw ziekenhuis later zou het er komen, genoopt door nieuwe bezuinigingen, maar gekanaliseerd door uiterst adequaat handelen van Vredevoogd aan de ene kant en de directeur van het ziekenhuis, de neuroloog O.J.S. Buruma, aan de andere.

Omdat het ziekenhuis daarbij de faculteit van de universiteit overnam, was de vrees niet denbeeldig dat er tussen het medisch centrum en de universiteit een zekere bestuurlijke afstand zou ontstaan. Dat gebeurde ook, maar die bleek van korte duur. Ook hier had Vredevoogd gelijk toen hij zei: 'Je ziet dat eigenlijk overal in het land, dat de vorming van UMC's ten koste gaat van de bestuurlijke invloed van de universiteit op het medisch onderwijs en onderzoek. Tegelijkertijd zie je in Leiden dat er wel goede contacten bestaan tussen 
het LUMC en de andere faculteiten, met name Wiskunde en Natuurwetenschappen en Sociale Wetenschappen. Ik verwacht dat eг op de lange termijn weer meer toenadering zal komen. Ik geloof in de kracht van de academische traditie; voor de Leidse universiteit een traditie van meer dan 400 jaar.'

\section{Wiskunde en natuurwetenschappen}

Ook de faculteit der wiskunde en natuurwetenschappen maakte in de afgelopen decennia een ingrijpend proces van reorganisatie door. Wat daarbij onveranderd bleef, was de klemtoon op onderzoek. Ook toen de studentenaantallen sterk terugliepen, in de jaren negentig, behielden promovendi hun beschermde status. Dat neemt niet weg dat de slinkende aantallen ook hier noopten tot vernieuwing van het onderwijs. De invoering van onderscheiden afstudeervarianten (onderzoek, middelbaar onderwijs en management), keuzecolleges en masterclasses was het antwoord егор.

Ook wiskunde en natuurwetenschappen zag zich geconfronteerd met het probleem van de eenheid van de faculteit en de diversiteit en zelfstandigheid van de disciplines. Uiteindelijk werd de faculteit opgedeeld in onderzoeksinstituten en koos men weliswaar voor een gecentraliseerd bestuur, maar werd een deel van de beheersbevoegdheden gedelegeerd aan de wetenschappelijk directeuren. Het aantal en de aard van de opleidingen ondergingen eveneens wijziging. In 1983 verloor de faculteit de studierichting farmacie en een jaar later werd geologie opgeheven. Daar staat tegenover dat in 1982 de studierichting informatica startte en in 1985 een onderzoeksopleiding biofarmaceutische wetenschappen. Ook herbarium en hortus horen bij de faculteit, maar in 1996 ging het Leidse herbarium op in het Nationaal Herbarium, dat door het overgrote Leidse deel van de samenstelling in Leiden gehuisvest bleef. Uiteindelijk telde de faculteit zeven dagopleidingen: wiskunde, informatica, sterrenkunde, natuurkunde, scheikunde, biologie en biofarmaceutische wetenschappen.

De wiskunde verdeelde het onderzoek over algebra en getaltheorie, meetkunde, analyse, mathematische statistiek en mathematische besliskunde. In

- Oude sterrenwacht 


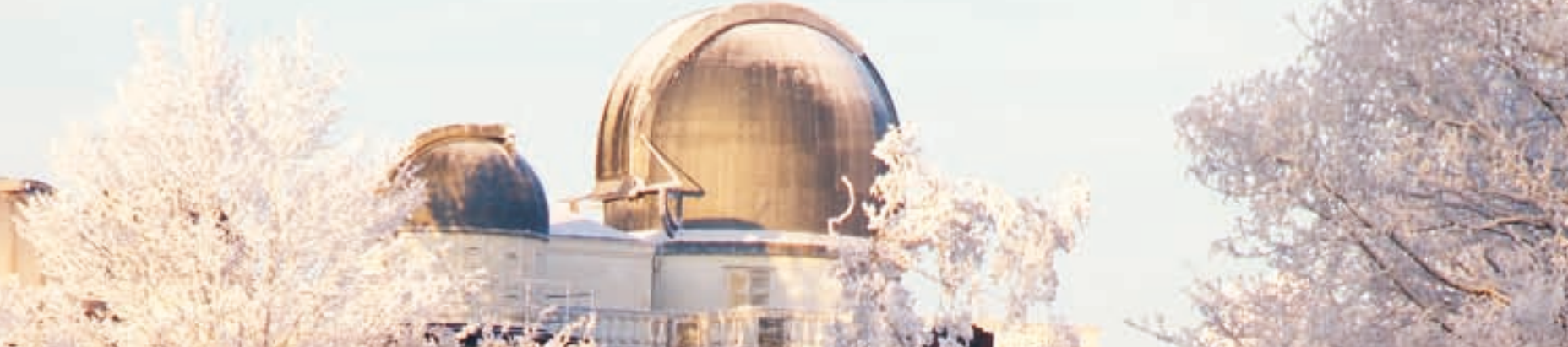

W. (2)

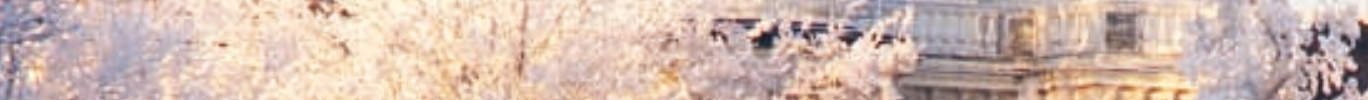
(2) Q

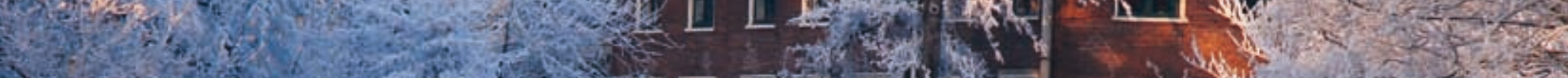

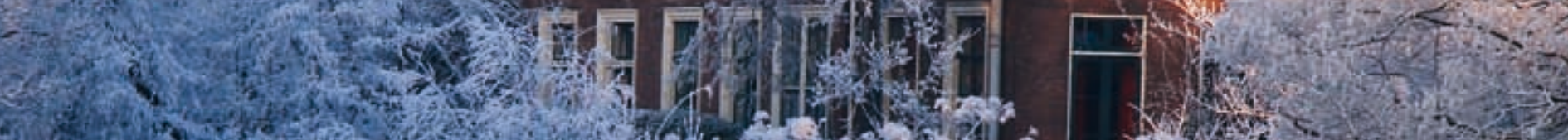

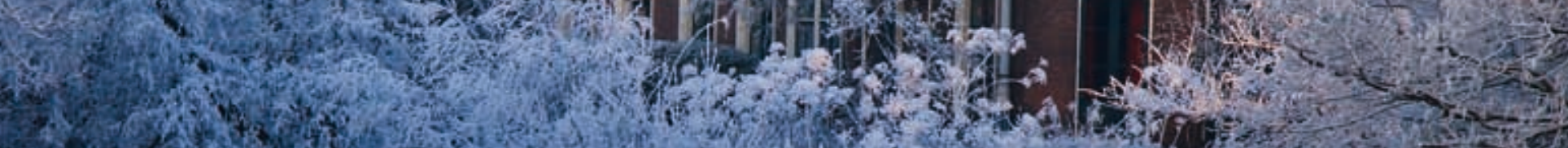

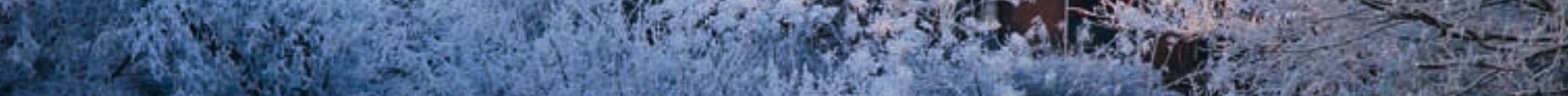

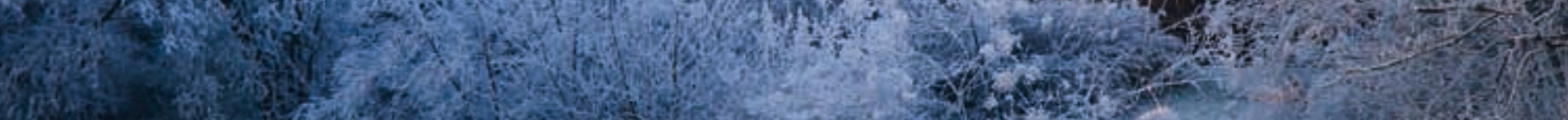

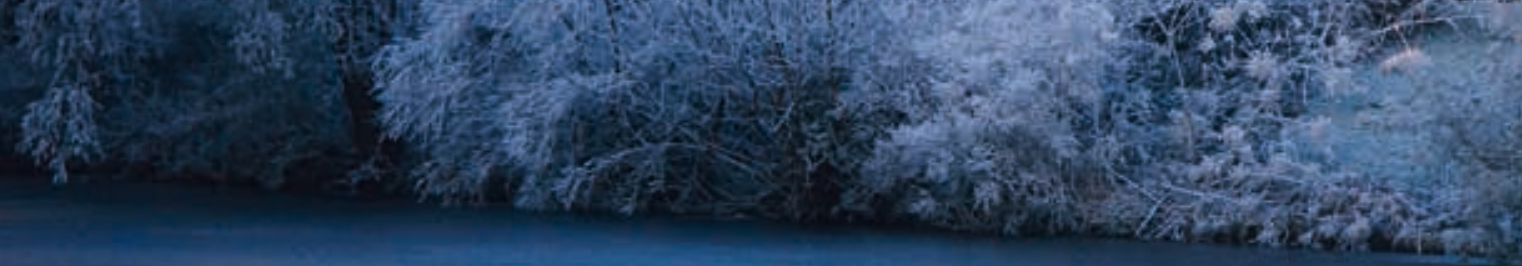




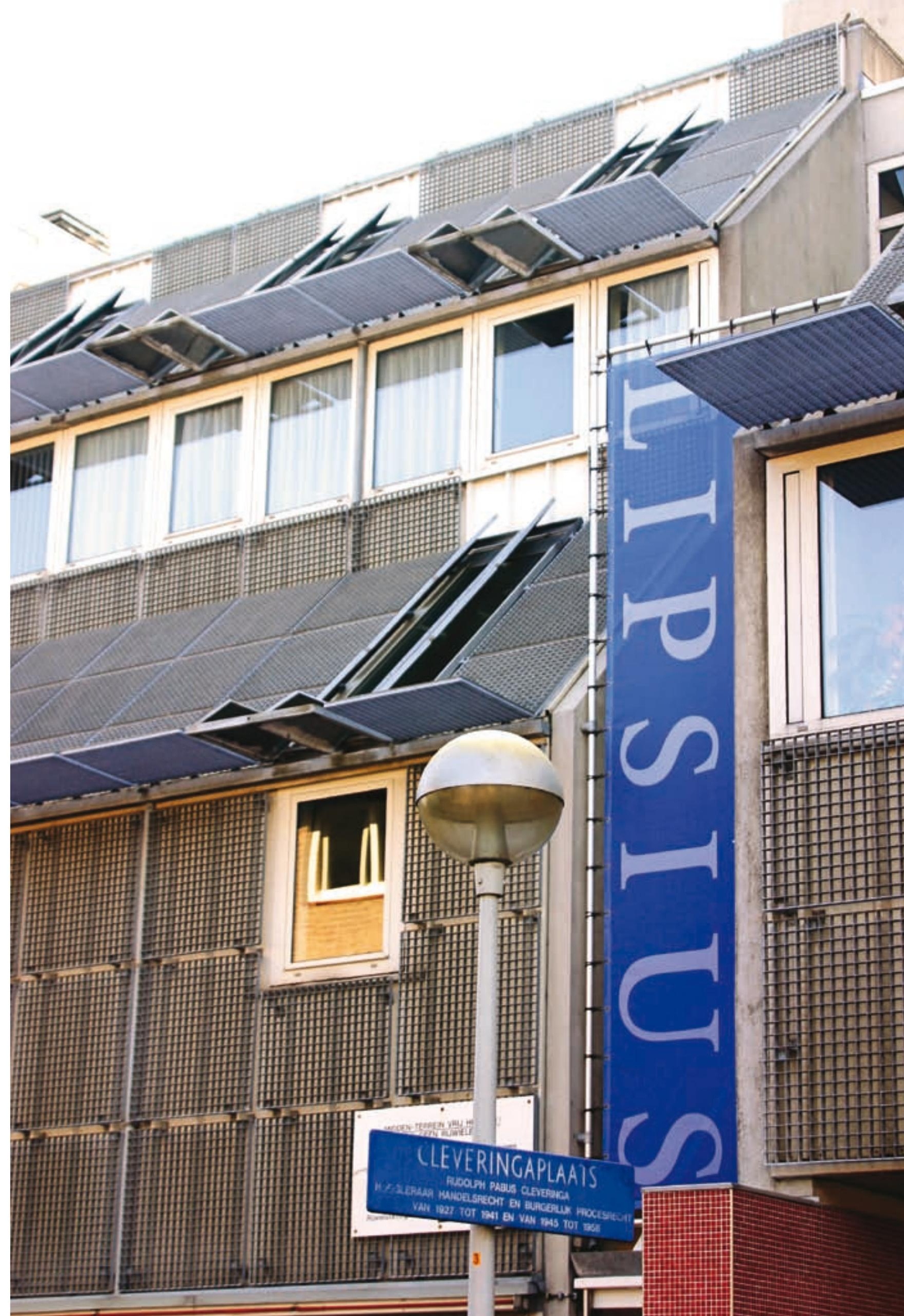


1992 werd het Thomas Stieltjes Institute for Mathematics opgericht, een samenwerkingsverband van zeven instellingen waarvan Leiden penvoerder werd. De informaticaopleiding die in 1982 van start ging, concentreerde haar activiteiten in het Leiden Institute of Advanced Computer Science. Nieuwe thema's werden aan de orde gesteld: natural computing, artificial life en evolutionary algorithms, neurocomputing en high performance computing. Sterrenkunde, vanouds een Leids paradepaard, kende een sterke betrokkenheid bij de landelijke en internationale sterrenkunde. De interferentie van radioastronomie met optische of infraroodwaarnemingen leidde tot vruchtbare samenwerking, zowel met de Groningse sterrenwacht als met Engelse instellingen. In 1991 was Leiden betrokken bij de oprichting van de European Association for Research in Astronomy, waaraan inmiddels vijf belangrijke instellingen deelnemen. Van 1992 dateert de oprichting van de Nederlandse onderzoeksschool voor astronomie, die in 1998 een landelijke dimensie kreeg.

Ook de natuurkunde is traditioneel sterk internationaal gericht. Het onderzoek kan grofweg verdeeld worden in drie hoofdlijnen: de theoretische natuurkunde, studie van de gecondenseerde materie bij lage temperaturen en de moleculaire natuurkunde en biofysica. Interdisciplinaire verbanden tussen biofysica en chemie zouden op termijn leiden tot de Leidse School voor Fundamenteel Onderzoek aan de Levende Materie, waarbij naast de genoemde groepen ook theoretisch fysici, biologen, medici en wiskundigen betrokken zijn. Bij scheikunde leidden de vaak spontaan begonnen samenwerkingsverbanden eveneens tot opmerkelijke initiatieven, zoals de Werkgroep Fundamenteel Materialenonderzoek. De Leidse chemici participeren in het Nederlands Instituut vоor Onderzoek in de Katalyse, de Holland Research School of Molecular Chemistry en de Biotechnologieschool Delft/Leiden.

Bij de biologen werd begin jaren tachtig het aantal onderzoeksgroepen teruggebracht van twaalf naar zes: drie binnen de zoölogie, drie gevormd door botanie, met daarnaast het Rijksherbarium en het Instituut voor Theoretische Biologie. In 1989 wist het Rijksherbarium samen met de hortus botanicus de status van onderzoeksinstituut te verwerven. Een jaar later kwam het Instituut voor Moleculaire Plantkunde tot stand. De klemtoon op het evolutie-

\ Lipsiusgebouw, het centrale faciliteitengebouw van het Witte Singel/Doelencomplex 
onderzoek leidde tot een laatste concentratie van onderzoek in het Instituut voor Evolutionaire en Ecologische Wetenschappen. Het Centrum voor BioFarmaceutische Wetenschappen ten slotte is nadrukkelijk geen apothekersopleiding, maar een onderzoekersopleiding, die intensief samenwerkt met de farmaceutische industrie. Samenwerking met het academisch ziekenhuis leidde in 1987 tot de oprichting van het Centrum voor Humaan Geneesmiddelenonderzoek. Sluitstuk was de oprichting, samen met de Vrije Universiteit, van het Leiden/Amsterdam Center for Drug Research, dat in 1992 met een aantal buitenlandse partners een consortium van inmiddels vijf farmacieën opzette.

\section{Sociale wetenschappen}

Specialisatie en groei maakten dat de in 1963 opgerichte faculteit sociale wetenschappen in 1975 bestond uit 22 vakgroepen met wetenschappers uit zeven disciplines, werkzaam in vier subfaculteiten (sociologie, culturele antropologie en sociologie der niet-westerse volken, psychologie, pedagogische en andragogische wetenschappen), plus een interfacultaire vakgroep politieke wetenschappen. Bovendien was de faculteit gehuisvest in een dozijn bureaus en instituten, sommige op respectabele afstand van elkaar. Daar kwam nog bij dat sinds de invoering van de wub de besluitvorming bij de subfaculteiten lag. Een verdeeld rijk voorwaar.

De spectaculaire groei van het aantal studenten, vooral in de studierichtingen pedagogiek en psychologie, en de invoering van de studieduurverkorting, maakten intussen niet alleen een strakkere studieprogrammering nodig maar ook een reorganisatie. Vоогаl орегаties als TVC en skg brachten dramatische veranderingen, fusies van vakgroepen en hele subfaculteiten (pedagogiek en psychologie) en, het meest dramatische van alles, het verlies van de sociologie voor Leiden (behoudens een basisvoorziening) in uitruil voor politicologie met Rotterdam.

De andere grote ontwikkeling in deze periode was de oprichting (in 1978) en uitbouw van de Dienst Sociaal-Wetenschappelijk Onderzoek (DSwo), een

- Centrale hal van het Lipsiusgebouw 


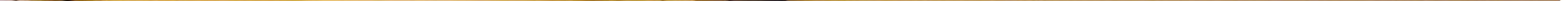


moneymaker van uitzonderlijk formaat. Van de 191 wetenschappers die de faculteit in 1983 telde, werden er 100 uit de eerste, 11 uit de tweede en niet minder dan 80 uit de derde geldstroom gefinancierd. Dit mocht spectaculair zijn, veel van het contractwerk had een minder geavanceerd wetenschappelijk karakter of was bij uitstek gericht op de Nederlandse problematiek. Uiteindelijk werd besloten dat derdegeldstroomonderzoek alleen geaccepteerd werd als het een aantoonbare meerwaarde had voor het eerstegeldstroomonderzoek. Eind jaren tachtig werd uit de boedel van het langzaam afgebouwde Dswo een facultair onderzoeksinstituut (LISwo) opgericht waarin vier van de acht oorspronkelijke groepen ondergebracht werden.

In 1989 werd de faculteit gehuisvest in de voormalige polikliniek voor interne geneeskunde. Via een prijsvraag kreeg het gebouw de naam van de zeventiende-eeuwse Leidse lakenfabrikant Pieter de la Court. Zonder gemor van progressieve zijde ging dit echter niet, wellicht omdat deze vriend van De Witt en intrigerend politiek-economisch theoreticus in de encyclopedie omschreven werd als 'woordvoerder van de nieuwe klasse der burgerkapitalisten'. Dit komische krakeel was wellicht symbolisch voor het onvermogen van het gebouw de relatieve autonomie van de studierichtingen, die elk hun eigen verdieping kregen, tegen te gaan.

Dit verschijnsel, dat zoals we zagen eigen is aan alle disciplines, werd bij de sociale wetenschappen versterkt door het feit dat het gamma van deze faculteit vrij bars uiteenviel in alfa- en bètakleuren. Echte alfavakken als religieuze antropologie en wijsgerige sociologie mengden moeilijk met echte bètadisciplines als functieleer (een tak van de experimentele psychologie), het politicologisch verkiezingsonderzoek of het wetenschappelijk citatieonderzoek. Toch zijn deze laatste vakken gaandeweg het profiel van de faculteit gaan bepalen. Met het wegvallen van sociologie en andragogische wetenschappen, de toenemende comparatistisch-kwantitatieve klemtoon in bestuurskunde en politicologie en het verleggen van het accent binnen de pedagogiek (het verdwijnen van disciplines als jeugdsociologie en interculturele pedagogiek) naаг de betekenis van neurale aspecten van het gedrag van kinderen, lijkt de faculteit te kiezen voor een bètasignatuur. Met name in de gedragswetenschappelijke disciplines, de psychologie en de pedagogische we-

^Voormalig Botanisch Laboratorium, nuP.J. Vethgebouw voor instituten op het gebied van niet-westerse talen en culturen 
tenschappen, heeft de aandacht voor de neurowetenschappelijke aspecten geleid tot een groeiende samenwerking met het onderzoek in het LUMC op dit terrein.

\section{Rechten}

Ook de rechtenfaculteit was in de jaren zeventig een brede faculteit met een grote diversiteit aan studierichtingen. Naast de doctoraalstudie Nederlands recht, met specialisaties civiel recht, staats- en administratief recht, straf- en bedrijfsrecht, kende Leiden aparte studierichtingen fiscaal recht, notarieel recht en drie staatkundige studies (bestuurswetenschappen, politieke wetenschappen en een internationaal juridische richting). Verder waren er unieke onderzoeksinstituten voor papyrologie, Oost-Europees recht en het recht van niet-westerse samenlevingen (het Van Vollenhoven Instituut). En tenslotte: Leiden kende weliswaar geen economische faculteit, maar de rechtenfaculteit herbergde een belangrijke afdeling economie.

Problemen waren eг ook: verouderde huisvesting, een zeer ongunstige staf-studentenratio en een verhoudingsgewijs karige toewijzing van onderzoeksmiddelen. Daarbij kende ook deze faculteit een sterke neiging tot eilandvorming. Vanaf de jaren tachtig is geprobeerd te komen tot de omschrijving van een kerncurriculum en de afbakening van kerndisciplines. Dit impliceerde dat de rechtspositieve vakken beklemtoond werden ten koste van de metajuridica (rechtsfilosofie, rechtssociologie, rechtsgeschiedenis, rechtseconomie) en van de nog zo recentelijk, samen met sociale wetenschappen opgezette, opleiding staatkunde.

Uiteindelijk zou het om de juiste combinatie gaan en de belangrijkste stap in die richting werd gezet in 2001, met de nota De weg naar de kern. Hierin zijn duidelijk de echo's hoorbaar van de algemene profieldiscussie. Ook hier ligt de klemtoon op de academische houding, de disciplinegerichte opzet, de samenhang van onderwijs en onderzoek. Toch ligt de verhouding hier anders. De faculteit weet zich een onderwijsrijke opleiding in een door onderzoek gedreven universiteit. Als academische discipline richt ze zich dan ook aller- 
eerst op de grote (burgerlijk recht, ondernemingsrecht) en iets minder grote maar wel beeldbepalende vakken (fiscaal recht, notarieel recht, strafrecht en bestuursrecht, volkerenrecht en Europees recht). Dat betekent dat ze zich concentreert op de vakken (burgerlijk recht en internationaal recht) waarin Leiden traditioneel sterk was.

Om te komen tot een betere integratie van het onderwijs en de kwaliteit ervan te bewaken werd in 2001 het Cleveringa Instituut in het leven geroepen. Eenheid en samenwerking werden belangrijke toetsingscriteria, de samenhang ervan met onderzoek en praktijk werd in de opzet verankerd. Elke master kent een sterk op onderzoeksvaardigheden gericht privatissimum en een practicum waarin de professionele vaardigheden van de praktijkjurist en de criminoloog centraal staan.

Het onderzoek van de faculteit werd in 1997 ondergebracht in het E.M. Meijers Instituut. De oprichting daarvan was een uitvloeisel van de gedachte dat juist langs de grenzen van de verschillende disciplines belangrijke onderzoeksvragen liggen. Het onderzoek werd dus niet zozeer geordend in vakgroepen, maar naаг thema's als rechtseenheid, rechtsgelijkheid en voorspelbaarheid voor de maatschappij als geheel én voor het individu. 'Bindende besluitvorming' werd de centrale notie in het onderzoeksprogramma, zowel op het niveau van wetgever en rechter, centrale en lokale overheid, als op dat van civiele partijen én tussen staten en internationale organen en organisaties.

Ten slotte zag de faculteit zich geplaatst voor het probleem van de toenemende internationalisering, ook in het - traditioneel nationaal gerichte deel van de rechtswetenschap. In 2003 nam men het initiatief tot de oprichting van de Strategic Alliance of Research Faculties of Law, waarin een tiental Europese faculteiten (waaronder Bologna, Leuven, Oxford en Heidelberg) samenwerken voor uitwisseling en de organisatie van expert meetings. Daarnaast is er het Grotius Centre for International Legal Studies binnen de Campus Den Haag.

Deze ontwikkelingen vielen wonderwel samen met de oplossing van de huisvestingsproblemen. In 2004 kon de faculteit het Kamerlingh Onnesgebouw betrekken, het vоormalige laboratorium, geгеstaureerd tot blinkende 


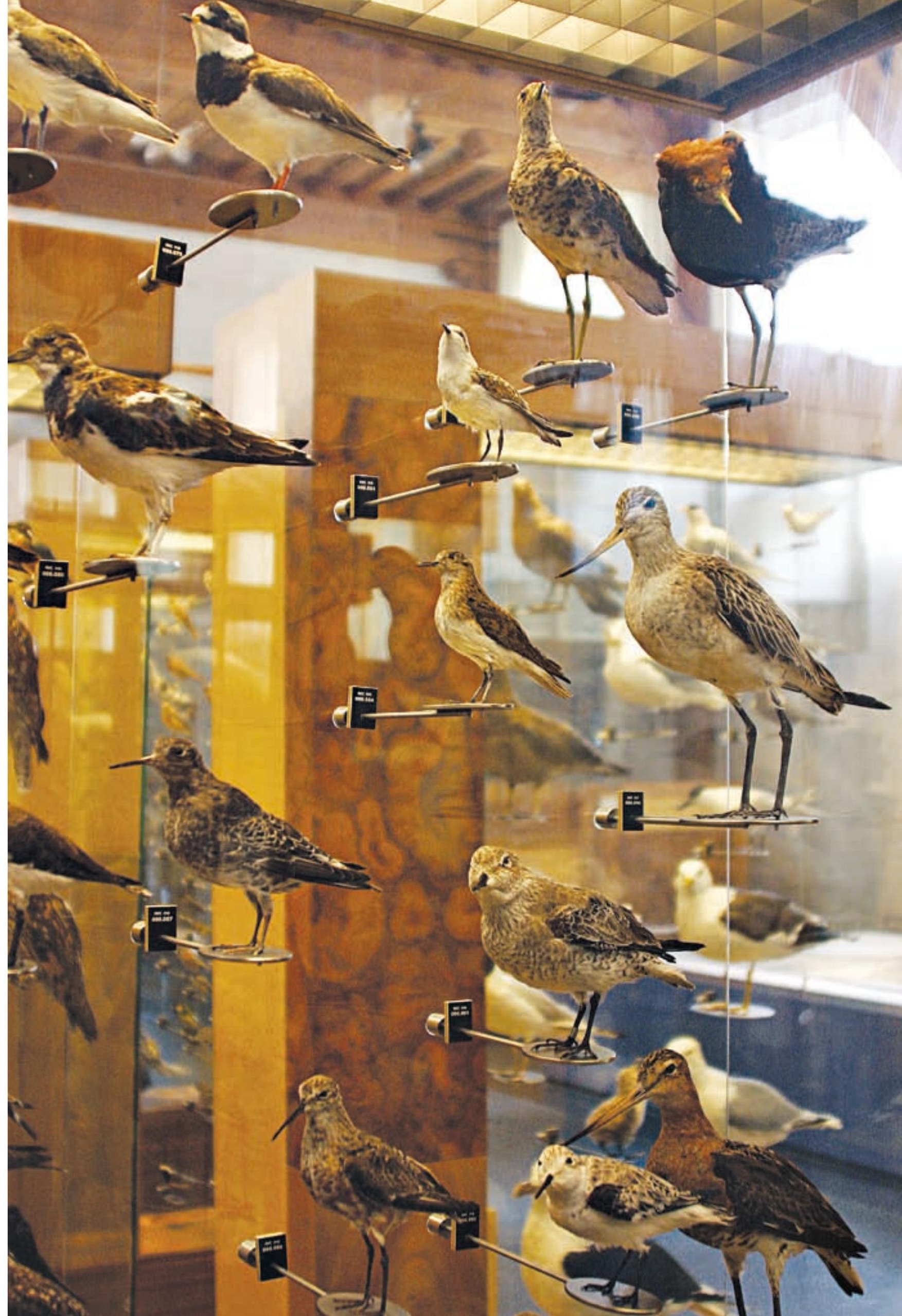



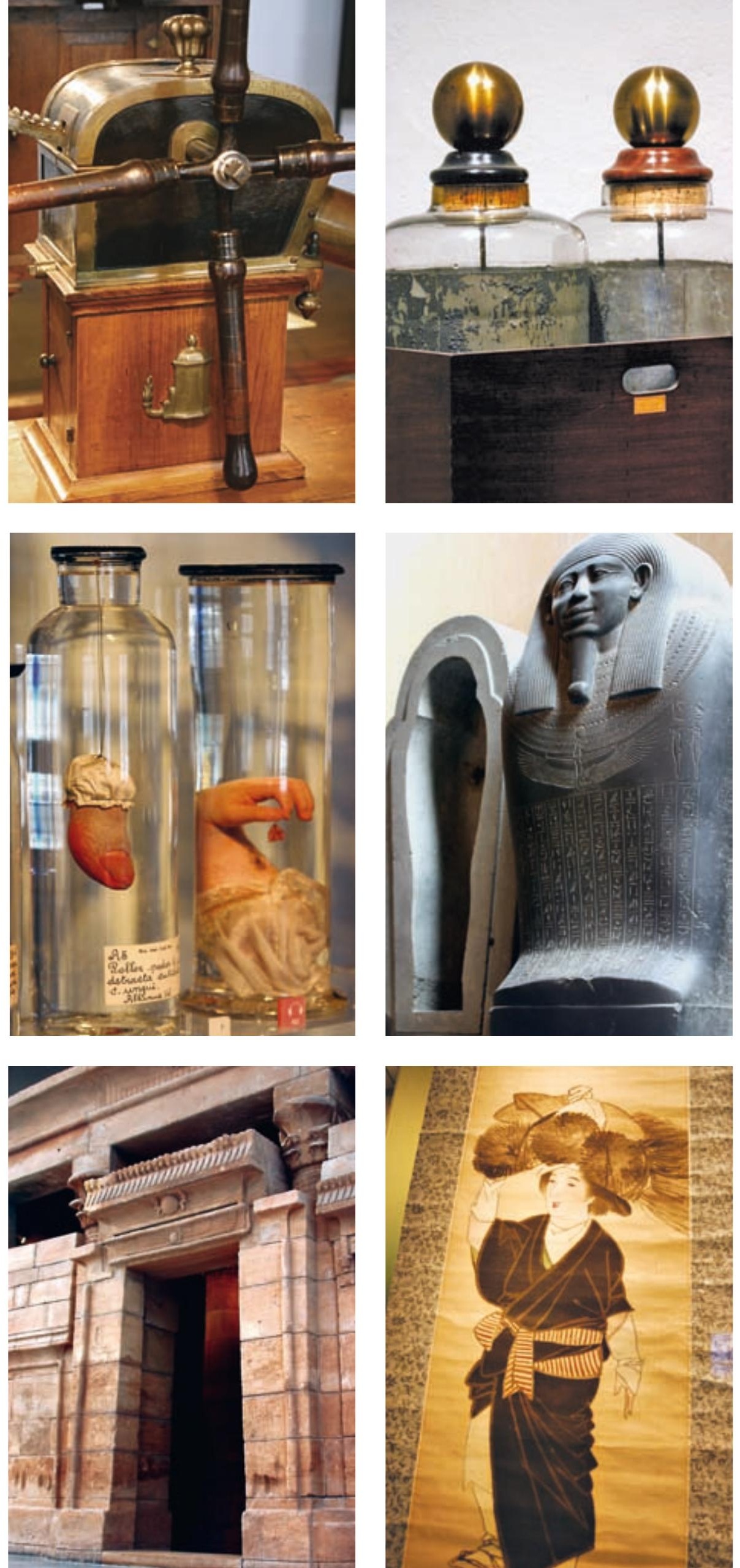
unilocatie, voorzien van goede lesruimten, een wondermooie bibliotheek en hoogwaardige ICT-voorzieningen. In 2000 somberde een chroniqueur van de faculteit nog onder de titel `Het kan dus beter'. Zeven jaar later was het ook zo.

\section{Letteren}

De archipel van de Leidse letteren kent in variëteit van omvang en verscheidenheid van onderwerp zijn weerga in de universiteit niet. Als de fabeldichter Phaedrus gelijk had met zijn 'varietas delectat', moet er van deze op zich niet eens zo heel grote faculteit een mate van bekoring uitgaan waarmee de rest van de universiteit toekan. Deze variëteit ten spijt, zijn er wel degelijk grote gemene delers aan te wijzen. Ten eerste is er de tweedeling in een 'westers' en een 'niet-westers' deel. Ten tweede werd er op methodische gronden wel een driedeling gehanteerd. Terwijl de westerse talen zich meer vakgericht bleven concentreren op de van oudsher bestaande indeling in taal- en letterkunde, richtte het 'niet-westen' zich veel meer op een regionale benadering en combineerde het de bestaande vakken met historische of sociaalwetenschappelijke disciplines.

Ten derde zijn er de specifiek historische disciplines zelf, geschiedenis en kunstgeschiedenis, die vanouds gewend zijn zowel het chronologische en geografische als het filologische en sociaalwetenschappelijke perspectief te combineren. Van zeer recente datum is de discussie binnen de faculteit om te komen tot een nieuwe structuur die zich richt op de graduatefase en die wil komen tot een indeling in vijf instituten. Geschiedenis, kunstgeschiedenis, taal- en letterkunde krijgen elk een instituut, waaraan een vijfde 'regio-instituut' wordt toegevoegd.

Het 'westen' hield grosso modo vast aan de vakgerichte studie. Naast opleidingen in bepaalde talen was er een studie geschiedenis en een studie kunstgeschiedenis. Uitzonderingen waren Griekse en Latijnse talen en culturen (GLTC) en Talen en culturen van Latijns-Amerika (TCLA). Bij GLTC vormen oude geschiedenis, wijsbegeerte en klassieke archeologie een vast bestanddeel van het onderwijsprogramma; bij TCLA, ontstaan nadat bij de taakverde-

^ Vacuümpomp en Leidse flessen van Van Musschenbroek, in Museum Boerhaave

- Preparaten van Albinus (Anatomisch Museum) en Ahmes-sarcofaag (Rijksmuseum van Oudheden)

、 DeEgyptische Taffehtempel in het Rijksmuseum van Oudheden. Boerin, begin 19e eeuw op zijde geschilderd doог Utagawa Toyokuni (1769-1825) in het Sieboldhuis 
lingsoperatie de vakgroep Spaans uit Leiden weggehaald werd, is er naast de leerstoelen taal- en letterkunde een leerstoel geschiedenis. Ook het onderzoek in deze afdeling werd ondergebracht in landelijke onderzoeksscholen, zoals het Holland Institute for Linguistics of oІкоs voor klassieke studies en in een aantal multidisciplinaire instituten, zoals het Leids Instituut voor de Nieuwe Tijd.

Misschien dat het grote verschil met het 'oosten' inderdaad in de achtergrond te zoeken is. Veel nadrukkelijker dan bij de louter filologische moederwetenschap van het westen, qualitate qua meer achterwaarts gericht, is de klemtoon op de praxis die de oriëntalistiek van oudsher kenmerkte er mede debet aan dat een groter engagement met de eigen tijd en met de context gezocht werd. Ook daarin heeft Leiden overigens eerder het accent op de continuïteit dan op de moderniteit gelegd en de daar beoefende area studies bezitten alle een stevige filologisch-historische component. In de jaren tachtig is wel geopperd alle area studies bijeen te voegen tot één faculteit, maar dit bleek een brug te ver. Wel werd, naar het voorbeeld van het succes van de opleiding talen en culturen van Zuid-Amerika, voorgesteld een Centrum voor de Niet-westerse Studies in het leven te roepen. In 1994 werd dit cNWs erkend als onderzoeksschool onder de titel School of Asian, African, and Amerindian Studies. Weldra kende Leiden ook een International Institute of Asian Studies en een International Institute for the Study of Islam.

De geschiedenisopleiding kent nog steeds de traditionele indeling in oudheid, middeleeuwen, vaderlandse, algemene en sociaaleconomische geschiedenis. Ook buiten de opleiding, in de afdelingen voor Aziatische studies, bestond een groot aantal leerstoelen geschiedenis. Dit geeft de faculteit een speciaal profiel en impliceert ook een intensieve samenwerking met het 'nietwesten'. Kunstgeschiedenis is altijd kleiner geweest. De aanvankelijke klemtoon op iconologie, met het zelfstandig ontwikkelde befaamde documentatiesysteem Iconclass, werd geleidelijk gesplitst in een accent op de renaissance aan de ene en op de kunstnijverheid aan de andere kant. De leerstoel bouwgeschiedenis dateert pas van 1971, toen ook een lectoraat vroegchristelijke kunst ingesteld werd. In 1996 werd deze laatste omgezet in een leerstoel moderne kunst. 


\section{De kleine faculteiten (theologie, filosofie, archeologie en kunsten)}

De theologische faculteit kende vanaf de Hoger onderwijswet van 1876 een zogenaamde duplex ordo: een deel van de vakken werd gegeven onder verantwoordelijkheid van de universiteit, een ander deel onder dat van de Nederlandse Hervormde Kerk en de Remonstrantse Broederschap. De zogenaamde staatsvakken waren: Oude Testament, Nieuwe Testament, kerkgeschiedenis, wijsbegeerte en ethiek, sociale wetenschappen en godsdienstgeschiedenis. De kerkelijke vakken omvatten dogmatiek, christelijke ethiek en vakken die te maken hadden met de praktijk van het predikantschap. In 1992 ging de opleiding islamologie van start, in 1999 het programma 'wereldgodsdiensten'. Het onderzoek van de faculteit richt zich vooral op de tekstgeschiedenis van het Oude Testament, de traditie van ideeën van jodendom naar vroeg christendom, de patristische theologie, de irenische theologie, de vегhouding protestantisme en verlichting. De Leidse faculteit neemt deel in de in 1994 erkende Nederlandse Onderzoeksschool voor Theologie en Religiestudies en richtte ook haar eigen Leiden Institute for the Study of Religion op, eveneens in 1994 erkend. De kerkelijke opleiding van de hervormden werd in 2007 vestiging van de nieuwe landelijke Protestantse Theologische Universiteit.

De filosofie in Leiden, bij de wet van 1960 kunstmatig opgeblazen tot Centrale Interfaculteit, en bij die van 1992 weer leeggepompt tot faculteit der wijsbegeerte, is vanouds sterk in de geschiedenis van de wijsgerige semantiek. Hoewel een groot deel van de systematische filosofie door het onderwijs wordt bestreken, zijn in het onderzoek de antieke wijsbegeerte, de geschiedenis van logica en semantiek, en de wijsgerige interpretatie in de traditie van Hegel, Nietzsche en Heidegger van belang. Daarnaast werd een belangrijk onderzoeksprogramma opgezet op de grens van kennistheorie, wetenschapsfilosofie, cognitieve psychologie en de geschiedenis van de contemporaine wijsbegeerte.

Bij de inrichting van het Archeologisch Centrum aan de Reuvensplaats werd een deel van de gevarieerde archeologische disciplines die Leiden bezat 
onder één dak gebracht. Uiteindelijk werden zes afstudeerrichtingen geformuleerd: prehistorie, klassieke archeologie, Nabije Oosten, Indiaans Amerika, (Zuidoost-)Azië en archeological sciences. Het onderzoek bestreek een zeer breed terrein. In eigen land richtte zich dat vooral op de bewoningssporen uit de ijzertijd en de Romeinse tijd, de bandceramische cultuur en de vroege neanderthalers. Maar ook in de Jordaanvallei, het Caraïbisch gebied, Guadeloupe en Niger wordt op grote schaal gegraven. De klassieke archeologie beklemtoonde de urbanisatie van de pre-Romeinse periode en bestudeerde de artistieke productie in architectonische en maatschappelijke context. In 1992 werd in landelijke samenwerking de onderzoeksschool ARCHON opgericht, die in 1996 door de KNAw werd erkend.

De faculteit der kunsten ten slotte richtte zich niet alleen op de dubbeltalenten onder de studenten, maar verrijkte het curriculum door het wederzijds beschikbaar stellen van keuzevakken. De kracht van deze samenwerking van universiteit en hogeschool lijkt te liggen in de ontwikkeling van nieuwe major-minorstudieprogramma's. Door haаг participatie in het studium generale beantwoordt dit algemeen-vormende onderdeel van het curriculum meer dan voorheen aan zijn doelstelling. Verder ontwierp de faculteit een aantal eigen onderzoeksprogramma's op het vlak van de transformatie van kunst en cultuur en mediatechnologie.

Aan het bestaan van de kleine faculteiten kwam in 2008 een einde. In het verlengde van het profiel als researchuniversiteit werd besloten tot een clustering van graduate schools en een herindeling van de faculteiten. De negen bestaande 'schools' werden teruggebracht tot vijf: Arts and Humanities, Law School, Science, Social and Behavioural Sciences en Leiden Universdity Medical Centre. Tegelijk werden de faculteiten tot vijf teruggebracht, waarbij het er naаг uitziet dat archeologie zich zal voegen bij Science en de overigen zullen opgaan in Graduate School of Arts and Humanities. 


\section{Een handvol instellingen}

Het organogram van een universiteit mag een redelijk geheel lijken, het is natuurlijk een historisch gegroeide gekte. Wie de Leidse universiteitsgids op internet bezoekt, krijgt bij 'organisatie en bestuur', om een voorbeeld te geven, niet alleen de samenstelling van het college van bestuur, decanen, raad van toezicht en universiteitsraad, maar wordt ook geïnformeerd over het bestaan van een bestuursbureau en zogeheten expertisecentra. Hoewel dit nieuwigheden zijn die van 1999 dateren, hebben ze een respectabele voorgeschiedenis. Het secretariaat van de universiteit is per slot een op Jan van Hout

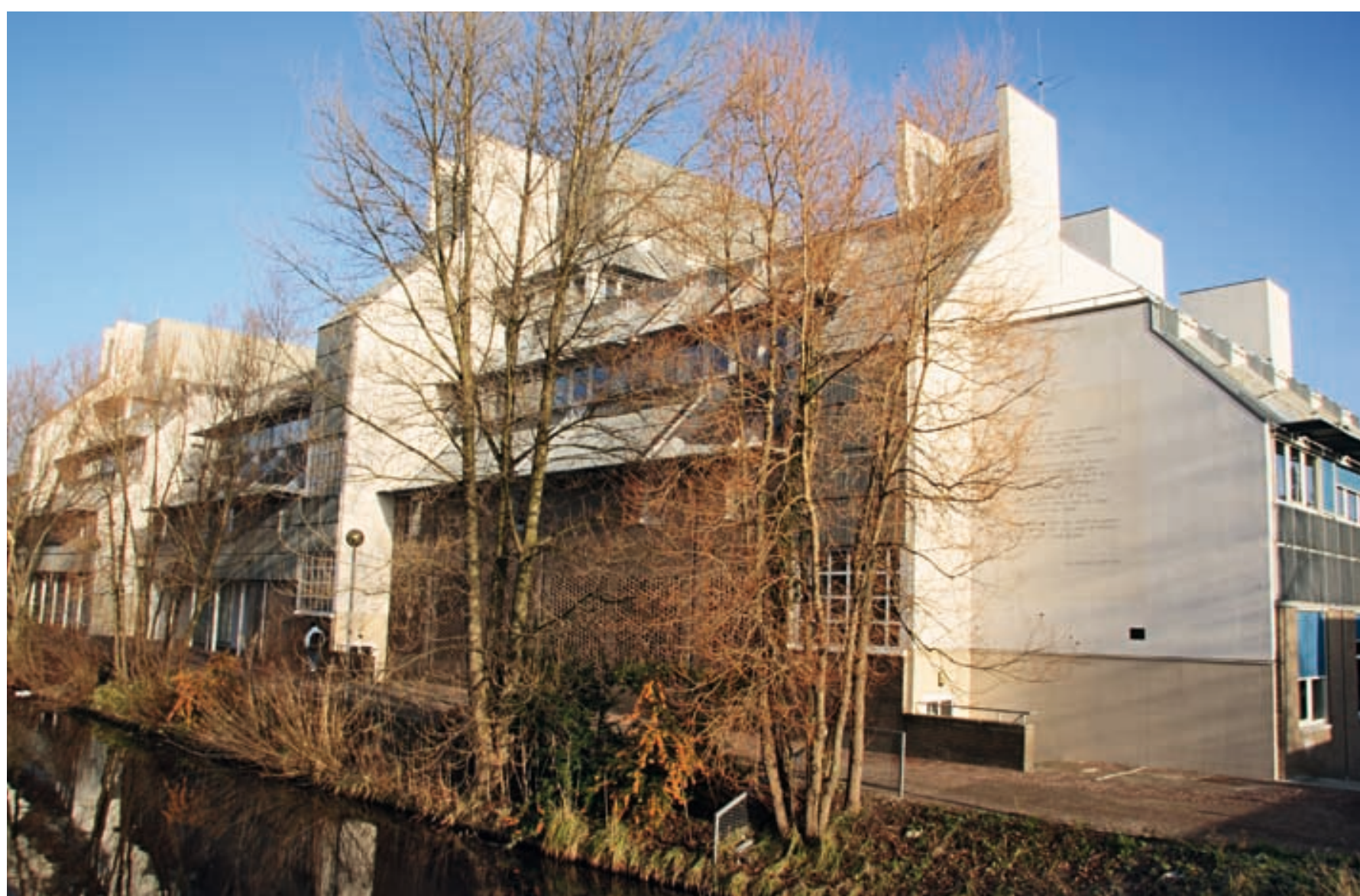

^ Lipsiusgebouw aan de Singelzijde 
taris D.P. den Os (1983-1993) moest werken, liet vooral een decentralisatie ten behoeve van de faculteiten en een verzwaring van de taken zien - een ongelukkige combinatie die tot veel aanpassingsplannen maar geen oplossing leidde. Met het aantreden van de nieuwe secretaris, W.L.C.H.M. van den Berg, kwam er een Bureau voor de Universiteit en los daarvan een facilitair bedrijf (restauratie, post, drukkerij, informatiseringstaken, onderhoud gebouwen). Beleid en beheer werden definitief gescheiden. Het beleid werd ondergebracht in een bestuursbureau ten behoeve van het college van bestuur; beheer en voorzieningen werden toevertrouwd aan expertisecentra voor de hele universiteit.

Er kwamen zeven expertisecentra, ICs (informatie, communicatie en studenten), een informatiseringsgroep, een instelling voor kennistransfer (Leiden University Research and Innovation Services), een International Office, een facilitair bedrijf, vastgoed en de universiteitsbibliotheek. De bibliotheek mag in dit geheel een beetje 'oud' klinken, maar zij is, in haar nieuwe onderkomen en met een volledig geautomatiseerde catalogus, een modern bedrijf dat zich richt op twee zaken: het beschikbaar stellen van een aantal internationaal zeer in aanzien staande bijzondere collecties (oosterse handschriften, westerse gedrukte werken) en het toegankelijk maken van boeken, tijdschriften en andere informatiedragers voor medewerkers en studenten. De rol van die andere informatiedragers wordt snel belangrijker dan die van papier. Dit, in combinatie met ruimtegebrek, heeft ertoe geleid dat de aanschaf van monografieën en tijdschriften is teruggelopen van een kilometer per jaar in de jaren tachtig naar ongeveer 250 jaarlijks. Daar staat tegenover dat het aantal digitale bibliotheekdiensten zich snel uitbreidde.

Naast faculteiten kent de universiteit een aantal interfacultaire instellingen, zoals het Centrum voor Bedrijfswetenschappen, LiBC (Brain and Cognition) en het Studiecentrum voor Criminaliteit en Rechtshandhaving. Daaronder bevinden zich ook het Interfacultair Centrum voor Leraren, Onderwijsontwikkeling en Nascholing en het Centrum voor Milieukunde. Daarnaast kent de universiteit een aanzienlijke reeks interuniversitaire instellingen, van het Afrika Studiecentrum tot het Thomas Stieltjes Institute for Mathematics, onderzoeksscholen meestal, maar ook zoiets als het Neder- 
lands Instituut te Rome en het Nederlands-Vlaams Instituut te Cаїго.

Ten slotte biedt de gids zicht op een reeks 'overige voorzieningen', van het Academisch Historisch Museum, via Faculty Club, Kinderdagverblijf 'Kattekop' en studentencentrum Plexus naar het studium generale en het universitair sportcentrum. Twee daarvan kennen een lange, boeiende geschiedenis en hebben de beeldvorming van de Leidse universiteit in niet geringe mate beïnvloed. De eerste daarvan is het Leids Academisch Kunstcentrum, ooit opgericht tot 'aesthetische vorming van de academieburger' en vanaf 1971 ondergebracht in een verlaten dekenfabriek aan het Levendaal, die het centrum een shabby uitstraling verleende die goed paste bij het progressieve kunstklimaat van de jaren zeventig. Het faciliteitengebouw van het Witte Singel Doelencomplex gaf het theater een geheel andere sfeer, рrofessioneler vooral, ook al wordt grotendeels met vrijwilligers gewerkt. Het cursusaanbod loopt inmiddels van Gregoriaans via Afrikaanse dans naar creatief taalgebruik.

Op dat laatste terrein bewoog zich ook de onafhankelijke krant van de universiteit, Mare geheten, in 1977 opgericht als opvolger van Acta et agenda. Niet alleen befaamde schrijvers als Maarten Biesheuvel, Boudewijn Büch en Maarten 't Hart lieten daar hun ontwrichtende berichten los, het blad ontwikkelde zich ook als proeftuin voor journalistiek talent, dat weldra zijn carrière voortzette bij de betere landelijke kranten. Het ontwikkelde daarbij een narrig soort distantie tegenover het studentenleven en de bestuursgremia. Het eerste leek vaak te bestaan uit louter uitwas, het tweede uit een overleefd regentendom. In het aftasten van elkaars gevoel voor humor hebben blad en universiteit nog steeds geen goed evenwicht gevonden.

\section{Universiteit en bedrijfsleven}

Sinds 1985 hoort dienstverlening aan maatschappij en bedrijfsleven formeel tot de kerntaken van de universiteit. Vanouds ligt dienstverlening aan de maatschappij verankerd in de beoefening van de wetenschap. Het LumC met zijn patiëntenzorg en zijn op de verbetering van de gezondheidszorg gerichte onderzoek, de letterenfaculteit met haar Huizinga-lezing, de gezamenlijke 
faculteiten met de Cleveringaleerstoel, de faculteit sociale wetenschappen met centra voor maatschappelijke tegenstellingen of voor verbetering van crisismanagement, ze dragen alle in brede zin bij aan het maatschappelijk bestel. Ook was via een lange reeks van deskundigen en columnisten de universiteit aanwezig in het maatschappelijk debat.

Van minstens zo groot belang is de veranderde verhouding tussen universiteit en bedrijfsleven. Lange tijd was die verre van vlekkeloos. Distantie en wantrouwen waren kenmerkender dan waardering en samenwerking. De omslag vond plaats in de tweede helft van de jaren zeventig, gemarkeerd door de Innovatienota van 1979. Daarin werden contacten tussen bedrijven (vooral midden- en kleinbedrijf) en de universiteit aangemoedigd en zogeheten transferpunten ingesteld om dit te bevorderen.

Die contacten waren voor de universiteit ook van belang, omdat het geld uit de zogenaamde derde geldstroom een belangrijk onderdeel van de financiële middelen ging vormen. Onder de eerste geldstroom verstaat de universiteit de uit de rijksbijdrage toegewezen geldmiddelen, de tweede stroom bestaat uit middelen toegekend via Nwo/zwo of afgeleide organisaties. De derde geldstroom kent grosso modo drie bronnen: middelen afkomstig uit het bedrijfsleven, van overheidsinstellingen (rijk, provincie, gemeenten) en van internationale organisaties (Fullbright, NAvo, EU, Rockefeller Foundation en dergelijke) en van charitatieve instellingen (Nierstichting, Hartstichting, Wilhelmina Fonds et cetera). Naast de veranderende houding bij staf en studenten en de groeiende behoefte in het bedrijfsleven aan contacten was de reductie in personele en materiële middelen, met name bij de faculteiten voor medicijnen en wis- en natuurkunde, in de tweede helft van de jaren zeventig gerede aanleiding om de steun van het bedrijfsleven te zoeken.

Die steun kon verschillende vormen aannemen: subsidies voor fundamenteel onderzoek, contractonderzoek, preadviezen, adviseurschappen en dergelijke. Maar ook bijvoorbeeld de verhuur van ruimten en faciliteiten, de verkoop van cursussen en van licenties en octrooien. In 1981 werd, in samenwerking met de Technische Hogeschool Delft, een Transferpunt ingesteld. Dit hielp mogelijke opdrachtgevers de goede onderzoeker of onderzoeksgroep te vinden, steunde onderzoekers om hun vindingen te commer-

- Studiekeuzefestival in de Pieterskerk 

cialiseren of goede partners in het bedrijfsleven te vinden, en adviseerde het college van bestuur over derdegeldstroomactiviteiten. In samenwerking met de gemeente Leiden en de Kamer van Koophandel stimuleerde het Transferpunt de totstandkoming van het Academisch Bedrijvencentrum, incubator van het Science Park in de Leeuwenhoek. Heel concreet was het samenwerkingsverband met Delft inzake biotechnologie en de activiteiten van het Leidse Centrum voor Bio-Farmaceutische Wetenschappen.

Om deze activiteiten beter te stroomlijnen werd in 1995 de Taakgroep Benutting Kennispotentieel opgericht, een jaar later geïnstitutionaliseerd als Leiden University Institutional Development (LUID). Als uitvoerend orgaan werd de Leiden University Research and Innovation Services in het leven geroepen, dat de benodigde bedrijfsmatige en juridische kennis, expertise en contacten verzorgt. Parallel hieraan kent het Leids Universitair Medisch Centrum zijn eigen valorisatiefunctie, waarvan de activiteiten op elkaar afgestemd worden. Samen met het LuMc wist de universiteit belangrijke projecten buiten de eerste geldstroom binnen te halen als het Centre for Medical Systems Biology en Cyttron (bio-imaging techniques). Daarnaast richtte LuID in 1996, onder de naam Libertatis Ergo, een heuse holding op, die als zelfstandig rechtspersoon opereert en een aantal succesvolle bedrijven opzette, waaronder Archol B.V. voor archeologisch onderzoek met name in de Betuweroute, het Crisis Onderzoeksteam, Screentec en Heartcore.

Het Science Park concentreerde zich vooral op biomedische en life sciences. Met een veertigtal ondernemingen huisvest Leiden momenteel de helft van de gespecialiseerde life science-bedrijven in Nederland. De belangrijkste betrokkenen organiseerden zich in 2003 onder het motto `Leiden - Life Meets Science'. Een vergelijkbaar initiatief is de Haagse Campus, die zich vooral richt op publiek-bestuurlijke studies en die opleidingen op maat ontwikkelt vоor de publieke sector. Gevolg van deze activiteiten was dat gemiddeld over de jaren 2001-2003 WEN 29 procent, FSW 19 procent, rechtsgeleerdheid 14 procent, letteren 13 procent en archeologie en theologie beide 10 procent van hun budget uit de tweede en derde geldstroom haalden. 


\section{Internationalisering}

Sinds de jaren zeventig maakt de universiteit ook in toenemende mate werk van de internationalisering van haar onderwijs en onderzoek. Naast het bestaande netwerk van individuele contacten van onderzoekers en de praktijk om studenten op stage te sturen of excursies te organiseren, kende de universiteit natuurlijk een International Centre (1967). Een echt beleid kwam echter pas twee jaar later van de grond met de oprichting van een Vaste commissie

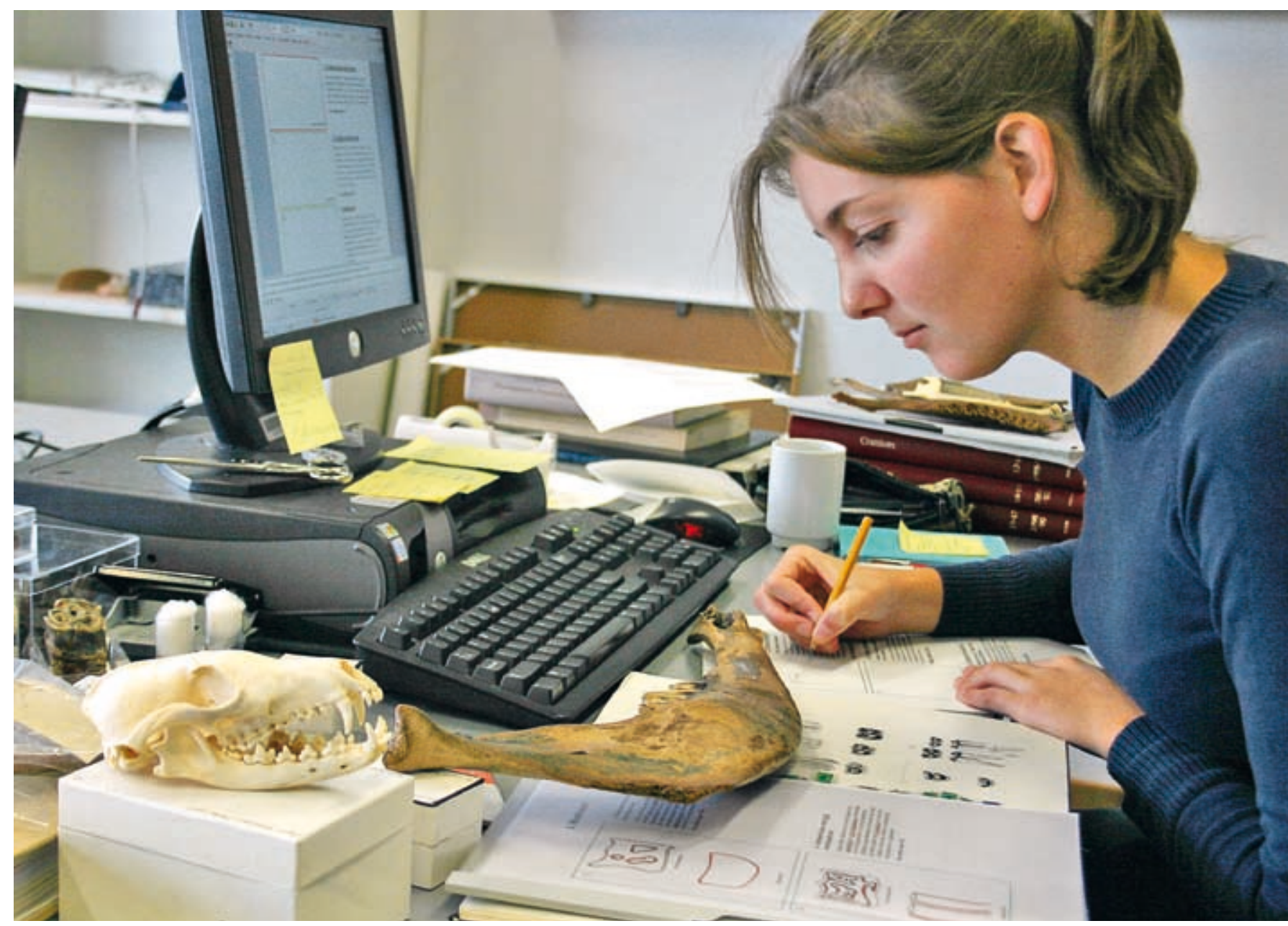

\ Studente paleontologie aan hetwerk 


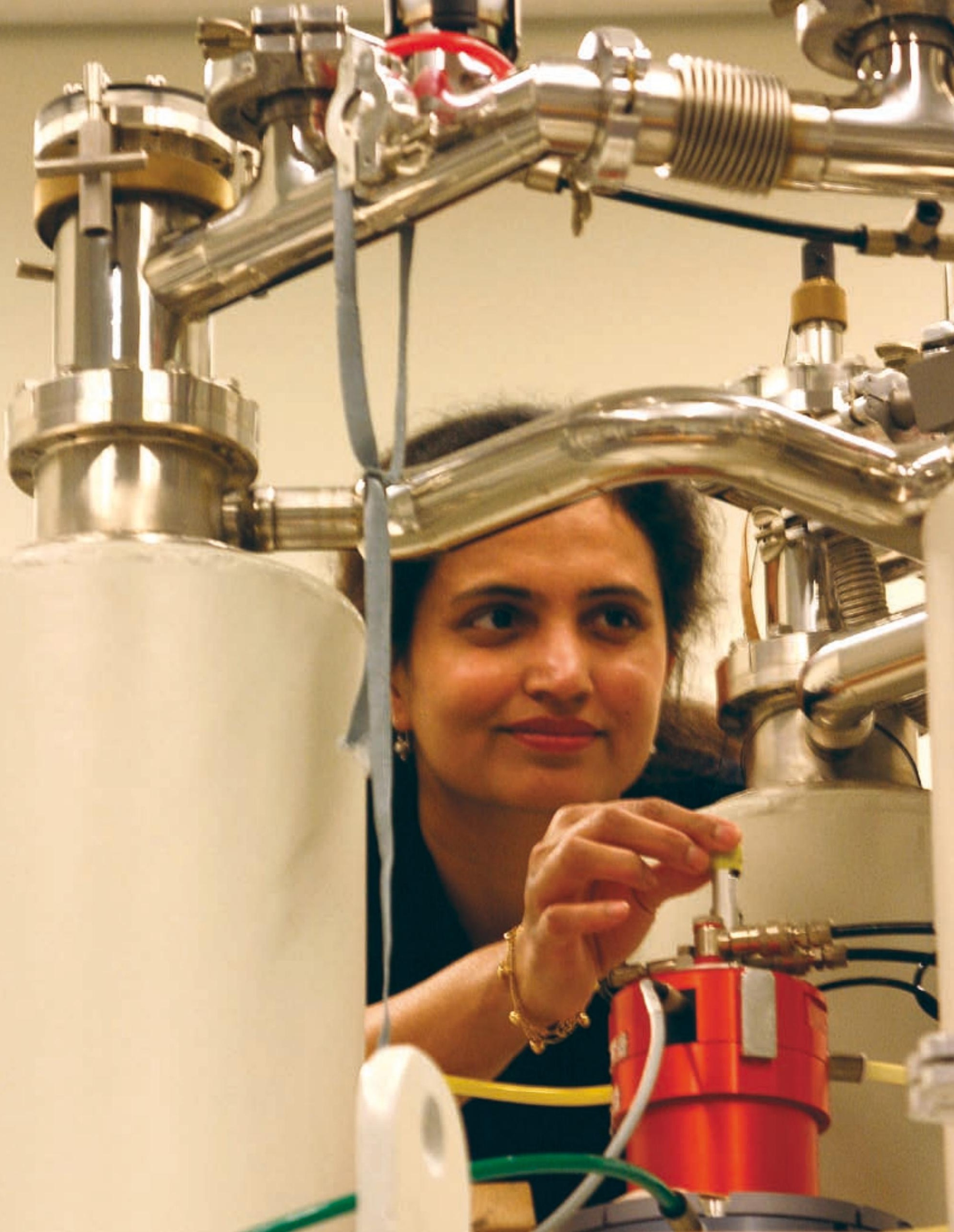


buitenland, die niet alleen de internationale wetenschappelijke contacten moest bevorderen, maar ook de studie van buitenlanders te Leiden en van Leidse studenten elders.

Aanvankelijk kende dit initiatief een onmiskenbaar ideële inspiratie: de behoefte een bijdrage te leveren aan vraagstukken als het milieu, de verhouding arm-rijk en het probleem van oorlog en vrede. Pragmatischer van inslag was de poging het traditionele wetenschappelijke verkeer in één richting te doorbreken door intensieve participatie van geleerden en instellingen ter plekke. De Werkgroep (later Instituut) voor de Geschiedenis van de Europese Expansie en de Reacties daarop (IGEER), opgericht in 1975, is een voorbeeld daarvan. Vergelijkbare initiatieven waren de postdoctorale opleidingen die de vakgroep talen en culturen van Zuidoost-Azië organiseerde en die deels in Leiden, deels in Indonesië plaatsvonden. Het herstel van de culturele betrekkingen met Indonesië vanaf 1968 gaf eveneens de aanzet tot allerlei projecten waarin taalkundige, cultuurhistorische en sociologische disciplines samenwerkten.

Het bestaan van collecties als die van het Rijksmuseum voor Volkenkunde vormde vanouds een belangrijke bron van inspiratie. Рага-universitaire instellingen als het Nederlands Instituut voor het Nabije Oosten, het Afrika Studie Centrum en het Koninklijk Instituut vоor Taal-, Land- en Volkenkunde (KITLV, vanaf 1967 in Leiden) werden dichter bij de universiteit getrokken. Nieuwe collecties, zoals van het Documentatiecentrum voor het moderne China (sinds 1965) en van IGEER, werden opgezet. Instellingen als het Institute for Asian Studies, het Indonesia-Netherlands Cooperation Programme for Islamic Studies en het Centrum voor Internationale Juridische Samenwerking werden hieraan toegevoegd.

Hierdoor kregen belangrijke culturele instituten in het buitenland, zoals in Jakarta, Caïro en Tokio, die een sober of bijna bedreigd bestaan leidden, een nieuwe raison d'être. In Caїro werden leergangen voor studenten Аrabisch en archeologie opgezet en kreeg een samenwerkingsverband met enkele Vlaamse universiteiten gestalte. Het Japan-Netherlands Institute in Tokio verzorgt de postdoctorale opleiding Japan Prize Winners Programma vоог een twintigtal getalenteerde studenten. Ook werden in bepaalde landen

\ Studente biochemie achter NMR-apparaat 
officiële vertegenwoordigers benoemd, personen die door langdurige ervaring met het land in kwestie de belangen van de Leidse universiteit ter plekke goed konden behartigen.

Dit alles impliceerde een andere oriëntatie. De klemtoon op ontwikkelingssamenwerking kwam te vervallen en een grotere nadruk kwam te liggen op de ondersteuning van onderwijs en onderzoek. Vanuit Brussel kreeg vooral onderzoek van interdisciplinaire aard ondersteuning. Mobiliteitsprogramma's als ERASMus (European Action Scheme for the Mobility of University Students), gevolgd door LEONARDo, ISEP en TEMPUS, alle acroniemen voor beurzen van verschillende strekking, zorgden егvoor dat ook Leiden een aanzienlijke aanwas van buitenlandse studenten te zien kreeg (en een substantieel deel van de eigen studenten wereldwijd kon uitsturen).

Vooruitlopend op ERASMus sloot Leiden in 1985 een samenwerkingsovereenkomst met een aantal traditionele, meestal oude Europese universiteiten, de zogenaamde Coimbra Groep, waarvan ze tussen 1986 en 1997 het voorzitterschap had. De gedachte was dat de ruim twintig aangesloten universiteiten elkaars studenten zonder heffing van collegegelden zouden opnemen. Samen met Oxford was Leiden in 1993 tevens de oprichter van EuRopeum, een 'international university without walls', met inmiddels tien participerende universiteiten. De samenwerking vindt plaats op het gebied van onderwijs en wetenschap in vooral de sociale wetenschappen, de humaniora en het wetenschapsbeleid.

Als gevolg hiervan maakte de internationalisering van het Leidse onderwijs in de periode 1985-1995 een enorme ontwikkeling door. In 1994-1995 nam niet minder dan 21 procent van de Leidse doctoraalstudenten deel aan enig trimester of semester van een buitenlandse universiteit. Op dat moment onderhield de Leidse universiteit zelf ongeveer negentig bilaterale contacten en was ze via de verschillende groepen en beurzenprogramma's verbonden met ongeveer tweehonderd andere potentiële programma's 


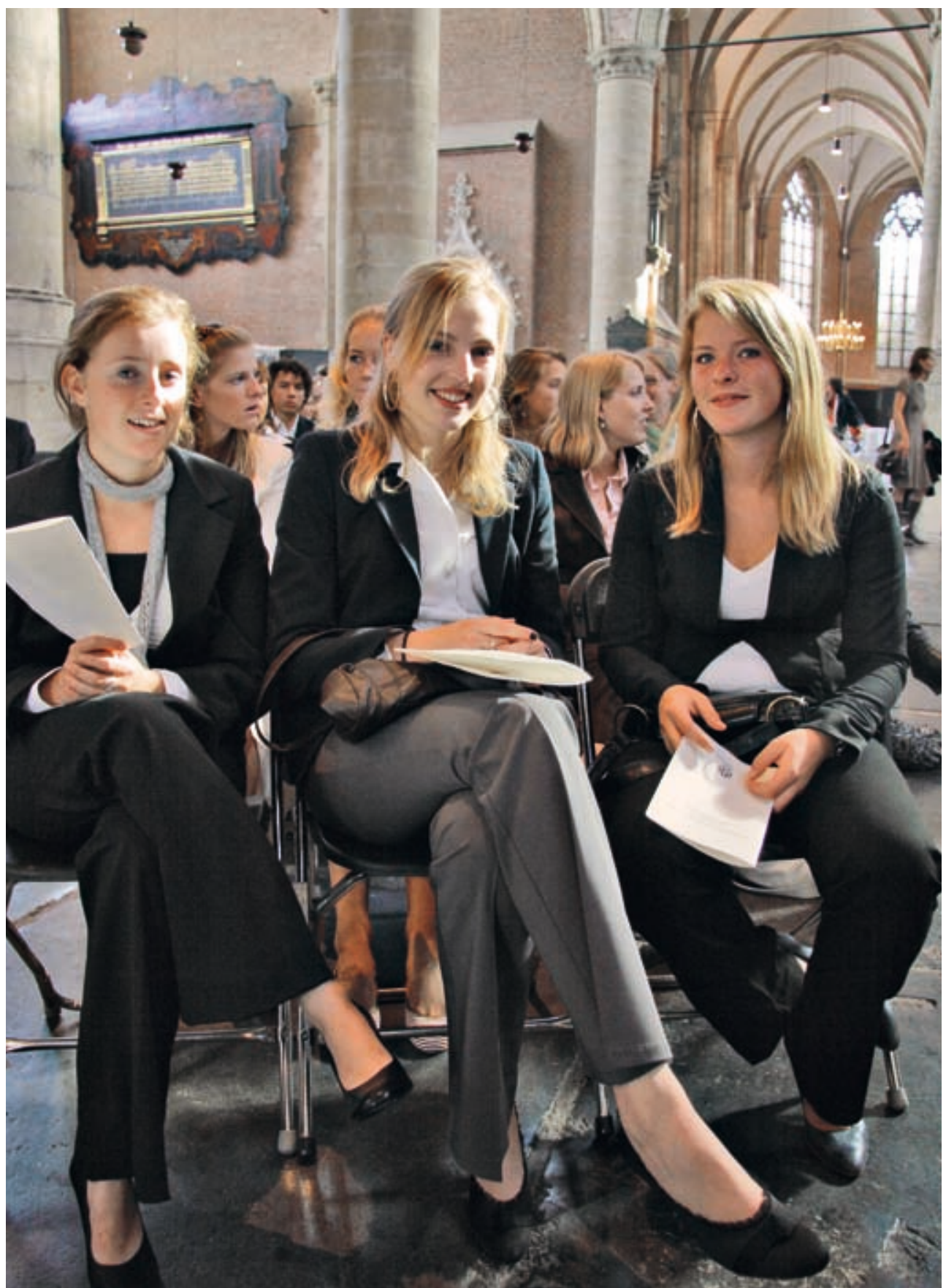

^ Bestuursfunctionarissen studentenvereniging bij opening academisch jaar 


\section{Studentenleven}

'Sous les pavés la plage', was de utopische slogan waarmee de Parijse studenten in mei 1968 de straat veroverden. Ze hoopten onder het plaveisel het zachte strand te vinden, onder de eeltlaag van het kapitalisme het kloppende hart van de mens. De straat is inmiddels weer gewoon de straat, met zijn ietwat pejoratieve connotatie, en het strand oefent wel aantrekkingskracht uit, maar dan toch als goede tweede na het terгas. En op dat terras worden studenten bediend door medestudenten. Als er een pregnant beeld is waarmee de stille revolutie te vangen is die het studentenleven sinds de jaren zeventig heeft ondergaan, dan is dat wel het terras, een perpetuum mobile waar 'de' student tegelijk geld verdient en uitgeeft, werkt en relaxt, en eigenlijk geen student meer is.

Want dat is wat er, na de roerige jaren zestig en zeventig, en de rustige jaren tachtig en negentig, gebeurd is: de student werd een geëngageerde burger, zij het dat 'engagement' in die eerste decennia iets heel anders betekende dan tegenwoordig. De filosofen hadden volgens Marx de wereld alleen maar op verschillende manieren geïnterрreteerd. Het kwam eropaan de wereld te veranderen. De studenten hebben het omgekeerde parcours afgelegd. Het brandende verlangen de maatschappij te verbeteren is omgeslagen in een groot aanpassingsvermogen aan de wereld, en dat is de wereld van het kapitalisme en de tucht van de markt.

Een blik op de activiteiten van het vormingswerkcentrum van de Leidse universiteit dat in 1971 zijn poorten opende, is informatief. Een inventarisatie in het universiteitsblad Mare van oktober 1980 leverde niet minder dan 33 activiteiten op. Hieronder waren verschillende werkgroepen (Chemie en samenleving, Milieubeheer, Indonesië, Vrouwengeschiedenis, Oorlog en vrede) en actiegroepen (Stop de Neutronenbom, Boycot Outspan, Schaf de armoe af, Amnesty International), maаг ook de AвvA/каво en andere belangengroeperingen. Verder de Leidse rechtswinkel, de Wetenschapswinkel, de Chemiewinkel, verschillende faculteitsverenigingen (medici, biologen, politicologen) en een mêlee aan vormingswerk, politieke en religieuze clubs. En ten slotte emanciperende initiatieven en bijlesdiensten. En natuurlijk het onvolprezen LAK. 
Niet alleen de diversiteit maar vooral de omvang van dit vormingswerk, bij lange na niet volledig vermeld, toont aan dat de studentenmaatschappij een intense behoefte had zichzelf en de omgevende wereld niet alleen te kennen maar ook te beïnvloeden. Die behoefte lijkt de huidige Leidse studentenbevolking vrijwel geheel te ontberen. In dit verband veelgebruikte termen zijn 'individualisering' en 'verzakelijking'. Veel meer dan twintig jaar geleden zou de student van nu gericht zijn op individueel gewin of persoonlijk plezier. Het gaat hem of haаг niet meer om vorming maar om training, niet meer om ontplooiing ten dienste van de maatschappij maar om oefening ten behoeve van een carrière. Organiseerden de verenigingen voorheen discussieclubs en pressiegroepen, nu concentreren ze zich op excursies naar bedrijven en banenmarkten.

Verschil in samenstelling van de studentenpopulatie en een veranderde studiefinanciering werkten hierbij samen. De populatie veranderde in twee opzichten: van sociaal zeer gemengd naar tamelijk homogeen en van dominant mannelijk naar evenwichtig verdeeld over de seksen. De sobere studiefinanciering noopte de studenten massaal tot bijverdienen. Dit alles had tot gevolg dat het studentenleven geen uitzondering meer vormde in het maatschappelijk leven. In de jaren zeventig hadden 'gewone' jongeren weinig behoefte aan contact met studenten. Nu zijn de studenten nauwelijks meer te onderscheiden in wat men de jongerencultuur noemt.

Ook seks en politiek vermochten de Leidse student niet langer in gewetensnood brengen. De condoomautomaten legden het af tegen de seriële monogamie, elke vereniging kreeg haаг homoclub en vrouwelijke preses; aan een Vrouwennetwerk, zoals de universiteit dat zelf vanaf 1984 kende, hadden de studenten geen behoefte. De belangstelling vоor raads- of commissiewerk liep sterk terug en om zijn stem uit te brengen in universitaire verkiezingen komt nog geen dertig procent van de studenten zijn bed uit. Dit komt overigens niet doordat de Leidse studenten hun politieke belangstelling verloren hebben, maar omdat zij die veeleer beleven op landelijk niveau.

Dit alles laat zich gemakkelijk bewijzen aan de hand van een korte geschiedenis van de gezelligheidsverenigingen die Leiden kent. Daarvoor is in het bestek van dit boek geen plaats, hooguit kan hier de diversiteit die - ondanks 
6.
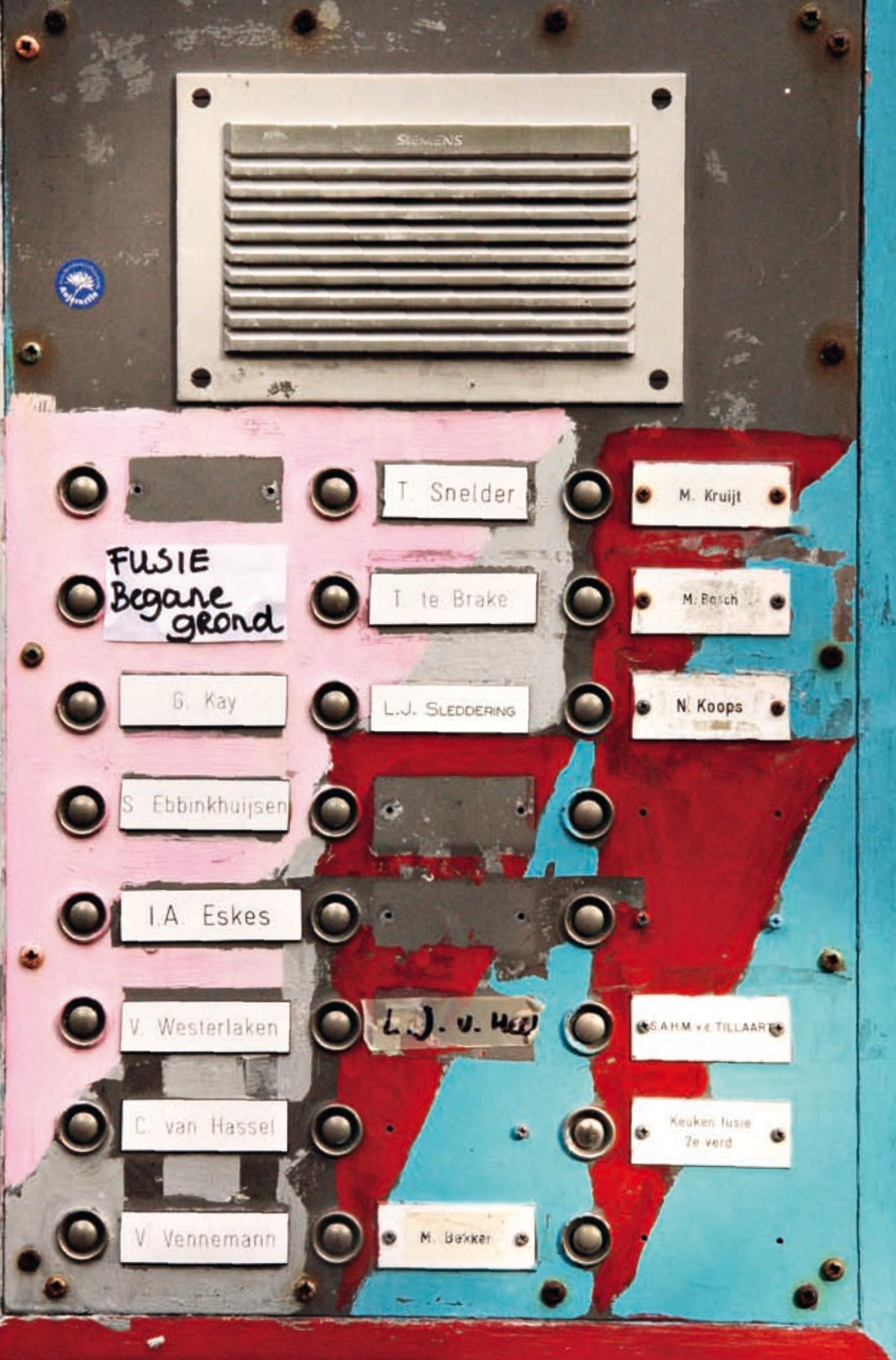
de eenheidsbevorderende tendensen - binnen het studentenleven bestaat, geïllustreerd worden. Naast de oudere verenigingen als het Leids Studenten Corps (LSC) en de VVsL, Augustinus en SsR, kreeg Leiden in 1952 met Catena een vereniging die nadrukkelijk het sleetse Civitas-ideaal doorbrak en zich openstelde voor niet-confessionele niet-corpsleden. Dit wat dwarse imago heeft de kleine vereniging altijd behouden.

In de jaren zestig verlieten de beide religieuze studentenverenigingen hun confessionele grondslag en hervonden die ook niet meer, zij het dat wat bij de één 'humanisme' heet en bij de ander 'nestgeur' nog steeds historische connotaties kent. Aanvankelijk leken deze verenigingen op te lossen in hun maatschappelijke openheid, maar in de jaren tachtig legden ze zich weer toe op jaarclubs en disputen en werden ze weer studentikozer van aard. Dat kan zeker gezegd worden van Quintus, de nieuwe, vijfde vereniging. Opgericht in 1969 was dit aanvankelijk een epifyt, die de andere verenigingen leegzoog door 'het primaat van de onverbiddelijke gezelligheid'. Маar naarmate de andere weer gezelliger werden, werd Quintus gewoner.

De teneur en de smaak van het Leidse studentenleven worden, althans voor de buitenwacht, nog steeds bepaald door de grootste vereniging, het in 1972 uit een fusie van Lsc en vvsl ontstane Minerva. Dit was niet alleen de grootste en de oudste, ze wist moeiteloos de vooroordelen jegens de student als prachtvee op temperatuur te houden. Of het nu jasje-dasje was en broek met plooien, of twinset en pennyshoes, het Minervalid meende men van verre te kunnen herkennen. Dat bleek vaak lastiger dan gedacht, al moest men ook in de heyday van lang haаг en baarden toegeven dat dergelijke dracht ter sociëteit schaars was.

Naast de gezelligheidsverenigingen kent Leiden vanaf de negentiende eeuw studieverenigingen en vakdisputen. Ze zijn nog steeds kenmerkend voor het studentenleven in de zin dat ze in hun activiteiten steeds de organisatie en werking van senaat en universiteit kopiëren. Studieverenigingen kwamen op voor de 'studeerbaarheid' van het curriculum, voor de opvang van eerstejaars, de organisatie van introductiedagen (te Leiden El Cid geheten) en mentoraten. Inmiddels is gezelligheid ook daar troef, evenals bij de disputen. De meeste daarvan bevinden zich in de alfafaculteiten en sommige 
zijn van eerbiedwaardige oudheid, Quisque suis viribus bijvoorbeeld, dat sedert 1841 de theologen dient. De kern van de activiteiten, het houden van voordrachten en het bekritiseren van elkaars producten, lijkt steeds minder eerstejaars aan te spreken. De vlucht in de gezelligheid ligt ook hier voor de hand.

\section{Onze manieren}

Kennis en kunde hebben behoefte aan tradities, niet alleen in de humaniora, ook in de exacte wetenschappen. Dit is de centrale stelling van Edward Shils in zijn boek Tradition. Het zelfbewustzijn van de universiteit voegt daaraan een dimensie toe: mores hebben hier een gevarieerder en intensiever bestaan dan elders. En ten slotte: het permanente proces van verandering waaraan de universiteiten al een eeuw blootstaan, leidt vanzelf tot het 'uitvinden' van tradities. 'Invention of tradition neemt toe', schrijven Hobsbawm en Ranger, ‘wanneer een snelle maatschappelijke verandering het sociale patroon waarvoor oude tradities ontworpen waren uitholt of vernietigt.' Dergelijke tradities symboliseren sociale cohesie, ze bevestigen het lidmaatschap van reële of artificiële groepen, ze trachten de status van een instelling te markeren.

Dit proces laat zich goed illustreren aan de hand van het Leidse studentenleven. Uit een naar leeftijd, achtergrond en herkomst gefragmentariseerde groep, die niets met de stad en weinig met de rest van de universiteit te maken had, groeide in de loop van de negentiende eeuw onder grote spanning een hecht studentencorps dat erkenning zocht, zowel in de stedelijke omgeving als bij het professoraat. Het kopiëren van de eigen sociëteit naar de burgerlijke sociëteiten, van de ontgroening naar de promotie, van de gang van zaken bij het studentikoze dispuut naar het professorale college, het op zich nemen van zoiets als vrijwillige dienstplicht, het organiseren van maskerades, stadsfeesten en armenconcerten, het zijn evenzovele mores die de interne cohesie bewerkstelligden en de band met universiteit en stad bevestigden.

Vоor de historische beeldvorming is de evolutie van mores dan ook een belangrijk signaal. Centraal voor het idee van een sociëteit was de leestafel. In zijn ijver zich aan de burgerlijke sociëteit te spiegelen, schiep het studenten-

- Studentenhuis aan hetRapenburg 


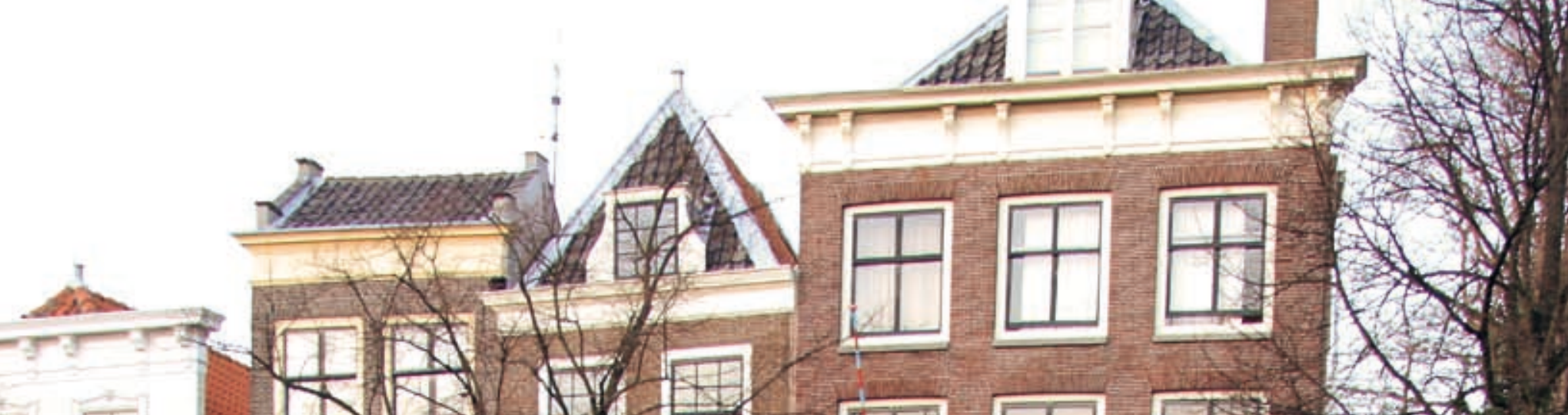
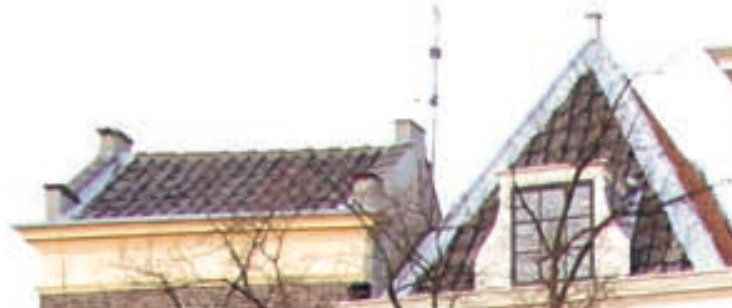
$\therefore \rightarrow$ The

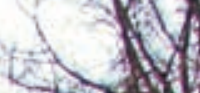
II
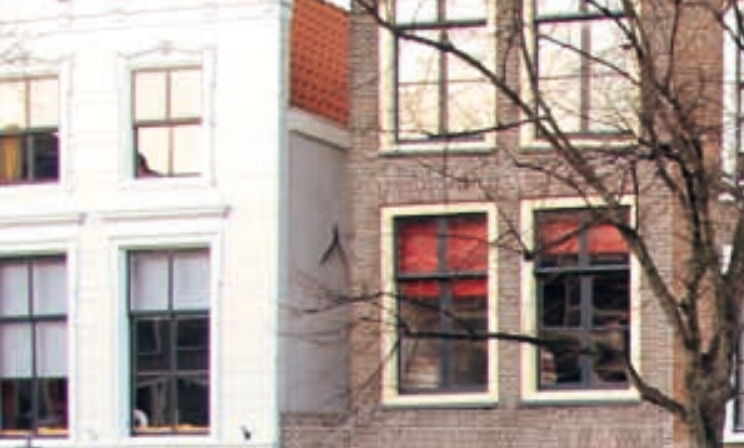

(2)

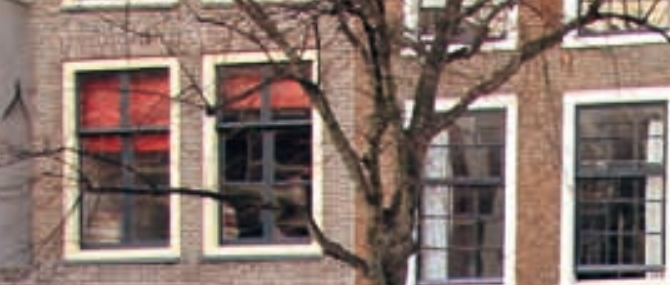

12
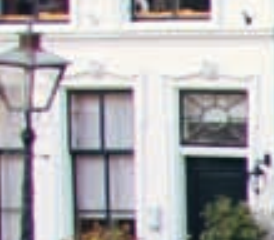

ation
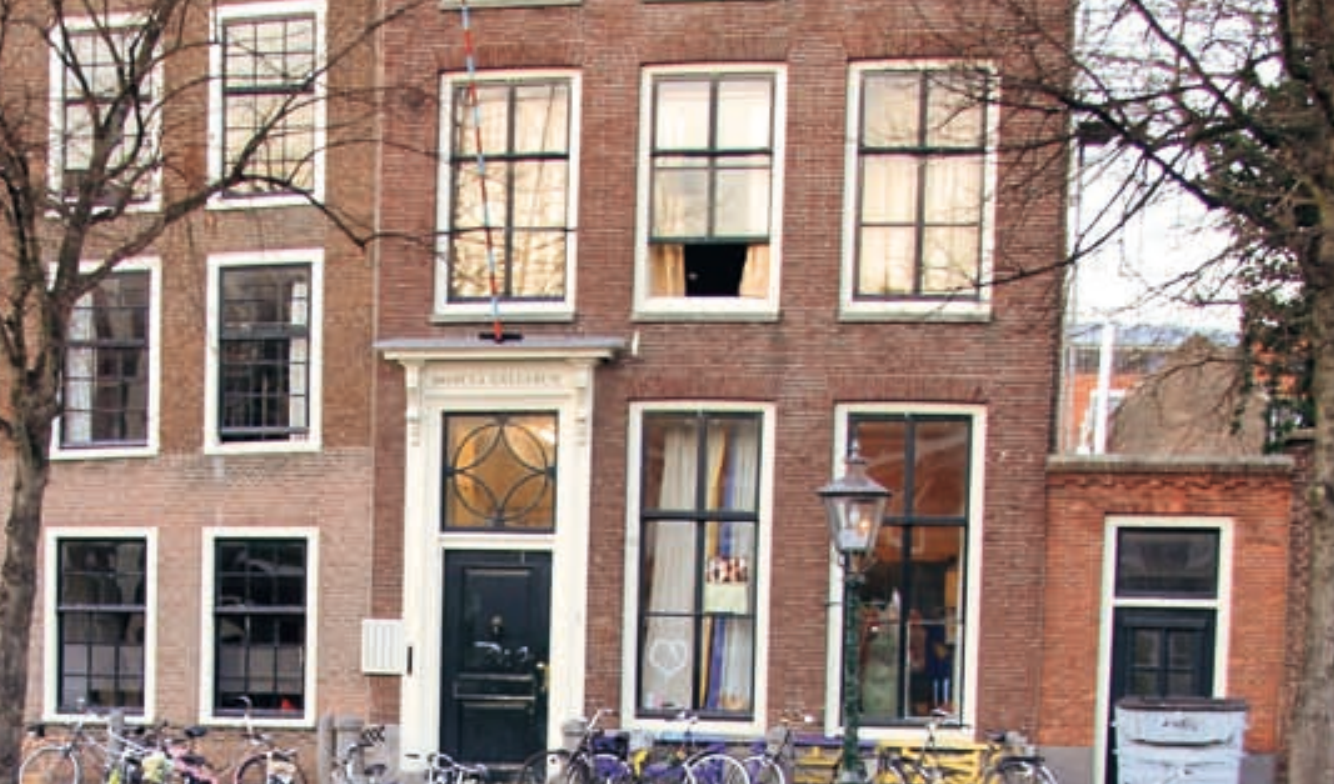

(1) 102 (M)

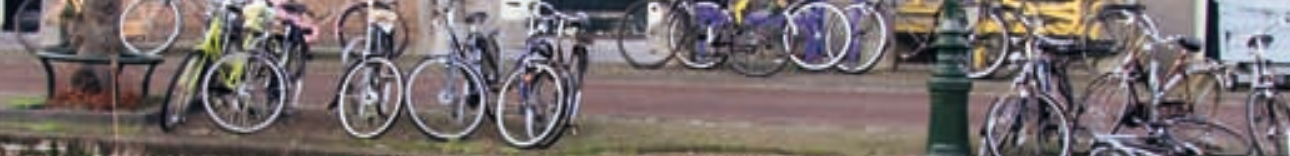

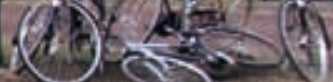

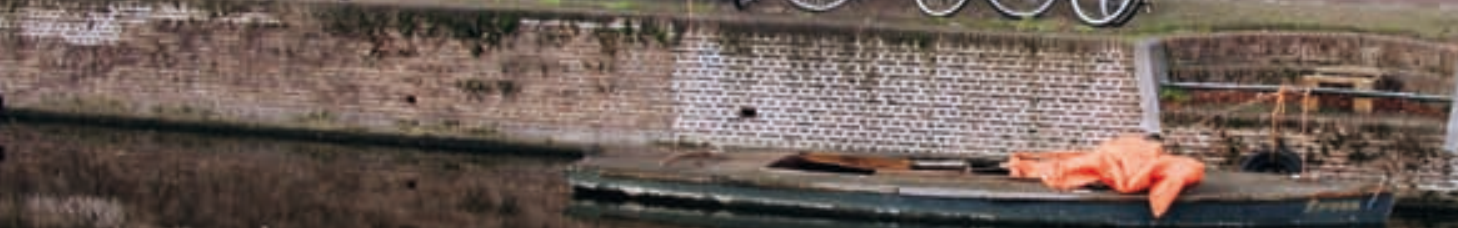

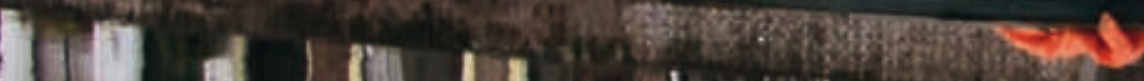

Et

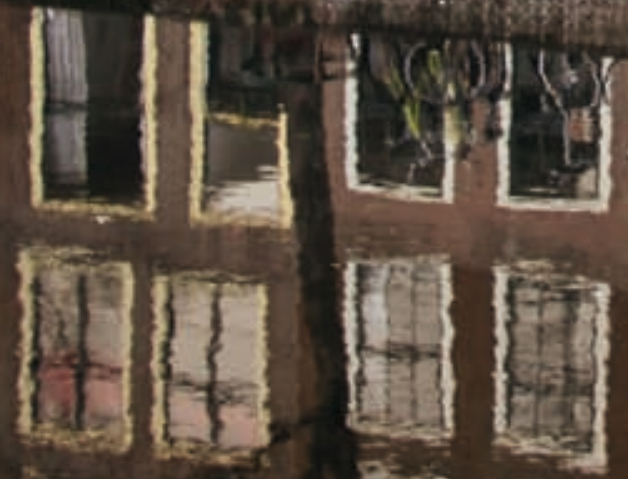

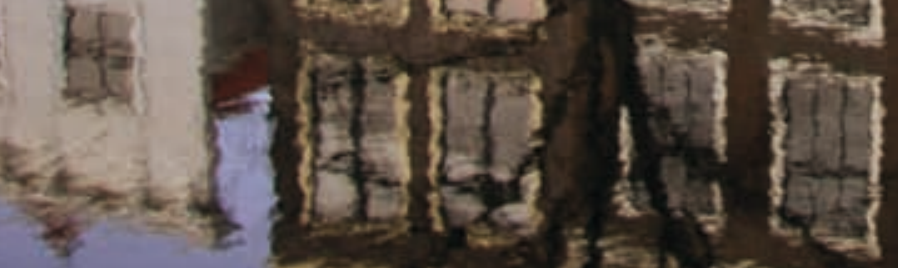
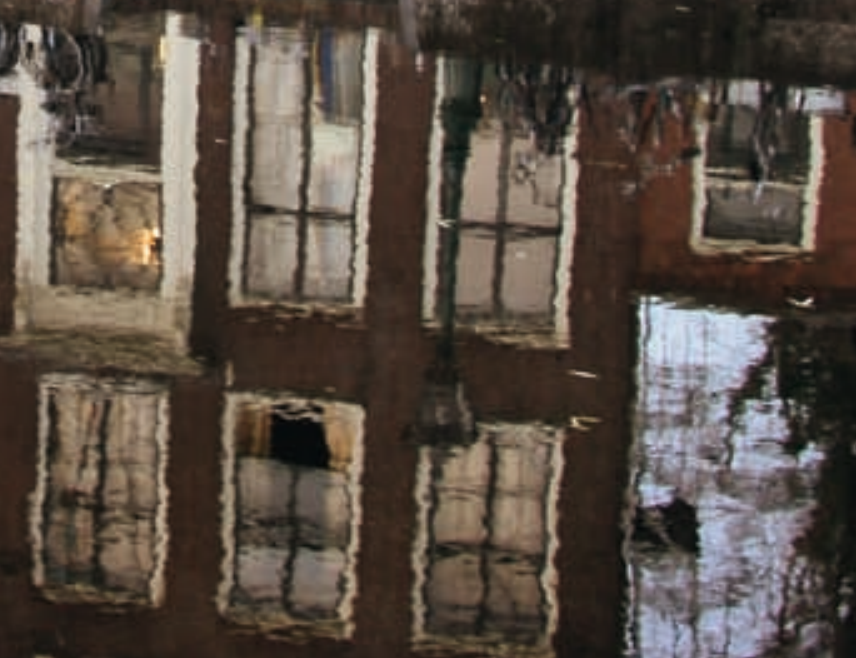

MB: IAI

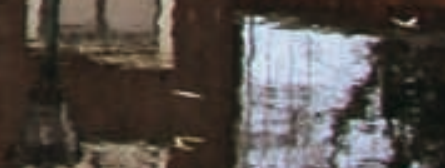

$2 i=8$ 
corps zich een leestafel van indrukwekkende overdaad. Rond 1900 waren ег op die leestafel van sociëteit Minerva niet minder dan 93 bladen te raadplegen, waarvan 33 in een vreemde taal. Daaronder waren 25 dagbladen en van de resterende periodieken hadden 25 een ontspannend, 25 een breed intellectueel karakter; 18 waren wetenschappelijk van aard. Het was die tafel die aan het einde van de eeuw strijdtoneel werd van maatschappelijke emancipatie. De debatten over de aanschaf van sociaaldemocratische bladen barstten door de blinden heen en die bladen kwamen er wel, maar men vond ze vaak verscheurd terug aan de voet van de leestafel.

In het huidige tijdsgewricht is de leestafel nog steeds het centrum van een reeks mores, al hebben die vrijwel niets meer met lezen van doen. Men kan 'leestafeltjetillen', zoals dat heet. Ook wordt de tafel wel geschoffeerd om er bierestafettes te houden. 'Bolletjedrinken' noemt men dat en het bestaat uit het zo snel mogelijk leegdrinken van een lampenbol vol bier. Het verst van zijn oorspronkelijke gebruik verwijderd is het 'blaadjeglijden', waarbij de leestafel schuin op de balustrade gelegd wordt. Een remweg van kleinere tafeltjes wordt eraan toegevoegd en vervolgens laat men zich op een dienblad naar beneden roetsjen. Ook het 'leestafelzooien', getrek en geduw aan het meubel door verschillende jaargroepen, lijkt moeilijk met lezen gecombineerd te kunnen worden.

Uit dit nadrukkelijk antithetische gebruik kan men ook een ander aspect van het mos afleiden, dat van (zelf)ironisering. Zo is de oude band die de Leidse universiteit heeft met het Koninklijk Huis vervlochten met andere leestafelmores. De tafel heet ook wel agora, en wie wat op zijn lever heeft en dat kwijt wil, kan dat vanaf de tafel doen. Dat kost een fles champagne (op de sociëteit 'poepel' genoemd), tenzij de spreker erin slaagt bij het openen daarvan met de kurk het ruitje te treffen dat de Alexanderpokel beschermt. Door te proberen een geschenk van het Koninklijk Huis te beschadigen, kan de student kosteloos zijn mening verkondigen.

De gemeenzame omgang met het Koninklijk Huis van 'Hare Majesteits Eerste', zoals het Leidse studentencorps zich noemt, blijkt ook uit het bestaan van de zogenaamde lippjes. Sinds prins Bernhard (von Lippe Biesterfeld) het verbod om de voeten te laten rusten op het haardtafeltje overtrad, werden 
daar lippjes op aangebracht: uitschuifbare stukjes hout waarop men de voeten kan laten rusten. Het vierde јаar en later mag zelfs van deze lippjes eten.

Ook de universiteit zelf houdt een mos in stand dat direct met het Koninklijk Huis van doen heeft: een telegram waarmee ze aankondigt dat ze haar dies, haar stichtingsdag, viert en daarmee haar stichter, Willem van Oranje, eert. Voorheen placht de senaat in zijn vaste vergadering op de ochtend van de dies de tekst vast te stellen en dan was er 's middags een antwoord dat op het senaatsdiner voorgelezen kon worden. Nu er geen senaat meer is en dus geen senaatsdiner, verzendt het college van bestuur het telegram en leest de rector het antwoord voor aan het einde van de diesplechtigheid. Soms is er nog geen antwoord en dan vraagt men trouw waar het blijft.

Er zijn ook negatieve mores, en ook die dienen ter afbakening van de eigen identiteit. Zo had de Leidse rector tot voor enige decennia geen ambtsketen. De ontstentenis daarvan werd verklaard op grond van de eenheid en gelijkheid van de hoogleraren als leden van de senaat. Маar het aardige bijverschijnsel was dat de Leidse rector zo wél opviel te midden van alle nationale rectoren die er wel eentje hadden. In het buitenland bleek deze eenvoud echter minder te werken en leek de Leidse rector een gewone professor die verdwaald was zeker. Op zeker moment werd dit als lastig ervaren en kwam er, begin jaren zeventig, een ketting.

Wel hield Leiden vast aan de eenvoudigste toga. Het officiële kledingvoorschrift daагоvег dateert van 1877. Toen werd bij кв bepaald dat hoogleraren bij publieke promotie en andere plechtigheden een toga van zwarte zijde en een muts van zwart fluweel zouden dragen, met, zo luidde de toevoeging, 'zwarte onderkleding en een witte das en bef'. Te Leiden werd op niet meer vast te stellen tijdstip besloten dit befvoorschrift, zoals het wat naïef heet, te negeren. Oud-rector Cohen, die een kleine kroniek van de Leidse mores schreef, herinnerde zich meegemaakt te hebben dat een van elders gekomen collega, die voorafgaand aan een oratie in toga met bef de senaatskamer betrad, toegeroepen werd: 'bef weg!'

Eveneens Leids zijn twee mores rond de promotie. Zo betekent het binnenkomen van de pedel en zijn 'hora est' het onverbiddelijke einde van de gedachtewisseling, inderdaad midden in de zin. Ook verbiedt het mos de promo- 
vendus in het voorwoord van zijn proefschrift dank te betuigen aan de promotor. Vindt een promotie of oratie plaats in het Groot Auditorium, dan wordt 'degenen gezeten onder het orgel', dat wil zeggen: het dichtst bij de deur, immer tot zekere hilariteit verzocht het laatste de zaal te verlaten. Houdt een nieuwe hoogleraar zijn oratie, dan wordt hij voorafgaand aan de plechtigheid welkom geheten in de senaatskamer door de rector die zijn verdiensten opsomt en hem daarna steevast vraagt of hij weet waar zich op dat moment zijn rede bevindt. Het bevestigende antwoord alleen is dan voldoende.

Ook bij het afstuderen kende de Leidse universiteit haar eigen ongeschreven regels. Wanneer een student bij het doctoraalexamen door de pedel uit het zweetkamertje werd opgeroepen met de woorden 'meneer die en die mét gevolg', dan betekende dit dat de kandidaat was geslaagd. Het bestaan van dat zweetkamertje zelf, op de wanden waarvan geslaagde studenten vervolgens hun handtekening mogen zetten, is een van de diepst gekoesterde mores van de universiteit. Ook bij de promotie is een bepaald woordgebruik veelzeggend. Spreekt de voorzitter van de commissie in termen van 'op voortreffelijke wijze verdedigd' of 'bijzondere verdiensten' dan weet men dat het predicaat cum laude gegeven gaat worden, een 'cummetje' in de wandelgangen.

Het bestaan van veel van dergelijke mores kwam in de jaren zestig en zeventig sterk onder druk te staan. De massaliteit van het onderwijs maakte de handhaving ervan vaak ingewikkeld, de associatie ervan met burgerlijkheid en repressiviteit maakte naleving ervan suspect. Zo kon het dragen van een toga omschreven worden als onderdeel van 'een ouderwets, semi-aristocratisch, bloedserieus, burgerlijk ritueel'. Kralenketting in plaats van zwarte das, sneakers in plaats van zwarte schoenen, zetten deze overtuiging kracht bij. Ook minder progressieve geesten егvoeren Leiden als 'een pre-literaire maatschappij, waar niets op schrift stond en waar de ouden het voor het zeggen hadden'.

Sinds de tweede helft van de jaren tachtig is er een duidelijke revival van de mores waаr te nemen. Allereerst keerden de afstudeerrituelen terug. De formalisering van het examen werd ongedaan gemaakt, studenten kleedden zich weer op hun paasbest en kwamen onder begeleiding van ouders en familie nаar de buluitreiking. Toespraken en champagne, afstudeerliederen en 


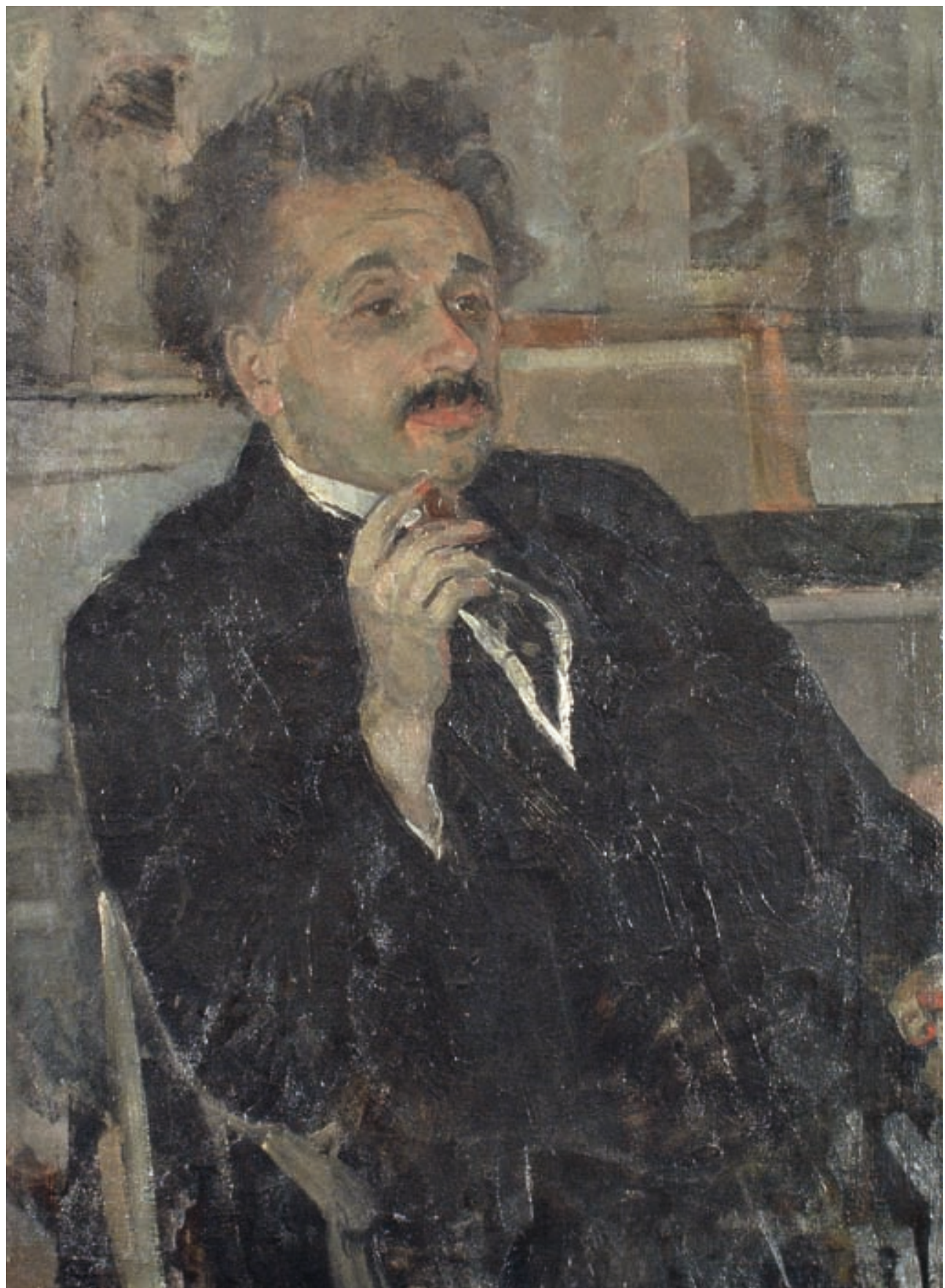

\ AlbertEinstein (1879-1955). Bijzonder hoogleraar natuurkunde (1920-1946) 
gefilmde studiebiografieën, alles op het stramien van de negentiende eeuw, beleefden hun kleurrijke comeback. De opleidingen houden hun eigen opening van het academisch jaar, met hoogleгагеncortège. Een decaan van de rechtenfaculteit beijverde zich om in het Guiness Book of Records te komen met het гесогd van vierduizend met speech en al uitgereikte bullen.

Deze terugkeer van het ritueel is niet specifiek voor Leiden en evenmin voor de universiteit. Toch is het zeker daar dat men er de traditionele vruchten van plukt in de vorm van 'a method to disagree', bij gebrek aan modieusheid. 'Nergens lopen de meningen zo sterk uiteen als daar,' herinnerde zich een psycholoog die Leiden verruilde voor Maastricht. 'En toch verdraagt iedereen elkaar en gaan de mensen ongedwongen met elkaar om.' Tolerantie en liberalisme, het was de ervaring van veel van buiten komende hoogleraren. De Leidse slavist Karel van het Reve beschrijft in zijn afscheidsrede hoe juist de mores егуоог zorgden dat zelfs iemand afkomstig uit het goddeloze Amsterdam, uit het proletarische Betondorp, uit een communistisch gezin, van een als 'rood' bekendstaand gymnasium en van een nog rodere universiteit, toch welkom was aan 'de Вогоboedoer der bourgeoisie'.

Het impliceerde een zekere ontoegankelijkheid voor modes. Het was, opnieuw in de woorden van Van het Reve, alsof de mores een dempende werking hadden op de manier waarop het nieuws te Leiden doordrong. Hij herinnerde zich dat het senaatstelegram van de dies ooit gericht was aan prinses Juliana. Gelukkig kwam men er op tijd achter dat ze al tien jaar koningin was. Zo konden Leidse studenten de enige jaren tevoren overleden Jan Romein uitnodigen voor een lezing. Zijn weduwe moet haar antwoord begonnen zijn met de woorden: 'Hoewel het mijn gewoonte niet is andermans brieven open te maken...' Of, zoals de weduwe van de Leidse natuurkundige Paul Ehrenfest, Tatjana Afanesjeva, ooit opmerkte: 'Nergens verloopt de overgang tussen leven en dood zo ongemerkt als in Leiden.' Ze zei dit wel tegen Einstein, die zich in het Leiden van Lorentz op zijn gemak voelde.

- Universiteitsvlag bestuursgebouw 


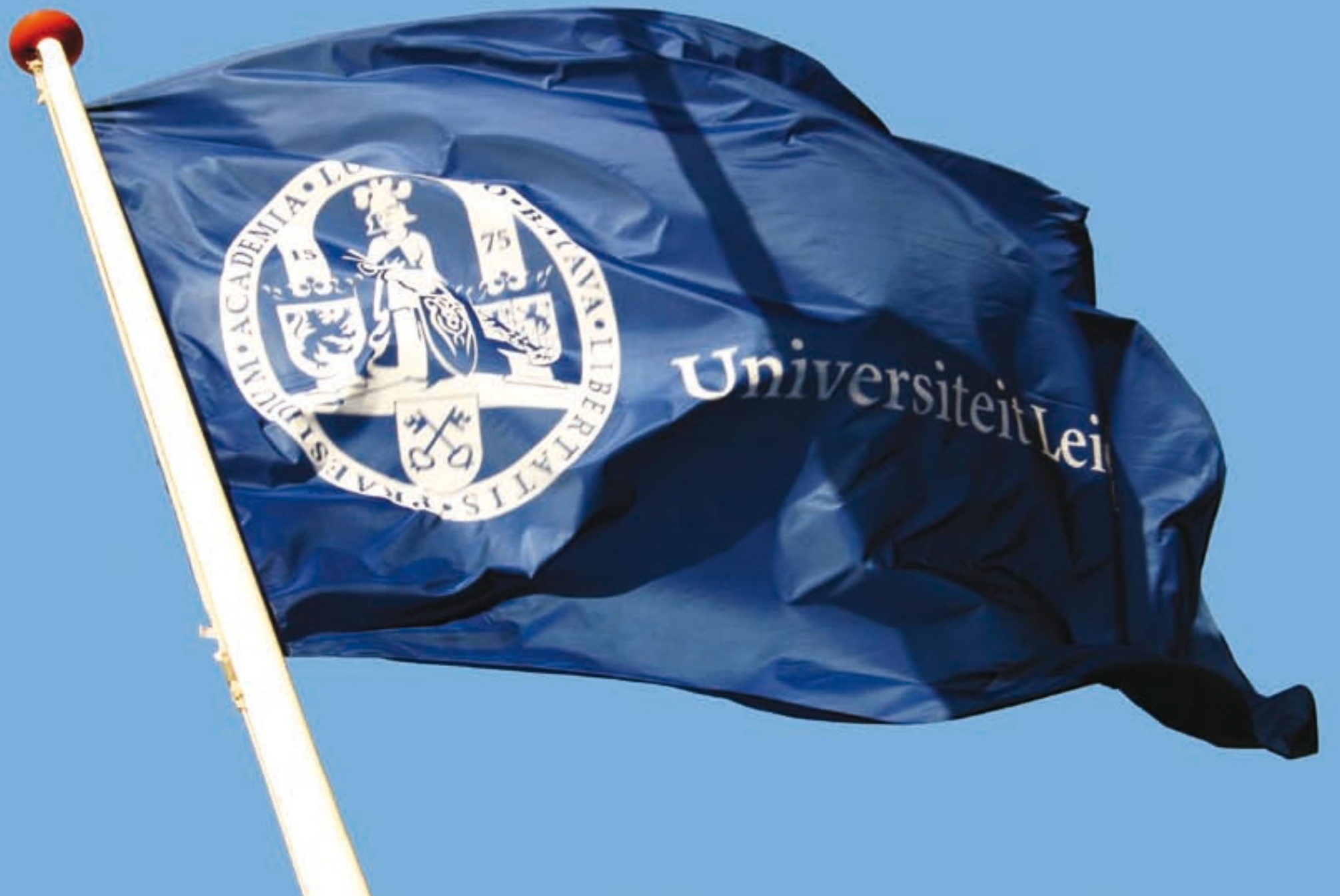




\section{HENDRIK ANTOON LORENTZ ARNHEMENSIS}

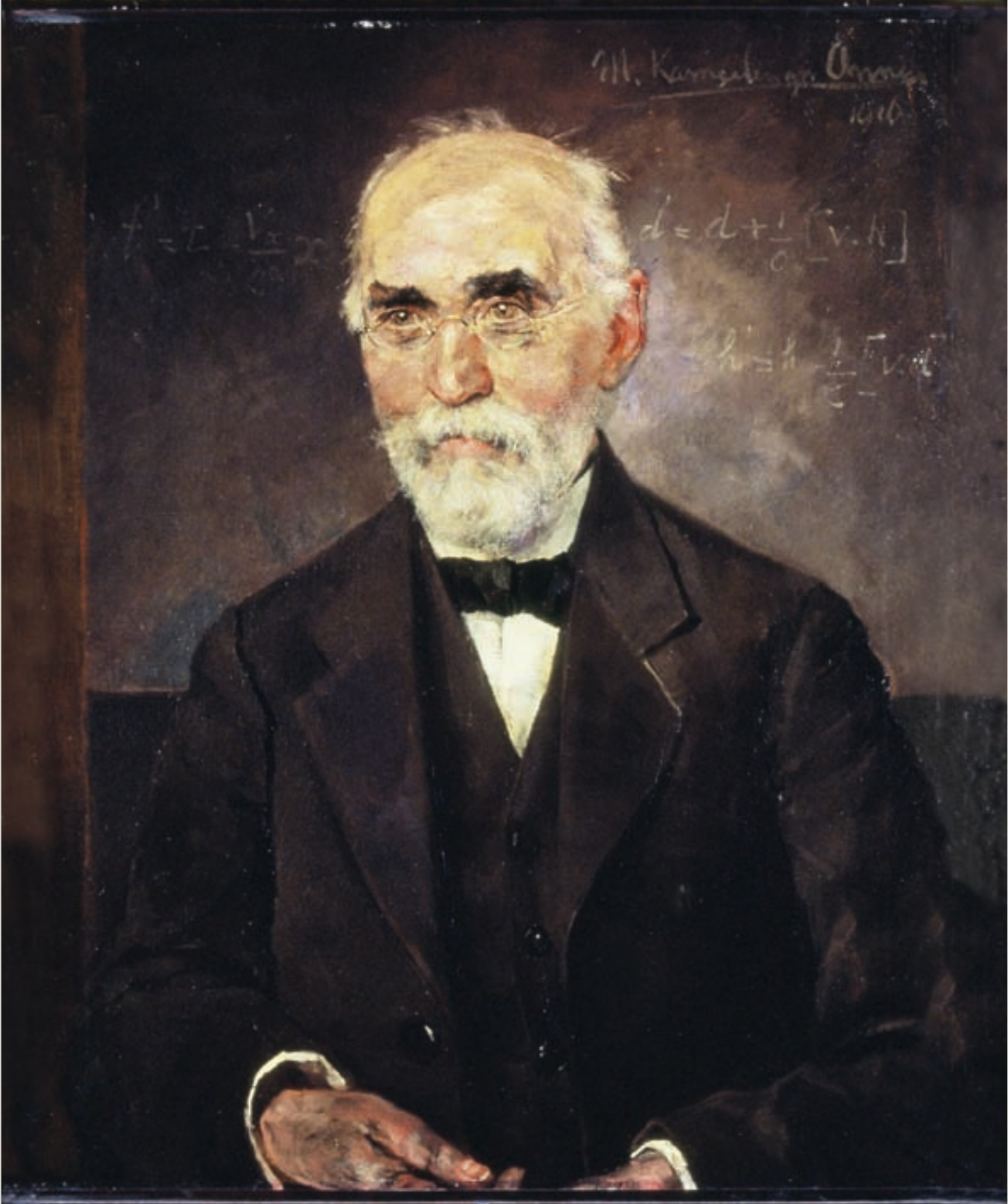

NATUS 18 JULII 1853 . PROF. PHYS. THEOR. IN AGAD. LUGD.BAT. 1878 . OBIIT HARLEMII 4 FEBR.1928. 


\section{HEIKE KAMERLINĞH DNNES. gRONINGENSIG.}

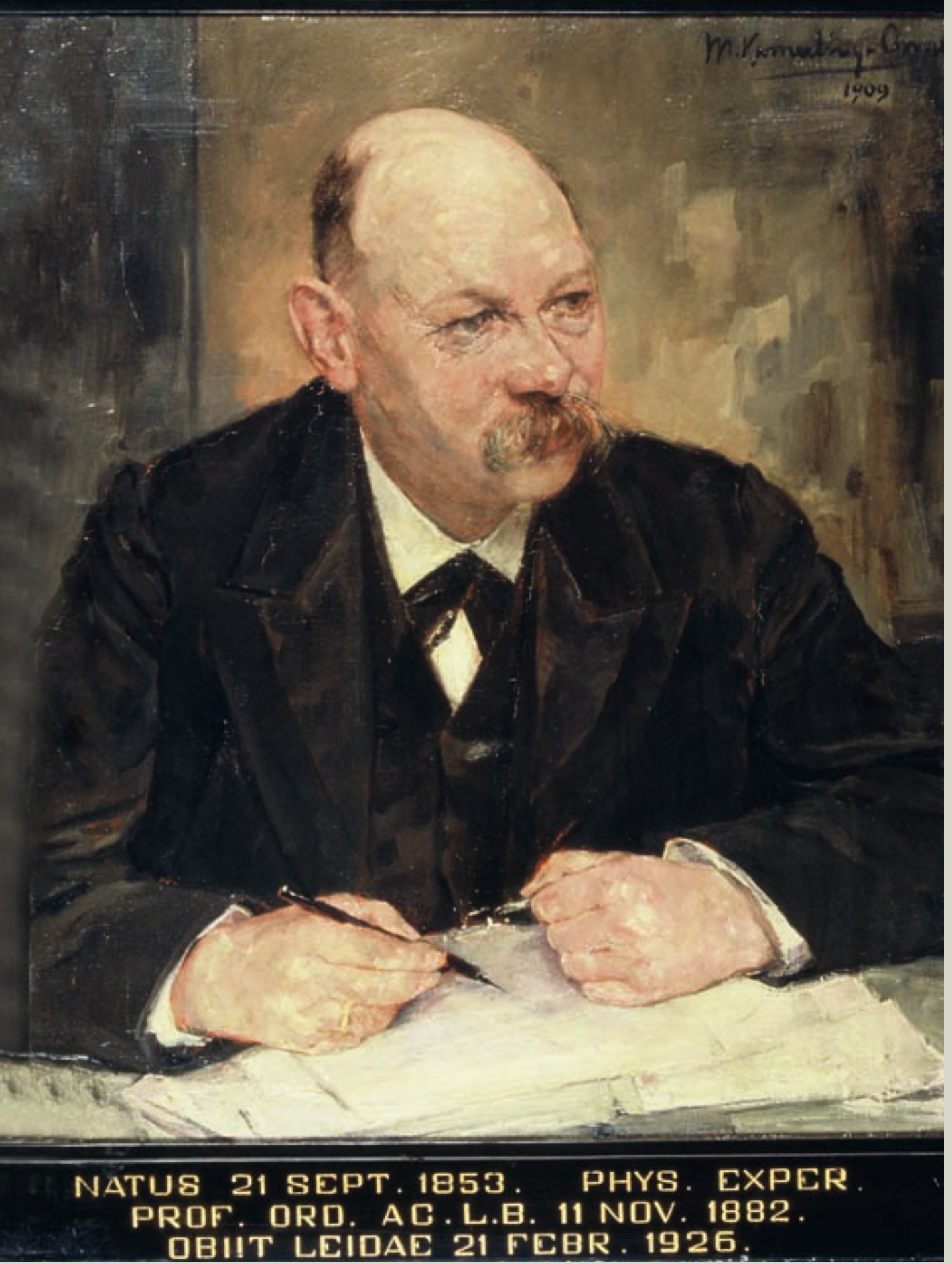




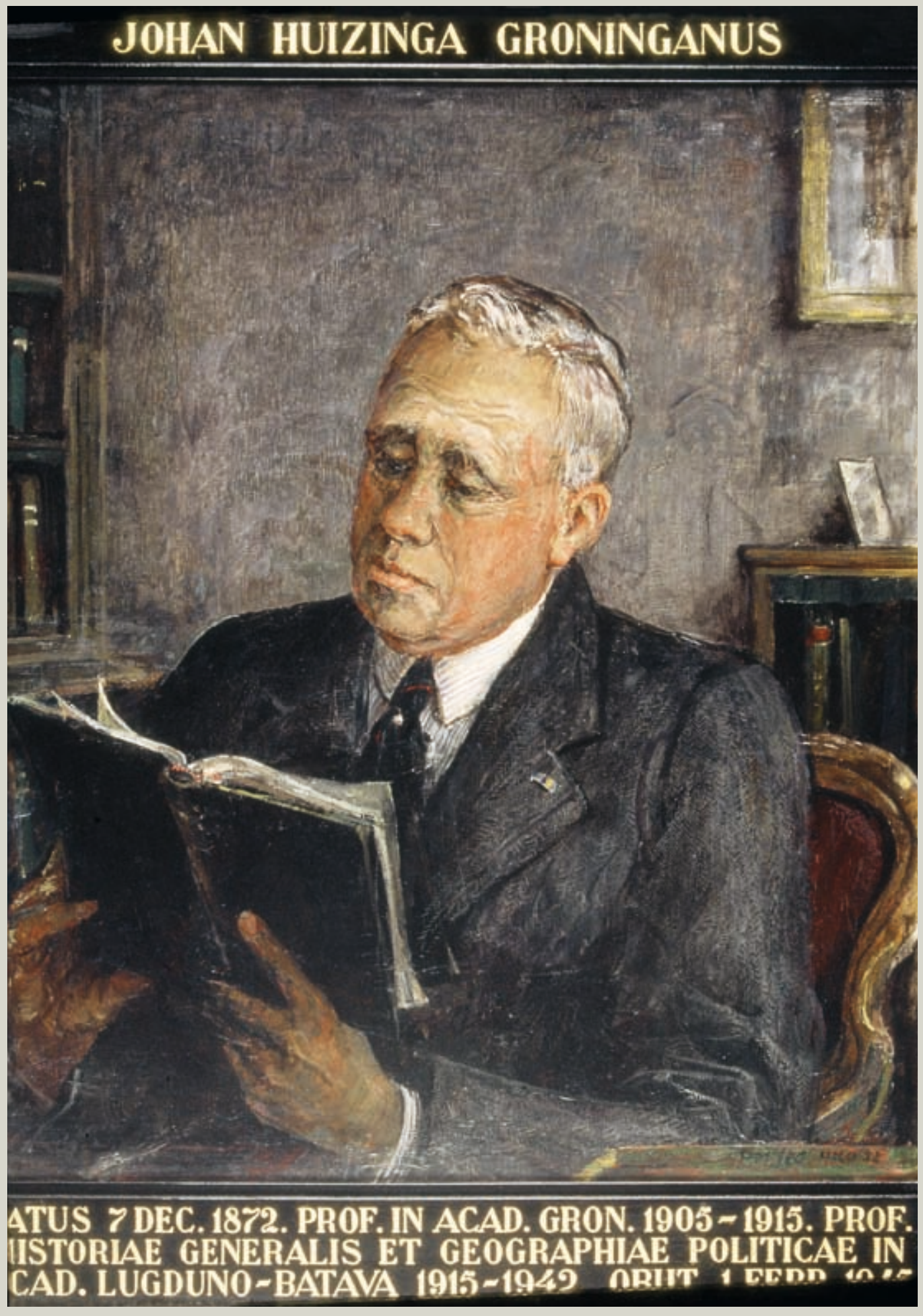




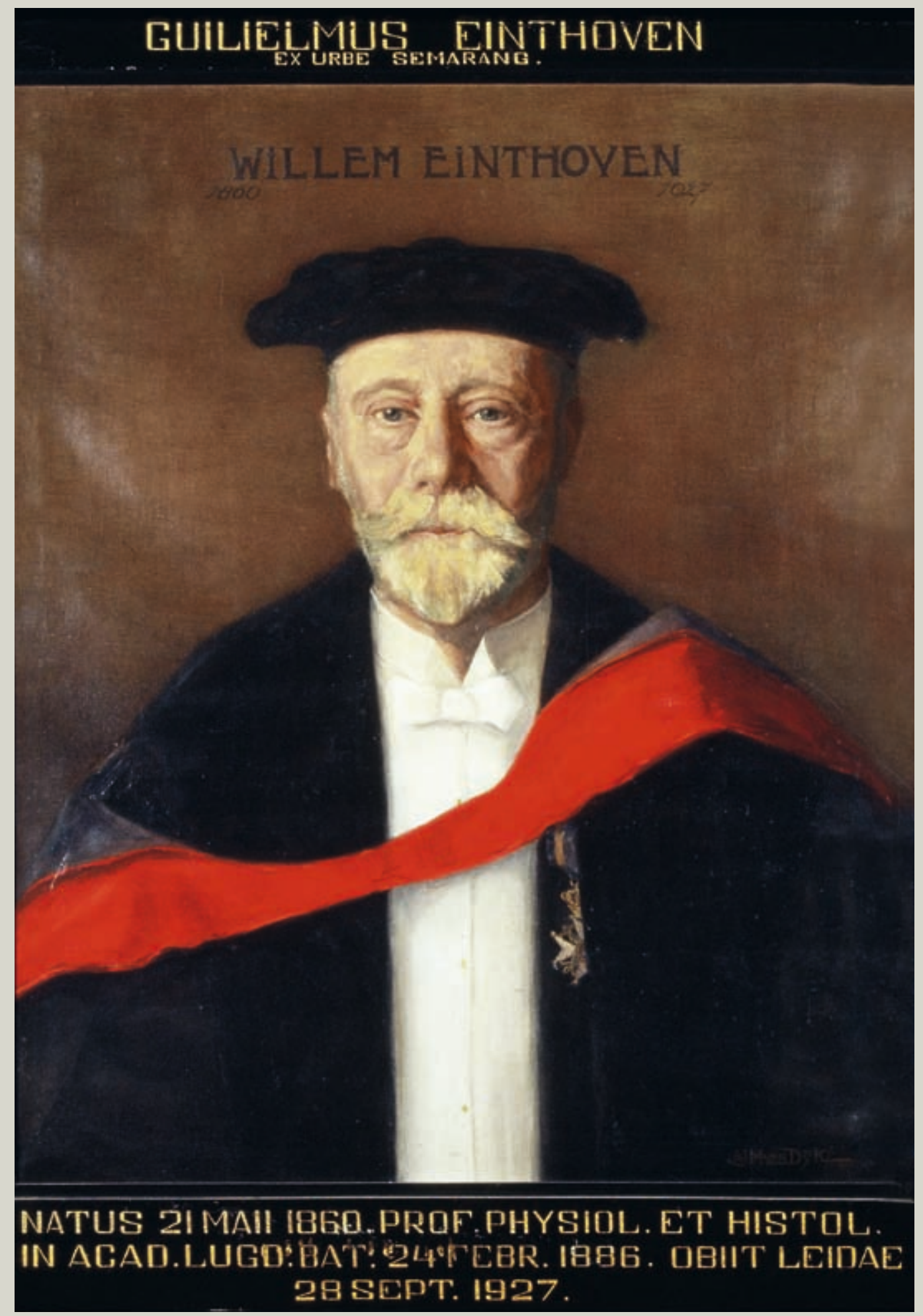




\section{Grafieken en tabellen}

In dit boek zijn op diverse plaatsen kwantitatieve gegevens opgenomen met betrekking tot aantallen studenten en (uit de laatste periode) aantallen wetenschappelijk en ander personeel. De gegevens over studenten zijn gebaseerd op verschillende bronnen: voor de periode 1575 tot 1875 is gebruik gemaakt van het Album Studiosorum, het boek waarin alle studenten vanaf de stichting van de universiteit werden ingeschreven en waarvan twee gedrukte versies bestaan (1575-1875 en 1875-1925). De gegevens over de periode daarna zijn gebaseerd op de jaarboeken van de universiteit, de gegevens vanaf 1975 zijn aangeleverd door de afdeling Informatiemanagement van het Bestuursbureau.

Hoewel de gegevens over de gehele periode redelijk compleet zijn is het moeilijk de lijn door te trekken aangezien er voortdurend wijzigingen plaatsvinden in de naamgeving van studierichtingen en faculteiten, de definitie van wat een student is en het inschrijvingsbeleid. Door vergelijking van verschillende bronnen en extrapolatie zijn de gegevens zo goed mogelijk op elkaar afgestemd.

De gegevens over medewerkers zijn eveneens geleverd door Informatiemanagement, op basis van jaarverslagen. 


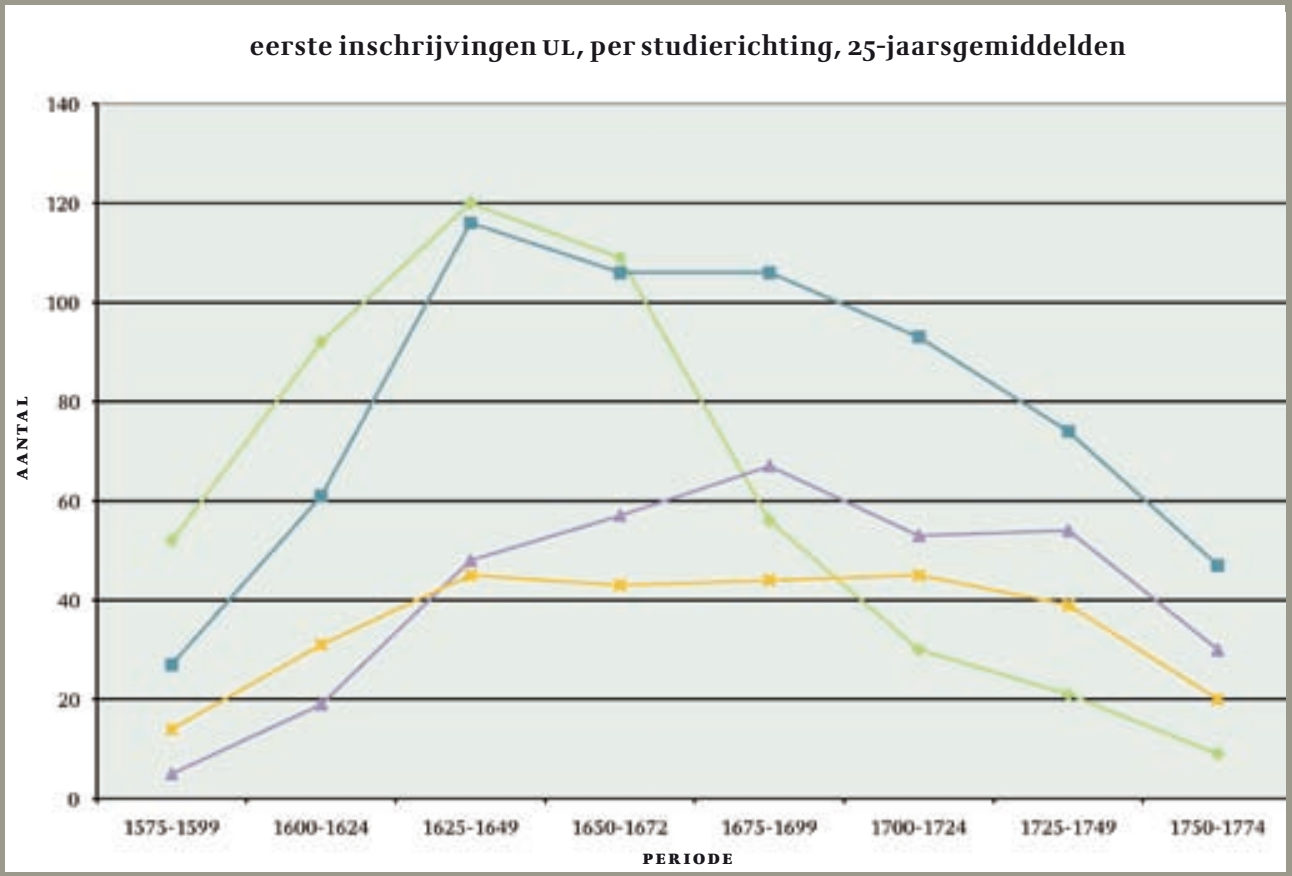

$\triangle$ Artes

Rechten

$\triangle$ Geneeskunde

$\times$ Theologie

eerste inschrijvingen UL, per faculteit , 25-jaarsgemiddelden

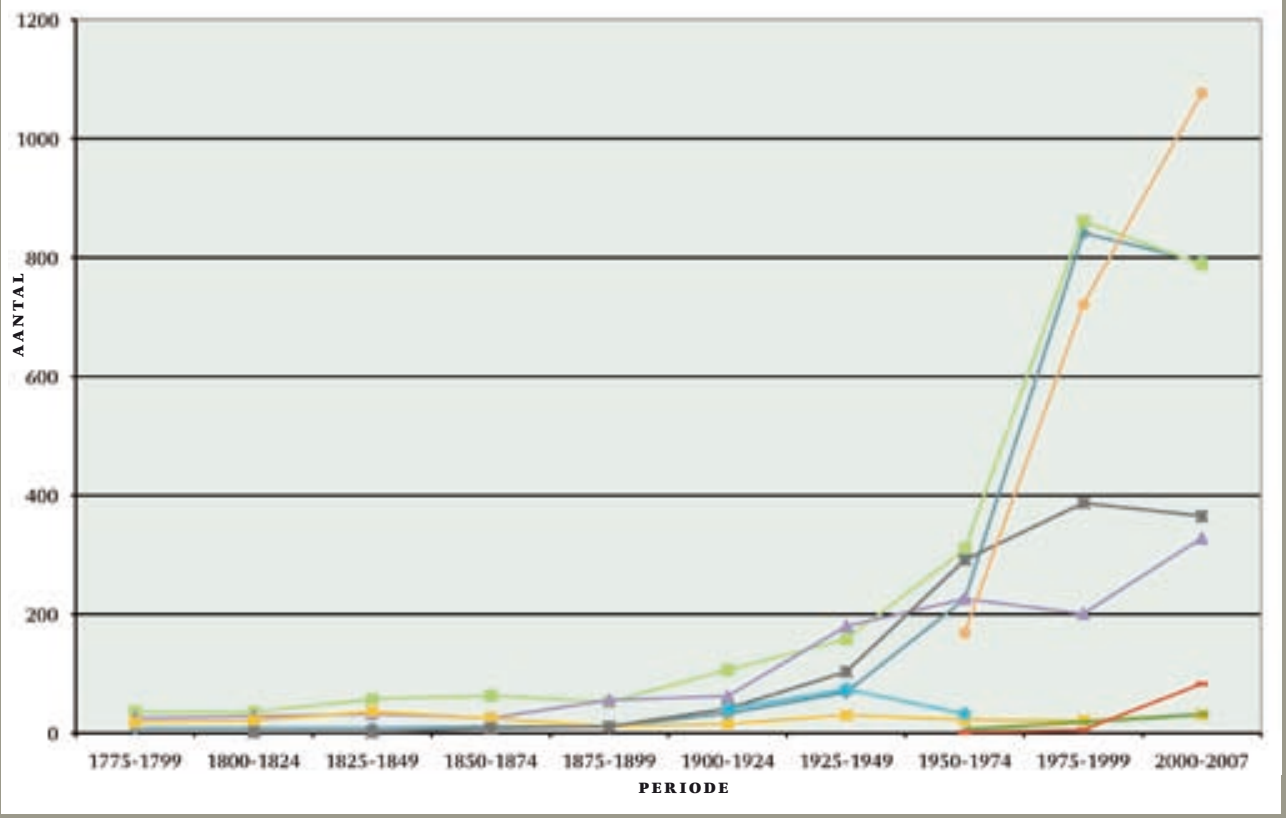

\section{Artes}

Rechten

$\triangle$ Geneeskunde

$\times$ Theologie

$\times$ Wis- en Natuurkunde

- RGL+Letteren

Sociale Wetensch.

- Wijsbegeerte

- Prehistorie 

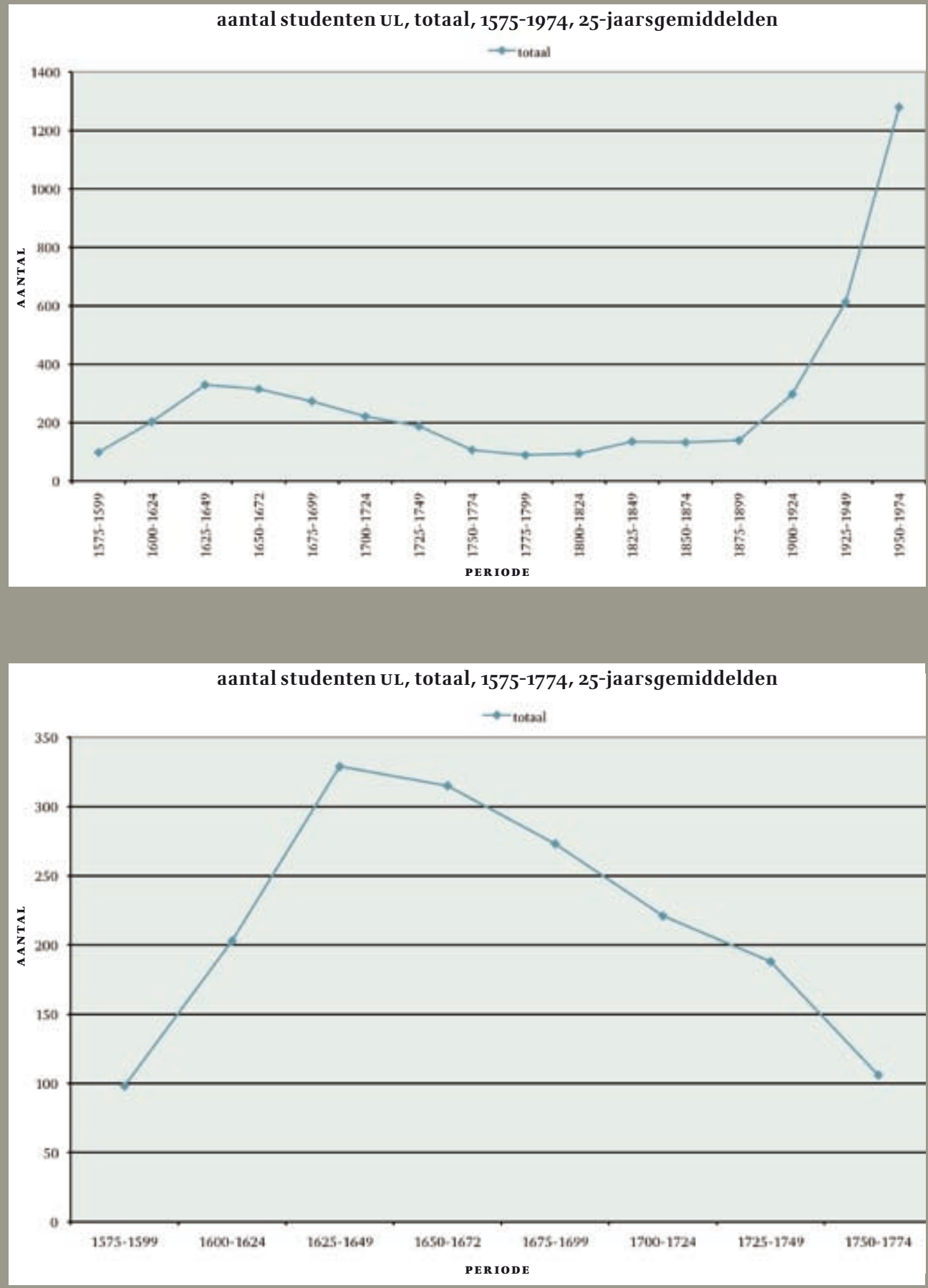


\begin{tabular}{|c|c|c|c|c|c|c|c|c|c|c|c|}
\hline & 葸 & 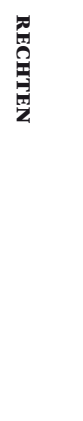 & 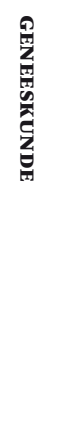 & 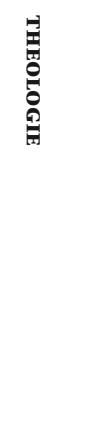 & 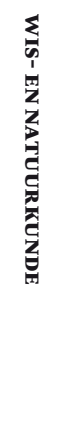 & 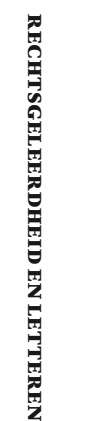 & 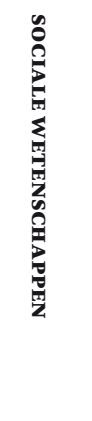 & 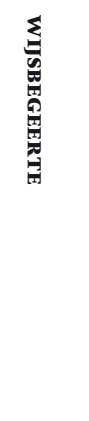 & 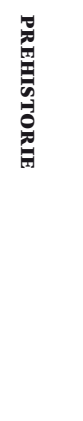 & 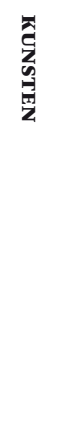 & 葛 \\
\hline 1575-1599 & 52 & 27 & 5 & 14 & & & & & & & 98 \\
\hline $1600-1624$ & 92 & 61 & 19 & 31 & & & & & & & 203 \\
\hline $1625-1649$ & 120 & 116 & 48 & 45 & & & & & & & 329 \\
\hline $1650-1672$ & 109 & 106 & 57 & 43 & & & & & & & 315 \\
\hline $1675-1699$ & 56 & 106 & 67 & 44 & & & & & & & 273 \\
\hline $1700-1724$ & 30 & 93 & 53 & 45 & & & & & & & 221 \\
\hline $1725-1749$ & 21 & 74 & 54 & 39 & & & & & & & 188 \\
\hline $1750-1774$ & 9 & 47 & 30 & 20 & & & & & & & 106 \\
\hline $1775-1799$ & 9 & 36 & 26 & 18 & & & & & & & 89 \\
\hline $1800-1824$ & 9 & 35 & 28 & 21 & 1 & & & & & & 94 \\
\hline $1825-1849$ & 8 & 57 & 32 & 36 & 2 & & & & & & 135 \\
\hline $1850-1874$ & 11 & 63 & 25 & 25 & 8 & & & & & & 132 \\
\hline $1875-1899$ & 10 & 52 & 55 & 11 & 11 & & & & & & 139 \\
\hline 1900-1924 & 33 & 106 & 62 & 15 & 41 & 40 & & & & & 297 \\
\hline 1925-1949 & 68 & 158 & 180 & 30 & 103 & 74 & & & & & 613 \\
\hline 1950-1974 & 225 & 309 & 226 & 22 & 291 & 32 & 168 & 6 & 1 & & 1280 \\
\hline 1975-1999 & 841 & 861 & 201 & 21 & 387 & & 721 & 18 & 5 & & 3055 \\
\hline $2000-2007$ & 793 & 789 & 328 & 31 & 365 & & 1076 & 31 & 83 & 4 & 3500 \\
\hline
\end{tabular}




\begin{tabular}{|c|c|c|c|c|c|c|c|c|c|c|c|c|}
\hline & 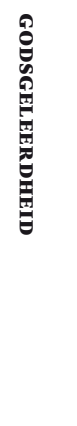 & 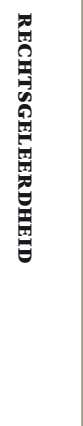 & 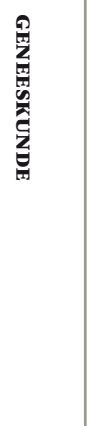 & 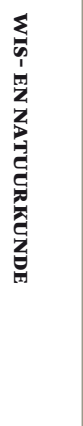 & 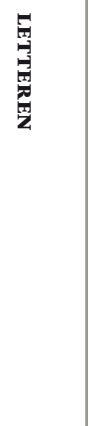 & 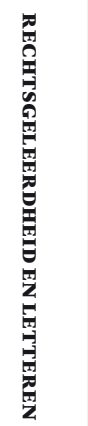 & 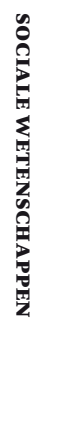 & 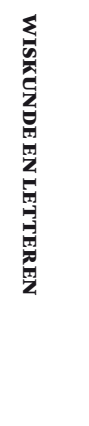 & 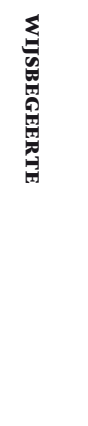 & 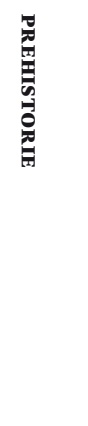 & 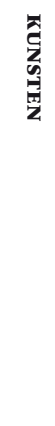 & $\begin{array}{l}0 \\
0 \\
0 \\
0 \\
0\end{array}$ \\
\hline 1950 & 30 & 219 & 258 & 189 & 105 & 94 & & 19 & & & & 914 \\
\hline 1951 & 34 & 211 & 216 & 154 & 169 & 43 & & 20 & & & & 847 \\
\hline 1952 & 18 & 194 & 200 & 121 & 105 & 29 & & 26 & & & & 693 \\
\hline 1953 & 19 & 172 & 137 & 129 & 106 & 27 & & 23 & & & & 613 \\
\hline 1954 & 19 & 159 & 141 & 126 & 116 & 27 & & 15 & & & & 603 \\
\hline 1955 & 18 & 157 & 139 & 186 & 141 & 31 & & 34 & & & & 706 \\
\hline 1956 & 13 & 144 & 147 & 178 & 148 & 41 & & 34 & & & & 705 \\
\hline 1957 & 15 & 161 & 147 & 197 & 160 & 49 & & 53 & & & & 782 \\
\hline 1958 & 14 & 166 & 177 & 201 & 179 & 63 & & 46 & & & & 846 \\
\hline 1959 & 13 & 160 & 181 & 234 & 214 & 64 & & 46 & & & & 912 \\
\hline 1960 & 13 & 171 & 210 & 248 & 241 & 59 & & 51 & & & & 993 \\
\hline 1961 & 11 & 201 & 184 & 283 & 242 & 55 & & 55 & & & & 1031 \\
\hline 1962 & 19 & 207 & 213 & 293 & 200 & 65 & & 66 & & & & 1063 \\
\hline 1963 & 13 & 192 & 238 & 287 & 218 & 82 & & 66 & & & & 1096 \\
\hline 1964 & 25 & 255 & 309 & 299 & 272 & 80 & & 71 & & & & 1311 \\
\hline 1965 & 26 & 303 & 295 & 367 & 246 & & 192 & & 9 & 1 & & 1439 \\
\hline 1966 & 30 & 414 & 290 & 395 & 255 & & 290 & & 10 & & & 1684 \\
\hline 1967 & 28 & 430 & 276 & 399 & 259 & & 292 & & 5 & 3 & & 1692 \\
\hline 1968 & 35 & 394 & 257 & 410 & 252 & & 322 & & 11 & 3 & & 1684 \\
\hline 1969 & 26 & 544 & 327 & 386 & 283 & & 337 & & 17 & 1 & & 1921 \\
\hline 1970 & 20 & 531 & 230 & 434 & 250 & & 371 & & 14 & 2 & & 1852 \\
\hline 1971 & 25 & 609 & 320 & 418 & 370 & & 445 & & 22 & 2 & & 2211 \\
\hline 1972 & 27 & 617 & 320 & 459 & 370 & & 429 & & 28 & 3 & & 2253 \\
\hline 1973 & 31 & 556 & 269 & 438 & 252 & & 479 & & 23 & 2 & & 2050 \\
\hline 1974 & 34 & 555 & 181 & 434 & 471 & & 413 & & 22 & 0 & & 2110 \\
\hline 1975 & 29 & 583 & 179 & 466 & 588 & & 448 & & 25 & 0 & & 2318 \\
\hline 1976 & 33 & 593 & 179 & 512 & 666 & & 542 & & 21 & 0 & & 2546 \\
\hline 1977 & 29 & 755 & 200 & 513 & 727 & & 568 & & 33 & 0 & & 2825 \\
\hline 1978 & 22 & 870 & 185 & 507 & 743 & & 566 & & 30 & 1 & & 2924 \\
\hline
\end{tabular}




\begin{tabular}{|c|c|c|c|c|c|c|c|c|c|c|c|c|}
\hline & 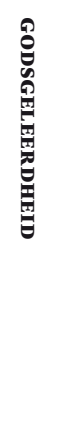 & 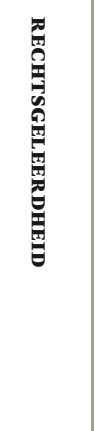 & 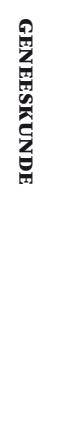 & 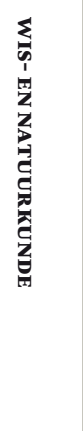 & 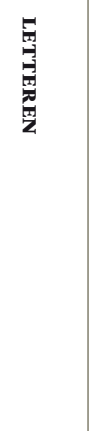 & 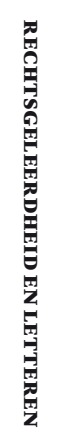 & 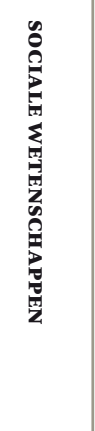 & 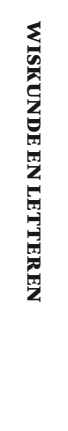 & 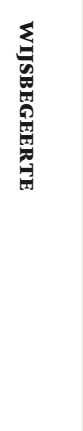 & 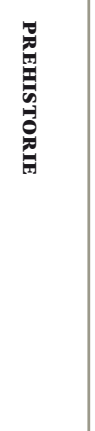 & 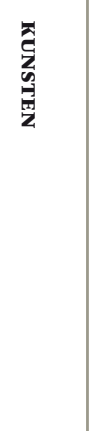 & 定 \\
\hline 1979 & 22 & 752 & 184 & 467 & 801 & & 545 & & 11 & 0 & & 2782 \\
\hline 1980 & 29 & 763 & 195 & 462 & 797 & & 567 & & 18 & 0 & & 2831 \\
\hline 1981 & 37 & 766 & 180 & 452 & 843 & & 546 & & 17 & 1 & & 2842 \\
\hline 1982 & 17 & 825 & 187 & 407 & 812 & & 556 & & 18 & 0 & & 2822 \\
\hline 1983 & 18 & 980 & 235 & 460 & 859 & & 624 & & 26 & 5 & & 3207 \\
\hline 1984 & 15 & 893 & 188 & 364 & 874 & & 512 & & 8 & 0 & & 2854 \\
\hline 1985 & 26 & 980 & 214 & 373 & 1016 & & 830 & & 24 & 0 & & 3463 \\
\hline 1986 & 11 & 916 & 207 & 354 & 922 & & 649 & & 9 & 1 & & 3069 \\
\hline 1987 & 19 & 1028 & 190 & 436 & 1046 & & 843 & & 12 & 1 & & 3575 \\
\hline 1988 & 11 & 1054 & 214 & 427 & 1082 & & 839 & & 18 & 0 & & 3645 \\
\hline 1989 & 19 & 1086 & 217 & 418 & 1172 & & 1038 & & 22 & 1 & & 3973 \\
\hline 1990 & 15 & 1112 & 202 & 406 & 1135 & & 1042 & & 20 & 0 & & 3932 \\
\hline 1991 & 14 & 1005 & 197 & 312 & 1063 & & 978 & & 14 & 0 & & 3583 \\
\hline 1992 & 23 & 933 & 206 & 293 & 884 & & 860 & & 21 & & & 3220 \\
\hline 1993 & 20 & 858 & 199 & 324 & 843 & & 839 & & 20 & & & 3103 \\
\hline 1994 & 13 & 912 & 216 & 288 & 813 & & 810 & & 14 & 2 & & 3068 \\
\hline 1995 & 20 & 923 & 203 & 294 & 730 & & 731 & & 12 & & & 2913 \\
\hline 1996 & 28 & 854 & 207 & 288 & 756 & & 762 & & 9 & & & 2904 \\
\hline 1997 & 25 & 781 & 216 & 314 & 680 & & 730 & & 15 & 24 & & 2785 \\
\hline 1998 & 12 & 681 & 215 & 281 & 598 & & 779 & & 17 & 43 & & 2626 \\
\hline 1999 & 13 & 631 & 211 & 267 & 577 & & 826 & & 20 & 51 & & 2596 \\
\hline 2000 & 21 & 657 & 252 & 294 & 602 & & 903 & & 28 & 47 & & 2804 \\
\hline 2001 & 22 & 763 & 288 & 313 & 691 & & 1044 & & 36 & 78 & & 3235 \\
\hline 2002 & 35 & 787 & 317 & 349 & 720 & & 1151 & & 34 & 67 & & 3460 \\
\hline 2003 & 24 & 894 & 355 & 419 & 803 & & 1321 & & 27 & 94 & & 3937 \\
\hline 2004 & 32 & 854 & 359 & 349 & 745 & & 1130 & & 23 & 95 & & 3587 \\
\hline 2005 & 28 & 762 & 360 & 346 & 801 & & 1032 & & 37 & 110 & 6 & 3482 \\
\hline 2006 & 42 & 742 & 351 & 418 & 997 & & 946 & & 27 & 93 & 10 & 3626 \\
\hline 2007 & 41 & 849 & 344 & 431 & 987 & & 1077 & & 38 & 77 & 12 & 3856 \\
\hline
\end{tabular}




\section{Illustratieverantwoording}

De illustraties in dit boek zijn gekozen еегdег om een eigen verhaal te vertellen dan om de tekst te ondersteunen, laat staan die te vervangen. Vandaar de ze weliswaar niet geheel willekeurig, maar toch lang niet altijd 'ter plekke' door de tekst gestrooid zijn.

Academiegebouw 17, 50, 72, 110, 111, 112, 113, 118, 120, 121, 181, 185, 196, 197, $198,199,283,286,287,288,289$

Academisch Historisch Museum 24-25, 26, 39, 40, 42, 45, 49, 56, 57, 75, 79, $82-83,86,90,91,94,97,117,123,126,129,130,131,134,136,137,140,141$, $143,146,158,161,164-165,167,168,169,172,173,174,177,178,182,186$, 188-189, 190-191, 193, 194

Anatomisch Museum LuMC 102, 103

Gemeentearchief Leiden 29, 104

Jos van den Broek 2, 6, 8, 11, 12, 202, 205, 206, 209, 210, 213, 216, 217, 219, 220, 223, 224, 228, 229, 231, 232, 235, 236-237, 238, 241, 242, 245, 246, 249, 250,

$254,255,256,261,262,263,267,269,270,273,276,279,285$

Koninklijke Bibliotheek 32

Museum Boerhaave 99

Rijksmuseum, Amsterdam 108

Rijksmuseum Naturalis 150

Rijksmuseum van Oudheden 61,149

Rijksmuseum vоог Volkenkunde 153, 154, 157

Stedelijk Museum de Lakenhal 46

Universiteitsbibliotheek Leiden 16, 18, 19, 30, 34, 35, 53, 54, 62, 64, 65, 66, $69,76,107$ 


\section{Bibliografie}

Dit boek is in hoofdzaak gebaseerd op de drie delen van mijn Leidse universiteitsgeschiedenis (en op wat er van het vierde deel inmiddels in manuscript aanwezig is). Voor een gedetailleerde bibliografie verwijs ik naar die drie delen van mijn Groepsportret met Dame, te weten: Het bolwerk van de vrijheid. De Leidse universiteit, 1575-1672 (Amsterdam 2000), De vesting van de macht. De Leidse universiteit, 1673-1775 (Amsterdam 2002) en De werken van de wetenschap. De Leidse universiteit, 1776-1876 (Amsterdam 2005).

\section{Gedrukte bronnen en bibliografieën}

Album Scholasticum Academiae Lugduno-

Batavae (drie delen, 1575-1940 (Leiden 1941), 1940-1974 (Leiden 1975) en 1975-1989 (Leiden 1991))

Album Studiosorum Academiae LugdunoBatavae (twee delen, 1575-1875 ('s-Gravenhage 1875) en 1875-1925 (Leiden 1925))

Bibliografie van hoogleraren in de rechten aan de Leidse universiteit tot 1811, M. Ahsmann en R. Feenstra (Amsterdam 1984)

‘Bibliographie selective de l'université de Leiden', R.E.O. Ekkart in: Bibliographie internationale de l'histoire des universités II (1976) 83-128

Bronnen tot de geschiedenis der Leidsche Universiteit, P.C. Molhuysen (zeven delen, 's-Gravenhage 1913-1924)

Icones Leidenses. De portretverzameling van de Rijksuniversiteit te Leiden, R.E.O.Ekkart (Leiden 1973)

Leiden Medical Professors 1575-1940 (Leiden 2007)

\section{Wetenschappelijke context}

A History of the University in Europe. General editor Walter Rüegg (drie delen, Cambridge 1992, 1996 en 2004)

M. Albrecht, Eklektik (Stuttgart 1994)

H.J. Berman, Law and Revolution. The Formation of the Western Legal Tradition (Cambridge Mass. 1983)

H. Bots en F. Waquet (red.), Commercium Litterarium 1600-1750 (Amsterdam 1994)

W. Clark e.a. (red.), The Sciences in Enlightened Europe (Chicago 1999)

H. Coing (red.), Handbuch der Quellen und Litteratur der nеuегеn Europäischen Privatrechtsgeschichte (twee delen, München 1973, 1977)

L.I. Conrad e.a. (red.), The Western Medical Tradition (Cambridge 1995) 
P. Dear, Revolutionizing the Sciences.

European Knowledge and its Ambitions, 1500-1700 (Basingstoke 2001)

J.V. Field en F.A.J.L. James (red.), Renaissance and Revolution. Humanists, Scholars, Craftsmen, and Natural Philosophers in Early Modern Europe (Cambridge 1993)

A. Grafton, New Worlds, Ancient Texts. The Power of Tradition and the Shock ofDiscovery (Cambridge Mass. 1992)

N. Jardine e.a. (геd.), Cultures of Natural History (Cambridge 1996)

M. Herberger, Dogmatik. Zur Geschichte vom Begriff und Methode in Medizin und Jurisprudenz (Frankfurt am Main 1981)

A. Moss, Printed Commonplace-Books and the Structuring of Renaissance Thought (Oxford 1996)

J.V.Pickstone, Ways of Knowing. A New History of Science, Technology and Medicine (Manchester 200o)

J. Platt, Reformed Thought and Scholasticism (Leiden 1982)

R.H. Popkin, The History of Scepticism from Erasmus to Descartes (Assen 1964)

Henning Graf Reventlow, Epochen der Bibelauslegung (vier delen, München 1990-2001)

C.B. Schmitt, Aristotle and the Renaissance (Cambridge Mass. 1983)

P. Stein, The Character and Influence of the Roman Civil Law (Londen 1988)
A. Waquet, Le latin ou l'empire d'un signe 16e-20e siècle (Рагijs 1998)

\section{Nationale context}

K. van Berkel e.a. (red.), A History of Science in the Netherlands (Leiden 1999)

W. Frijhoff, La société Néerlandaise et ses gradués, 1575-1814 (Amsterdam 1981)

W. Frijhoff en M. Spies, 165o. Bevochten eendracht (Den Haag 1999)

J. Israel, The Dutch Republic. Its Rise, Greatness and Fall, 1477-1806 (Oxford 1995)

G. Jensma en H. de Vries, Veranderingen in het hoger onderwijs in Nederland tussen 1815 еп 1940 (Hilversum 1997)

G.A. Lindeboom, Geschiedenis van de medische wetenschap in Nederland (Bussum 1972)

P. de Rooy, Republiek van rivaliteiten. Nederland sinds 1813 (Amsterdam 2002)

B. Theunissen, 'Nut en nog eens nut'. Wetenschapsbeelden van Nederlandse natuuronderzoekers, 1800-19oo (Hilversum 200o)

\section{Algemeen}

H.J. de Jonge en W. Otterspeer (red.), Altijd een vonk of twee. De Universiteit Leiden van 1975 tot 2000 (Leiden 2000)

S.A. Knöll, Creating Academic Communities. Funeral monuments to professors at Oxford, Leiden and Tübingen, 
1580-1700 (Oss 2003)

Leidse universiteit 40o. Stichting en eerste bloei 1575-ca. 1650. Catalogus Rijksmuseum (Amsterdam 1975)

Th.H. Lunsingh Scheurleer en G.H.M. Posthumus Meyjes (red.), Leiden University in the Seventeenth Century. An Exchange of Learning (Leiden 1975)

W. Otterspeer (red.), Een Universiteit herleeft. Wetenschapsbeoefening aan de Leidse Universiteit vanaf de tweede helft van de negentiende eeuw (Leiden 1984)

Pallas Leidensis MCMXXV (Leiden 1925)

G. Wiesenfeldt, Lеегег Raum in Minervas Haus. Experimentelle Naturlehre an der Universität Leiden, 1675-1715 (Amsterdam 2002)

\section{Bestuur}

H.L. Clotz, Hochschule für Holland. Die Universität Leiden im Spannungsfeld zwischen Provinz, Stadt und Kirche, 1575-1619 (Stuttgart 1998)

J.A. van Dorsten, Poets, Patrons, and Professors. Sir Philip Sidney, Daniel Rogers and the Leiden Humanists (Leiden 1962)

S. Groenveld e.a. (red.), Bestuurders en geleerden (Leiden 1985)

C.L. Heesakkers en W. Reinders, Genoeglijk bovenal zijn mij de Muzen. De Neolatijnse dichter Janus Dousa (1545-1604) (Leiden 1993)

P.C. Molhuysen, De voorrechten der
Leidsche Universiteit (Amsterdam 1924)

R.G.H. Sluijter, 'Tot ciraet, vermeerderinge ende heerlijckmaeckinge der universiteyt'. Bestuur, instellingen, personeel en financiën van de Leidse universiteit, 1575-1812 (Hilversum 2004)

H.J. Witkam, De financiën van de Leidse universiteit in de zestiende eeuw (vijf delen, Leiden 1979-1982)

\section{Devies}

P. van Heck, 'Libertatis praesidium. Over de herkomst van een devies', in: Leids Jaarboekje 95 (2003) 197-210

H.J. de Jonge, 'Ouderdom en herkomst van het devies dег Leidse universiteit', in: Leids Jaarboekje 70 (1978) 143-146

\section{Anatomisch theater}

J.P. Cavaillé, Un théatre de la science et de la mort à l'époque baroque. L'amphithéatre d'anatomie de Leiden (Fiesola 1990)

T. Huisman, The Finger of God. Anatomical Practice in 17th Century Leiden (Leiden 2008)

\section{Bibliotheek}

C. Bergvens-Stevelinck, Magna Commoditas. Geschiedenis van de Leidse universiteitsbibliotheek 1575-200o (Leiden 2001) 


\section{Hortus}

L.G.M. Baas Becking en H. Veendorp, Hortus Botanicus Lugduno-Batavus 1587-1937 (Наarlem 1938)

W.K.H. Karstens, De Leidse Hortus, een botanische erfenis (Zwolle 1982)

L.A. Tjon Sie Fat (red.), The Authentic Garden (Leiden 1991)

\section{Rechtbank}

P.A.M. Geurts, Het eerste grote conflict over de eigen rechtspraak der Leidse universiteit (Utrecht 1964)

M.F.M. Wingens, 'Zur Vermeidung der Schande. Огganisation und strafrechtliche Tätigkeit der Universitätsgerichte in der Republik der Niederlände (1575-1811)', in: H. Mohnhaupt en D. Simon (red.), Vorträge zurJustizforschung. Geschichte und Theorie (Frankfurt am Main 1992) 79-100

\section{Colleges}

P.A.M. Geurts, Voorgeschiedenis van het Statencollege te Leiden 1575-1593 (Leiden 1984)

G.H.M. Posthumus Meyjes, Geschiedenis van het Waalse college te Leiden, 1606-1699 (Leiden 1975)

\section{Universiteitsdrukkers}

R. Breugelmans, Christoffel Plantijn in Leiden (1583-1585) (Leiden 1989)
P.G. Hoftijzer, Pieter van der Aa (1659-1733). Leids drukker en boekverkoper (Hilversum 1999)

O.S. Lankhorst en P.G. Hoftijzer, Drukkers, boekverkopers en lezers in Nederland tijdens de Republiek (Den Haag 1995)

A. Willems, Les Elzeviers (Nieuwkoop 1974)

\section{Ingenieursschool}

C.A. Davids, 'Universiteiten, illustere scholen en de verspreiding van technische kennis in Nederland', in: Batavia Academica 8 (1990) 4-34

P.J.van Winter, Hoger beroepsonderwijs avant-la-lettre. Bemoeiingen met de vorming van landmeters en ingenieurs bij de Nederlandse universiteiten van de 17e en 18e eeuw (Amsterdam 1988)

\section{Fysisch kabinet}

P.R. de Clercq, Het Leids Fysisch Kabinet (Leiden 1989)

P.R. de Cleгcq, At the Sign of the Oriental Lamp. The Musschenbroek Workshop in Leiden 1660-175o (Rotterdam 1997)

\section{Chemisch kabinet}

W.P. Jorissen, Het Chemisch (Thans Anorganisch Chemisch)Laboratorium der Universiteit te Leiden van 1859-1909 en de Chemische Laboratoria dier 
Universiteit vóór dat tijdvak en zij, die er doceerden (Leiden 1909)

\section{Herbarium}

W.A. Goddijn, "s Rijks Herbarium 1830-1930', in: Mededeelingen van 's Rijks Herbarium, Leiden 62b (1931) 1-53

\section{Sterrenwacht}

G. van Herk, De Leidse sterrenwacht. Vier eeuwen wacht bij dag en nacht (Zwolle 1983)

\section{Prentenkabinet}

Het Leidse Prentenkabinet. De geschiedenis van de verzameling (Ваarn 1994)

\section{Museum voor Volkenkunde}

R. Effert, Volkenkundig verzamelen. Het Koninklijk Kabinet van Zeldzaamheden en het Rijks Ethnografisch Museum, 1816-1883 (Leiden 2003)

G. van Wengen, Wat is er te doen in Volkenkunde? De bewogen geschiedenis van het Rijksmuseum voor Volkenkunde in Leiden (Leiden 2002)

\section{Museum van Natuurlijke Historie}

Gijzen, 's Rijks Museum van Natuurlijke Historie 1820-1915 (Rotterdam 1938)
L.B. Holthuis, Rijksmuseum van Natuurlijke Historie 1820-1958 (Leiden 1958)

‘Rijksmuseum van Geologie en Mineralogie 1878-1978', in: Scripta Geologica 48 (1978) 3-96

\section{Museum van Oudheden}

R.B. Halbertsma, Scholars, Travellers, and Trade. The Ioneer Years of the National Museum of Antiquities, 1818-184o (Londen 2003)

H.D. Schneider, Rijksmuseum van Oudheden (Haarlem 1981)

\section{FACULTEITEN}

\section{Theologie}

W.J. van Asselt, Amicitia Dei. Een onderzoeknaar de structuur van de theologie van Johannes Coccejus (1603-1669) (Utrecht 1988)

W.J.van Asselt e.a. (red.), Een richtingenstrijd in de Gereformeerde Kerk. Voetianen en coccejanen 1650-1750 (Zoetermeer 1994)

P. Bange e.a. (red.), Kerk en Verlichting (Zwolle 1990)

C. Bangs, Arminius. A Study in the Dutch Reformation (New York 1981)

J. van den Berg, ‘Orthodoxy, Rationalism and the World in Eighteenth Century Holland', in: D. Baker (геd.), Sanctity and Secularity. The Church and the World (Oxford 1973) 173-192 
J. van den Berg, Een Leids pleidooi voor verdraagzaamheid. Het optreden van Jan Jacob Schultens in de zaak-Van der Os (Leiden 1976)

L.J.M. Bosch, Petrus Bertius 1565-1629 (Nijmegen 1979)

A. Eekhof, De theologische faculteit te Leiden in de zeventiende eeuw (Utrecht 1921)

O. Fatio, Méthode et théologie. Lambert Daneau et les débuts de la scolastique réformée (Genève 1976)

J. van Genderen, Herman Witsius. Bijdrage tot de kennis der gегеformeerde theologie ('s-Gravenhage 1953)

H. Honders, Andreas Rivetus als invloedrijkgereformeerd theoloog in Holland's bloeitijd ('s-Gravenhage 1930)

C. de Jong, De irenische ecclesiologie van Franciscus Junius (1545-1602) (Nieuwkoop 1980)

H.J. de Jonge, De bestudering van het Nieuwe Testament aan de Noordnederlandse universiteiten en het Remonstrants Seminarie van 1575 tot 1700 (Amsterdam 1980)

A.J. Lamping, Johannes Polyander. Een dienaar van Kerk en Universiteit (Leiden 1980)

W. Nijenhuis, Adrianus Saravia (c. 1532-1613) (Leiden 1980)

L. Rimbault, Ріеге du Moulin 1568-1658. Un pasteur classique à l'âge classique (Рагіjs 1966)

H.W.M. van de Sandt, Joan Alberti, een Nederlands theoloog en classicus in de achttiende eeuw (Utrecht 1984)

C. Sepp, Het godgeleerd onderwijs in Nederland gedurende de 16e en $17 \mathrm{e}$ eeuw (twee delen, Leiden 1873, 1874)

P.L. Slis, L.W.E. Rauwenhoff (1828-1889). Apologeet van het modernisme (Kampen 2003)

\section{Rechten}

M. Ahsmann, Collegia en colleges. Juridisch onderwijs aan de Leidse universiteit 1575-1630 (Groningen 1990)

G.C.J.J. van den Bergh, The Life and Work of Gerard Noodt (1647-1725). Dutch Legal Scholarship between Humanism and Enlightenment (Oxford 1988)

G.C.J.J. van den Bergh, Die Holländische elegante Schule (Frankfurt am Main 2002)

Jan Drentje, Thorbecke. Een filosoof in de politiek (Amsterdam 2004)

R. Feenstra, Legal Scholarship and Doctrines of Private Law, 13th-18th Centuries (Leiden 1996)

R. Feenstra en C.D.J. Waal, SeventeenthCentury Leiden Law Professors and Their Influence of the Development of the CivilLaw. A Study of Bronchorst, Vinnius and Voet (Amsterdam 1975)

C.J.H. Jansen, Natuurrecht of Romeins recht. Een studie over leven en werk van F.A. van der Marck (1719-180o) in het licht van de opvattingen van zijn tijd (Leiden 1987) 
C.J.H. Jansen, Van Kemper tot Hamaker. Eеn onderzoeknaаr de encyclopedie van het recht in de negentiende eeuw (Zwolle 1990)

E. Poortinga, De scheiding tussen publieken privaatrecht bijJohan Rudolph Thorbecke (1798-1872) (Nijmegen 1987)

I.H. Stamhuis, 'Cijfers en Aequaties' en 'Kennis der Staatskrachten'. Statistiek in Nederland in de negentiende eeuw (Amsterdam 1989)

T.J. Veen en P.C. Knop (геd.), Zestig juristen. Bijdragen tot een beeld van de geschiedenis der Nederlandse rechtswetenschap (Zwolle 1987)

\section{Medicijnen}

J.A.J. Barge, Het geneeskundig onderwijs aan de Leidse universiteit in de 18e eeuw (Leiden 1934)

E.D. Baumann, Fraençois dele Boe Sylvius (Leiden 1949)

H. Beukers en J. Moll (геd.), Clinical Teaching, Past and Present (Amsterdam 1989)

A.L. Bierman, Van artsenijmengkunde naar artsenijbereidkunde. Ontwikkelingen in de Nederlandse farmacie in de negentiende eeuw (Amsterdam 1988)

A.M. Elshout, Het Leids cabinet der anatomie uit de 18e eeuw. De betekenis van een wetenschappelijke collectie als cultuurhistorisch monument (Leiden 1952)

R. Knoeff, Herman Boerhaave (1668-1738).
Calvinist Chemist and Physician

(Cambridge 200o)

J.E. Kroon, Bijdragen tot de geschiedenis van het geneeskundig onderwijs aan de Leidsche universiteit 1575-1625 (Leiden 1911)

M.M. Lamens-van Malenstein, Oefening en bespiegeling. Het verloskundig onderwijs van M.S. du Pui (1754-1834) te Leiden (Rotterdam 1997)

G.A. Lindeboom, Herman Boerhaave. The Man and His Work (Londen 1968)

G.A. Lindeboom, Florentius Schuyl (1619-1669) en zijn betekenis voor het Cartesianisme in de geneeskunde (Den Haag 1974)

H. Punt, Bernard Siegfried Albinus (1697-1770). On 'Human Nature'. Anatomical and Physiological Ideas in Eighteenth Century Leiden (Amsterdam 1983)

L.J. Rather, Mind and Body in Eighteenth Century Medicine. A Study Based on Jerome Gaub's De regimine mentis (Londen 1965)

J. Schouten, Johannes Walaeus. Zijn betekenis voor de verbreiding van de leer van de bloedsomloop (Assen 1972)

M.J. Sirks (геd.), Botany in the Netherlands (Leiden 1935)

W.T. Stearn, The Influence of Leyden on Botany in the Seventeenth and Eighteenth Century (Leiden 1961)

G. van der Waa, De irritabilitate. Een onderzoek naar de betekenis van het irritabiliteitsbegrip in de geschiedenis 
van de achttiende-eeuwse fysiologie

(Rotterdam 1992)

P. van der Zwaag, Wouter van Doeveren

(1730-1783) (Assen 1970)

Filosofie en natuurwetenschap

E.P. Bos en H.A. Кгор (red.), Franco

Burgersdijk (1590-1635). Neo-Aeristotelianism in Leiden (Amsterdam 1993)

D. van Delft, Heike Kamerlingh Onnes. De man van het absolute nulpunt (Amsterdam 2005)

P. Dibon, L'Enseignement Philosophique dans les Universités Néerlandaises à l'Époque Pré-Cartésienne (1575-1650) (Leiden 1954)

S.W.Hamers-van Duynen, Hiеronymus David Gaubius (1705-1780). Zijn согтеspondentie met Antonio Nunes Ribeiro Sanches en andere tijdgenoten (Amsterdam 1978)

J.E. Hofmann, Frans van Schooten der Jüngere (Wiesbaden 1962)

J.A. van Maanen, Facets of Seventeenth Century Mathematics in the Netherlands (Utrecht 1987)

C. de Pater, Petrus van Musschenbroek (1692-1761), een newtoniaans natuuronderzoeker (Leiden 1979)

C. de Pater (red.), Willem Jacob 's Gravesande. Welzijn, wijsbegeerte en wetenschap (Ваагn 1988)

E.G. Ruestow, Physics at 17th and 18th Century Leiden (Den Haag 1973)

G.A.Steffens, Pieter Nieuwland en het evenwicht (Zwolle 1964)

C.L. Thijssen-Schoute, Nederlands

Cartesianisme (Amsterdam 1954)

T. Verbeek, Descartes and the Dutch. Early Reactions to Cartesian Philosophy, 1637-1650 (Carbondale 1992)

R. Vermij, Secularisering en natuurwetenschap in de zeventiende en achttiende eeuw: Bernard Nieuwentijt (Amsterdam 1991)

H. Wansink, Politieke wetenschappen aan de Leidse Universiteit, 1575-ca. $165^{\circ}$ (Utrecht 1981)

\section{Letteren en geschiedenis}

B. Becker-Cantarino, Daniel Heinsius (Boston 1978)

S. Bugter, J.F. Gronovius en de Annales van Tacitus (Leiden 1980)

P. Dibon en F. Waquet, Johannes Fredericus Gronovius. Pèlerin de la République des Lettres (Genève 1984)

K.A. Enenkel en C. Heesakkers (red.), Lipsius in Leiden. Studies in the Life and Works of a Great Humanist (Voorthuizen 1997)

A. Gerlo (red.), Juste Lipse (1547-1606) (Brussel 1988)

J.G. Gerretzen, Schola Hemsterhusiana. De herleving der Grieksche studiën aan de Nederlandsche universiteiten in de achttiende eeuw van Perizonius t ot en met Valckenaer (Nijmegen 1940)

A. Grafton, Joseph Scaliger. A Study in the History of Classical Scholarship (twee 
delen, Oxford, 1983, 1993)

E. Hulshoff Pol, Studia Ruhnkeniana. Enige hoofdstukken over het leven en werk van David Ruhnkenius (1723-1798) (Leiden 1953)

G. Karstens, 10o jaar Nederlandse philologie. M. de Vries en zijn school (Leiden 1949)

A. van der Lem, Johan Huizinga. Leven en werk in beelden en documenten (Amsterdam 1993)

P. Leroy, Le dernier voyage à Paris et en Bourgogne, 1640-1643, du réformé Claude Saumaise (Amsterdam 1983)

L.H. Maas, Pro Patria. Werken, leven en streven van de literatuurhistoricus Gerrit Kalff (1856-1923) (Hilversum 1998)

Th.J. Meijer, Kritiek als herwaardering. Het levenswerk van Jacob Perizonius (1651-1715) (Leiden 1971)

M. Morford, Stoics and Neostoics. Rubens and the Circle of Lipsius (Princeton 1991)

J. Noordegraaf, Norm, geest en geschiedenis. Nederlandse taalkunde in de negentiende eeuw (Leiden 1985)

C.S.M. Rademaker, Leven en werkvan Gerardus Joannes Vossius (1577-1649) (Hilversum 1999)

D.C.A.J. Schouten, Het Grieks aan de Nederlandse universiteiten in de negentiende eeuw (Utrecht 1964)

J. Tollebeek, De toga van Fruin. Denken over geschiedenis in Nederland sinds 1860 (Amsterdam 1990)

\section{Oosterse letteren}

J. Brugman en F. Schröder, Arabic Studies in the Netherlands (Leiden 1979)

W.M.C. Juynboll, Zeventiende-eeuwsche beoefenaars van het Arabisch in Nederland (Utrecht 1931)

J. Nat, Studie van de oostersche talen in de 18e en 19e eeuw (Рurmerend 1929)

W. Otterspeer (геd.), Leiden Oriental Connections 1850-1940 (Leiden 1989)

P.T. van Rooden, Constantijn l'Empereur (1591-1648). Professor Hebreeuws te Leiden (Leiden 1985)

J.Ph. Vogel, The Contribution of the University of Leiden to Oriental Research (Leiden 1954)

W.D. van Wijngaarden, Van Heurnius tot Boeser. Drie eeuwen Egyptologie in Nederland (1620-1935). (Leiden 1935)

\section{Beeldvorming}

J. Bientjes, Holland und der Holländer im Urteil deutscher Reisender 1400-1800 (Groningen 1967)

R. Feenstra en C. Coppens (red.), Die rechtswissenschaftlichen Beziehungen zwischen den Niederlanden und Deutschland in historischer Sicht (Nijmegen 1991)

E. Hulshoff Pol, ‘What About the Library? Travellers' Comments on the Leiden Library in the 17th and 18th Century', in: Quaerendo 5 (1975) 166-179 
J.N. Jacobsen Jensen, Reizigers te Amsterdam (Amsterdam 1919)

C.S. Maffioli en L.C. Palm (red.), Italian Scientists in the Low Countries in 17th and 18th Centuries (Amsterdam 1989)

H. de Ridder-Symoens en J.M. Fletcher (red.), Academic Relations between the Low Countries and the British Isles 1450-1700 (Gent 1989)

H. Schneppen, Niederländische Universitäten und Deutsches Geistesleben. Von der Gründung der Universität Leiden bis ins späte 18. Jahrhundert (Münster 1960)

C.D. van Strien, Touring the Low Countries. Accounts of the British Travellers, 1660-1720 (Amsterdam 1998)

\section{Tweede Wereldoorlog}

P.J. Idenburg, De Leidse universiteit 1928-1946. Vernieuwing en verzet ('s-Gravenhage 1978)

\section{Studentenleven}

Gedenkboek van het Leidsche Studentencorps (Leiden 1919)

Geschiedboek van de Leidse Studenten Vегеniging Міпегva, 1814-1989 (Leiden 1989)

Geschiedenis van het Leidsche Studenten Corps (Leiden 1950)

A.C.J. de Vrankrijker, Vier Eeuwen Nederlandsch Studentenleven (Voorburg 1939)

\section{Dankwoord}

Wie een geschiedenis van een universiteit schrijft heeft veel hulp nodig. Ik spreek dan ook graag mijn dank uit aan de decanen van de grote faculteiten die mij van informatie voorzagen; Frans Saris, Carel Stolker en Eduard Klasen moest ik zelfs meerdere keren raadplegen. Ook de kennis en ervaring van Henk Jan de Jonge en Pieter Janse zijn het boek ten goede gekomen. Ik dank mijn promovenda Martine Zoeteman, die een belangrijk deel van de kwantitatieve gegevens ter beschikking stelde en Yvo van Marle die er nog meer bij zocht en het geheel bewerkte. Ik dank John Kroes en Corrie van Maris voor wijze raad, Arlette van Kouwenhoven en Kasper van Ommen voor het bijeenzoeken van de illustraties, Jos van den Broek vоor het ter beschikking stellen van zijn foto's en Pieter Slaman voor onvermoeibare steun. Ik dank ook Amsterdam University Press voor het enthousiasme en de goede smaak aan het boek besteed. Zelf blijf ik natuurlijk verantwoordelijk voor alles wat er mis aan het boek. 


\section{Register}

A

Aa, P. van der 98

Achilles 28

Acqoy, J.G.R. 155

Aerssen, F. van 33

Afanesjeva, T. 284

Aldegonde, M. van Sint 119

Alembert, J. d' 104

Aquino, T. van 14

Aristoteles 13-14, 59-60, 71

Arkel, A.E. van 160

Arminius, J.H. 58

Asbeck, F.M. van 160

Assen, C.J.van 144

Assendelft, W. van 40-41

Asser, T.M.C. 155, 187

Augustinus 14

B

Bachrach, A.G.H. 160

Bake, J. 152

Bakhuizen van de Brink, J.N. 160

Barge, J.A.J. 124

Barlaeus, C. 95

Bastet, F.L. 160

Baudius, D. 51

Bazel, K.P.C. de 187

Beenakker, J.J.M. 160, 214, 225

Benthem, H.L. 88

Bentinck, W. 32-33

Berg, W.L.C.H.M. van den 264
Bergh,J.van den 33

Berkhof, H. 160

Berlin, I. 195

Bernhard von Lippe Biesterfeld 280

Веггу, J. 87

Bertius, P. 47

Beuningen, C. van 33

Beveren, C.van 33

Beverninck, H. van 33

Biesheuvel, M. 265

Blok, P.J. 155-156, 184, 186

Blom, D. van 156

Blume, C.L. 135

Boer, K. de 138

Boer, P.A.H. de 160

Boer, W. den 160

Boerhaave, H. 55, 63, 103, 156

Bontius, R. 47

Boon Mesch, A.H. van der 180

Bornius, H. 51

Boxhorn, M.Z.van 67

Boyle, R. 65

Brandt Corstius, H. 208

Braudel, F. 204

Вгеimer, D.D. 226

Brink, J.ten 155

Bronchorst, E. 43, 45, 89

Brugmans, S.J. 135, 151

Büch, B. 265

Buikhuisen, W. 208 
Burgersdijk, F. 77

Burgersdijk, P. 59

Buruma, O.J.S. 243

Buys, J.T. 155, 159

Buys, P. 33

Byvanck, A.W. 160

\section{C}

Camp, H.F.G.N. 135

Canisius, P. 41

Capellus, L. 106

Carlyle, A. 87

Carp, E.A.D.E. 156

Castle, G. 65

Cath, K.J. 203, 221-222

Cato de Oudere 71

Cats, J. 33

Celsus, C. 27

Ceulen, L. van 98

Cicero 28, 51

Clarisse, J. 152

Cleveringa, R.P. 123-124, 160

Cloucq, A. 105

Clusius, C. 45

Cobet, C.G. 152

Coccejus, J. 58, 71

Cohen, A.E. 204, 207, 214, 225, 281

Cohen, J.A. 160

Colenbrander, H.T. 184

Coolhaas, C. 22

Copernicus, N. 59

Cornelisz, P. 22

Court, P. de la 251

Cunaeus, P. 92, 109
D

Daalder, H. 160

Danaeus, L. 52

Dankmeijer, J. 160

Dante 10

Descartes, R. 58-6o

Diderot, D. 104

Diekstra, R. 212, 214

Don Quichote 28

Donellus, H. 45, 48

Doorninck, P. 37

Dousa, J. 26-28, 33, 45, 106, 109

Dozij, R.P.A. 155

Drelincourt, C. 50, 65

Dresden, S. 160

Drion, H. 160

Drucker, H.L. 155

Duyff, J.W. 160

Duyvendak, J.J.L. 160

E

Ehrenfest, P. 284

Einstein, A. 284

Einthoven, W. 139, 156

Elzevier, M. 98

Erpenius, T. 52

Evelyn,J. 87

Evers, J.C.G. 155

Eysinga, W.J.M.van 159, 187

F

Fabricius, F. 109

Feenstra, R. 160

Fernel, J. 73

Fischer, H.F.W.D. 160

Fortuyn, P. 203 
Franchimont, A.P.N. 155

Frederik Вагbarossa 38

Frederik II 13

Fruin, R. 155, 184, 186

G

Galenus 73

Geer, P. van 169

Goeje, M.J. de 155

Gogh, T. van 203

Golius, J. 55

Gorter, C.J. 160

Gorter, E. 160

Goudsmit, J.E. 155, 159

Gratianus 14

Gravesande, W.J. 's 63,103

Greven, H.B. 156

Groningen, B.A. van 160

Gronovius, J.F. 73

Groot, C. de 51

Groot, J.J.M. de 155, 172

Groot, S.R. de 160

Grundmann, H. 11

Gunning, J.H. 155

\section{H}

Halbertsma, H.J. 155

Haller, A. von 88, 98

Hamaker, H.A. 152

Hart, A. van der 133

Hart, M. 't 265

Havinga, E. 160

Hazelhoff, R. 222

Heek, F. van 160

Hеereboord, A. 59

Heesterman, J.C. 160
Hegel, G.W.F. 259

Heidegger, M. 259

Hemsterhuis, F. 116

Heurnius, J. 47, 51

Heynsius, A. 155

Hippocrates 13,63

Hoeve, J. van der 156

Hoeven, J. van der 151, 159

Hoeven, P. van der 152

Holk, L.J. van 124

Holwerda, A.E.J. 156

Homerus 28

Hommius, F. 88

Hoornbeek, J. 58

Ногnius, J. 64

Hout, J. van 261

Huizinga, J. 125, 130, 133, 148, 156, 179, 190-192, 195

Hulst, H.C. van de 160

\section{I}

Israel, J. 74

Itterson, J.E. van 155

\section{J}

Jack, G. 58-59

Jan van Brabant 109

Jelgersma, G. 156

Job 29, 31

Jonckbloet, W.J.A. 155

Josselin de Jong, J.P.B. de 159-16o

Juliana 284

Justitianus 73

Juynboll, T.W.J. 155 


\section{K}

Kaiser, F. 135

Kalff, G. 155

Kamerlingh Onnes, H. 139, 155-156

Kassenaar, A.A.H. 225

Kemper, J.M. 152, 192

Кегn, J.H.C. 155

Kist, A.W. 223, 226

Kistemaker, J. 160

Kloosterman, H.D. 160

Knapton 88

Korteweg, J.A. 155

Krabbe, H. 159

Kramers, H.A. 160

Kranenburg, R. 124

Kuenen, A. 155, 160, 225

Kuenen, D.J. 155, 160, 225

Кuурег, A. 192, 195

$\mathbf{L}$

Lam, H.J. 160

Lansbergen, Ph. van 59

Leers, J. von 176

Leertouwer, L. 225

Leeuwenhoek, A. van 234

Levinas, E. 204

Lijphart, A. 160

Linde, G. van de 175

Linden, J.A. van der 63-64

Lipsius, J. 45, 48, 51-52, 77, 92

Livius 119, 122

Locher, Th.J.G. 160

Lokhorst, J. van 134, 138-139

Lombroso, C. 208, 214

Lorentz, H.A. 155-156, 187, 190, 192, 195, 284
Louter, J. de 187

Luca, F. 38, 87

Luchtmans, S. 98

Lunsingh Scheurleer, Th.H. 160

M

Macquelin, M.J. 152

Maestertius, J. 27-28

Маiге, J. 98

Mandel, M. 160

Marx, K. 274

Maurits 36, 52,103

Mazur, P. 160

Meerman, M. 65

Meijers, E.M. 123-124, 159-16o

Melanchton 14

Metzelaar, J.F. 138

Meursius, J. 105

Mijle, C. van der 33

Milo, T.H. 160

Miskotte, K.H. 160

Modderman, A.E.J. 159

Molinaeus, L. 65

Molinaeus, P. 36, 58

Morгis, W. 139

Mulder, J. 160

Muller, F. 122

Muller, P.L. 155

Murdison, J. 47

Musschenbroek, P. van 63,103

$\mathbf{N}$

Nero 95

Nietzsche, F. 259

Nuchelmans, G.R.M.F. 160 
o

Offredi, C. 65

Oldenbarneveldt, J. van 52

Oomen, C.P.C.M. 210-211, 222

Оогt, J.H. 159-160

Oosterhoff, L.J. 160

Oppenheim, J. 155, 159

Orlers, J.J. 22, 105

Os, D.P. den 264

Oven, J.C. van 160

$$
\mathbf{P}
$$

Palm, J.H. van der 152

Paulus 31, 67

Pauw, A. 33

Peerlkamp, P. Hofman 119

Peursen, C.A. van 160

Plantijn, P. 98

Plato 28-29

Plinius 51

Poellnitz, von 88

Polyander, J. 51,67

Ponec, V. 160

Powell, P. 87

Pynacker, C. 47

\section{Q}

Querido, A. 160

Quispel, A. 160

\section{R}

Rademaker, G.G.J. 160

Radzivill, J. 85, 92

Raei, J. de 58-60

Ramus 15

Raphelengius, F. 52
Rauwenhoff, L.W.E. 155

Ray, J. 63

Reinwardt, C.G.C. 151

Reuvens, C.J.C. 152

Reve, K. van het 284

Revius, J. 67

Rijk, L.M. de 160

Rivet, A. 45

Romein, J. 284

Rood, J.J. van 160

Rosenstein, S.S. 155

Rüegg, W. 9

Rypрегda Wierdsma, J.V. 160

\section{S}

Salmasius, C. 45, 67

Saravia, A. 52

Scaliger, J.J. 36, 45

Schaap, J.W. 135

Schnitzler, A. 179

Scholten, J.H. 155

Schrant, J.M. 155

Schreinemakers, F.A.H. 155

Schulte Northolt, J.W. 160

Scriverius, P. 106

Seneca 29

Senguerdius, W. 60,63

Seyss-Inquart, A. 122

Shils, E. 278

Snellius, R. 89

Snouck Нurgronje, C. 159, 184, 239

Snow, C.P. 155

Sobels, F.H. 160

Sopper, A.J. de 147

Sosius, T. 52

Staverman, A.J. 160 
Steenis, C.G.G.J. 160

Steinmetz, H. 156

Stevin, S. 103

Steyn, P. 33

Stochius, N. 89

Stuart, A. 59-60, 63

Stuart, D. 59-60, 63

Stutterheim, C.F.P. 160

Suárez, F. 59

Swanenburch, C.P. van 47

Swanenburgh, W. 105

Sylvius, F. 64

$\mathbf{T}$

Tabaksblat, M. 222

Telders, B.M. 122, 124

Temminck, C.J. 134

Thibault, J.F. 133

Thorbecke, J.R. 152, 186

Thysius, A. 43

Tiele, C.P. 155

Trelcatius, L. $5^{8}$

Treub, H. 155

Trigland, J. 58

Tuning, G. 52

$\mathbf{U}$

Uhlenbeck, E.M. 160

$\mathbf{V}$

Valerius 204

Visscher, C. 106

Vissering, S. 155
Vlugt, W.van der 155

Voigt, W. 187

Volder, B. de 6o, 63

Vollenhoven, C. van 159, 184, 187, 190, 195, 239

Voorst, J. van 152

Vorstius, A.E. 36, 51

Vorstius, C. 58

Vossius, G.J. 47, 77

Vredevoogd, L.E.H. 222-223, 227, 243

Vries, M. de 119, 184

Vulcanius, B. 52, 107

\section{W}

Waal, H.van de 160

Wagenaar, W.A. 225

Waszink, J.H. 160

Westenhout, J.van 133

Westerwolt, V. 89

Wijnpersse, D. van de 152

Willem I 180

Willem III 36

Willem IV 36

Willem van Огапje 23, 36, 107, 116, 119, 281

Willis, T. 65

Witt, C. de 33

Witt, J. de 251

Woud, J.C.van't 105

Wyttenbach, D.A. 152

Z

Zoutendijk, G. 160

Zürcher, E. 160 